\title{
Tecnologias para Canteiro de Obras Sustentável
}

Sheyla Mara Baptista Serra Dayana Bastos Costa Tarcísio Abreu Saurin Francisco Ferreira Cardoso (Organizadores)

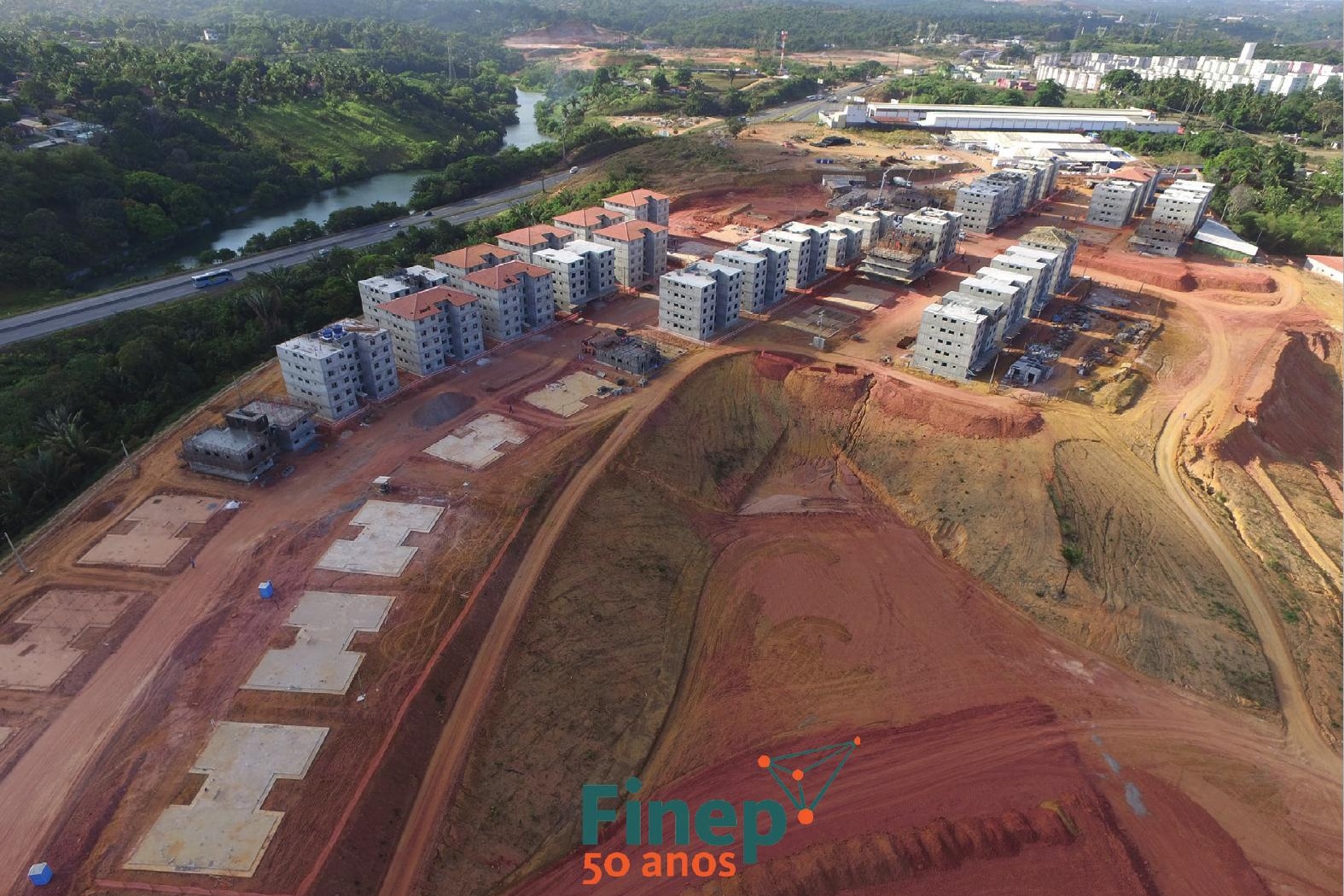



Sheyla Mara Baptista Serra

Dayana Bastos Costa

Tarcísio Abreu Saurin

Francisco Ferreira Cardoso

(Organizadores)

\section{Tecnologias para Canteiro de Obras \\ Sustentável}

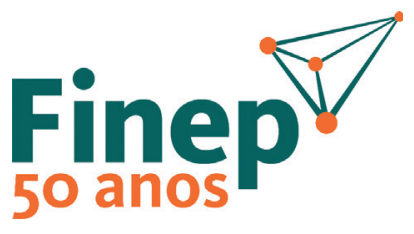

2017 
Copyright (C) 2017- Todos os direitos reservados.

Distribuição gratuita, venda não autorizada.

Foto da Capa: Dayana Bastos Costa

Obra Residencial Jardim das Margaridas, Salvador, BA.

T2559t Tecnologia para canteiro de obras sustentável [recurso eletrônico] / organizadores: Sheyla Mara Baptista Serra; Dayana Bastos Costa; Tarcísio Abreu Saurin; Francisco Ferreira Cardoso. - [São Carlos]: FINEP, 2017.

1 livro eletrônico

$412 \mathrm{p}$.

ISBN 978-85-5953-027-8

DOI- http://dx.doi.org/10.26626/978-85-5953-027-8.2017B0001

1. CANTECHIS. 2. Habitação. 3. Sustentabilidade. 4. Canteiro de obras.

5. Tecnologia e inovação. I. Orgs. II. Título.

CDD 600

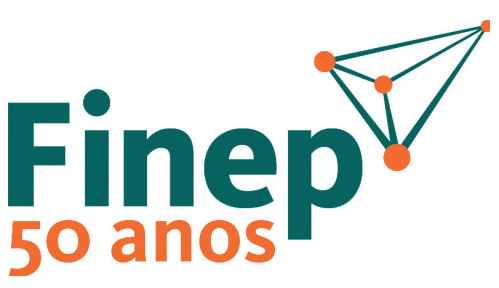

Revisão, Editoração, E-pub e Impressão:

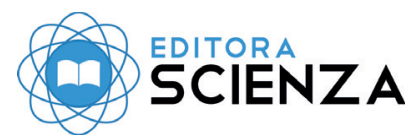

Rua Juca Sabino, 21 - São Carlos, SP

(16) 3364-3346 | (16) 9 9285-3689 www.editorascienza.com.br gustavo@editorascienza.com 


\section{Agência concedente}

\section{Financiadora de Estudos e Projetos - FINEP}

Presidência (PRES)

Marcos Cintra Cavalcanti de Albuquerque

Diretoria de Desenvolvimento Científico e Tecnológico (DRCT)

Wanderley de Souza

Diretoria Financeira e Controladoria (DRFC)

Ronaldo Souza Camargo

Diretoria de Gestão Corporativa (DGES)

Francisco Rennys Aguiar Frota

Diretoria de Inovação I (DRIN1)

Márcio Ellery Girão Barroso

Diretoria de Inovação II (DRIN2)

Victor Hugo Gomes Odorcyk

Área de Tecnologia para o Desenvolvimento Sustentável (ATDS)

Maurício B. de França Teixeira

Departamento de Tecnologia para o Desenvolvimento Urbano e Mudanças Climáticas (DURB)

Carlos Eduardo Sartor

Analista técnica: Angela Mazzini

Consultora técnica: Maria Lúcia Malard, UFMG

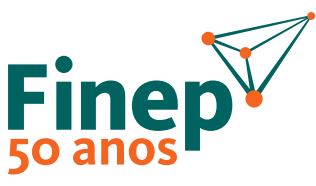

MINISTÉRIO DA

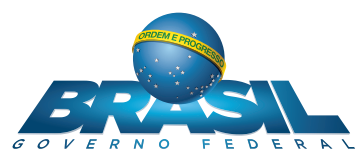





\section{Agradecimentos}

À FINEP pelo suporte à rede de pesquisa CANTECHIS - Tecnologias para Canteiro de Obras Sustentável de Habitações de Interesse Social (HIS) - e pelo apoio financeiro para publicação deste livro.

Às empresas que colaboraram com o desenvolvimento das pesquisas apresentadas neste livro:

- Ampla Construtora e Incorporadora Ltda.

- C. Rolim Engenharia Ltda.

- Camargo Corrêa Desenvolvimento Imobiliário S.A.

- Canteiro Construções Racionalizadas Ltda.

- Casoi Desenvolvimento Imobiliário Ltda.

- Civil Construtora Ltda.

- Concreta Incorporação e Construção Ltda.

- Sertenge S.A.

- Cyrela Brazil Realty S.A Empreendimentos e Participações

- Engefack Serviços e Participações Ltda.

- Espaço Certo Edificações Pré-Fabricadas Ltda.

- Eurobras Construções Metálicas Moduladas Ltda.

- Even Construtora e Incorporadora S.A.

- Fujita Engenharia Ltda.

- Goldsztein Cyrela Empreendimentos Imobiliários S.A.

- Gráfico Empreendimentos Ltda.

- Imecon Indústria de Máquinas e Estruturas para Construção Ltda.

- Jotagê Engenharia Comércio e Incorporações Ltda.

- Jotanunes Construtora Ltda.

- Kubo Engenharia e Empreendimentos Imobiliários Ltda.

- LP Brasil OSB Indústria e Comércio S.A.

- Maiojama Empreendimentos Imobiliários Ltda.

- Melnick Even Incorporações e Construções S.A.

- Modularis Indústria, Comércio e Montagem de Estruturas Modulares Ltda.

- MoreFácil Construtora e Incorporadora Ltda.

- Moura Dubeux Engenharia e Empreendimentos S.A.

- MRV Engenharia e Participações S.A.

- Muza Construtora Ltda.

- Nanotech do Brasil Indústria, Importação e Exportação Ltda. 
- Nex Group Participações S.A.

- OAS Empreendimentos S.A.

- Odebrecht Realizações Imobiliárias S.A.

- PDG Realty S.A. Empreendimentos e Participações

- Prefacc Ltda.

- Promonature Empreendimentos Imobiliários Ltda.

- Proposta Engenharia de Edificações Ltda.

- Protensão Impacto Ltda.

- R. Correa Engenharia Ltda.

- Rio Verde Engenharia e Construções Ltda.

- Rossi Residencial S.A.

- São Conrado Empreendimentos Ltda.

- Scanmental Indústria, Comércio, Importação e Exportação de Ferramentas Ltda.

- SFZ Empreendimentos Ltda.

- Soldatopo Containers Ltda.

- Souza Neto Engenharia Ltda.

- Syene Empreendimentos e Participações Ltda.

- Talgatti Edificações Moduladas Eireli

- Tecnisa S.A.

- Tecnobra Tecnologia em Construção a Seco Ltda.

- Villare Engenharia Ltda.

- Viver Eco Canteiros Ltda.

Às instituições e organizações que colaboraram com o desenvolvimento das pesquisas:

- $A B C I C$ - Associação Brasileira da Construção Industrializada de Concreto

- CBIC - Câmara Brasileira da Indústria da Construção

- CETESB - Companhia de Tecnologia de Saneamento Ambiental do Estado de São Paulo

- LAPAt - Laboratório de Análise dos Processos Atmosféricos da Universidade de São Paulo (IAG/USP)

- SINDUSCON-BA - Sindicato da Indústria da Construção do Estado da Bahia

- SINDUSCON-RS - Sindicato da Indústria da Construção do Estado do Rio Grande do Sul

- SINDUSCON-SP - Sindicato da Indústria da Construção do Estado de São Paulo

- SRTE-RS - Superintendência Regional do Trabalho e Emprego do Rio Grande do Sul

- Hong Kong Polytechnic University, Department of Building and Real Estate

- The Hong Kong Housing Authority Department 


\section{Lista de Autores}

\section{Sheyla Mara Baptista Serra}

\section{Coordenação geral}

\section{UFSCar}

sheylabs@ufscar.br
Possui graduação em Engenharia Civil pela Universidade Federal de Juiz de Fora (1990), mestrado em Engenharia de Estruturas pela Escola de Engenharia de São Carlos da USP (1994) e doutorado na área de Construção Civil pela Escola Politécnica da USP (2001). É professora associada do Departamento de Engenharia Civil da UFSCar. Atualmente, é diretora do Centro de Ciências Exatas e de Tecnologia (CCET). É docente do Programa de Pós-graduação em Estruturas e Construção Civil (PPGECiv). Participa dos grupos de pesquisa do CNPq: NETPRE - Núcleo de Estudos e Tecnologia em Pré-moldados de Concreto, e NUPRE - Núcleo de Pesquisa em Racionalização e Desempenho de Edificações. É membro da ABENGE - Associação Brasileira de Educação em Engenharia e da ANTAC - Associação Nacional de Tecnologia do Ambiente Construído. Tem pesquisas na área de gestão da produção da construção civil, atuando nos seguintes temas: planejamento e controle da construção, gestão de subempreiteiros, projeto do canteiro de obra, construção enxuta, canteiro sustentável, análise organizacional e saúde e segurança do trabalhador.

\section{Dayana Bastos Costa}

\section{Coordenação \\ UFBa}

dayanabcosta@ufba.br
Possui graduação em Engenharia Civil pela Universidade Federal da Bahia (2001), Mestrado em Engenharia Civil (Construção Civil) pela Universidade Federal do Rio Grande do Sul (2003), Doutorado em Engenharia Civil (Construção Civil) pela Universidade Federal do Rio Grande do Sul (2008) com doutorado sanduíche na Universidade de Salford (20062007) no Reino Unido e Pós Doutorado na Georgia Institute of Technology nos EUA (2014-2015). É Professora Adjunta IV do Departamento de Construção e Estruturas da Escola Politécnica da Universidade Federal da Bahia e do Programa de Pós Graduação em Engenharia Civil (Mestrado e Doutorado). É coordenadora do Programa de Pós Graduação em Engenharia Civil da UFBA e vice coordenadora da Especialização em Gerenciamento de Obras da UFBA. Tem experiência na área de Construção Civil, com ênfase em Gerenciamento e Economia de Construções, atuando principalmente nos seguintes temas: gestão de obras, incluindo medição de desempenho, planejamento e controle de obra, gestão da qualidade, gestão sustentável em canteiros, Building Information Modelling e Veículos Aéreos Não Tripulados. 


\section{Tarcísio Abreu Saurin}

\section{Coordenação \\ UFRGS}

saurin@ufrgs.br
Pós-doutorado na University of Salford (2012), doutorado em Engenharia de Produção pela Universidade Federal do Rio Grande do Sul (2002), mestrado em Engenharia Civil pela Universidade Federal do Rio Grande do Sul (1997), Graduação em Engenharia Civil pela Universidade Federal de Santa Maria (1994). Atualmente é professor associado II da Universidade Federal do Rio Grande do Sul no Departamento de Engenharia de Produção e Transportes. Suas pesquisas têm ênfase nos seguintes temas: gestão da segurança e da produção em sistemas complexos; sistemas de produção enxuta e engenharia de resiliência. Nesses temas, atualmente tem participação como coordenador e/ou pesquisador em projetos de pesquisa aplicada junto a empresas dos setores de distribuição e geração de energia elétrica, assistência à saúde, manufatura e construção civil. Tais projetos contam com auxílio financeiro de empresas privadas e/ou agências de fomento à pesquisa, como FINEP, CNPq, FAPERGS e CYTED.

\section{Francisco Ferreira Cardoso}

Coordenação

USP

ff.cardoso@usp.br
Professor Titular da Escola Politécnica da USP da Especialidade Tecnologia e Gestão da Produção na Construção Civil, vice chefe do Departamento de Engenharia de Construção Civil, Presidente da Comissão de Graduação da Escola Politécnica e membro do Conselho de Graduação da USP. É graduado em Engenharia Civil pela USP (1980), fez mestrado em Engenharia de Construção Civil e Urbana na USP (1986), doutorado na subárea de Économie et Sciences Sociales na École Nationale des Ponts et Chaussées (1996) e Pós-doutorado no Centre Scientifique et Technique du Bâtiment (2001), ambos na França. É membro do Conselho Fiscal do Conselho Brasileiro de Construção Sustentável (CBCS) (suplente). Foi presidente da Associação Nacional de Tecnologia do Ambiente Construído (ANTAC) (2008-10), vice-presidente (2010-12), diretor de Relações Interinstitucionais em duas gestões (2006-08 e 201214) e primeiro secretário (1998-2000). Atua no Programa Brasileiro de Qualidade e Produtividade do Habitat (PBQP-H) do Ministério das Cidades e é membro do Comitê Nacional de Desenvolvimento Tecnológico da Habitação (CTECH). Tem experiência na área de Engenharia Civil (Construção Civil), com ênfase nas linhas Competitividade, qualidade e modernização produtiva, Gestão da produção na construção civil e Inovação e racionalização nos processos construtivos. 


\section{Carlos Torres Formoso}

UFRGS

formoso@ufrgs.br

Possui graduação em Engenharia Civil pela UFRGS (1980), mestrado em Engenharia Civil pela UFRGS (1986) e Ph.D. pela University of Salford (1991). Fez pós-doutorado na Universidade da Califórnia, Berkeley, EUA (1999-2000) e na University of Salford (2011). É Professor Titular da UFRGS e coordenador do Grupo de Gestão e Economia da Construção do Núcleo Orientado para a Inovação da Edificação (NORIE). É docente permanente do Programa de Pós-Graduação em Engenharia Civil da UFRGS (nota 7 na CAPES). Faz parte do Conselho Editorial de seis revistas científicas internacionais. Tem atuado como consultor ad hoc da FINEP, FAPESP, CAPES, CNPq, CYTED, entre outras agências de fomento. Atua na área de gerenciamento na construção civil, principalmente nos seguintes temas: projeto e gestão de sistemas de produção, produção enxuta (lean production), gestão da segurança do trabalho, aprendizagem organizacional, medição de desempenho de empresas e empreendimentos de construção, habitação de interesse social e gestão do processo de desenvolvimento do produto.

\section{Emerson de Andrade Marques Ferreira}

UFBa

\author{
ferreira.eam@gmail.com
}

Possui graduação em Engenharia Civil pela Universidade Federal da Bahia (1981), mestrado em Arquitetura (EESC) pela Universidade de São Paulo (1991) e doutorado em Engenharia Civil (Escola Politécnica) pela Universidade de São Paulo (1998). Atualmente é professor Titular da Universidade Federal da Bahia. Tem experiência na área de Gerenciamento, com ênfase em Administração da Produção, atuando principalmente nos seguintes temas: planejamento e controle, canteiro de obras, sustentabilidade, segurança do trabalho, gestão de resíduos, análise da viabilidade, tecnologia da informação e BIM.

\section{Fernando Menezes de Almeida Filho}

UFSCar

almeidafilho@ufscar.br
Possui graduação em Engenharia Civil pela Universidade Federal do Ceará (1998), especialização em Engenharia de Estruturas pela Universidade de Fortaleza (2000), mestrado em Engenharia de Estruturas pela Universidade de São Paulo (2002) e doutorado em Engenharia de Estruturas pela Universidade de São Paulo (2006) e pós-doutorado em Engenharia de Estruturas pela Universidade de São Paulo (2010). Participa do grupo de pesquisa NETPRE - Núcleo de Estudos e Tecnologia em Prémoldados de concreto na UFSCar. Atualmente, é professor adjunto do curso de Engenharia Civil da Universidade Federal de São Carlos com ênfase em Estruturas de Concreto, atuando principalmente nos seguintes temas: Estruturas de concreto, concreto protendido, materiais, análise experimental, aderência, mecânica das estruturas, simulações numéricas e variabilidade. 


\section{Jardel Pereira Gonçalves}

\section{UFBa}

jardelpg@gmail.com
Possui graduação em Engenharia Civil pela Universidade Estadual de Feira de Santana (1998), mestrado em Engenharia Civil pela Universidade Federal do Rio Grande do Sul (2000) e doutorado em Engenharia Civil pela Universidade Federal do Rio de Janeiro (2005). Atualmente é professor associado da Escola PolitécnicaDepartamento de Construção e Estruturas da Universidade Federal da Bahia. Tem experiência na área de Engenharia Civil atuando principalmente nos seguintes temas: construção civil, tecnologia da construção, sistemas construtivos, materiais cimentíceos, novos materiais e meio ambiente.

\section{José Carlos Paliari UFSCar \\ jpaliari@ufscar.br}

Possui graduação em Engenharia Civil pela UFSCar (1994), mestrado em Engenharia Civil (1999) e doutorado em Engenharia Civil (2008), ambos pela Universidade de São Paulo. Atualmente é professor Associado I e Pró-Reitor Adjunto de Pós-graduação da UFSCar. Foi coordenador do Programa de Pós-Graduação em Estruturas e Construção Civil - PPGECiv entre 2010 e 2015 e membro do Conselho de Coordenação do Curso de Engenharia Civil, representando a área de gestão e tecnologia de construção civil. É vice-líder do Grupo de Pesquisa NUPRE - Núcleo de Pesquisa em Racionalização e Desempenho de Edificações. Tem experiência na área de engenharia civil, com ênfase em tecnologia e gestão da produção de edificações. Também desenvolve pesquisas na área de ergonomia na construção civil, Lean Construction, produtividade da mão de obra e desperdício de materiais nos canteiros de obras. É responsável pelo Laboratório de Modelagem e Simulação com Informática (LMSI) vinculado ao PPGECiv.

\section{UFSCar \\ marcelof@ufscar.br}

Marcelo de Araujo Ferreira

Coordenador do Núcleo de Estudo e Tecnologia em PréMoldados de Concreto (NETPRE). Professor Associado do Departamento de Engenharia Civil da UFSCar. Professor do Programa de Pós-Graduação em Construção Civil da UFSCar. Engenheiro Civil com Ênfase em Sistemas Construtivos pela UFSCar (1990), Mestre e Doutor em Engenharia de Estruturas pela EESC-USP (1993 e 1999). Pós-doutorado (Visiting Scholar) pela University of Nottingham na Inglaterra (2000-2001; 20092010). Pós-doutorado pela EESC-USP (2002-2003). Pesquisador há 20 anos sobre estruturas pré-moldadas de concreto. Recebeu o Prêmio Henry Adams 2004 do Institution of Structural Engineers na Inglaterra. Membro do Comitê de Revisão da NBR 9062:06 - Estruturas de Concreto Pré-Moldado. Membro do Comitê de Pré-Fabricados da Federação Internacional de Concreto Estrutural (CEB-FIP). Delegado brasileiro na Federação Internacional do Concreto Estrutural FIB (CEB-FIP). Foi coordenador da Comissão de Estudos de Lajes Alveolares da ABNT:CE 18:600.19 (2008-2009). Membro Convidado do Comitê Técnico: Connection Details do Precast Concrete Institute PCIUSA desde 2008. Revisor do PCI Journal a partir de 2011. 


\section{Racine Tadeu Araujo Prado}

USP

racine.prado@usp.br
Possui graduação em Engenharia Civil [SP Capital] pela Universidade de São Paulo (1987), mestrado e doutorado em Engenharia Civil pela Universidade de São Paulo (1996). Atualmente é professor Associado III da Escola Politécnica da Universidade de São Paulo. Seus temas principais de pesquisas são Física das Construções, Engenharia Solar e Sistemas Prediais, que se desdobram em vários outros, tais como transferência de calor através da envoltória dos edifícios, propriedades térmicas e óticas de materiais, conforto térmico, aquecimento de água, sistemas de ar condicionado e automação predial. A maior parte de suas publicações tem como foco o aproveitamento de energia solar com coletores passivos, dedicando-se também à geração de energia com coletores concentradores e fotovoltaicos em edifícios.

\section{Ricardo Fernandes Carvalho}

\section{UFBa}

carvalho_rf@hotmail.com
Possui graduação em Engenharia Civil pela Universidade Federal da Bahia (1990), mestrado em Engenharia Civil pela Universidade Federal Fluminense (1994) e doutorado em Ciência e Engenharia de Materiais [São Carlos] pela Universidade de São Paulo (2005). Atualmente é adjunto da Universidade Federal da Bahia. Tem experiência na área de Engenharia de Materiais e Metalúrgica, com ênfase em Materiais Conjugados Não-Metálicos, atuando principalmente nos seguintes temas: compósitos, construção, fibras vegetais, canteiro e segurança. 


\section{Adriana Gouveia Rodrigo} USP

Arquiteta e urbanista pela Universidade de São Paulo (USP), adriana_rodrigo@hotmail.com mestra em Engenharia Civil pela Escola Politécnica da USP, Mestre Profissional em Gestão de Projetos e Concessões pelo Centro Superior de Edificação - Fundação Antonio Camuñas. Atua nas áreas de construção sustentável e certificação de sustentabilidade para edifícios. Foi consultora em Bioconstrução para o Programa das Nações Unidas para o Desenvolvimento (PNUD) no Comitê Nacional de Organização (CNO) Rio+20. Foi auxiliar da coordenação técnica na elaboração do referencial da certificação pelo Processo AQUA para edifícios habitacionais. Atuou como auditora para a certificação AQUA-HQE junto à Fundação Vanzolini. Atualmente é professora da Universidade de Mogi das Cruzes, nas áreas de Arquitetura e Urbanismo, Gestão de Projetos e Metodologia de Pesquisa.

\section{André Luiz Vivan UFSCar}

andreluizvivan@gmail.com

Possui graduação em Engenharia Civil pela Universidade Federal de São Carlos, UFSCar (2008), mestrado em Construção Civil pela UFSCar (2011) e doutorado em Estruturas e Construção Civil pela mesma instituição (2016). É membro do Grupo de Pesquisa NUPRE - Núcleo de Pesquisa em Racionalização e Desempenho de Edificações. Desenvolve pesquisas relativas a esforços de industrialização dos processos de construção de habitações unifamiliares, atuando principalmente nos seguintes temas: lean construction, simulação de processos e light steel frame, além do desenvolvimento de tipos específicos de projetos como o design for assembly e o design for manufacture com o objetivo de reduzir ciclos de produção e custos.

\section{Christine Miranda Dias} UFSCar

christinemdias@gmail.com

Possui graduação em Engenharia Civil pela Universidade Federal de São Carlos (2014). Mestra pelo Programa de Mestrado Profissional em Inovação na Construção pela Escola Politécnica da Universidade de São Paulo (2017), com pesquisa na área de sistemas prediais de água não potável. Possui experiência profissional em orçamentos de obras de infraestrutura, contenções, geotecnia, fundações e recuperação estrutural. 


\section{Clarice Menezes Degani}

USP

claricedegani@gmail.com
Engenheira Civil, mestre e doutora em Tecnologia e Gestão da Produção pela Escola Politécnica da USP, Especialista em Gestão de empreendimentos de construção civil pelo PECE/ USP, participou da equipe técnica para experimentação da certificação ambiental francesa NF Bâtiments Tertiaires Démarche HQE pelo CSTB na França, sócia curadora do CBCS Conselho Brasileiro de Construção Sustentável. Atualmente é assessora técnica da vice-presidência de sustentabilidade do SECOVI-SP, é docente em disciplinas dos cursos de MBA Gerenciamento de Facilidades e MBA Tecnologia da Gestão da Produção, ambos na FDTE POLI/USP. Participa dos comitês Avaliação da Sustentabilidade, Água e Urbano no CBCS e é consultora para projetos e construções sustentáveis, especialmente para o processo AQUA de certificação, e também para o gerenciamento da sustentabilidade de edifícios em operação.

\section{Cristina Toca Pérez}

\section{UFBa}

cristina.toca.perez@hotmail.es
Possui graduação em Engenharia Técnica de Obras Públicas Universidade de Cantabria, Espanha (2011) e Mestrado em Engenharia Ambiental Urbana na Universidade Federal da Bahia (2015). Possui especialização em Gestão das Construções, assim como em Estruturas e Patologias das edificações pela Universidade de Cantabria, Espanha (2011). Atualmente é Doutoranda do Programa de Pós-graduação em Engenharia Civil da UFBA e pesquisadora do Grupo de Pesquisa e Extensão em Gestão e Tecnologia das Construções (GETEC) da UFBA. Tem experiência na área de Engenharia Civil, com ênfase na área de Gestão das Construções, atuando principalmente nos temas: Lean Construction, gestão da produção, 4D BIM, logística interna do canteiro de obras e inovações tecnológicas, tais como argamassa projetada e Light Steel Framing.

\section{Daniela Dietz Viana UFRGS}

danidietz@gmail.com

Arquiteta e Urbanista pela Universidade Federal do Rio Grande do Sul, UFRGS (2008). Mestre em Engenharia Civil pela UFRGS (2011). Doutora em Engenharia Civil (2015) pela mesma instituição com doutorado sanduíche pela Universidade da Califórnia, em Berkeley. Pós-doutorado em Engenharia Civil (2016), com ênfase em Gestão e Economia da Construção. Tem atuado nos seguintes temas: Last Planner System, Lean Construction, sistemas pré-fabricados, sistemas de produção engineer-to-order, e Perspectiva Linguagem-Ação. 
daniellegazarini@gmail.com

\section{Débora Cristina Rosa Faria da Costa} USP

debora.costa@usp.br
Possui graduação em Arquitetura e Urbanismo pela Faculdade de Arquitetura da USP (2008), Especialização em Arquitetura Bioecológica pela ANAB - Associação Nacional de Arquitetura Bioecológica (2012) e Mestrado em Ciências pelo Programa de Pós-Graduação em Engenharia da Construção Civil e Urbana da Escola Politécnica da USP (2015), com pesquisa nas áreas de Conforto Térmico, Medições Térmicas, Desempenho, Simulação Computacional e Eficiência Energética. Doutoranda e pesquisadora do Laboratório de Tecnologia LABAUT-FAU/ USP. Docente do Instituto Federal de São Paulo nas áreas de Arquitetura e Urbanismo/Design de Interiores.

\section{Fernando Braga de Souza UFSCar}

engenheirofernandobraga@ gmail.com
Possui graduação em Engenharia Civil pela Universidade de Uberaba - UNIUBE (2015), Graduação em Engenharia de Produção pelo Centro Universitário Central Paulista (UNICEP, 2012) e Mestrado pelo Programa de Pós-Graduação em Estruturas e Construção Civil pela UFSCar (2016) na área de pesquisa em Gestão, Tecnologia e Sustentabilidade na Construção Civil. É membro do Grupo de Pesquisa NUPRE Núcleo de Pesquisa em Racionalização e Desempenho de Edificações. Professor e coordenador no Centro Universitário de Araras dos cursos de Engenharia Civil e Engenharia de Produção.

\section{Glauco Fabrício Bianchini}

\section{UFSCar}

glaucofb@yahoo.com.br
Engenheiro civil formado pela Escola de Engenharia de São Carlos (EESC-USP), possui especialização em Engenharia de Segurança do Trabalho pela Universidade de Franca e Mestrado pelo Programa de Pós-graduação em Estruturas e Construção Civil, UFSCar. É membro do Grupo de Pesquisa NUPRE - Núcleo de Pesquisa em Racionalização e Desempenho de Edificações. Atualmente é docente em tempo integral na Universidade de Franca, ministrando disciplinas e desenvolvendo pesquisas nas áreas de estruturas e gerenciamento da construção civil. 


\section{Guillermina Andrea Peñaloza UFRGS}

arq.guillerminapenaloza@

gmail.com
Possui Mestrado em Engenharia Civil pela Universidade Federal do Rio Grande do Sul (2015) e graduação em Arquitetura e Urbanismo pela Universidad Nacional de Córdoba (2010). Atualmente é aluna de Doutorado em Engenharia Civil na Universidade Federal do Rio Grande do Sul. Tem experiência na área de Engenharia Civil, com ênfase em Gerenciamento e Economia da Construção, atuando principalmente nos seguintes temas: gestão da segurança e da produção, gestão de requisitos, sistemas de produção enxuta.

\section{Ingrid Priscylla Silva Araújo}

UFBa

ingrid.pri@gmail.com
Possui graduação em Arquitetura e Urbanismo pela Universidade Federal de Alagoas (2009) e Mestrado em Engenharia Ambiental Urbana pela Universidade Federal da Bahia (2014). Atualmente é pesquisadora do Grupo de Pesquisa e Extensão em Gestão das Construções (GETEC) da Universidade Federal da Bahia e Docente dos Cursos de Engenharia Civil e Engenharia de Produção da Faculdade de Ciências e Empreendedorismo. Tem experiência na área de Construção Civil, com ênfase na área de Gestão das Construções, atuando principalmente no seguinte tema: poluição atmosférica proveniente de canteiros de obra da construção civil. Possui experiência em Arquitetura e Urbanismo.

\section{Juliana Sampaio Álvares}

\section{UFBa}

alvares.juliana@hotmail.com
Bolsista de iniciação científica da Universidade Federal da Bahia, pesquisadora do Grupo de Pesquisa e Extensão em Gestão e Tecnologia das Construções (GETEC). Tem experiência na área de Engenharia Civil, com ênfase em gestão, tecnologia, qualidade, segurança e sustentabilidade das construções.

\section{Laísa Cristina Carvalho}

UFSCar

laisacarvalho2809@gmail.com
Possui graduação em Engenharia Civil pela Universidade Estadual de Minas Gerais (2013), mestrado em Estruturas e Construção Civil pela Universidade Federal de São Carlos (2016). Atualmente é doutoranda deste mesmo Programa de PósGraduação. É membro do Grupo de Pesquisa NUPRE - Núcleo de Pesquisa em Racionalização e Desempenho de Edificações. Desenvolve pesquisas relativas ao esforço despendido pelos trabalhadores nas diversas tarefas da construção civil. Atua principalmente nos seguintes temas: ergonomia, produtividade e gestão do canteiro de obras. 


\section{Lucila Sommer UFRGS}

englusommer@gmail.com
Possui mestrado em Engenharia Civil pela UFRGS (2010) e graduação em Engenharia Civil pela UFRGS (2007). Tem experiência na área de Engenharia Civil, com ênfase em Engenharia Civil, atuando principalmente nos seguintes temas: making-do, perdas, planejamento e controle da produção, construção enxuta. Atualmente é bolsista do CNPq desenvolvendo sua tese sobre implementação de sistemas construtivos industrializados inovadores a partir do projeto do sistema de produção.

\section{Ludimilla de Oliveira Zeule}

\section{UFSCar}

zeule.eu@gmail.com
Graduada em Tecnologia em Construção Civil (2011) pela Universidade Estadual de Maringá. Mestre em Estruturas e Construção Civil no Programa de Pós-graduação em Estruturas e Construção Civil - PPGECiv da UFSCar (2014). Atualmente, doutoranda no mesmo programa. É membro do Grupo de Estudos NUPRE - Núcleo de Pesquisa em Racionalização e Desempenho de Edificações. Áreas de atuação: sustentabilidade na construção civil e gestão em canteiros de obras, método de tomada de decisão, seleção de materiais de menor impacto ambiental.

\section{Marcelo Fabiano Costella}

\section{UFRGS}

costella@unochapeco.edu.br
Engenheiro civil desde 1997, mestre em Engenharia Civil pela UFRGS (1999) e doutor em Engenharia de Produção pela UFRGS (2008). Atualmente é coordenador do Mestrado Profissional em Tecnologia e Gestão da Inovação da Universidade Comunitária da Região de Chapecó (UNOCHAPECÓ) e ministra disciplinas em especializações de Engenharia de Segurança do Trabalho em várias instituições no sul do Brasil. Também é professor pesquisador do Núcleo Stricto Sensu em Engenharia Civil na Faculdade Meridional (IMED). Tem experiência na área de Engenharia Civil, na área de Gestão de Produção Civil e Engenharia de Produção, com ênfase em Segurança do Trabalho.

\section{Maria Sacramento Oliveira Guimarães UFBa}

maria.guimaraes@

pro.unifacs.br
Possui graduação em Arquitetura e Urbanismo pela Universidade Federal da Bahia (1981). Especialização em Projetos Educacionais e Informática pela Faculdade de Educação da Bahia (2001). Mestre em Engenharia Ambiental Urbana (MEAU) da UFBA. Atualmente é Professora Adjunto e Assistente de Coordenação do Curso de Arquitetura e Urbanismo da Universidade Salvador. Tem experiência na área de Arquitetura e Urbanismo, com ênfase em Construção Sustentável. 


\section{Natasha Ilse Rothbucher Thomas}

UFBa

nashatasha@hotmail.com
Possui graduação em Engenharia Civil pela Universidade de Brighton, Inglaterra (2004), mestrado em Engenharia Ambiental Urbana (2011) e pós graduação (Latu-Sensu) em Gerenciamento de Obras pela UFBa. É auditora do BREEAM Internacional e Assistente AQUA - HQE. Trabalhou como assessora técnica do Sindicato da Indústria da Construção do Estado da Bahia (Sinduscon-BA), na área de sustentabilidade, materiais e inovação. Trabalha como pesquisadora há mais de sete anos na área de construção sustentável e ciência e engenharia de materiais. Foi professora na Universidade Federal da Bahia, ensinando "Técnicas Construtivas". Atualmente é professora do Instituto Brasileiro de Educação Continuada (INBEC) num MBA em Construção Sustentável, ensinando Gestão Ambiental de Canteiros de Obras e fornece serviços de Consultoria em Sustentabilidade e Inovação Tecnológica na Construção e Políticas Públicas Sustentáveis. É pesquisadora honorária da De Montfort University, Inglaterra.

\section{Nery Knöner UFSCar}

nery_knoner@hotmail.com
Possui graduação em Engenharia Civil pela Universidade Estadual de Maringá (1983). Mestrado em Estruturas e Construção Civil na Universidade Federal de São Carlos (UFSCar), em 2014, e doutorando na mesma instituição com o tema "Contribuição ao Estudo dos Mecanismos no Dimensionamento em Painéis Estruturais tipo Sanduíche". Tem experiência na área de Engenharia Civil em Cálculos em Concreto Protendido e em Estruturas Pré-Fabricadas; Execução de obras Residenciais e Industriais e como Engenheiro de Segurança do Trabalho. Atualmente é professor substituto na Universidade Tecnológica Federal do Paraná (UTFPR), Campo Mourão.

\section{Paula Venticinque Pompeu de Toledo Soares}

\section{USP}

papompeu@gmail.com
Engenheira civil pela Escola Politécnica da Universidade de São Paulo (2013) e especialista em Gestão de Projetos de Estruturas pelo Programa de Educação Continuada da Escola Politécnica da Universidade de São Paulo (2016). Atua na área de projetos de estruturas. 
Rita Jane Brito de Moraes

UFBa

ritacodesal@gmail.com

Possui graduação em Engenharia Civil pela Universidade Católica do Salvador (1990). Atualmente Subcoordenadora das Ações Comunitárias e Educativas da Defesa Civil de Salvador. Tem experiência na área de Engenharia Civil, com especialização em Engenharia de Segurança do Trabalho- UFBA (2005). Possui mestrado em Engenharia Ambiental Urbana pela Universidade Federal da Bahia- UFBA (2015).

\section{Roseneia Rodrigues Santos de Melo}

\section{UFBa}

roseneia.engcivil@gmail.com
Possui graduação em Engenharia Civil pela Universidade Federal da Bahia (2014). Mestre em Engenharia Civil pela Universidade Federal da Bahia. Doutoranda no Programa de Pós Graduação em Engenharia Civil (PPEC/UFBA). Pesquisadora do Grupo de Pesquisa e Extensão em Gestão da Construção (GETEC), na Universidade Federal da Bahia. Tem experiência na área de Engenharia Civil, com ênfase em gestão de obras, principalmente nos temas: orçamento, planejamento, medição de desempenho, Segurança do Trabalho e Veículos Aéreos Não Tripulados. 


\section{Alex Alves Bandeira UFBa}

alexbandeira@ufba.br

Possui Graduação (1990-1994) em Engenharia Civil pela Universidade Federal da Bahia, Mestrado (1995-1997) e Doutorado (1997-2001) em Engenharia Civil pelo Departamento de Engenharia de Estruturas e Fundações da Escola Politécnica da Universidade de São Paulo. Durante o doutoramento na USP realizou Estágio de Doutorado Sandwich na Universidade de Hannover (Alemanha, 1999-2000) e na Universidade de Pádova (Itália, 2000) na área de contato mecânico e micromecânico. Realizou Pós-Doutorado na Universidade de Berkeley (Califórnia, EUA, 2015-2016) na área da mecânica das partículas e tecidos estruturais. Atualmente é professor e pesquisador do Departamento de Construção e Estruturas da Escola Politécnica da Universidade Federal da Bahia. Atua principalmente na área da mecânica computacional, otimização, análise não linear, método dos elementos finitos, elastoplasticidade, contato mecânico, impacto, dinâmica não linear, estruturas de concreto e concreto reforçado com fibra de carbono, mecânica das partículas e tecidos estruturais. É membro do Comitê Editorial do seguinte periódico: Journal of Civil Engineering and Architecture (USA).

\section{Emanuela Rizzoto UnoChapecó}

emanuelarizzotto@

unochapeco.edu.br

Graduada em Engenharia Civil na Unochapecó (2014). Atualmente trabalha como engenheira civil em uma incorporadora em Chapecó/SC. Atua como pesquisadora no Grupo de Pesquisa em Sistemas Integrados de Gestão na Unochapecó.

\section{Letícia Nonennmacher}

\section{UnoChapecó}

letician@unochapeco.edu.br
Graduada em Engenharia Civil na Unochapecó (2015), Mestranda em Tecnologia e Gestão da Inovação na Unochapecó e é gestora de uma empresa de construção no interior do Rio Grande do Sul. Atua como pesquisadora no Grupo de Pesquisa em Sistemas Integrados de Gestão na Unochapecó. 

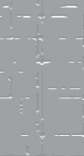


\section{Sumário}

\section{Seção 1 - Subprojeto Diagnóstico das Principais}

\section{Necessidades de Soluções Tecnológicas em}

\section{Canteiros de Obras (SPDIG)}

Capítulo 1 - Diagnóstico das Necessidades Prioritárias de

Pesquisas e Soluções Tecnológicas para Canteiros de

Obra de Baixo Impacto Ambiental

Dayana Bastos Costa, Maria Sacramento Oliveira Guimarães, Natasha llse Rotbucher Thomas, Clarice Menezes Degani

Capítulo 2 - Boas Práticas de Sustentabilidade em Canteiros de Obras

Ludimilla de Oliveira Zeule, Sheyla Mara Baptista Serra

Capítulo 3 - Diretrizes para Novas Políticas de Ciência, Tecnologia e Inovação para Canteiro de Obras de Baixo Impacto Ambiental

Natasha llse Rotbucher Thomas, Dayana Bastos Costa, Maria Sacramento Oliveira Guimarães, Clarice Menezes Degani

\section{Seção 2 - Subprojeto Desenvolvimento de Soluções para Redução da Emissão de Materiais Particulados em Canteiros de Obras (SPEMP)}

Capítulo 4 - Boas Práticas para Redução da Emissão de Material Particulado Proveniente dos Canteiros de Obras

Ingrid Priscylla Silva Araújo, Rita Jane Brito de Moraes,

Dayana Bastos Costa 


\section{Seção 3 - Subprojeto Aperfeiçoamento de Sistemas de Proteção Coletiva em Canteiros de Obras (SPSPC)}

Capítulo 5 - Avaliação de Requisitos de Desempenho de Sistemas de Proteção Periférica (SPP) em Obras de Edificações

Guillermina Andrea Peñaloza, Carlos Torres Formoso, Tarcisio Abreu Saurin

Capítulo 6 - Sistemas de Proteção Contra Quedas com Cabo de Segurança na Construção

Marcelo Fabiano Costella, Emanuela Rizzotto, Letícia Nonennmacher

Capítulo 7 - Inovação em Plataformas de Proteção

Alex Alves Bandeira, Ricardo Fernandes Carvalho,

Emerson de Andrade Marques Ferreira

Capítulo 8 - Diretrizes para o uso de Veículo Aéreo não Tripulado (VANT) Para Inspeção de Segurança em Canteiros de Obra

Roseneia Rodrigues Santos de Melo, Dayana Bastos Costa, Juliana Sampaio Álvares

Capítulo 9 - Aplicação do Instrumento de Análise Ergonômica - MET na Construção Civil

Laísa Cristina Carvalho, Glauco Fabrício Bianchini, José Carlos Paliari

Capítulo 10 - Embargos e Interdições em Canteiros de Obras: Uma Perspectiva Sistêmica

Tarcisio Abreu Saurin 


\section{Seção 4 - Subprojeto Soluções Tecnológicas Sustentáveis}

\section{para Instalações Provisórias de Canteiros de Obras (SPIPC)}

Capítulo 11 - Instalações Provisórias Pré-fabricadas para

Canteiros de Obras

Christine Miranda Dias, Sheyla Mara Baptista Serra

Capítulo 12 - Projeto de Contêineres Metálicos para Instalações Provisórias em Canteiros de Obras

Adriana Gouveia Rodrigo, Danielle Gazarini,

Francisco Ferreira Cardoso

Capítulo 13 - Fabricação, Montagem e Desmontagem de Instalações Provisórias para Canteiros de Obras

Fernando Braga de Souza, Sheyla Mara Baptista Serra

Capítulo 14 - Desempenho de Contêineres Metálicos para Instalações Provisórias em Canteiros de Obras

Francisco Ferreira Cardoso, Adriana Gouveia Rodrigo,

Paula Venticinque Pompeu de Toledo Soares

Capítulo 15 - Contêineres Metálicos para Instalações Provisórias em Canteiros de Obras no Brasil.

Débora Cristina Rosa Faria da Costa, Racine Tadeu Araújo Prado

Capítulo 16 - Sistema Pré-Fabricado em Pré-Moldado de Concreto para Instalações Provisórias de Canteiros de Obra

Nery Knöner, Fernando Menezes de Almeida Filho,

Marcelo de Araújo Ferreira 
Seção 5 - Subprojeto Desenvolvimento de tecnologias de execução relacionadas a métodos e sistemas construtivos inovadores (SPTEC)

Capítulo 17 - Novas Categorias de Perdas e sua Incidência em

Sistemas Industrializados na Habitação

Lucila Sommer, Carlos Torres Formoso, Daniela Dietz Viana

Capítulo 18 - Linha de Montagem para a Produção de Habitações de Interesse Social Modular em Light Steel Frame. .363

André Luiz Vivan, José Carlos Paliari

Capítulo 19 - Avaliação do Processo de Revestimento com Argamassa Projetada: Aspectos Econômicos

e Ambientais .383

Cristina Toca Pérez, Dayana Bastos Costa, Jardel Pereira Gonçalves

Conclusões: Avanços e Perspectivas Futuras 


\section{Prefácio}

Esta coletânea de artigos é fruto de dois fatores convergentes. O primeiro fator é a obstinação dos técnicos da Finep, criadores e operadores do programa Habitare, que sem dúvida foi, nos últimos 30 anos, a mais relevante política pública de fomento à pesquisa voltada para a habitação de interesse social no país. O segundo fator é a abnegação de pesquisadores de universidades públicas, cuja opção foi trabalhar para o desenvolvimento econômico e social das camadas populares, acreditando que a geração de conhecimento é uma arma poderosa na luta por melhorias das condições de vida do nosso povo.

Infelizmente, nem a obstinação de uns, nem a abnegação de outros foram capazes de sustentar o programa, que estava se tornando uma sólida base técnica e conceitual para a formulação de políticas públicas habitacionais de interesse social.

Esta coletânea fala em sustentabilidade. Para não instaurar mais uma divergência na definição do que seja esse conceito, recorro ao senso comum: sustentável é o que é bom para muita gente e não prejudica ninguém. Obviamente, o que é bom para poucos, mas pode trazer prejuízo a muitos é insustentável. É o caso das restrições financeiras que se colocam como obstáculos às políticas públicas de interesse social; é o caso da interrupção do Habitare, descontinuando metodologias, tecnologias e processos criativos e produzindo um peculiar descarte: o conhecimento.

Ao enfatizar a importância deste livro - independentemente de qualquer outro atributo que ele possa ter - recorro à explicação de Karl Popper acerca da teoria dos nossos mundos: o mundo 1, que se constitui dos objetos físicos; o mundo 2, que compreende os processos mentais; o mundo 3, que são os produtos da mente humana. O livro, na condição de papel impresso, é um objeto do mundo 1, que pode ser destruído ou descartado. Porém, enquanto produto da mente de pesquisadores, pertence ao mundo 3: é abstrato, portanto, imperecível. A concretude do livro que veicula o conhecimento abstrato permite a crítica objetiva. Esta, por sua vez, abre caminho para o avanço desse conhecimento. Através do livro, o conhecimento gerado pelos pesquisadores ao longo do desenvolvimento do CANTECHIS poderá ser analisado criticamente, propiciando o seu avanço. Por isso, um livro que corporifica conhecimentos é tão importante: porque os tornam passíveis de serem criticados objetivamente e de evoluírem a partir dessas críticas. 
As palavras do próprio Popper expressam melhor essa ideia :

(...) nosso trabalho cresce através de nós e crescemos através do nosso trabalho. Esse crescimento, essa auto-transcendência, tem um lado racional e um lado não-racional. A criação de novas ideias, de novas teorias, é em parte não racional. É uma questão que pode ser chamada de 'intuição' ou 'imaginação'. Mas a intuição é falivel, como tudo o que é humano. A intuição deve ser controlada através da crítica racional, que é o produto mais importante da linguagem humana. Este controle através da crítica é o aspecto racional do crescimento do conhecimento e do nosso crescimento pessoal. É uma das três mais importantes coisas que nos tornam humanas. Os outros dois são compaixão, e a consciência de nossa falibilidade.

O projeto CANTECHIS desenvolveu-se através de cinco subprojetos, os quais trouxeram à avaliação crítica 19 artigos. Esses subprojetos são:

- Diagnóstico das principais necessidades de soluções tecnológicas em canteiro de obras de empreendimentos de habitação de interesse social;

- Desenvolvimento de soluções para redução da emissão de materiais particulados em canteiros de obras de empreendimentos de habitação de interesse social;

- Aperfeiçoamento de sistemas de proteção coletiva em canteiros de obras de empreendimentos do Programa Minha Casa Minha Vida;

- Soluções tecnológicas sustentáveis para instalações provisórias de canteiros de obras de empreendimentos de habitação de interesse social;

- Desenvolvimento de tecnologias de execução relacionadas a métodos e sistemas construtivos inovadores para empreendimentos do Programa Minha Casa Minha Vida, com foco em sistema construtivo industrializado.

Estou certa de que a leitura desses 19 artigos suscitará críticas objetivas, que muito contribuirão para o crescimento do conhecimento da área de tecnologia de construções, principalmente se apontarem erros, pois temos consciência da nossa falibilidade.

\author{
Maria Lucia Malard \\ Belo Horizonte, MG \\ Julho de 2017
}




\section{Introdução}

\section{O Edital FINEP}

O projeto de pesquisa CANTECHIS - Tecnologias para Canteiro de Obras Sustentável de Habitações de Interesse Social (HIS) - também denominado Rede CANTECHIS, se caracteriza como uma resposta à Chamada Pública MCT/FINEP/Ação Transversal Saneamento Ambiental e Habitação 06/2010.

Quatro universidades brasileiras trabalharam na forma de rede de pesquisa colaborativa e estiveram envolvidas no desenvolvimento do Projeto CANTECHIS: Universidade Federal da Bahia (UFBA), Universidade Federal do Rio Grande do Sul (UFRGS), Universidade Federal de São Carlos (UFSCar) e Universidade de São Paulo (USP). No estabelecimento do convênio entre as partes, a Financiadora de Estudos e Projetos (FINEP) atuou como concedente, as quatro universidades como executoras, sendo a UFSCar a coordenadora geral, e a Fundação de Apoio Institucional ao Desenvolvimento Científico e Tecnológico (FAI-UFSCar) atuou como convenente. Também colaboraram com a Rede como intervenientes e apoiadoras, as instituições: Sindicato da Indústria da Construção do Estado da Bahia (SINDUSCON-BA), Associação Brasileira da Construção Industrializada em Concreto (ABCIC) e a Câmara Brasileira da Indústria da Construção (CBIC).

Foram objetivos específicos da Chamada Pública:

- Promover a pesquisa científica e tecnológica e a inovação a fim de contribuir para a melhoria das condições de habitação, em especial a de interesse social;

- Promover o desenvolvimento de soluções inovadoras aplicáveis à habitação, que sejam de fácil aplicabilidade, baixo custo de implantação, operação e manutenção;

- Contribuir para a sustentabilidade da habitação de interesse social;

- Contribuir para a elaboração e atualização das normas e resoluções técnicas aplicáveis às áreas de habitação;

- Propiciar a articulação entre Instituições de Pesquisa Científica e Tecnológica (ICTs) e organizações atuantes nas áreas de habitação;

- Promover a atuação integrada de ICTs em torno das áreas e temas prioritários definidos nesta Chamada Pública. 
O convênio foi firmado em dezembro de 2010, sendo a primeira reunião para estabelecimento da Rede realizada em agosto de 2011.

\section{A Rede}

A Rede teve duração até março de 2017 e tratou do tema prioritário contido no item 2.2 da referida chamada: "desenvolvimento de soluções tecnológicas aplicadas a canteiros de obras de empreendimentos habitacionais, especialmente de interesse social, visando à sustentabilidade ambiental e melhoria das condições de trabalho". A ênfase do projeto decorreu da expansão das habitações de interesse social (HIS), das crescentes preocupações com sustentabilidade na sociedade de modo geral, bem como da necessidade de reduzir as perdas no setor da construção civil.

A Rede CANTECHIS, integralmente apoiada pela FINEP, foi estruturada em cinco subprojetos que tratam de temáticas relacionadas entre si, além de um subprojeto específico para a gestão e articulação da rede. São eles:

- Subprojeto diagnóstico das necessidades de inovações tecnológicas (SPDIG): identificação de prioridades de pesquisa e desenvolvimento tecnológico em cinco temáticas: consumos, emissões e resíduos, interfaces com o meio exterior, qualidade intrínseca;

- Subprojeto emissão de materiais particulados (SPEMP): avaliação de emissões de materiais particulados em canteiros de obras, bem como identificação e proposta de soluções para o controle desses resíduos;

- Subprojeto sistemas de proteções coletivas (SPSPC): desenvolvimento de aperfeiçoamentos tecnológicos e gerenciais relacionados aos sistemas de proteções coletivas e identificação de fatores de fiscalização da segurança e saúde do trabalho nos empreendimentos pesquisados;

- Subprojeto instalações provisórias em canteiros de obras (SPIPC): identificação e desenvolvimento de soluções de projeto e tecnológicas para melhoria da eficiência e condições ambientais em instalações provisórias, tais como: vestiários, refeitórios, almoxarifados e áreas administrativas;

- Subprojeto tecnologias construtivas (SPTEC): avaliação e proposição de melhorias gerenciais e tecnológicas para um conjunto de métodos e sistemas construtivos inovadores aplicado às HIS, visando à melhoria das condições de trabalho nos canteiros de obras e à redução da produção de resíduos decorrentes de perdas e retrabalhos. 
As quatro universidades participaram de forma diferenciada nos subprojetos, conforme mostrado no Quadro 1. A coordenação de cada subprojeto pode ser observada por meio da célula destacada com sombreamento.

Quadro 1 - Participação das universidades em cada subprojeto.

\begin{tabular}{lccccc}
\hline Instituição/Subprojeto & SPDIG & SPEMP & SPSPC & SPIPC & SPTEC \\
\hline UFBA & $X$ & $X$ & $x$ & & $X$ \\
\hline UFRGS & $X$ & $X$ & $x$ & & $x$ \\
\hline UFSCar & $X$ & & $x$ & $x$ & $x$ \\
\hline USP & $X$ & $X$ & & $x$ & $x$ \\
\hline
\end{tabular}

Durante os seis anos da Rede, foram desenvolvidos vários trabalhos e atividades, que podem ser consultados na página do projeto.

Este livro apresenta contribuições de todos os subprojetos, oferecendo exemplos práticos e reflexões teóricas relevantes para diferentes agentes da indústria da construção civil e para pesquisadores. O presente capítulo apresenta brevemente a Rede CANTECHIS e traz uma visão inicial do conteúdo deste volume.

\section{O Livro}

Os capítulos estão agrupados em cinco seções, cada uma associada a um subprojeto. A primeira seção é referente ao SPDIG e organiza-se em em três capítulos. O capítulo 1 trata do diagnóstico das necessidades prioritárias de pesquisas e soluções tecnológicas para canteiros de baixo impacto. O levantamento dos dados foi realizado por meio da colaboração de 66 participantes, localizados nas quatro regiões das universidades participantes da Rede de pesquisa, sendo 22 empresas situadas em Salvador (BA), 19 empresas em São Paulo (região da capital), 13 empresas na grande Porto Alegre (RS) e 12 empresas no interior de São Paulo, próximas a São Carlos.

O capítulo 2 aborda boas práticas de sustentabilidade em canteiros de obras. Tais boas práticas foram identificadas com base em uma revisão da literatura e em visitas a seis canteiros de obras, sendo agrupadas em cinco categorias: canteiro sustentável, uso racional da água, uso racional de energia, materiais e recursos, qualidade do ambiente, inovações e processos. Todas as boas práticas identificadas são apresentadas ao longo do texto. A partir da análise detalhada dessas práticas, constatou-se que algumas são de simples implantação, podem reduzir os conflitos com a vizinhança ou trazer maior produtividade e conforto aos trabalhadores. 
O capítulo 3 apresenta diretrizes para novas políticas de ciência, tecnologia e inovação que podem ser aplicadas em canteiro de obras de baixo impacto ambiental.

O capítulo 4 corresponde à segunda seção do livro e discute boas práticas verificadas durante o desenvolvimento do SPEMP para a redução da emissão de material particulado proveniente dos canteiros de obras.

A seção 3 possui cinco capítulos correspondentes ao SPSPC. O capítulo 5 apresenta um protocolo para a avaliação de requisitos de desempenho de Sistemas de Proteção Periférica (SPP) em obras de edificações. Os SPP cumprem função importante na prevenção de quedas de altura, as quais constituem uma das principais causas de acidentes de trabalho na construção civil. Dentre os resultados, o capítulo apresenta uma lista abrangente de requisitos ligados à segurança, eficiência e flexibilidade dos SPP, bem como mostra a comparação entre diversos sistemas de uso corrente no setor.

O capítulo 6 descreve um método de avaliação de requisitos de desempenho similar ao apresentado no capítulo anterior, porém com foco nos sistemas de linha de vida. Tais sistemas, embora cumpram papel de equipamento de proteção individual, costumam ser necessários ao menos em algumas etapas das obras de construção. 0 capítulo relata a avaliação de sete diferentes sistemas de linhas de vida.

O capítulo 7 descreve um sistema alternativo para a montagem e desmontagem das plataformas de proteção periférica, as quais têm a função de aparar a queda de materiais e resíduos de construção. O sistema proposto evita que os trabalhadores estejam sobre as plataformas, que ficam em balanço, durante as atividades de montagem e desmontagem.

O capítulo 8 discute o uso de veículos aéreos não tripulados para inspeções de segurança em canteiros de obra. Com base em estudos de caso em empreendimentos habitacionais, são apresentadas recomendações para o planejamento e análise de dados decorrentes das inspeções, bem como limitações técnicas e legais para o uso desses equipamentos.

O capítulo 9 trata da avaliação das condições de trabalho em canteiros de obras sob o ponto de vista ergonômico. É descrita a aplicação do método denominado Estimativa do Equivalente Metabólico na atividade de recebimento de ferragens, em um canteiro de obras. Os resultados da aplicação do método estabelecem uma base empírica para justificar melhorias no projeto da atividade estudada.

O capítulo 10 discute os embargos e interdições (EI) em canteiros de obras sob uma perspectiva sistêmica. Os El abordados são aqueles realizados pelos órgãos reguladores do Ministério do Trabalho, tendo em vista a preservação da segurança e da saúde dos trabalhadores. Com base em 13 estudos de casos, o capítulo aponta que há impactos positivos e negativos dos El, os quais afetam diversos agentes internos e externos aos canteiros. Com base nessa visão sistêmica, podem ser elaboradas 
melhores estratégias, por parte de governo, empresas e trabalhadores, para prevenção e reação aos El.

A seção 4 apresenta os principais resultados do SPIPC e é composta por seis capítulos. O capítulo 11 apresenta a diversidade de tipologias existentes no mercado brasileiro de Instalações Provisórias (IP) pré-fabricadas para canteiros de obras. Foram identificadas oito diferentes tipologias de IP, sendo apresentadas as suas principais características em relação aos aspectos da sustentabilidade.

O capítulo 12 apresenta diagnóstico sobre as IP existentes em canteiros de obras situados na cidade de São Paulo. Foram pesquisadas cinco empresas e oito obras, e analisadas as IP referentes, a fim de apresentar condicionantes de projeto de sistema modular em aço para instalações provisórias de obras, com base em um programa de necessidades típico para tais estruturas, capazes de possibilitar que a sua configuração se transforme em função das fases das obras.

O capítulo 13 apresenta estudo sobre o processo de fabricação, montagem e desmontagem de instalações provisórias pré-fabricadas em madeira para canteiros de obras, introduzindo a adoção de ferramentas BIM (Building Information Modeling/ Modelagem da Informação da Construção) para a elaboração dos projetos das IP. O capítulo enfatiza a necessidade de elaboração de projeto executivo que considere as etapas de montagem e de desmontagem da IP, de forma a tornar o produto mais sustentável e possível de ser reutilizado várias vezes.

O capítulo 14 trata dos requisitos de desempenho das edificações, mesmo aquelas classificadas como provisórias, reconhecendo que elas constituem um local de trabalho e/ou permanência prolongada dos trabalhadores. A análise tem como base a norma NBR 15575: Edificações Habitacionais - Desempenho (ABNT, 2013), conhecida como Norma de Desempenho, bem como o documento European Technical Approval Guidelines (ETAG) 023 - Guideline for European Technical Approval of Prefabricated Building Units (2006). O ETAG é um documento semelhante à Diretriz para Avaliação Técnica de Produtos do Sistema Nacional de Avaliações Técnicas (SINAT), elaborado pelo Programa Brasileiro da Qualidade e Produtividade do Habitat (PBQP-H). O capítulo enfoca os contêineres metálicos do tipo estrutura reticulada em aço, que são fabricados com a finalidade específica para o uso em canteiro de obras, sendo um produto de oferta e aplicação crescente no Brasil.

O capítulo 15 apresenta uma contribuição tecnológica para melhorar o desempenho dos contêineres metálicos em IP por meio da aplicação de revestimento externo refletivo. Após realização da pesquisa experimental, foi possível obter dados que confirmam a melhora nas condições de conforto térmico, bem como a redução da demanda energética quando usado sob condicionamento artificial. A aplicação do revestimento refletivo também demonstrou ser uma solução durável e de baixo custo para a utilização nos contêineres. 
O capítulo 16 apresenta o processo de desenvolvimento de um protótipo em prémoldados de concreto para IP e os resultados dos ensaios dos componentes propostos. O sistema construtivo desenvolvido possibilita atender a demanda de mercado para construção das IP em canteiros de obra de acordo com os quesitos da NBR 15575: Edificações Habitacionais - Desempenho (ABNT, 2013) e várias outras normas.

A quinta seção do livro é referente ao SPTEC, composta por três capítulos. O capítulo 17 apresenta uma proposta de novas categorias de perdas e sua incidência em sistemas industrializados em HIS.

O capítulo 18 descreve o uso de linhas de montagem manuais como técnica de produção para unidades habitacionais modulares em Light Steel Frame. O sistema foi modelado e simulado computacionalmente, a fim de que o seu comportamento fosse avaliado em termos de rapidez de entrega das unidades habitacionais e redução de perdas.

O capítulo 19 apresenta a análise do processo de revestimento com argamassa projetada do ponto de vista de aspectos econômicos e ambientais, a partir de quatro estudos de caso realizados na região metropolitana de Salvador. Para tanto, foi definido um conjunto de indicadores com o objetivo de se fazer a avaliação de desempenho e uma comparação entre os estudos.

Por fim, são apresentadas as Conclusões e perspectivas futuras para a indústria e academia.

Esperamos que você faça uma boa leitura e que o texto e as ideias apresentadas se tornem realidade e contribuam de fato para melhorar as condições de sustentabilidade e segurança nos canteiros de obra.

Tarcísio Abreu Saurin

Dayana Bastos Costa

Francisco Ferreira Cardoso

Sheyla Mara Baptista Serra

(Organizadores) 


\section{Seção I}

Subprojeto Diagnóstico das

Principais Necessidades de

Soluções Tecnológicas em

Canteiros de Obras (SPDIG)

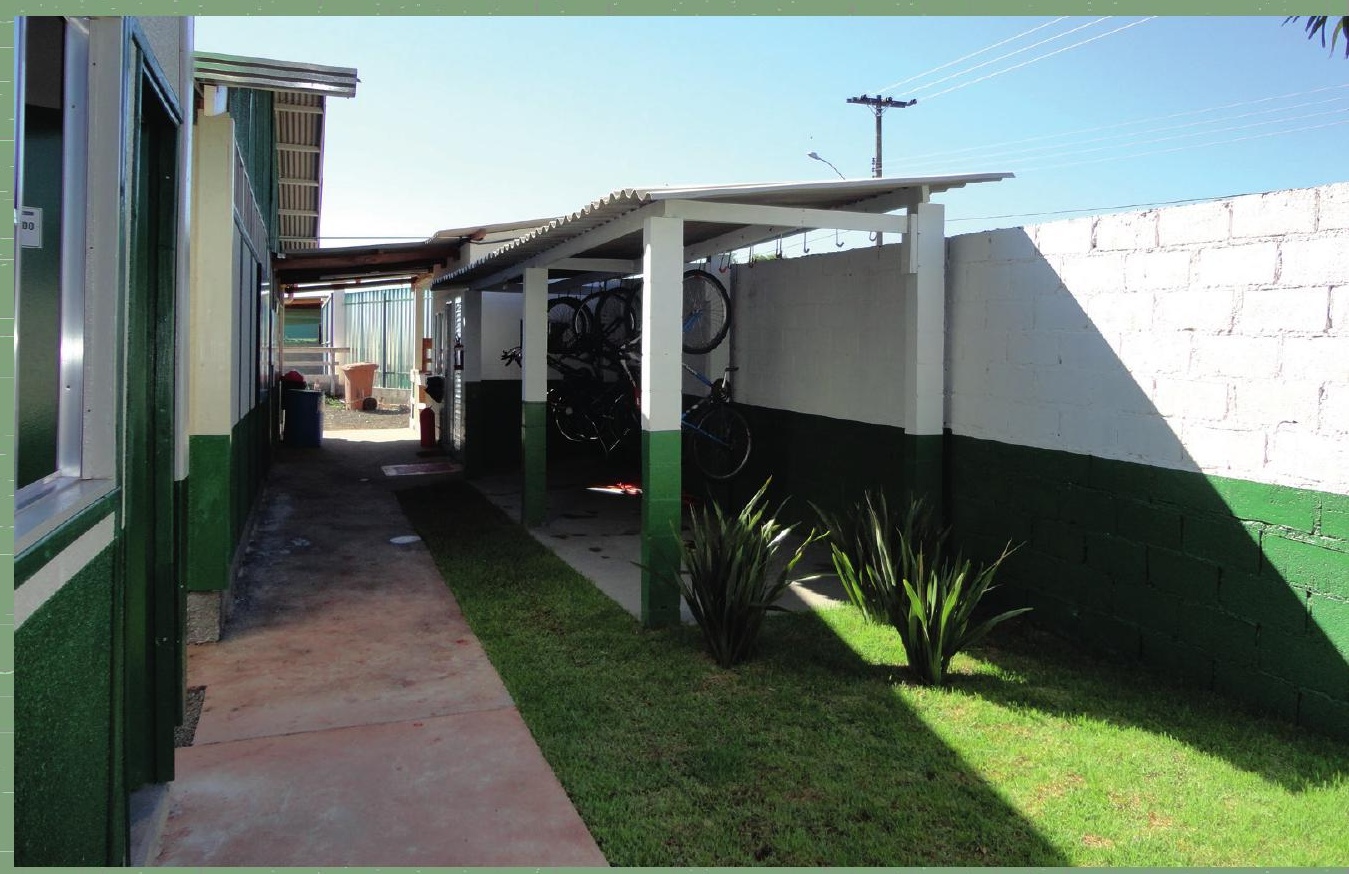




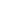




\title{
Diagnóstico das Necessidades Prioritárias de Pesquisas e Soluções Tecnológicas para Canteiros de Obra de Baixo Impacto Ambiental
}

\author{
Dayana Bastos Costa \\ Maria Sacramento Oliveira Guimarães \\ Natasha Ilse Rotbucher Thomas \\ Clarice Menezes Degani
}

\section{Introdução}

O processo de construção propriamente dito causa diferentes impactos ambientais (KILBERT, 2005; USEPA 2006). Grandes quantidades de materiais, água e energia elétrica, entre outros recursos de vários tipos e origens são consumidos em canteiros de obras durante as diferentes atividades de produção e de instalações temporárias. Além da geração de resíduos, estas atividades emitem partículas que causam contaminação do solo e a poluição do ar, bem como riscos de poluição das águas e de indução de processos erosivos. Além disso, os impactos decorrentes direta ou indiretamente das atividades de produção no canteiro de obra podem criar problemas relacionados com a saúde, a segurança e o bem-estar dos trabalhadores do local e da vizinhança. 
Portanto, considerando o tamanho e a importância dos impactos ambientais causados pelas atividades do canteiro de obras, é necessário que o setor da construção reduza os impactos da etapa de execução da obra. A partir da priorização dos impactos que precisam ser reduzidos ou eliminados, pode-se definir as tecnologias e as ações de natureza gerencial. Podem ser ainda estabelecidos os recursos que precisam ser implementados, as necessidades de pesquisa, as proposições de melhores práticas que visam diminuir o consumo e as perdas no canteiro de obras, os equipamentos a serem comprados, os profissionais a serem treinados ou contratados, ferramentas gerenciais a serem implementadas e os prazos e custos envolvidos (CARDOSO; ARAUJO, 2007).

Este capítulo tem o objetivo de apresentar as necessidades prioritárias de pesquisas e soluções tecnológicas para canteiros de obra habitacional de baixo impacto ambiental, considerando consumos de recursos materiais, energia e água, resíduos de construção, poluição do ar, da água e do solo, qualidade urbana, poluição sonora e visual, além da qualidade intrínseca do canteiro, incluindo saúde e segurança do canteiro e instalações provisórias.

\section{Método de Pesquisa}

O presente trabalho visou identificar, priorizar e validar as necessidades de pesquisa para a sustentabilidade ambiental e melhorias das condições de trabalho em canteiro de obras nas cidades de Salvador-BA, São Paulo-SP, São Carlos-SP e Porto Alegre-RS, contando com o apoio da Câmara Brasileira da Indústria da Construção CBIC juntamente com os Sindicatos da Indústria da Construção - Sinduscons.

A etapa inicial da pesquisa envolveu a revisão da literatura de diferentes métodos não obrigatórios de avaliação ambiental de construções sustentáveis. Embora estes métodos apresentem os requisitos, que devem ser atendidos para que um empreendimento seja certificado como uma construção sustentável, a revisão bibliográfica do presente trabalho focou nas contribuições para o alcance de canteiros de obra de baixo impacto. As metodologias estudadas foram: BREEAM (Building Research Establishment Environmental Assessment Method) (BREEAM, 2009), LEED (Leadership in Energy and Environmental Design) (U.S. GREEN BUILDING COUNCIL, 2000), Processo AQUA - Alta Qualidade Ambiental (FUNDAÇÃO VANZOLINI, 2010), que foi adaptada à realidade brasileira a partir do HQE (Haute Qualité Environnementale) e Selo Casa Azul (JOHN; PRADO, 2010).

Embora os métodos de avaliação apresentem diferenças dentro dos seus critérios de análise, bem como nos de categorias e temas em que são distribuídos, foi possível categorizá-los em tópicos semelhantes. Assim, a fim de comparar a contribuição de cada método de avaliação ambiental e identificar as diretrizes específicas para a etapa de execução de um empreendimento, quatro temas genéricos foram identificados: 
(1) Consumos; (2) Emissões e Resíduos; (3) Interface com Meio Exterior e (4) Qualidade Intrínseca do Canteiro, tomando como base as definições estabelecidas por Degani (2003).

Foram identificados ainda os diferentes aspectos ambientais para cada tema, seguido da seleção de um conjunto de diretrizes para a implementação de canteiros de obra de baixo impacto ambiental, conforme será apresentado ao longo deste capítulo. Considerando o número elevado de possíveis diretrizes a ser observado no canteiro, esta pesquisa não buscou aprofundar nas questões de segurança e instalações provisórias, pois estes dois temas serão discutidos em estudos específicos, que fazem parte do Projeto Cantechis.

O questionário foi estruturado em duas seções: a primeira visou à identificação do perfil das empresas respondentes (tempo de atuação no mercado, número de funcionários, mercado de atuação, sistemas de gestão utilizados); já a segunda foi destinada às perguntas fechadas relacionadas às diretrizes. Para cada tema, foi desenvolvido um parágrafo situando o entrevistado, que, por sua vez, deveria atribuir um nível de importância a cada uma das diretrizes propostas, usando a seguinte escala: 1) Nenhuma importância; 2) Pouca importância; 3) Sem opinião definida; 4) Importante; 5) Muito Importante. Ainda para cada pergunta, o respondente deveria identificar se mais de $50 \%$ dos canteiros de obras da empresa já adotavam as diretrizes de sustentabilidade em canteiro sugeridas.

A partir de bancos de dados de empresas de Sinduscon locais, bem como o conhecimento de empresas que adotavam princípios de sustentabilidade reconhecidos pelos pesquisadores das instituições participantes, foi definida uma amostra de 151 empresas construtoras nas quatro localidades estudadas, sendo: 61 empresas construtoras em Salvador-BA; 33 empresas construtoras do Interior- SP; 30 empresas construtoras em Porto Alegre-RS e 27 empresas construtoras em São Paulo-SP.

A pesquisa obteve um retorno de 66 respondentes, o que corresponde a um nível de confiança de $90 \%$, com o erro amostral de $10 \%$, sendo 22 empresas de Salvador, 19 empresas de São Paulo, 13 empresas do Rio Grande do Sul e 12 empresas do interior de São Paulo.

Após o levantamento e análise dos dados iniciais do questionário, foram aplicadas entrevistas semiestruturadas em nove (9) canteiros de obras de empresas participantes da pesquisa na cidade de Salvador, visando validar as diretrizes e identificar as práticas sustentáveis por tema, já aplicadas em canteiro de obras, assim como para levantar as carências que dificultam a adoção das diretrizes sustentáveis sugeridas.

As entrevistas foram aplicadas aos gerentes de obras de canteiros residenciais (RES) e/ou de habitação de interesse social (HIS), sendo acompanhadas de registro fotográfico e observação direta. Os canteiros foram selecionados a partir das respostas 
encontradas no levantamento quantitativo, relativo ao nível de adoção das diretrizes pesquisadas. Os canteiros foram classificados em Canteiros de "Alta Adoção", "Baixa Adoção" e "Média Adoção". A opção por identificar dados para estas três categorias liga-se à busca de melhores práticas nos canteiros com alta adoção e à identificação das carências e dificuldades dos canteiros de média e baixa adoção.

Vale ressaltar que as delimitações geográficas restringem a representatividade e possíveis generalizações das informações, e que os resultados encontrados estão limitados a uma realidade regional, podendo, portanto, não representar a realidade da maioria dos empreendimentos habitacionais.

\section{Perfil das Empresas Respondentes}

Em relação ao perfil das 66 empresas participantes, observou-se que mais de 50\% delas têm acima de 21 anos de atuação no mercado; 74\% possuem mais de 20 funcionários; $57 \%$ atuam no mercado de incorporação imobiliária e $15 \%$ atua em HIS.

Observou-se também que 33\% das empresas possuem sistema de gestão NBR ISO 9001; 27\% já usam o Programa Brasileiro de Qualidade e Produtividade no Habitat, o SIAC (PBQP-H), o qual promove a qualidade da construção e, consequentemente, contribui para a sua sustentabilidade. Constatou-se ainda que 15\% das empresas entrevistadas não possuem nenhum sistema de gestão.

Em termos de certificação ambiental, 43\% das empresas respondentes não possui empreendimento certificado ou estão em processo de certificação de qualidade ambiental. Já entre as empresas que apresentam certificação ambiental, o certificado LEED é mais encontrado ( $17 \%$ dos respondentes), seguido do AQUA (6\% dos respondentes), do PROCEL EDIFICA (4\% dos respondentes) e, por último, 3\% dos respondentes afirmaram possuir a certificação Selo Casa Azul. Observa-se que nenhum dos entrevistastes portavam o certificado BREEAM.

\section{Diagnóstico das Necessidades Prioritárias de Pesquisas e Soluções Tecnológicas para Canteiros de Baixo Impacto}

Esta seção apresenta os resultados relativos às necessidades prioritárias de pesquisa e soluções tecnológicas para canteiros de baixo impacto. A Figura 1 apresenta os resultados gerais da aplicação do questionário referente ao nível de importância e à adoção das diretrizes para desenvolvimento de canteiro de baixo impacto. 


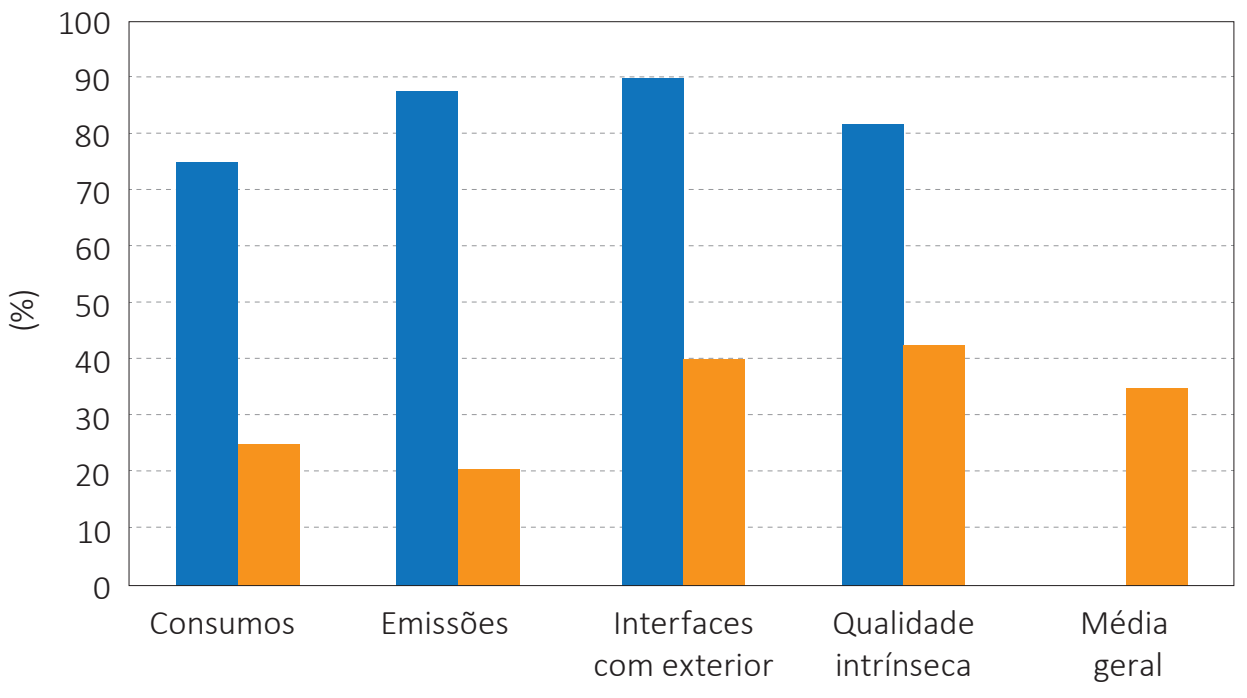

$\%$ de respostas importante e muito importante por tema

\% de adoção das diretrizes por tema

Figura 1 - Percentual de respostas quanto ao nível de importância e de adoção das diretrizes.

A partir desses dados, é possível identificar que existe uma lacuna entre a preocupação das empresas respondentes e a real adoção das diretrizes por parte das empresas. Neste sentido, é importante entender as razões pelas quais existe tal lacuna e quais são as carências e necessidades a serem suprimidas, no intuito de se fazer com que a adoção das diretrizes seja de fato coerente e reflita a importância atribuída pelas construtoras.

Os resultados a seguir buscam detalhar estas lacunas encontradas em cada um dos temas pesquisados, assim como identificar as práticas em uso e as carências para adoção dessas diretrizes.

\subsection{Consumo}

A Figura 2 apresenta os resultados obtidos para o tema consumo, apresentando os diferentes valores obtidos referentes à importância da diretriz para os entrevistados em face da média de adoção da referida diretriz no canteiro. 


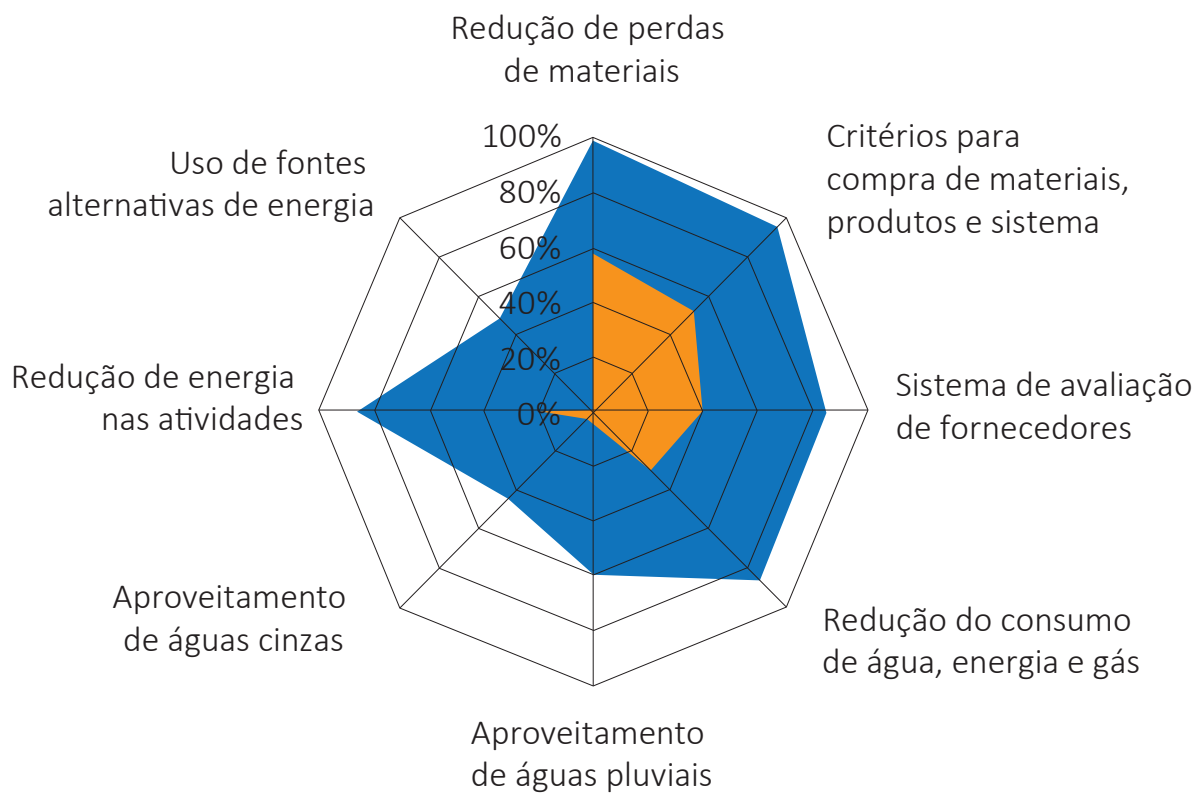

Média de importância da diretriz

Média de adoção da diretriz

Figura 2 - Diretrizes "Muito Importante" e "Importante" e Adoção em mais de 50\% dos canteiros referentes ao tema "Consumo".

Entre as diretrizes relacionadas ao consumo, a Figura 7 apontou as seguintes observações:

a) Redução de perdas de materiais na execução dos serviços, no recebimento, no transporte interno, na estocagem e no manuseio de materiais no canteiro de obras: $100 \%$ dos respondentes acreditam que essa diretriz é importante ou muito importante e $60 \%$ deles já adotam a diretriz em seus canteiros.

b) Desenvolvimento de critérios para compra dos materiais, produtos e sistemas construtivos a partir de fontes confiáveis e que incluam informações sobre análise do ciclo de vida (procedência, processamento, uso e manutenção, durabilidade e descarte) e propriedades como o desempenho técnico: $100 \%$ dos respondentes acreditam que essa diretriz é importante ou muito importante e mais de $50 \%$ deles já adotam a diretriz em seus canteiros. 
c) Desenvolvimento de um sistema de avaliação dos fornecedores de materiais e produtos, incentivando a formalização em relação à Receita Federal, com licença ambiental para operar de forma socialmente responsável e com respeito às normas: mais de $80 \%$ dos respondentes acreditam que essa diretriz é importante ou muito importante, e $40 \%$ deles adotam essa diretriz em seus canteiros.

Foi ainda identificado que as diretrizes consideradas menos importantes têm adoção quase nula pelas empresas respondentes. A seguir estão destacadas as diretrizes "não adotadas", que podem indicar a necessidade de pesquisas e soluções tecnológicas: (a) Redução do consumo de água, energia e gás nas instalações provisórias; (b) Aproveitamento de águas pluviais; (c) Aproveitamento de águas cinzas; (d) Redução de consumo de energia nas atividades; (e) Uso de fontes alternativas de energia.

A partir das visitas e entrevistas realizadas nos nove canteiros de obra, observouse que, embora o questionário apresente um percentual baixo de diretrizes adotadas nesse tema, os canteiros denominados de "Alta Adoção", que abrangem as empresas sob certificação ambiental, já adotam um número razoável de práticas sustentáveis, seja no consumo de materiais ou no consumo de água, incluindo a utilização das águas pluviais e a reutilização de águas cinzas, na contratação de fornecedores, além de práticas de redução do consumo de energia, por exemplo. Essas diretrizes e práticas já aplicadas pelos canteiros de "Alta Adoção" corroboram com práticas sugeridas por autores como Cardoso e Araújo (2007), John e Prado (2010), Yagi et al. (2011) e Tello e Ribeiro (2012).

Identificaram-se também, nos canteiros de "Baixa Adoção" e de "Média Adoção", dificuldades de aplicação de diretrizes e práticas sustentáveis simples, como a seleção de materiais. Nessas obras, a seleção ainda é realizada levando-se em consideração apenas o melhor preço, qualidade e facilidade da entrega, em vez de optarem por selecionar materiais e componentes dando preferência aos que provêm de fábricas preocupadas com questões socioambientais e procedentes de fontes renováveis ou que contenham componentes reciclados ou reutilizados.

É fundamental destacar a importância das empresas construtoras de garantir o conhecimento e rastreabilidade da procedência dos materiais, dando preferência àqueles que apresentam certificações ou que possam garantir tecnicamente a qualidade da produção e do uso, observando as distâncias de transporte, optando por recursos disponíveis nas proximidades do canteiro. Além disso, diversos autores (CARDOSO; ARAUJO, 2007; YAGI et al., 2011; TELLO; RIBEIRO, 2012) ressaltam a importância de analisar e ponderar a energia embutida nos materiais a selecionar, de escolher materiais com maior aproveitamento e maior vida útil e também na escolha 
e uso consciente da madeira, observando a coerência de sua natureza e aplicação e garantia da sustentabilidade dos métodos de exploração e comercialização.

Especificamente relativo a esta diretriz, vale ressaltar que, desde 2007, o Conselho Brasileiro de Construção Sustentável (CBCS) vem contribuindo para a geração e difusão do conhecimento e de boas práticas acerca da seleção de materiais, por meio da ferramenta "Seleção em 6 passos" (CBCS, 2016), visando à sustentabilidade na construção civil e suas inter-relações com a indústria de materiais de construção, com o setor financeiro, o governo, a academia e a sociedade civil. Além disso, o PBQP-H possui um sistema de avaliação de empresas de materiais, componentes e sistemas construtivos (SiMaC), além do Sistema de Avaliação da Conformidade de Serviços e Obras da Construção Civil - SiAC (MINISTÉRIO DAS CIDADES, 2015).

Com relação à contratação dos fornecedores, apenas um dos nove canteiros pesquisados já faz uso de cadastro nacional de fornecedores, com avaliação periódica e exigência de documentação. Os demais ainda adotam a seleção somente pelo preço e qualidade. Essa diretriz aponta para a necessidade de contratação de empresas e fornecedores capacitados, com vínculo legal e formal de seus funcionários, e que ofereçam produtos e serviços legalizados e em conformidade com padrões e normas. Esta prática pode reduzir riscos de perdas financeiras com processos trabalhistas e indenizatórios, contribuindo para a segurança jurídica, idoneidade e imagem da empresa, além do aumento da produtividade nas atividades e promoção da justa concorrência (JOHN; PRADO, 2010; NETREGS ENVIRONMENT AGENCY UK, 2012).

Em relação à gestão e consumo da água, tanto nos canteiros de "Baixa Adoção" quanto nos canteiros de "Média Adoção", destaca-se o controle da conta, porém sem emprego de equipamentos hidráulicos e componentes economizadores, tais como restritores de vazão, bacias sanitárias de volume reduzido, arejadores, torneiras de acesso restrito, entre outros, práticas sustentáveis indicadas por autores como Santander (2011).

Na gestão de água pluvial, as empresas entrevistadas fazem a captação para o escoamento, no lugar de utilizar sistema composto por captação, reservatório, tratamento e desinfecção e distribuição das águas provenientes das chuvas com base no volume máximo de chuva (índices pluviométricos), para serem utilizadas em pontos de consumo que não exijam potabilidade, tais como sistemas de irrigação para controle de material particulado, bacias sanitárias e torneiras de lavagem das rodas (SANTANDER, 2011; YAGI et al., 2011;TELLO; RIBEIRO, 2012).

Os canteiros de "Baixa Adoção" e "Média Adoção" pesquisados ainda não reutilizam água servida, alegando falta de conhecimento da técnica e alto custo para o canteiro. Entretanto, já existem estudos que mostram que é possível a utilização de sistema que permite a reutilização dos efluentes dos equipamentos sanitários (chuveiros, lavatórios) com a construção de pequenas estações de tratamento e 
armazenamento da água servida para posterior utilização em pontos de consumo que não exijam potabilidade, tais como descargas em bacias sanitárias, lavagem de pátios, entre outros (SANTANDER, 2011; YAGI et al., 2011; TELLO; RIBEIRO, 2012).

$\mathrm{Na}$ gestão do consumo de energia, as obras visitadas adotam práticas conservadoras e não utilizam fontes alternativas de energia, alegando alto custo para a etapa do canteiro e falta de soluções tecnológicas para baratear o processo. Por outro lado, é sabido que as fontes alternativas de energia já começam a entrar na matriz energética brasileira, e aquela com maior potencial de uso direto incorporado à arquitetura do edifício é a energia solar fotovoltaica (LAMBERT, 2013). A fonte eólica, por sua vez, poderia ser agregada ao edifício em certas regiões do país onde há a predominância de vento (LAMBERT, 2013).

\subsection{Emissões e Resíduos}

No tema "Emissões e Resíduos", a Figura 8 mostra que todas as diretrizes foram consideradas "muito importante" e "importante" por mais de $80 \%$ das 66 empresas respondentes, porém com baixa adoção nos canteiros de obras (média de 20\%). Apenas duas diretrizes aparecem com $40 \%$ de adoção pelas empresas respondentes, sendo elas: (a) Controle da geração, estocagem e descartes de resíduos; (b) Preservação de vegetação remanescente.

Nota-se na Figura 3 que, apesar da existência da resolução CONAMA no 307 desde 2002 (BRASIL, 2002), com relação à gestão dos resíduos, existe uma baixa adoção das diretrizes nos canteiros entrevistados. Entre os resultados encontrados, observa-se que o aproveitamento ou descarte de resíduo classe $C$ era adotado em 20\% das empresas; soluções de descarte para resíduos classe D aparece adotado em $10 \%$ das empresas; aproveitamento de resíduos de construção era adotado em 20\% das empresas.

Pela resolução CONAMA no 307 (BRASIL, 2002), os resíduos devem ser geridos e classificados em A, B, C ou D e destinados ao local correto, conforme determina o documento, não sendo permitida a disposição em aterros de resíduos domiciliares, áreas de "bota fora", encostas, corpos d'água, lotes vagos e áreas protegidas por lei. Em 2010, também foi sancionada a Lei no 12.305, que instituiu a Política Nacional de Resíduos Sólidos e apresentou as diretrizes relativas à gestão integrada e ao gerenciamento de resíduos sólidos, às responsabilidades dos geradores e do poder público e aos instrumentos econômicos aplicáveis (BRASIL, 2010).

Outro foco de atenção nos resultados da pesquisa é o fato das diretrizes relacionadas a emissões voltadas à poluição do ar, como "Controle das Emissões de Material Particulado" e "Riscos destas Emissões para os Trabalhadores", e emissões voltadas à poluição das águas, como "Controle do lençol freático" e "Tratamento de 
esgoto e efluentes", terem adoção ainda mais baixa que a de resíduos (menos de 20\%), sugerindo uma necessidade de pesquisas e soluções tecnológicas.

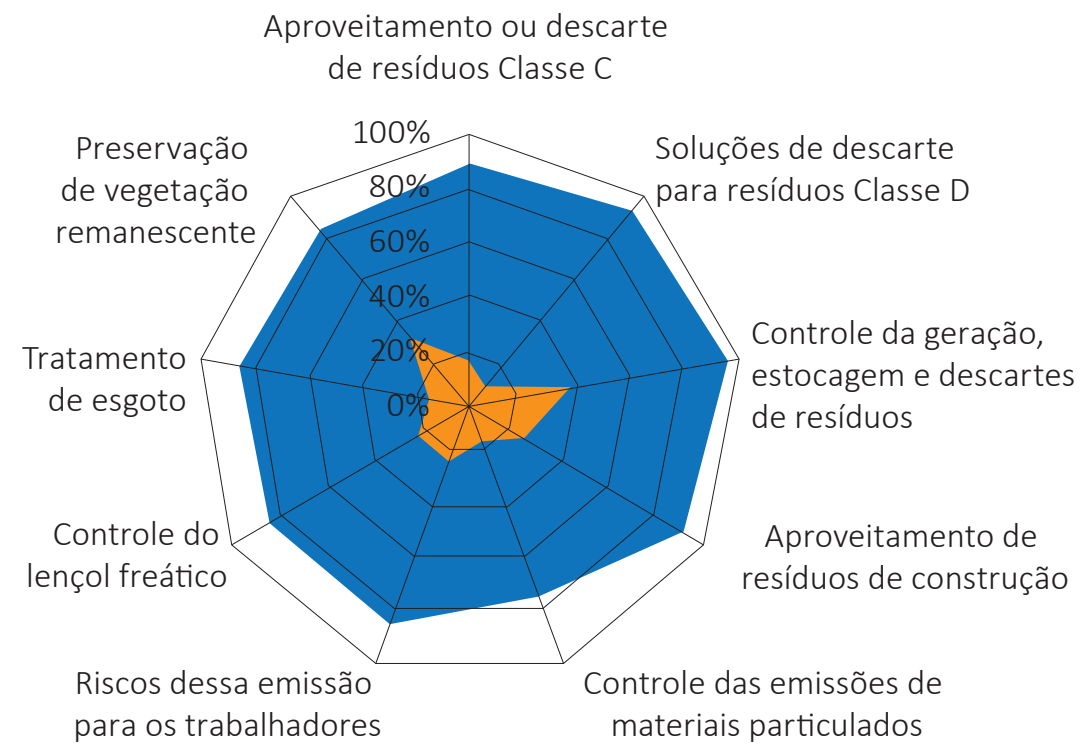

Média de importância da diretriz

Média de adoção da diretriz

Figura 3 - Diretrizes "Muito Importante" e "Importante" e Adoção em mais de 50\% dos canteiros referentes ao tema "Emissões e Resíduos".

A partir das entrevistas, notou-se que o tema emissões é pouco mencionado pelos gerentes de obras dos canteiros das empresas de "Baixa Adoção" e "Média Adoção", mostrando um desconhecimento sobre o tema, as suas diretrizes e práticas. Por outro lado, os canteiros de "Alta Adoção"estão buscando realizar ações mitigadoras quanto às emissões de materiais particulados para trabalhadores e vizinhança com práticas simples, como o uso de caminhão pipa na fase de terraplenagem, a cobertura das caçambas com lona, a aspersão de água das áreas em atividade e o monitoramento da emissão do canteiro.

Além disso, as obras com "Alta Adoção" das diretrizes têm adotado o controle do nível do lençol freático e de sua contaminação, bem como o sistema de captação e tratamento de efluentes com a adoção de práticas como efluentes ligados à rede pública de esgoto local e efluentes da betoneira jogados em tanque para tratamento 
e destino adequado. O uso destas práticas possibilita que os efluentes com resíduos da lavagem do canteiro que contenham material sólido ou contaminantes não sejam lançados à rede pluvial (SANTANDER, 2011; YAGI et al., 2011; TELLO; RIBEIRO, 2012).

Na separação e armazenamento das diversas classes de resíduos e descarte, incluindo a logística reversa, observou-se que os canteiros de "Alta Adoção" já vêm valendo-se de práticas que criam condições de espaço, local e equipamentos específicos para separação e armazenagem das diversas classes de resíduos na etapa de obra, facilitando o descarte e praticando destinação de forma correta e monitorada. Por outro lado, observou-se, nos canteiros de "Baixa Adoção" e "Média Adoção", o não cumprimento da legislação de resíduos e a não adoção de práticas simples já adotadas nos canteiros de "Alta Adoção". Quanto à logística reversa, foi destacada por todos a dificuldade encontrada de fornecedores comprometidos disponíveis.

Na solução do descarte para os resíduos perigosos, classe D, os canteiros de "Alta Adoção" utilizam práticas de armazenamento individualizado no almoxarifado e no descarte com uso de baias específicas, kits de emergência para vazamento de materiais perigosos no canteiro e descarte com rastreamento. Apenas um dos nove canteiros adota tinta à base de água e cuidados especiais com os resíduos perigosos. 0 uso dessas práticas assegura a destinação adequada dos resíduos, contribuindo para a preservação da saúde da comunidade, redução do uso do sistema de coleta da cidade, além de prolongar a vida útil de aterros sanitários e contribuir para a boa imagem da empresa (KARPINSK et al., 2009; YAGI et al., 2011; TELLO; RIBEIRO, 2012).

Quanto à diretriz de aproveitamento e uso de resíduos de construção, pôde-se observar a adoção limitada de práticas referentes ao uso de máquina trituradora para aproveitamento de resíduos inertes no canteiro de obras. Em relação à utilização de agregados reciclados em substituição aos agregados naturais para redução do descarte dos resíduos, nota-se também falta de conhecimento por parte dos gerentes de obra dos canteiros visitados sobre as soluções tecnológicas disponíveis, apesar dos diversos estudos no tema. Apenas um dos nove canteiros investigados estava utilizando moinho para triturar resíduos de bloco, argamassa e concreto para substituir o pó de pedra. Nesse item, é importante esclarecer que já existem no mercado empresas prevendo a reciclagem de resíduos de demolição (com trituradores e peneiras) no próprio local da obra, com o objetivo de reaproveitar materiais, como a brita, e reutilizá-los em locais de pavimentação e outras aplicações que não necessitem de materiais de alta qualidade ou elevada resistência. Essa ação reduz a utilização de materiais mais nobres e os impactos causados pelo transporte e destinação dos resíduos descartados (CARDOSO; ARAUJO, 2007; KARPINSK et al., 2009; YAGI et al., 2011; TELLO; RIBEIRO, 2012).

Por fim, quanto à preservação da vegetação remanescente, observou-se que todos os canteiros visitados adotam práticas para apenas atender as exigências legais 
da Secretaria de Meio Ambiente com avaliação cautelar da vegetação existente visando à preservação e proteção das áreas de preservação ambiental no entorno.

\subsection{Interfaces com Meio Exterior}

Quanto ao tema "Interface com o Meio Exterior" (Figura 4), os dados mostram que $80 \%$ a $100 \%$ dos respondentes acreditam que as diretrizes pesquisadas são "importante" e "muito importante". No entanto, as diretrizes que apresentaram uma adoção de 40\% são: (a) Acesso e fluxo seguro de pedestres; (b) Interferências no transito local; e (c) Processos erosivos e risco de desmoronamento.

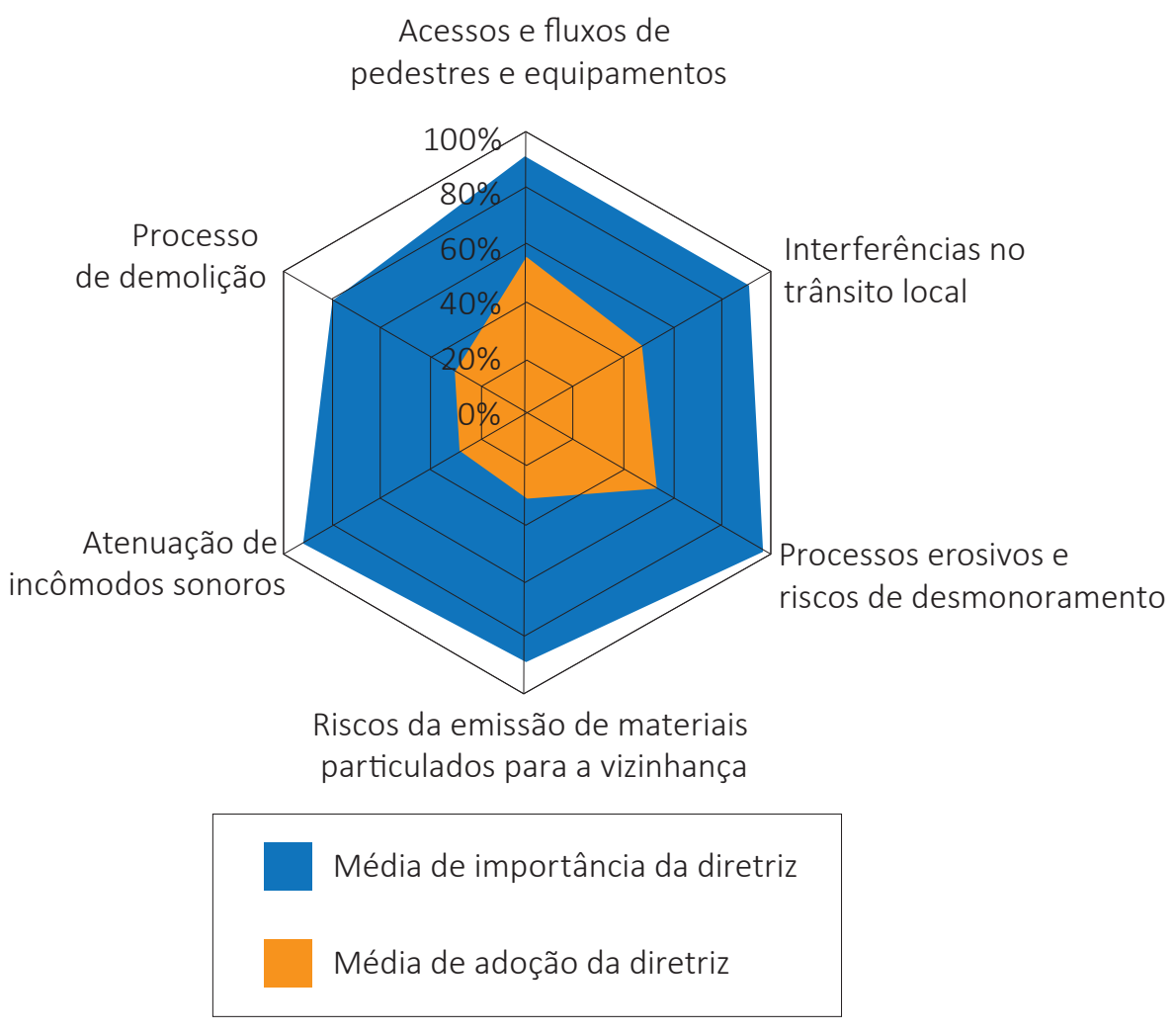

Figura 4 - Diretrizes "Muito Importante" e "Importante" e Adoção em mais de 50\% dos canteiros referentes ao tema "Interfaces com Meio Exterior".

Ao analisar a Figura 9, é possível identificar as diretrizes "não adotadas" com pouco mais de $20 \%$ de adoção, fato que revela a necessidade de pesquisa e soluções tecnológicas referentes ao tema "Interface com o Meio Exterior", quais sejam: (a) riscos 
da emissão de materiais particulados para a vizinhança; (b) atenuação de incômodos sonoros; e (c) processo de demolição.

A partir das entrevistas nos nove canteiros, observou-se que aqueles classificados como de "Alta Adoção" já utilizam um número razoável de práticas sustentáveis simples de "boa vizinhança", mostrando ações para mitigar os impactos do canteiro de obras, buscando ouvir e informar a comunidade do entorno, além de comunicar a política socioambiental da empresa à comunidade e aos possíveis interessados por meio de placas, sites, panfletos, tapumes e outros meios. Essas práticas corroboram com práticas já discutidas na literatura (CARDOSO; ARAUJO, 2007; KARPINSK et al., 2009; YAGI et al., 2011; TELLO; RIBEIRO, 2012).

Embora o questionário aponte a baixa adoção das diretrizes "Atenuação de Incômodos Sonoros", as entrevistas mostram algumas práticas sustentáveis já aplicadas nos canteiros das empresas de "Alta Adoção", tais como proteção auricular dos operários, acordos de horários com a vizinhança, monitoramento de ruídos, suspensão de serra elétrica e de betoneira no canteiro. Entretanto, os respondentes destacaram a "falta de conscientização no momento do projeto de layout do canteiro", que precisa contemplar a minimização das emissões de ruídos e atenuação de incômodos sonoros com a vizinhança. Por outro lado, nota-se um desconhecimento sobre os riscos da emissão do material particulado para a vizinhança, bem como baixo conhecimento sobre ações para mitigar esses impactos, mesmo nas obras com "Alta Adoção" de diretrizes no canteiro.

Por fim, observa-se, nos canteiros de "Baixa Adoção" e de "Média Adoção", a adoção da prática de vistoria cautelar, com o objetivo de informar sobre a realização de vistoria dos imóveis do entorno, avaliando seu estado e garantindo reparos a possíveis danos, conforme apontado pela literatura no tema (CARDOSO; ARAUJO, 2007; KARPINSK et al., 2009; YAGI et al., 2011; TELLO; RIBEIRO, 2012). Entretanto, observou-se dificuldades de adesão a práticas sustentáveis simples, as quais já são aplicadas em outros canteiros, tais como a manutenção de vias e calçadas, limpeza do entorno e comunicação com moradores sobre o empreendimento, abordando suas características finais quando finalizada a obra.

\subsection{Qualidade Intrínseca do Canteiro de Obras}

Acerca do tema "Qualidade Intrínseca do Canteiro de Obras", no que se refere ao item "segurança", 100\% dos respondentes acreditam que as diretrizes pesquisadas são "importante" e "muito importante". De forma alinhada com as respostas sobre a importância, entre 60\% a 80\% dessas mesmas diretrizes já são adotadas nos canteiros das empresas respondentes, conforme mostra a Figura 5. A diretriz certificação dos equipamentos de proteção coletiva foi a que apresentou menos índice de adoção ( $20 \%$ das empresas). 
Proteções contra quedas

de pessoas com diferença de...

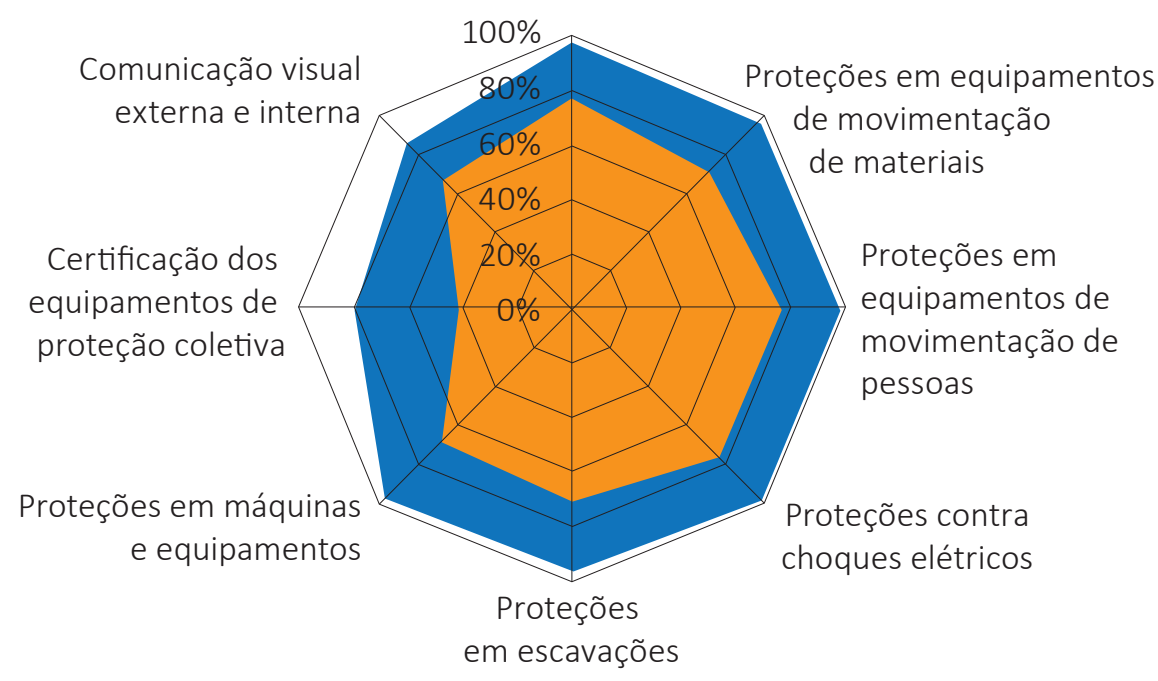

Média de importância da diretriz

Média de adoção da diretriz

Figura 5 - Diretrizes "Muito Importante" e "Importante" e Adoção em mais de 50\% dos canteiros referentes ao tema "Qualidade Intrínseca do Canteiro de Obras- Segurança".

Em relação ao item "Instalações Provisórias", nota-se que 80\% a 100\% dos respondentes acreditam que as diretrizes pesquisadas são "importante" e "muito importante", porém, conforme apresentado na Figura 6, apenas duas diretrizes das doze apresentadas são adotadas, sendo elas: (a) melhoria das condições de segurança do trabalho, com adoção nos canteiros de mais de $50 \%$ das empresas respondentes; (b) melhoria das condições de saúde e higiene, com adoção de mais $60 \%$ das empresas respondentes.

As diretrizes "não adotadas" que podem necessitar de pesquisa e soluções tecnológicas referentes ao tema "Qualidade Intrínseca do Canteiro de Obras Instalações Provisórias"são: (a) melhoria do conforto térmico e acústico; (b) melhoria das condições de iluminação e ventilação; (c) flexibilidade arquitetônica do canteiro; (d) mobiliários e equipamentos fixos internos; (e) reutilização dos componentes e sistemas construtivos em outros canteiros; (f) melhoria da segurança estrutural, considerada importante por $80 \%$, porém adotada em $40 \%$ das empresas respondentes; 
(g) melhoria da segurança contra fogo; (h) melhoria da conectividade das instalações com rede de água, esgoto e energia; (i) melhoria das condições de uso e operação das instalações; (j) melhoria da estanqueidade das instalações.

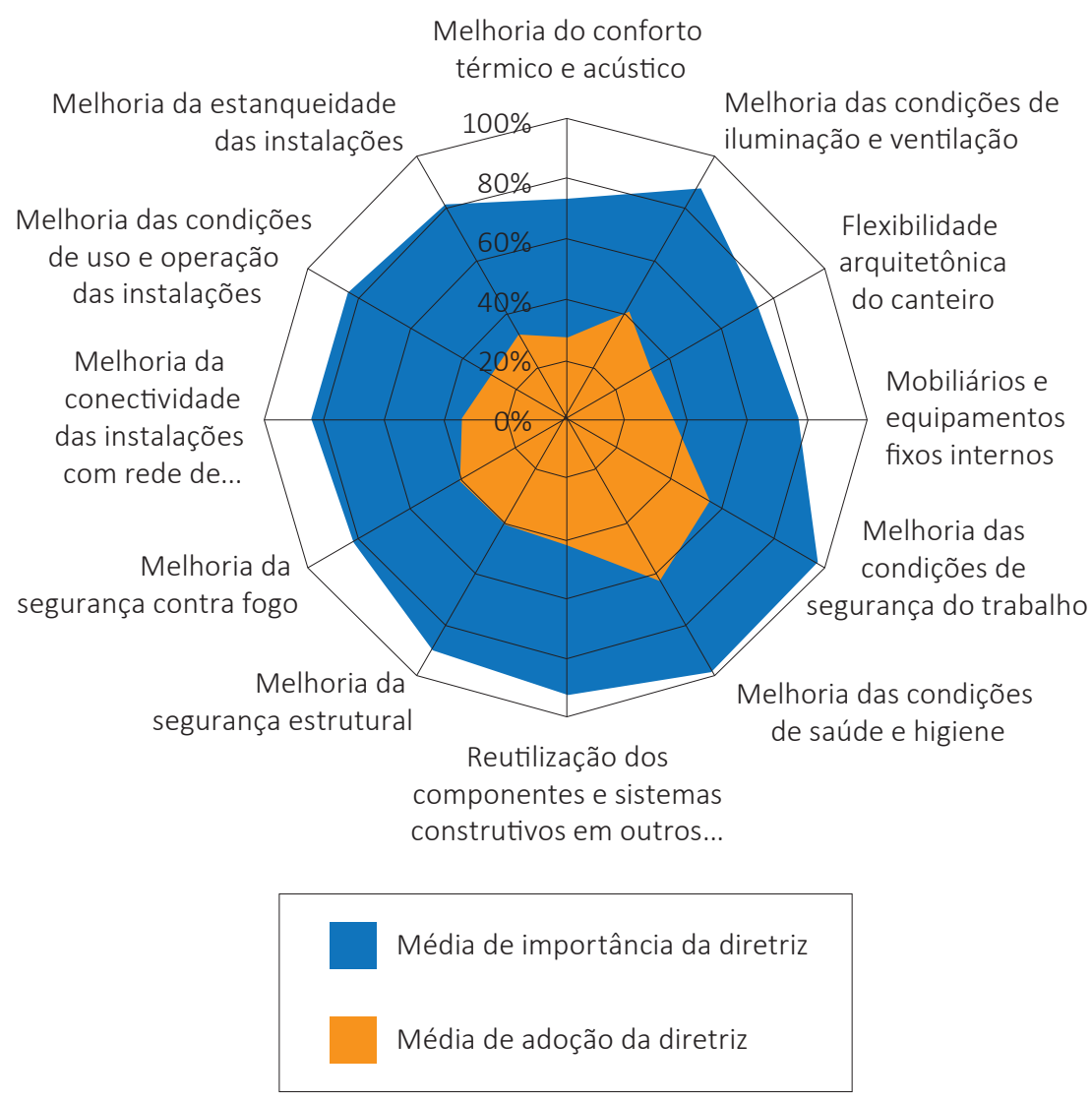

Figura 6 - Diretrizes "Muito Importante" e "Importante" e Adoção em mais de 50\% dos canteiros referentes ao tema "Qualidade Intrínseca do Canteiro de Obras - Instalações Provisórias".

Nesse item, os canteiros de "Maior Adoção" aderem a práticas sustentáveis, buscando garantir desempenho térmico do canteiro por meio da aplicação de componentes adequados e da própria concepção do layout, aliado com ventilação e iluminação natural, visando promover o conforto do usuário, como também a diminuição dos gastos energéticos com o condicionamento artificial, conforme orientações da literatura (SANTANDER, 2011; YAGI et al., 2011; TELLO; RIBEIRO, 2012).

Em relação a "Novas Tecnologias em Instalações Provisórias", a Figura 7 mostra que, das cinco diretrizes, apenas duas aparecem como "muito importante" e 
"importante" por mais de $80 \%$ e com adoção considerada nula (20\%) em canteiros de obras das empresas respondentes. São elas: (a) soluções de instalações provisórias em aço; (b) soluções de instalações provisórias em madeira e derivados.

Por outro lado, as diretrizes a seguir, com adoção entre $20 \%$ a $0 \%$, podem necessitar de pesquisa e soluções tecnológicas: (a) soluções de instalações provisórias em madeiras e derivados; (b) soluções de instalações provisórias com pré-fabricado de concreto; (c) Soluções de instalações provisórias utilizando placas cimentícias; (d) soluções de instalações provisórias utilizando chapas de gesso acartonado. Neste item, as empresas respondentes reforçaram a necessidade de buscar novas tecnologias.

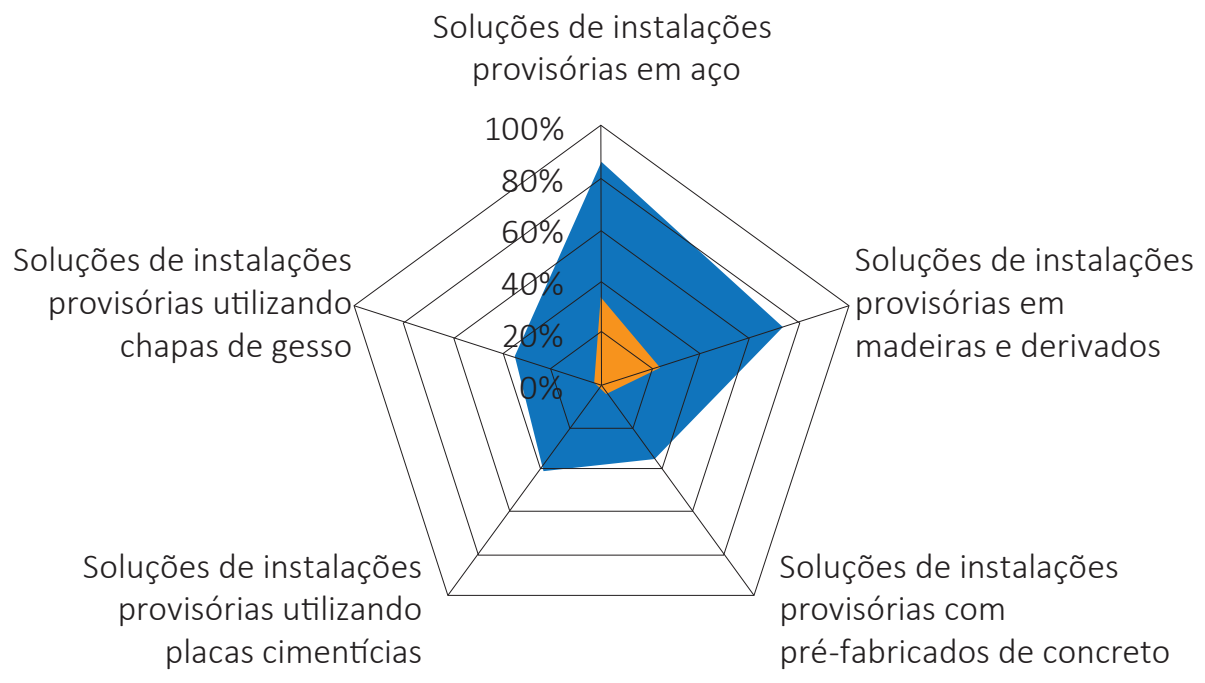

Média de importância da diretriz

Média de adoção da diretriz

Figura 7 - Diretrizes "Muito Importante" e "Importante" e Adoção em mais de 50\% dos canteiros referentes ao tema "Qualidade Intrínseca do Canteiro de Obras - Novas Tecnologias".

\section{Conclusões}

A principal contribuição prática deste trabalho é a identificação da atual situação em termos de importância e da adoção de diretrizes para o desenvolvimento de canteiros de baixo impacto ambiental, com destaque para os temas de "Consumo", 
"Emissões e Resíduos", "Interface com o Meio Exterior" e "Qualidade Intrínseca do Canteiro de Obras", mostrando uma lacuna significativa entre a preocupação das empresas respondentes e a real adoção destas diretrizes.

Os canteiros das empresas "Menor Adoção" e "Média Adoção", onde estão incluídos os canteiros de habitação de interesse Social-HIS, apresentaram dificuldades e falta de conhecimento para a adoção de diretrizes e de práticas simples já utilizadas pelos canteiros com "Maior Adoção", como abordado nos resultados em diferentes temas como "Consumo", "Emissões e Resíduos" e "Interface com o exterior". Observouse, por exemplo, dificuldades em adotar diretrizes legais, apresentando grande volume de resíduos, perdas por armazenamento inadequado, gerando um volume significativo de resíduos a ser descartado, práticas conservadoras no consumo de materiais, de energia, além do pouco uso da água da chuva e o não reaproveitamento de água servida.

$\mathrm{O}$ atendimento das diretrizes de sustentabilidade por meio dos processos de certificação ambiental ou pela implementação de boas práticas de sustentabilidade pode contribuir para a realização de canteiro de obras de baixo impacto ambiental. Assim, torna-se essencial uma maior divulgação das diretrizes de sustentabilidade aplicáveis aos canteiros de obras e já identificadas em diversos estudos. Faz-se ainda necessário exigir o compromisso dos diversos intervenientes de setor e a elaboração de uma Política para Ciência, Tecnologia e Inovação para o desenvolvimento de canteiro de obras de baixo impacto.

\section{Referências}

BRASIL. Ministério do Meio Ambiente. Conselho Nacional do Meio Ambiente - CONAMA. RESOLUÇÃO n. 307, julho 2002. Disponível em http://www.mma.gov.br/port/conama/res/ res02/res30702.html). Acesso em: nov. 2016.

BRASIL. Ministério do Meio Ambiente. Lei de Política Nacional de Resíduos Sólidos, LEI n. 12.305, de 2 de agosto de 2010. Disponível em: http://www.planalto.gov.br/ccivil_03/_ ato2007-2010/2010/lei//12305.htm. Acesso em: nov. 2016.

BRASIL. Ministério das Cidades. Programa Brasileiro de Qualidade e Produtividade no Habitat - PBQPH. http://pbqp-h.cidades.gov.br. Acesso em: nov. 2016.

BRASIL. Ministério do Trabalho e Emprego. Norma Regulamentadora 18 (NR-18): Condições e Meio Ambiente de Trabalho na Indústria da Construção. Rio de Janeiro: 2015. Disponível em: <http://trabalho.gov.br/seguranca-e-saude-no-trabalho/normatizacao/ normas-regulamentadoras/norma-regulamentadora-n-18-condicoes-e-meio-ambientede-trabalho-na-industria-da-construcao>. Acesso em: nov. 2015.

BREEAM. Europe Commercial Assessor. Manual. BRE Global Ltd, 2009. 346p. 2009. 
CARDOSO, F.F., ARAUJO, V.M. Levantamento do estado da arte: Canteiro de obras. Projeto Tecnologias para construção habitacional mais sustentável- Finep 2386/04. São Paulo, 2007

CHEMLA, P.; LABOUZE, E. Ranking environmental impacts: applications to buildings. In: 2nd International Conference of the Building and Environment - CIB, Paris, 1997.

DEGANI, C.M. Sistemas de gestão ambiental em empresas construtoras de edifícios. Dissertação (Mestrado em Engenharia Civil) - Escola Politécnica, USP. São Paulo, 2003. $223 p p$.

FCAV. Fundação Vanzolini. Referencial Técnico de Certificação "Edifícios Habitacionais Processo AQUA". USP, São Paulo, 2010.

GUIMARÃES, M.S.O. Diretrizes para desenvolvimento de canteiro de obras habitacional de baixo impacto ambiental. Dissertação (Mestrado em Engenharia Ambiental Urbana) Escola Politécnica, UFBA, Salvador - BA, 2013.

JOHN, V.M.; PRADO, R.T.A. Selo Casa Azul - Boas práticas para habitação mais sustentável São Paulo: Páginas \& Letras- Editora e Gráfica, 2010.

KARPINSK, L.A. et al. Gestão diferenciada de resíduos da construção civil: uma abordagem ambiental [recurso eletrônico]. Porto Alegre: Edipucrs, 2009. 163 p.

KILBERT, C.J. Sustainable construction: Green building design and delivery. John Wiley and Sons Inc, 2005.

LAMBERT, R. Eficiência Energética. Boletim Informativo CBCS, Abril 2013. Disponível em: http://www.cbcs.org.br/userfiles/download/cbcsnoticias_7ed.pdf. Acesso em: maio 2013.

NETREGS ENVIRONMENT AGENCY UK. Good practice guide and how to abide to environmental laws. 2012. Acesso em: nov 2012.

PULASKI, M. H. (ed.) Field Guide For Sustainable Construction. Washington: Pentagon Renovation and Construction Program Office, June, 312p. 2004.

SANTANDER. Guia de Boas Práticas na Construção Civil. Programa de Sustentabilidade na Construção Civil. 2011. Disponível em: <http://sustentabilidade.santander.com.br/ oquefazemos/produtoseservicos/Paginas/RealObraSustentavel.aspx>. Acesso em: nov. 2012.

TELLO, R; RIBEIRO, F.B. Guia CBIC de boas práticas em sustentabilidade na indústria da Construção - Brasília: Câmara Brasileira da Indústria da Construção; Serviço Social da Indústria; Nova Lima: Fundação Dom Cabral, 2012. 160p. Disponível em: http://www.cbic. org.br/arquivos/Guia_de_Boas_Praticas_em_Sustentabilidade_CBIC_FDC.pdf. Acesso: abr. 2013.

USGBC. U. S. Green Building Council. LEED Green Building Rating System 2.0. San Francisco, March 2000. 25 pp.

YAGI, C. et al. Caderno Condutas de Sustentabilidade no Setor Imobiliário Residencial. CBCS. 2011. Disponível em: http://www.cbcs.org.br/userfiles/download/CadernoCondutas DeSustentabilidade.pdf. Acesso em: jul. 2012. 


\title{
Boas Práticas de Sustentabilidade em Canteiros de Obras
}

\author{
Ludimilla de Oliveira Zeule \\ Sheyla Mara Baptista Serra
}

\section{Introdução}

Ações e práticas sustentáveis podem ser entendidas em diferentes contextos. No âmbito da ação, Cavalcanti et al. (2012) propõem que a sustentabilidade pode ser uma estratégia fundamental para a preservação do ambiente, da cultura e da dignidade social das gerações. Já as práticas sustentáveis são um conjunto de ações inter-relacionadas, segundo Brasil (2016b), que resultam a médio e longo prazo numa nova perspectiva de vida para nossos sucessores ao garantir a manutenção dos recursos naturais necessários para uma melhor qualidade de vida.

Segundo Viggiano (2010), as ações sustentáveis podem ser classificadas de acordo com as diretrizes de sustentabilidade ambiental, social e econômica. De forma geral, indicam-se:

- Ações econômicas: necessitam da aplicação de capital e incentivo financeiro;

- Ações tecnológicas: subentendem o uso de equipamentos e tecnologias que proporcionem mais eficiência na busca da sustentabilidade;

- Ações sociais: tomadas junto aos trabalhadores e sociedade em geral, como treinamentos e campanhas de conscientização.

No caso do canteiro de obras, as ações sustentáveis podem ser transformadas em boas práticas que organizem e facilitem as tarefas diárias, não agridam o meio em 
que estão inseridos, utilizem alternativas oferecidas gratuitamente (água de chuva, insolação, ventos, iluminação) em benefício das atividades a serem realizadas, e ainda padronizem essas práticas para as obras seguintes (ZEULE, 2014).

A construção civil é um setor de grande potencial para a implantação de tecnologias sustentáveis, e as características dos empreendimentos têm contribuído para se disseminar o uso de programas de certificações sustentáveis. Segundo o órgão certificador Green Building Council Brasil (GBC BRASIL, 2015), existem atualmente, no Brasil, 279 edifícios certificados com o selo LEED (sigla, em inglês, para Leadership in Energy and Environmental Design), concedido pela entidade às construções que atendam a padrões de sustentabilidade. Para esse Conselho, o desenvolvimento da indústria da construção sustentável envolve a adoção de boas práticas e um processo integrado de concepção, construção e operação de edificações e de espaços construídos (GBC BRASIL, 2015).

Existem atualmente vários programas de selagem de certificação ambiental que se destacam por levar em conta práticas sustentáveis em todas as fases do empreendimento, considerando as fases de projeto, de execução e de ocupação. A implantação dos selos de certificação sustentável traz benefícios não apenas ambientais, mas econômicos e sociais. As construções que levam em conta os "critérios verdes" ganham com a diminuição de custos operacionais, melhora na saúde dos ocupantes, uso racional dos recursos naturais, entre outras vantagens (HALLIDAY, 2010).

Cada um dos selos ambientais possui características que orientam a seu favor a escolha feita pelas empresas na construção civil. Não há necessidade, contudo, do selo para que o canteiro de obras implemente práticas de sustentabilidade. Há, porém, a necessidade de que os métodos e práticas sejam mais divulgados para a sua efetiva implantação durante a fase de construção do empreendimento.

Segundo Costa e Moraes (2013), no Brasil as grandes construtoras perceberam que a aplicação de métodos de gestão sustentável durante todo o ciclo do empreendimento, inclusive durante a fase de construção, é a única maneira de garantir a melhoria do desempenho ambiental das edificações.

A proposta deste capítulo é exibir práticas e diretrizes de sustentabilidade em canteiros de obras nas quais as empresas da construção civil possam se basear e passem a adotá-las em seus canteiros, tornando-se assim empreendimentos sustentáveis nesta importante fase do processo de produção do empreendimento.

\section{Método de Pesquisa}

Este trabalho se baseia na dissertação de mestrado de Zeule (2014). A pesquisa utilizou o método de estudo de caso proposto por Yin (2009). A estratégia inicial de pesquisa consistiu em elaborar um quadro comparativo das diretrizes e regras de 
pontuações dos selos de certificações ambientais a fim de obter um formulário de avaliação da implementação da sustentabilidade em canteiro de obras. O quadro comparativo foi baseado em quatro programas de certificações - Building Research Establishment Environmental Assessement Method - BREEAM (BRE, 2009), Leadership in Energy and Environmental Design (LEED) for New Construction \& Major Renovation (LEED NC, 2009), Processo AQUA ${ }^{\circledR}$, baseado no selo francês HQE (Haute Qualité Environnementale) (FCAV, 2010), Selo Casa Azul da Caixa Econômica Federal (GUIA CAIXA, 2010). Além disso, as pesquisas de Cardoso e Araújo (2007) e de Brandão (2011) serviram como referência de práticas sustentáveis em canteiro de obras.

Foram visitados seis canteiros de obras brasileiros, localizados nos estados de São Paulo e do Ceará, sendo três obras certificadas ambientalmente e quatro obras definidas como Empreendimentos de Habitação Social (EHIS), com a intenção de analisar a viabilidade e aplicabilidade do método proposto por Zeule (2014).

Os critérios de avaliação da sustentabilidade foram divididos em seis níveis, de acordo com a organização do LEED, e as perguntas da lista de verificação foram baseadas nas recomendações dos programas de certificações para pontuação das práticas no canteiro. As práticas de sustentabilidade foram classificadas em: Canteiro Sustentável, Uso Racional da Água, Uso Racional de Energia, Materiais e Recursos, Qualidade do Ambiente, Inovações e Processos, e estão detalhadas a seguir. Ao final da aplicação da lista de verificação em cada canteiro de obras, foi possível obter um nível comparativo de nota de implantação da sustentabilidade (ZEULE, 2014).

\section{Práticas de Sustentabilidade no Canteiro de Obras}

A adoção de várias práticas ajuda a caracterizar um canteiro sustentável, e o conhecimento das possibilidades ajuda a tornar a sustentabilidade do empreendimento um fato.

\subsection{Canteiro Sustentável}

Deve-se pensar em premissas básicas de sustentabilidade que sejam possíveis de serem atendidas por qualquer obra, cobrindo várias etapas do empreendimento, desde a compra do terreno, escolha de materiais, preservação de vegetações existentes, entre outras.

Os itens a serem avaliados em um canteiro sustentável são: 1) Adequação de transporte; 2) Redução de ilhas de calor e priorização do conforto térmico; 3) Evitar emissão de particulados; 4) Preservação da vegetação nativa; 5) Seleção responsável do terreno. 
Neste sentido, as práticas de sustentabilidade recomendadas são listadas a seguir.

1) Adequação de transporte: voltado ao transporte de trabalhadores, entrega de materiais e componentes e logística interna no canteiro:

- Estabelecer fretamento de ônibus particular para buscar e levar os trabalhadores;

- Disponibilizar vale transporte, quando a medida anterior não for possível;

- Aumentar a demanda por materiais de construção e produtos que são extraídos e produzidos na região;

- Minimizar os transportes dentro do canteiro para reduzir a poluição e impactos causados pelo uso do automóvel;

- Criar estacionamento adequado para veículos leves;

- Separar vias de pedestres e veículos leves e pesados (Figura 1).

- Criar local com guarita e pavimentação para entrega de materiais;

- Criar local para bicicletário (Figura 2a);

2) Redução de ilhas de calor e priorização do conforto térmico: melhoria das condições de permanência dos trabalhadores dentro do canteiro, preservação ou construção de espaços verdes:

- Deixar uma área descoberta (se possível), sombreada e ventilada para uso comum dos trabalhadores do canteiro junto às demais áreas de vivência;

- Instalar janelas e aberturas nos refeitórios e demais instalações provisórias do canteiro que garantam ventilação e iluminação adequada;

- Construir as instalações provisórias preferencialmente com materiais reciclados, porém livres de Compostos Orgânicos Voláteis (COV) e que forneçam devido conforto térmico;

- Utilizar materiais isolantes térmicos em fachadas e coberturas das instalações, se necessário;

- Utilizar materiais de alta refletância solar, priorizando cores claras;

- Fazer uso de telhado verde e calçadas verdes para redução de ilhas de calor (Figura 2b).

3) Evitar emissão de particulados: estratégias para redução da emissão de poeiras no canteiro e vizinhanças:

- Empregar lava-rodas utilizando água de chuva (Figura 3);

- Empregar lava-bicas utilizando água de chuva (Figura 3); 
- Fazer a recuperação de águas do lava-rodas, bicas, ralos para posterior uso, como para irrigação do canteiro e diminuição da poeira;

- Implantar sistema simplificado de captação de água de chuva para lavagem de equipamentos e irrigação do canteiro;

- Fazer a limpeza umidificada diária nos ambientes de trabalho, de preferência com águas reaproveitadas.

4) Preservação da vegetação nativa: principalmente quando for prevista a manutenção da vegetação durante a fase de ocupação do empreendimento:

- Preservar as árvores e vegetações nativas que existiam anteriormente no terreno (Figura 4).

5) Seleção responsável do terreno: observação dos parâmetros urbanísticos e ambientais relacionados com o terreno:

- Manter o terreno de acordo com a proposta de gestão ambiental da obra;

- Verificar se o terreno não está inserido em zona de proteção ambiental. Se estiver, deve-se verificar se atende às leis correspondentes;

- Atender ao plano diretor municipal;

- Verificar se o solo foi ou está contaminado e realizar, se necessário, processo de recuperação antes da construção;

- Realizar sondagem do terreno;

- Realizar, registrar e acompanhar durante toda a construção o relatório de impacto do empreendimento sob a vizinhança.

As Figuras 1, 2, 3 e 4 a seguir exibem imagens de canteiros com algumas das práticas citadas anteriormente.

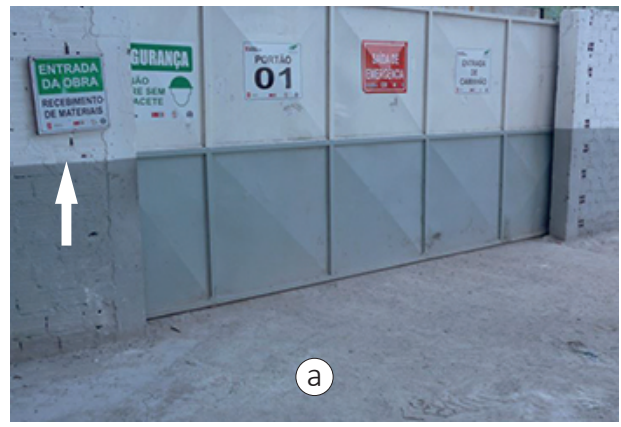

Entrada somente para

"Recebimento de materiais" como diz na placa

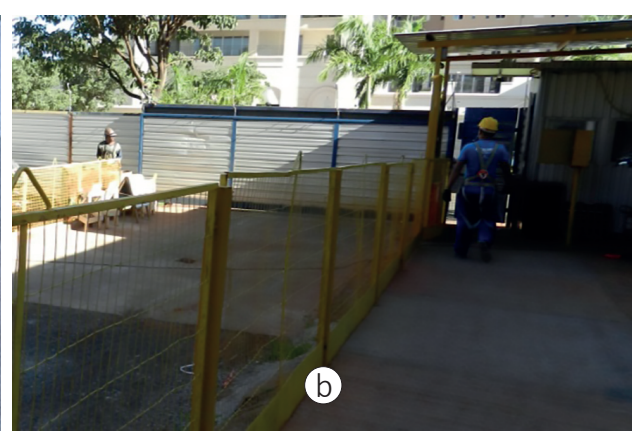

Entrada de veículos (leves e pesados) à esquerda e de pessoas à direita separação das vias por guarda-corpos

Figura 1 - Separação de vias para entrada no canteiro. Fonte: Autoras (2016). 


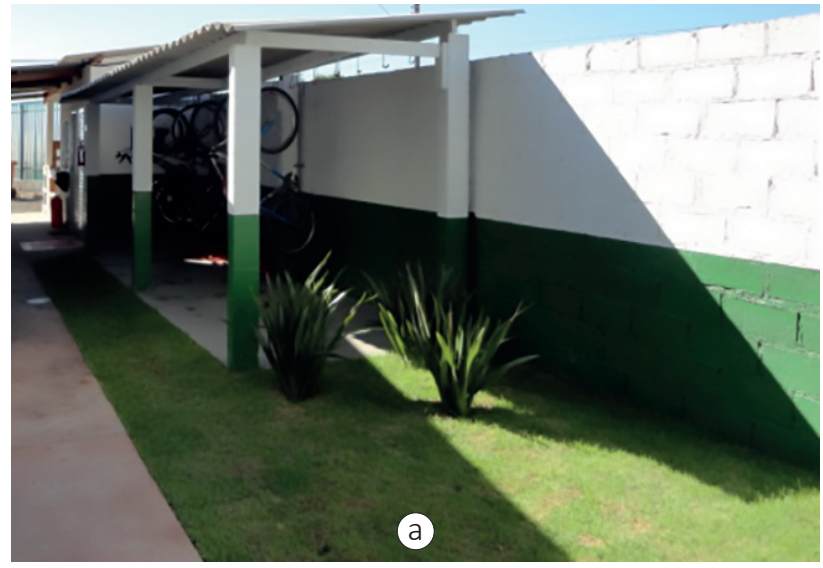

Implementação de bicicletário

e área verde ao redor

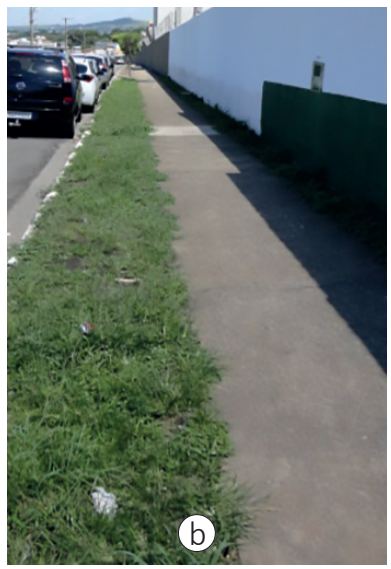

Calçada verde no entorno de toda a obra

Figura 2 - Implementação de bicicletário e áreas verdes. Fonte: Zeule (2014).

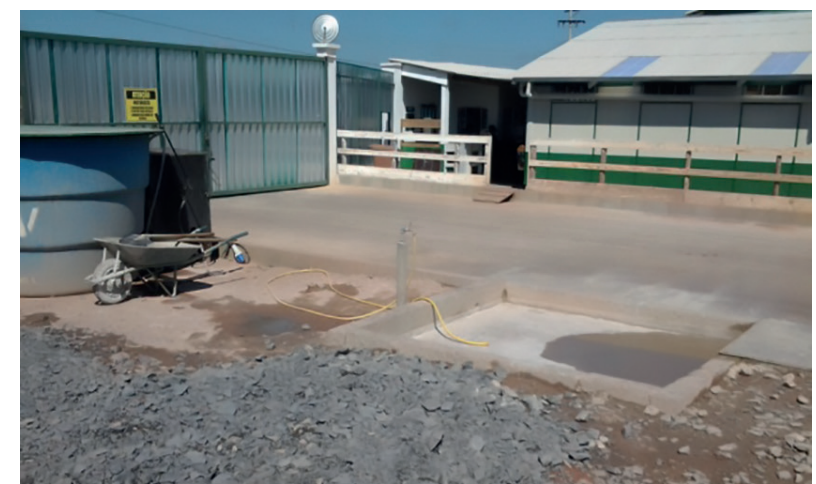

Figura 3 - Local para lavagem de rodas e bicas dos caminhões. Fonte: Zeule (2014).

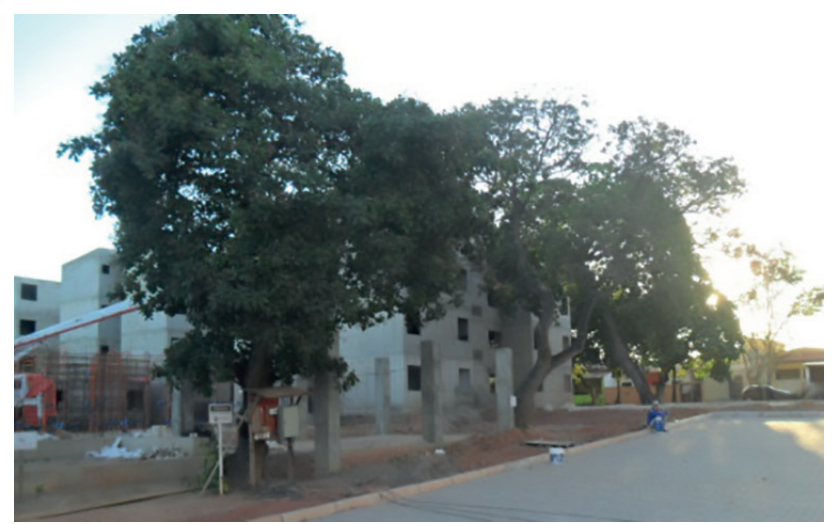

Figura 4 - Preservação da vegetação nativa existente no canteiro. Fonte: Zeule (2014). 


\subsection{Uso Racional da Água}

As possibilidades de uso racional da água dentro do canteiro de obra muitas vezes são desprezadas, gerando enormes desperdícios. Sabe-se que a água é um recurso finito e é muito utilizada em várias atividades diárias do canteiro, sendo necessária a inserção de práticas de sustentabilidade para que seu uso seja mais eficiente e econômico.

Observa-se que existem algumas pesquisas e orientações para o uso de estratégias de minimização e controle do consumo da água dentro dos canteiros de obras. Entretanto, ainda não há implantação massiva nos canteiros de obra, devido talvez ao desconhecimento e à falta de incentivo das normalizações.

De acordo com a Norma Regulamentadora 18: Condições e Meio Ambiente de Trabalho na Indústria da Construção (NR-18), que descreve as "Condições e Meio Ambiente de Trabalho na Indústria da Construção" (BRASIL, 2015), a utilização de água nos canteiros de obras está relacionada às demandas essenciais dos funcionários e devem estar presentes nos itens básicos: a) refeitórios; b) instalações hidrossanitárias; c) bebedouros. De modo geral, a água também deve estar presente nas frentes de trabalho para atender as demandas das atividades e serviços.

Entre as principais práticas encontradas na literatura estão: 1) Captação de água pluvial e cinza e consequente tratamento para reutilização em canteiro; 2) Tecnologias utilizadas para águas servidas em canteiros; 3) Redução do consumo de água.

A seguir, são listadas as práticas aplicáveis aos canteiros para uso racional da água.

1) Captação de água pluvial e cinza e consequente tratamento para reutilização em canteiro

- Realizar captação de águas cinzas (pias e chuveiros) e de chuva (pluviais) (Figura 5a);

- Fazer o correto tratamento das águas a serem reutilizadas;

- Observar se as águas captadas (pluviais e/ou cinzas) foram corretamente tratadas para posterior reuso;

- Manter as tubulações e os dispositivos de coleta de água de chuva totalmente separados das instalações de água potável;

2) Tecnologias utilizadas para águas servidas em canteiros: para fins de separação e reuso, as águas servidas compõem-se das águas negras (vasos sanitários e pias de cozinha) e águas cinzas (chuveiros, lavatórios de banheiro, tanques):

- Prever sistema para escoamento das águas negras da obra;

- Estabelecer manutenção periódica das instalações de águas servidas; 
3) Redução do consumo de água: prever a instalação de dispositivos e estratégias de conscientização:

- Instruir os trabalhadores nas formas de gerar economia de água por meio de cursos de conscientização ou orientações por escrito (Figura 6);

- Utilizar equipamentos redutores de consumo de água nas instalações provisórias, como torneiras com fechamento automático, caixa de descarga com capacidade menor que 6 litros, redutor de pressão, arejador etc.;

A seguir, as Figuras 5 e 6 exibem imagens de canteiros com algumas das práticas citadas anteriormente.

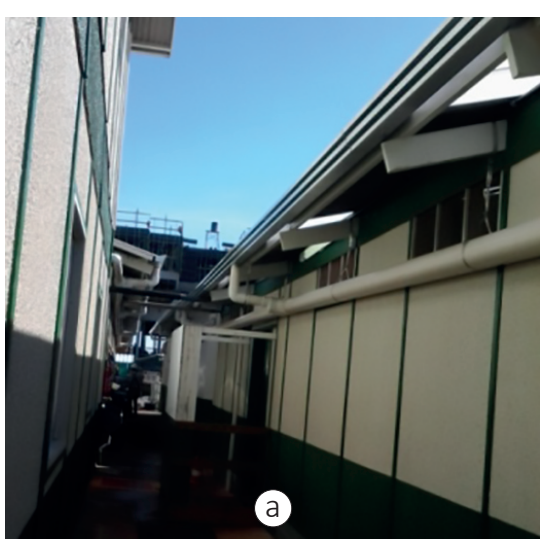

Sistema de Captação de água pluvial (chuva) pelo telhado nas instalações provisórias

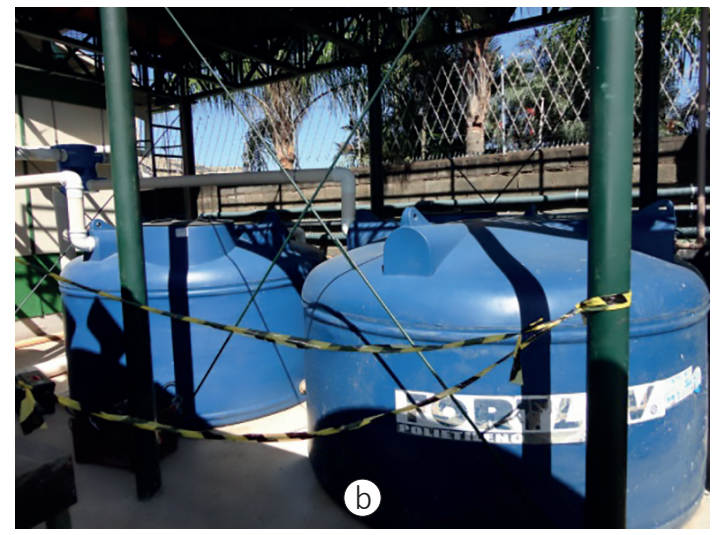

Sistema para tratamento da água de pluvial para reuso no próprio canteiro

Figura 5 - Captação e tratamento de água pluvial e economia de água. Fonte: Zeule (2014).

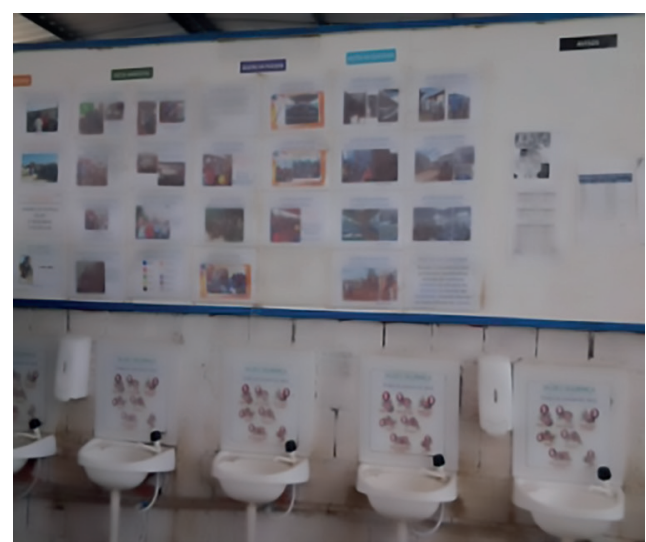

Figura 6 - Instruções aos trabalhadores para economizar água e cuidados com a saúde e segurança no trabalho. Fonte: Zeule (2014). 


\subsection{Uso Racional da Energia}

Esse item incentiva o uso de energias renováveis no canteiro, oferecendo conforto aos operários, reduzindo a emissão de ruídos e melhorando o uso dos vestiários, a fim de propiciar o bem-estar dos trabalhadores e a economia de energia elétrica.

Dessa forma, as práticas elencadas com relação ao uso racional da energia no canteiro de obras são: 1) Geração local de energia renovável; 2) Tecnologias para redução do consumo de energia. As diretrizes para essas práticas são listadas a seguir.

1) Geração local de energia renovável: dependendo da localização geográfica e disponibilidade, verificar a existência de outros tipos de energia:

- Fazer uso de energias renováveis disponíveis: eólica, solar, geotérmica, fotovoltaica;

2) Tecnologias para redução do consumo de energia:

- Priorizar o uso de iluminação e ventilação natural nas instalações provisórias do canteiro (Figura 7);

- Fazer a medição do consumo de energia, visando ao controle e à redução deste consumo;

- Evitar o uso de geradores de energia;

- Utilizar lâmpadas etiquetadas com selo PROCEL/INMETRO;

- Utilizar equipamentos economizadores e com selo PROCEL de eficiência energética;

- Instalar sensores de presença em ambientes de passagem rápida, nos quais normalmente se esquece a luz acesa.

A Figura 7, a seguir, exibe imagens de canteiros com algumas das práticas citadas anteriormente.

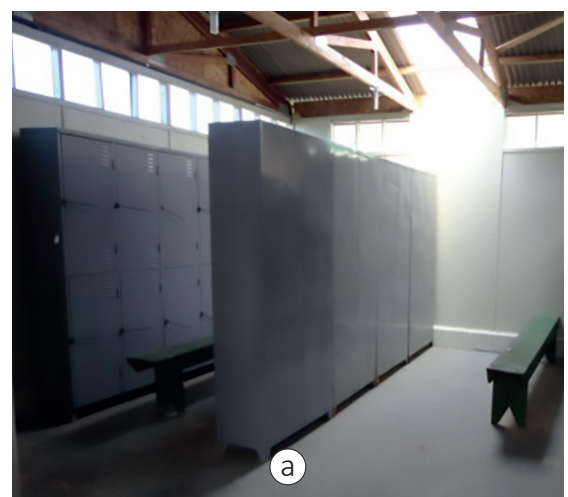

Iluminação e ventilação natural no vestiário

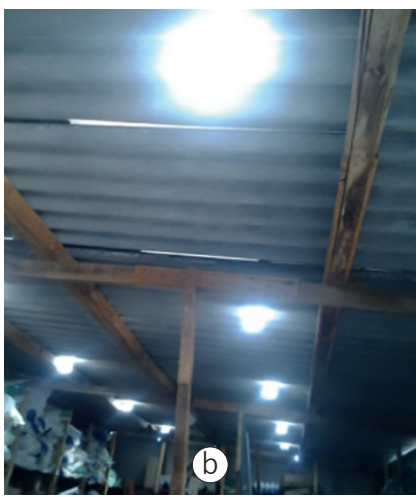

Alternativa para economia de energia, com garrafas PET com água no lugar de lâmpadas

Figura 7 - Iluminação natural nas instalações provisórias. Fonte: Zeule (2014). 


\subsection{Materiais e Recursos}

A gestão e logística de materiais e recursos dentro do canteiro de obras são de suma importância, uma vez que lidam com a disposição adequada dos materiais que serão utilizados durante toda a fase de execução. Não menos importante é a deposição adequada dos resíduos e seus reusos no próprio canteiro. No canteiro, são gerados vários tipos de resíduos além do resíduo da construção, normalmente conhecido como entulho.

Sob estes aspectos, definiu-se que os fatores importantes de serem avaliados no canteiro referentes ao assunto são: 1) Realização de depósito e coleta para materiais recicláveis; 2) Gestão dos resíduos da construção; 3) Reuso de materiais; 4) Uso de madeira certificada.

A seguir, são apresentadas as diretrizes com as práticas relacionadas.

1) Realização de depósito e coleta para materiais recicláveis:

- Estabelecer baias de separação por tipo de resíduo (Figura 8a);

- Separar os resíduos contaminantes (classe D) dos demais (Figura 8b);

- Separar lixo orgânico do inorgânico;

- Praticar a coleta seletiva em todos os empreendimentos da empresa;

- Proteger os estoques de materiais contra intempéries;

- Armazenar os materiais conforme orientações das normas técnicas e dos fabricantes.

2) Gestão dos resíduos da construção:

- Priorizar o uso de materiais passíveis de reciclagem;

- Controlar a entrada de materiais no canteiro;

- Realizar inspeção de produtos conformes e não conformes no ato da entrega;

- Especificar produtos tóxicos e acondicioná-los isolados do solo;

- Fazer controle de utilização de produtos/materiais por prazo de validade;

- Manter o local de armazenamento de resíduos bem iluminado e ventilado, com pontos de água, tubulação de esgoto e ralo sifonado;

- Criar um programa de bonificação aos trabalhadores que reduzirem a geração e quantidade de resíduos.

3) Reuso de materiais:

- Utilizar materiais sustentáveis e reciclados que sejam livres de Compostos Orgânicos Voláteis (COV) sempre que possível (Figura 9a);

- Reaproveitar materiais que seriam descartados para outros fins (Figura 9b); 
- Reutilizar materiais, por exemplo, argamassa e cimento endurecido, que podem ser triturados e virar cascalho para vias.

\section{4) Uso de madeira certificada:}

- Ter controle de todas as madeiras utilizadas, verificando os certificados de conformidade;

- Utilizar madeiras recicladas livres de Compostos Orgânicos Voláteis e outros produtos químicos.

As Figuras 8 e 9 a seguir exibem imagens de canteiros com algumas das práticas citadas anteriormente.

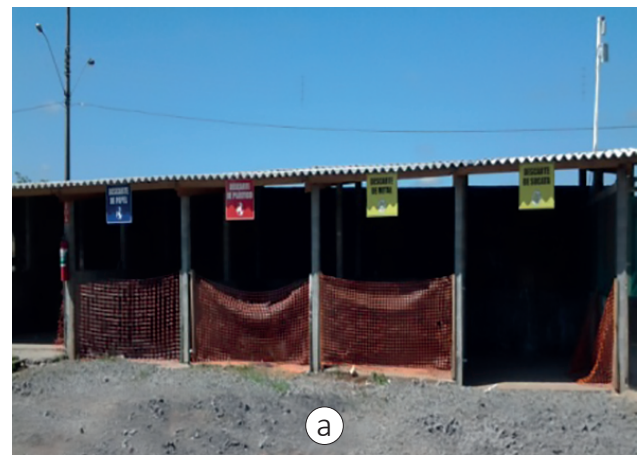

Baias cobertas para separação dos vários tipos de resíduos

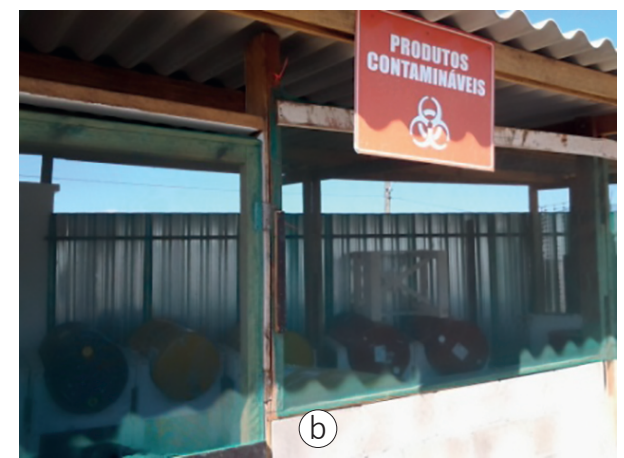

Acondicionamento de produto contaminante, afastado do solo

Figura 8 - Acondicionamento de resíduos no canteiro de obras. Fonte: Zeule (2014).

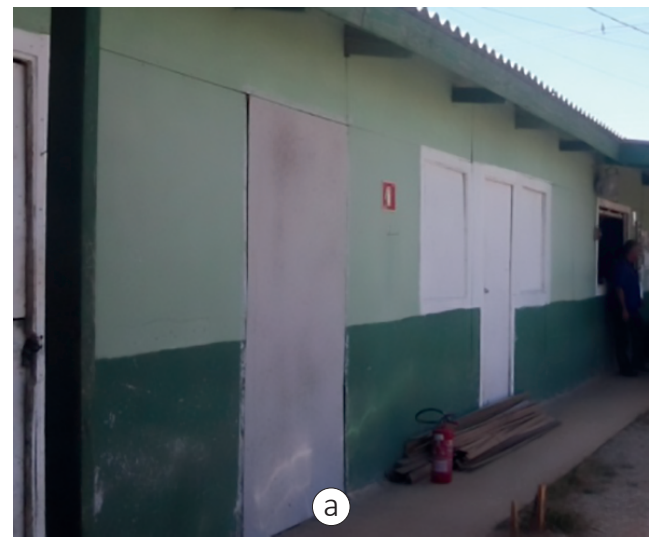

Instalação provisória feita com chapas de madeira reciclada

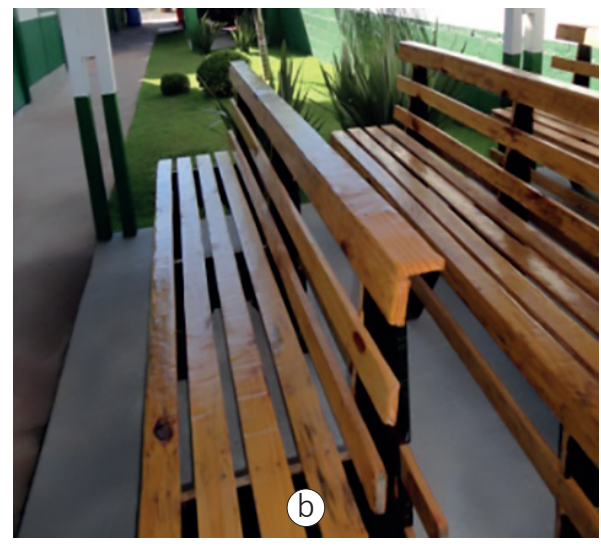

Reuso de madeira de formas

Figura 9 - Uso de materiais reciclados e reuso de materiais que seriam descartados. Fonte: Zeule (2014). 


\subsection{Qualidade do Ambiente}

A qualidade do ambiente está relacionada diretamente às necessidades e conforto dos trabalhadores e usuários do canteiro de obras, sendo considerados na análise desse item todos os ambientes destinados às atividades dos operários e a existência dos confortos olfativo, térmico, acústico e visual presentes nos canteiros de obras.

Definiu-se que os fatores importantes a serem avaliados no canteiro referentes ao assunto são: 1) Conforto aos usuários do canteiro e entorno; 2) Redução nas emissões de Cloro-Flúor-Carbono (CFC's) e Dióxido de Carbono $\left(\mathrm{CO}_{2}\right)$.

As principais boas práticas identificadas são listadas a seguir.

1) Conforto aos usuários do canteiro e entorno:

- Manter o canteiro de obras livre de odores prejudiciais à saúde dos usuários (por exemplo, produtos tóxicos exalantes);

- Preservar os ambientes salubres de acordo com orientações da NR-18 Condições e Meio Ambiente de Trabalho na Indústria da Construção (BRASIL, 2015);

- Controlar e minimizar as fontes de poluição;

- Criar um "fumódromo" - local específico para consumo do tabaco;

- Manter o entorno (ruas e calçadas) do canteiro limpo (Figura 10b);

- Garantir que os portões de acesso à obra sejam monitorados por câmeras ou vigias;

- Verificar se o local oferece conforto térmico aos usuários, mantendo locais bem dimensionados sombreados e ventilados, áreas verdes, espelhos d'água;

- Verificar se o local oferece conforto visual, apresentando-se limpo e organizado;

- Verificar se o local oferece conforto acústico aos usuários e entorno, observando o uso correto de equipamentos de proteção coletiva (EPI), a localização adequada de equipamentos, a existência de máquinas que emitam menores ruídos e vibrações etc.;

- Preservar as instalações provisórias em boas condições de uso e ocupação, conforme NR-18 - Condições e Meio Ambiente de Trabalho na Indústria da Construção (BRASIL, 2015);

- Projetar as instalações provisórias com tecnologias e dispositivos passíveis de desmontagem e reutilização, mantendo-se as boas condições;

- Limpar os banheiros e refeitórios diariamente (Figura 10a);

2) Redução nas emissões de Cloro-Flúor-Carbono (CFC's) e Dióxido de Carbono $\left(\mathrm{CO}_{2}\right)$

- Realizar os procedimentos de neutralização de carbono quando se fizer uso de produtos/equipamentos emitentes de $\mathrm{CFC} / \mathrm{CO}_{2}$; 
- Conservar os equipamentos de uso nas instalações provisórias, tais como geladeiras e ar condicionados, com menos de cinco anos de uso;

- Realizar manutenção periódica nos veículos e maquinários de uso no canteiro.

A Figura 10 a seguir exibe imagens de canteiros com algumas das práticas citadas anteriormente.

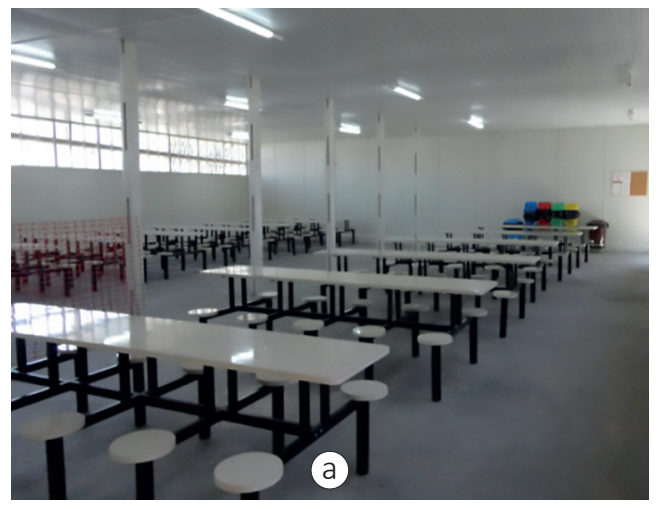

Refeitório em perfeitas condições de uso e limpeza

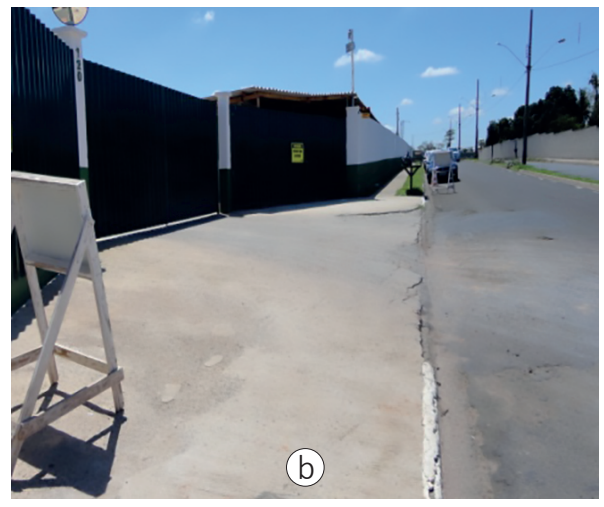

Entorno da obra

(ruas e calçadas) limpas

Figura 10 - Práticas relacionadas à qualidade do ambiente do canteiro. Fonte: Zeule (2014).

\subsection{Inovações e Processos}

Considera-se inovações gerenciais e tecnológicas aquelas que podem ser inseridas no canteiro, como a bonificação paga aos trabalhadores por incentivo à produção, a possibilidade de customização (isto é, permissão para mudança nos ambientes de acordo com os desejos dos futuros usuários), industrialização de equipamentos e materiais etc. (ZEULE, 2014).

A seguir, são apresentadas as diretrizes para cumprimento desse ponto de avaliação.

1) Inovações e processos:

- Organizar um plano de chegada de caminhões (evitando que fiquem estacionados nas vizinhanças da obra, causando incômodos à vizinhança e grande interferência no tráfego local);

- Verificar se os veículos utilizados na obra estão com os impostos pagos, principalmente no caso deles não serem da empresa executante; 
- Verificar também se existe controle de manutenção individual por veículo ou equipamento de obra;

- Certificar-se da qualificação da mão de obra e fornecedores contratados;

- Verificar se a mão de obra está apta ao serviço e se realizou treinamento;

- Não realizar queima de materiais em canteiro;

- Prever área para instalação da caixa de decantação de águas de lavagem de equipamentos como betoneira, argamassadeira, caminhão betoneira (Figura 11);

- Fazer uso de materiais industrializados pensando na eliminação de processos internos ao canteiro (argamassa industrializada, argamassa projetada, concreto usinado, concreto autoadensável, gesso projetado, gesso acartonado, sistema flexível de tubulação, guinchos ou gruas, lajes nervuradas, entre outros) (Figura 12);

- Elaborar plano de prevenção de riscos ambientais orientada pela NR-9 Programa de Prevenção de Riscos Ambientais (BRASIL, 2016a) (Figura 13);

- Manter registro e implantar programa de segurança no trabalho específico para construção- o Programa de Condições e Meio Ambiente de Trabalho na Indústria da Construção (PCMAT), disposto na NR-18 - Condições e Meio Ambiente de Trabalho na Indústria da Construção (BRASIL, 2015);

- Registrar os impactos ambientais e desempenho dos materiais e produtos durante seu processo de aquisição.

As Figuras 11 a 13 a seguir exibem imagens de canteiros com algumas das boas práticas citadas anteriormente.

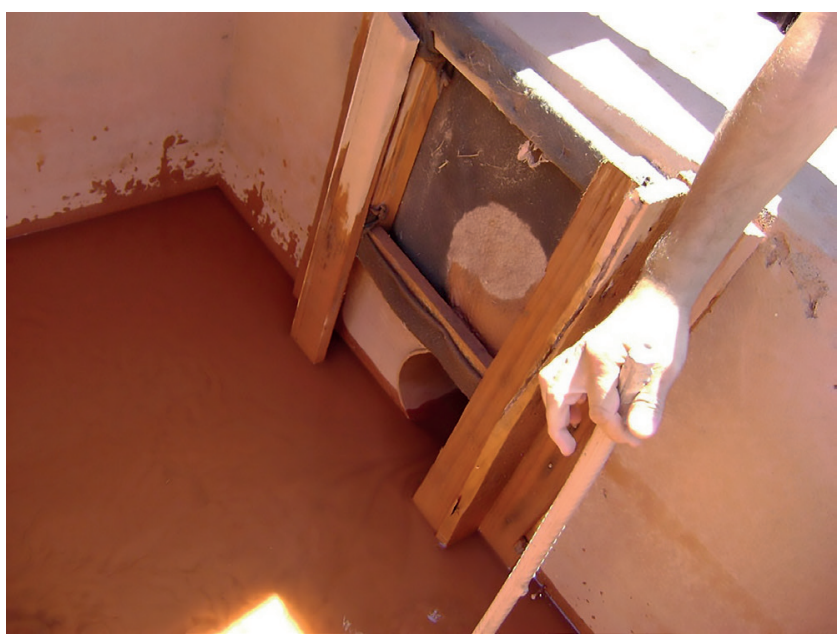

Figura 11 - Caixa de decantação da água com material particulado instalada no terreno. Fonte: Autoras (2016). 


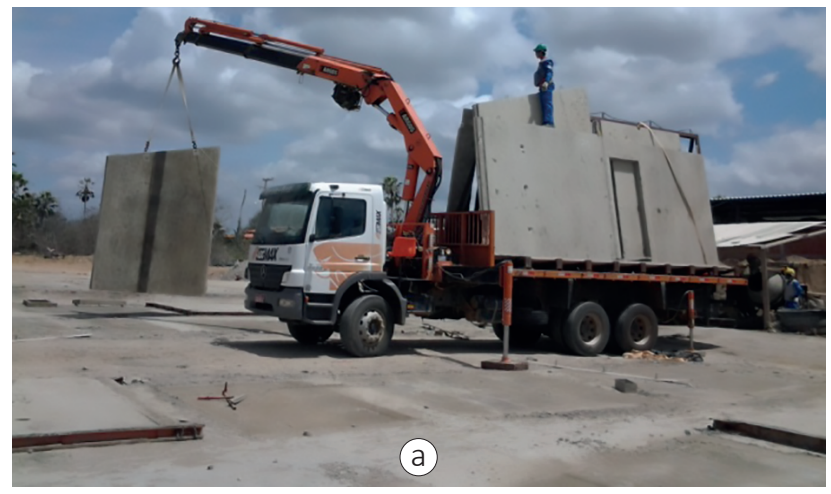

Uso de painéis pré-moldados de concreto sendo içados, eliminando vedações com blocos

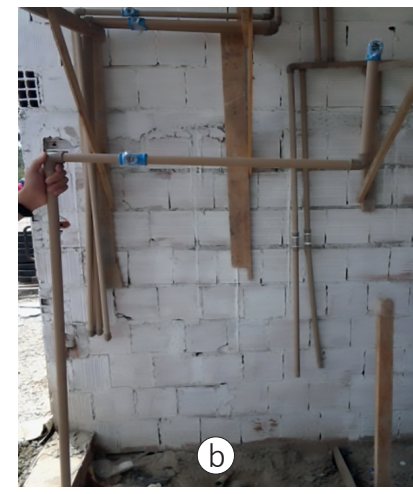

Kits de tubulações de água fria prontas para serem instaladas nos painéis pré-moldados

Figura 12 - Práticas para eliminação e simplificação de processos produtivos no canteiro. Fonte: Zeule (2014).

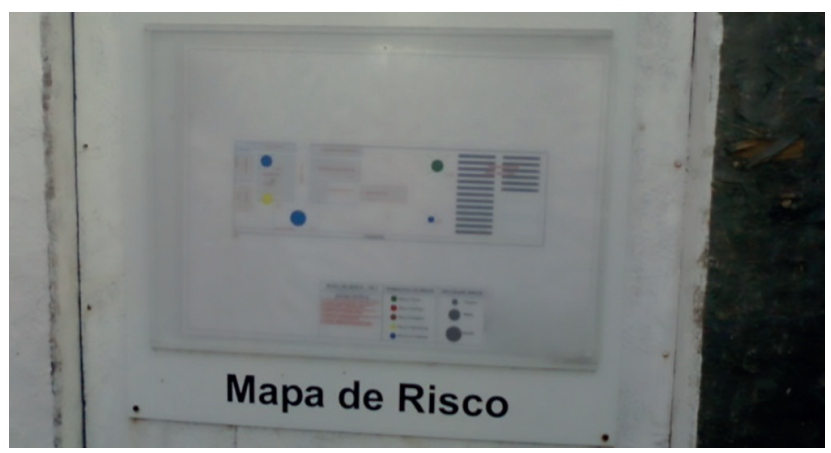

Figura 13 - Fixação do Mapa de Riscos (NR-9 - Programa de Prevenção de Riscos Ambientais) em Canteiro de Obra. Fonte: Autoras (2016).

\section{Conclusões}

A implantação das boas práticas apresentadas neste trabalho auxiliarão as empresas na adoção de estratégias modernas de gestão, com a incorporação de aspectos de sustentabilidade e responsabilidade social. Além de muitas das práticas terem valores significativamente baixos para implantação, os retornos do investimento podem ser intangíveis, como a melhoria da imagem e a comparação com empresas concorrentes.

É recomendado que as empresas de construção de edificações busquem alternativas que atuem na redução de impactos ambientais e adotem ferramentas 
gerenciais, como a implantação de um sistema de gestão ambiental. O planejamento antecipado aplicado à construção civil contribui para minimização dos impactos gerados pelas edificações, principalmente na fase de produção da construção, já que o canteiro de obras é uma fase considerada como grande causadora de danos ao meio ambiente.

Este estudo permitiu identificar a influência que a fase de execução (canteiro de obras) tem sobre o empreendimento como um todo, avaliando as diversas ocorrências de possibilidade de implantação das boas práticas de sustentabilidade.

Os órgãos públicos e financiadores das Habitações de Interesse Social (HIS) precisam ser mais contundentes em orientar a adoção de tais práticas, visto que existem vários empreendimentos desse tipo em todo o país e as práticas adotadas por eles refletem em grande porcentagem o setor da construção civil, trazendo benefícios para toda a sociedade.

Por fim, recomenda-se como necessária a obtenção de indicadores de sustentabilidade em empreendimentos, visando, além de uma mudança atual da construção civil, à melhoria nos processos produtivos, ao desenvolvimento tecnológico na fabricação dos materiais e componentes e à conscientização e treinamento de pessoal técnico e operacional.

\section{Referências}

BRANDÃO, G.B.M. Tecnologias e Certificações para Canteiros Sustentáveis. 2011. $66 f$. Trabalho de Conclusão de Curso. Engenharia Civil. Universidade Federal de São Carlos, São Carlos.

BRASIL. Ministério do Trabalho e Emprego. Norma Regulamentadora 18 (NR-18): Condições e meio ambiente de trabalho na indústria da construção. 2015. Brasília-DF. Disponível em: <http://trabalho.gov.br/seguranca-e-saude-no-trabalho/normatizacao/ normas-regulamentadoras/norma-regulamentadora-n-18-condicoes-e-meio-ambientede-trabalho-na-industria-da-construcao>. Acesso em: nov. 2016.

BRASIL. Ministério do Trabalho e Emprego. Norma Regulamentadora 9 (NR-9): Programa de Prevenção de Riscos Ambientais. 2016a. Brasília-DF. Disponível em: <http://trabalho. gov.br/images/Documentos/SST/NR/NR09/NR-09-2016.pdf >. Acesso em: nov. 2016.

BRASIL. Sustentável. Economia e meio ambiente no Brasil: Sustentabilidade. 2016b. Disponível em: <http://www.brasilsustentavel.org.br/sustentabilidade>. Acesso em: nov. 2016.

BRE. British Research Establishment Environment. Assessement Method (BREEAM). EuropeCommercial 2009 Assessor. Manual. BRE Global Ltda., 346 p. 2009.

CARDOSO, F.F.; ARAUJO, V.M. Levantamento do estado de arte: Canteiro de obras. Projeto Finep: Tecnologias para construção habitacional mais sustentável. São Paulo, 38p. 2007. 
CAVALCANTI, A.L.B.L.; PRETO, S.C.S.; PEREIRA, F.A.F.; FIGUEIREDO, L.F.G. Design para a Sustentabilidade: um conceito interdisciplinar em construção. Projética Revista Científica de Design, Londrina, v. 3, n. 1, julho, 2012.

COSTA, E.D.; MORAES, C.S.B. Construção civil e a certificação ambiental: análise comparativa das certificações LEED (Leadership in Energy and Environmental Design) e AQUA (ALTA Qualidade Ambiental). Engenharia Ambiental, Espírito Santo do Pinhal, v. 10, n. 3, p. 160-177, maio/jun. 2013.

FCAV. Fundação Carlos Alberto Vanzolini. Referencial técnico de certificação: edifícios do setorde serviços - processo AQUA. Francisco Ferreira Cardoso (coord.), São Paulo, 2010.

GBC BRASIL. Green Building Council Brasil. Certificação sustentável ganha espaço nos imóveis residenciais. Publicado em: out. 2015. Disponível em: <http://gbcbrasil.org.br/ detalhe-noticia.php?cod=130>. Acesso em: nov. 2016.

GUIA CAIXA. Selo Casa Azul: Boas práticas para habitação mais sustentável. Sustentabilidade Ambiental. JOHN, V.M.; PRADO, R.T.A. (coords.) Realização CAIXA. São Paulo: Páginas \& Letras- Editora e Gráfica, 2010.

HALLIDAY, S. Sustainable Construction. Burlington, USA: Butterworth-Heinemann, 2010.

LEED. Leadership in Energy and Environmental Design. LEED for New Construction \& Major Renovation, Version 2.2, Reference Guide. 2. ed., sep. 2009.

VIGGIANO, M.H.S. Edifícios públicos sustentáveis. 2010. Brasília: Senado Federal, Subsecretaria de Edificações Técnicas, 85p.

YIN, R.K. How to know whether and when to use case studies as a research method. In: Case Study Research: design and methods. 4. ed. Thousand Oaks: SAGE Publications. Applied Social Research Methods Series; v. 5. 2009.

ZEULE, L.O. Práticas e avaliação da sustentabilidade nos canteiros de obras. 2014. 263f. Dissertação (Mestrado em Estruturas e Construção Civil) - Universidade Federal de São Carlos, São Carlos, 2014. 


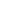




\section{Diretrizes para Novas Políticas de Ciência, Tecnologia e Inovação para Canteiro de Obras de Baixo Impacto Ambiental}

Natasha llse Rotbucher Thomas Dayana Bastos Costa Maria Sacramento Oliveira Guimarães Clarice Menezes Degani

\section{Introdução}

Apesar da importância, no Brasil, há uma carência de conhecimento sobre as necessidades prioritárias para a implementação de canteiros de obra de baixo impacto ambiental. Dessa forma, ainda permanecem sem resposta satisfatória inúmeros questionamentos, tais como: o que é preciso fazer para ter canteiros de obras mais produtivos? Quais são os intervenientes na implementação das práticas? Quais as necessidades de pesquisas, de capacitação e de políticas para o incentivo e a indução por parte da indústria da construção com o apoio do governo para se realizar esse tipo de empreendimento?

Nesse sentido, este capítulo tem como objetivo contribuir com a formulação de novas políticas de ciência, tecnologia e inovação para canteiros de obra de baixo 
impacto ambiental e com melhores condições de trabalho, apresentando indutores estratégicos que possam contribuir para a sustentabilidade nos canteiros de obra.

A formulação dessas diretrizes para novas políticas de ciência, tecnologia e inovação para canteiros de obra de baixo impacto considerou o levantamento das necessidades prioritárias de pesquisa e solução tecnológica nesse sentido, bem como as respectivas carências e dificuldades de implementação, apresentadas no Capítulo 1 deste livro.

Para sistematizar o processo de formulação das novas políticas, criou-se uma planilha com o intuito de definir um plano de ação para cada uma das práticas identificadas no Capítulo 1, com base no levantamento e entrevistas realizadas (colunas 1 e 2), conforme Quadro 1.

Em seguida, a primeira e a segunda coluna da planilha foi preenchida por pesquisadores da Universidade de São Paulo e da Universidade Federal da Bahia. A terceira coluna, denominada "como", foi deixada em branco para ser preenchida com as opiniões dos pesquisadores a respeito de soluções e de possibilidades capazes de influenciar as construtoras na adesão a cada diretriz. A quarta coluna, por sua vez, refere-se a "quem" ou "quais os intervenientes responsáveis" pela implementação ou realização do "como" em cada diretriz.

Foram estabelecidos os seguintes intervenientes:

(1) Academias/Universidades;

(2) Sindicatos/Associações;

(3) Instituições Tecnológicas;

(4) Indústrias;

(5) Construtoras;

(6) Órgãos Regulamentadores;

(7) Instituições financiadoras).

A quinta coluna refere-se ao tempo destinado à adoção efetiva da diretriz, podendo ser de curto, médio ou longo prazo.

A partir destes resultados, buscou-se definir a forma de implementação das diretrizes, as quais foram classificadas de acordo com seis indutores estratégicos, conforme será discutido a seguir. 


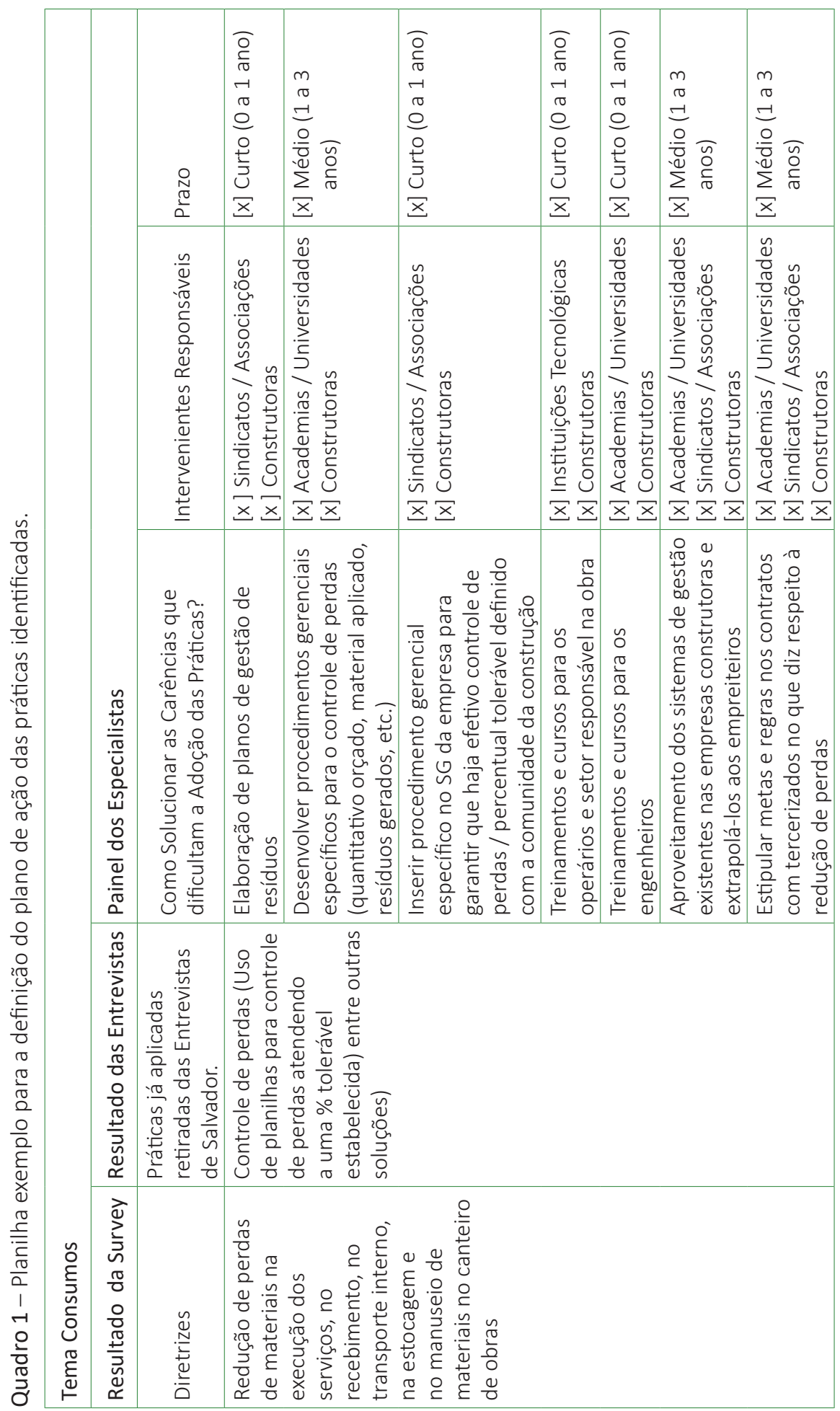




\section{Indutores Estratégicos}

Foram identificados seis indutores estratégicos relevantes para a sustentabilidade dos canteiros de obra no Brasil.

O primeiro indutor estratégico são as linhas de pesquisas para o desenvolvimento de soluções tecnológicas nos quatro temas estudados (consumos, emissões, interfaces com o meio exterior e qualidade intrínseca), específicos para aplicação em canteiros de obra, incluindo-se a análise de custo dessas soluções.

O segundo indutor são as políticas públicas e incentivos para o desenvolvimento de materiais e tecnologias pelas indústrias de construção civil, visando à industrialização dos processos construtivos no Brasil, a partir da criação de subsídios técnicos para viabilizá-las, considerando o uso racional dos recursos, sejam eles energia, água ou materiais.

O terceiro indutor é o incentivo ao desenvolvimento de projetos de canteiros de obra que privilegiem melhores soluções de projetos e práticas gerenciais sustentáveis e que possam ser adotados nas instalações provisórias (arquitetura, elétrica, hidrossanitárias, contenções e demais complementares) em cada fase da construção, além de passarem por aprovação do órgão municipal responsável e efetiva fiscalização, a fim de garantir o cumprimento da legislação vigente sobre os diversos temas.

Os três últimos indutores estão associados à própria falta de conhecimento das equipes operacionais e gerenciais nos canteiros de obra, quais sejam: a capacitação operacional na pauta das empresas construtoras, das políticas públicas e das entidades setoriais; a capacitação gerencial e tecnológica na pauta das políticas públicas e das entidades setoriais; e os fóruns para a integração da indústria da construção, academia e governo.

Os itens a seguir detalham os indutores estratégicos que, em conjunto, compreendem a formação de uma nova política para a Ciência, Tecnologia e Inovação no que diz respeito a canteiros de obra de baixo impacto ambiental e com melhores condições de trabalho. Esses itens são abordados do ponto de vista de consumos, emissões, interfaces com o meio exterior e da qualidade intrínseca do canteiro de obra.

\subsection{Linhas de Pesquisa}

As linhas de pesquisa direcionam-se às universidades e aos centros tecnológicos e devem ser fomentadas por agências de pesquisa do governo ou pela própria indústria da construção civil. Essas ações têm um horizonte de aplicação de médio a longo prazo e dependem de financiamento e investimento da iniciativa privada. 


\section{Consumos:}

- Avaliar a modulação de sistemas construtivos quanto ao custo, ao prazo de execução, à segurança do instalador, ao consumo de recursos na montagem e à emissão de resíduos (particulados, sólidos, gasosos e efluentes);

- Desenvolver tecnologias e procedimentos gerenciais específicos para o controle de perdas;

- Realizar estudos acerca da análise do ciclo de vida dos materiais, contribuindo para definir critérios para compra dos materiais, produtos e sistemas construtivos, a partir de fontes confiáveis e locais;

- Desenvolver sistema de avaliação dos fornecedores de materiais e produtos com baixo impacto ambiental, incentivando a formalização e conformidade em relação à Receita Federal, licença ambiental, responsabilidade social e normas técnicas;

- Desenvolver e aprimorar sistemas de instalações provisórias visando reduzir o consumo de água potável, de energia elétrica e gás, bem como dos equipamentos, sistema de iluminação e sistema de condicionamento de ar no canteiro de obras, avaliando as condições de uso e ocupação de cada tipo de dependência das instalações provisórias;

- Desenvolver métodos para a gestão, controle e redução do consumo de energia elétrica, água e gás nas atividades de produção no canteiro de obras;

- Investigar pertinência do aproveitamento de águas de chuva em atividades de produção no canteiro de obras.

\section{Emissões:}

- Desenvolver novos produtos e tecnologias para aproveitamento e descarte de resíduos classe C;

- Desenvolver métodos de descontaminação e soluções de descarte dos resíduos perigosos, como tintas, solventes, óleos, ou contaminados oriundos de demolições, reformas e reparos de clínicas radiológicas, instalações industriais e outros (resíduos classe D);

- Desenvolver metodologia de identificação dos riscos, caracterização e monitoramento de emissões de materiais particulados, tanto pelo impacto na vizinhança quanto para o trabalhador;

- Desenvolver método para controle do nível do lençol freático, sistemas de captação e tratamento de efluentes (esgoto) e minimização de riscos decorrentes do sistema de drenagem no canteiro de obras. 
Interfaces com o Meio Exterior:

- Desenvolver métodos e ferramentas para o controle das emissões de material particulado na vizinhança.

\section{Qualidade Intrínseca do Canteiro de Obras:}

- Desenvolver Sistema Nacional de Certificação dos equipamentos de proteção coletiva industrializados, como atualmente é realizado em equipamentos de proteção individual no canteiro de obras, além de aprimorar as Normas Regulamentadoras de Segurança existentes, incluindo memorial de cálculo dos equipamentos de proteção coletiva, proteções contra queda, etc.;

- Desenvolver soluções para proteções de equipamentos de movimentação de materiais, proteções contra choques elétricos e proteções em escavações;

- Desenvolver diretrizes para projetos de instalações provisórias, alinhando-as às soluções de projeto e práticas gerenciais que serão adotadas nas edificações e que podem ser aproveitadas nos projetos das instalações provisórias, visando à maior flexibilidade arquitetônica (layout), conforto térmico e acústico, iluminação, ventilação e qualidade de ar e à reutilização dos componentes e sistemas construtivos de instalação provisória em outros canteiros de obras.

- Desenvolver soluções de instalações provisórias industrializadas modulares em aço (contêineres), pré-fabricadas de concreto e placas cimentícias em sistemas de vedação como alternativa para as instalações tradicionais, com sistema de certificação quanto à segurança, à resistência estrutural e à segurança contra fogo.

\subsection{Política e Incentivos Fiscais para o Desenvolvimento de Materiais e Tecnologias na Indústria da Construção}

As políticas públicas com incentivos fiscais que facilitam o aporte de capitais e os subsídios governamentais oferecidos às empresas (comércio e indústria) para redução do preço final de seus produtos direcionam-se aos governos nas escalas federal, estadual e municipal e aos órgãos regulamentadores.

Esse indutor envolve ações de médio a longo prazo de aplicação, pois depende da atuação de diversos intervenientes, como governos, representantes da cadeia da construção, entre outros. 


\section{Consumos:}

- Incentivar a industrialização e pré-fabricação de produtos, componentes e sistemas construtivos, bem como o uso de elementos pré-moldados, deixando apenas a montagem para o momento de execução da obra (obras secas);

- Incentivar a instalação de fábricas de materiais e produtos de construção (esquadrias, alumínio composto, elementos pré-fabricados, gesso acartonado, tintas, cimentos, vidros, cerâmica, porcelanato, entre outros) de forma descentralizada no país;

- Incentivar o desenvolvimento de novas soluções e kits de materiais para instalações elétrica, de água e gás, nas instalações provisórias e na edificação como um todo, visando reduzir o consumo de água potável, de energia elétrica e gás, além de sistemas de iluminação e sistema de condicionamento de ar no canteiro de obras;

- Criar subsídios para lâmpadas e equipamentos que comprovem uma redução no consumo de energia e água, e kits de instalações que sejam vinculados a certificados de qualidade, passando-se o desconto para o comprador do produto final;

- Incentivar a fabricação de equipamentos e ferramentas de produção de menor consumo de energia, água e gás;

- Criar subsídios financeiros para compra de máquinas, tais como equipamentos para proteções coletivas, retroescavadeiras, gruas e outros equipamentos pesados;

- Incentivar o uso e desenvolvimento de soluções e fontes de geração de energia alternativa, que possam ser utilizadas durante a fase de execução no canteiro de obra com subsídios e incentivos fiscais;

- Incentivar o uso de BIM para o desenvolvimento de projetos e compatibilização dos mesmos.

\section{Emissões:}

- Desenvolver novos produtos e tecnologias para aproveitamento de resíduos classe C e D;

- Desenvolver alternativas para o descarte temporário dos resíduos que permitam a triagem e a não contaminação;

- Desenvolver opções de embalagens para armazenamento e descontaminação de resíduos perigosos, como tintas, solventes, óleos ou aqueles contaminados, 
oriundos de demolições, reformas e reparos de clínicas radiológicas, instalações industriais e outros (resíduos classe D);

- Criar subsídios para aquisição de equipamentos de aproveitamento e tratamento de resíduos, bem como de trituradores e dispositivos de gestão de resíduos, como estocagem e coleta especializada;

- Criar incentivos fiscais aos fabricantes para efetuar logística reversa;

- Incentivar a criação de centrais de reciclagem para recebimento e aproveitamento de resíduos;

- Desenvolver equipamentos e ferramentas com dispositivos contenedores ou com dispositivos que reduzam a emissão de poeiras;

- Criar incentivos fiscais para o controle das emissões de materiais particulados;

- Incentivar o uso de boas práticas para a redução das emissões de material particulado e o volume de ruído;

- Desenvolver tecnologias para tratamento de esgoto compactas para canteiros de obra.

\section{Interfaces com o Meio Exterior:}

- Incentivar o uso e desenvolvimento de equipamentos e ferramentas com dispositivos de atenuação de ruídos por meio de subsídios para aquisição de tais instrumentos;

- Incentivar o uso e desenvolvimento de equipamentos e ferramentas para o controle das emissões de material particulado na vizinhança.

\section{Qualidade Intrínseca do Canteiro de Obras:}

- Incentivar o desenvolvimento de novas soluções e o aprimoramento dos sistemas de proteções coletivas já existentes, incluindo aqueles contra quedas de pessoas em diferença de nível, contra choques elétricos, equipamentos de movimentação de materiais e em escavações com certificação;

- Incentivar a industrialização e desenvolvimento de componentes, produtos e sistemas construtivos de instalações provisórias (pré-fabricação) em canteiros de obra, que visam à redução no consumo de água, energia e recursos em geral e que possam ser reutilizados em outros canteiros de obras, promovendo maior flexibilidade desses abrigos e gerando melhorias na conectividade das instalações provisórias do canteiro de obras, com redes de água, tratamento dos efluentes, energia e comunicação; 
- Incentivar o desenvolvimento e uso de soluções para industrialização de provisórias modulares em aço (contêineres), em madeira e seus derivados (OSB) e em concreto, atentando-se para uma maior segurança estrutural e quanto a incêndios. Proporcionar subsídios para aquisição dessas instalações.

\subsection{Projetos de Canteiros de Obra com Baixo Impacto Ambiental}

Esse é um indutor que orienta ações de curto prazo, porém a sua efetividade conta com o apoio de fiscalização e exigência de responsabilidade técnica na elaboração de projetos executivos para as instalações provisórias.

\section{Consumos:}

- Especificar equipamentos com baixo consumo energético e certificados PBE/ Procel Inmetro (lâmpadas, eletrodomésticos, eletroeletrônicos), adotar dispositivos de controle (sensores de presença e fotoelétricos) e buscar fontes alternativas (geotermia, eólica, solar térmica e solar fotovoltaica).

\section{Emissões:}

- Elaborar planos de gerenciamento de resíduos da construção civil mais detalhados do que o exigido pela resolução CONAMA 307. Utilizar na própria obra, efetivamente, os resíduos classe A gerados;

- Prever a gestão dos efluentes da obra, o tratamento do esgoto, os sistemas de aproveitamento de águas pluviais, o reuso de águas cinzas e das provenientes de sistemas de limpeza de rodas, betoneiras e bicas de caminhões de concreto;

- Desenvolver projeto que considere os impactos sonoros e a emissão de particulados das atividades de canteiro, incluindo planos de monitoramento e controle, levando em conta o detalhamento dos documentos PPRA e PCMAT e prevendo uma política de boa vizinhança.

\section{Interfaces com o Meio Exterior:}

- Analisar o entorno, mapeando a vizinhança e garantindo adequada definição de acessos de diferentes tipos de veículos na obra, estabelecendo os procedimentos e fixando as rotinas de carga e descarga, limpeza e conservação dos fechamentos e comunicação com vizinhos, por exemplo;

- Desenvolver projeto de sinalização interna e externa, considerando saúde ocupacional, segurança e aspectos ambientais (por exemplo, placas sinalizadoras de áreas preservadas, informações destinadas à vizinhança acerca de prazos e meios de contato com a obra, orientações de trânsito, dentre outros); 
- Desenvolver plano de preservação e compensação da vegetação, além do exigido pela regulamentação, com medidas de isolamento e proteção, replantio local e em outras obras ou doação de mudas.

\section{Qualidade Intrínseca do Canteiro de Obras:}

- Considerar, nas instalações provisórias, o conforto térmico, a trajetória, a ventilação e iluminação naturais, a flexibilidade e reuso em outras obras, a qualidade do ar interno e soluções contra emissão de particulados, etc.;

- Desenvolver projeto de segurança coletiva e individual para o canteiro de obra;

- Desenvolver projeto de segurança contra incêndio;

- Desenvolver projeto logístico do canteiro de obra, considerando movimentação, estoque e descarga de materiais e resíduos, além da descrição de rotas até as transportadoras;

- Exigir ART para os projetistas das instalações provisórias;

- Exigir adequação ao Selo Azul ou a qualquer outro tipo de certificação para obras habitacionais financiadas pelo Governo.

\subsection{Capacitação Operacional das Empresas Construtoras e das Entidades do Setor da Construção}

Esse indutor foca no desenvolvimento de programas com intuito de reduzir a rotatividade e capacitar terceirizados, elevando a qualidade operacional e a formação técnica das equipes. O propósito da capacitação é aumentar a produtividade dos indivíduos em seus cargos, influenciando seus comportamentos. Nesse caso, também se torna importante a criação de políticas públicas que exijam a capacitação na realização de determinados serviços, indicando seu formato e o tempo de capacitação para cada função.

\section{Consumos:}

- Treinar a redução de perdas de materiais na execução dos serviços, no recebimento, no transporte interno, na estocagem e no manuseio, além da fidelidade aos projetos de paginação;

- Treinar quanto ao processo de aquisição de materiais e equipamentos e de contratação de serviços (critérios e políticas de compras, logística reversa, rotinas de inspeção, avaliação de fornecedores). 


\section{Emissões:}

- Treinar as rotinas do plano de gerenciamento de resíduos da construção civil (PGRCC), assegurando a triagem na fonte e garantia da qualidade do resíduo;

- Treinar as rotinas de descontaminação, descarte e cuidados especiais com os resíduos perigosos como tintas, solventes, óleos ou aqueles contaminados, oriundos de demolições, reformas e reparos de clínicas radiológicas, instalações industriais e outros (resíduos classe D);

- Treinar as rotinas de aproveitamento dos resíduos classe A no canteiro e de uso de agregados reciclados;

- Treinar as rotinas de monitoramento e minimização da emissão de particulados, inclusive indicando as responsabilidades das empreiteiras em contrato.

\section{Interfaces com Meio Exterior:}

- Treinar as rotinas de gestão de acessos e fluxos de pedestres, equipamentos, carga e descarga no canteiro de obras, boas práticas relacionadas aos impactos do canteiro nos fluxos do entorno, aspectos sanitários, de conforto e visuais, interferências do canteiro de obras no trânsito local e conservação das vias e calçadas para garantir acessibilidade;

- Treinar os procedimentos de prevenção e mitigação de processos erosivos e riscos de desmoronamento;

- Treinar e conscientizar a respeito dos incômodos sonoros, métodos de caracterização das atividades emissoras de ruídos e planos de atenuação.

\section{Qualidade Intrínseca do Canteiro de Obras:}

- Treinar e conscientizar a respeito do uso adequado dos equipamentos do canteiro;

- Treinar e conscientizar a respeito da importância de manter limpos os ambientes internos nas instalações provisórias;

- Treinar e conscientizar a respeito do uso de EPIs.

\subsection{Capacitação Gerencial e Tecnológica das Entidades do Setor da Construção}

O processo de capacitação gerencial e tecnológico deve ser compreendido como algo dinâmico e inserido nas estratégias das empresas quando se trata da decisão de desenvolver, adaptar ou adquirir tecnologia para atender à determinada demanda. 


\section{Consumos:}

- Treinar a redução de perdas de materiais na execução dos serviços, no recebimento, no transporte interno, na estocagem e no manuseio, incluindo:

- uso integrado do Building Information Modeling por escritórios de projeto;

- coordenação modular definida no início do desenvolvimento do projeto, padronização de módulos entre sistemas, elementos e componentes, acordos entre projetistas e construtoras com seus fabricantes para fornecimento de tamanhos padronizados;

- adoção de projetos de paginação incluídos nos contratos de projeto e entrega no executivo;

- coordenação de projetos formal com garantia de qualidade e uso de engenharia a montante;

- adoção de projetos executivos completos antes do início da obra, com planejamento para a produção e análises críticas indicadas em cronograma;

- avaliação de sistemas inovadores quanto ao custo, ao prazo de execução, à segurança do instalador, ao consumo de recursos na montagem e à emissão de resíduos;

- adoção de projetos das instalações provisórias nas diversas disciplinas e com memorial descritivo;

- escopos de contrato pré-elaborados, com metas e regras claras a respeito de redução de perdas, por exemplo.

- Treinar os critérios de compra dos materiais, produtos e sistemas construtivos a partir de fontes confiáveis e locais que incluam informações sobre análise do ciclo de vida e propriedades, como o desempenho técnico:

- seleção de fornecedores, considerando características de desempenho, desde as mais explícitas às mais específicas, entrando em análises de ciclo de vida mais consistentes;

- declarações de análise de ciclo de vida;

- especificações detalhadas de desempenho técnico, durabilidade, métodos de manutenção, patologias, vida útil mínima e outras características a indicar no memorial descritivo e a recolher os respectivos comprovantes, certificados e laudos.

- Treinar as soluções para reduzir o consumo de água potável, de energia elétrica e gás pelas instalações provisórias, bem como pelos equipamentos, sistemas de iluminação e condicionamento de ar. Treinar o aproveitamento das águas pluviais e das águas cinzas, assim como para rotinas de monitoramento e gestão dos consumos nas instalações provisórias e processos produtivos. 


\section{Emissões:}

- Treinar a elaboração e implantação dos PGRCC, assegurando a triagem na fonte e garantia da qualidade dos resíduos, assim como as estratégias de minimização de resíduos e maximização do seu aproveitamento, incluindo:

- inserção dessas estratégias em contrato com as empreiteiras;

- controle da geração, quantificação, triagem, estocagem e descartes de resíduos, incluindo a logística reversa;

- planos de armazenagem, incluindo a classificação dos resíduos, as possibilidades de aproveitamento e as opções de descarte;

- métodos de aproveitamento e uso de resíduos no canteiro e utilização de agregados reciclados em substituição aos agregados naturais, dosagem e outras informações e normas técnicas;

- métodos de descontaminação, soluções de tratamento e descarte de resíduos perigosos, como tintas, solventes, óleos ou aqueles contaminados, oriundos de demolições, reformas, reparos de clínicas radiológicas, instalações industriais e outros (classe D);

- sinalização dos locais de aproveitamento e descarte, método de rastreamento.

- Treinar o controle do nível do lençol freático e sistemas de captação e tratamento de efluentes (esgoto), minimizando os riscos a partir do sistema de drenagem. Divulgar os métodos de controle do nível freático, dos sistemas de captação de efluentes e as estratégias de minimização de riscos e outras medidas gerenciais;

- Treinar os procedimentos para preservação de vegetação remanescente, incluindo:

- novos conceitos de paisagismo com a adoção de espécies que demandem menor necessidade de adubagem, irrigação e poda; espécies menos invasivas; espécies não tóxicas e não alergênicas. Contribuições para redução das ilhas de calor, sombreamento de fachadas, dentre outros;

- boas práticas na preservação de vegetação remanescente na forma de procedimentos operacionais a serem seguidos pela equipe própria e as empreiteiras.

\section{Interfaces com Meio Exterior:}

- Treinar a gestão de acessos e fluxos de pedestres, equipamentos, carga e descarga no canteiro de obras: fluxos, aspectos sanitários e de conforto, segurança, comunicação visual, política de boa vizinhança, transparência;

- Treinar a observação das interferências do canteiro no trânsito local e da conservação das vias e calçadas, garantindo acessibilidade: fluxos de pessoas e veículos, aspectos sanitários, de conforto e visuais; 
- Treinar a observação dos processos erosivos e riscos de desmoronamento, incluindo projetos de canteiros contemplando contenções e memorial descritivo, além de medidas preventivas e de mitigação de processos erosivos e riscos de desmoronamento;

- Treinar a caracterização, monitoramento, minimização e controle das emissões de materiais particulados, a identificação dos riscos decorrentes dessas emissões provenientes das atividades de produção para a vizinhança e as boas práticas para a minimização dos danos inseridas nos procedimentos operacionais da própria equipe e das empreiteiras;

- Treinar a caracterização das atividades emissoras de ruídos e aplicação de planos de atenuação de incômodos sonoros: monitoramento e controle das atividades emissoras, locais adequados, planejamento de horário, previsão de ações de comunicação com a vizinhança (comunicados, reuniões, entrevistas), memoriais descritivos contemplando os níveis sonoros máximos a respeitar, sugestão de equipamentos e tecnologias menos ruidosas e com menos vibração;

- Treinar a efetiva comunicação com a vizinhança nas fases seguintes ao canteiro por meio da disponibilização de conteúdo informativo de qualidade projetada para o futuro uso da obra, operação e manutenção dos edifícios no momento de sua entrega e desenvolvimento dos manuais de entrega do empreendimento, a partir de investigação criteriosa da vizinhança e inspeção cautelosa das unidades.

\section{Qualidade Intrínseca com o Canteiro de Obras:}

- Treinar a respeito de proteção contra quedas de pessoas em diferença de nível, proteção em máquinas e equipamentos de movimentação de materiais e pessoas, proteção contra choques elétricos e proteção em escavações, com sensibilização quanto às vantagens custo-benefício do uso de equipamentos e máquinas de ponta, incluindo:

- projeto de segurança para proteções coletivas, incluindo os materiais e dispositivos, prevendo o local das diversas fases e atividades, recomendações de manutenção e elaboração de projetos de comunicação visual orientativa e preventiva.

- Capacitar profissionalmente os funcionários e absorver a mão de obra local: treinamento integrado dos serviços (passo-a-passo do serviço a ser realizado) pela obra, cursos de Educação Ambiental e inclusão digital para os operários e comunidade.

- Treinar para a elaboração de projetos de canteiros de obra, incluindo os projetos complementares, memoriais de cálculos e memoriais descritivos para cada fase da obra, resgatando as diversas soluções de projeto e práticas gerenciais, no intuito de melhorar o conforto térmico e acústico, a iluminação, ventilação 
e qualidade de ar, as condições de segurança do trabalho, saúde e higiene nos ambientes internos das instalações provisórias, a segurança estrutural, conectividade, condições de uso e operação, estanqueidade, manutenibilidade e posterior reutilização dos componentes e sistemas construtivos de instalação provisória em outros canteiros.

\subsection{Fóruns para Integração da Indústria da Construção, Academia e Governo}

A integração da pesquisa desenvolvida nas universidades com as demandas da indústria da construção civil contribui para uma engenharia mais sustentável. Assim, é preciso unir as necessidades do mercado com as pesquisas aplicadas, integrando a indústria da construção, a academia e o governo. A criação de fóruns pretende estabelecer um canal de diálogo entre esses atores.

\section{Consumos:}

- Definir as etapas de desenvolvimento do produto, uso de engenharia a montante (100\% dos projetos prontos antes do início da obra), planejamento dos projetos para a produção e análises críticas inseridos no cronograma, aplicação da plataforma BIM;

- Criar um banco de dados de indicadores de perda de materiais por serviço: no recebimento, no transporte interno, na estocagem e no manuseio de materiais no canteiro de obra. Definir um percentual tolerável de perdas e avaliar os números alcançados. Discutir dificuldades e soluções e propor metas de melhoria;

- Esclarecer as tecnologias e divulgar seus custos e benefícios, incentivando a industrialização, pré-fabricação e pré-moldagem, o uso de maquinários de ponta, deixando apenas a montagem para o momento de execução da obra (conceito da obra seca), a fim de reduzir o emprego de mão de obra, induzir o mercado e aumentar a concorrência, fato que propicia os menores custos dos sistemas construtivos;

- Definir critérios para compra dos materiais, produtos e sistemas construtivos, a partir de fontes confiáveis e de locais que incluam informações sobre análise do ciclo de vida, desempenho técnico, certificações de qualidade, conformidade ao PSQ do PBPQ-H, procedência dos materiais naturais, como a madeira, areia, gesso e pedras;

- Apoiar os sistemas de avaliação de fornecedores, incentivando a formalização e conformidade em relação à Receita Federal, licença ambiental, responsabilidade social e normas técnicas, além de promover a divulgação às construtoras e projetistas de informativos dos sites disponíveis para consulta de cadastros, 
formalidades e desempenhos. Desenvolver campanha setorial sobre a legalização dos funcionários terceirizados;

- Aperfeiçoar as características das instalações provisórias e desenvolver mercado para melhores custos de kits, sistemas e dispositivos para que também sejam utilizados nas instalações provisórias e reaproveitados nas seguintes.

\section{Emissões:}

- Rever as responsabilidades dos agentes da cadeia produtiva e negociar acordos entre os diferentes setores industriais para garantir melhor gestão de resíduos no canteiro de obras. Identificar as possibilidades de logística reversa e atuar especificamente com cada agente, buscando alternativas tecnológicas, de gestão e de logística com o objetivo de reduzir perdas e maximizar o reaproveitamento dos materiais;

- Discutir a aplicação dos resíduos inertes no próprio canteiro e o uso dos agregados reciclados em substituição aos agregados naturais. Divulgar usos potenciais, métodos de descontaminação e soluções de descarte para os resíduos perigosos. Desenvolver parcerias com fornecedores, inclusive considerando suas embalagens.

\section{Interfaces com Meio Exterior:}

- Discutir a gestão de acessos e fluxos de pedestres, equipamentos, carga e descarga no canteiro de obras, processos erosivos e riscos de desmoronamento, controle do nível do lençol freático e sistemas de captação e tratamento de efluentes (esgoto) e minimização de riscos decorrentes do sistema de drenagem no canteiro de obras.

\section{Qualidade Intrínseca do Canteiro de Obras:}

- Discutir as técnicas de proteção contra quedas de pessoas em diferença de nível, equipamentos de movimentação de materiais, equipamentos de movimentação de pessoas, contra choques elétricos, contra desmoronamentos em escavações. Divulgar vantagens, custos e benefícios do uso de equipamentos e máquinas de ponta;

- Divulgar o apoio institucional de cada Estado e seus programas de capacitação profissional de funcionários e absorção da mão de obra local. Instigar o desenvolvimento de novos programas em parceria com a indústria e as instituições tecnológicas, inclusive considerando aspectos de segurança e saúde ocupacional;

- Compartilhar soluções de projetos de canteiros de obra, contemplando conforto térmico e acústico, iluminação, ventilação e qualidade de ar, sistemas 
hidrossanitários e elétricos de baixo consumo, flexibilidade arquitetônica, possibilidade de reuso de componentes e sistemas construtivos, conectividade das instalações provisórias com redes de água, tratamento dos efluentes, energia e comunicação, tecnologias para instalações provisórias industrializadas e modulares, pré-fabricação, uso de kits.

\section{Conclusões}

Este documento apresentou as diretrizes para a formulação de novas políticas de ciência, tecnologia e inovação para canteiros de obra de baixo impacto ambiental e com melhores condições de trabalho.

Entende-se que a adoção de práticas e tecnologias para o desenvolvimento do canteiro de obras de baixo impacto exige compromisso de diversos intervenientes de setor, sejam eles as Academias/Universidades, os Sindicatos/Associações, as Instituições Tecnológicas, Indústrias, Construtoras, Órgãos Regulamentadores ou as Instituições financiadoras, com o estabelecimento de políticas públicas de incentivo e cobrança eficiente, metas progressivas e indicadores constantemente atualizados, formação de recursos humanos, desenvolvimento e adoção de inovações tecnológicas.

Espera-se que este trabalho ofereça subsídios para a definição de programas de fomento ao desenvolvimento cientifico e tecnológico na área de conhecimento de canteiros de obra com ênfase no seu baixo impacto ambiental e de melhores condições de trabalho, assim como no processo de tomada de decisão a respeito dos investimentos em inovação e gestão por parte de todas as empresas do setor da construção civil envolvidas. 


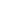




\section{Secão II}

\section{Subprojeto Desenvolvimento}

de Soluções para Redução

da Emissão de Materiais

Particulados em Canteiros de

Obras (SPEMP)

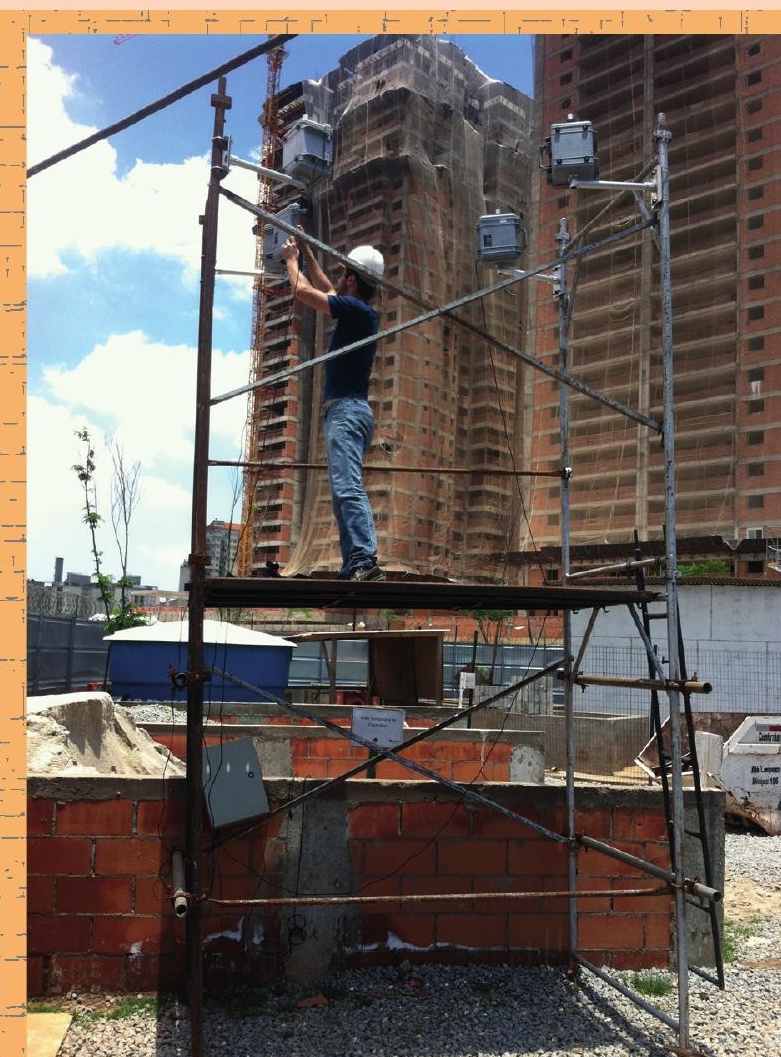




\title{
Boas Práticas para Redução da Emissão de Material Particulado Proveniente dos Canteiros de Obras
}

\author{
Ingrid Priscylla Silva Araújo \\ Rita Jane Brito de Moraes \\ Dayana Bastos Costa
}

\section{Introdução}

Uma construção é composta de uma série de operações e atividades diferentes, cada uma com um tempo de duração próprio e uma geração potencial de material particulado (MP). A emissão de material particulado tem uma origem definida e um destino que pode variar substancialmente em fases diferentes do processo de construção, tais como: demolição, terraplanagem, superestruturas, vedações e acabamento (MUÑOZ, PALACIOS, 2001; RESENDE, 2007).

Na construção civil, em especial durante a execução da obra, diariamente ocorre geração de poeira. O mecanismo de emissão dessa poeira está relacionado à ação dos ventos que atuam durante a realização de atividades, como a mistura e a subdivisão de diversas matérias primas de diferentes granulometrias, tais como: areia, cimento, cal, gesso, argamassas, madeira, cerâmica, granito, aço, entre outras. Ademais, por meio de suas atividades construtivas, por exemplo: fabricação de concreto e argamassa, jateamento de argamassa, corte de aço, de madeira, de cerâmica ou de granito, aplicação de gesso, varrição a seco, lixamento de superfícies, escavações, estocagem 
de pilhas de materiais ao ar livre, movimentação nas vias de tráfego, especialmente as não pavimentadas, ou de veículos e equipamentos movidos à combustão, entre outras atividades geradoras de diversos tipos de poeiras, que se propagam no ambiente de trabalho e na vizinhança da construção (ENVIRONMENT AGENCY, 2004; RESENDE, 2007; RESENDE, CARDOSO, 2007; MARTINS, 2009).

Neste sentido, as obras de construção civil representam fontes significativas de partículas com diversas composições para a atmosfera, causando sérios incômodos aos trabalhadores e à vizinhança das edificações. Essas emissões na maioria das vezes não podem ser confinadas, o que dificulta o seu controle. Contudo, boas práticas são conhecidas e disponíveis para a redução dessas emissões.

Este capítulo apresenta orientações para o desenvolvimento de um plano de gestão da emissão do material particulado da obra, destacando a fontes de MP provenientes do canteiro de obra e as atuais boas práticas para controle de poeira e partículas geradas pelas atividades de construção civil.

\section{Padrões de Qualidade do Ar}

Material particulado é definido como um conjunto de poeiras, fumaças e todo tipo de material sólido ou líquido que se mantém suspenso na atmosfera em decorrência de seu pequeno tamanho (CETESB, 2004). Essas partículas são classificadas de diferentes formas, dentre as quais se destacam as Partículas Totais em Suspensão (PTS), as Partículas Inaláveis (MP10) e as Partículas Inaláveis finas (MP2,5).

As Partículas Totais em Suspensão (PTS) são aquelas cujo diâmetro aerodinâmico é menor que $50 \mu \mathrm{m}$. Uma parte dessas partículas é inalável e pode causar problemas à saúde, a outra pode prejudicar a qualidade de vida da população, interferindo nas condições estéticas do ambiente e prejudicando as atividades normais da comunidade. Já as Partículas Inaláveis (MP10) são aquelas cujo diâmetro aerodinâmico é menor que $10 \mu \mathrm{m}$, dependendo da distribuição de tamanho na faixa de 0 a $10 \mu \mathrm{m}$. Podem ficar retidas na parte superior do sistema respiratório ou penetrar profundamente, alcançando os alvéolos pulmonares. Por fim, as Partículas Inaláveis finas (MP2,5), também denominadas Partículas Respiráveis, são aquelas cujo diâmetro aerodinâmico é menor que $2,5 \mu \mathrm{m}$, e devido ao seu tamanho diminuto, penetram profundamente no sistema respiratório, podendo atingir os alvéolos pulmonares, CETESB (2004).

Os padrões de qualidade do ar são valores de referência para diferenciar uma atmosfera poluída de uma não poluída. No Brasil, os padrões de qualidade do ar e episódios críticos de poluição foram estabelecidos pela Resolução CONAMA no 03 de 1990 (CONAMA, 1990) e ainda hoje estão em vigor (Tabela 1), porém permanecem desatualizados em face dos novos conhecimentos científicos, especialmente aqueles 
reconhecidos pela Organização Mundial da Saúde - OMS (PACYNA, 2005). Soma-se a isso, o fato de as metas propostas pela OMS serem mais restritivas se comparadas a alguns padrões adotados no mundo, inclusive os brasileiros (Tabela 2).

Tabela 1 - Padrões Nacionais de Qualidade do Ar (Resolução CONAMA no 03, 1990).

\begin{tabular}{|c|c|c|c|c|}
\hline Poluentes & $\begin{array}{l}\text { Tempo de } \\
\text { amostragem }\end{array}$ & $\begin{array}{l}\text { Padrões } \\
\text { Primários } \mu \mathrm{g} / \mathrm{m}^{3}\end{array}$ & $\begin{array}{l}\text { Padrões } \\
\text { Secundários } \mu \mathrm{g} / \mathrm{m}^{3}\end{array}$ & $\begin{array}{l}\text { Método de } \\
\text { medição }\end{array}$ \\
\hline $\begin{array}{l}\text { Partículas Totais } \\
\text { em Suspensão }\end{array}$ & $\begin{array}{l}24 \text { horas }^{(1)} \\
\text { mga }^{(2)}\end{array}$ & $\begin{array}{l}240 \\
80\end{array}$ & $\begin{array}{l}150 \\
60\end{array}$ & $\begin{array}{l}\text { Amostrador de } \\
\text { Grande Volume }\end{array}$ \\
\hline $\begin{array}{l}\text { Partículas } \\
\text { Inaláveis (MP10) }\end{array}$ & $\begin{array}{l}24 \operatorname{horas}^{(1)} \\
\operatorname{maa}^{(3)}\end{array}$ & $\begin{array}{l}150 \\
50\end{array}$ & $\begin{array}{l}150 \\
50\end{array}$ & $\begin{array}{l}\text { Separação } \\
\text { Inercial/ Filtração }\end{array}$ \\
\hline
\end{tabular}

Fonte: CETESB, 2004.

${ }^{1}$ Não deve ser excedido mais de uma vez ao ano.

${ }^{2}$ Média geométrica anual.

${ }^{3}$ Média aritmética anual.

O padrão brasileiro para o MP10 estabelece concentração média anual de $50 \mu \mathrm{g} / \mathrm{m}^{3}$, embora o ideal, segundo a OMS, seja de $20 \mu \mathrm{g} / \mathrm{m}^{3}$. Para concentração de MP10 em 24 horas, o padrão nacional é de $150 \mu \mathrm{g} / \mathrm{m}^{3}$, enquanto a OMS estabelece o valor de concentração máximo de $50 \mu \mathrm{g} / \mathrm{m}^{3}$.

Tabela 2 - Critérios de Qualidade do Ar adotados no mundo.

\begin{tabular}{lllll}
\hline $\begin{array}{l}\text { País/Poluente - } \\
\text { Padrão }\end{array}$ & $\begin{array}{l}\text { MP2,5 } \\
\text { Padrão Primário }\end{array}$ & $\begin{array}{l}\text { MP10 } \\
\text { Padrão Primário }\end{array}$ & $\begin{array}{l}\text { Tempo de } \\
\text { amostragem }\end{array}$ & \\
\hline \multirow{2}{*}{ OMS } & 10 & 20 & Fonte \\
& 25 & 50 & Anual & PACYNA (2005) \\
\multirow{2}{*}{ EUA } & 15 & Revogado & Anual & US EPA (2006) \\
& 35 & 150 & 24 horas & \\
\multirow{2}{*}{ REINO UNIDO } & 25 & 40 & Anual & Environmental \\
& - & 50 & 24 horas & Protection (2010) \\
\hline
\end{tabular}

Fonte: Adaptado de Pacyna, 2005; USEPA, 2006 e Environmental Protection 2010.

A legislação brasileira não leva em consideração o canteiro de obra como fonte geradora de resíduos para estabelecer padrões de qualidade do ar, tampouco considera a composição química dos materiais gerados, levando apenas em conta a concentração das partículas em termos de massa, o que pode representar um risco potencial tóxico significante. 


\section{Medição de Material Particulado na Construção}

Embora haja o reconhecimento de que a atividade de construção civil constitui uma importante fonte de emissão de material particulado, até recentemente, poucas pesquisas haviam sido direcionadas à caracterização desse tipo de resíduo (MULESKI et al., 2005).

De acordo com Countess Environmental (2006), Resende (2007) e California Natural Resources Agency Guide (CEQA, 2009), as emissões geradas a partir de atividades de construção comuns incluem:

a) Emissões de escape de material particulado (MP) e óxidos de nitrogênio (NOX) oriundos da queima de combustíveis de veículos pesados a diesel e equipamentos movidos à gasolina, equipamento auxiliar portátil, caminhões de entrega de material e de viagens diárias de troca de trabalhadores;

b) Poeira de MP fugitiva (proveniente de atividades não fixas) geradas pela movimentação de solo e da atividade de demolição, limpeza e estocagem, perfuração, serragem, produção de concretos e argamassas;

c) Emissões por evaporação de gases orgânicos reativos, compostos orgânicos voláteis (COV) derivados de atividade e da aplicação de revestimentos arquitetônicos de pavimentação. A aplicação de revestimentos arquitetônicos normalmente é uma das maiores fontes de emissões ROG (Reactive Organic Gases) ou COV durante a atividade de construção;

d) Emissões de escape de gases de efeito estufa (GEE), como o dióxido de carbono $\left(\mathrm{CO}_{2}\right)$, metano $\left(\mathrm{CH}_{4}\right)$ e óxido nitroso $\left(\mathrm{N}_{2} \mathrm{O}\right)$.

No caso específico do canteiro de obras, o material particulado é constituído de pó de cimento, gesso, cal, argamassa industrializada, poeira do solo, entre outros (RESENDE, 2007). As emissões secundárias (emissões não relacionadas diretamente às atividades de construção), apesar de não tão significativas, devem ser consideradas na elaboração de estratégias de redução do impacto ambiental no canteiro de obras, como é o caso das emissões de gases provenientes da queima de combustíveis de veículos e da queima de madeira (RESENDE, 2007). Não só as atividades de construção devem ser consideradas, mas também as emissões dos veículos em estrada associadas com o local de construção.

Recentemente, foram desenvolvidas pesquisas no âmbito do subprojeto SPEMP acerca da medição da concentração de material particulado provenientes de canteiro de obras (ARAÚJO, 2014; ARAÚJO, COSTA, MORAES, 2014; MORAES, 2015; MORAES, COSTA, ARAÚJO, 2016), com o objetivo de identificar as fases da construção e atividades potenciais geradoras de material particulado, bem como suas concentrações (MP2,5; MP10 e PTS). 
Tais estudos experimentais foram desenvolvidos em cinco canteiros de obras habitacionais, localizados em Salvador na Bahia, sendo aplicado em apenas um deles algumas das boas práticas para a redução da emissão de material particulado, ao passo que em quatro dos canteiros não se utilizou nenhuma boa prática para minimização dessas emissões e redução dos impactos para a vizinhança das obras. Os estudos foram desenvolvidos em fases distintas da obra, como a terraplanagem, a superestrutura e o acabamento.

Os principais resultados dessas pesquisas evidenciaram que os canteiros de obra lançam, no ambiente, partículas de vários tamanhos. O perfil apresentado demonstra que as frações MP10 e MP2,5 estão numa faixa de 40\% e 17\%, respectivamente, da fração PTS (ARAÚJO, COSTA, MORAES, 2014). Como as frações maiores (PTS e MP10) tendem a permanecer menor tempo no ambiente, uma vez que se sedimentam mais rápido, elas causam os maiores incômodos na vizinhança, além de representarem o maior percentual emitido pelos canteiros (ARAÚJO, COSTA, MORAES, 2014).

De acordo com o estudo de Moraes (2015), foram encontradas as seguintes faixas de valores mínimos para as frações PTS, num intervalo de 350 a $40 \mu \mathrm{g} / \mathrm{m}^{3}$ e valores máximos de 700 a $150 \mu \mathrm{g} / \mathrm{m}^{3}$. Para a fração MP10 a faixa de valores mínimos obtidos foi de 150 a $20 \mu \mathrm{g} / \mathrm{m}^{3}$ e os valores máximos de 280 a $50 \mathrm{\mu g} / \mathrm{m}^{3}$ em um período de 8 horas diárias (MORAES, 2015). Esses dados não podem ser diretamente comparáveis aos valores de referência da OMS ou da resolução CONANA n 3 , pois os padrões normativos são para um período de 24h. Entretanto, observa-se que, mesmo para 8 horas de medição no período de atividade do canteiro, reconhecendo as contribuições de emissões externas, por vezes, estes limites foram superiores a legislação nacional e a OMS.

A análise química das amostras da fração MP10 que foram coletadas na entrada e na saída dos canteiros estudados mostrou claramente a contribuição dos canteiros e a constituição do material gerado, tendo-se como principais elementos químicos identificados, que fazem parte dos materiais de construção, o Si (Silício), Ca (Cálcio), Fe (Ferro), Al (Alumínio), S (Enxofre) e K (Potássio) (MORAES, COSTA, ARAÚJO, 2016).

\section{Gestão e Monitoramento do MP em Canteiro de Obras}

Para realizar a gestão de MP, é necessário que sejam seguidos alguns princípios capazes de ajudar a estruturar um "plano de gestão" (RESENDE, 2007). O ciclo PDCA ou ciclo de Deming é frequentemente utilizado para estruturar sistemas de gestão (RESENDE, 2007). Segundo Resende (2007), um sistema de gestão deve estar baseado em quatro etapas fundamentais: 
I. Planejamento (P - planning) - estabelece objetivos e metas, processos e metodologias para se obter o resultado esperado;

II. Execução $(D-d o)$ - consiste em colocar em prática o planejado;

III. Verificação/controle ( $\mathrm{C}$ - check)- monitorar e avaliar periodicamente resultados, avaliar metodologias, confrontar com o inicialmente planejado;

IV. Ação (A - act) - de acordo com o encontrado nas atividades de verificação e controle, tomar ações para melhoria imediata ou de processos futuros.

O Quadro 1 apresenta algumas medidas para um plano de gestão de MP.

A aplicação sucessiva desses passos aumenta as possibilidades de que a gestão de um determinado processo ou de um conjunto de processos tenha sua eficiência melhorada (RESENDE, 2007). De qualquer modo, cada canteiro tem suas particularidades, portanto, em cada uma das etapas, devem ser propostas medidas específicas para atender com eficiência os objetivos do plano de ação.

Quadro 1 - Sugestão de ações para plano de gestão.

\begin{tabular}{|l|l|l|}
\hline Planejamento & Implementação e Operação & Verificação e Ação corretiva \\
\hline - Iniciação da fase de & - Integração - iniciação & - Verificação do grau de risco; \\
planejamento; & execução; & -Verificação das atividades \\
- Avaliação de grau de risco e & - Definição de & geradoras correntes; \\
estimativa de emissões; & responsabilidades; & - Verificação dos \\
- Verificação de aspectos & - Contratações; & procedimentos de \\
legais; & - Treinamentos internos e & monitoramento; \\
- Apoio à concepção projetos & externos; & - Verificação da eficácia das \\
e planejamento de & - Comunicações internas e & atividades de prevenção, \\
execução; & com vizinhança. & controle e monitoramento; \\
-Identificação das atividades & & - Verificação dos \\
emissoras de MP, & & equipamentos de \\
procedimentos de controle; & & monitoramento; \\
- Elaboração dos & & - Verificação de treinamentos \\
procedimentos de controle; & & e planos de comunicação; \\
- Plano de monitoramento; & & - Planos de ações corretivas e \\
- Avaliação de custos e & & emergenciais; \\
prazos; & & - Encerramento - término da \\
- Definição de & & execução. \\
responsabilidades; & & \\
- Plano de comunicação; & & \\
- Requisitos para & & \\
contratações; & & \\
-Encerramento da etapa de & & \\
planejamento. & & \\
\hline
\end{tabular}

Fonte: Resende e Cardoso, 2007. 
Além do planejamento, o controle das emissões de material particulado depende de uma transferência adequada dessas informações às equipes de produção e de um controle contínuo para sua aplicação (RESENDE; CARDOSO, 2007).

\section{Fontes de emissão e boas práticas para redução da emissão de material particulado}

Como já mencionado, devido ao desprendimento de MP ao longo das atividades de construção, que afetam os trabalhadores, os animais, as plantas, a vizinhança, entre outros, faz-se necessário adotar medidas de controle, a partir da utilização de equipamentos e atividades adequadas, a fim de mitigar a emissão desses resíduos de acordo com as atividades construtivas, bem como priorizar os cuidados necessários dentro do canteiro de obra e na sua vizinhança.

Contudo, é preciso salientar que cada construção possui particularidades. Portanto, as características de emissão de MP são alteradas de acordo com suas especificidades e, consequentemente, as intervenções devem ser estudadas caso a caso.

A seguir, são apresentadas algumas boas práticas em função das atividades, identificadas na literatura sobre o tema (BREEAM, 2009; GBC BRASIL, 2014; FUNDAÇÃO VANZOLINI, 2014).

\subsection{Atividades de Demolição}

As atividades de demolição podem ser praticadas de três formas distintas: a manual, a mecanizada e com a utilização de explosivos. Dentre elas, a manual é a mais indicada por emitir menor quantidade de MP em relação as demais.

Segundo EPA (1998), GLA (2005), Araújo e Cardoso (2007) e Resende (2007), algumas boas práticas podem ser adotadas durante a demolição, tais como:

a) Cercar a obra ou pontos de emissão com telas de poliéster de malha fina ou com chapas de madeira;

b) Remover os resíduos de demolição da obra o quanto antes, evitando sua exposição a ventos e chuvas. Quando a retirada não for possível, os resíduos devem ser cercados, umedecidos e cobertos;

c) Evitar atividades de demolição quando as velocidades do vento estiverem elevadas;

d) Manter a área umedecida após o término da demolição;

e) Aspergir água com mangueiras de alta vazão, antes e durante a atividade de demolição (Figura 1). 


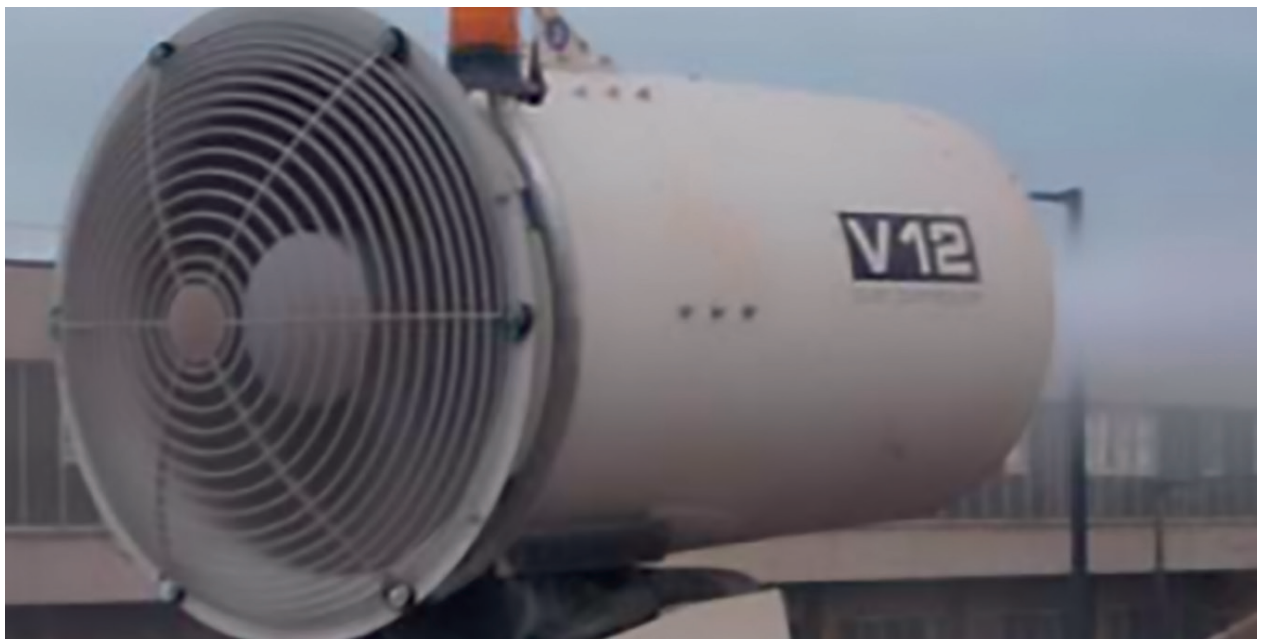

Figura 1 - Aspersão de água durante a demolição. Fonte: IAQM, 2016.

\subsection{Movimentação de Terra}

A emissão de MP nas atividades de movimentação de terra é muito significativa, sendo potencializada nos períodos de seca e ventos fortes. Tal emissão está ligada às atividades de corte e aterro, carga e descarga, movimentação de veículos e ao transporte de lama aderida aos pneus dos veículos.

Segundo EPA (1998), GLA (2005), Araújo e Cardoso (2007) e Resende (2007), as seguintes boas práticas podem ser adotadas para esta atividade:

a) Remover a vegetação existente conforme o avanço das atividades de movimentação de terra;

b) Evitar serviços de escavação durante períodos muito secos e com ventos fortes;

c) Realizar a remoção de terra da obra, preferencialmente, logo após sua escavação/movimentação;

d) Umedecer o solo periodicamente e prever barreiras físicas ao redor da obra ou das áreas de trabalho (Figura 2);

e) Manter as áreas em escavação umedecidas e cobertas nos períodos de paralisação;

f) Controlar a altura de lançamento de terra nos trabalhos de carga e descarga. É importante esvaziar a caçamba lentamente, evitando formação de nuvens de poeira;

g) Lavar os pneus dos veículos antes da saída dos canteiros (Figura 3). 


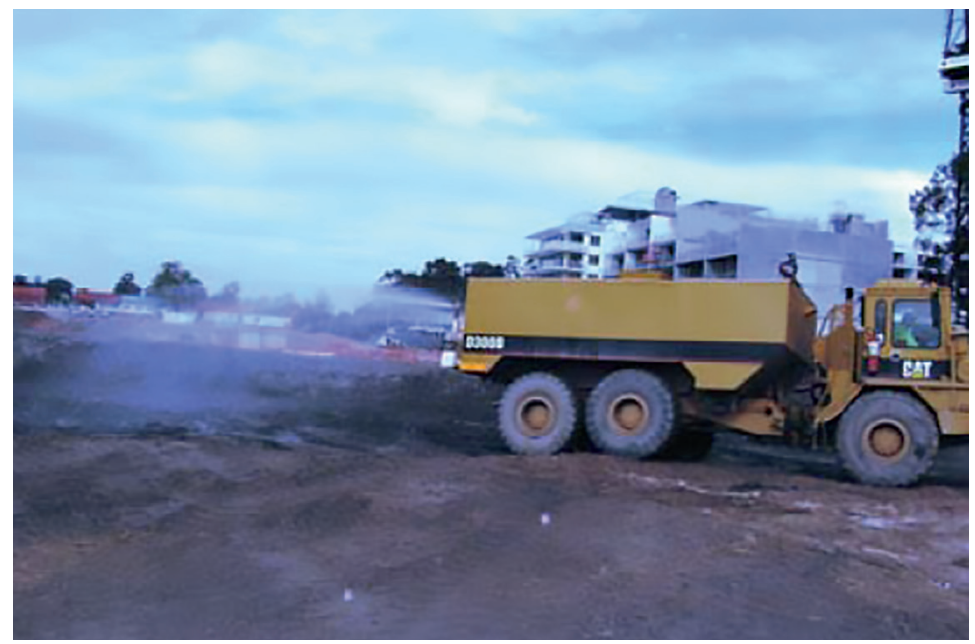

Figura 2 - Molhação durante a movimentação de terra. Fonte: Air Quality Guidance Note, 2016.

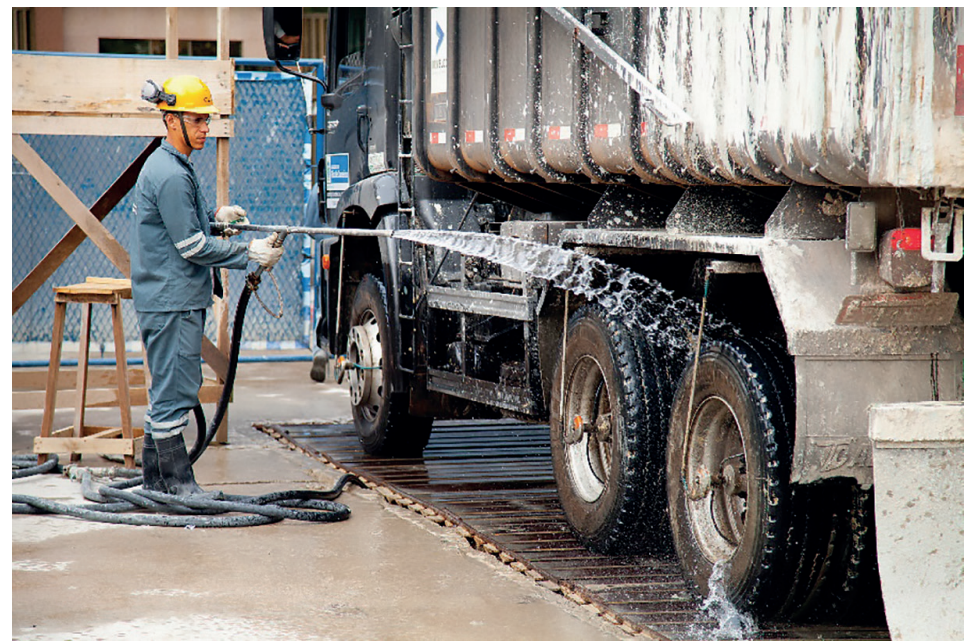

Figura 3 - Lavagem de pneus. Fonte: Revista CNT Transporte, 2016.

\subsection{Armazenamento}

Planejamento e gestão do sistema de armazenamento são importantes para otimização das áreas dos canteiros. Além disso, faz-se necessário que o armazenamento fique protegido da ação dos ventos e da chuva. O armazenamento inadequado de materiais também pode gerar emissão de MP na atmosfera. 
Segundo EPA (1998), GLA (2005), Araújo e Cardoso (2007) e Resende (2007), algumas boas práticas podem ser adotadas para armazenamento, como:

a) Manter os materiais e resíduos armazenados pelo menor período possível no canteiro;

b) Armazenar os materiais e resíduos protegidos da ação dos ventos e chuvas (Figura 4);

c) Manter as pilhas de materiais dispostas em condições que reduzam riscos de desmoronamentos;

d) Manter grandes pilhas de materiais e resíduos umedecidos constantemente, limitando a altura das pilhas a 2,50 metros;

e) Realizar limpezas periódicas dos locais de armazenamento;

f) Instalar exaustores com filtros, quando houver grande geração de MP no local de armazenamento;

g) Armazenar os materiais e resíduos longe das divisas e ambientes sensíveis ao MP (cursos d'água, hospitais, escolas, residências, locais com aglomerações de pessoas e outros);

h) Armazenar equipamentos de aspiração e limpeza para o caso de "vazamentos" acidentais.

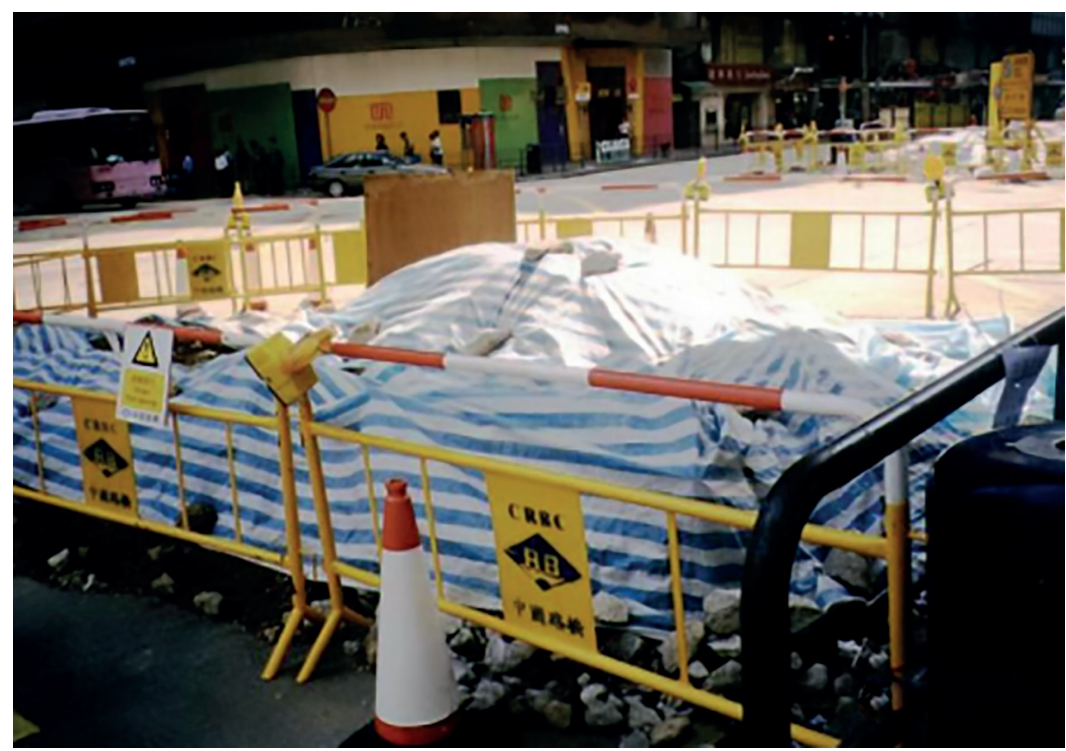

Figura 4 - Materiais armazenados protegidos da ação dos ventos e chuvas. Fonte: EPD Hong Kong, 2006. 


\subsection{Construção}

A variedade de atividades desenvolvidas dentro de um canteiro de obras faz com que, ao longo da execução da obra, sejam criadas fontes de emissão de material particulado de características diversificadas, sob vários aspectos, tais como: concentração produzida, tamanho das partículas, tempo de emissão, entre outros (RESENDE, 2007).

A avaliação das emissões do canteiro deve ser feita mediante a análise da sobreposição das diversas atividades desenvolvidas. Para tanto, o controle das emissões deverá ser feito por meio do conhecimento das características particulares de cada atividade.

Segundo EPA (1998), GLA (2005), Araújo e Cardoso (2007) e Resende (2007), algumas práticas podem minimizar a emissão de partículas em atividades construtivas:

a) Utilizar dispositivo de coleta de pó de serragem acoplado ao equipamento (Figura 5);

b) Utilizar serra manual acoplada à mangueira de água (Figura 5);

c) Realizar a atividade em ambiente com coifa exaustora e filtro, em caso de grande quantidade de emissões;

d) Fazer corte/perfuração em local protegido da ação dos ventos e dentro de caixote coletor;

e) Sempre que possível, evitar a produção de concreto e argamassas durante a execução da obra. Quando produzidos, fazê-los em local protegido da ação de ventos e chuvas;

f) Cobrir com lonas as misturas que forem deixadas de um dia para o outro;

g) Sempre que possível, evitar a realização de atividades que exijam desgaste superficial, substituindo a tecnologia construtiva;

h) Realizar varrição úmida ou aspiração com frequência;

i) Racionalizar o processo de produção de forma a diminuir a perda de argamassas e concretos por queda;

j) Verificar a estanqueidade dos equipamentos utilizados para transporte de concretos e argamassas;

k) Criar barreiras físicas de modo a evitar que as argamassas e concretos sejam lançados fora de um espaço controlável (telas nos andaimes fachadeiros, tapumes, lonas, entre outros) (Figura 6);

I) Evitar os serviços de queima, sempre que possível, nos canteiros de obra, pois lançam MP e gases;

m) Fazer a queima de materiais em incineradores públicos, quando for inevitável; 
n) Sempre que possível e necessário, realizar a escavação em partes, procurando manter a camada de proteção vegetal existente pelo maior tempo possível;

o) Compactar a superfície ou plantar vegetação, o mais breve possível, após o término dos serviços;

p) Utilizar barreiras físicas (tapumes, telas, lonas, entre outros) no contorno das áreas de serviço, evitando ou diminuindo a ação dos ventos e chuvas (Figura 6);

q) Desenvolver o planejamento físico da obra, procurando otimizar o tempo de duração desta atividade, para que, tão breve, as superfícies possam ser finalizadas;

r) Realizar a limpeza com a maior frequência possível para evitar o acúmulo de partículas.
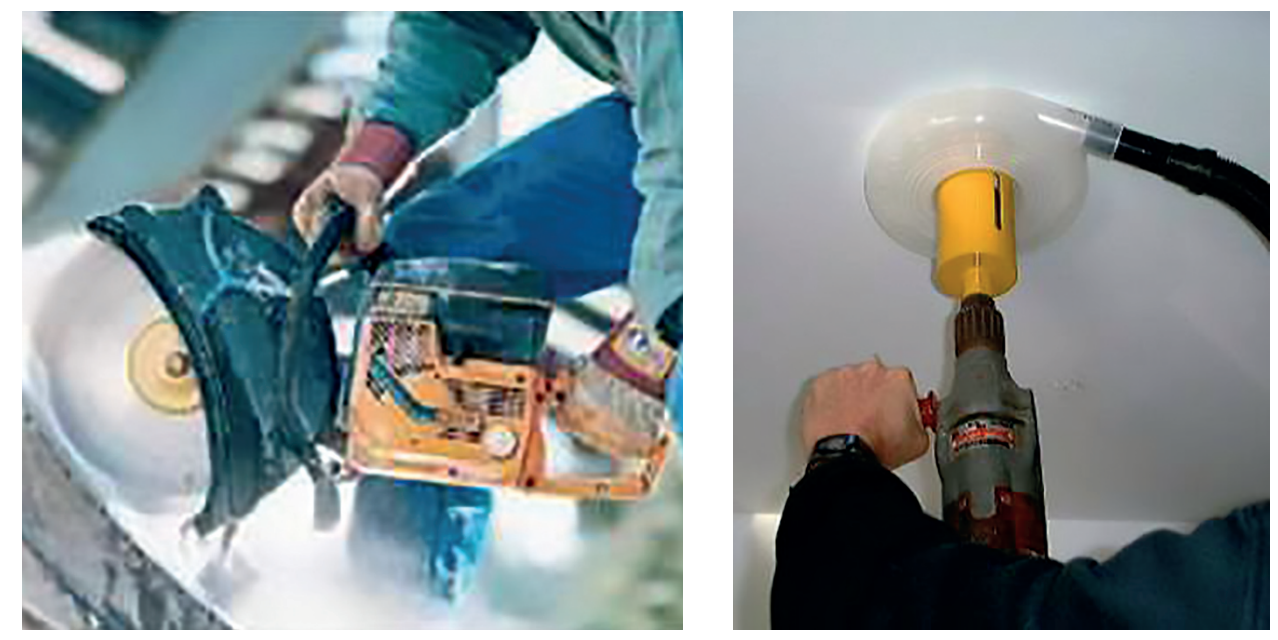

Figura 5 - Serra manual acoplada à mangueira de água e pefuratriz acoplada a sistema de coleta de pó. Fonte: www.contractorstools.com; www.dustmuzzle.com. Acesso em Nov. 2016.

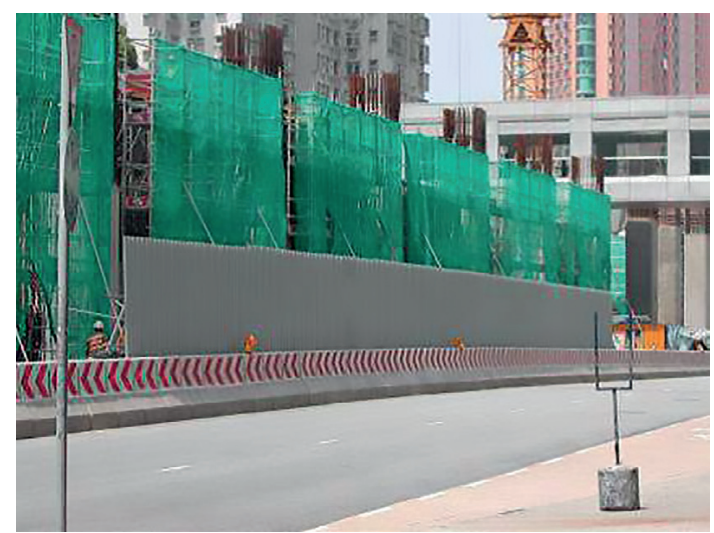

Figura 6 - Obra protegida com lona e andaimes fachadeiros. Fonte: EPD- Hong Kong, 2006. 
Vale salientar, que a eficácia e os resultados das medidas apresentadas, ainda que sejam preventivas, só podem ser garantidos a partir de uma continuidade cíclica de monitoramento durante toda a etapa de produção. É importante que o gestor da obra tenha o conhecimento adequado acerca de emissões de MP ou esteja amparado por profissional habilitado para que seja inserida a mitigação correta a cada atividade impactante.

\section{Conclusões}

O presente capítulo destacou a importância do controle e monitoramento das emissões de partículas provenientes dos canteiros de obra por meio das melhores práticas, com vista a proteger a saúde do trabalhador, da vizinhança da obra e do meio ambiente local. A geração de poeira pode ser substancialmente reduzida com a aplicação de técnicas cuidadosamente selecionadas de mitigação e gerenciamento eficaz da obra, uma vez que essas poeiras são difusas, tornando difícil o seu controle. O controle eficaz dessas emissões deve ser feito na sua fonte.

O controle da poeira pode mitigar alguns efeitos causados pela poluição, trazendo inúmeros benefícios tanto para os diferentes intervenientes da construção como para os construtores, por meio da melhor reputação empresarial com as autoridades reguladoras, além de proporcionar evoluções nas relações de trabalho com clientes, vizinhança e trabalhadores. Para a vizinhança e a comunidade, tal prática de controle possibilita menos interrupções na vida cotidiana, reduz os riscos para a saúde, além de diminuir os danos causados às propriedades. Já para o ambiente, pode reduzir a poluição do ar, água e os distúrbios provocados na fauna e flora existentes no entorno da edificação (LONDON COUNCILS, 2006).

O construtor deve ter como objetivo principal, portanto, não causar impactos no ambiente, o que impõe uma forte mudança na cultura hoje estabelecida pela construção civil e uma alteração nos sistemas construtivos existentes. Para que isso aconteça, é necessário reestudar os processos, visando estabelecer formas de evitar os impactos.

\section{Referências}

ARAÚJO, V.M; CARDOSO, F. Redução de impactos ambientais do canteiro de obras. Projeto Finep: Habitações mais sustentáveis. Finep. São Paulo, 2007.

ARAÚJO, I.P.S. Metodologia para Avaliação e Redução de Impactos Ambientais causados pela emissão de material particulado de canteiros de obras habitacionais com foco no impacto à vizinhança da obra. Dissertação (Mestrado) - Escola Politécnica de Salvador BA, 2014. 
ARAÚJO, I.P.S.; COSTA, D.B.; MORAES, R.J.B. Identification and Characterization of Particulate Matter Concentrations at Construction Jobsites. Sustainability (Basel), v. 6, p. 7666-7688, 2014.

BREEAM. Europe Commercial 2009 Assessor. Manual. BRE Global Ltd. 346p. 2009

CEQA. California Natural Resources Agency Guide. Construction Generated Criteria Air Pollutant and Precursor Emissions. CEQA 1-3. Farmington Hill, MI. 2009

CETESB. Companhia de Tecnologia de Saneamento Ambiental. Relatório da qualidade do ar de São Paulo. 2004. Disponível em: <http://www.cetesb.sp.gov.br>. Acesso em: abr. 2015.

CONAMA. Conselho Nacional do Meio Ambiente. 1990. Resolução conama $\mathrm{n}^{\circ} 003$. Disponível em: http:www.mma.conama.gov.br/conama. Acesso em: maio 2015.

COUNTESS ENVIRONMENTAL. 2006. WRAP fugitive dust handbook. Disponível em: http:// ulpeis.anl.gov/documents/dpeis/references/pdfs/Countess_Environmental_2006_ WRAP_Fugitive.pdf. Acesso em: set. 2015.

ENVIRONMENT AGENCY. Monitoring of particulate matter in ambient air around waste facilities. Technical Guidance Document (Monitoring) M17. Disponivel em: http:// www. environment-agency.gov.uk. Acesso em: mar. 2017.

ENVIRONMENTAL PROTECTION. The Air Quality Standards Regulations. 2010. Disponível em: http://www.legislation.gov.uk/uksi/2010/1001/pdf. Acesso em: jun. 2014.

EPA. Environmental Protection Agency. Characterization of buildingrelated construction and demolition debris in the United States Office of solidwaste. Estados Unidos, Junho de 1998. Reportn.o EPA 530-R-98-010.

EPD HONG KONG. Environmental Protection Department- Honk Kong. Air pollution control regulation relevant to the construction industry. Manual de treinamento da EPD - Hong Kong, 45p, 2006. Disponível em: http://www.epd-asg.gov.hk. Acesso em: nov. 2016.

LONDON COUNCILS. The Control of Dust and Emissions from Construction and Demolition - Best Practice Guidance. Londres: Greater London Authority, nov./ 2006.

GLA. Greater London Authority. The control of dust emissions from construction and demolition. Versão Draft London Best Practice Guide. London: Greater London authority e Association of London government, 2005.

GBC BRASIL. Green Building Council Brasil. Disponível em: http://www.gbcbrasil.org.br/ sistema/certificacao. Acesso em: ago. 2014.

IAQM. Institute Of Air Quality Management. Guidance on the Assessment of Dust from Demolition and Construction. Disponível em: http://www.iaqm.co.uk. Acesso em: Nov. 2016.

MARTINS, A. R. B. Caracterização e avaliação de poeiras presentes em canteiros de obras de edifícios verticais. Dissertação (Mestrado) - Escola Politécnica de Pernambuco. Recife, 2009. 
MUÑOZ, I.S.C.; PALACIOS, J.C.M. Gestiónen el control de emisionesdifusasenla actividad de la construcción. Universidad de Santiago de Chile, Facultad de Ingeniería. Santiago. 2001.

MORAES, R.J.B. Avaliação da emissão do material particulado proveniente de canteiros de obras habitacionais na fase de estrutura e alvenaria. Dissertação (Mestrado em Mestrado em Engenharia Ambiental Urbana) - Universidade Federal da Bahia, Bahia. 2015.

MORAES, R.J.B. ; COSTA, D. B.; ARAÚJO, I.P.S . Particulate matter concentration from construction sites focusing on concrete and masonry works. Journal of Environmental Engineering (New York, N.Y.), v. 1, p. 05016004-1, 2016.

PACYNA, J.M. The origin of artic air pollutants: lessons learned and future research. Science ofthe Total Environment, v. 160-161, p. 39-53, 1995.

MULESKI , G. E.; COWHERD, C. JR.; KINSEY, J. S. Particulate Emissions from Construction Activities. Journal of the Air \& Waste Management Association, 55:6, pp. 772-783, 2005.

RESENDE, F. Poluição atmosférica por emissão de material particulado: avaliação e controle nos canteiros de obras de edifícios. Dissertação (Mestrado) - Departamento de Engenharia de Construção Civil. Escola Politécnica, Universidade de São Paulo, São Paulo, 2007.

RESENDE, F.; CARDOSO, F. Gestão da emissão de material particulado no canteiro de obras de edifícios. V Simpósio Brasileiro de Gestão e Economia da Construção. Criação de Valor na Construção Civil: teoria e prática, Campinas, 2007.

US EPA. United States Environmental Protection Agency. Particle pollution and your health. Estados Unidos: US EPA, 2006. 2p.

\section{Sites consultados}

AIR QUALITY GUIDANCE NOTE. Disponível em: http://www.epa.nsw.gov.au. Acesso em: nov. 2016.

FUNDAÇÃO VANZOLINI. Disponível em: http://www.vanzolini.org.br. Acesso em: maio 2014.

Guidance on the Assessment of Dust from Demolition and Construction. Disponivel em: http://www.iaqm.co.uk. Acesso em: nov. 2016.

Revista CNT Transporte. Disponível em: http://www.cnt.org.br/Paginas/revista-cnttransporte-atual. Acesso em: nov. 2016.

http://www. contractorstools.com. Acesso em: nov. 2016.

http://www.dustmuzzle.com. Acesso em: nov. 2016 


\section{Seção III}

Subprojeto Aperfeiçoamento de

Sistemas de Proteção Coletiva em

Canteiros de Obras (SPSPC)

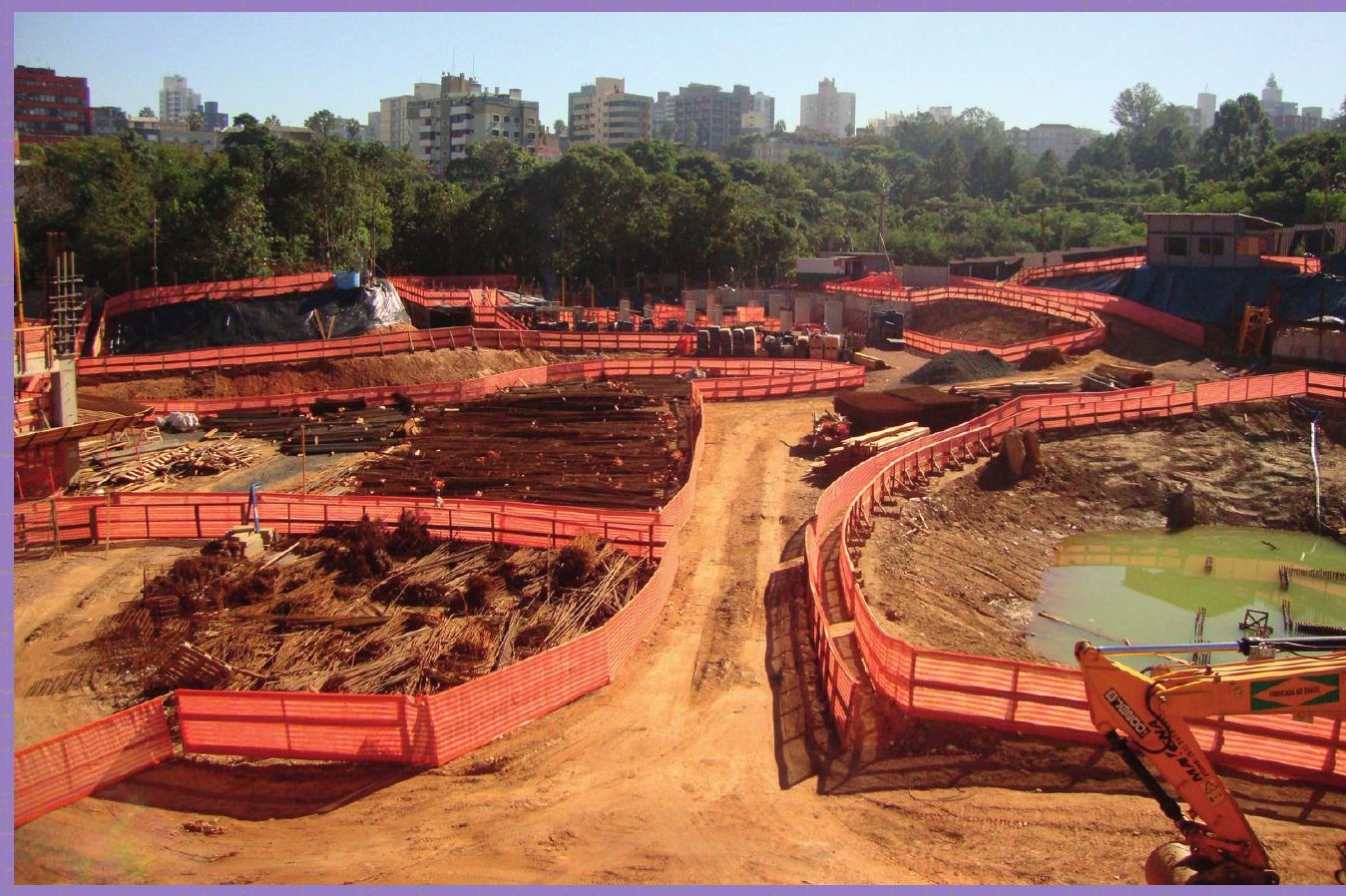




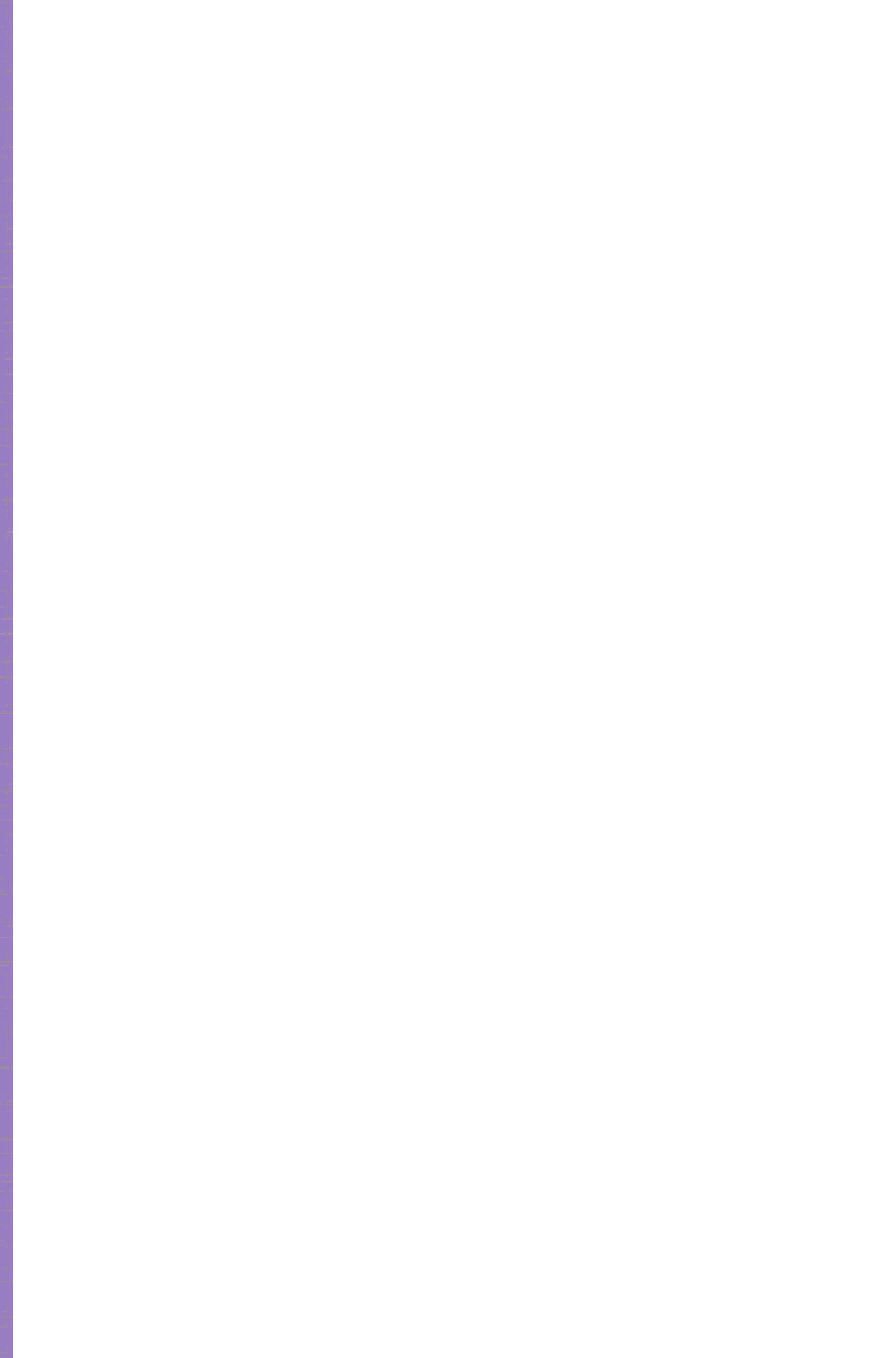




\title{
Avaliação de Requisitos de Desempenho de Sistemas de Proteção Periférica (SPP) em Obras de Edificações
}

\author{
Guillermina Andrea Peñaloza \\ Carlos Torres Formoso \\ Tarcisio Abreu Saurin
}

\section{Introdução}

Uma das proteções físicas comumente utilizadas nos canteiros de obra são os sistemas de proteção periférica (SPP), os quais oferecem proteção passiva e simultânea a vários trabalhadores, impedindo a queda de altura (GARCIA, 2010). No Brasil, de acordo com o Ministério de Trabalho e Emprego (BRASIL, 2013), os SPP encontram-se entre os dez equipamentos que frequentemente causam interdições de canteiros de obras. De fato, há evidências de que os requisitos associados aos SPP costumam ser os menos atendidos entre aqueles da NR 18 - Condições e Meio Ambiente de Trabalho na Indústria da Construção (SAURIN et al., 2000; MALLMANN, 2008; CAMBRAIA; FORMOSO, 2011; COSTELLA et al., 2014).

Apesar disso, é reconhecida a crescente expansão do número de fornecedores de equipamentos de proteção coletiva tanto no mercado brasileiro como em outros países (SCANMETAL, 2011; METRO..., 2009; ORMAN, 2012). Contudo, a quantidade de requisitos disseminados em diversos regulamentos e a falta de métodos para verificar a aderência dos SPP aos requisitos das normas e outros requisitos relevantes criam dificuldades para 
todas as partes interessadas, tais como: órgãos de fiscalização, os operários encarregados pela execução dos SPP e empresas construtoras, as quais carecem de ferramentas para comparar a eficiência e eficácia dos diferentes sistemas disponíveis no mercado.

Entre as proteções contra quedas dispostas na NR 18-Condições e Meio Ambiente de Trabalho na Indústria da Construção (BRASIL, 2014), este trabalho enfatiza os SPP do tipo guarda-corpo e rodapé (GCR) por serem os mais comumente utilizados nos canteiros de obra de edificações verticais e objeto frequente de embargos e interdições. A maioria das normas consultadas neste trabalho, como NR 18 - Condições e Meio Ambiente de Trabalho na Indústria da Construção (OCCUPATIONAL..., 1996), RTP 01 (FUNDACENTRO, 2003), OSHA 1926.502 (OCCUPATIONAL..., 1996), UNE-EN (ASOCIACIÓN..., 2004), S-2.1 (CANADIAN..., 1981), apresenta requisitos de resistência estrutural e configuração geométrica dos SPP, negligenciando a eficiência e a flexibilidade deles, bem como não tratam dos processos de montagem e desmontagem. Por outro lado, no Brasil os órgãos regulamentadores e de fiscalização costumam considerar os requisitos de normas estrangeiras para aperfeiçoar as normas nacionais e lidar com lacunas.

O objetivo deste trabalho é propor um conjunto de requisitos de desempenho para SPP. Foram definidos critérios qualitativos e quantitativos, utilizados para a construção de um protocolo de avaliação de desempenho desses sistemas. São apresentados exemplos de aplicação desse protocolo em três tipos de SPP, de madeira, misto e metálico. A avaliação de um conjunto de equipamentos disponíveis no mercado da Região Metropolitana de Porto Alegre, RS, ilustra como esse protocolo pode contribuir para a análise de soluções existentes no mercado, que podem ser objeto de aperfeiçoamento.

\section{Método de Pesquisa \\ 2.1 Delineamento da Pesquisa}

A primeira etapa desta pesquisa foi desenvolvida por meio da identificação de requisitos provenientes de normas nacionais e internacionais. Por outro lado, a definição de novos requisitos e das fontes de evidências surgiu a partir de entrevistas e grupos de discussão com engenheiros responsáveis por obras que usavam SPP, engenheiros e técnicos em segurança no trabalho, projetistas de proteções coletivas, auditores fiscais, representantes de empresas que fornecem SPP e trabalhadores responsáveis pela execução dos SPP.

$\mathrm{Na}$ segunda etapa, houve a classificação dos requisitos de acordo com a natureza de cada um, em três categorias: segurança, eficiência e flexibilidade. Também foi realizado um workshop, que envolveu a participação conjunta de representantes de várias partes, com a finalidade de discutir os resultados de novas aplicações do protocolo e identificar oportunidades de melhorias nos SPP avaliados. 
Na terceira etapa da pesquisa, o protocolo foi dividido em duas partes: a primeira com ênfase na avaliação dos requisitos na situação de projeto; e a segunda na situação de uso dentro do canteiro de obras. Para cada requisito, foram estabelecidos critérios de avaliação.

Na quarta e última etapa, foram realizadas aplicações do protocolo por outros pesquisadores, como forma de avaliar a facilidade de uso dele. Dessa forma, a partir da retroalimentação desses outros pesquisadores, bem como da experiência acumulada ao longo de todas as etapas, foi consolidado o protocolo de avaliação de requisitos de desempenho de SPP.

\subsection{Identificação de Requisitos}

Os requisitos de SPP foram identificados a partir de pesquisa bibliográfica, análise documental e entrevistas. No que diz respeito às duas primeiras fontes, foram consultadas normas e regulamentos nacionais como NR-18-Condições e Meio Ambiente de Trabalho na Indústria da Construção (BRASIL, 2014) e RTP 01 (FUNDACENTRO, 2003), normas internacionais, tais como a EN 13374 (ASOCIACIÓN..., 2004), OSHA 1926.502 (OCCUPATIONAL, 1996), S-2.1, r.6, (CANADIAN..., 1981), artigos científicos (LAN; DAIGLE, 2009; CHEUNG, 2012; SULOWSKI, 2014), três memoriais descritivos de SPP patenteados (MCLAUGHLIN; McCOY, 1976; HOLLOMAN, 1994; OSTROW, 2001) e análise de relatórios técnicos de ensaios laboratoriais, encomendados pelo Sindicato da Industria da Construção (SINDUSCON/RS), para verificação dos requisitos de carga estática de três tipos de SPP (madeira, misto e metálico) e realizados pelo Instituto Tecnológico em Desempenho e Construção Civil da Universidade do Vale do Rio dos Sinos (UNISINOS). A segunda fonte de identificação de requisitos foram entrevistas individuais semiestruturadas e discussões em seminários e workshops com um grupo de trabalho. Tal grupo era integrado por representantes de sete empresas construtoras, as quais tinham interesse numa avaliação independente dos SPP, bem como auditores fiscais do trabalho, projetistas e fornecedores de SPP. A Tabela 1 apresenta o perfil dos participantes entrevistados. As entrevistas foram gravadas e transcritas, tiveram duração média de uma hora e foram baseadas num roteiro de quinze questões que dava origem a outras no decorrer da entrevista. A partir das transcrições de entrevistas, discussões e dos documentos consultados, foram identificados 33 requisitos de SPP.

\subsection{Categorização dos Requisitos}

Os 33 requisitos identificados foram agrupados em três categorias: (a) 15 requisitos de segurança; (b) 12 requisitos de eficiência e (c) 6 requisitos de flexibilidade. Os requisitos da categoria segurança tem origem, em sua maioria (87\%), nas normas e estão associados à resistência estrutural, durabilidade e dimensões. Já a maioria (83\%) dos requisitos da categoria eficiência dos SPP teve origem em entrevistas, indicando 
que as normas negligenciam esse tipo de demanda. Os requisitos ligados à eficiência contemplam questões de ergonomia, de produtividade, reaproveitamento e de custo ao longo do ciclo de vida.

No que se refere à flexibilidade, o SPP deve ser adaptável à mudança em relação a configurações geométricas, detalhes, distintas etapas de obra e diferentes técnicas construtivas. Similarmente à categoria eficiência, os requisitos associados à flexibilidade tiveram origem, em sua maioria (83\%), nas entrevistas, indicando que as normas também negligenciam esse tipo de requisito.

Tabela 1 - Perfil dos participantes entrevistados.

\begin{tabular}{|c|c|c|c|}
\hline Qtd. & Atividade profissional & Empresa/Instituição & Tempo de experiência \\
\hline 12 & Engenheiros civis & Empresas construtoras & entre 4 e 13 anos \\
\hline 06 & Engenheiros em SST & Empresas construtoras & entre 1 e 6 anos \\
\hline 10 & Técnicos em SST & Empresas construtoras & entre 6 meses e 2 anos \\
\hline 03 & Projetistas de SPP & Empresas de consultoria em SST & 6,11 e 30 anos \\
\hline 03 & $\begin{array}{l}\text { Auditores Fiscais do } \\
\text { Trabalho }\end{array}$ & $\begin{array}{l}\text { Ministério do Trabalho e } \\
\text { Emprego }\end{array}$ & 18,20 e 25 anos \\
\hline 02 & $\begin{array}{l}\text { Fornecedores de SPP } \\
\text { industrializados }\end{array}$ & $\begin{array}{l}\text { Empresas nacionais e regionais } \\
\text { fornecedoras de SPP }\end{array}$ & 13 e 18 anos \\
\hline 18 & $\begin{array}{l}\text { Trabalhadores que } \\
\text { executam SPP }\end{array}$ & Empresas terceirizadas em SST & entre 5 meses e 7 anos \\
\hline
\end{tabular}

\subsection{Níveis de Atendimento}

Para cada requisito ( $R$ ), foram estabelecidos critérios de avaliação (C). Ao todo, foram propostos 40 critérios entre os requisitos de análise de projeto e análise em uso dos SPP. Contudo, no presente estudo, alguns critérios possuem caráter qualitativo, visto que parte dos requisitos não pode ser quantificada em razão de sua natureza. Além disso, foi proposto um sistema de avaliação em quatro níveis: atende (1 ponto); atende parcialmente (0,5 pontos); não atende (0 ponto); e não se aplica. Devido à limitação de tempo deste estudo, a caracterização da amostra estabelece que a avaliação em uso de cada requisito deve ser realizada em dois pavimentos-tipo de cada obra visitada. Em cada pavimento devem ser escolhidos quatro trechos diferentes de SPP na periferia da edificação. Em cada trecho, devem ser escolhidos três módulos adjacentes de SPP para serem avaliados (Figura 1). Por sua vez, no momento da escolha, devem ser consideradas situações na quais há claramente uma falha entre os módulos de cada trecho, como instabilidade ou deslocamento dos montantes verticais, incorreta fixação à estrutura de sustentação, frestas entre o rodapé e a superfície de trabalho 
e componentes deteriorados. A nota do requisito é dada pela média de atendimento entre os dois pavimentos.

\subsection{Fontes de Evidências}

A fim de facilitar a aplicação do protocolo, foram definidas as fontes de evidências para avaliar cada requisito. Por exemplo, requisitos vinculados ao projeto do SPP exigem a análise de especificações, dimensões, materiais e procedimentos de execução, entre outros. De modo similar, a avaliação da resistência dos SPP aos esforços solicitantes necessariamente requer a consulta aos laudos técnicos de ensaio laboratorial. Já outros requisitos exigem a análise em uso, principalmente aqueles associados às tarefas de montagem e desmontagem do SPP. Ainda, outros requisitos exigem a realização de entrevistas com a gerência da obra, trabalhadores e projetistas, como no caso dos requisitos "o SPP tem baixo custo ao longo do ciclo de vida".

\subsection{Escolha dos SPP e Caracterização das Obras Visitadas}

Foram escolhidos nove tipos de SPP para a aplicação do protocolo. A escolha deles ocorreu em função de empresas construtoras locais terem desenvolvido recentemente projetos de SPP de madeira, metálicos e mistos e terem interesse em uma avaliação independente deles. O Quadro 1 apresenta as características de cada sistema avaliado.

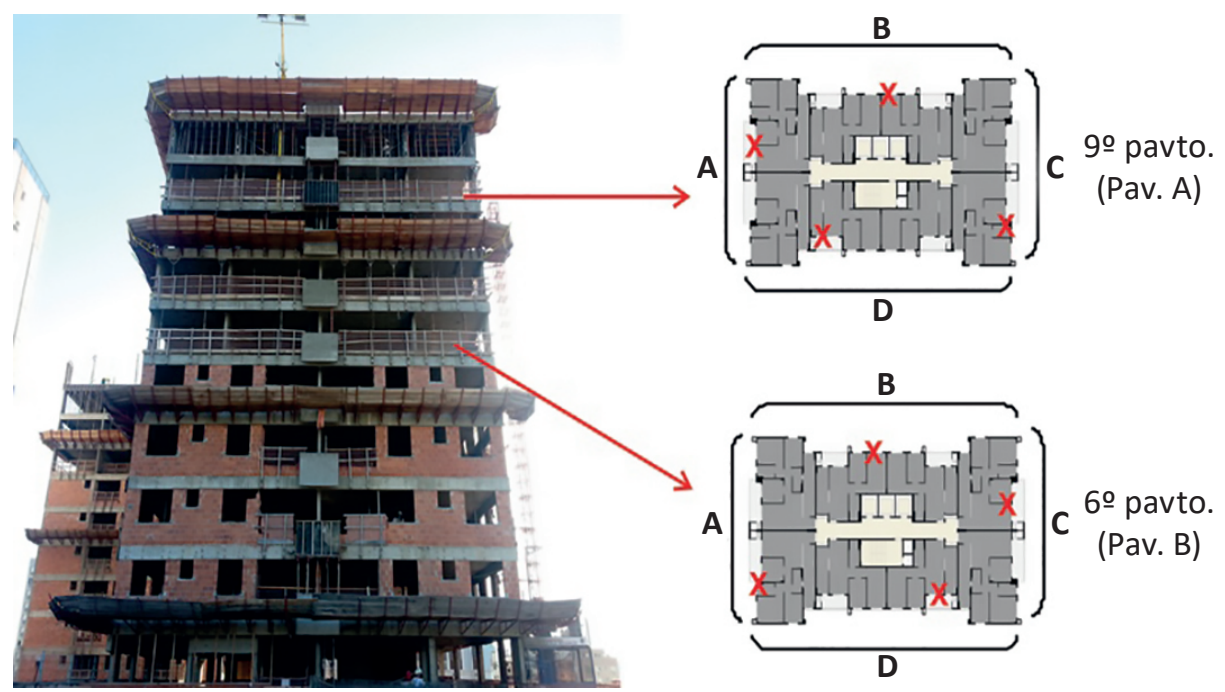

Figura 1 - Escolha dos trechos de SPP a serem avaliados. Fonte: Peñaloza, 2015. 
Quadro 1 - Características dos SPP avaliados.

MADEIRA (MA-1)

Constituído em madeira com tela de proteção. A união dos componentes ocorre mediante pregos. Os montantes são fixados na viga por meio de barra de ancoragem, arruela e porca do tipo borboleta. Uso: sistema construtivo tradicional com estrutura de concreto armado moldada in loco.

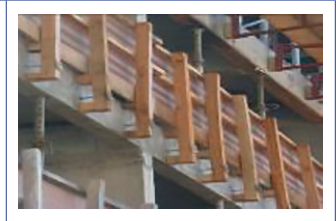

MADEIRA (MA-2)

Constituído em madeira com tela de proteção. A união dos componentes ocorre mediante pregos. Os montantes são fixados à superfície da laje utilizando-se barras de ferro de $8 \mathrm{~mm}$. Uso: sistema construtivo tradicional.

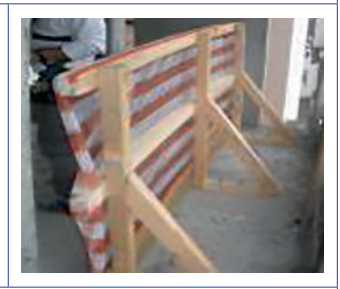

\section{METÁLICO (ME-1)}

Constituído por módulos metálicos, nas dimensões 1,50×1,30 m. A união dos módulos ocorre mediante encaixe. A fixação dos montantes ocorre em área grauteada da alvenaria por meio de uma alça de ancoragem, já incorporada ao sistema. Uso: sistema construtivo em alvenaria estrutural.

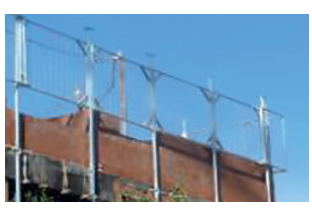

\section{METÁLICO (ME-2)}

Constituído por módulos metálicos, nas dimensões $0,80 \times 1,30$ $\mathrm{m}$ e 1,10 m x 1,30 m. A união dos módulos é feita mediante encaixe, travas e pinos de correr. A fixação dos montantes ocorre na alvenaria grauteada ou viga com o uso de barra de ancoragem, já incorporada ao sistema. Uso: sistema construtivo em alvenaria estrutural e tradicional.

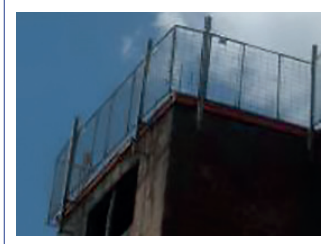

\section{MISTO (MI-1)}

Constituído por travessões e rodapé em madeira com tela de proteção e montantes metálicos. A união dos elementos horizontais é realizada mediante encaixe nas alças dos montantes. A fixação à fôrma da viga é do tipo sargento, a qual consiste em braçadeiras reguláveis acopladas ao montante. Uso: sistema construtivo tradicional.

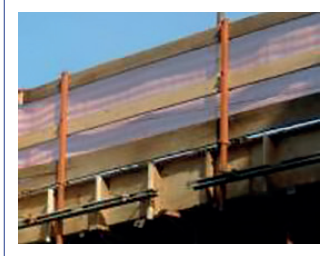

\section{MISTO (MI-2)}

Constituído por travessões e rodapé em madeira com tela de proteção e montantes metálicos. A união dos elementos horizontais ocorre mediante encaixe nas alças dos montantes. Os montantes são fixados às escoras das lajes por meio de uma treliça incorporada aos mesmos. Uso: sistema construtivo tradicional.

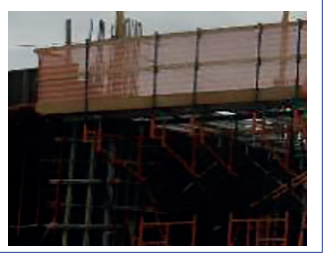




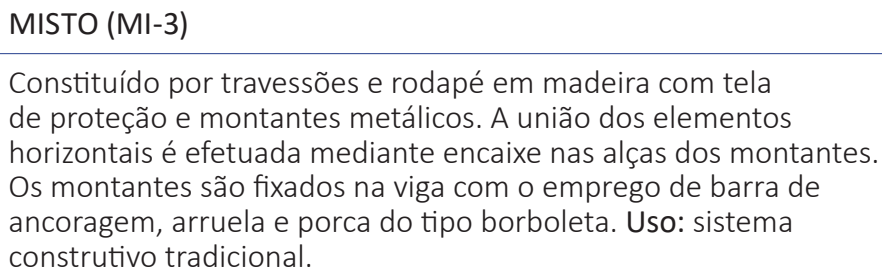

Constituído por travessões e rodapé em madeira com tela de proteção e montantes metálicos. A união dos elementos horizontais é mediante encaixe nas alças dos montantes. Os montantes são fixados à superfície da laje por meio de parafusos. Uso: sistema construtivo tradicional.

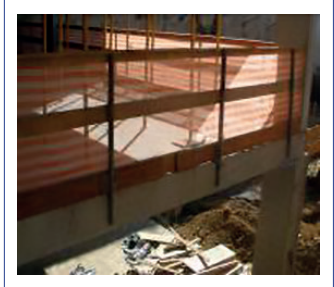

MISTO (MI-5)

Constituído por travessões e rodapé em madeira com tela de proteção e montantes metálicos. A união dos elementos horizontais é feita mediante encaixe nas alças dos montantes. Os montantes são fixados na viga fazendo-se uso de barra de ancoragem, arruela e porca do tipo borboleta. Uso: sistema construtivo tradicional.

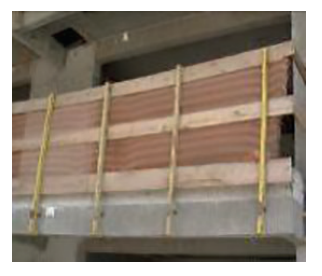

A Tabela 2 apresenta a quantidade de obras em que cada tipo de SPP foi avaliado. Tais obras correspondem a edifícios residenciais de quatro ou mais pavimentos de sete empresas construtoras de médio e grande porte, atuantes na Região Metropolitana de Porto Alegre. Os SPP em madeira e mistos eram comumente utilizados pelas construtoras nas obras com sistema construtivo tradicional. A avaliação deles foi realizada após a retirada das fôrmas, nas fases de montagem e desmontagem, quando já havia a estrutura de concreto armado. Já no sistema de alvenaria estrutural eram utilizados SPP metálicos, e a avaliação foi realizada na única fase em que o sistema era empregado. No total, foram realizadas 39 aplicações do protocolo em 26 canteiros de obra, sendo o protocolo, em algumas obras, aplicado em fases diferentes da construção. A coleta de dados, em cada aplicação do protocolo, teve uma duração média de $4 \mathrm{~h}$ entre observações, medições e entrevistas, envolvendo de dois a três pesquisadores. Em todas as aplicações, inicialmente, foi realizada a avaliação do projeto de SPP conforme a lista de requisitos estabelecidos para essa etapa, seguida da análise em uso, em dois pavimentos-tipo, em cada obra visitada. 
Tabela 2 - Quantidade de obras em que cada SPP foi avaliado.

\begin{tabular}{lll}
\hline Sistema Construtivo & SPP & Qtde. Obras \\
\hline Tradicional & MA-1 & 9 \\
\cline { 2 - 3 } & MA-2 & 3 \\
\cline { 2 - 3 } & MI-1 & 2 \\
\cline { 2 - 3 } & MI-2 & 2 \\
\cline { 2 - 3 } & MI-3 & 1 \\
\cline { 2 - 3 } & MI-4 & 2 \\
\hline Alvenaria Estrutural & ME-1 & 2 \\
\cline { 2 - 3 } & ME-2 & 4 \\
\hline Total & & 1 \\
\hline
\end{tabular}

\subsection{Oportunidades de Melhoria}

A partir dos resultados decorrentes das aplicações do protocolo, foi realizada uma reunião individual com cada uma das empresas construtoras participantes. Tais reuniões eram integradas por um engenheiro em segurança ou engenheiro responsável pela obra e por pelo menos um técnico em segurança. Como as empresas construtoras não tinham projetistas de SPP em seus quadros, foram realizadas duas reuniões individuais com dois projetistas de SPP que prestam serviços a seis das oito empresas construtoras. As entrevistas individuais foram gravadas e transcritas, tiveram duração média de 1,5 h e foram baseadas nos requisitos menos atendidos. A partir das entrevistas, buscou-se entender quais as dificuldades das empresas e projetistas em respeitar os requisitos menos atendidos conforme as avaliações. Isso possibilitou identificar oportunidades de aperfeiçoamentos necessários aos SPP.

\section{Resultados}

\subsection{Avaliação de Requisitos de Segurança}

O Quadro 2 apresenta os dez requisitos de desempenho referentes à segurança e compara o atendimento aos requisitos de projeto dos diferentes SPP, sendo apresentada uma média das várias obras em que cada sistema é usado. Pode-se observar que os SPP metálicos (SPP-ME) apresentam maior porcentagem de atendimento que os SPP em madeira (SPP-MA). Por exemplo, os projetos dos SPP-MA não apresentavam a especificação das etapas de montagem, desmontagem e manutenção, bem como os correspondentes riscos. Os projetos de SPP mistos (SPP-MI), embora também não 
especifiquem etapas de montagem, desmontagem e manutenção, possuem maior grau de detalhamento em função do montante pré-fabricado, o qual tem pouca tolerância a irregularidades na execução.

Quadro 2 - Comparação do atendimento aos requisitos de segurança em projeto.

\begin{tabular}{|c|c|c|c|c|c|c|c|c|c|c|c|}
\hline 员 & & & & GURA & $A-F$ & uisitc & de Proj & & & & \\
\hline 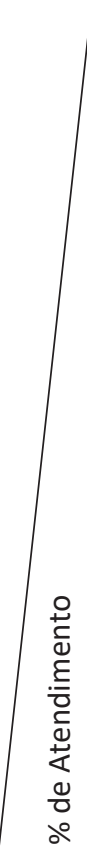 & 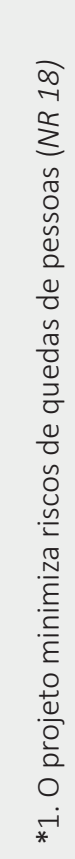 & 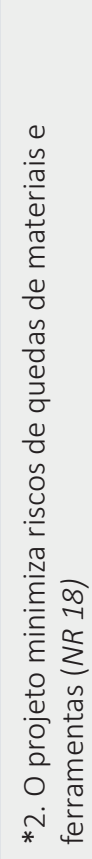 & 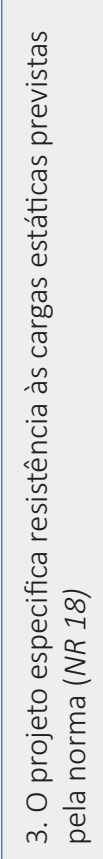 & 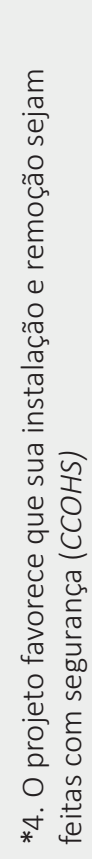 & 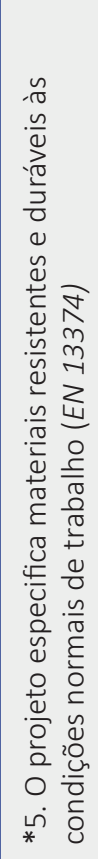 & 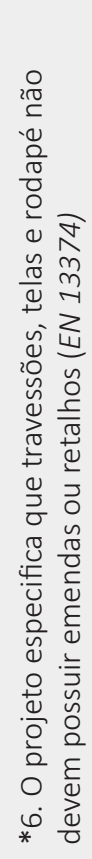 & 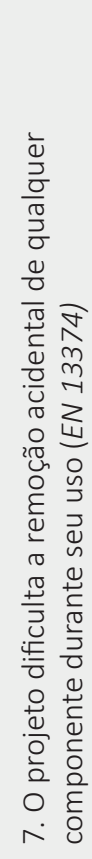 & 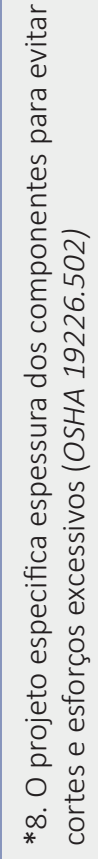 & 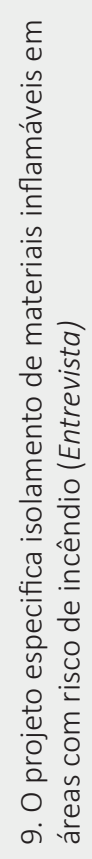 & 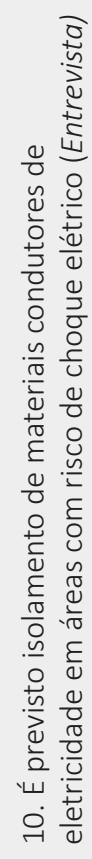 & 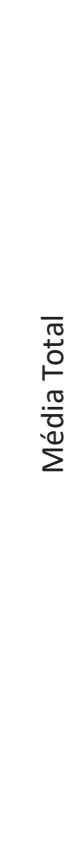 \\
\hline MA-1 & 100 & 100 & 100 & 0 & 50 & 0 & 0 & 100 & 0 & $N A$ & 50 \\
\hline MA-2 & 100 & 100 & 100 & 0 & 50 & 0 & 0 & 100 & 0 & NA & 50 \\
\hline MI-1 & 100 & 100 & 0 & 0 & 50 & 0 & 100 & 100 & 0 & 0 & 45 \\
\hline MI-2 & 100 & 100 & 100 & 0 & 50 & 0 & 100 & 100 & 0 & 0 & 55 \\
\hline MI-3 & 100 & 100 & 100 & 0 & 50 & 0 & 100 & 100 & 0 & 0 & 55 \\
\hline MI-4 & 100 & 100 & 0 & 0 & 50 & 0 & 100 & 100 & 0 & 0 & 45 \\
\hline MI-5 & 100 & 100 & 100 & 0 & 50 & 0 & 100 & 100 & 0 & 0 & 55 \\
\hline ME-1 & 100 & 100 & 100 & 100 & 100 & 100 & 100 & NA & NA & 0 & 88 \\
\hline ME-2 & 100 & 100 & 100 & 100 & 100 & 100 & 100 & NA & NA & 0 & 88 \\
\hline
\end{tabular}

*requisitos aplicáveis tanto na etapa de análise de projeto como na análise de uso.

O Quadro 3 apresenta onze requisitos de desempenho quanto à segurança e compara as médias de atendimento de uso dos SPP-MA com os SPP-MI e SPP-ME. Contudo, ao comparar os SPP-MA e SPP-MI com os SPP-ME, pode-se observar que os 
SPP-ME apresentam o maior atendimento aos requisitos de uso. Por exemplo, seis dos oito SPP-MA-1 avaliados atendiam parcialmente ao requisito 5 (a instalação e a remoção do SPP devem ser feitas com segurança). Nessa situação, o atendimento parcial deviase à falta ou uso incorreto de EPIs, ao uso de ferramentas e equipamentos inadequados e, em muitos casos, à falta de informação sobre as ferramentas e equipamentos adequados e disponíveis para realizar a tarefa, bem como à ausência de definição de uma sequência de montagem e desmontagem. As deficiências de concepção dos SPP contribuem para atitudes inseguras dos operários, tais como segurar nas escoras para não perder o equilíbrio, utilizar escadas sem proteção, posicionar-se sobre as plataformas de proteção ou sobre o rodapé para fixá-lo, como ilustrado na Figura 2.

Quadro 3 - Comparação do atendimento aos requisitos de segurança em uso.

\begin{tabular}{|c|c|c|c|c|c|c|c|c|c|c|c|c|}
\hline 용 & & & & SEG & RANÇA & - Requ & isitos d & e Uso & & & & \\
\hline 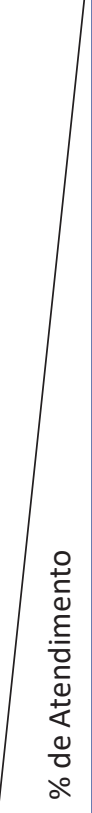 & 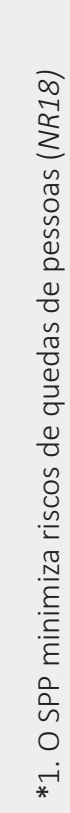 & 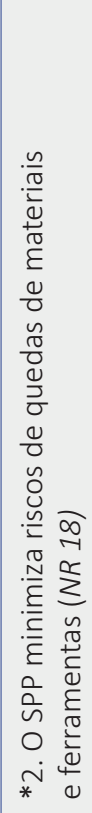 & 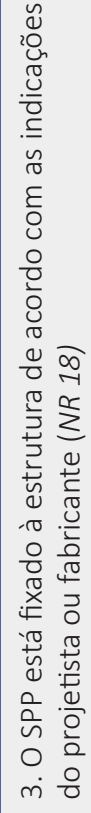 & 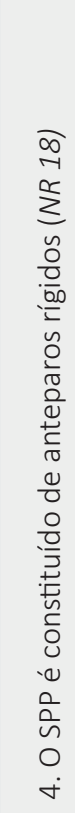 & 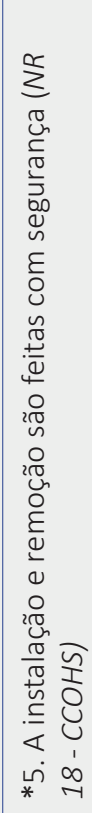 & 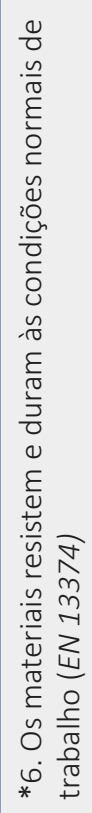 & 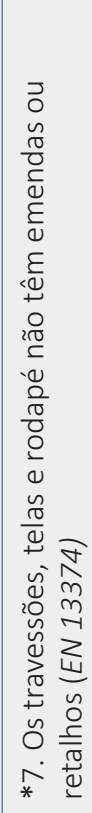 & 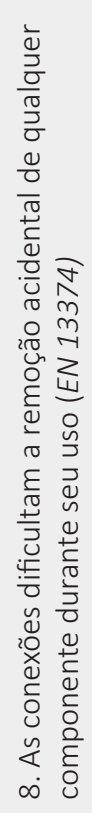 & 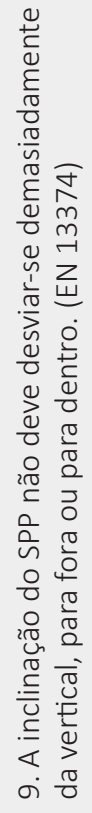 & 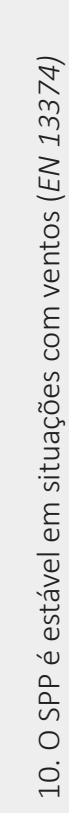 & 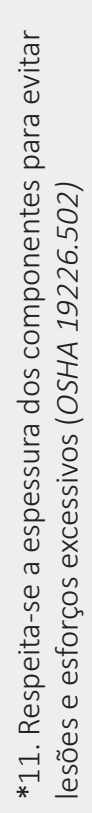 & 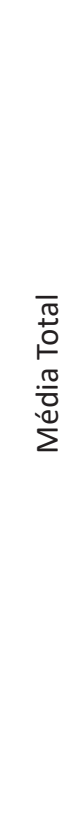 \\
\hline MA-1 & 62 & 57 & 63 & 79 & 42 & 44 & 38 & 73 & 100 & 95 & 75 & 66 \\
\hline MA-2 & 73 & 96 & 100 & 100 & 50 & 50 & 56 & 78 & NA & 97 & 67 & 77 \\
\hline MI-3 & 88 & 73 & 63 & 87 & 58 & 38 & 44 & 63 & 87 & 97 & 100 & 73 \\
\hline MI-4 & 100 & 87 & 100 & 92 & 75 & 63 & 69 & 75 & 100 & 95 & 100 & 87 \\
\hline MI-5 & 100 & 68 & 100 & 81 & 100 & 44 & 50 & 56 & 100 & 90 & 100 & 81 \\
\hline ME-1 & 100 & 0 & 100 & 100 & 100 & 100 & 100 & 100 & 100 & 100 & NA & 90 \\
\hline ME-2 & 100 & 0 & 50 & 100 & 100 & 100 & 100 & 100 & 100 & 100 & NA & 85 \\
\hline
\end{tabular}

* requisitos aplicáveis tanto na etapa de análise de projeto como na análise de uso 

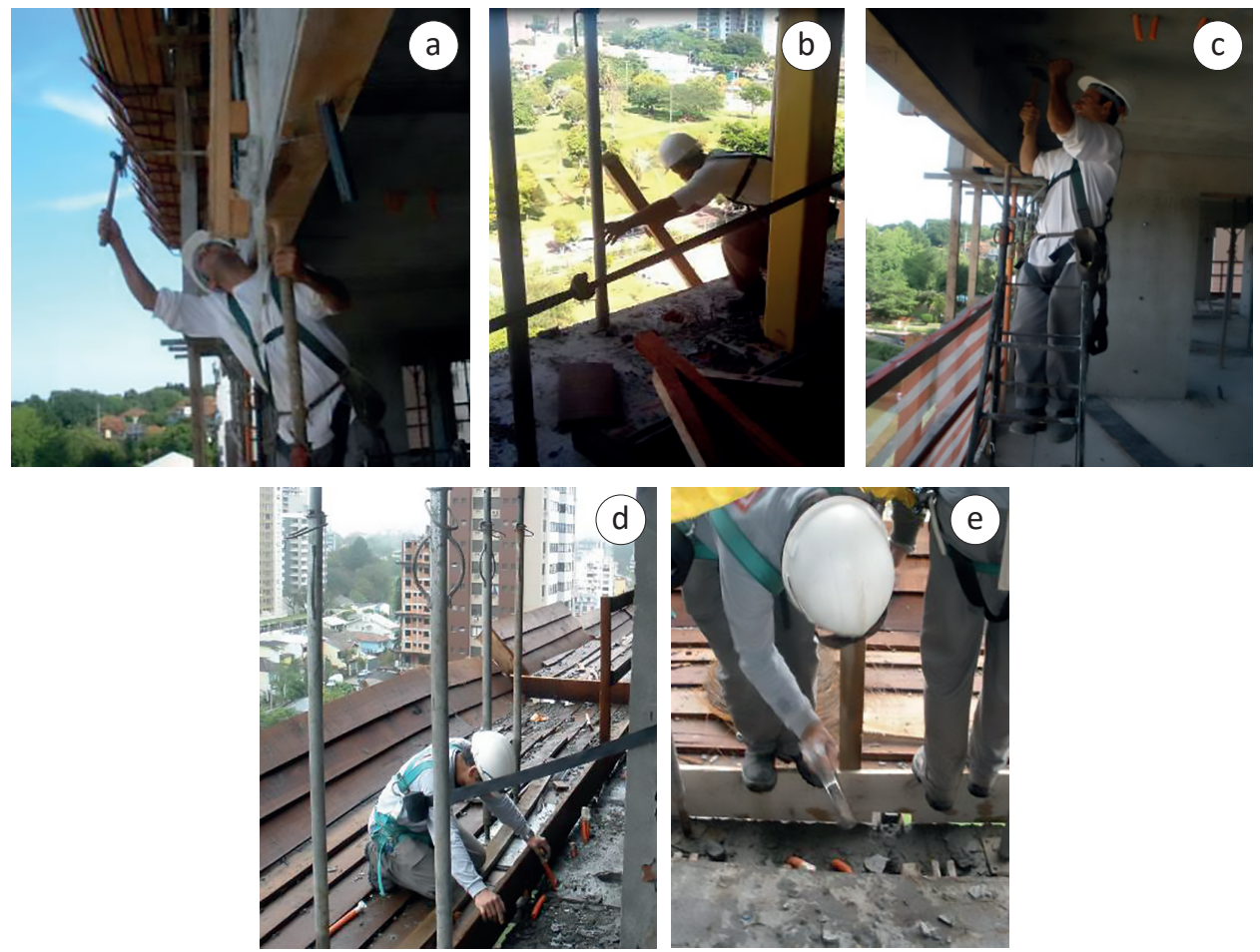

Figura 2 - Exemplo de atendimento parcial ao requisito 5 - montagem SPP-MA-1. Fonte: Peñaloza, 2015.

\subsection{Avaliação de Requisitos de Eficiência}

O Quadro 4 apresenta os requisitos de eficiência dos SPP e compara o atendimento a estes requisitos na fase de projeto. Mais uma vez, os SPP-ME obtiveram maior grau de atendimento em comparação com os SPP-MI e SPP-MA. Isso se deve principalmente aos mecanismos de conexão entre componentes, como encaixes, travas e pinos, que facilitam a montagem e desmontagem. Tais mecanismos evitam esforços excessivos, ao mesmo tempo que aumentam a produtividade. Além disso, os componentes de conexão integrados ao montante, e este, por sua vez, integrado às telas modulares, diminuem a variedade e quantidade de componentes, além de reduzir a quantidade de manuseios durante o transporte, diminuindo em consequência a exposição dos trabalhadores aos riscos nessa atividade. 
Quadro 4 - Comparação do atendimento aos requisitos de eficiência em projeto.

\begin{tabular}{|c|c|c|c|c|c|c|c|c|}
\hline$\frac{0}{n}$ & \multicolumn{6}{|c|}{ EFICIÊNCIA - Requisitos de Projeto } & \multirow{2}{*}{\multicolumn{2}{|c|}{ 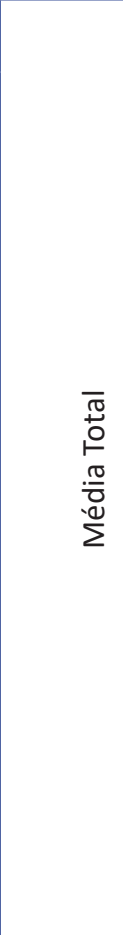 }} \\
\hline 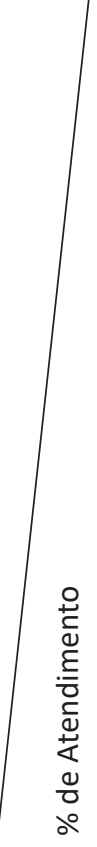 & 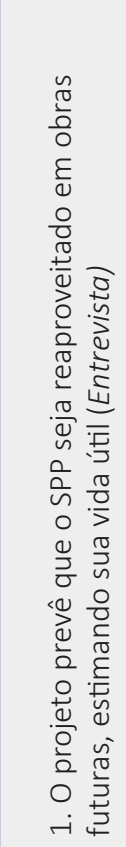 & 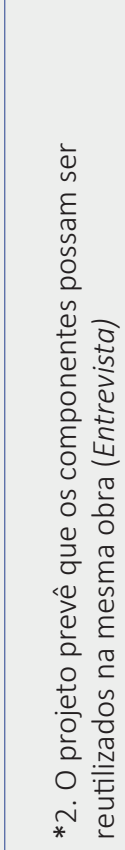 & 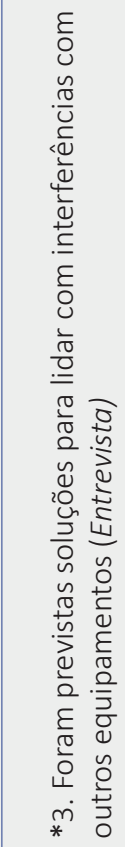 & 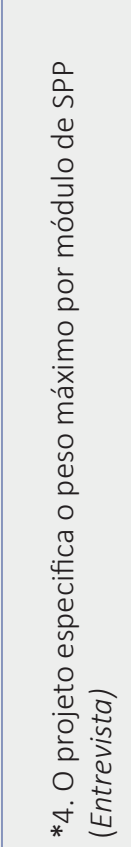 & 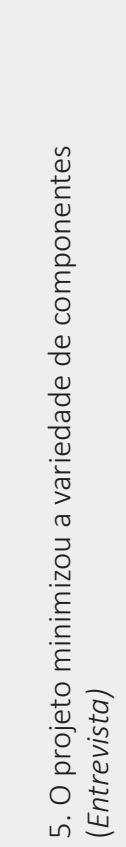 & 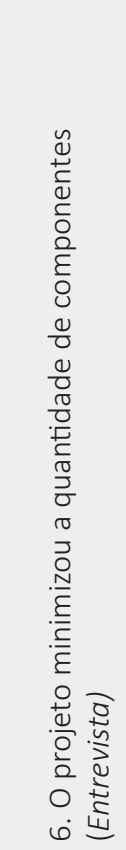 & & \\
\hline MA-1 & 0 & 100 & 0 & 0 & 0 & 0 & 16 & \\
\hline MA-2 & 0 & 100 & 0 & 0 & 0 & 0 & 16 & \\
\hline MI-1 & 50 & 50 & 0 & 0 & 0 & 100 & 33 & \\
\hline MI-2 & 50 & 50 & 100 & 0 & 0 & 100 & 50 & \\
\hline MI-3 & 50 & 50 & 0 & 0 & 0 & 0 & 16 & \\
\hline $\mathrm{MI}-4$ & 50 & 50 & 0 & 0 & 0 & 100 & 33 & \\
\hline MI-5 & 50 & 50 & 0 & 0 & 0 & 100 & 33 & \\
\hline ME-1 & 100 & 100 & 100 & 0 & 100 & 100 & 83 & \\
\hline ME-2 & 100 & 100 & 100 & 0 & 100 & 100 & 83 & \\
\hline
\end{tabular}

* requisitos aplicáveis tanto na etapa de análise de projeto como na análise de uso.

O Quadro 5 compara a porcentagem de atendimento aos requisitos de uso. Destaca-se que doze dos dezoito SPP-MA avaliados não atenderam ao requisito 7 (reduzir o esforço físico nas atividades de montagem do SPP). Ao analisar a carga postural dos SPP-MA, a postura de pé apoiado sobre os dois joelhos curvados ocorreu em 75\% das observações, estando então na categoria de risco 4 (risco alto), conforme o método OWAS (Figura 3). Já a postura de costas curvadas, a qual encontra-se no 
limite da categoria de risco 2 (risco médio), foi constatada em 75\% das observações. As posturas desfavoráveis de costas e joelhos devem-se principalmente à fixação de peça por peça mediante pregos (Figura 4).

Quadro 5 - Comparação do atendimento aos requisitos de eficiência em uso.

\begin{tabular}{|c|c|c|c|c|c|c|c|c|c|c|c|c|}
\hline \multirow[b]{2}{*}{ : } & \multicolumn{11}{|c|}{ EFICIÊNCIA - Requisitos de Uso } & \multirow[b]{2}{*}{$\begin{array}{l}\bar{\pi} \\
\stackrel{0}{0} \\
. \frac{\pi}{0} \\
\stackrel{.0}{\Sigma}\end{array}$} \\
\hline & 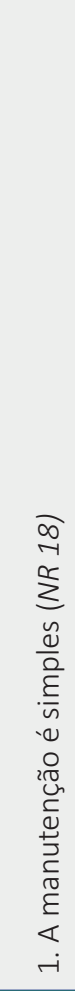 & 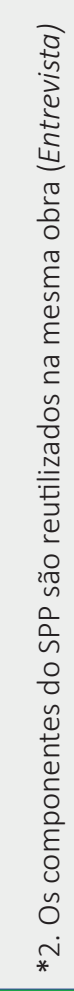 & 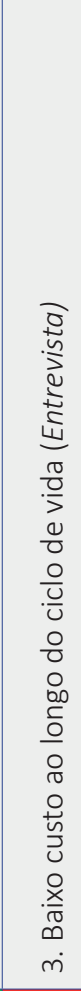 & 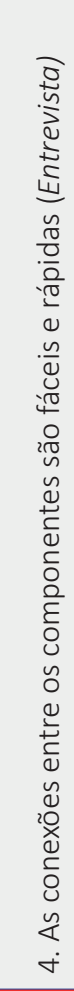 & 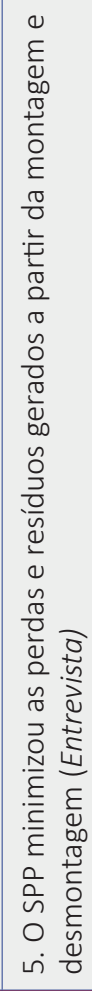 & 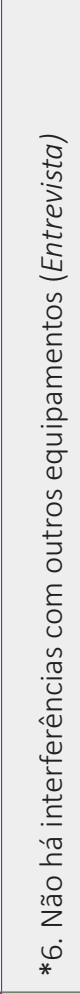 & 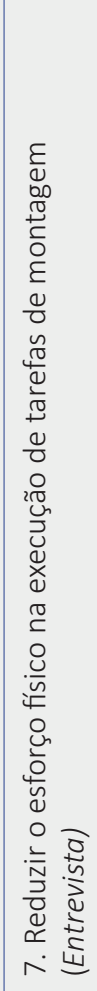 & 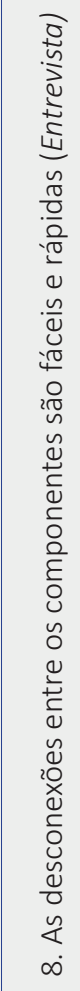 & 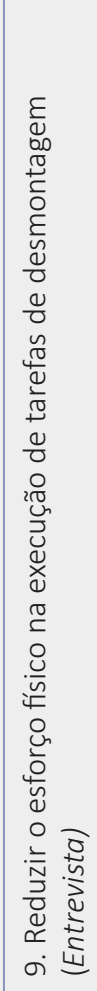 & 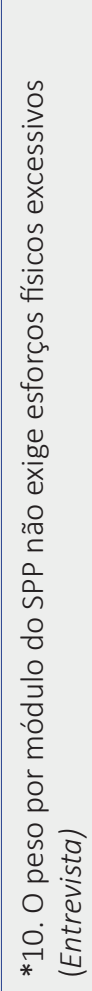 & 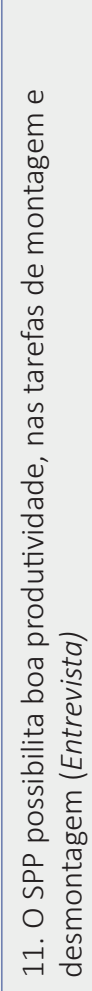 & \\
\hline MA-1 & 100 & 100 & 0 & 0 & 0 & 50 & 0 & 50 & 50 & NA & 0 & 35 \\
\hline MA-2 & 100 & 0 & 0 & 0 & 0 & 50 & 0 & 50 & 50 & NA & 0 & 22 \\
\hline MI-1 & 50 & 100 & 50 & 100 & 50 & 50 & 100 & 100 & 100 & 100 & 100 & 81 \\
\hline MI-2 & 100 & 100 & 50 & 100 & 50 & 100 & 100 & 100 & 100 & 100 & 100 & 91 \\
\hline MI-3 & 50 & 100 & 50 & 50 & 0 & 50 & 100 & 100 & 100 & 100 & 0 & 64 \\
\hline $\mathrm{MI}-4$ & 50 & 100 & 50 & 100 & 50 & 100 & 100 & 100 & 100 & 100 & 100 & 86 \\
\hline MI-5 & 50 & 100 & 50 & 100 & 50 & 50 & 100 & 100 & 100 & 100 & 100 & 81 \\
\hline ME-1 & 50 & 100 & 100 & 50 & 100 & 100 & 100 & 100 & 100 & 50 & 100 & 86 \\
\hline ME-2 & 50 & 100 & 100 & 100 & 100 & 100 & 100 & 100 & 100 & 100 & 100 & 95 \\
\hline
\end{tabular}

* requisitos aplicáveis tanto na etapa de análise de projeto como na análise de uso. 


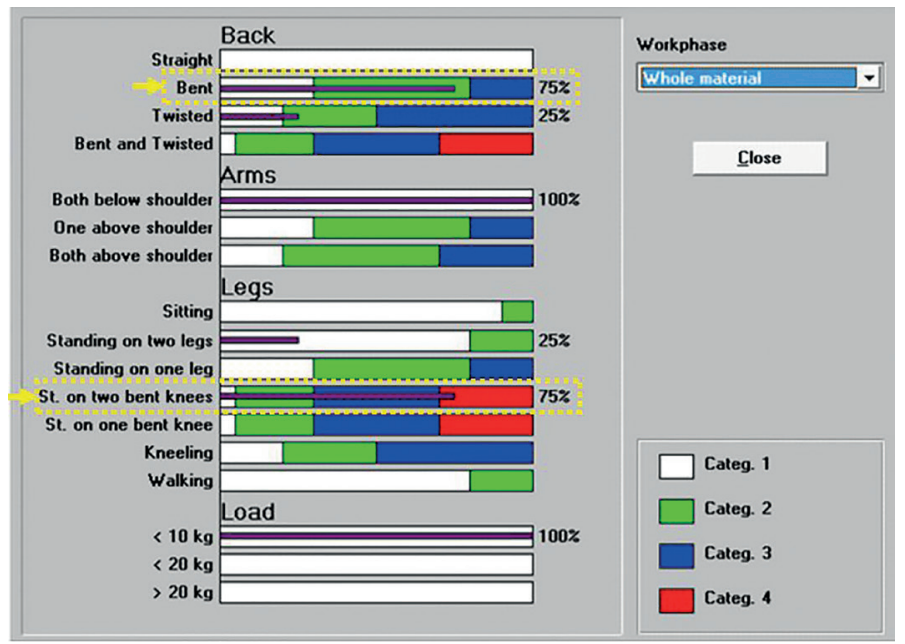

Figura 3 - Gráfico das posturas, analisadas com WinOWAS, na montagem dos SPP-MA-1.

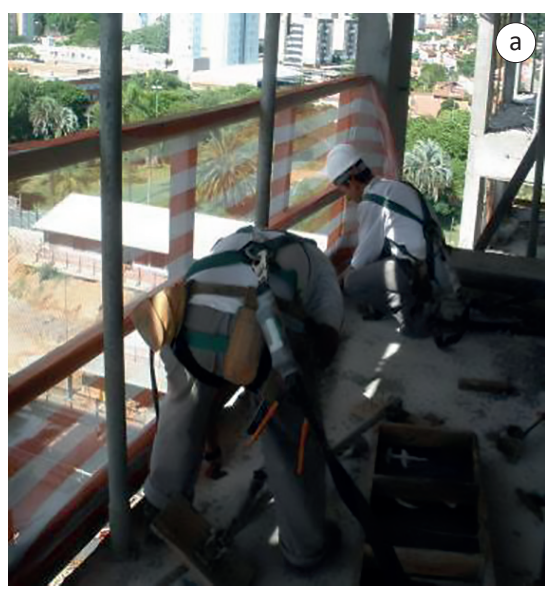

Fixação do componente rodapé do SPP-MA-1

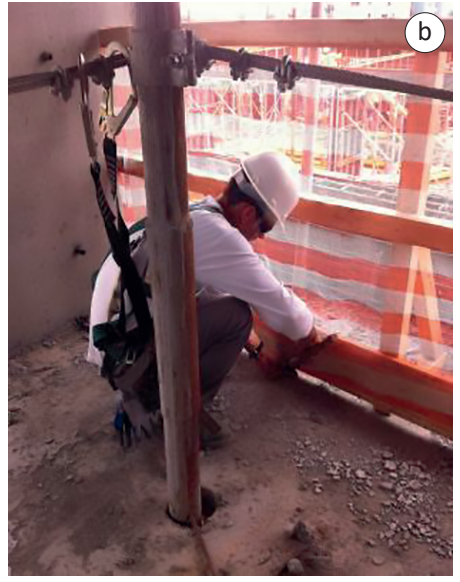

Fixação da tela de proteção do SPP-MA-2

Figura 4 - Posturas de pé, apoiado sobre os dois joelhos curvados e costas curvadas. Fonte: Peñaloza, 2015.

\subsection{Avaliação de Requisitos de Flexibilidade}

Os resultados indicaram que os SPP-ME têm melhor desempenho em relação à flexibilidade, ao se ajustarem a todas as etapas da obra, bem como às diferentes configurações geométricas (Quadro 6). Por exemplo, os montantes e quadros metálicos dos SPP-ME-2 são reguláveis em comprimento e articuláveis, o que permite melhor adaptação à periferia da edificação (Figura 5). Nos SPP-MA e SPP-MI, o principal aspecto 
de flexibilidade a salientar é a adaptação a diferentes configurações geométricas, uma vez que os componentes em madeira podem ser recortados e acoplados entre si, de forma a ajustar o SPP a situações específicas ou inesperadas, somente detectadas no canteiro de obras. No caso dos SPP-ME, o projeto é adaptado a cada obra em particular em função dos diferentes módulos que compõem o SPP.

Quadro 6 - Comparação do atendimento aos requisitos de flexibilidade em projeto.

\begin{tabular}{|c|c|c|c|c|c|c|c|}
\hline \multirow[b]{2}{*}{ 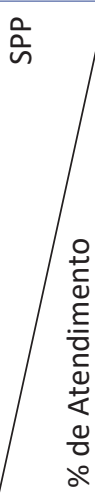 } & \multicolumn{6}{|c|}{ FLEXIBILIDADE - Requisitos de Projeto } & \multirow[b]{2}{*}{$\begin{array}{l}\bar{\pi} \\
\stackrel{0}{0} \\
\stackrel{0}{0} \\
\stackrel{0}{0} \\
\sum\end{array}$} \\
\hline & 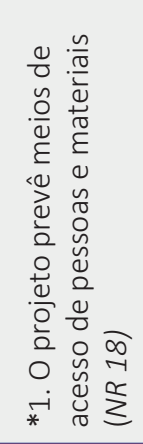 & 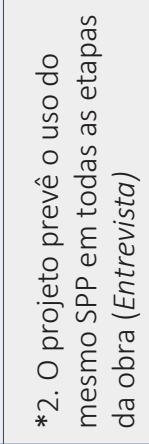 & 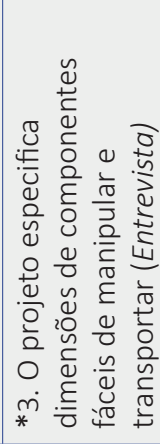 & 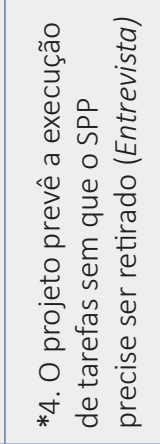 & 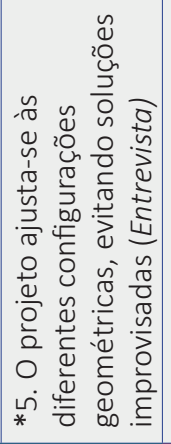 & 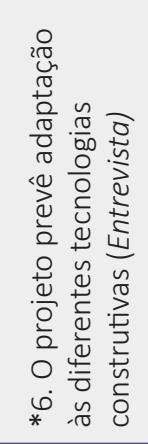 & \\
\hline MA-1 & 0 & 100 & 50 & 100 & 100 & 0 & 58 \\
\hline MA-2 & 0 & 0 & 100 & 0 & 0 & 0 & 16 \\
\hline MI-1 & 0 & 0 & 100 & 0 & 100 & 0 & 33 \\
\hline MI-2 & 0 & 0 & 100 & 100 & 100 & 0 & 50 \\
\hline $\mathrm{MI}-3$ & 0 & 100 & 0 & 100 & 100 & 0 & 50 \\
\hline MI-4 & 0 & 0 & 100 & 0 & 100 & 0 & 33 \\
\hline MI-5 & 0 & 100 & 100 & 100 & 100 & 0 & 66 \\
\hline ME-1 & 100 & 100 & 50 & 100 & 100 & 0 & 75 \\
\hline ME-2 & 100 & 100 & 100 & 100 & 100 & 0 & 83 \\
\hline
\end{tabular}

* requisitos aplicáveis tanto na etapa de análise de projeto como na análise de uso.

O Quadro 7 compara o atendimento aos requisitos de flexibilidade na fase de uso. Um aspecto a salientar refere-se aos SPP-MA-1, SPP-MI-3 e SPP-MI-5, os quais foram atendidos no projeto, mas não no uso, como ocorreu com o requisito 4 (o SPP permite a execução de tarefas sem precisar ser retirado, eliminando o cinto de segurança). Embora tais SPP estejam um pouco projetados para fora da periferia, o que permite a elevação da alvenaria de vedação externa, algumas empresas optam por remover o SPP antes ou durante a elevação da alvenaria, enquanto outras preferem manter o SPP instalado até finalizar as tarefas, requerendo uso de meios para removê-lo, tais como andaimes suspensos. Esta última situação gera riscos adicionais, já que muitas vezes ficam isolados em locais inacessíveis, podendo cair e atingir os trabalhadores no nível do solo (Figura 6). 


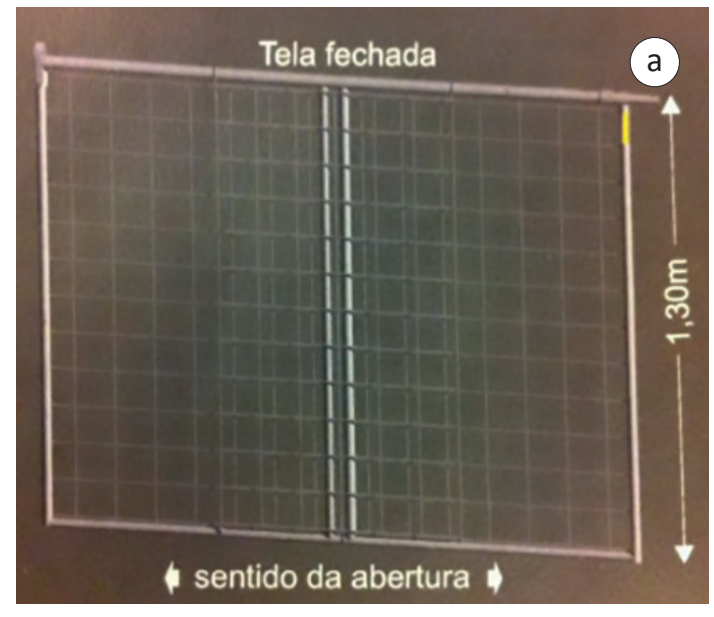

Telas reguláveis em comprimento

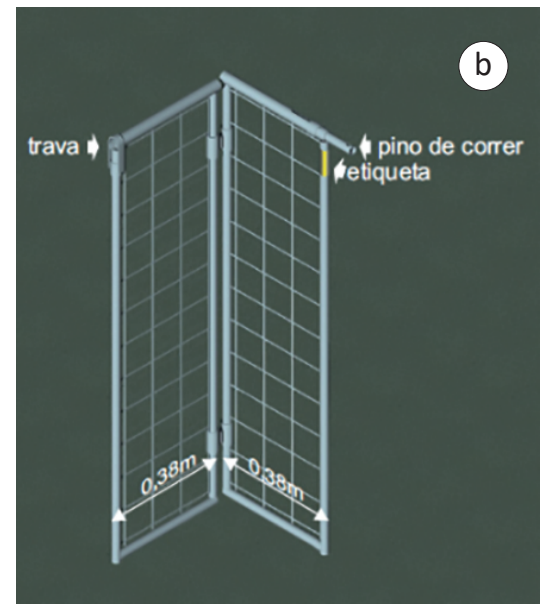

Telas articuláveis em quina
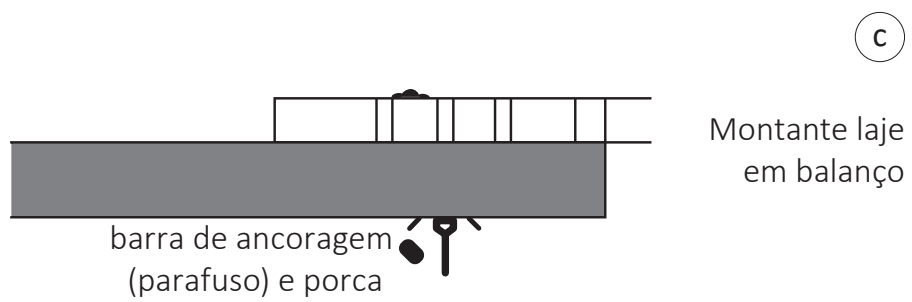

Montante laje em balanço

(parafuso) e porca

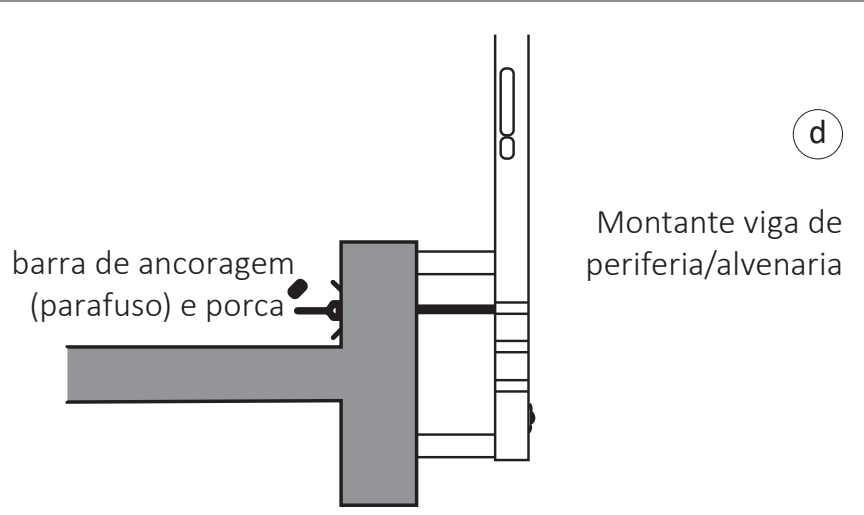

Figura 5 - Aspectos de flexibilidade do SPP-ME-2. Fonte: Scanmetal, 2011. 
Quadro 7 - Comparação do atendimento aos requisitos de flexibilidade em uso.

\begin{tabular}{|c|c|c|c|c|c|c|c|}
\hline$\frac{0}{2}$ & & FLE $>$ & IBILIDADE - & Requisitos de & Uso & & \\
\hline 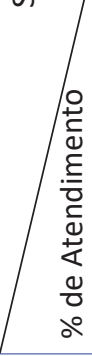 & 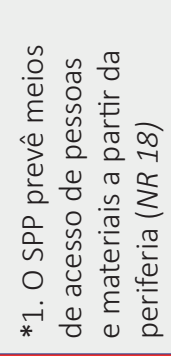 & 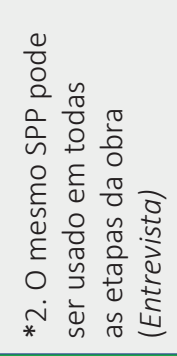 & 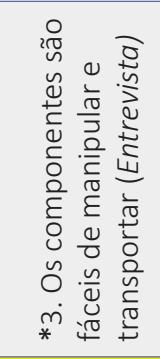 & 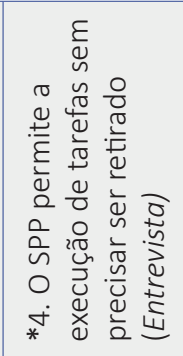 & 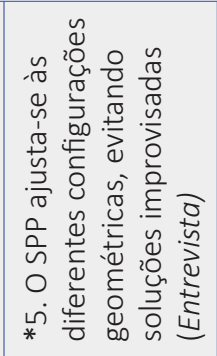 & 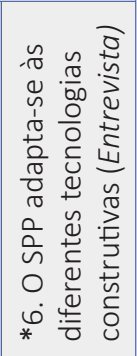 & 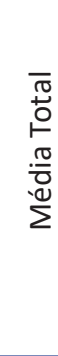 \\
\hline MA-1 & 0 & 100 & 50 & 0 & 100 & 0 & 42 \\
\hline MA-2 & 0 & 0 & 50 & 0 & 100 & 0 & 25 \\
\hline MI-1 & 0 & 0 & 50 & 0 & 100 & 0 & 25 \\
\hline MI-2 & 0 & 0 & 50 & 100 & 100 & 0 & 42 \\
\hline MI-3 & 0 & 100 & 0 & 100 & 50 & 0 & 42 \\
\hline MI-4 & 0 & 0 & 50 & 0 & 100 & 0 & 25 \\
\hline MI-5 & 0 & 0 & 50 & 50 & 100 & 0 & 33 \\
\hline ME-1 & 50 & 100 & 50 & 100 & 100 & 0 & 66 \\
\hline ME-2 & 0 & 100 & 100 & 100 & 100 & 0 & 66 \\
\hline
\end{tabular}

* requisitos aplicáveis tanto na etapa de análise de projeto como na análise de uso do SPP.
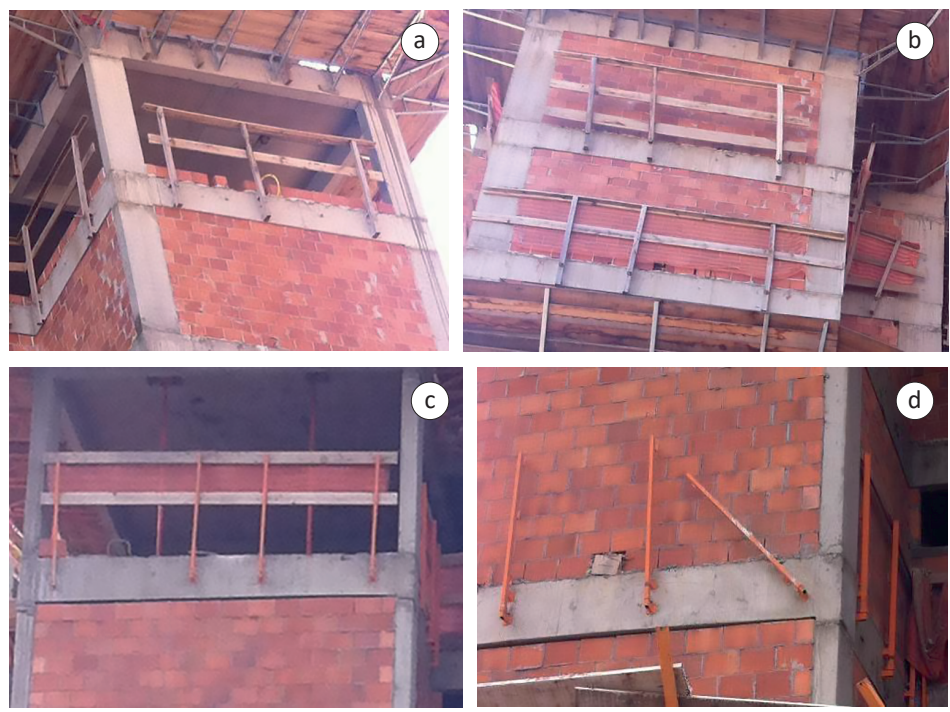

Figura 6 - (a) Remoção do SPP-MA-1 antes da vedação vertical; (b) SPP-MA-1 após vedação vertical; (c) remoção do SPP-MI-5 antes da vedação vertical; e (d) SPP- MI-5 após vedação vertical. Fonte: Peñaloza, 2015. 


\subsection{Oportunidades de Melhoria nos SPP}

Em função dos requisitos menos atendidos, foram identificados exemplos de SPP disponíveis no mercado nacional e internacional, os quais apresentam soluções que contribuem para um melhor desempenho dos SPP avaliados, bem como amenizam as dificuldades das empresas em atender tais requisitos. Um dos requisitos menos atendidos refere-se ao requisito "o SPP permite a execução de tarefas sem precisar ser retirado". Um exemplo existente no mercado serviu de inspiração para o desenvolvimento de um conjunto de soluções técnicas que podem ser incorporadas a diferentes SPP. O conjunto de soluções foi denominado de recomendação e permite a aplicação do protocolo proposto, dado que foi pensado com o objetivo atender a vários requisitos simultaneamente. O sistema Parapet Clamp (2005) possui um suporte de aço o qual se fixa à estrutura mediante um mecanismo tipo mordaça, permitindo ajustar-se às dimensões da estrutura (Figura 7).

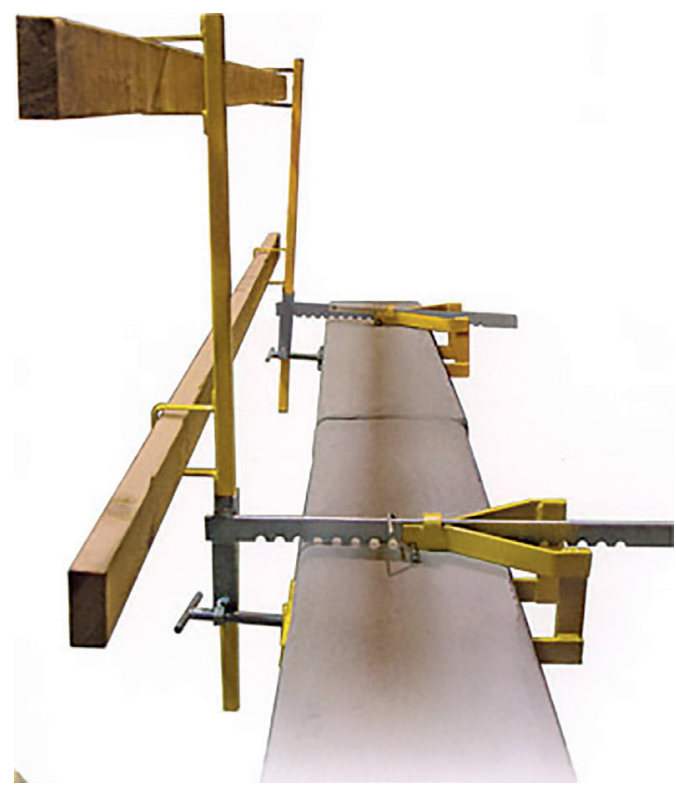

Figura 7 - Sistema de proteção de parapeitos. Fonte: Parapet Clamp, 2005.

Para o desenvolvimento da recomendação, adotou-se o formato em " $U$ " do suporte Parapet Clamp (2005), o qual foi invertido no sentido contrario, isto é, a fixação acontece de baixo para cima na viga de borda (Figura 8). Outra solução incorporada ao suporte é o afastamento à periferia (Figura 8), similarmente a alguns montantes de SPP avaliados, os afastadores evitam que o SPP fique sobre o piso de trabalho, possibilitando, a execução da alvenaria de vedação. 


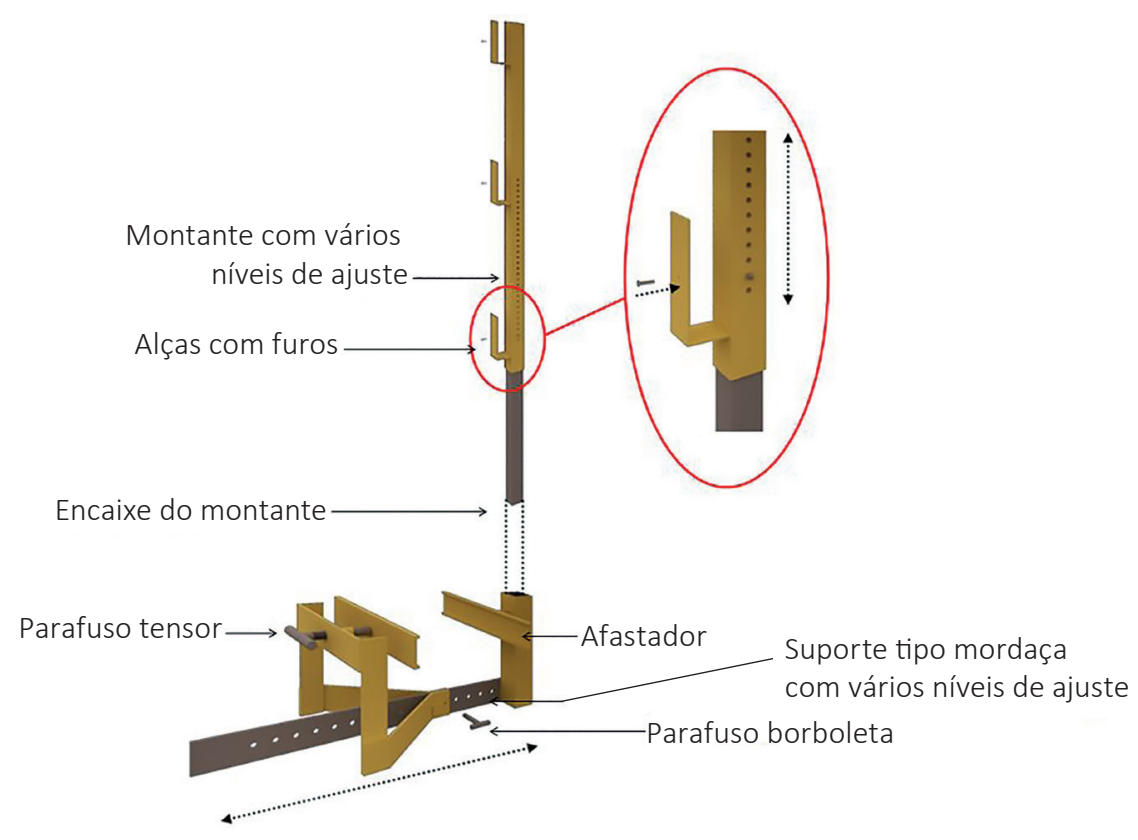

Figura 8 - Perspectiva e componentes. Fonte: Peñaloza, 2015.

Em relação à flexibilidade, o montante permite a combinação de componentes em madeira bem como telas metálicas (Figura 9). A Figura 10 ilustra uma alternativa de como o SPP pode ser instalado. Nota-se que os montantes foram posicionados um do lado do outro para facilitar a desmontagem por módulos (Figura 11).

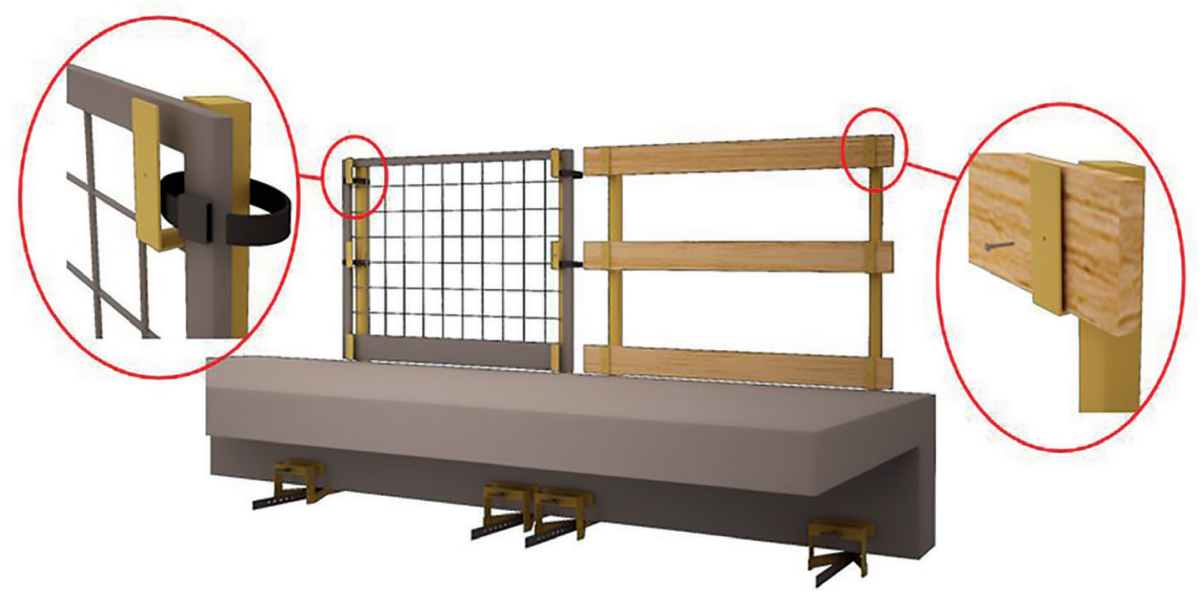

Figura 9 - Combinação de travessões e rodapé em madeira e tela metálica. Fonte: Peñaloza, 2015. 


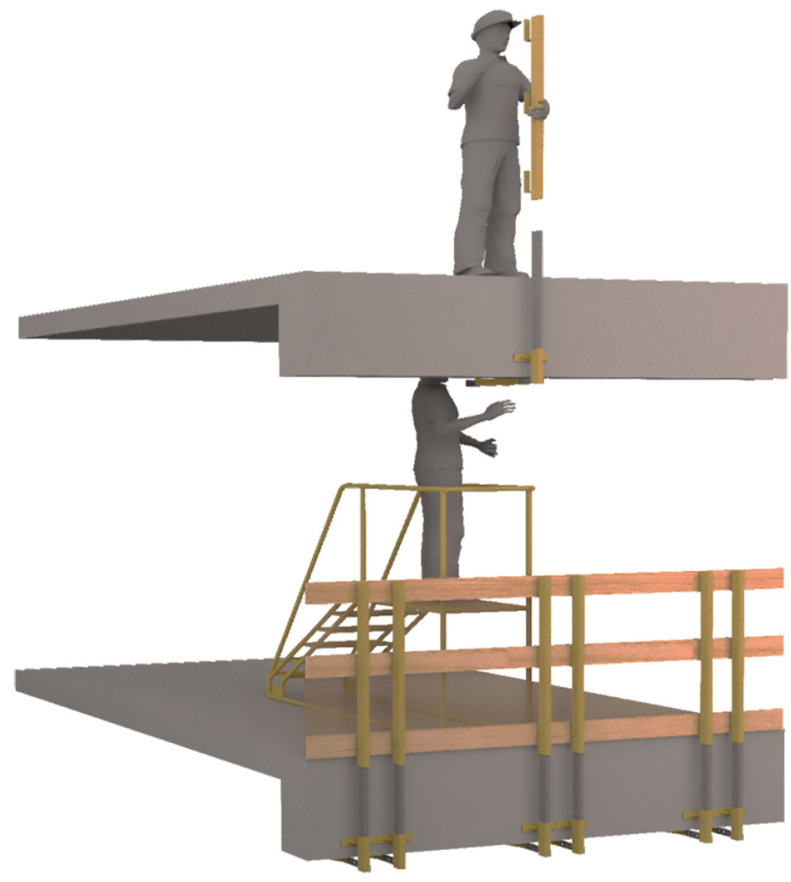

Figura 10 - Montagem do SPP. Fonte: Peñaloza, 2015.

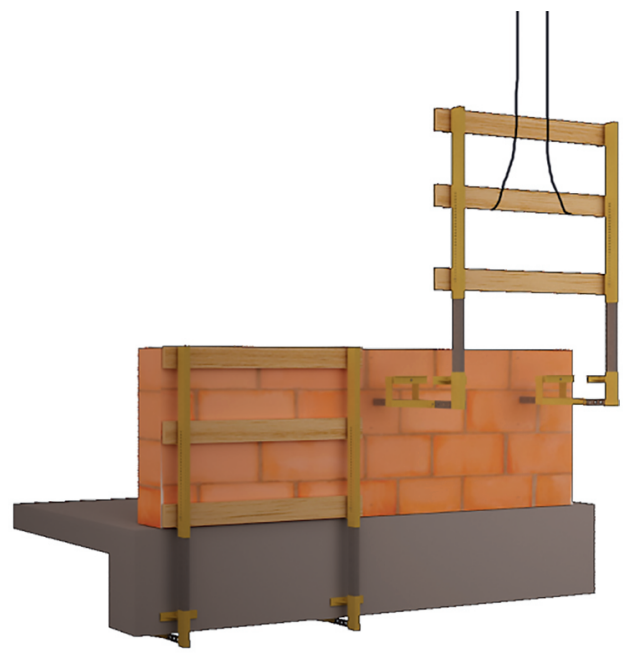

Figura 11 - Desmontagem por módulos. Fonte: Peñaloza, 2015. 


\section{Conclusões}

As principais contribuições deste estudo foram: (a) identificação e organização de requisitos; (b) identificação de requisitos não citados em normas, a partir da compreensão das necessidades dos usuários; e (c) categorização dos requisitos segundo a natureza de cada um.

Outra contribuição deste trabalho refere-se à identificação das principais vantagens e desvantagens dos SPP em madeira, mistos e metálicos. Por um lado, as principais vantagens dos SPP em madeira e mistos são: (a) baixo custo de aquisição em comparação com os SPP metálicos e (b) adaptação a diferentes configurações geométricas do ponto de vista da maleabilidade do sistema. Uma das vantagens dos SPP mistos sobre os SPP em madeira é a reutilização dos montantes metálicos, seja dentro da obra ou em obras futuras. Por outro lado, as principais desvantagens dos SPP em madeira e mistos são: (a) maior quantidade e variedade de componentes avulsos (10 unidades) em comparação com os SPP metálicos (3 componentes); (b) a fixação dos componentes requer prega manual peça por peça, sem seguir um critério definido; (c) baixo reaproveitamento da madeira. Já as principais vantagens dos SPP metálicos são: (a) materiais mais resistentes e duráveis em comparação com os SPP e madeira e misto; (b) mecanismos de conexão rígidos e seguros mediante encaixes e travamentos integrados ao sistema; (c) alto reaproveitamento; (d) baixo custo ao longo do ciclo de vida; (e) menos perdas e resíduos; e (f) fácil de manipular por ser um sistema compacto com dispositivos incorporados.

O principal ponto fraco do SPP metálico refere-se ao projeto do rodapé. Alguns desses sistemas não possuem rodapé ou este é rejeitado pelos trabalhadores por ser um elemento solto da tela de proteção. Nesse sentido, foram identificadas algumas oportunidades para estudos futuros: (i) testar as oportunidades de melhoria identificadas em possíveis soluções tecnológicas, contribuindo para incentivar o setor da construção a desenvolver inovações; e (ii) refinar e atualizar o conjunto de requisitos e critérios propostos.

\section{Referências}

ASOCIACIÓN ESPAÑOLA DE NORMALIZACIÓN Y CERTIFICACIÓN. UNE-EN 13374: sistemas provisionales de protección de borde: especificaciones del producto, métodos de ensayo. Madrid, 2004.

BRASIL. Ministério do Trabalho e Emprego. Norma Regulamentadora 18 (NR-18): Condições e meio ambiente de trabalho na indústria da construção. 2015. Brasília-DF. Disponível em: <http://trabalho.gov.br/seguranca-e-saude-no-trabalho/normatizacao/ normas-regulamentadoras/norma-regulamentadora-n-18-condicoes-e-meio-ambientede-trabalho-na-industria-da-construcao>. Acesso em: abr. 2014. 
BRASIL. Resultados da Fiscalização em Segurança e Saúde no Trabalho: Brasil, 1996 a 2012. 2013. Disponível em: <http://portal.mte.gov.br/seg_sau/resultados-da-fiscalizacaoem-seguranca-e-saude-no-trabalho-brasil-1996-a-2009.htm>. Acesso em: jul. 2014.

CAMBRAIA, F.B.; FORMOSO, C.T. Análise de Avanços e Retrocessos no Atendimento às Especificações da NR 18 nos Últimos Dez Anos. In: SIMPÓSIO BRASILEIRO DE GESTÃO E ECONOMIA DA CONSTRUÇÃO, Belém, 2011. Anais... Belém: ANTAC, 2011.

CANADIAN CENTRE FOR OCCUPATIONAL HEALTH AND SAFETY (CCOHS). Safety Code for the Construction Industry S-2.1, r.6: installation of guard-rails. 1981. Disponível em: <http:// www2.publicationsduquebec.gouv.qc.ca/dynamicSearch/telecharge. $p h p$ ?type=3\&file= /S_2_1/S2_1R4_A.HTM>. Acesso em: jul. 2014.

CHEUNG, E. Rapid Demountable Platform (RDP): a device for preventing fall from height accidents. Journal of Accident Analysis and Prevention, v. 48, n. 1, p. 235-245, 2012.

COSTELLA, M.F.; JUNGES, F.C.; PILZ, S.E. Avaliação do Cumprimento da NR 18 em Função do Porte de Obra Residencial e Proposta de Lista de Verificação da NR-18. Ambiente Construído, Porto Alegre, v. 14, n. 3, p. 87-102, jul./set. 2014.

FUNDACENTRO. Recomendações Técnicas de Procedimentos 01: medidas de proteção contra quedas de altura. Fundacentro, 2003. Disponível em: <http://www.fundacentro.gov. br dominios/CTN/anexos/Publicação/rtp01.pdf>. Acesso em: abr. 2013.

GARCIA, M.D.L.N.G. Consideraciones Respecto a los Sistemas Provisionales de Proteccíon de Borde. Universidad politécnica de Madrid, 2010.

HOLLOMAN, J.H. United States Patent and Trademark Office. 1994. Disponível em: <http:// www.uspto.gov/patentsUS5314167>. Acesso em: jul. 2014.

LAN, A.; DAIGLE, R. Development and Validation of a Method For Evaluating Temporary Wooden Guardrails Built and Installed on Construction Sites. Safety Science, v. 47, p. 215226, 2009.

MALLMANN, B. S. Avaliação do atendimento aos requisitos da NR 18 em canteiros de obra. 2008. Trabalho de Conclusão de Curso (Engenharia Civil) - Escola de Engenharia, Universidade Federal do Rio Grande do Sul, Porto Alegre, 2008.

MCLAUGHLIN, J.; MCCOY, J. United States Patent and Trademark Office. 1976. Disponível em: <http://www.uspto.gov/patentsUS3995833>. Acesso em: jul. 2014.

METRO FORM SYSTEM. Produtos: sistema de proteção Metro Form. 2009. Disponível em: <http://www.metroform.com.br/produto4.1.html>. Acesso em: abr. 2014.

OCCUPATIONAL SAFETY AND HEALTH ADMINISTRATION (OSHA). United States Department of Labour. 1926. 502: fall protection systems criteria and practices. 1996. Disponível em: <http://www.osha.gov/pls/oshaweb/owadisp.show_document?p_table=STANDARDS\&p_ id=1 0758>. Acesso em: ago. 2013.

ORMAN. Orman: sistemas de prevenção e proteção. 2012. Disponível em: <http://www. grupoorman.com.br/page.aspx>. Acesso em: set. 2014.

OSTROW, P. United States Patent and Trademark Office. 2001. Disponível em: <http:// www.uspto.gov/patentsUS6220577>. Acesso em: maio 2014. 
PARAPET CLAMP. Temporary Rooftop Guardrails. 2005. Disponível em: <http://wssafety. com/products/rooftop-guardrails-temporary>. Acesso em: out. 2015.

PEÑALOZA, G.A. Identificação de requisitos de desempenho de Sistemas de Proteção Periférica (SPP) em obras de edificações. 2015. Dissertação (Mestrado em Engenharia Civil) - Programa de Pós-Graduação em Engenharia Civil, Universidade Federal do Rio Grande do Sul, Porto Alegre, 2015.

SAURIN, T.A.; LANTELME, E.; FORMOSO, C.T. Contribuições para aperfeiçoamento da NR-18: condições e meio ambiente de trabalho na indústria da construção. Porto Alegre: Universidade Federal do Rio Grande do Sul, 2000. Relatório de Pesquisa.

SCANMETAL. Trabalho e vida: proteção modulada de periferia de obras civis. 2011. Disponível em: <http://www.trabalhoevida.com.br/download/scanmanual.pdf>. Acesso em: mar. 2013.

SULOWSKI, A. C. Collective Fall Protection for Construction Workers. Informes de la Construcción, v. 66, n. 533, 2014. 


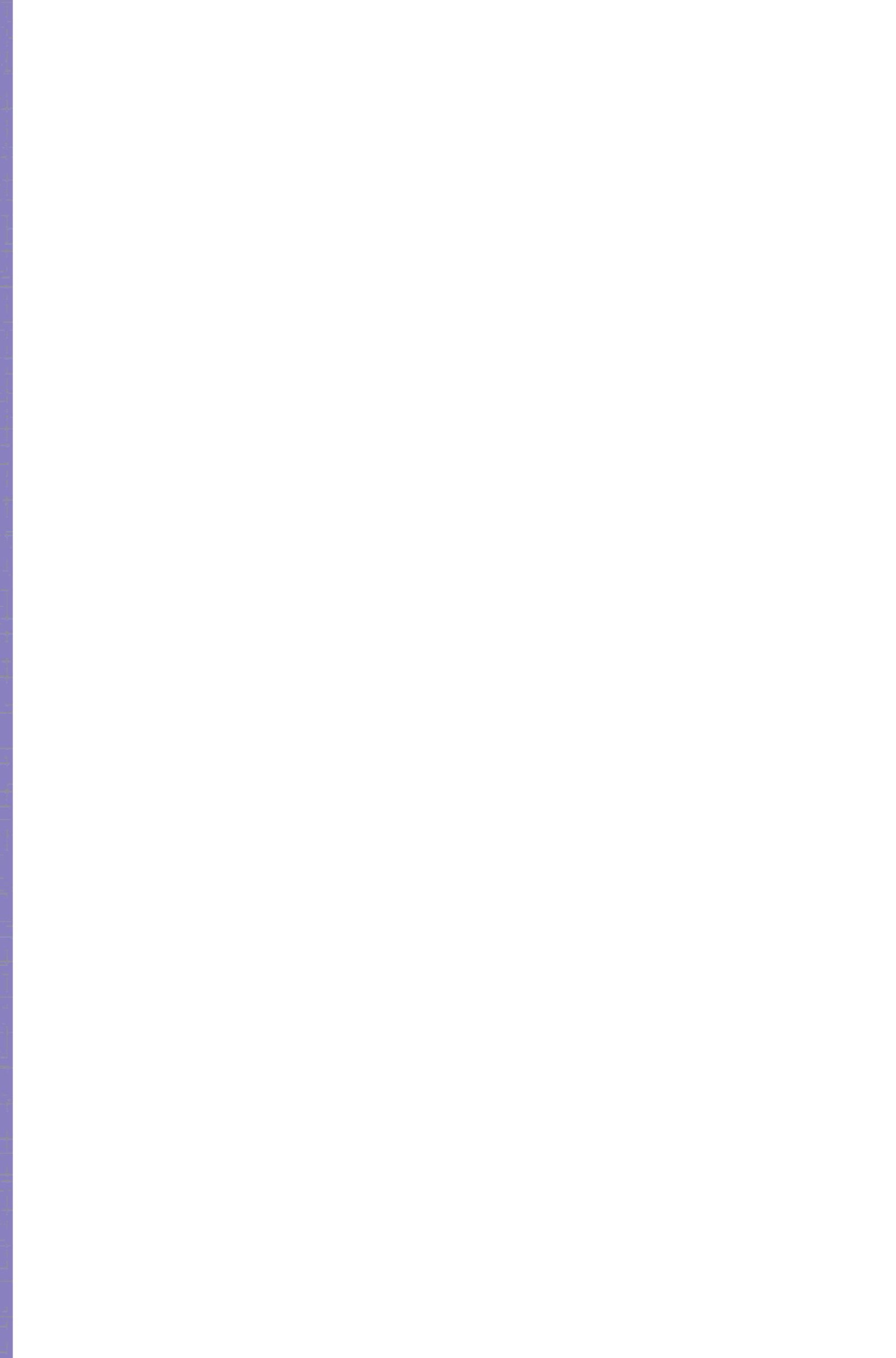




\title{
Sistemas de Proteção Contra Quedas com Cabo de Segurança na Construção'
}

\author{
Marcelo Fabiano Costella \\ Emanuela Rizzotto \\ Letícia Nonennmacher
}

\section{Introdução}

Sabe-se que a construção civil é responsável por um grande número de acidentes e mortes de trabalhadores, sendo a queda de altura o principal problema enfrentado em obras de diferentes países (BRANCHTEIN, et al., 2015).

Fatalidades desse tipo ocorrem principalmente devido à falta de proteção adequada ou à deficiência dos sistemas utilizados, condicionados, segundo Borjan et al. (2016), pelo comportamento dos empregadores, a indisponibilidade de equipamentos e o tamanho da empresa.

Referente aos empregadores, Cherri e Argudin (2016) explicam que tais responsáveis pela contratação e gestão de pessoal ainda apresentam certa dificuldade em tratar do tema. Consequentemente, os colaboradores são submetidos a tarefas em altura sem que possuam experiência, sem aprender métodos de trabalho e receber equipamentos de proteção adequados (EVANOFF et al., 2016).

1 Versão resumida do artigo publicado na Revista SODEBRAS, v. 11, n. 128 de Agosto de 2016, nas páginas 133 a 140, pelos mesmos autores. 
Dentre os equipamentos de uso obrigatório em qualquer atividade executada a partir de 2,0 metros de altura, com risco de queda, tais como telhados, estruturas e coberturas, estão os cintos de segurança, conforme a NR 18 - Condições e Meio Ambiente de Trabalho na Indústria da Construção (BRASIL, 2016). Entretanto, ainda que normas regulamentadoras do trabalho em altura estejam em vigor, como a já citada NR 18 Condições e Meio Ambiente de Trabalho na Indústria da Construção (BRASIL, 2016) e a NR 35 - Trabalho em Altura (BRASIL, 2014), é grande o número de problemas envolvendo a má qualidade do planejamento, aplicação e controle dos sistemas de proteção. Um dos possíveis fatores contribuintes diz respeito à maneira como as normas abordam os requisitos de desempenho, não incorporando pontos relevantes, como eficiência e flexibilidade, além da falta de especificações quanto à forma de avaliar seu uso.

Desta forma, é necessário desenvolver métodos e materiais que auxiliem na análise da utilização dos sistemas de segurança contra quedas, fazendo com que os requisitos atualmente estabelecidos também contemplem questões práticas do dia a dia da obra e proporcionem sistemas mais seguros e práticos.

Com o foco de proporcionar uma visão mais ampla dos requisitos necessários ao eficaz projeto e aplicação de cabos de segurança, bem como à análise de conformidades para utilização, este estudo pretende apontar níveis de atendimento a requisitos de segurança, eficiência e flexibilidade.

\section{Método}

\subsection{Delineamento da Pesquisa}

A presente pesquisa consistiu na elaboração de um protocolo de avaliação de desempenho de cabos de segurança. Um teste do protocolo é apresentado com base na sua aplicação em obras da cidade de Chapecó, Santa Catarina.

Foi realizado o levantamento e estudo de requisitos importantes para a avaliação de diversos cabos usados na proteção dos trabalhadores da construção civil com base nas categorias de segurança, contemplando-se questões de projeto e operação, de eficiência e flexibilidade.

\subsection{Identificação dos Requisitos}

Para identificação dos requisitos foram utilizadas as normas brasileiras NR 18 Condições e Meio Ambiente de Trabalho na Indústria da Construção (BRASIL, 2016) e NR 35 - Trabalho em Altura (BRASIL, 2014), bem como as normas inglesas OSHA 1926.501 (OCCUPATIONAL..., 1996a), OSHA 1926.502 (OCCUPATIONAL..., 1996b) e OSHA 1926.503 (OCCUPATIONAL..., 1996c). Além disso, a identificação dos requisitos teve como fundamento as disposições recomendadas pelos sistemas de proteção 
periférica (SPP), propostos no protocolo elaborado por Peñaloza et al. (2015), bem como falhas observadas a partir do acompanhamento de atividades que utilizavam cabos de segurança nas obras selecionadas.

Dessa forma, foram identificados 30 requisitos para compor o protocolo, distribuídos da seguinte forma: 5 requisitos referem-se à segurança na etapa de projeto, 12 requisitos referem-se à segurança na etapa de operação; 7 requisitos referem-se à eficiência e 6 referem-se à flexibilidade.

\subsection{Níveis de Atendimento}

Com os requisitos definidos, identificados e devidamente separados por categoria, foi elaborado o protocolo para avaliação do cabo de segurança. O responsável por responder ao protocolo pode escolher entre as seguintes opções, para cada requisito: SIM, se a situação analisada atendesse totalmente o requisito; NÃO, caso o requisito não fosse atendido na obra; PARCIALMENTE quando a situação da obra atendia parcialmente o requisito; e NÃO SE APLICA, caso o requisito não fosse aplicável às características da obra. Para analisar os dados e interpretar os resultados, foi atribuída uma pontuação para cada resposta, da seguinte forma: SIM, 100\%; NÃO 0\%; PARCIALMENTE 50\%. Caso a resposta seja NÃO SE APLICA, ela não será considerada.

\subsection{Seleção das Obras e Coleta de Dados}

Como meio de efetivar a pesquisa, foram definidos sete canteiros de obras da cidade catarinense para realização de visitas. Escolhidos os locais, foi caracterizado o sistema de cabo de segurança utilizado na obra, identificando-se o material utilizado nos cabos, a forma de fixação e os cuidados tomados com o sistema. A Tabela 1 apresenta as características dos sistemas utilizados em cada obra. Foi observado ainda qual era o profissional responsável pela segurança do trabalho presente na obra, seja o técnico de segurança, o engenheiro de segurança do trabalho ou, na maioria dos casos, o próprio engenheiro civil responsável pela execução da obra.

Foram coletados os dados nos canteiros de obras através de aplicação do protocolo de avaliação, verificando-se todos os requisitos para o sistema de cabo de segurança. Nesta etapa, as questões foram respondidas pelo profissional responsável por fiscalizar a obra, junto ao cabo de segurança instalado, o que permitiu também a observação direta do sistema. O local avaliado foi sempre o último pavimento, observado em sua totalidade, no qual o cabo de segurança estava instalado. Por fim, os dados recolhidos por meio do protocolo de avaliação foram analisados e os resultados foram discutidos. 
Tabela 1 - Características dos cabos de segurança.

\begin{tabular}{|c|c|c|c|c|c|c|}
\hline Obra & $\begin{array}{l}\text { Etapa de } \\
\text { utilização }\end{array}$ & $\begin{array}{l}\text { Material } \\
\text { do cabo }\end{array}$ & $\begin{array}{l}\text { Fixação } \\
\text { do cabo }\end{array}$ & $\begin{array}{l}\text { Tipo de } \\
\text { montante }\end{array}$ & $\begin{array}{l}\text { Fixação do } \\
\text { montante }\end{array}$ & $\begin{array}{l}\text { Registro } \\
\text { fotográfico }\end{array}$ \\
\hline Obra A & Alvenaria & $\begin{array}{l}\text { Cabo } \\
\text { de fibra } \\
\text { sintética }\end{array}$ & $\begin{array}{l}\text { Transpassado } \\
\text { por aberturas } \\
\text { existentes } \\
\text { em pilares ou } \\
\text { vigas }\end{array}$ & $\begin{array}{l}\text { Pilares } \\
\text { e vigas } \\
\text { funcionam } \\
\text { como } \\
\text { montantes }\end{array}$ & $\begin{array}{l}\text { Pilares } \\
\text { e vigas } \\
\text { funcionam } \\
\text { como } \\
\text { montantes }\end{array}$ & \\
\hline Obra B & Estrutura & $\begin{array}{l}\text { Cabo de } \\
\text { aço }\end{array}$ & $\begin{array}{l}\text { Transpassado } \\
\text { em } \\
\text { abraçadeiras } \\
\text { presas ao } \\
\text { montante }\end{array}$ & $\begin{array}{l}\text { Tubos de } \\
\text { ferro }\end{array}$ & $\begin{array}{l}\text { Sustentação } \\
\text { em formato } \\
\text { de tripé } \\
\text { fixado à laje } \\
\text { por meio de } \\
\text { parafusos }\end{array}$ & \\
\hline Obra C & Alvenaria & $\begin{array}{l}\text { Cabo } \\
\text { de fibra } \\
\text { sintética }\end{array}$ & $\begin{array}{l}\text { Transpassado } \\
\text { em barras } \\
\text { de ferro com } \\
\text { dobra em sua } \\
\text { ponta }\end{array}$ & $\begin{array}{l}\text { Barras de } \\
\text { ferro }\end{array}$ & $\begin{array}{l}\text { A partir de } \\
\text { solda na laje } \\
\text { superior }\end{array}$ & \\
\hline Obra D & Alvenaria & $\begin{array}{l}\text { Cabo de } \\
\text { aço }\end{array}$ & $\begin{array}{l}\text { Transpassados } \\
\text { em aberturas } \\
\text { feitas a } 1,20 \\
\text { m de altura no } \\
\text { montante }\end{array}$ & $\begin{array}{l}\text { Tubos de } \\
\text { ferro com } \\
8 \mathrm{~m}\end{array}$ & $\begin{array}{l}\text { Sistema de } \\
\text { encaixe, } \\
\text { no qual os } \\
\text { cabos são } \\
\text { passados } \\
\text { em espaços } \\
\text { já deixados } \\
\text { na laje e } \\
\text { fixados } \\
\text { com pino } \\
\text { metálico }\end{array}$ & \\
\hline
\end{tabular}

Fonte: Elaboração dos autores. 
Tabela 1 - Continuação.

\begin{tabular}{|c|c|c|c|c|c|c|}
\hline Obra & $\begin{array}{l}\text { Etapa de } \\
\text { utilização }\end{array}$ & $\begin{array}{l}\text { Material } \\
\text { do cabo }\end{array}$ & $\begin{array}{l}\text { Fixação } \\
\text { do cabo }\end{array}$ & $\begin{array}{l}\text { Tipo de } \\
\text { montante }\end{array}$ & $\begin{array}{l}\text { Fixação do } \\
\text { montante }\end{array}$ & $\begin{array}{l}\text { Registro } \\
\text { fotográfico }\end{array}$ \\
\hline Obra E & Estrutura & $\begin{array}{l}\text { Cabo de } \\
\text { aço }\end{array}$ & $\begin{array}{l}\text { Transpassado } \\
\text { em } \\
\text { abraçadeiras } \\
\text { presas ao } \\
\text { montante }\end{array}$ & $\begin{array}{l}\text { Tubos de } \\
\text { ferro com } \\
6 \mathrm{~m}\end{array}$ & $\begin{array}{l}\text { Encaixados } \\
\text { através dos } \\
\text { espaços } \\
\text { deixados } \\
\text { entre as } \\
\text { lajes }\end{array}$ & \\
\hline Obra F & Estrutura & $\begin{array}{l}\text { Cabo de } \\
\text { aço }\end{array}$ & $\begin{array}{l}\text { Transpassado } \\
\text { em } \\
\text { abraçadeiras } \\
\text { presas ao } \\
\text { montante ou } \\
\text { em encaixe } \\
\text { fixo a } 1,5 \mathrm{~m} \text { de } \\
\text { altura }\end{array}$ & $\begin{array}{l}\text { Tubos de } \\
\text { ferro com } \\
7 \mathrm{~m}\end{array}$ & $\begin{array}{l}\text { Encaixados } \\
\text { através dos } \\
\text { espaços } \\
\text { deixados } \\
\text { entre as } \\
\text { lajes }\end{array}$ & 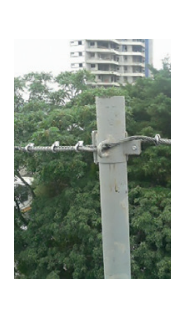 \\
\hline Obra G & Estrutura & $\begin{array}{l}\text { Cabo de } \\
\text { aço }\end{array}$ & $\begin{array}{l}\text { Transpassado } \\
\text { em } \\
\text { abraçadeiras } \\
\text { presas ao } \\
\text { montante }\end{array}$ & $\begin{array}{l}\text { Tubos de } \\
\text { ferro }\end{array}$ & $\begin{array}{l}\text { Possui } \\
\text { sustentação } \\
\text { de tripé e os } \\
\text { tubos são } \\
\text { encaixados } \\
\text { através dos } \\
\text { espaços } \\
\text { deixados } \\
\text { entre as } \\
\text { lajes }\end{array}$ & \\
\hline
\end{tabular}

Fonte: Elaboração dos autores.

\section{Resultados}

\subsection{Segurança nos Projetos dos Cabos}

A Tabela 2 apresenta os resultados da avaliação quanto aos requisitos concernentes à categoria segurança na fase de concepção dos projetos, a média de cada empresa, média de cada requisito e média geral da categoria. 
Tabela 2 - Atendimento da categoria segurança no projeto dos cabos.

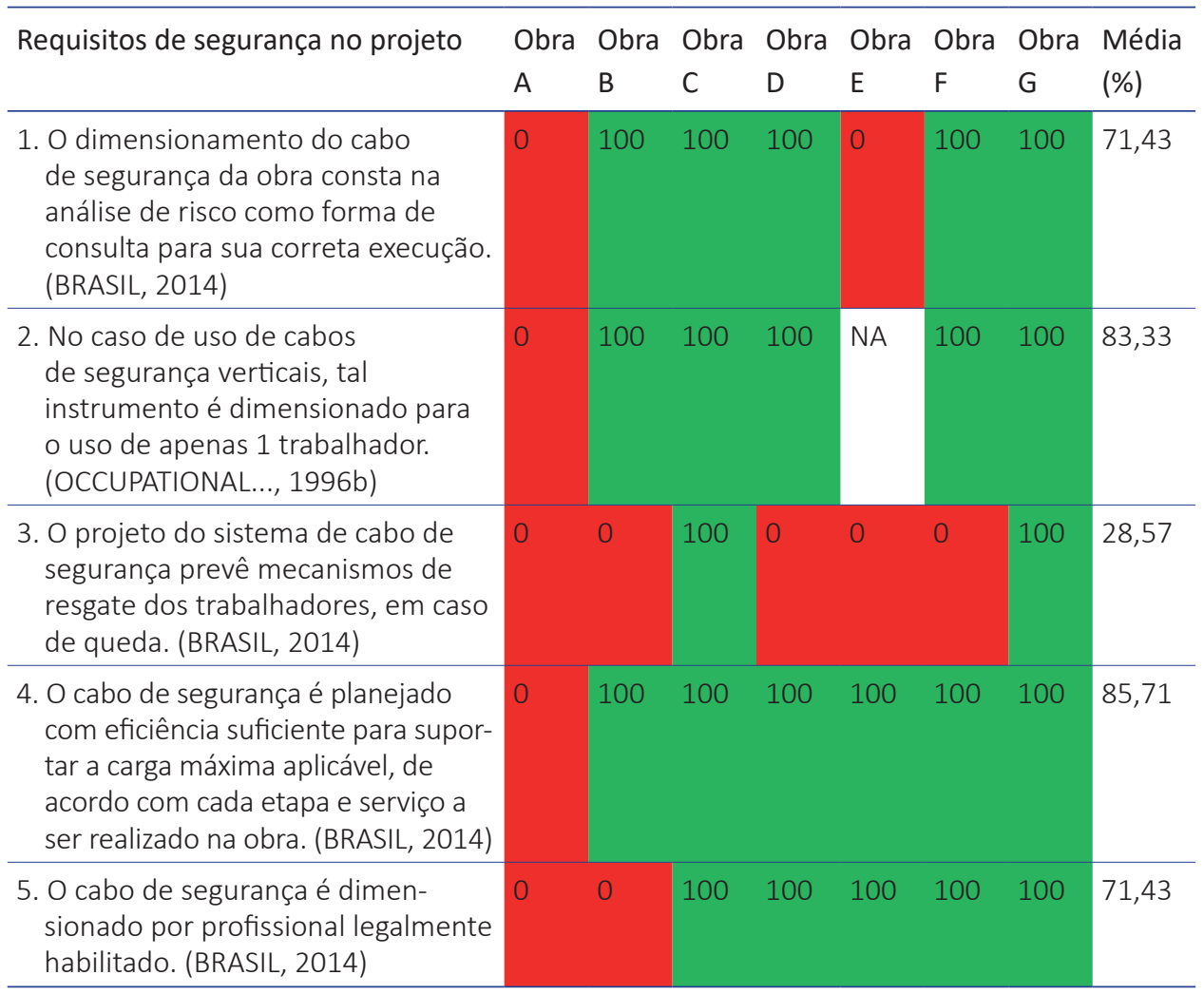

Fonte: Elaboração dos autores.

Percebe-se que a maioria das empresas preocupa-se em dimensionar seus sistemas seguindo as especificações de um profissional habilitado, que considera a análise de risco, as cargas e número real de usuários do sistema.

Em contrapartida, as porcentagens de atendimento do requisito 3 possibilitam identificar como inconformidade comum, entre a maioria das empresas, a não incorporação de formas de resgate ao dimensionamento dos cabos, visto que é obrigação da empresa assegurar que a equipe possua os recursos necessários para as respostas a emergências, conforme exige a NR 35 - Trabalho em Altura.

\subsection{Segurança na Fase de Operação}

A Tabela 3 apresenta os resultados de atendimento das obras quanto aos requisitos referentes à categoria segurança na fase de uso dos cabos, a média de cada empresa, média de cada requisito e média geral da categoria. 
Quanto à operação, o requisito de número 14 foi o menos atendido entre as obras, de modo que apenas a obra D possuía sinalização, no local de uso, informando a quantidade máxima de trabalhadores que podem estar conectados ao cabo de segurança ao mesmo tempo. Esse foi o requisito menos atendido dentre os 30 analisados.

Verifica-se que o não atendimento ao item 14 interfere no total desempenho quanto ao cumprimento dos requisitos 2 e 4 da categoria segurança na fase de projeto, pois mesmo que haja um correto dimensionamento da carga e número máximo de trabalhadores suportados pelo sistema, não é realizada a eficiente sinalização destas informações aos trabalhadores em obra, durante a etapa de operação dos cabos.

Tabela 3 - Atendimento da categoria segurança na fase de operação dos cabos.

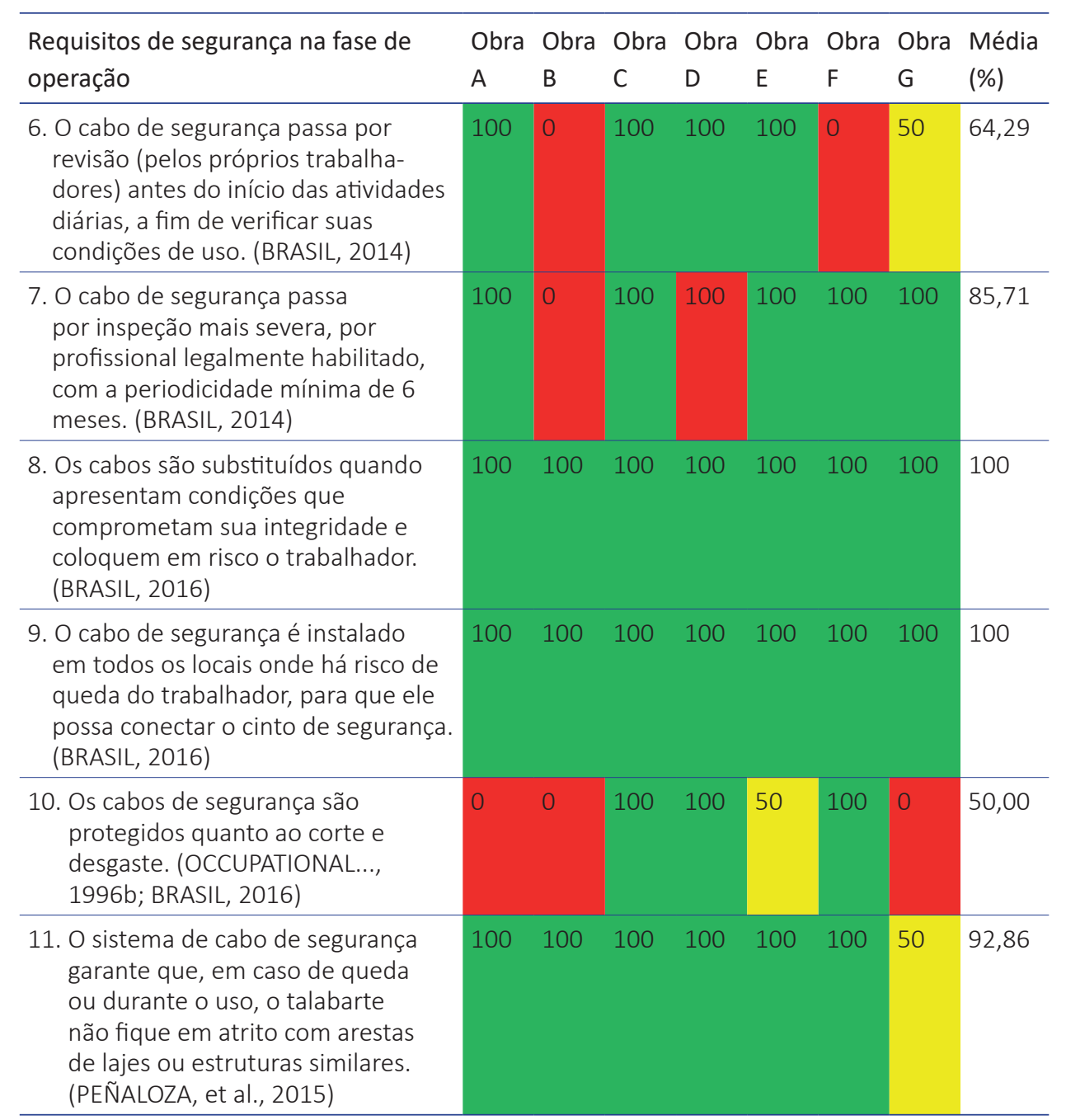

Fonte: Elaboração dos autores. 
Tabela 3 - Continuação.

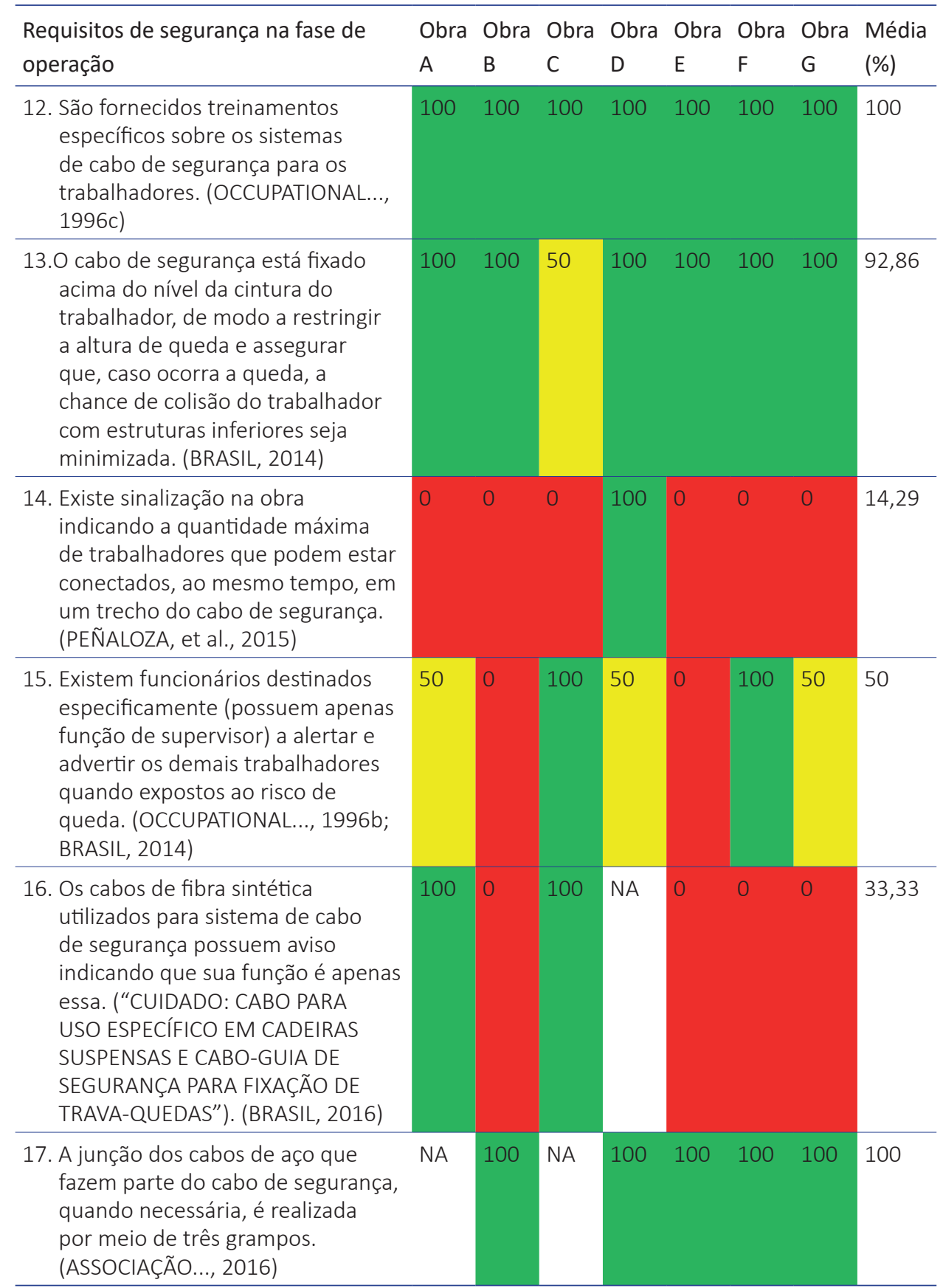

Fonte: Elaboração dos autores. 
Já os requisitos 8, 9, 12 e 17 são cumpridos em todas as obras. Assim, constatouse a preocupação das empresas em instalar cabos de segurança em todos os locais com risco de queda, de maneira a preservar a integridade do trabalhador e também oferecer treinamentos para capacitar seus funcionários.

\subsection{Categoria Eficiência}

A Tabela 4 apresenta os resultados de atendimento das obras quanto aos requisitos na categoria eficiência, a média de cada empresa, média de cada requisito e média geral da categoria.

Tabela 4 - Atendimento da categoria eficiência.

\begin{tabular}{|c|c|c|c|c|c|c|c|c|}
\hline Requisitos de eficiência & $\begin{array}{l}\text { Obra } \\
\text { A }\end{array}$ & $\begin{array}{l}\text { Obra } \\
\text { B }\end{array}$ & $\begin{array}{l}\text { Obra } \\
\text { C }\end{array}$ & $\begin{array}{l}\text { Obra } \\
\text { D }\end{array}$ & $\begin{array}{l}\text { Obra } \\
E\end{array}$ & $\begin{array}{l}\text { Obra } \\
\text { F }\end{array}$ & $\begin{array}{l}\text { Obra } \\
\text { G }\end{array}$ & $\begin{array}{l}\text { Média } \\
\text { (\%) }\end{array}$ \\
\hline $\begin{array}{l}\text { 18. O sistema de cabo de } \\
\text { segurança interfere } \\
\text { negativamente no } \\
\text { desenvolvimento do } \\
\text { serviço do trabalhador. } \\
\text { (OCCUPATIONAL..., 1996a) }\end{array}$ & 50 & 0 & 0 & 0 & 0 & 100 & 100 & 35,71 \\
\hline $\begin{array}{l}\text { 19. O sistema de cabo de } \\
\text { segurança garante ao } \\
\text { trabalhador autonomia para } \\
\text { realizar a atividade por todo } \\
\text { período que estiver exposto } \\
\text { ao risco de queda. (BRASIL, } \\
\text { 2014) }\end{array}$ & 50 & 100 & 100 & 100 & 100 & 100 & 100 & 92,86 \\
\hline $\begin{array}{l}\text { 20. O sistema de cabo de } \\
\text { segurança é de rápida } \\
\text { instalação e retirada. } \\
\text { (PEÑALOZA et al., 2015) }\end{array}$ & 50 & 0 & 50 & 50 & 0 & 100 & 50 & 42,86 \\
\hline $\begin{array}{l}\text { 21. O sistema de cabo de } \\
\text { segurança tem pouca ou } \\
\text { nenhuma interferência com } \\
\text { outras proteções coletivas } \\
\text { (proteções periféricas, } \\
\text { plataformas de proteção) } \\
\text { e escoramentos, não } \\
\text { prejudicando a segurança e } \\
\text { eficiência da movimentação } \\
\text { de materiais e pessoas. } \\
\text { (PEÑALOZA et al., 2015) }\end{array}$ & 50 & 100 & 100 & 50 & 50 & 100 & 100 & 78,57 \\
\hline
\end{tabular}

Fonte: Elaboração dos autores. 
Tabela 4 - Continuação.

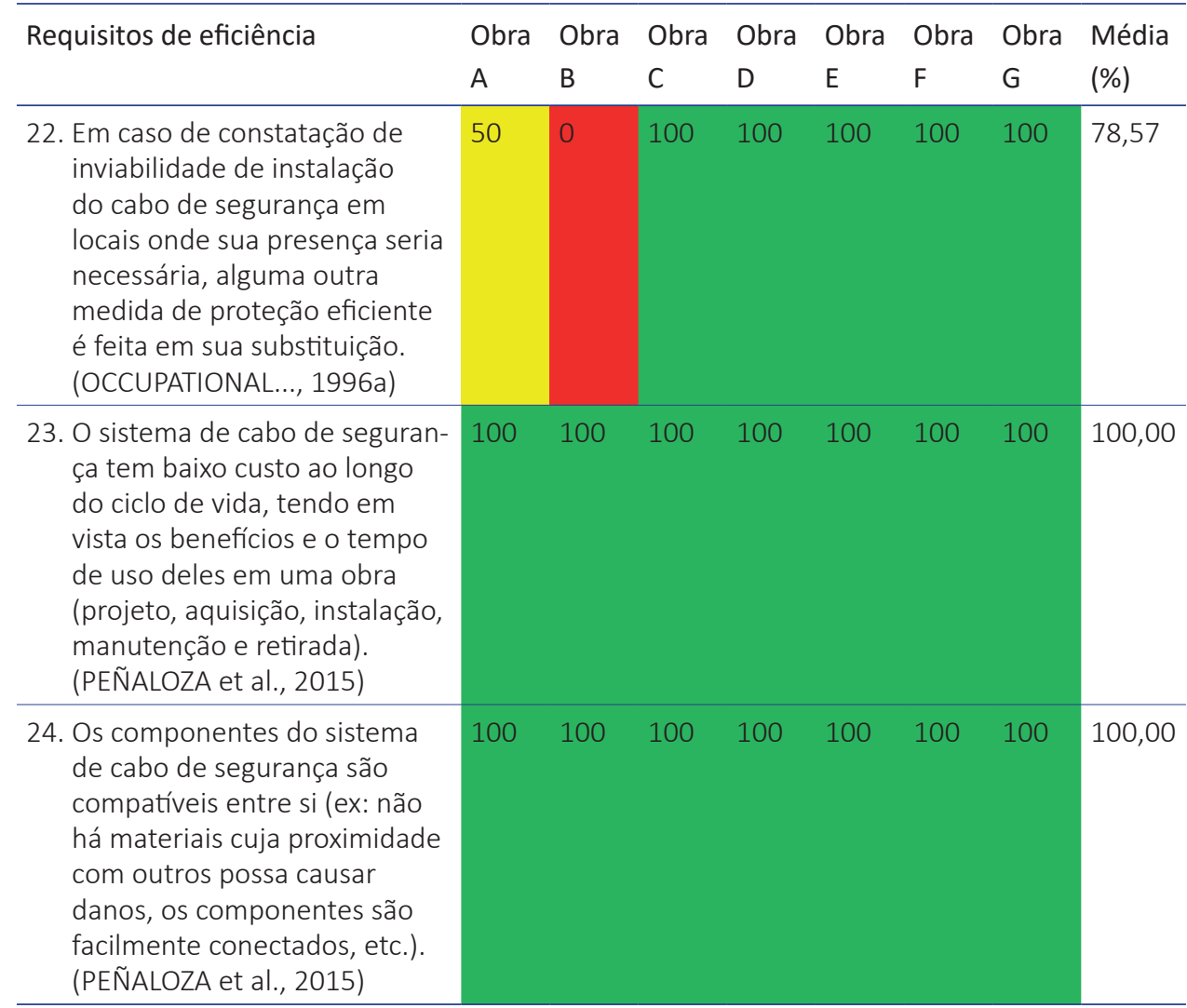

Fonte: Elaboração dos autores.

De acordo com a Tabela 4, os requisitos 23 e 24 obtiveram atendimento máximo, posto que todos os engenheiros entrevistados consideram o custo dos cabos de segurança baixo, tendo em vista seus benefícios ao longo do ciclo de vida. O requisito de número 18, atendido totalmente em duas obras e parcialmente em uma, obteve média de somente $35,71 \%$, pois a maioria dos engenheiros entrevistados considera que o cabo influencia negativamente no desenvolvimento das atividades, diminuindo a produtividade.

Analisando os requisitos 18 e 20 em conjunto, pode-se observar que há uma relação entre os sistemas não permitirem uma rápida instalação e retirada e a interferência negativa nos serviços dos trabalhadores. Esse fato se explica, dentre outros motivos, pela necessidade de repetidas retiradas e conexões do cinto de segurança por parte do trabalhador e pela grande variedade e número de sistemas existentes nos canteiros. 


\subsection{Categoria Flexibilidade}

A Tabela 5 apresenta os resultados de atendimento das obras quanto aos requisitos na categoria flexibilidade, a média de cada empresa, média de cada requisito e média geral da categoria. Nessa categoria, todos os itens superaram os $70 \%$ de atendimento, sendo o requisito 25 o mais atendido, pois todas as empresas possuíam sistemas que poderiam ser utilizados em todas as etapas da obra.

Tabela 5 - Atendimento da categoria flexibilidade.

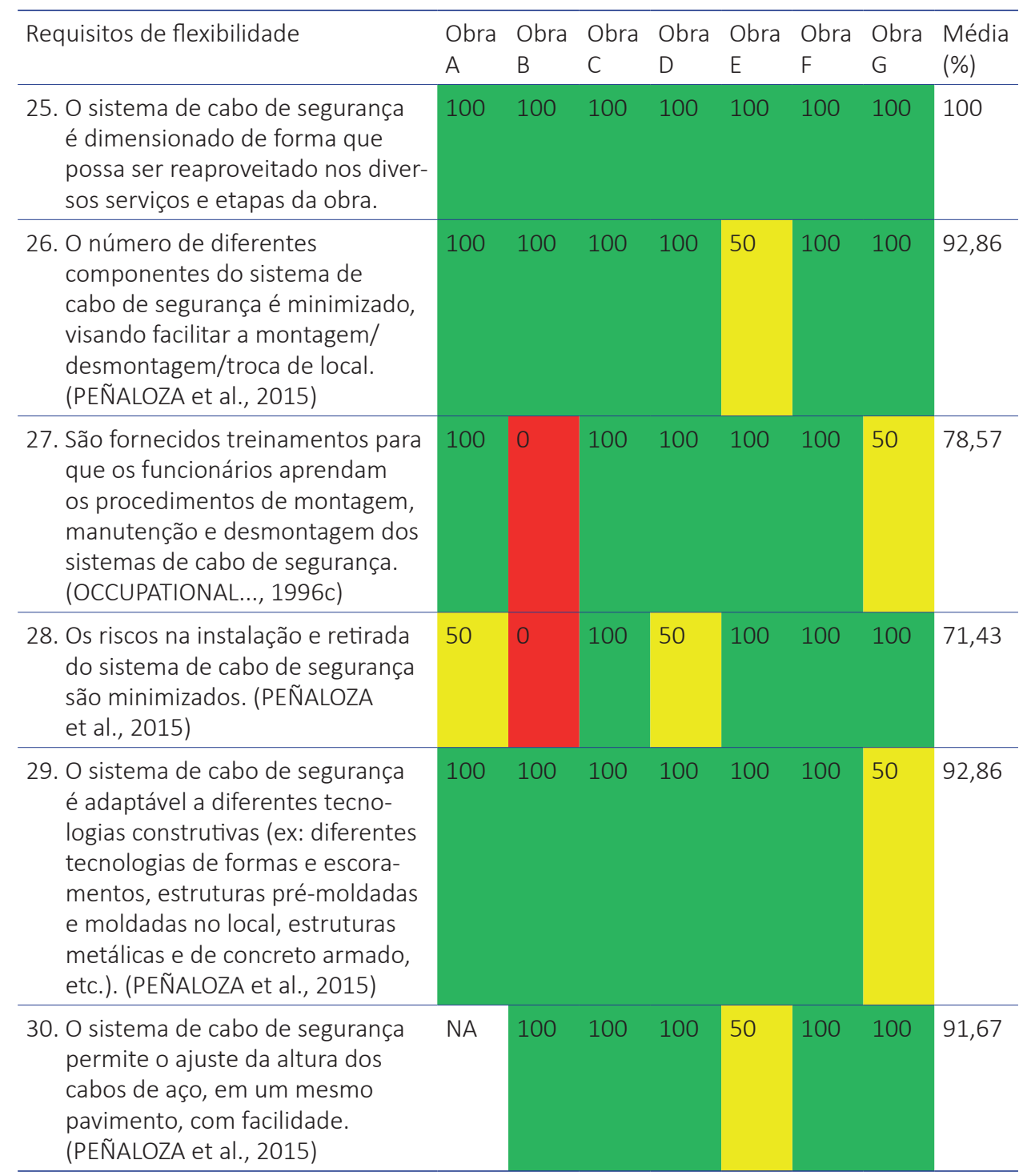

Fonte: Elaboração dos autores. 
Nessa categoria, sete requisitos obtiveram $100 \%$ de atendimento. Os principais fatos que levaram ao alcance destes resultados foram a relevância que as empresas deram ao dimensionamento envolvendo praticidades em montagem, utilização e desmontagem do sistema, além da análise efetiva das possibilidades de interferência entre os sistemas existentes nos canteiros.

A facilidade de desmontagem e a minimização de peças, abordada pelo projeto de dimensionamento, bem como o fornecimento de treinamentos aos trabalhadores, contribuíram com a possibilidade de uma reutilização eficiente dos cabos, nas diferentes etapas da obra ou em obras futuras, buscando dessa forma diminuir seu custo ao longo do ciclo de vida.

\subsection{Comparação de Atendimento entre as Categorias e entre as Obras}

Observando a Figura 1, pode-se perceber que a categoria flexibilidade foi a mais atendida, obtendo média de atendimento de $87,86 \%$. Já a categoria segurança nos projetos foi a que obteve menor atendimento entre as obras.

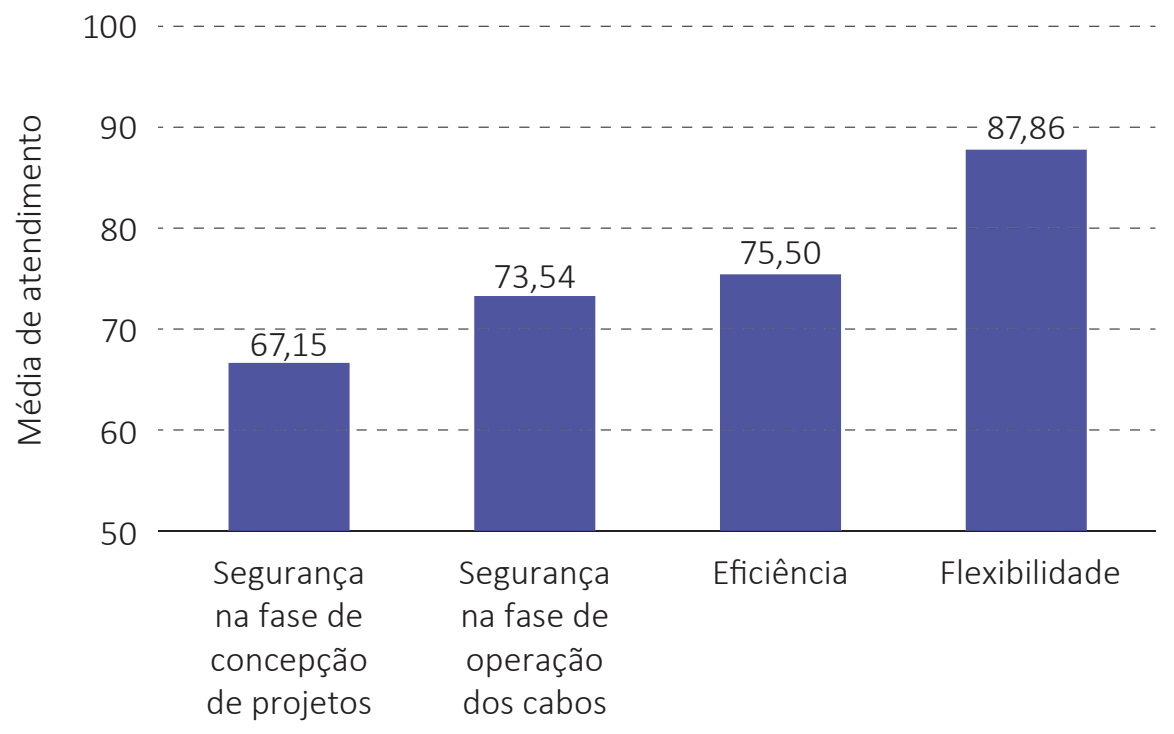

Categoria

Figura 1 - Média de atendimento das categorias. Fonte: Autores.

A Figura 2 permite observar as porcentagens de atendimento de cada uma das sete empresas analisadas, de maneira individual para cada categoria. Referente 
à primeira categoria, nota-se que as obras C e G obtiveram os melhores resultados com níveis máximos de atendimento aos requisitos de segurança na fase de projeto, sendo a obra $\mathrm{A}$ a responsável pelas piores porcentagens. Esta atingiu o resultado de $0 \%$ de atendimento devido ao fato de não realizar o dimensionamento por profissional habilitado e não apresentar grau de detalhamento adequado nos projetos fornecidos aos funcionários responsáveis pela montagem do sistema, os quais acabavam por efetuar de maneira empírica.

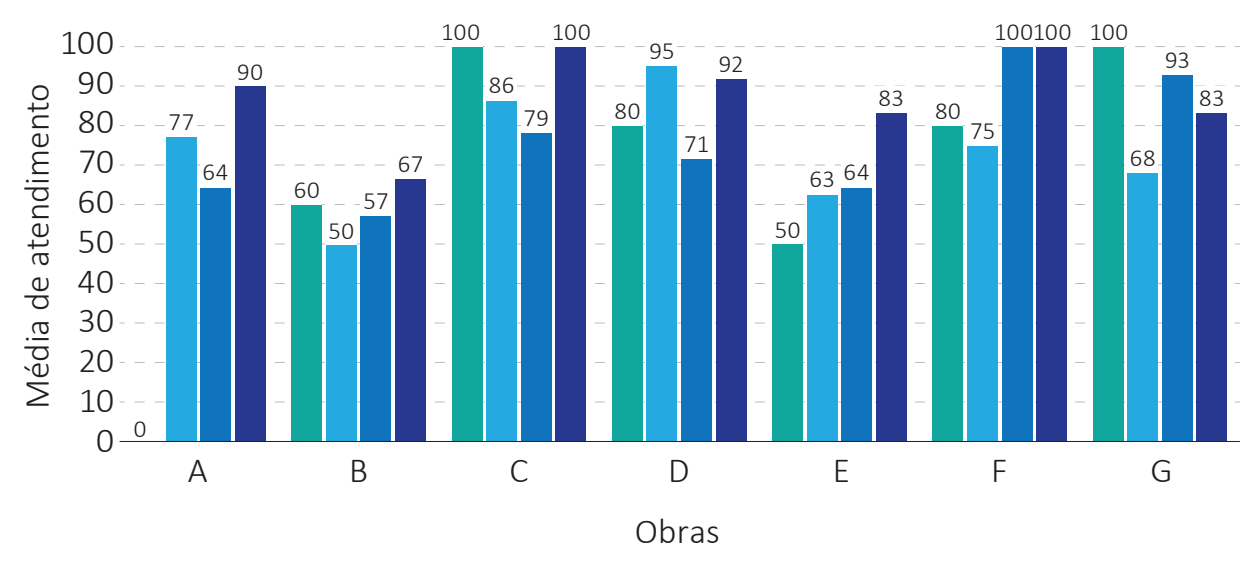

Segurança na fase de concepção de projetos

- Segurança na fase de operação dos cabos

Eficiência

- Flexibilidade

Figura 2 - Média total de atendimento por cada obra. Fonte: Autores.

Quanto à categoria "Segurança na fase de operação dos cabos", foram obtidos os melhores resultados na obra $D$, a qual atingiu $95,45 \%$ de cumprimento aos requisitos. O pior desempenho nessa categoria foi apresentado pela obra B, uma vez que pontos importantíssimos à aplicação segura do sistema foram descumpridos, como revisões, inspeções e sinalizações aos usuários.

A categoria "Eficiência" teve a obra F como a de melhor desempenho com $100 \%$ dos requisitos atendidos. Esta se preocupava em garantir um fácil manuseio e utilização do sistema mediante o emprego de montantes, cabos reutilizados de andaimes e ajuste de altura a partir de abraçadeira, conforme Figura 3. Salienta-se ainda a compatibilidade entre os componentes, sem que houvesse interferência entre o cabo de segurança e outros equipamentos instalados em obra. Novamente, nessa categoria, a obra B obteve o pior desempenho, pois o sistema não proporcionava rapidez na instalação e retirada, interferia de maneira negativa na produtividade dos 
trabalhadores e não previa outro meio de proteção para casos de inviabilidade de instalação do cabo.

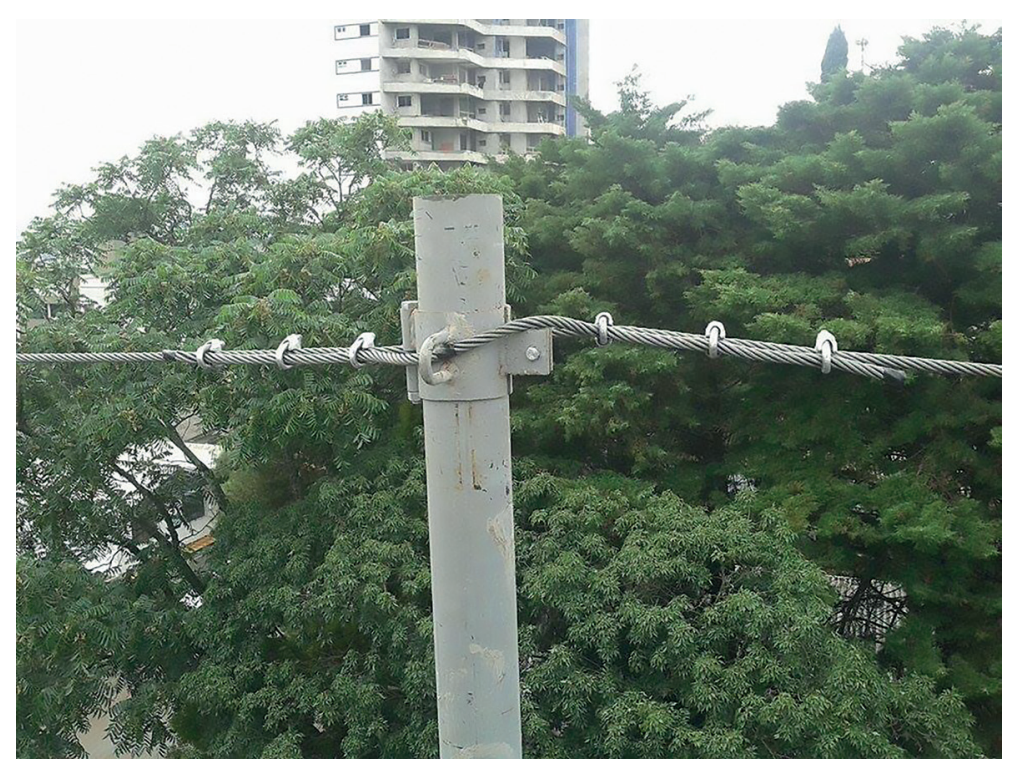

Figura 3 - Montantes, cabos de aço e abraçadeiras na obra F. Fonte: Autores.

A última categoria analisada foi "Flexibilidade", na qual duas obras obtiveram o mesmo desempenho, com $100 \%$ dos requisitos atendidos, sendo elas as obras $\mathrm{C}$ e F. Além destas, pode-se citar como referência de bom resultado a obra $D$, que obteve 91,67\% de atendimento, com apenas um requisito sem atingir total conformidade.

Em relação a desempenho negativo, essa foi a terceira categoria em que a obra B atingiu os piores resultados, apresentando 66,67\% de atendimento, uma vez que não era disponibilizado treinamento aos trabalhadores nem, em nenhum momento da instalação do sistema, buscava-se minimizar os riscos de queda aos envolvidos.

Avaliando os resultados por categoria, destacam-se as obras B, C e F. A obra B obteve os piores resultados em três das quatro categorias analisadas, e as obras $\mathrm{C}$ e $\mathrm{F}$ atingiram o melhor desempenho dentre todas as sete obras.

\section{Conclusões}

Ainda que a utilização de equipamentos de segurança contra quedas seja crescente na busca por índices menores de acidentes, métodos que permitam avaliar seu uso como meio de aplicar melhorias e de atingir maiores conformidades com requisitos normativos e de natureza prática são necessários. 
Realizou-se, desta forma, a aplicação de um protocolo de avaliação em obra, que incorporou tanto os requisitos de normas, quanto os originados a partir de vivência em canteiros, sendo classificados dentro das categorias "Segurança", na etapa de projeto e operação, "Eficiência" e "Flexibilidade".

Como principais resultados, salienta-se a categoria "Segurança na fase de concepção de projetos" como a de menor desempenho e a "Flexibilidade" como a mais atendida. Pode-se assim aferir que a maioria das empresas não valoriza um projeto e planejamento eficazes como principais certificadores das condições de segurança adequada aos trabalhadores e até mesmo do aumento do rendimento desses atores da construção civil. Além do mais, conclui-se que maiores esforços concentram-se em cumprir os requisitos que envolvam a redução de custos, como a possibilidade de reutilização e adaptação do equipamento a diferentes arranjos e obras.

Já os cabos de fibra sintética transpassados em barras de ferro com uma dobra em sua ponta, utilizado pela obra $\mathrm{C}$ durante a etapa de levantamento de alvenaria, apresentou o maior desempenho, sendo possível apontar a presença e exercício constante do técnico e engenheiro de segurança do trabalho no canteiro de obras como promotores deste resultado. Tais profissionais realizavam o planejamento semanal das atividades em altura e controle dos trabalhos por meio de registro de Permissão para Trabalho (PT).

Além disso, pode-se concluir que o projeto de dimensionamento era efetuado de modo a cumprir com requisitos de segurança para cabos em fibra sintética, como os estabelecidos pela NR 18 - Condições e meio ambiente de trabalho na indústria da construção, em seu item 18.16 e Anexo I, comprovado pelos 100\% de atendimento à categoria segurança na fase de projeto.

Especificamente à avaliação das categorias e seus requisitos, todos os resultados ressaltam a importância de aplicar o método de avaliação proposto no estudo como ferramenta às empresas na análise dos processos utilizados na concepção, uso e manuseio de seus cabos de segurança.

\section{Referências}

ASSOCIAÇÃO BRASILEIRA DE NORMAS TÉCNICAS. NBR 11900-4: Terminal para cabo de aço. Parte 4: Grampos leve e pesado. Rio de Janeiro, 2016.

BORJAN, M.; PATEL, T.; LEFKOWITZ, D.; CAMPBELL, C.; LUMIA, M. Assessing barriers to the use of fall protection in small residential construction companies in New Jersey. New solutions: a journal of environmental and occupational health policy, v. 26, n. 1, p. 40-54, 2016. 
BRANCHTEIN, M.C.; SOUZA, G.L.; SIMON, W.R. Sistema de proteção ativa contra quedas com Linha de Vida Horizontal Flexível. In: FILGUEIRAS, V. A. (Org.). Sergipe: Procuradoria Regional do Trabalho da $20^{\circ}$ região, 2015. p. 159-176.

BRASIL. Ministério do Trabalho e Emprego. Norma Regulamentadora 18 (NR-18): Condições e meio ambiente de trabalho na indústria da construção. 2015. Brasília-DF. Disponível em: <http://trabalho.gov.br/seguranca-e-saude-no-trabalho/normatizacao/ normas-regulamentadoras/norma-regulamentadora-n-18-condicoes-e-meio-ambientede-trabalho-na-industria-da-construcao>. Acesso em: nov. 2016.

BRASIL. Ministério do Trabalho e Emprego. Norma Regulamentadora 35 (NR-35): Trabalho em Altura. Rio de Janeiro: 2014. Disponível em: <http://portal.mte.gov.br/images/ Documentos/SST/NR/NR4.pdf>. Acesso em: nov. 2015.

CHERRI, S.; ARGUDIN, R. Fall rescue plans \& dropped object prevention: what every safety manager should know. Professional Safety, v. 61, n. 5, p. 38-41, 2016.

EVANOFF, B.; DALE, A.M.; ZERINGUE, A.; FUCHS, M.; GAAL, J.; LIPSCOMB, H.J.; KASKUTAS, $V$. Results of a fall prevention educational intervention for residential construction. Safety Science, v. 89, n. 9, p. 301-307, 2016.

OCCUPATIONAL SAFETY AND HEALTH ADMINISTRATION. United States Department of Labour. 1926.501 - Duty to have fall protection. 1996a. Disponível em: https://www.osha. gov/pls/oshaweb/owadisp.show_document?p_table=STANDARDS\&p_id=10757. Acesso em: set. 2015.

OCCUPATIONAL SAFETY AND HEALTH ADMINISTRATION. United States Department of Labour. 1926.502 - Fall protection systems criteria and practices. 1996b. Disponível em: https://www.osha.gov/pls/oshaweb/owadisp.show_document?p_table=STANDARDS\&p_ id=10758 Acesso em: set. 2015.

OCCUPATIONAL SAFETY AND HEALTH ADMINISTRATION. United States Department of Labour. 1926.503 - Training requirements. 1996c. Disponível em: https://www.osha.gov/ pls/oshaweb/owadisp.show_document?p_table=STANDARDS\&p_id=10759 Acesso em: set. 2015.

PEÑALOZA, G.A.; FORMOSO, C.T.; SAURIN, T.A. Avaliação de requisitos de desempenho de Sistemas de Proteção Periférica (SPP). Ambiente Construído, Porto Alegre, v. 15, n. 4, p. 267-289, out./dez. 2015. 


\title{
Inovação em Plataformas de Proteção
}

\author{
Alex Alves Bandeira \\ Ricardo Fernandes Carvalho \\ Emerson de Andrade Marques Ferreira
}

\section{Introdução}

A Indústria da Construção Civil é um dos setores de maior relevância socioeconômica, principalmente por sua capacidade de gerar postos de trabalho. Entretanto, devido à natureza das atividades, os trabalhadores são expostos a diversas situações de risco durante a jornada de trabalho. A probabilidade de acidentes no trabalho é grande, refletindo nos índices de acidentes do setor. Como exemplo, dados do Departamento Intersindical de Estudos e Pesquisas de Saúde e dos Ambientes de Trabalho, DIESAT (2009), apontam que o setor da construção civil é o líder em acidentes do trabalho (54.142), sendo 19.131 ocorridos na construção de edifícios.

Historicamente, pode-se observar a persistência dos elevados índices de acidentes na construção, o que conduziu ao poder público reforçar o sistema de normas e diretrizes para melhorar as condições do meio ambiente de trabalho na indústria da construção. O principal instrumento normativo tem sido a Norma Regulamentadora 18 (BRASIL, 2013), utilizada como referência do Ministério do Trabalho para ação de fiscalização em canteiros.

As causas de óbito com maior recorrência em canteiros de obras são os de quedas em altura, exposição ocupacional às forças mecânicas inanimadas, exposição a cargas elétricas e agentes físicos, riscos à respiração e outros fatores. Sendo, cerca de $1 / 3$ dos óbitos referentes aos acidentes de queda em altura. 
A NR 18 - Condições e meio ambiente de trabalho na indústria da construção, item 13 , trata do projeto e da instalação dos sistemas de proteções coletivas contra quedas. Plataformas primárias fixas e secundárias estão entre essas medidas de proteção. A indústria da Construção tem desenvolvido esforços para o aprimoramento de tais equipamentos e, entre essas inovações, está o sistema modular proposto por Silva et al. (2007). O presente trabalho pretende avaliar um protótipo do sistema modular, tanto em canteiro, observando os processos de montagem desmontagem e transporte, como mediante o uso de simulações por Elementos Finitos, prevendo o comportamento do sistema quando submetido a impactos de quedas. Desta forma, visa oferecer suporte para a tomada de decisão sobre a adoção de modelos de plataformas atualmente observadas em canteiros pelo País.

\section{Sistema Tradicional}

O Relatório Técnico de Procedimento (RTP) 01 - Medidas de Proteção Contra Quedas de Altura apresenta, no item 4.3, os Dispositivos de Proteção para Limitação de Quedas, no qual trata especificamente de plataformas de periferia. O sistema de plataformas de proteção usual é composto por uma estrutura metálica de suporte (Figura 1) e um assoalho em tábuas de madeira ou compensados. A Norma Regulamentadora 18 (BRASIL, 2013) prevê a construção provisória, em todo perímetro da construção de edifícios com mais de quatro pavimentos ou altura equivalente, de plataformas, como parte das medidas de proteção contra quedas de altura. As dimensões são variáveis em função do local de implantação, podendo classificar-se em primárias fixas ou secundárias móveis. A Plataforma principal, na altura da primeira laje, deve ter $2,50 \mathrm{~m}$ de projeção horizontal da face externa da construção e complemento com $0,80 \mathrm{~m}$ de extensão, enquanto as plataformas secundárias de proteção, em balanço, de 3 em 3 lajes. Essas plataformas devem ter 1,40 m de balanço e um complemento de $0,80 \mathrm{~m}$ de extensão.
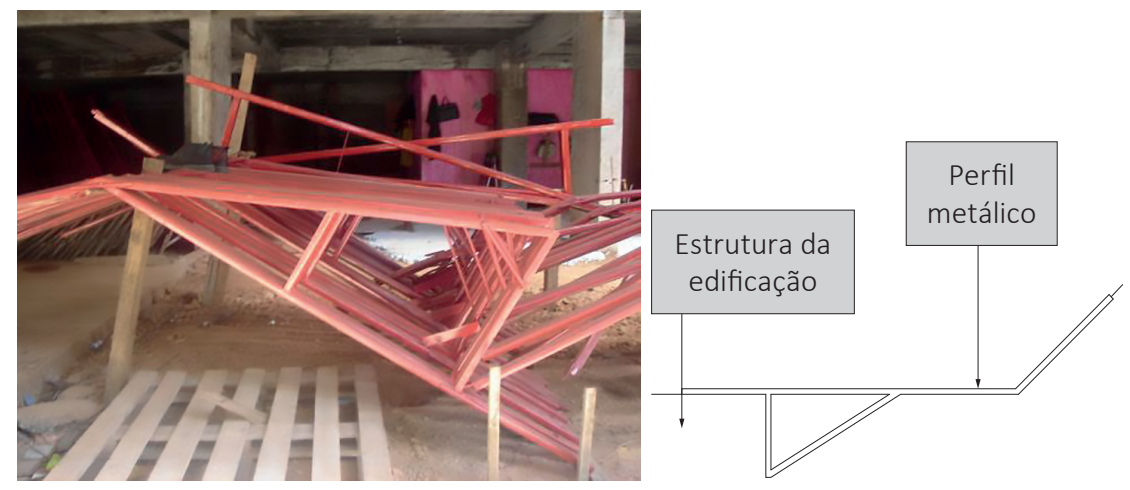

Figura 1 - Suporte metálico para plataformas de proteção secundárias 
O processo de movimentação da plataforma secundária tem início com transporte dos materiais até o pavimento determinado para a instalação, por meio do elevador de carga da obra. O elevador utilizado comporta um número limitado de tábuas ou perfis metálicos. Após chegar ao pavimento, os materiais são movimentados para próximo do local em que acontecerá a instalação da plataforma. O sistema de fixação dos perfis na laje é tipicamente realizado por vergalhões ancorados à estrutura recém concretada, que servem para fixar a plataforma na estrutura da edificação. Entretanto, além do desperdício de tempo e ocupação do sistema de transporte vertical no canteiro, a montagem das plataformas secundárias expõe os operários a graves riscos de quedas, Figura 2.

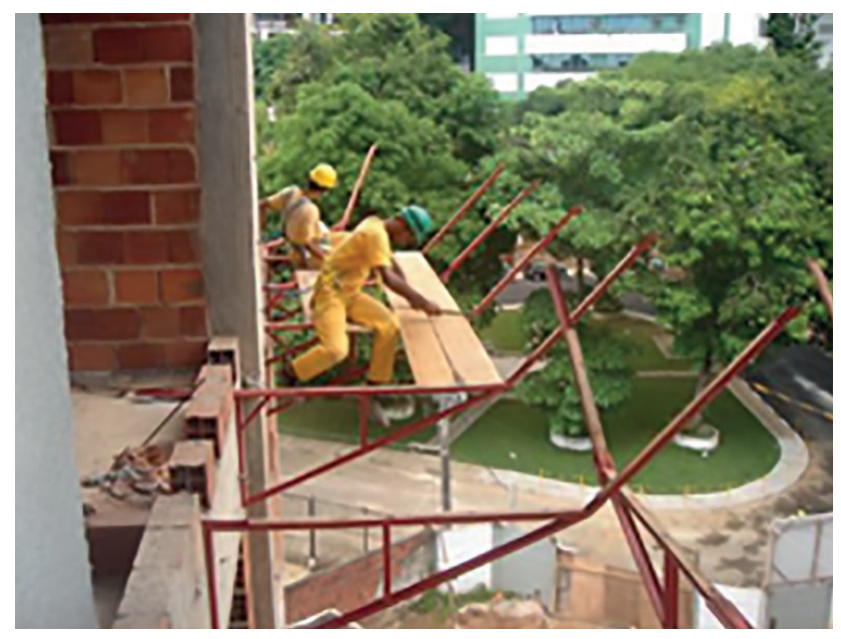

Figura 2 - Montagem de plataformas secundárias.

\section{Inovação Proposta}

O modelo de solução inovadora proposto por Silva et al. (2007) consiste em um sistema de plataforma com dois suportes metálicos de aço, espaçados em 1,40 $\mathrm{m}$ de largura, com 3 folhas de madeira compensada, apoiadas sobre os suportes e fixadas conforme a Figura 3a. Os suportes metálicos são presos na laje por meio de braçadeiras fixadas nesse mesmo local durante a fase de concretagem, Figura 3b. No ponto de início da inclinação da estrutura metálica, existem argolas que têm a função de prender os cabos de aço que serão presos nas braçadeiras localizadas na laje superior. 


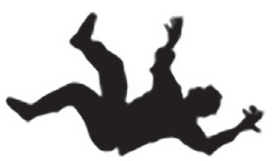

(a)

Força de impacto aplicada
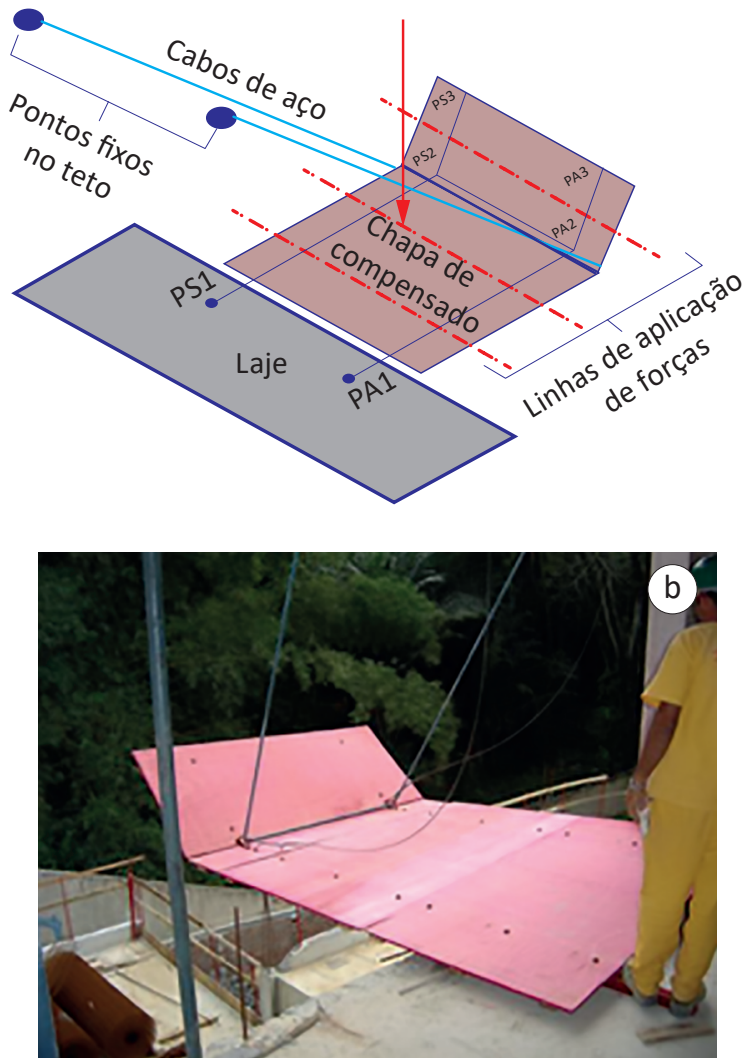

Figura 3 - Estrutura Fixada na Laje Inferior e Superior: a) esquema; b) imagem.

O objetivo das plataformas de proteção não é aparar a queda de operários, mas como é algo que eventualmente pode ocorrer, é necessário prever esse tipo de acidente no projeto da plataforma. Na avaliação de comportamento estrutural, foi considerado a queda de massa igual a $110 \mathrm{Kg}$ e a uma altura de 0,7 m em relação à plataforma fixada.

As peças da estrutura são todas projetadas para serem montadas visando à redução de perdas no corte da chapa de compensado, que servirá de base para a superfície inclinada, pois a "sobra" será reutilizada no preenchimento da lacuna deixada pelas duas placas de compensado fixadas mediante encaixe. 
Após a montagem da estrutura da plataforma e fixação das chapas de compensado, as pontas dos dois cabos de aço são presas nos ferros fixados durante a concretagem da laje. Feito isso, são presos os cabos na seção de início da inclinação do suporte, para posterior içamento por guindaste ou por operários, pela laje superior até que se tenham condições de encaixa-la nas braçadeiras fixadas no momento da concretagem da laje.

Dessa forma, o sistema modular de plataforma de proteção estará fixado, com a vantagem de não necessitar ser desmontado para ser transferido para a laje superior. É necessário apenas afrouxar a fixação dos cabos de aço da laje superior e prender na posterior e repetir todo o processo de encaixe na próxima laje.

Esse tipo de plataforma torna-se bastante dinâmica, na medida em que só precisa ser montada uma única vez, e o seu conjunto modular é de fácil armazenagem.

A proposta de inovação resulta também num sistema mais leve, possível pela substituição de tábuas de madeira com espessuras entre $20 \mathrm{~mm}$ e $25 \mathrm{~mm}$ por compensados com espessura de $10 \mathrm{~mm}$, assim como pela adoção de perfis metálicos leves. Na Figura 4, apresenta-se o momento de içamento do módulo para uma nova posição na construção, utilizando uma minigrua. A substituição do trabalho manual de desmontagem, transporte e remontagem das plataformas, envolvendo uma equipe de carpinteiros, por operações mais simples e conjunto de elementos solidarizados, potencialmente reduz a quantidade de horas de trabalho envolvida na operação de movimentação das plataformas secundárias.

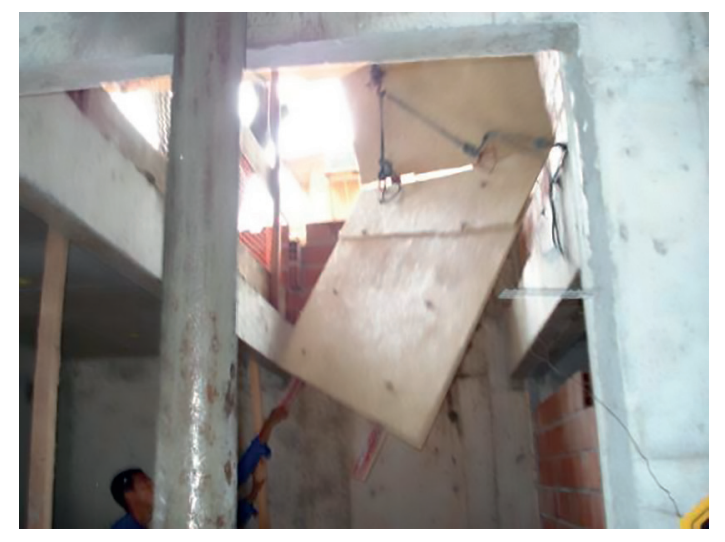

Figura 4 - Içamento do módulo da plataforma.

O suporte utilizado consiste em um sistema em perfis metálicos em "I" e ripas de madeira com as dimensões indicadas na Figura 5. O suporte é montado ainda sobre 
a laje e são encaixadas as chapas de madeira compensada, conforme ilustra a Figura 5. Depois de fixados os cabos de aço, o sistema já está pronto.

$\mathrm{Na}$ Figura 5, é apresentado o esquema utilizado para a análise estrutural, sem as chapas de compensado, o que facilita identificar os tipos de elementos usados e as dimensões dos perfis.

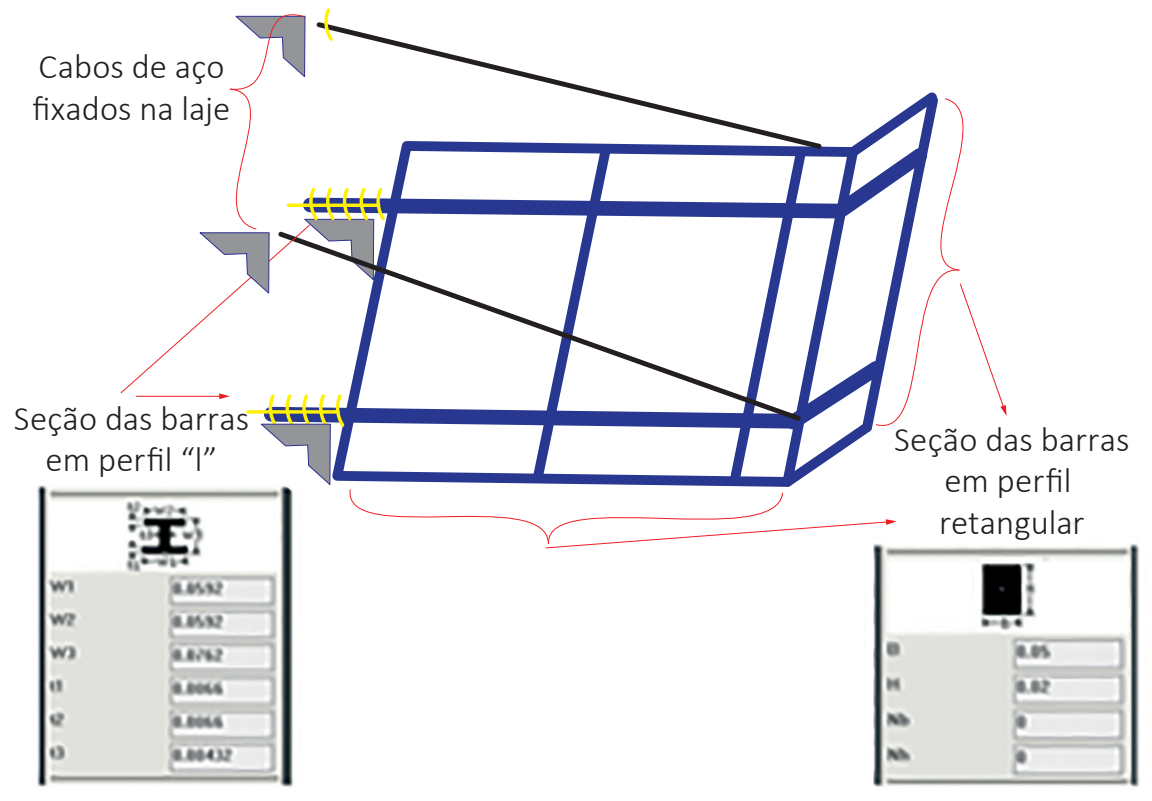

Figura 5 - Estrutura da plataforma sem as chapas de compensado.

Este protótipo foi modelado no ambiente gráfico do ANSYS, programa de engenharia que permite fazer simulações de modelos numéricos com todas as propriedades e solicitações de cargas a que uma estrutura é submetida. Para a análise numérica, é utilizado o Método dos Elementos Finitos. Estudos sobre modelagens numéricas utilizando o Método dos Elementos Finitos e Contato Mecânico podem ser vistos em detalhes em Bandeira et al. (2001), Bandeira et al. (2006), Bathe (1996), Bertsekas (1995) e Curnier (1984).

Os efeitos de impacto sobre a plataforma foram avaliados considerando o coeficiente de impacto calculado em 15, resultando numa carga equivalente de $32800 \mathrm{~N} / \mathrm{m}^{2}$. Foram utilizados critérios de resistência para atender as tensões admissíveis dos materiais. Foi aplicada a relação bilinear, simulando um modelo elástico com plasticidade perfeita. 
O Quadro 1 apresenta os dados dos componentes do protótipo por plataformas modular de largura $2,20 \times 3,00 \mathrm{~m}$.

Quadro 1- Quantitativo de componentes.

\begin{tabular}{ll}
\hline Quantidade & Componentes do Protótipo \\
\hline $7,60 \mathrm{~m}$ & Barra de perfil em "I" \\
\hline $17,60 \mathrm{~m}$ & Barrote retangular de seção $0,05 \times 0,02 \mathrm{~m}$ \\
\hline 3 unidades & Chapa resinada cola branca $2,20 \times 1,10$ metros, $10 \mathrm{~mm}$ de espessura \\
\hline $20,00 \mathrm{~m}$ & Cabo de Aço com $\varnothing=6,40 \mathrm{~mm}, \approx 1 / 4$ " (ref. $18 \times 7)$ \\
\hline
\end{tabular}

Os resultados da análise estão apresentados na forma de deslocamentos verticais ampliados em 15 vezes (Figura 6). Observa-se que, na posição em que ocorre o choque do corpo humano, há um deslocamento vertical de aproximadamente 4,1 $\mathrm{cm}$. Próximo à borda da plataforma, ocorre um deslocamento estimada de $1,3 \mathrm{~cm}$. A plataforma inclinada, no momento do impacto, tende a fechar, ou seja, aumenta seu ângulo de inclinação.

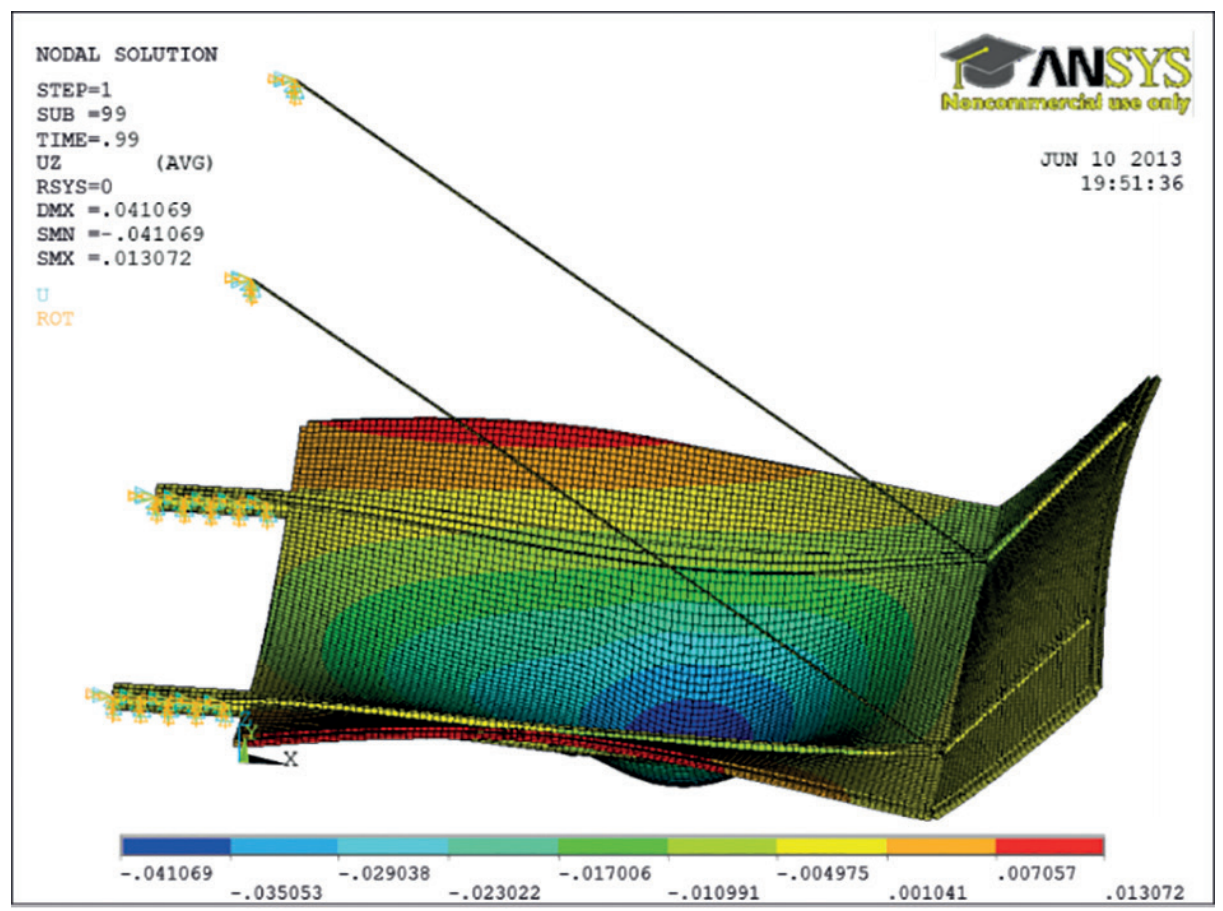

Figura 6 - Deslocamento vertical da plataforma de proteção. 
Na Figura 7, estão apresentados os resultados de tensões principais máximas. Observa-se que a maior tensão atuante na placa de madeira é de aproximadamente 26.8 MPa.

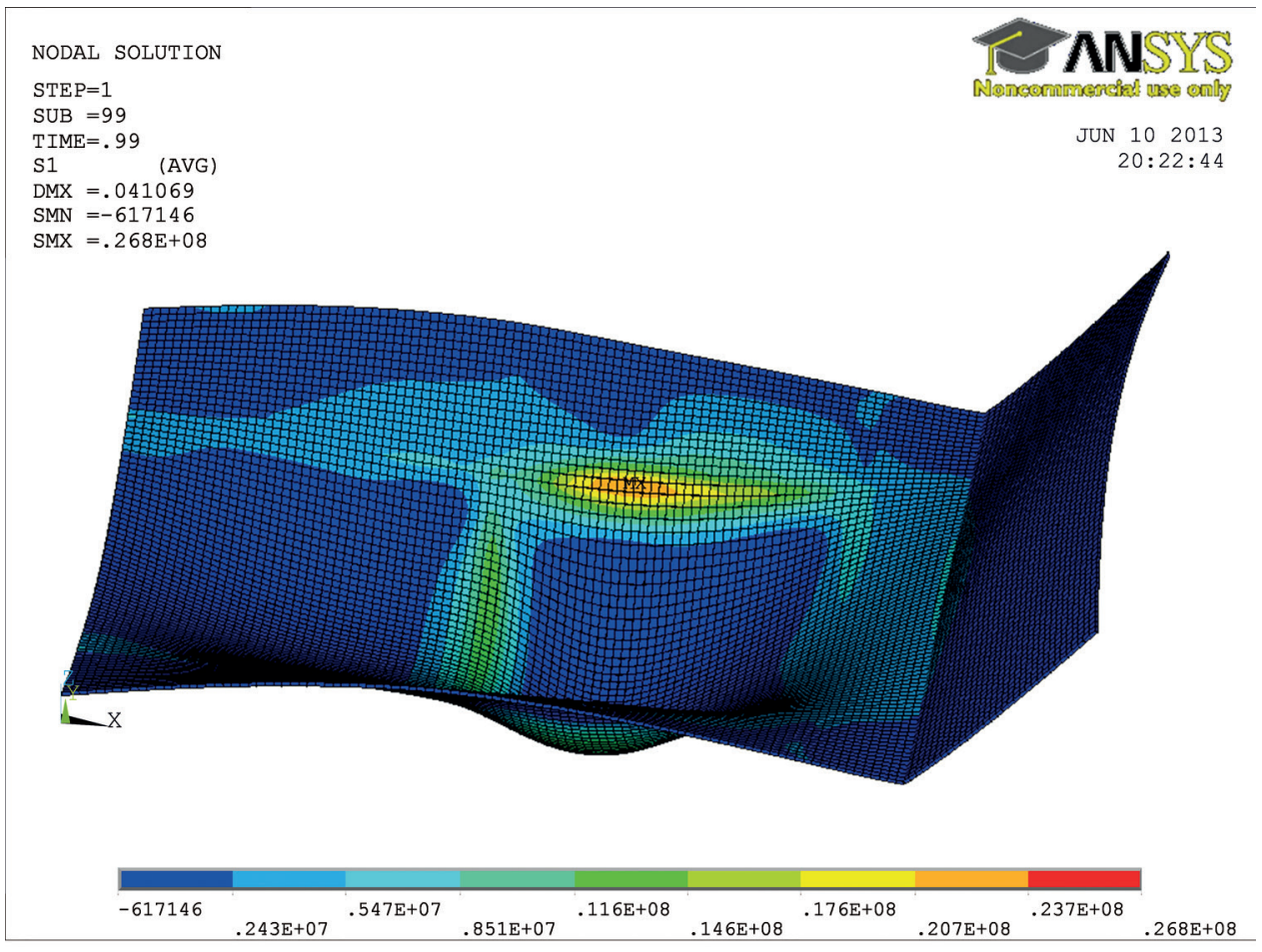

Figura 7 - Tensões principais nas chapas da plataforma de proteção.

\section{Análise Funcional e Estrutural da Inovação Proposta}

A solução modular das plataformas permite maior eficiência dos trabalhos de montagem, desmontagem e transporte nos canteiros por reduzir a quantidade de componentes.

A solução mais leve e mais flexível demanda análise de comportamento estrutural mais apurado. Neste trabalho, demonstra-se que a estrutura proposta apresenta comportamento mecânico para cargas estáticas ou quase-estática adequado. O comportamento sob cargas dinâmicas também se mostra adequado. Além disso, os resultados indicam que o sistema aqui discutido apresenta grande deformabilidade e absorve grandes quantidades de energia, reduzindo danos aos acidentados. 
Entretanto, a geometria diferenciada não é prevista nas normas utilizadas como referência para as ações fiscalizadoras do MTE. O risco gerencial na adoção de medidas inovadora é a aceitação não uniformizada entre os agentes de fiscalização.

\section{Considerações Finais}

A construção civil continua sendo um desafio aos profissionais envolvidos com a segurança do trabalho, sendo a NR 18 - Condições e meio ambiente de trabalho na indústria da construção, a principal referência para orientação das medidas de segurança do trabalho. Tal norma indica as proteções coletivas como as medidas primárias de proteção que devem ser priorizadas, assim como as quedas de pessoas e objetos são apontas como importantes causas de óbitos. As plataformas de periferia são apresentadas como medida contra quedas de objetos.

A comparação entre as soluções usuais observadas em canteiros e solução modular das plataformas avaliadas permite observar que nos trabalhos de montagem, desmontagem e transporte a proposta modular, examinada neste estudo, reduz a quantidade de material empregado, volume de madeiras e derivados e massa de aço, abrindo a possibilidade de redução de custo nos canteiros por diminuir a quantidade de componentes. Tanto a redução da massa de materiais como a disponibilidade modular permite o transporte em blocos modulares, viabilizando a mecanização do transporte.

A estrutura da solução modular apresenta comportamento mecânico para cargas estáticas ou quase-estática adequado, o comportamento sob cargas dinâmicas também se mostra apropriado. A solução modular é um sistema estrutural de grande deformabilidade e absorve grandes quantidades de energia.

A pesquisa de novas soluções e novos produtos destinados à proteção coletiva na construção permite o desenvolvimento de soluções inovadoras que podem se consolidar como mais eficientes, contribuindo para redução de custos e facilidade de implantação das proteções coletivas em canteiros.

\section{Referências}

BANDEIRA, A.A.; WRIGGERS, P.; PIMENTA, P.D.M. Homogenization Methods Leading to Interface Laws of Contact Mechanics - A Finite Element Approach for Large 3D Deformation using Augmented Lagrangian Method. London, England, s.n. 2001.

BANDEIRA, A.A.; PIMENTA, P.D.M.; WRIGGERS, P. A 3D study of the contact interface behavior using elastic-plastic constitutive equations. Lecture Notes In Applied And Computational Mechanics, v. 27, pp. 313-324. 2006.

BATHE, K.-J. Finite Element Procedures. First ed. New Jersey: Prentice-Hall, Englewood Cliffs. 1996. 
BERTSEKAS, D.P. Nonlinear programming. Belmont: Athena Scientific. 1995.

BRASIL. Ministério do Trabalho e Emprego. Norma Regulamentadora 18 (NR-18): Condições e meio ambiente de trabalho na indústria da construção. 2013. Disponível em: http:// portal.mte.gov.br/legislacao/norma-regulamentadora-n-18-1.htm. Acesso em: set. 2013.

CURNIER, A. A Theory of Friction. International Journal for Solids Structures, pp. 637-647. 1984.

DIESAT. Departamento Intersindical de Estudos e Pesquisas de Saúde e dos Ambientes de Trabalho. Anuário Estatístico de Acidentes do Trabalho. São Paulo, 2009. Disponível em http://diesat.org.br/arquivos/anuario_2009.pdf. Acesso em: set. 2013.

SILVA, R.C.; CÂMARA, G.A.B.; NASCIMENTO, L.M.B.; OLIVEIRA, V.M.B.; ROCHA, J.A.L.; FERREIRA, E.A.M.; CARVALHO, R.F. Plataforma de proteção contra queda de material na construção civil. Patente: Modelo de Utilidade. Número do registro: MU87020 INPI. Brasil, 2007. 


\section{Diretrizes para o uso de Veículo Aéreo não Tripulado (VANT) Para Inspeção de Segurança em Canteiros de Obra}

Roseneia Rodrigues Santos de Melo

Dayana Bastos Costa Juliana Sampaio Álvares

\section{Introdução}

A indústria da construção civil ainda enfrenta dificuldades quanto à gestão da segurança nos canteiros de obras, cuja ineficiência está diretamente relacionada à ocorrência de acidentes. Embora a inspeção seja um elemento importante do sistema de gestão de segurança, responsável pela detecção e correção dos riscos (WOODCOCK, 2014), ainda se observam deficiências quanto a este processo, tais como a ausência de procedimento estruturado para conduzir a inspeção (LIN et al., 2014), supervisão insuficiente e a dificuldade em visualizar as condições de trabalho (SHRESTHA et al., 2011).

Para Irizarry et al. (2012), o processo de inspeção de segurança na construção civil deve possuir três características principais: frequência, observação direta e interação direta com os funcionários. Para isso, devem ser estabelecidas rotinas de inspeção consistentes, baseando-se em critérios e requisitos de segurança estipulados por normas e regulamentações. Entretanto, o tamanho do canteiro e a quantidade de 
atividades a serem observadas influenciam no tempo gasto para a avaliação de suas condições (CAMBRAIA et al., 2010; IRIZARRY et al., 2012).

Além disso, determinados estudos (KIM et al., 2008; PARK et al., 2013) e a prática mostram que os processos de monitoramento e inspeção gerencial apresentam uma série de problemas, que acabam por reduzir a eficiência e eficácia destas avaliações. Segundo os autores citados, tais problemas estão associados a: (a) insuficiência de pessoal para análise dos requisitos de segurança e a alta demanda de preenchimento manual de dados; (b) excesso de trabalho na coleta de dados, devido ao grande número de requisitos a serem avaliados; (c) falta de padronização dos checklists de avaliação, bem como dos meios de processamento e análise dos dados; (d) perdas de informação entre coleta e processamento de dados; (e) pouca comunicação entre os intervenientes do projeto; (f) dificuldade de agir em tempo real para corrigir problemas e de realizar ações preventivas.

Em vista disso, e com o surgimento de novas tecnologias, muitos pesquisadores têm buscado conhecer o potencial delas para a melhoria dos processos gerenciais de construção. Estudos recentes aplicados a domínios da engenharia civil apontam que os Veículos Aéreos Não Tripulados (VANTs), com câmeras digitais acopladas, podem fornecer informações visuais em alta resolução, contribuindo com o monitoramento em tempo real (THEMISTOCLEOUS et al., 2014).

O VANT, conhecido, em inglês, como Unmanned Aerial Vehicles/Systems (UAV/ UAS), é definido como toda aeronave projetada para operar sem piloto a bordo (IRIZARRY et al., 2012). Inicialmente desenvolvido para fins militares, o VANT tem sido empregado em diferentes domínios da engenharia nos últimos anos. Na engenharia civil, destacam-se aplicações para inspeção de rodovias (ZHANG, 2008); inspeção de danos e rachaduras (ESCHMANN et al., 2012); monitoramento de patologias em fachada (EMELIANOV et al., 2014); e inspeção de pontes (METNI; HAMEL, 2007).

Além de tais aplicações, estudos realizados por Irizarry et al. (2012) e Irizarry e Costa (2016) têm explorado o potencial dessa tecnologia como uma ferramenta para auxiliar na gestão da segurança dentro dos canteiros de obras. Para Kim e Irizarry (2015), o VANT pode contribuir na redução do tempo gasto para realizar tarefas de monitoramento, na melhoria do desempenho geral do projeto e na agilidade do processo de reação aos potenciais riscos. Tal potencialidade está diretamente relacionada ao baixo custo, à alta mobilidade, à velocidade e à segurança oferecida pela ferramenta durante o procedimento de aquisição de dados (imagens e vídeos). Além disso, o VANT pode diminuir os custos operacionais envolvidos no processo de inspeção e ser utilizado em situações em que uma inspeção tripulada não seja possível. (MORGENTHAL; HALLERMANN, 2014).

Embora haja grandes expectativas quanto ao impacto econômico do crescimento da indústria de tecnologia VANT no Brasil e no mundo, a falta de regulamentação para 
o uso comercial da aeronave é um dos grandes entraves para a sua disseminação. No Brasil, as atividades de aviação comercial são reguladas e monitoradas pela Agência Nacional de Aviação Civil (ANAC). Segundo a proposta de regulamentação da ANAC (2015), os critérios exigidos para a operação legal do VANT variam de acordo com a classificação das aeronaves, baseada em seu Peso Máximo de Decolagem (PMD), nos tipos de operação e de acordo com os critérios visuais.

Apesar das recentes aplicações da tecnologia VANT para a gestão de obras, ainda se desconhece qual o seu impacto no processo de inspeção da segurança. Este capítulo visa avaliar a aplicabilidade do Veículo Aéreo Não Tripulado para inspeção de segurança em canteiros de obra. Para tal, foram desenvolvidos estudos de caso com a realização de voos experimentais e elaboração de protocolo para sistematizar o processo de inspeção.

\section{Método de Pesquisa}

A pesquisa foi dividida nas seguintes etapas: (a) revisão da literatura; (b) adaptação de protocolos de pesquisa e escolha da tecnologia VANT; (c) estudos de caso e (d) avaliação da aplicabilidade do VANT para inspeção de segurança e análise prévia da não conformidade dos requisitos de segurança dos elementos inspecionados.

Foram adaptados para o contexto brasileiro os protocolos para uso de VANT em monitoramento de obras, com ênfase em inspeção de segurança, desenvolvidos nos estudos de Irizarry et al. (2015), conforme a seguir:

- Formulário de Planejamento: informações gerais da obra e planejamento do voo;

- Checklist para Missão VANT: checklist de procedimentos para realização dos voos em condições de segurança e cadastro de informações operacionais;

- Checklist de Segurança segundo o tipo de captura: checklist adaptado às normas NR 18 - Condições e Meio Ambiente de Trabalho na Indústria da Construção e NR 35 - Trabalho em Altura. Inicialmente, foram selecionados os itens relativos às normas que necessitam de verificação visual e estão situados na área externa das construções. Esses itens foram divididos em categorias de acordo com o tipo de captura, quais sejam: (1) Overview - visão geral do canteiro, com ênfase em limpeza e organização de canteiro, instalações temporárias e gestão de resíduos; (2) Medium View - requisitos de segurança que envolvem Equipamentos de Proteção Coletiva (EPC) e Equipamentos de Proteção Individual (EPI); (3) Close Up View - avalia os requisitos de segurança por serviço, tais como cobertura, concretagem e alvenaria, operação de equipamentos e fachada. No total, o checklist contemplou 45 itens. 
Além disso, foi desenvolvida uma versão do Checklist de Segurança para coleta em campo, no qual se apresenta o resumo dos itens de segurança a serem avaliados (total de 24 itens), usado para orientar o piloto e observá-lo durante a coleta de dados com o VANT.

O equipamento selecionado para realização do estudo foi um DJI Phantom 3 Advanced (Figura 1), com câmera Sony EXMOR 1/2.3" acoplada, que possui resolução de 12,76 megapixels, tamanho de imagem de $4000 \times 3000$, gerando fotos nos formatos JPEG e DNG e vídeos em MP4. Tal escolha justifica-se pelo fato desse modelo de VANT ser uma tecnologia acessível e comercial, facilitando sua adoção por construtoras e empresas de consultoria. Além disso, utilizou-se um conjunto de 3 baterias visando garantir a autonomia de voo necessária.
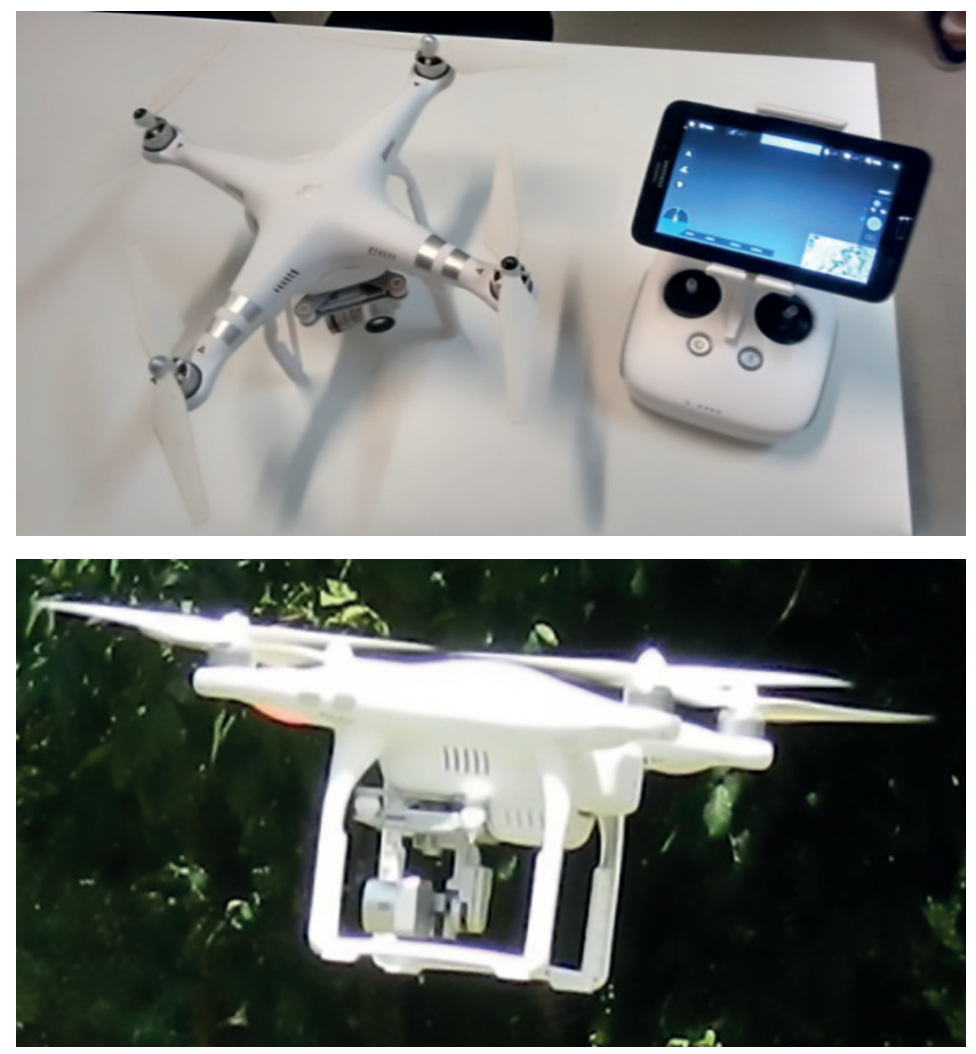

Figura 1 - DJI Phantom 3 Advanced. Fonte: Projeto de Pesquisa GETEC/UFBA.

O estudo foi realizado em duas obras residenciais, cujas características estão apresentadas na Tabela 1. 
Tabela 1 - Características dos Estudos de Caso.

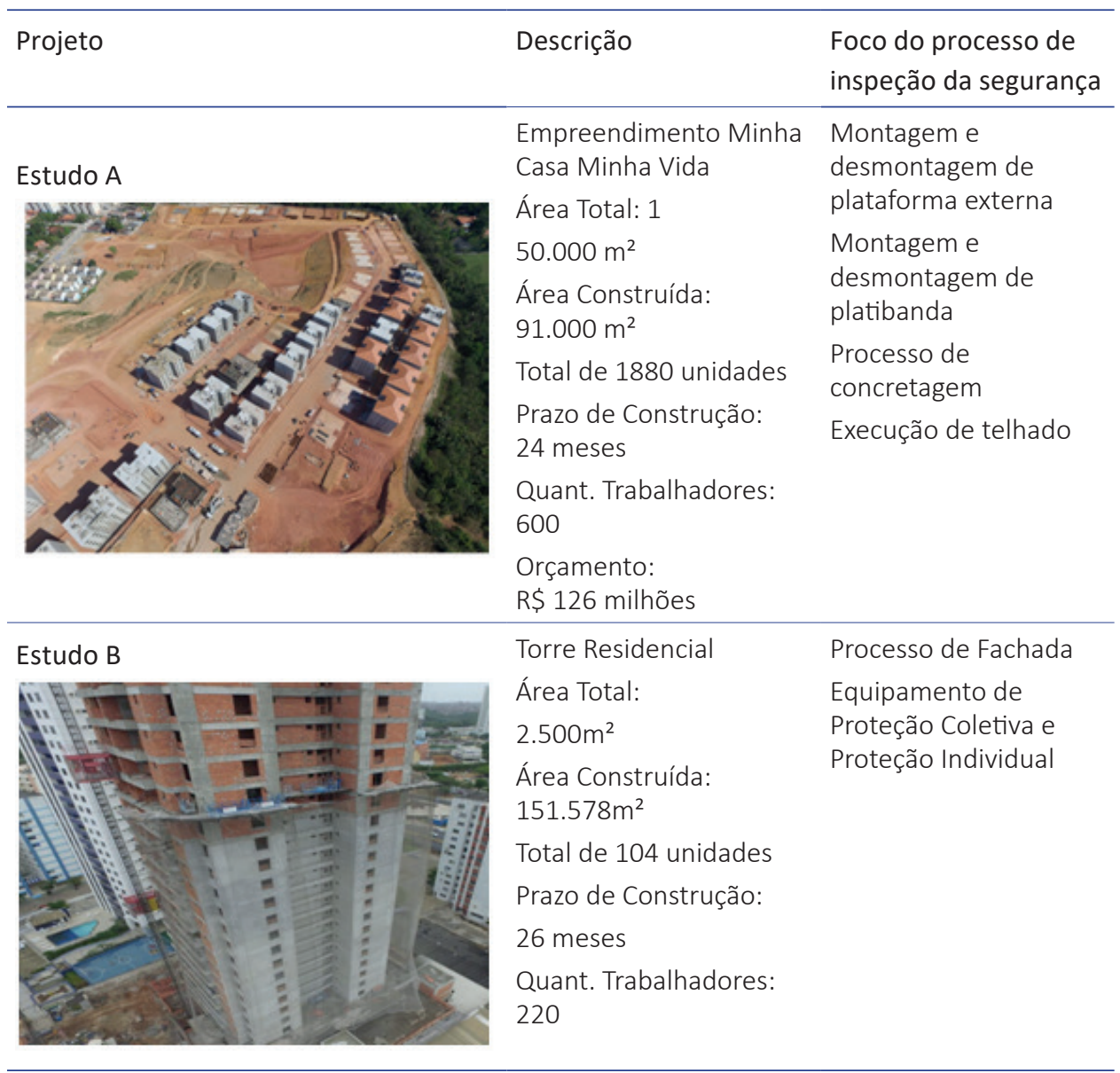

O processo de monitoramento e inspeção de segurança com o uso do VANT foi estruturado em quatro etapas: (1) planejamento; (2) coleta de dados com VANT; (3) processamento; e (4) análise de dados, conforme apresentado na Figura 2.

No total, foram realizados 26 voos com duração média de 9 minutos cada. Os dados coletados foram organizados em banco de dados. Para todos os voos, pelo menos três membros da equipe de pesquisa foram envolvidos: o piloto, o primeiro observador, que auxiliou o piloto na coleta de dados de inspeção de segurança, e o segundo observador, que se concentrou nos requisitos relativos à segurança do voo. Após os voos, em cada visita realizada, foram feitas reuniões de feedback com a equipe do projeto, para a avaliação imediata das não conformidades observadas. A Tabela 2 apresenta um resumo dos dados coletados. 


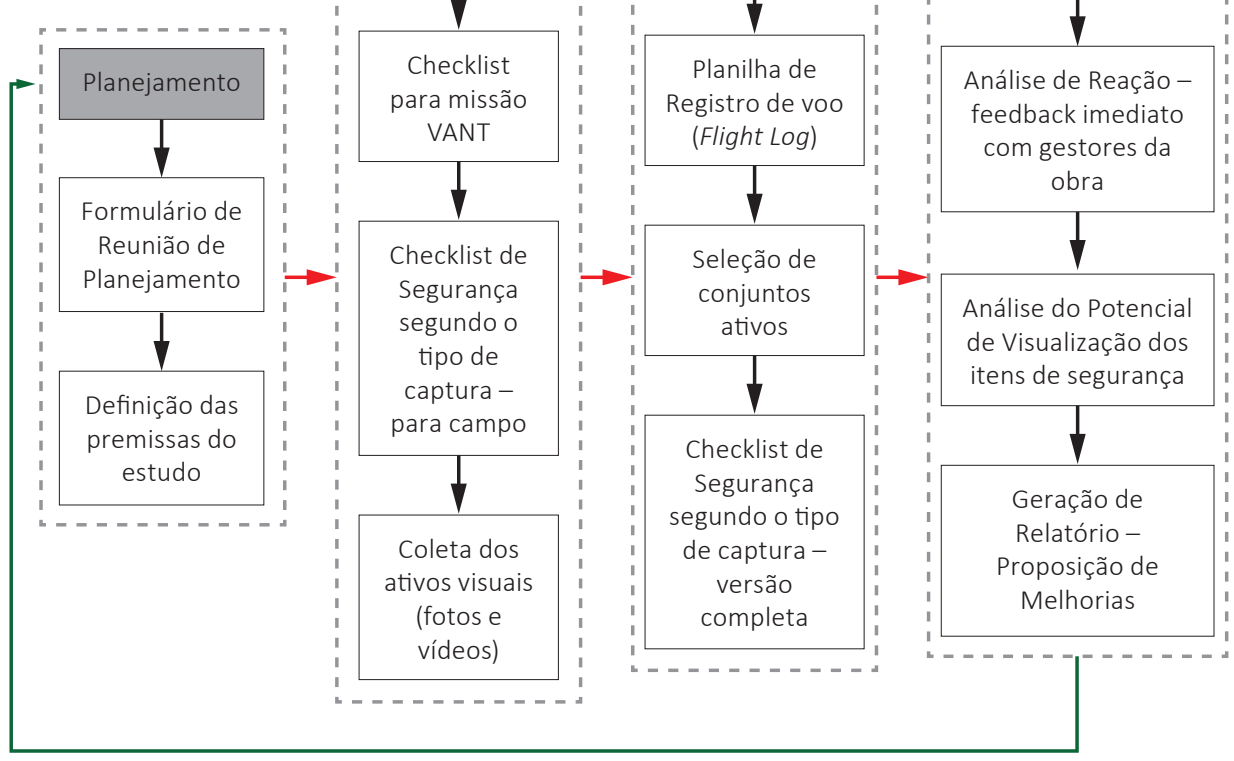

Figura 2 - Protocolo de inspeção de segurança com VANT.

Tabela 2 - Ativos visuais (fotos e vídeos) coletados durante os voos.

\begin{tabular}{llllllll}
\hline $\begin{array}{l}\text { Projeto } \\
\text { visitas }\end{array}$ & $\begin{array}{l}\text { № de } \\
\text { voos }\end{array}$ & $\begin{array}{l}\text { № de } \\
\text { fotos de }\end{array}$ & $\begin{array}{l}\text { Duração } \\
\text { dos } \\
\text { vídeos }(\mathrm{h})\end{array}$ & $\begin{array}{l}\text { Distância } \\
\text { máxima } \\
(\mathrm{m})\end{array}$ & $\begin{array}{l}\text { Altitude } \\
\text { máxima } \\
(\mathrm{m})\end{array}$ & $\begin{array}{l}\text { Tempo } \\
\text { duração dos } \\
\text { voos }(\mathrm{h})\end{array}$ \\
\hline A & $\begin{array}{l}\text { Outubro/15 a } \\
\text { Março/16 }\end{array}$ & 14 & 579 & $00: 39: 02$ & 734,0 & 120,0 & $02: 07: 43$ \\
\hline B & $\begin{array}{l}\text { Novembro/15a } \\
\text { Março/16 }\end{array}$ & 11 & 835 & $00: 14: 34$ & 173,5 & 60,0 & $01: 15: 43$ \\
\hline
\end{tabular}

Os dados foram processados com base no Checklist de Segurança por tipos de captura - versão completa (45 itens). No total, foram realizadas 8 inspeções, sendo 4 para o Projeto A e 4 para o Projeto B. Cada inspeção correspondeu a um dia de visita ao canteiro, com uma média de 3 voos por visita.

Para ambos os estudos, foram realizadas duas análises distintas. A primeira buscou avaliar a utilidade do VANT para o processo de inspeção, na qual foi verificado se era possível visualizar os itens de segurança por meio das fotos e vídeos. Com base nos itens 
vistos, a segunda análise consistiu na verificação da conformidade dos itens de segurança, baseando-se nos requisitos apontados pelas NR 18 - Condições e meio ambiente de trabalho na indústria da construção (BRASIL, 2015) e NR 35 - Trabalho em altura (BRASIL, 2014).

\section{Resultados e Discussão}

Esta seção apresenta os resultados relativos à aplicabilidade do VANT para inspeção de segurança e à análise da não conformidade dos requisitos de segurança.

\subsection{Aplicabilidade}

Dos 45 itens que compõem o Checklist de Segurança, em média, foram avaliados 34 itens para a Obra A e 36 itens para a Obra B. Os demais itens que compõem o Checklist não foram avaliados, pois não se aplicavam ao contexto da obra. De acordo com os dados obtidos por meio da análise dos ativos visuais coletados em canteiro com - VANT, $87 \%$ e $60 \%$ dos itens de segurança avaliados foram visualizados nos Estudos $A$ e $B$, respectivamente, conforme apresenta a Figura 3.

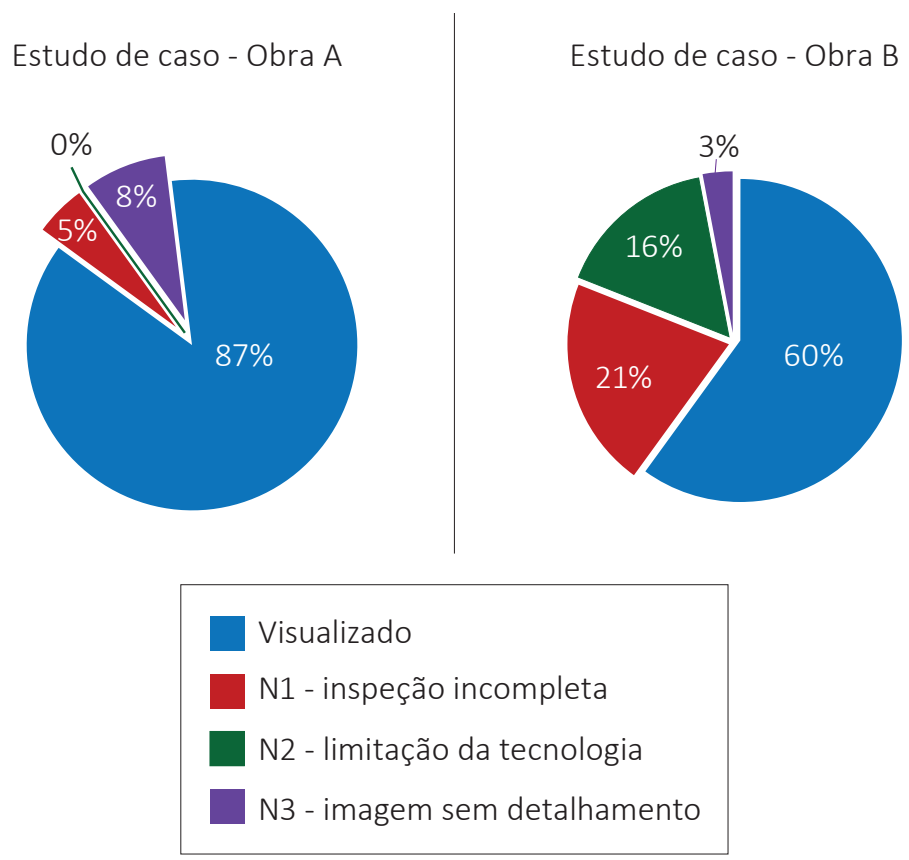

Figura 3 - Análise do Potencial de Visualização baseado no Checklist de Segurança.

No Estudo A, 5\% dos itens de inspeção de segurança não foram visualizados por motivos diretamente associados a falhas no procedimento de inspeção. Alguns 
destes itens, por alguma razão, não foram registrados nos ativos coletados em canteiro (N1 - inspeção incompleta). Destacando-se itens relacionados à montagem e desmontagem das formas, ao içamento de cargas e à sinalização e isolamento da área de movimentação de cargas. Essas falhas ocorreram devido à extensão do canteiro $\left(150.000 \mathrm{~m}^{2}\right)$ e à grande quantidade de tarefas desenvolvidas simultaneamente. Além disso, os outros $8 \%$ dos itens não visualizados ocorreram por conta de ativos coletados que não forneciam informações suficientes para a inspeção, incluindo itens como as rampas, escadas e passarelas protegidas com guarda-corpo (N3 - imagem sem detalhamento suficiente). Esses dois resultados indicam a necessidade de maior precisão na inspeção com o VANT, no que tange a um treinamento mais eficaz para piloto e observadores.

No Estudo B, devido ao caráter vertical do edifício e por possuir um canteiro restrito em termos de área livre, $16 \%$ dos itens do Checklist de Segurança não foram visualizados devido à limitação da tecnologia, tais como rampas, escadas e passarelas protegidas com guarda-corpo e itens relativos a serviços na cobertura. Além disso, $21 \%$ dos itens não visualizados foram provenientes de falhas no processo de inspeção. Entre eles, destacam-se principalmente trabalhadores protegidos de queda (guardacorpo e linha de vida), trabalhadores usando EPI, balancim, e remoção de resíduos por calhas. Em relação às barreiras que dificultaram o processo de inspeção na Obra B, ressalta-se a existência de telas de proteção ao longo da fachada, a altura limitada de voo de até $60 \mathrm{~m}$ para a área urbana, imposta por regulamentação de operação do VANT, impossibilitando a inspeção do topo do edifício de altura de $80 \mathrm{~m}$, o canteiro restrito, bem como ventos fortes no local, que limitaram a utilização do VANT por razões de segurança.

A Figura 4 apresenta os resultados da aplicabilidade segundo o tipo de captura.

Segundo a Figura 4, para a captura em Overview, foram visualizados 95\% (Estudo A) e $88 \%$ (Estudo B) dos itens do Checklist de Segurança, relativos à organização e limpeza, instalações provisórias e gestão de resíduos. Tais resultados indicam a possibilidade de visualização das condições de trabalho sob uma perspectiva global, capaz de fornecer informações para a tomada de decisão. Para a captura em Medium View, que tem como objetivo principal visualizar as proteções coletivas, houve dificuldade na aquisição de dados da Obra B, devido à existência de barreiras físicas e a condições climáticas desfavoráveis, impactando no percentual de visualização.

As capturas em Close Up, assim como no Medium View, em alguns casos tiveram seus resultados influenciados por barreiras físicas, limitação de altitude de voo, inexperiência do piloto e observadores, entre outros. Dessa forma, o Estudo B apresentou potencial de visualização de apenas 56\% em Close Up View, em função da presença de tais fatores citados. Contudo, no Estudo A, 81\% dos itens foram visualizados para o mesmo tipo de captura, por conta da menor interferência observada na aquisição de dados com o VANT. Apesar da identificação de algumas 
barreiras, os resultados foram eficazes na identificação de atos e condições inseguras para os serviços inspecionados, fornecendo feedback quase imediato para gestores e responsáveis pelas condições gerais de segurança do canteiro.

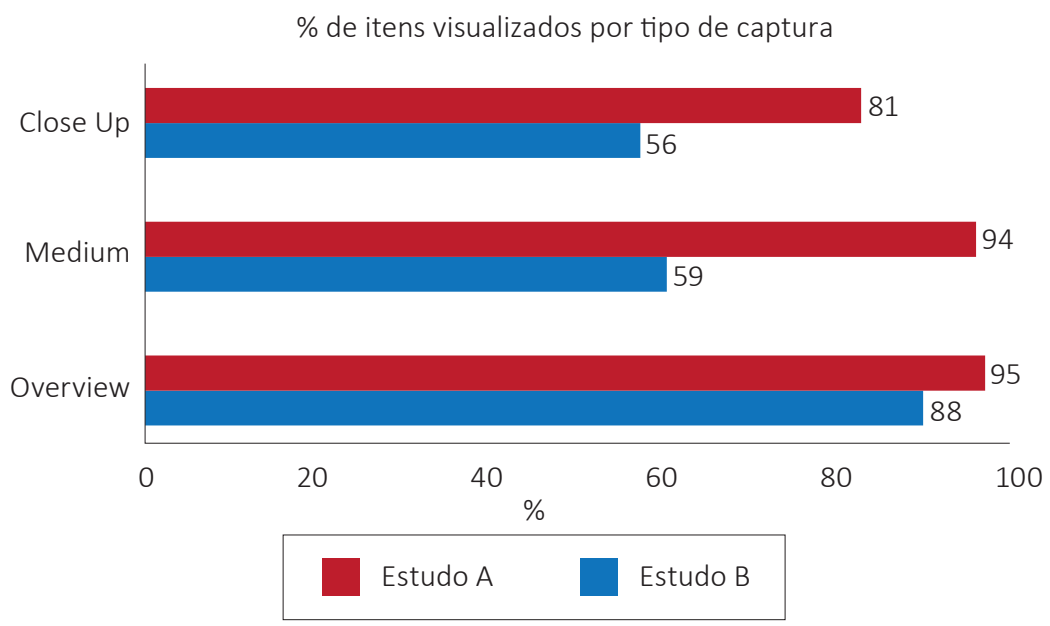

Figura 4 - Análise da aplicabilidade por tipo de captura.

\subsection{Análises das não Conformidades das Condições de Segurança}

Esta seção apresenta a análise da não conformidade dos itens de segurança inspecionados por meio dos ativos coletados com VANT nos Estudos A e B. Além disso, os resultados apresentam o status das condições de segurança no canteiro ao longo das inspeções. Para a análise das não conformidades, foram considerados apenas os itens visualizados (Figura 3), sendo 29 itens no Estudo A (que corresponde a 87\% dos 34 itens avaliados) e 21 itens no Estudo B (que corresponde a 60\% dos 36 itens avaliados). A Tabela 3 mostra um panorama do controle das não conformidades observadas nas inspeções, organizadas segundo o tipo de captura.

Tabela 3 - Análise geral do percentual de não conformidades.

\begin{tabular}{lllllllll}
\hline \multirow{2}{*}{$\begin{array}{l}\text { \% de não } \\
\text { conformidade }\end{array}$} & \multicolumn{2}{l}{ 1å Inspeção } & \multicolumn{2}{l}{ 2a Inspeção } & \multicolumn{2}{l}{ 3a Inspeção } & \multicolumn{2}{c}{ 4a Inspeção } \\
\cline { 2 - 9 } & Obra A & Obra B & Obra A & Obra B & Obra A & Obra B & Obra A & Obra B \\
\cline { 2 - 10 } & $17 \%$ & $45 \%$ & $14 \%$ & $50 \%$ & $12 \%$ & $52 \%$ & $19 \%$ & $68 \%$ \\
\hline
\end{tabular}


Observa-se que o grau de não conformidade dos itens de segurança avaliados na Obra B é expressivamente superior aos da Obra A, de modo que se tornam preocupantes as condições de segurança as quais os trabalhadores da Obra B são submetidos. Além das diferenças quanto às características físicas e construtivas, as obras diferem significativamente quanto ao sistema de gestão da segurança adotado. A Obra A possui uma equipe formada por engenheiro de segurança, 3 técnicos e 5 estagiários de segurança, com alguns procedimentos de inspeção já padronizados, como permissões de serviço diário para trabalho em altura e inspeção mensal para proteções coletivas. A obra B, no entanto, possui apenas um técnico para o desenvolvimento de todas as atividades relativas à gestão da segurança, sem nenhuma padronização dos processos. Em vista disso, tais resultados apresentados na Tabela 3 evidenciam o impacto da estruturação da gestão da segurança e seus processos nas condições de trabalho no canteiro de obra. As Tabelas 4 e 5 apresentam alguns itens avaliados na análise de não conformidade, realizada para ambos os estudos.

Tabela 4 - Itens avaliados no Checklist de Segurança (Estudo A).

\begin{tabular}{|c|c|c|c|c|c|}
\hline Item & Critério de Segurança & 1ㅡ Visita & 2a Visita & 3a Visita & 4a Visita \\
\hline \multicolumn{6}{|c|}{ 1) Tipo de Captura \# 1. Visualização geral (Overview) } \\
\hline 1.5 & $\begin{array}{l}\text { As rotas internas deverão estar limpas e } \\
\text { desobstruídas }\end{array}$ & & & & \\
\hline 1.11 & Resíduos protegidos das intempéries & $x$ & $x$ & $x$ & X \\
\hline \multicolumn{6}{|c|}{ 2) Tipo de Captura\# 2.Visualização de Altitudes Intermediárias (Medium altitude view) } \\
\hline 2.1 & $\begin{array}{l}\text { Plataforma de proteção (bandejas) } \\
\text { instalada em toda a periferia isenta de } \\
\text { sobrecarga não prevista e com forração } \\
\text { do piso completa }\end{array}$ & $x$ & & X & X \\
\hline 2.2 & $\begin{array}{l}\text { Escadas de uso coletivo, rampas e } \\
\text { passarelas são dotadas de corrimão e } \\
\text { rodapé }\end{array}$ & & & & \\
\hline
\end{tabular}

3) Tipo de Captura\# 3. Visualização aproximada por tipo de serviço (Close up view)

3.1) Cobertura

3.1.1 Os trabalhadores que se encontram na cobertura estão usando EPI

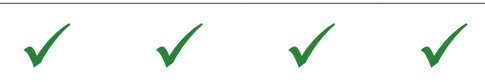

3.1.2 Os trabalhadores que se encontram na cobertura estão protegidos contra queda (cinto de segurança tipo paraquedista ligado a cabo-guia)

Legenda: $\quad \sqrt{\begin{array}{l}\text { Item } \\ \text { conforme }\end{array}} \times \begin{aligned} & \text { Item não } \\ & \text { conforme }\end{aligned}-\quad \begin{aligned} & \text { Não } \\ & \text { visualizado }\end{aligned}$




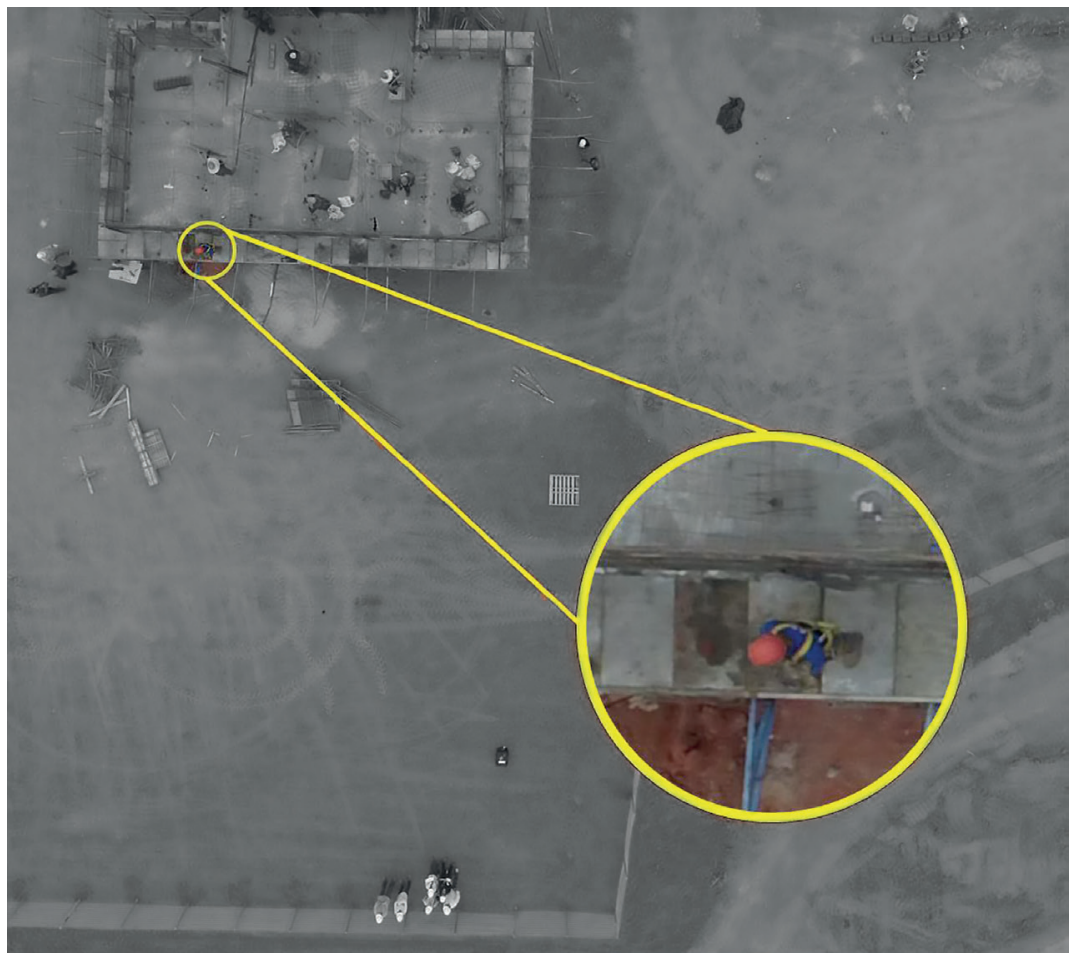

Figura 6 - Trabalhador desprotegido contra queda (sem cinto trava-quedas fixado na estrutura).

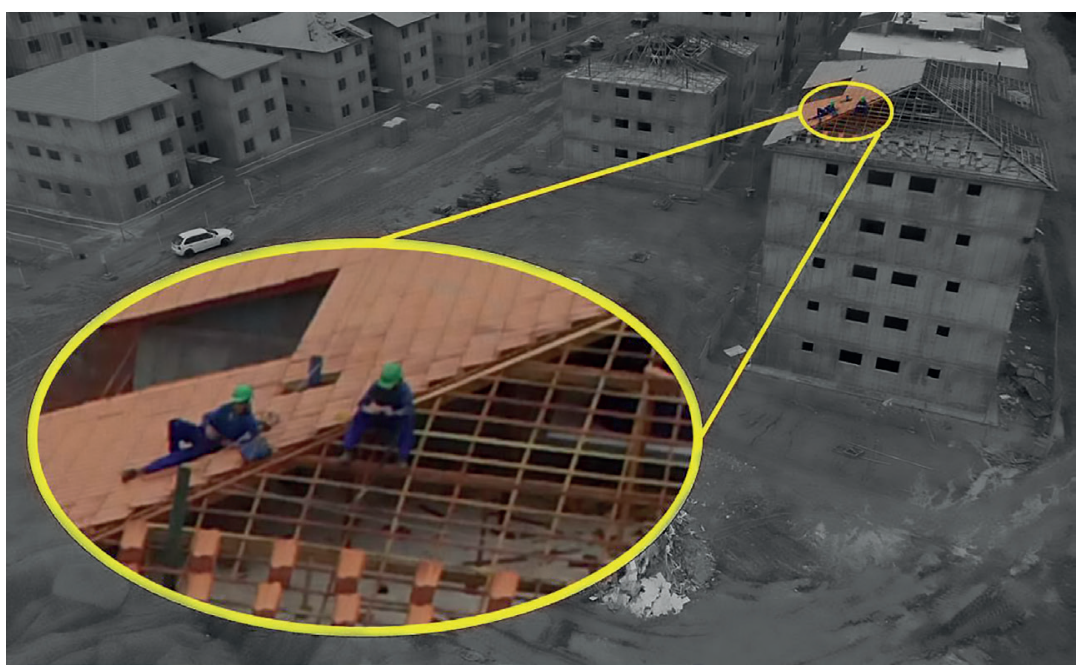

Figura 7 - Trabalhadores na cobertura desprotegidos contra queda (cinto não fixado a linha de vida). 


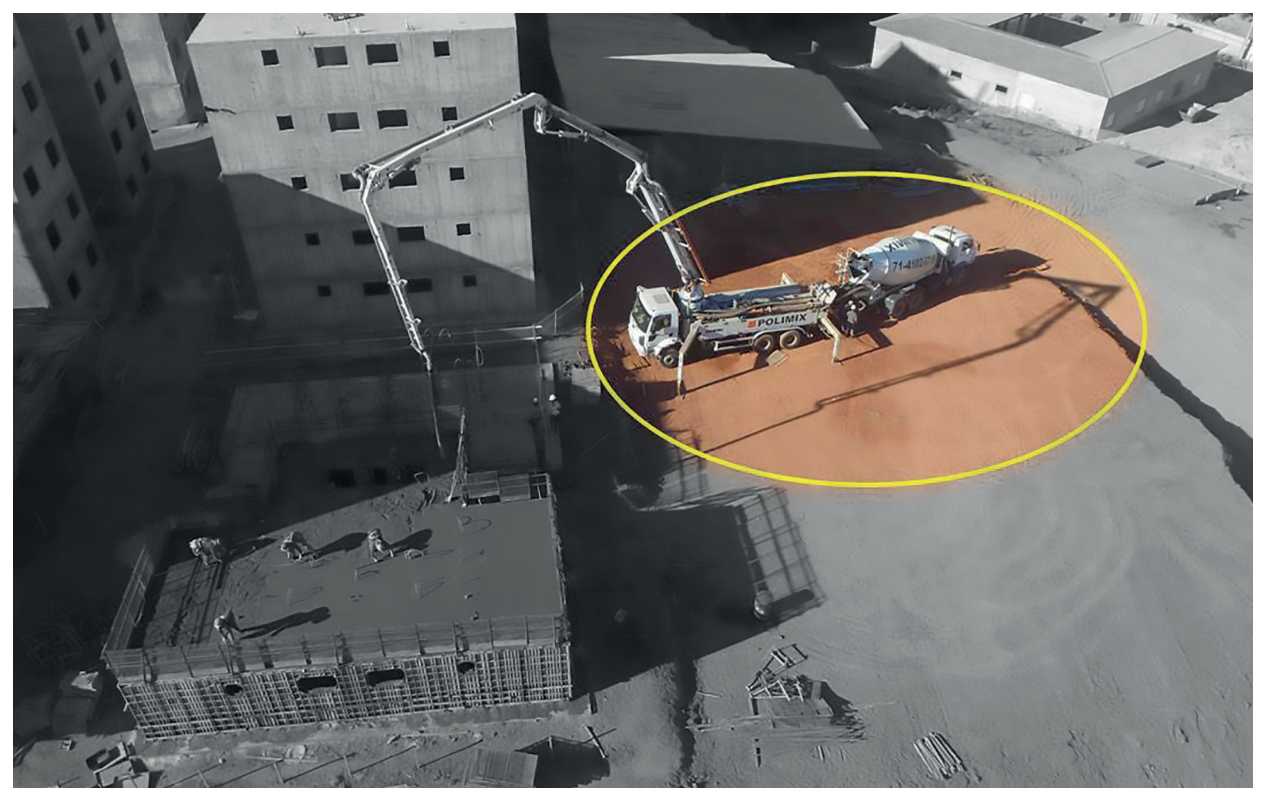

Figura 8 - Ausência de sinalização e isolamento na área de movimentação de carga.

Tabela 5 - Itens avaliados no Checklist de Segurança (Estudo B).

\begin{tabular}{llcccc}
\hline Item & Critério de segurança & 1a Visita & 2a Visita & 3a Visita & 4a Visita \\
\hline 1) Tipo de Captura \# 1. Visualização geral (Overview) & & & \\
\hline 1.5 & $\begin{array}{l}\text { As rotas internas deverão estar limpas e } \\
\text { desobstruídas }\end{array}$ & $\times$ & $\times$ & $\times$ & $\times$ \\
\hline 1.6 & $\begin{array}{l}\text { Os materiais estão armazenados de } \\
\text { forma adequada }\end{array}$ & $\times$ & $\times$ & $\times$ & $\times$ \\
\hline
\end{tabular}

2) Tipo de Captura\# 2.Visualização de Altitudes Intermediárias (Medium Altitude View)

\begin{tabular}{lllll}
\hline 2.1 & $\begin{array}{l}\text { Plataforma de proteção (bandejas) } \\
\text { instalada em toda a periferia isenta de } \\
\text { sobrecarga não prevista e com forração } \\
\text { do piso completa }\end{array}$ & $\times$ & $\times$ & $\times$ \\
\hline 2.6 & $\begin{array}{l}\text { No ponto de descarga da calha para } \\
\text { remoção dos entulhos, existe dispositivo } \\
\text { com fechamento }\end{array}$ & & & \\
\hline Legenda: & $\begin{array}{l}\text { Item } \\
\text { conforme }\end{array}$ & Item \\
não conforme & & - & Não Visualizado
\end{tabular}


Tabela 5 - Continuação.

Item

Critério de segurança

1a Visita 2a Visita 3a Visita 4a Visita

3) Tipo de Captura\# 3. Visualização aproximada por tipo de serviço (Close up view)

3.2) Concretagem e Alvenaria

\begin{tabular}{ll}
\hline 3.2.4 & $\begin{array}{l}\text { As barras ou telas de aço estão } \\
\text { armazenadas em camadas }\end{array}$ \\
\hline 3.2 .8 & $\begin{array}{l}\text { Os trabalhadores expostos aos serviços } \\
\text { de forma, armação, concretagem ou } \\
\text { alvenaria externa estão protegidos contra } \\
\text { queda }\end{array}$
\end{tabular}

3.3) Operação de Equipamentos

\begin{tabular}{lllll}
\hline 3.3.1 & $\begin{array}{l}\text { Sinalização e isolamento da área de } \\
\text { movimentação de carga e descarga }\end{array}$ & $\times$ & $\times$ \\
\hline 3.3 .2 & $\begin{array}{l}\text { Isolamento e delimitação das áreas de } \\
\text { carga e descarga de materiais e raio } \\
\text { de movimentação de gruas, guinchos, } \\
\text { guindastes, etc. }\end{array}$ & $\times$ & $\times$ & $\times$ \\
\hline
\end{tabular}

3.4) Fachada

\begin{tabular}{lllll}
\hline 3.4 .1 & $\begin{array}{l}\text { Os andaimes suspenso ou balancim } \\
\text { devem estar niveladas }\end{array}$ & Os trabalhadores que se encontram na \\
fachada estão usando EPI
\end{tabular}

Na Obra B, foi possível identificar não conformidades quanto à falta de limpeza e organização do canteiro, também se observou a obstrução dos acessos de equipamentos e pedestres (Figura 9), falhas na forração dos pisos das bandejas primárias e secundárias (Figura 10) e acúmulo de materiais e sobrecarga sobre tais locais (Figura 11), além de falhas nos guarda-corpos, comprometendo sua função de proteção contra queda (Figura 12).

Em ambos os estudos, observou-se o uso irregular do EPI, principalmente para as atividades realizadas em locais de menor visibilidade. Tal condição evidencia falhas no processo de inspeção e monitoramento dos atos e condições inseguras por parte da empresa responsável pela execução do serviço, comprovando assim a necessidade de tecnologias que favoreçam a visualização das condições de trabalho. 


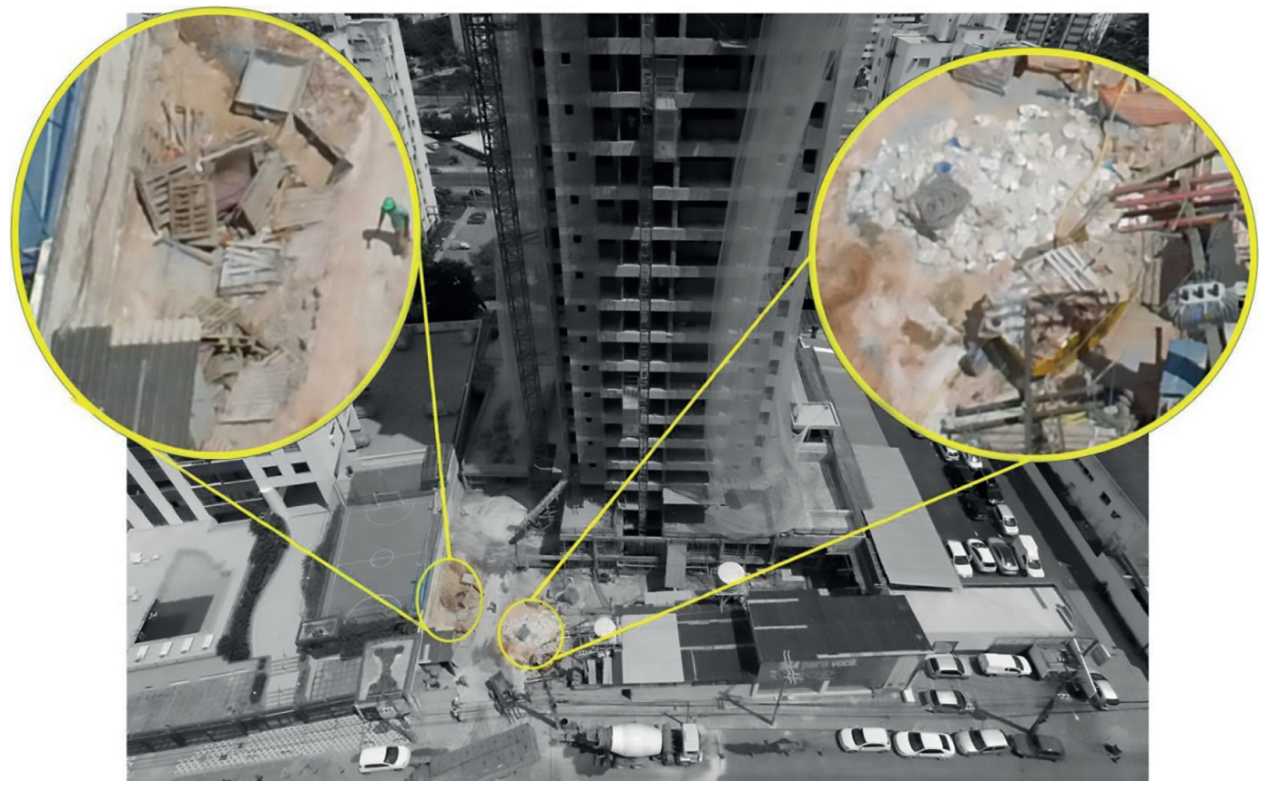

Figura 9 - Acúmulo de resíduos na área de acesso dos trabalhadores.

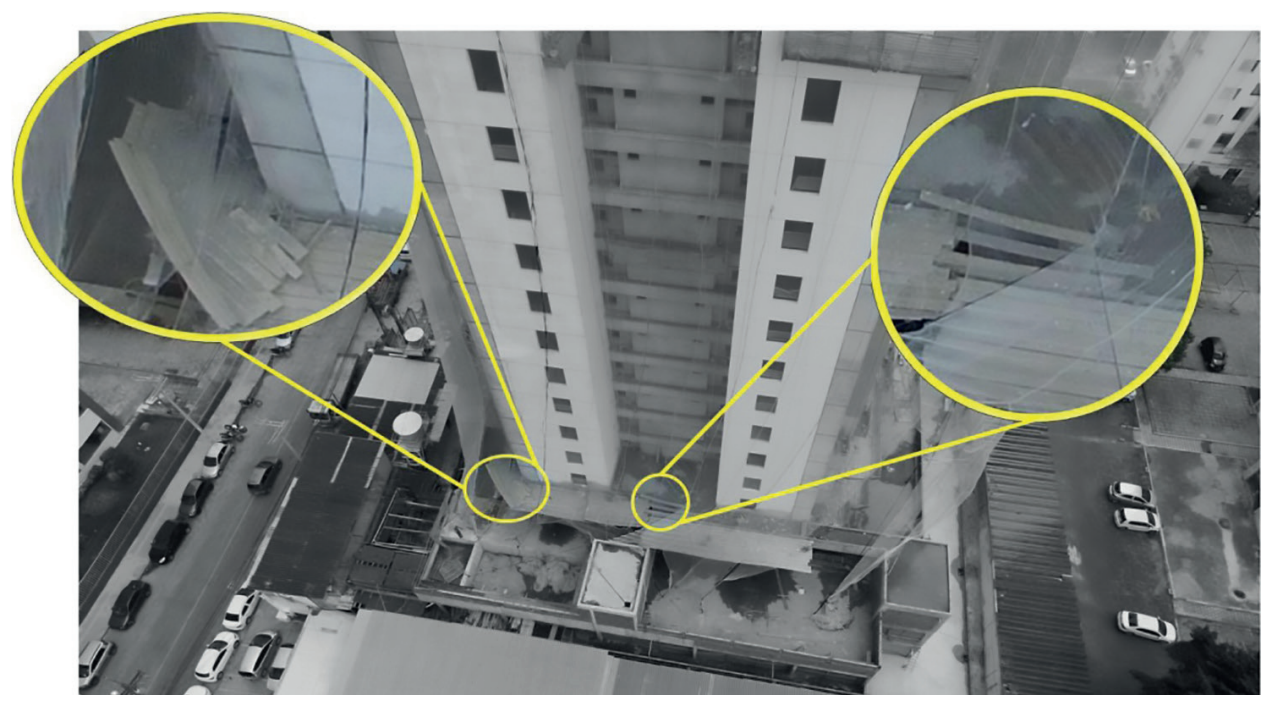

Figura 10 - Plataforma de proteção primária com forração do piso inadequado. 


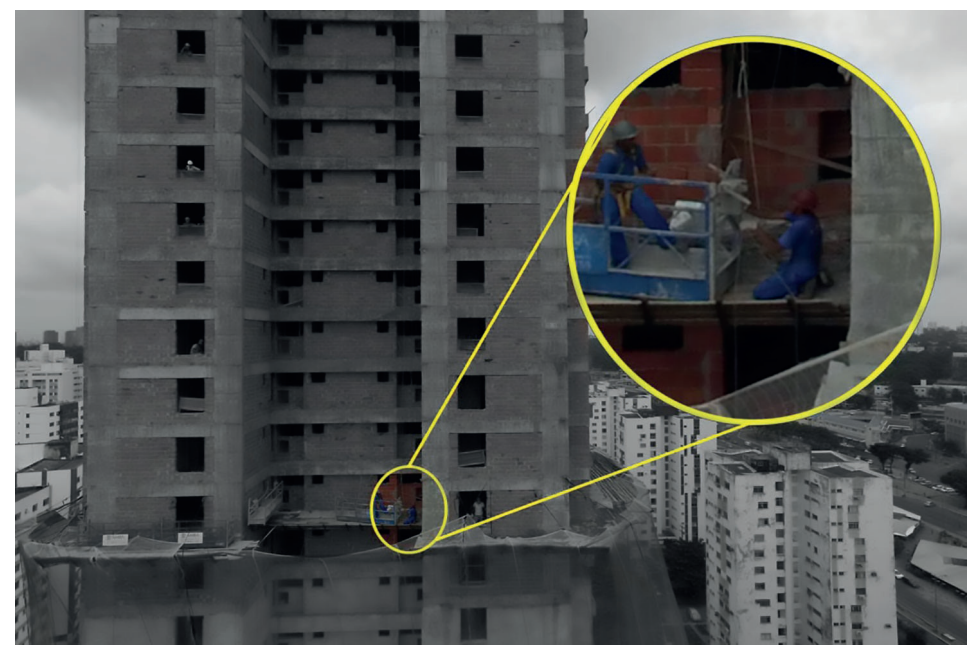

Figura 11 - Plataforma de proteção com sobrecarga não prevista (balancim apoiado sobre a plataforma).

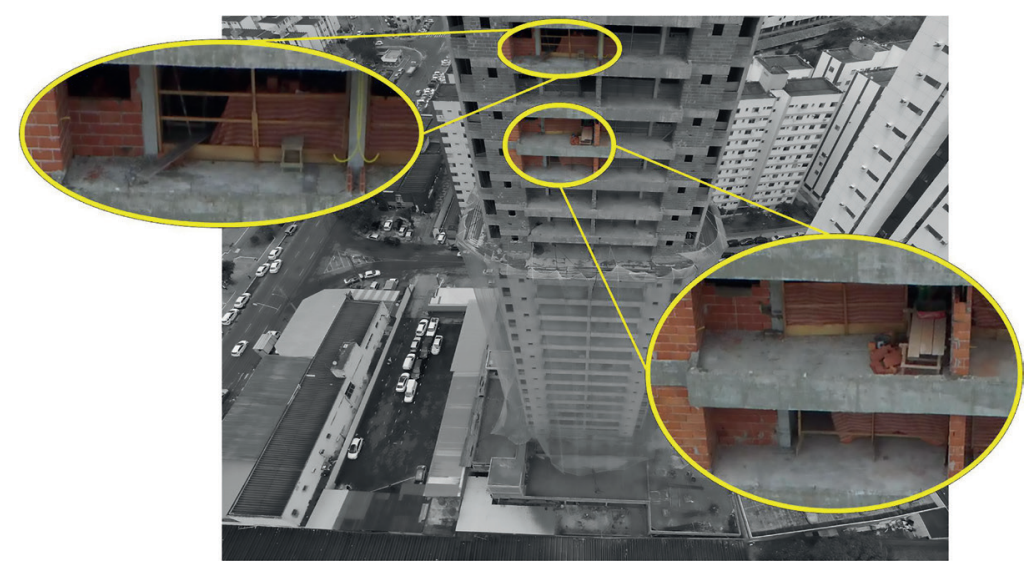

Figura 12 - Guarda corpos com estrutura danificada.

\subsection{Discussões}

O desempenho do equipamento DJl Phantom 3 Advanced satisfez as necessidades para a atividade de inspeção de segurança em termos de autonomia de voo, de estabilidade do VANT, da confiabilidade do sistema e da facilidade de uso. No total, 26 voos foram realizados sem maiores problemas que pudessem causar danos a bens ou pessoas. Além disso, o uso do VANT para inspeção não provocou interferências 
significativas nas atividades desenvolvidas no Canteiro A. Entretanto, no Canteiro B, devido à restrição de espaço para voo, foi solicitada a paralisação da grua, a fim de evitar choques com a aeronave e a ocorrência de acidentes. Em ambos os estudos, antes do início de toda aquisição de dados com o VANT, optou-se pela comunicação via rádio sobre a realização dos voos, para conscientizar os trabalhadores.

No geral, quanto ao potencial de visualização, a Obra A obteve um melhor desempenho (87\% dos itens foram visualizados) comparado à Obra B (60\% dos itens foram visualizados). Tal resultado está diretamente associado a um conjunto de fatores, tais como:

- Condições físicas do canteiro: a Obra A situava-se em região de baixa densidade populacional (permissão de voo com altitude máxima de $120 \mathrm{~m}$ ). Além disso, o Canteiro A possuía área para pouso e decolagem com segurança, enquanto no Canteiro B, os voos eram realizados a partir de áreas externas a ele, mediante autorização de terceiros;

- Barreiras físicas: o canteiro da Obra A quase não dispunha de barreiras físicas, como postes, árvores, fiações elétricas, e outras edificações, já o Canteiro B situava-se em centro urbano, rodeado por outras edificações;

- Fatores meteorológicos: não houve problemas devido a fortes ventos na Obra A, apenas na B;

- Fatores tecnológicos: em ambos os estudos de caso, houve perda do enlace de comando (perda de conexão) entre a estação de controle e a aeronave, no entanto, tal fato não impactou a atividade de inspeção, visto que o dispositivo contra falhas presente na aeronave utilizada (Return to home) funcionou satisfatoriamente;

- Fator humano: para ambos os estudos verificou-se a necessidade de treinamento quanto ao uso da tecnologia, além do conhecimento prévio sobre as questões segurança do canteiro.

Embora se tenha observado uma menor quantidade de itens visualizados na Obra B, ela destaca-se por um maior número de não conformidades identificadas. Além disso, observou-se a necessidade de métodos de inspeção para atividades críticas, como serviços em fachadas, visto a dificuldade de inspeção de tais itens na Obra B por meio de métodos tradicionais.

Referente à análise de não conformidade, foi perceptível o impacto de um sistema de gestão da saúde e segurança, no qual, apesar de diferenças observadas quanto à estruturação de tais sistemas em cada uma das obras, constata-se ainda falhas no processo de inspeção de ambas. A obra A, por possuir sistema de gestão mais consolidado, obteve melhor resultado do que a obra $B$, que não possuía sistema de gestão da segurança definido. 
A Tabela 6 apresenta o resumo dos fatores positivos e das barreiras relativos ao uso da tecnologia VANT para inspeção de segurança em canteiros de obras.

Tabela 6 - Fatores positivos e barreiras quanto ao uso do VANT para inspeção.

\begin{tabular}{|c|c|c|}
\hline Aspectos & Benefícios & Barreiras \\
\hline $\begin{array}{l}\text { Procedimentos e } \\
\text { tecnologia VANT - } \\
\text { Planejamento da } \\
\text { Missão }\end{array}$ & $\begin{array}{l}\text { - Identificação dos pontos de } \\
\text { interesse relativos à segurança. }\end{array}$ & $\begin{array}{l}\text { - Barreiras físicas (edifícios, } \\
\text { postes, árvores, fiações } \\
\text { elétricas, entre outros); } \\
\text { - Condições climáticas (chuva e } \\
\text { ventos fortes). }\end{array}$ \\
\hline $\begin{array}{l}\text { Procedimentos } \\
\text { e tecnologia } \\
\text { VANT - Coleta e } \\
\text { processamento de } \\
\text { dados }\end{array}$ & $\begin{array}{l}\text { - Redução do tempo de inspeção } \\
\text { devido à flexibilidade no } \\
\text { monitoramento mútuo de } \\
\text { diferentes atividades; } \\
\text { - Simplificação das etapas } \\
\text { de inspeção por meio da } \\
\text { eliminação do excesso de coleta } \\
\text { manual (redução de pessoal); } \\
\text { - Tecnologia de fácil uso; } \\
\text { - Redução da variabilidade com a } \\
\text { padronização dos dados. }\end{array}$ & $\begin{array}{l}\text { - Requisitos das regulamentações } \\
\text { (ex. limite de altitude); } \\
\text { - Treinamento de operação do } \\
\text { VANT para piloto e observador; } \\
\text { - Conhecimento prévio de } \\
\text { segurança para o piloto e } \\
\text { observador; } \\
\text { - Grande base de dados de ativos } \\
\text { visuais; } \\
\text { - Visualização de áreas internas } \\
\text { limitada. }\end{array}$ \\
\hline $\begin{array}{l}\text { Procedimentos e } \\
\text { tecnologia VANT - } \\
\text { Análise de dados } \\
\text { e proposição de } \\
\text { melhorias }\end{array}$ & $\begin{array}{l}\text { - Aumento da transparência das } \\
\text { condições inseguras; } \\
\text { - Informações detalhadas sobre } \\
\text { condições inseguras e seguras; } \\
\text { - Registro das não conformidades } \\
\text { de segurança e das boas } \\
\text { práticas, permitindo a análise } \\
\text { de diferentes perspectivas; } \\
\text { - Utilização de indicadores e } \\
\text { informações para tomada de } \\
\text { decisão; } \\
\text { - Utilização dos ativos visuais e } \\
\text { dos resultados de inspeção para } \\
\text { a educação de segurança. }\end{array}$ & $\begin{array}{l}\text { - Análise manual dos ativos } \\
\text { visuais; } \\
\text { - Necessidade de melhorar } \\
\text { o tempo de resposta aos } \\
\text { trabalhadores, visando } \\
\text { feedback em tempo real } \\
\text { (interação direta entre VANT e } \\
\text { trabalhadores); } \\
\text { - Necessidade de fornecer } \\
\text { informações em tempo real } \\
\text { para segurança (interação } \\
\text { direta entre o VANT e equipe de } \\
\text { segurança). }\end{array}$ \\
\hline $\begin{array}{l}\text { Sistema de } \\
\text { Segurança e Pessoas }\end{array}$ & $\begin{array}{l}\text { - Viabilidade de custo-benefício } \\
\text { do VANT (tecnologia de } \\
\text { baixo custo de aquisição e } \\
\text { manutenção); } \\
\text { - Potencial de melhoria do } \\
\text { comportamento do trabalhador } \\
\text { em relação à segurança. }\end{array}$ & $\begin{array}{l}\text { - Integração do VANT ao sistema } \\
\text { de gestão de saúde e segurança } \\
\text { da obra; } \\
\text { - Resistência à adoção de novas } \\
\text { tecnologias pela construção } \\
\text { civil; } \\
\text { - Sistema mal estruturado } \\
\text { de gestão da segurança em } \\
\text { canteiro de obras. }\end{array}$ \\
\hline
\end{tabular}


Dentre as principais recomendações para o uso do VANT para inspeção de segurança em canteiros, podem ser destacadas:

\section{- Planejamento:}

- Analisar os critérios de segurança para voo, estabelecidos pelas agências reguladoras de aviação no país;

- Conhecer os elementos principais sob a perspectiva de segurança do canteiro e os riscos associados a cada serviço;

- Realizar campanha com os trabalhadores em relação ao uso de VANT para inspeção de segurança;

- Definir os processos críticos possíveis de serem monitorados com o VANT sob a perspectiva de segurança;

- Analisar previamente as possíveis interferências físicas aos voos, tais como gruas, árvores, postes, entre outros;

- Definir a sequência dos pontos a serem monitorados;

- Atribuir responsabilidades quanto às etapas do protocolo de inspeção;

- Garantir treinamento do piloto e observador quanto ao uso do VANT e quanto aos itens e critérios de segurança que serão inspecionados;

- Definir indicadores para avaliar a eficácia do processo de inspeção.

\section{- Coleta e processamento de dados:}

- Padronizar o processo de coleta de dados (Checklist de Missão e Checklist de Segurança) com o objetivo de simplificar o processo, eliminar a coleta de informações redundantes e reduzir o tempo de inspeção;

- Estabelecer a periodicidade da inspeção conforme a necessidade de monitoramento dos processos, pois a inspeção com VANT tem caráter pontual, ou seja, registra as irregularidades para um determinado momento;

- Realizar o processamento dos dados logo após os voos, para possibilitar a análise imediata.

- Análise de dados e proposição de melhorias:

- Promover a análise aprofundada a partir dos ativos visuais coletados, visto que os mesmos possibilitam a reanálise por diferentes perspectivas, viabilizando a proposição de medidas preventivas;

- Promover encontros periódicos com os colaboradores e equipe gerencial para apresentação e discussão dos resultados obtidos, visando aumentar a eficácia no atendimento das metas estabelecidas; 
- Desenvolver clima e cultura de segurança com ênfase na observação das não conformidades, baseado em registros visuais, a fim de contribuir com a mudança de postura dos colaboradores;

- Usar os ativos visuais para treinamento dos colaboradores relativos a atos e condições inseguras, baseado em exemplos da realidade vivenciada pelos próprios trabalhadores.

\section{Conclusões}

Este estudo teve por objetivo avaliar a aplicabilidade da tecnologia VANT para inspeção de segurança em canteiros de obra, focando na capacidade de identificação de não conformidades que podem fornecer condições inseguras ao trabalhador. Os resultados encontrados apontam que o VANT permite uma melhor visualização das condições de trabalho, principalmente em locais com limitações de acesso (fachadas, coberturas e telhados).

Umas das contribuições deste estudo é o desenvolvimento de um conjunto de procedimentos para inspeção de segurança em canteiros de obra com VANT (protocolo de inspeção apresentado na Figura 2). Para tal, foram adaptados formulários desenvolvidos por Irizarry, Costa e Kim (2015), tais como: Formulário de Planejamento e Checklist de Missão. O Checklist de Segurança por tipo de captura foi adaptado às normas de segurança brasileiras (NR 18 - Condições e meio ambiente de trabalho na indústria da construção e NR 35 - Trabalho em altura). Para a análise dos dados, foi desenvolvida uma base de dados, além de métricas relacionadas com a visualização e não conformidade dos itens de segurança.

Além disso, os tipos de captura apresentam uma maneira inovadora para inspecionar itens de segurança, fornecendo informações em diferentes perspectivas. O Overview fornece informações gerais sobre a organização e limpeza do canteiro, o Medium View e o Close Up fornecem informações mais específicas sobre os itens de segurança relacionados a equipamentos de proteção coletiva e individual, além de possibilitar a inspeção de atividades específicas, como serviços em telhado.

Ainda há uma lacuna sobre como integrar de maneira efetiva a tecnologia VANT no processo de inspeção de segurança dos canteiros. Há uma expectativa de que o VANT possa impactar na melhor utilização dos recursos disponíveis para as inspeções. No entanto, novos estudos são necessários para avaliar o impacto do VANT no processo de inspeção de segurança de forma sistemática, com foco no feedback rápido, permitindo ações corretivas imediatas, reduzindo o tempo e simplificando o processo de inspeção de segurança. 


\section{Referências}

AGÊNCIA NACIONAL DE AVIAÇÃO CIVIL (ANAC). Regulamento Brasileiro da aviação Civil Especial (RBAC-E no94) .Brasilia, DF: 2015. Disponível em: <http://www2.anac.gov.br/ transparencia/audiencia/2015/aud13/anexol.pdf>. Acesso em: set. 2015.

BRASIL. Ministério do Trabalho e Emprego. Norma Regulamentadora 18 (NR-18): Condições e Meio Ambiente de Trabalho na Indústria da Construção. Rio de Janeiro: 2015. Disponível em: <http://trabalho.gov.br/seguranca-e-saude-no-trabalho/normatizacao/ normas-regulamentadoras/norma-regulamentadora-n-18-condicoes-e-meio-ambientede-trabalho-na-industria-da-construcao>. Acesso em: nov. 2015.

BRASIL. Ministério do Trabalho e Emprego. Norma Regulamentadora 35 (NR-35): Trabalho em Altura. Rio de Janeiro: 2014. Disponível em: < http://portal.mte.gov.br/images/ Documentos/SST/NR/NR4.pdf>. Acesso em: nov. 2015.

CAMBRAIA, F.B.; SAURIN, T.; FORMOSO, C. T. Identification, analysis and dissemination of information on near misses: a case study in the construction industry. Safety Science, v.48, p.91-99, 2010.

EMELIANOV, S.; BULGAKOW, A.; SAYFEDDINE, D. Aerial laser inspection of buildings facades using quadrator. Precedia Engineering, v. 85, p. 140-146, 2014.

ESCHMANN, C.; KUO, C.M.; KUO, C.H.; BOLLER, C. Unmanned aircraft systems for remote building inspection and monitoring. In: 6th European workshop on structural health monitoring. 2012. Proceedings...

IRIZARRY, J.; COSTA, D.B. Exploratory Study of potential Applications of Unmanned Aerial Systems for Construction Management Tasks. Journal of Management in Engineering, v. 32, n. 3, 2016.

IRIZARRY, J.; COSTA, D.B.; KIM, S. Evaluation of Unmanned Aerial Systems in Construction Safety Applications: A Case Study at Unilever Manufacturing Facility in Independence, MO. Final Report. Atlanta: Georgia Institute of Technology, School of Building Construction.2015.

IRIZARRY, J.; GHEISARI, M.; WALKER, B. N. Usability assessment of drone technology as safety inspection tools. Journal of Information Technology in Construction (ITcon), 2012, 17, 194-212. Proceedings...

KIM, S.; IRIZARRY, J. Exploratory study on factors influencing UAS performance on highway construction projects: as the case of safety monitoring systems. In: Conference on Autonomous and Robotic Construction of Infrastructure, Ames, 2015. Proceedings...

KIM, Y.S.; OH, S.W.; CHO, Y.K.; SEO, J.W. A PDA and Wireless Web-Integrated System for Quality Inspection and Defect Management of Apartment Housing Projects. Automation in Construction, v. 17, n. 2, p. 163-179. 2008. DOI: 10.1016/j.autcon.2007.03.006

LIN, K.-Y.; TSAI, M.-H.; GATTI, U.C.; LIN, J.J.-C.; LEE, C.-H.; KANG, S.-C. A User-Centered Information and Communication Technology (ICT) Tool to Improve Safety Inspections. Automation in Construction, v. 48, n. 1, p. 53-63, 2014. DOI: 10.1016/j.autcon.2014.08.012 
METNI, N.; HAMEL, T. A UAV for bridge inspection: visual servoing control law with orientation limits. Automation in Construction, v. 17, n. 1, p. 3-10, 2007.

MORGENTHAL, G.; HALLERMANN, N. Quality Assessment of Unmanned Aerial Vehicle (UAV) Based Visual Inspection of Structures. Advances in Structural Engineering, v. 17, n. 3, p. 289-302, 2014. Proceedings...

PARK, C.S.; LEE, O,-S.;WANG, W. A framework for proactive construction defect management using BIM, augmented reality and ontology-based data collection template. Automation in Construction, v. 33, n. 1, p. 61-71. 2013. DOI: 10.1016/j.autcon.2012.09.010

SHRESTHA, P.; YFANTIS, E.; SHRESTHA, K. Construction safety visualization. University of Nevada, Las Vegas (UNLV), 89154, U.S.A. 2011.

THEMISTOCLEOUS, K.; NEOCLEOUS K.; PILAKOUTAS, K.; HADJIMITSIS, D.G. Damage assessment using advanced non-intrusive inspection methods: Integration of Space, UAV, GPR and Field Spectroscopy. Proc. 2th International Conference on Remote Sensing and Geoinformation of the Environment. V. 9229. Paphos, Cyprus, 2014. Proceedings...

WOODCOCK, K. Model of safety inspection. Safety Science. V. 62, pp. 145-156, 2014.

ZHANG, C. Development of a UAV-based remote sensing system for unpaved road condition assessment. In: American Society for Photogrammetry and Remote Sensing Annual Conference, Portland, Oregon, 2008. Proceedings... 


\title{
Aplicação do Instrumento de Análise Ergonômica - MET na Construção Civil
}

\author{
Laísa Cristina Carvalho \\ Glauco Fabrício Bianchini \\ José Carlos Paliari
}

\section{Introdução}

O setor da construção civil, por sua natureza, requer de seus trabalhadores grande esforço físico para execução da maioria de suas atividades. Além disso, o canteiro de obras pode ser um local inóspito, associado à fadiga física, ao estresse e outros fatores gerados por grande quantidade de trabalhos manuais e pressões por produtividade (SAAD, 2008).

Tais características contribuem para um número significativo de distúrbios musculoesqueléticos relacionados ao trabalho, que poderiam ser evitados com mudanças nos materiais, equipamentos ou organização do trabalho.

A ergonomia aparece, nesse contexto, como alternativa para melhorar as condições de trabalho por meio da adaptação das práticas laborais ao homem. Busca ainda produzir conhecimentos sobre a atividade de trabalho, a fim de alcançar a segurança, a satisfação e o bem-estar dos trabalhadores, propondo o tratamento adequado, evitando prejuízos para empresas e colaboradores, em função de afastamentos, absenteísmos e incapacidades de trabalho (IIDA, 2005). Segundo a Associação Internacional de Ergonomia (IEA, 2000), ergonomia é a disciplina científica pertinente à compreensão das interações entre os seres humanos e os demais 
elementos do sistema, bem como a aplicação de métodos, dados e teorias para aprimorar o bem-estar das pessoas e o desempenho global do sistema.

Nesse processo, a utilização dos instrumentos de análise ergonômica é de suma importância, pois permite a identificação das condições de trabalho que podem levar o trabalhador a sofrer lesões musculoesqueléticas. Por meio desses instrumentos, é possível diagnosticar as situações que mais prejudicam a saúde do operário (SHIDA; BENTO, 2012).

Ressalta-se que questões relacionadas à ergonomia e à segurança do trabalhador não devem ser apenas uma obrigação legal. Cabe ao empregador cumprir a legislação vigente, proporcionando condições adequadas de trabalho, as quais resultarão na satisfação do trabalhador, com reflexos na melhoria do desempenho, redução de absenteísmo e, consequentemente, o aumento da produtividade.

Nesse sentido, este capítulo tem o objetivo de apresentar os procedimentos para aplicar o Instrumento de Análise Ergonômica - MET (Estimativa do Equivalente Metabólico) na Construção Civil, tendo como exemplo o serviço de armação, especificamente no que diz respeito ao recebimento do aço no canteiro de obras.

Inicialmente, é feita uma descrição do conceito de Análise Ergonômica do Trabalho (AET), na qual o instrumento em foco se insere. Em seguida, é feita uma explanação sobre o instrumento de análise ergonômica- MET, no que diz respeito ao conceito, procedimentos para utilização e exemplo de aplicação na construção civil. O presente capítulo se encerra com as considerações finais, nas quais se enfatiza a viabilidade e necessidade de ampliar estudos dessa natureza na construção civil.

\section{AET - Análise Ergonômica do Trabalho}

A Análise Ergonômica do Trabalho (AET) tem como objetivo o conhecimento da situação de trabalho por meio de um processo construtivo e participativo, exigindo conhecimento das tarefas e dificuldades enfrentadas para atingir o desempenho e a produtividade exigida (GUÉRIN et al., 2001).

Daniellou e Béguin (2007) pressupõem que a AET busca os meios de identificar a rede de exigências e constrangimentos na qual se insere a organização e os aspectos que norteiam as decisões sobre o problema a ser tratado no posto de trabalho. $\mathrm{O}$ percurso metodológico é desenvolvido a partir do modelo proposto por Guérin et al. (2001), cuja lógica permite que, conforme as informações e evidências vão se reconstruindo e se edificando, elas sejam aprendidas pelo pesquisador.

A AET é uma intervenção no ambiente de trabalho para o estudo dos problemas causados pela tarefa, decorrentes da atividade humana no meio produtivo, a fim de compreender a situação de trabalho, confrontar aptidões e limitações do trabalhador, diagnosticar as situações críticas e estabelecer sugestões de melhoria ao ambiente de 
trabalho (WISNER, 2003). Segundo Wisner (2003), a AET busca estabelecer e aproximar a compreensão geral de dificuldades relacionadas à organização do trabalho e, como isso, reflete em lesões físicas e transtornos psicofisiológicos.

A AET busca entender a situação geral (demanda) do trabalho prescrito, condições físicas e organizacionais (tarefa) e a forma como o trabalho é realmente executado pelo operador (atividade) (DUL; WEERDMEESTER, 2004). A Figura 1, a seguir, representa as etapas da AET: Situação Geral, Análise da Tarefa, Análise da Atividade e Diagnóstico.

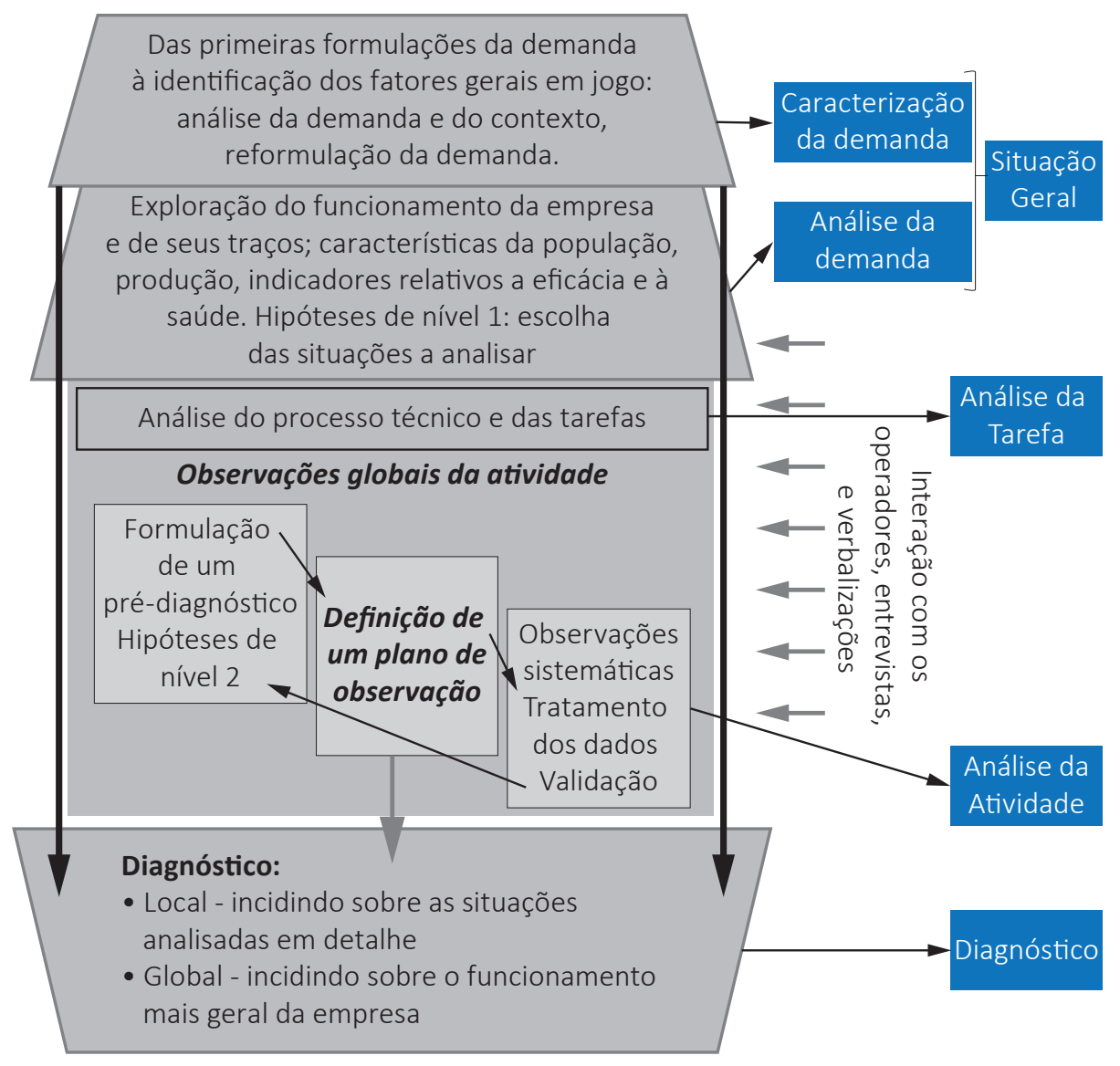

Figura 1 - Etapas da AET. Fonte: Adaptado de Guérin et al., 2001.

A situação geral engloba a caracterização e análise da demanda, em que são levantados dados gerais da empresa e o contexto no qual a empresa se insere. Nessa etapa, também é compreendida a situação do problema proposto pela tarefa 
em análise, levando em consideração o cenário interno e externo da empresa e as condições de trabalho.

A análise da tarefa compreende a assimilação e compreensão de dois aspectos: o trabalho prescrito (a instrução de trabalho) e as condições físicas para execução da tarefa. Portanto, a tarefa corresponde, em primeiro lugar, a um conjunto de objetivos propostos ao trabalhador e a um conjunto de prescrições determinadas para atingir esses objetivos; e, em segundo lugar, a tarefa é tratada como um princípio que impõe uma forma de definir o trabalho em relação ao tempo (GUÉRIN et al., 2001).

A análise da atividade é a etapa na qual se observa o modo operatório do trabalhador, ou seja, a forma como o trabalhador realmente executa o trabalho. Guérin et al. (2001, p.26) define a atividade de trabalho como:

A atividade de trabalho é o elemento central que organiza e estrutura os componentes da situação de trabalho. É uma resposta aos constrangimentos determinados exteriormente ao trabalhador, e ao mesmo tempo é capaz de transformá-los. Estabelece, portanto, pela sua própria realização, uma interdependência e uma interação estreita entre esses componentes.

Portanto, a atividade é definida como aquilo que realmente é executado e a forma como o trabalhador mobiliza e desempenha a tarefa. A atividade é concluída com obtenção do objetivo que foi fixado para ela, a partir do objeto da tarefa.
A atividade não se reduz ao comportamento. comportamento é a parte observável, manifesta, da atividade. A atividade inclui o observável e o inobservável: a atividade intelectual ou mental. A atividade gera o comportamento (FALZON, 2007, p. 9).

Assim a atividade é a base para análise ergonômica do trabalho e é entendida por meio do que o trabalhador faz (ações e decisões tomadas pelo trabalhador para alcançar os objetivos), de que forma o trabalhador faz (o que o trabalhador usa de si para atingir os objetivos) e os modos operatórios (estratégias adotadas pelo trabalhador para alcançar os objetivos) (ABRAHÃO et al., 2009).

Como é observado na Figura 2, a seguir, de um lado, tem-se o trabalhador e suas características (sexo, idade, altura, etc.) e, do outro, a empresa (organização) com suas diretrizes (funcionamento, objetivos, valores, etc.). No núcleo (centro), estão os fatores determinantes para a organização do trabalho (contrato, tarefas prescritas, tarefas reais). Diante das combinações desses fatores, surge a atividade de trabalho executada pelos operadores, a qual resulta em aspectos positivos para empresa 
(produção, qualidade) e aspectos negativos para os trabalhadores (saúde, acidentes, competências).

\section{O operador}

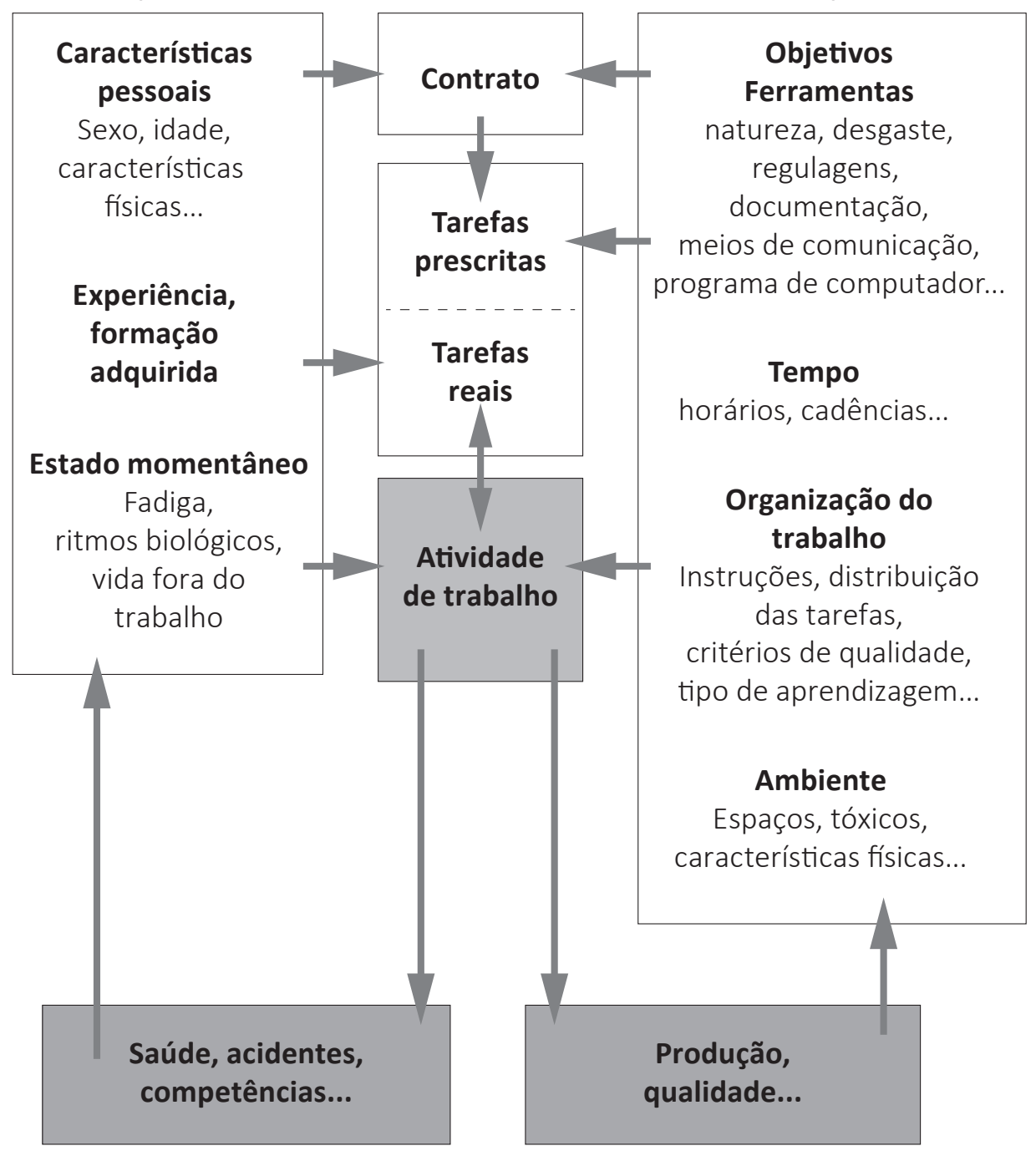

Figura 2 - Função integradora da atividade de trabalho. Fonte: Guérin et al., 2001.

Por fim, a partir da análise da atividade de trabalho, é apresentada a última etapa da AET: o diagnóstico ergonômico, que envolve o levantamento das condições de execução, ambientais e organizacionais do trabalho. 


\section{Instrumento de Análise Ergonômica MET - Equivalente Metabólico}

\subsection{Apresentação}

Segundo Abernethy et al. (1997) e Smith et al. (1997), toda atividade profissional exige um trabalho muscular e um consumo de energia, seja para manter a postura ou para a realização dos movimentos. Isso ocorre a partir da contração das fibras musculares e do gasto energético adicional, em que é superada a taxa de metabolismo de repouso. Para lida (2005), metabolismo de repouso é a quantidade de energia necessária para manter as funções vitais do organismo, sem que haja a realização de qualquer trabalho externo. Esse quantum de energia gasto varia, em adultos, entre $1800 \mathrm{kcal} / \mathrm{dia}$ (homem) e $1600 \mathrm{kcal} / \mathrm{dia}$ (mulher).

Conforme Costa (2013), a determinação exata do gasto calórico para uma pessoa durante a execução do trabalho é obtida por meio de instrumentos conectados ao corpo, com os quais são medidos os batimentos cardíacos, fluxo respiratório, massa corpórea e dados biométricos. A partir desses dados, determina-se o nível de intensidade da atividade física e, consequentemente, o esforço físico envolvido para sua execução.

Ainda segundo a autora, uma amostra da população passa por estudos capazes de quantificar o gasto energético médio despendido em cada atividade, criandose tabelas de referência de taxa metabólica. Assim, é possível aproximar o gasto energético de uma atividade específica ao parâmetro apresentado pela população desejada, podendo-se comparar com outra atividade, ou mesmo outra população.

O equivalente metabólico (MET) é um dos principais instrumentos empregados para descrever as necessidades energéticas requeridas em várias atividades, apresentando seu gasto energético em forma de tabelas (SMITH, 1997). Farinatti (2003) apresenta as análises do MET adaptadas para uma amostra da população brasileira, em forma de tabelas, com 605 atividades cotidianas (lazer, laboral e desportivas) sendo executadas em diferentes intensidades. Estas atividades são apresentadas em tabelas e o cálculo do gasto energético é dado em Kcal $\times \mathrm{Kg}^{-1} \times \mathrm{h}^{-1}$.

Assim, a intensidade física é determinada considerando a relação de Kcal/hora e, a partir desse parâmetro, é possível identificar a atividade como trabalho leve, moderado e pesado, de acordo com o Quadro 1 descrito na "NR 15 - Atividades e operações insalubres".

O MET é utilizado após a abordagem da AET, nas etapas de análise da atividade e diagnóstico, uma vez que apresenta, em números, o gasto energético do trabalhador em cada atividade da tarefa. 
Quadro 1 - Tipos de Atividade.

\begin{tabular}{|l|l|}
\hline Tipo de atividade & Kcal \\
\hline Trabalho leve & 125,00 \\
\hline Sentado, movimentos moderados com braços e troncos (ex: datilografia). & 150,00 \\
\hline Sentado, movimentos moderados com braços e pernas (ex: dirigir). & 150,00 \\
\hline De pé, trabalho leve, em máquina ou bancada, principalmente com os braços. & 180,00 \\
\hline Trabalho moderado & 175,00 \\
\hline Sentado, movimentos vigorosos com braços e pernas. & 220,00 \\
\hline De pé, trabalho leve em máquina ou bancada, com alguma movimentação. & 300,00 \\
\hline De pé, trabalho moderado em máquina ou bancada, com alguma movimentação. & \\
\hline Em movimento, trabalho moderado de levantar ou empurrar. & 440,00 \\
\hline Trabalho pesado & 550,00 \\
\hline Trabalho intermitente de levantar, empurrar ou arrastar pesos (ex.: remoção com pá). & \\
\hline Trabalho fatigante. & \\
\hline
\end{tabular}

Fonte: Brasil, 2014.

\subsection{Processo de Coleta, Processamento de Dados para Utilização do MET e Análise dos Resultados}

\subsubsection{Dados de Entrada}

O procedimento de coleta compreende inicialmente a situação geral, na qual é conhecida a empresa e suas demandas. Em seguida, dá-se a análise da tarefa e atividade do serviço a ser analisado, sob o ponto de vista da empresa e do trabalhador. Assim, no contexto da empresa, é necessário compreender o processo de como essa tarefa é transmitida ao trabalhador, ou seja, se há um procedimento de execução de serviço, treinamento antes do início da atividade ou se a tarefa é repassada ao trabalhador apenas de forma verbal pelo seu supervisor imediato. Com relação à atividade realizada pelo trabalhador, é importante entender como ele a executa, ou seja, se é de acordo com o procedimento da empresa (caso possua) ou conforme seu tempo de serviço e experiência. Além disso, é preciso verificar se as ferramentas estão adequadas e se o espaço do posto de trabalho é suficiente. Em outras palavras, é importante compreender como o trabalhador enxerga a atividade e sua execução.

Assim, com as informações obtidas sobre a tarefa, é possível analisar a atividade, compreendendo e identificando as variabilidades do posto de trabalho e do trabalhador, no intuito de entender o modo operatório- termo próprio da ergonomia, que caracteriza as diferentes maneiras de se executar uma mesma tarefa - desse agente da construção civil. Essa identificação leva à localização de competências não 
reconhecidas pela empresa, capazes de contribuir para evolução profissional ou para investimentos técnicos.

As informações obtidas mediante contato pessoal com a empresa e seus trabalhadores e filmagens, geram os seguintes dados de entrada para o instrumento de análise ergonomica MET:

- Os códigos da atividade (MET) são obtidos no Compêndio de Atividades Físicas: códigos, atividades e intensidade em MET's, apresentados por Farinatti (2003) e exemplificados no item 4.3. Informa como a tarefa é codificada em termos de função realizada, tipo específico e intensidade. 0 Compêndio pode ser usado para estudos com diferentes objetivos;

- Tempo das atividades na tarefa (etapas do serviço, em segundos): tempo em que se mede a quantidade de vezes que uma ação aparece ao longo da tarefa, quantas vezes se repete a ação (ciclo);

- Duração da tarefa e do ciclo do trabalho (em segundos): o tempo total gasto para cumprir a tarefa, a tarefa representa o ciclo de trabalho;

- Peso de um homem adulto médio (70 kg): indivíduo de referência estipulado para uso no MET.

Define-se o tempo de realização da tarefa como sendo uma hora, de tal forma que os valores resultantes sejam obtidos em Kcal/hora.

Procedimento de cálculo utilizado:

- Quantidade de ciclos = Tempo de realização da tarefa $\times 3.600$ / Duração do ciclo;

- Tempo da etapa $(h)=$ Duração da etapa $\times$ Quantidade de ciclos / 3.600;

- $\mathrm{Kcal} / \mathrm{hora}=\Sigma$ (Tempo da etapa (h) $\times$ MET $\times$ Peso adulto médio) .

O cálculo do dispêndio de energia na execução da tarefa foi dado pelo somatório dos dispêndios de energias em cada Atividade (etapa) que compõe a tarefa.

\subsubsection{Coleta de Dados}

Todos os dados são obtidos por meio de entrevistas informais e questionários semiestruturados com funcionários da obra, no intuito de compreender as situações de trabalho, tanto de ordem ambiental como técnica e organizacional, e de caracterizar o trabalhador, de modo a obter informações, tais como: peso, altura, tempo de serviço, nível de escolaridade, etc.

É realizada uma observação simples e direta dos trabalhadores, na qual o pesquisador permanece alheio às atividades do grupo observado e não interfere nas situações de trabalho. Essa observação está associada a registros fotográficos 
e filmagens com tempo variável conforme a complexidade da atividade, a fim de caracterizar a atividade desenvolvida e auxiliar na análise dos movimentos e posturas de cada trabalhador.

Para melhor compreenssão das etapas da coleta de dados, é apresentada, a seguir, a Figura 3, em que é especificado o passo a passo desse processamento.

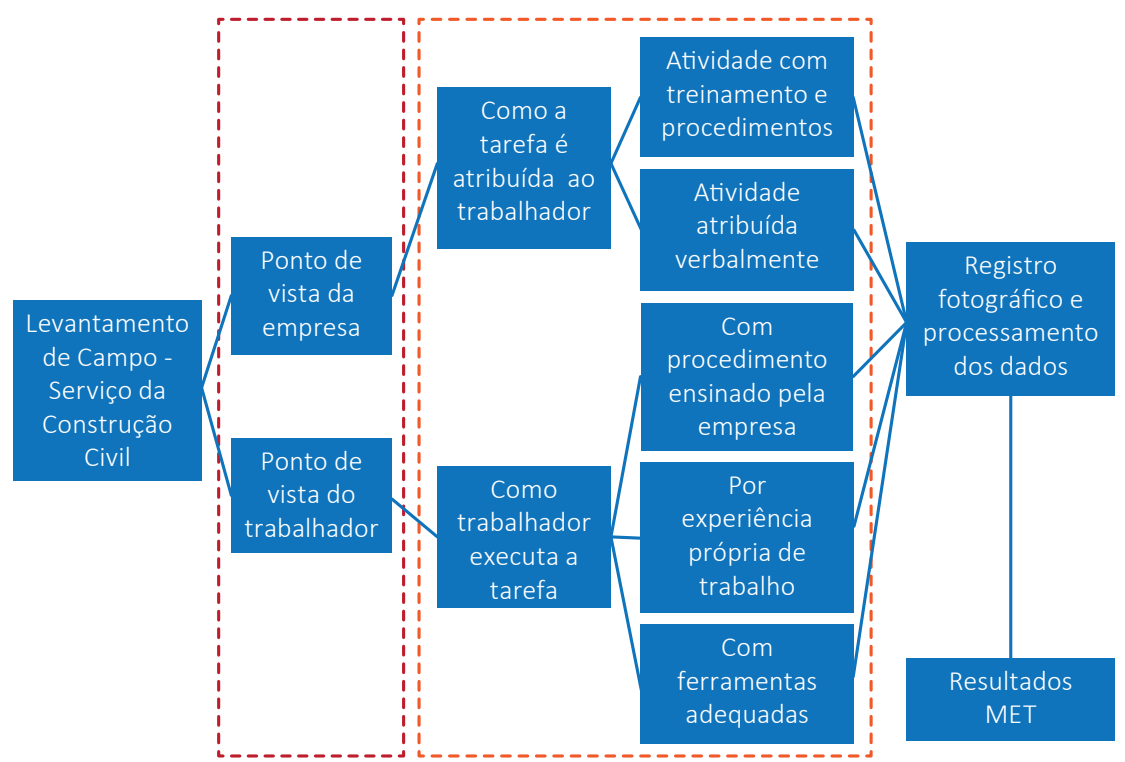

Figura 3 - Etapas da coleta de dados. Fonte: Autores.

O registro da tarefa ocorre em períodos distintos durante a jornada de trabalho, com o propósito de representar de modo fiel e real o cenário cotidiano da tarefa no canteiro de obras. Esse registro fotográfico e de filmagens ajuda o pesquisador nas análises de laboratório e facilita a obtenção dos tempos de ciclo (tempos para realizar cada atividade da tarefa). A partir desses dados, faz-se o uso do instrumento de análise ergonômica MET, que processa essas informações de forma qualitativa e quantititava de maneira a facilitar a sua compreensão, explicação e utilização.

\subsubsection{Processamento de Dados}

Partindo do princípio que as filmagens fornecem a possibilidade de obtenção de dados e possibilitam uma nova observação sem que se precise retornar ao local de trabalho, obtem-se os principais dados utilizados nas avaliações e no instrumento de análise ergonômica. Esses dados são identificados ao se assistir cada vídeo relacionado à tarefa, em que é possível determinar o tempo gasto em cada atividade da tarefa e quantas vezes essa atividade aconteceu para se cumprir o objetivo da tarefa. 


\subsubsection{Análise dos Resultados}

A análise dos resultados leva ao diagnóstico das situações de trabalho a que estão sujeitos os operários da construção civil. O diagnóstico se dá de modo global (ambiente de trabalho) e local (situação de trabalho). Tal etapa abrange as condições técnicas para a execução do trabalho, as condições ambientais em que a atividade ocorre, além das condições organizacionais do trabalho.

Assim, o diagnótico também busca propor melhorias com base na ergonomia de correção e concepção, a fim de motivar participação conjunta dos setores da empresa, com intuito de discutir a organização do trabalho, utilizar estratégias para melhorar a comunicação e o relacionamento da equipe, oferecer treinamentos e orientar os trabalhadores sobre os riscos a que estão expostos no canteiro de obras.

\section{Exemplo de Aplicação do Instrumento de Análise Ergonômica - MET}

Exemplifica-se a aplicação do instrumento de análise ergonômica - MET, focando a execução do serviço de armação, cujo resultado é oriundo de um estudo de caso realizado em um canteiro de obras localizado no município de São Carlos-SP, especificamente no que diz respeito ao recebimento do aço nos canteiros de obras.

\subsection{AET}

Para a AET, é necessária a compreensão do fluxograma de processos da tarefa e como essa tarefa é executada (conjunto de atividades). Na Figura 4, apresenta-se o fluxograma dos processos, tendo-se como tarefas o recebimento do aço no canteiro de obras, sua estocagem, processamento e aplicação final.

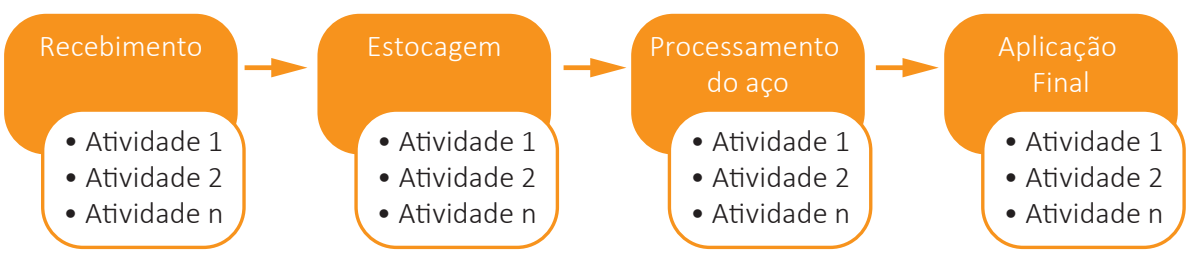

Figura 4 - Fluxograma de Processos (Exemplo: Serviço de Armação). Fonte: Autores.

Após entendimento do fluxograma de processos contendo as tarefas e suas respectivas atividades e de posse das filmagens das ações, é possível determinar quais são executadas para atingir o objetivo da tarefa e o respectivo modo operatório dos trabalhadores (o porquê se fazer daquele determinado modo). Com o detalhamento das atividades, é possível determinar o tempo de ciclo de cada uma e quantas vezes se repetem ao longo da tarefa. No Quadro 2, é apresentada a tarefa de recebimento do aço e suas respectivas atividades, para as quais se apresentam outras informações sobre o modo operatório, obtidas por meio da filmagem, conforme prescreve a AET. 


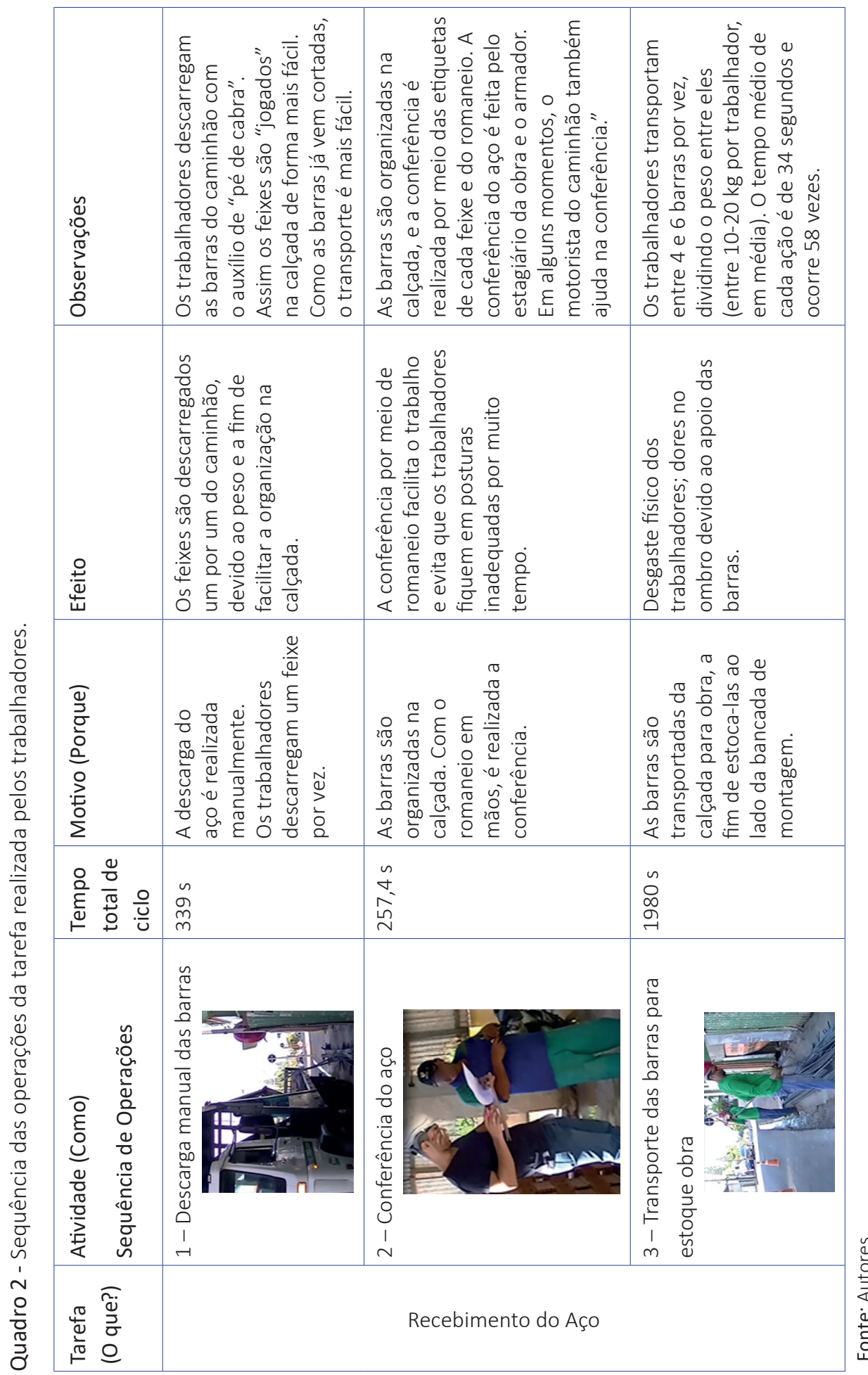




\subsection{Dados de Entrada}

Os dados determinantes de entrada para o cálculo do dispêndio de energia são:

- Código das atividades do serviço de armação;

- Tempo das atividades do serviço de armação (em segundos);

- Duração da tarefa e do ciclo do trabalho (em segundos);

- Peso de um homem adulto médio.

Procedimento de cálculo utilizado:

- Quantidade de ciclos = Tempo de realização da tarefa $\times$ 3.600/Duração do ciclo;

- Tempo da etapa $(h)=$ Duração da etapa $\times$ Quantidade de ciclos/3.600;

- $\mathrm{Kcal} /$ hora $=\Sigma($ Tempo da etapa $(\mathrm{h}) \times \mathrm{MET} \times$ Peso adulto médio $)$.

\subsection{Exemplo de Cálculo}

Para exemplificar a aplicação e cálculo do gasto energético (Kcal/hora) conforme demonstra o MET, foi analisado o serviço de recebimento do aço. A visita no canteiro de obras resultou na sequência de atividades da tarefa de recebimento do aço no canteiro de obras, conforme apresentado no Quadro 2. Para os cálculos do gasto energético nessa tarefa, foram consideradas as seguintes condições:

- Peso médio dos trabalhadores envolvidos na tarefa: 70,0kg;

- Determinação da duração dos ciclos: o ciclo é determinado por meio do tempo exigido para se executar a atividade (coluna 3 do Quadro 2). Os tempos médios foram determinados a partir do cálculo da média dos tempos para cada atividade obtidos nas filmagens;

- O ciclo da tarefa (tempo total de todas as atividades para se concluir o objetivo da tarefa) possui duração média de 2576,4 segundos, que equivale a 42,94 minutos ou 0,72 horas;

- Durações médias de cada atividade durante o recebimento do aço:

- Descarga manual das barras na calçada =339s;

- Conferência do aço com romaneio = 257,4s;

- Transporte das barras para estoque no interior da obra $=34 \mathrm{~s}$.

- Tempo gasto diariamente em cada operação da tarefa:

- Descarga manual das barras na calçada =339s; 
- Conferência do aço com romaneio = 257,4s;

- Transporte das barras para estoque no interior da obra $=1980 \mathrm{~s}$.

Código MET de cada atividade (Quadro 3, extraído de FARINATTI, 2003): O valor do MET é determinado pela atividade específica. Quando não há diretamente a atividade específica da construção civil, é realizada a correlação. Por exemplo, o código 11050 representa a atividade de transporte de cargas pesadas, o que caracteriza o transporte manual das barras:

Quadro 3-MET.

\begin{tabular}{|l|l|l|l|}
\hline Código & MET & Contexto Principal & Atividade específica (exemplos) \\
\hline 11050 & 8,0 & Atividades Ocupacionais & $\begin{array}{l}\text { Transporte de cargas pesadas } \\
\text { (por exemplo - tijolos) }\end{array}$ \\
\hline 11610 & 3,0 & Atividades Ocupacionais & $\begin{array}{l}\text { Em pé, leve/moderado (trabalhos } \\
\text { manuais pesados, etc.) }\end{array}$ \\
\hline
\end{tabular}

Fonte: Adaptado de Farinatti (2003).

- Descarga manual das barras na calçada = Código 11050- MET = 8,0;

- Conferência do aço com romaneio = Código 11610- MET = 3,0;

- Transporte das barras para estoque no interior da obra = Código 11050$\mathrm{MET}=8,0$.

- Cálculo da kcal gasta na atividade ao longo do dia em horas:

- Descarga manual das barras na calçada $=8,0 \times 70,0 \times 0,09=50,4 \mathrm{kcal}$;

- Conferência do aço com romaneio = 3,0 × 70,0 ×0,07 = 14,7 kcal;

- Transporte das barras para estoque no interior da obra $=8,0 \times 70,0 \times$ $0,55=308 \mathrm{kcal}$.

- Determinação da relação Kcal/ hora: 371,1/0,72 = 515,42.

De acordo com o resultado apresentado no Quadro 4, a operação que demandou maior esforço físico durante a jornada de trabalho foi a de número 3 (consumo 308 kcal), taxa justificada pelo número de vezes (58) em que as barras são transportadas. Comparando os resultados com os prescritos na "NR-15 - Atividades e Operações Insalubres" (Quadro 2 deste capítulo), conclui-se que, para um trabalhador de porte médio, a atividade de recebimento do aço pode ser considerada um trabalho pesado (fatigante) do ponto de vista da taxa de metabolismo.

Diante desse resultado, os gestores do serviço poderiam propor que tal transporte seja realizado por carrinho específico, grua ou que o aço seja descarregado diretamente no local de estocagem, evitando esse tipo de transporte. 
Quadro 4 - Resultados obtidos no MET.

\begin{tabular}{|l|l|l|l|}
\hline Sequência das etapas & 1 & 2 & 3 \\
\hline Tempo diário no ciclo $(\mathrm{h})$ & 0,09 & 0,07 & 0,55 \\
\hline Código & 11050 & 11610 & 11050 \\
\hline MET & 8,0 & 3,0 & 8,0 \\
\hline Kcal & 50,4 & 14,7 & 308 \\
\hline \multicolumn{2}{r|}{ Trabalho Pesado = MET > 440 (NR-15 - Atividades e Operações Insalubres) } \\
\hline
\end{tabular}

Fonte: Autores.

\section{Conclusões}

A ergonomia ainda é pouco aplicada na construção civil e, especialmente, no subsetor de edificações, no qual os trabalhadores ainda utilizam ferramentas e equipamentos manuais, muitas vezes danificados e inadequados para realização de suas atividades de trabalho.

Por meio da AET, é possível caracterizar de que forma o trabalho está sendo executado e quais as suas consequências para empregadores e trabalhadores. As melhorias nas condições de trabalho só podem ser executadas se houver uma perfeita compreensão da diferença entre a tarefa prescrita e a atividade realizada. Nesse sentido, os instrumentos de análise ergonômica auxiliam no processo de identificação das situações críticas de trabalho, quantificando e comparando os valores obtidos em campo com os valores determinados pela literatura.

Este capítulo apresentou o instrumento de análise ergonômica MET, detalhando seus procedimentos de aplicação e formas de obtenção de dados. A atividade selecionada para análise foi caracterizada como trabalho pesado, podendo ser fatigante para os trabalhadores em questão.

\section{Referências}

ABRAHÃO, J.I.; SZNELWAR, L.; SILVINO, A.; SARMET, M.; PINHO, D. Introdução à ergonomia: da prática à teoria. São Paulo: Editora Blucher, 2009.

ABERNETHY, B.; KIPPERS, V.; MACKINNON, L.T.; NEAL, R.J.; HANRAHAN, S. The Biophysical Foundations of Human Movement. Human Kinects Publishers, Australia. 425p. 1997. 
BRASIL. Ministério do Trabalho e Emprego. Norma Regulamentadora 15 (NR-15): Atividades e Operações Insalubres. 2014. Disponível em: <http://portal.mte.gov.br/data/ files/8A7C816A47594D040147D14EAE840951/NR-15\%20(atualizada\%202014).pdf>. Acesso em: nov. 2014.

COSTA, S.E.A. Análise Ergonômica do Trabalho de colheita de citros: comparativo dos métodos de colheita manual e semimecanizada. 2013. 152f. Dissertação (Mestrado) Universidade Federal de São Carlos, São Carlos, 2013.

DANIELLOU, F.; BÉGUIN, P. Metodologia da ação ergonômica: abordagens do trabalho real. In: FALZON, P. (Ed.). Ergonomia. São Paulo: Edgard Blucher, 2007.

DUL, J.; WEERDMEESTER, B. Ergonomia prática. São Paulo: Edgard Blucher, 2004.

FALZON, P. Natureza, objetivos e conhecimentos da ergonomia: elementos de uma análise cognitiva da prática. In: FALZON, P. (Ed.). Ergonomia. São Paulo: Edgard Blucher, 2007. p. 3-19.

FARINATTI, P.T.V. Apresentação de uma versão em português do compêndio de atividades físicas: uma contribuição aos pesquisadores e profissionais em fisiologia do exercício. Rev. Bras. Fisiol. Exerc. 2003; v. 2, p. 177-208.

GUÉRIN, F. et al. Compreender o trabalho para transformá-lo: a prática da ergonomia. São Paulo: Edgard Blucher, 2001.

IEA. Definição Internacional de ergonomia. Aprovação na Reunião do Conselho Científico da International Ergonomics Association. San Diego- USA. 2000.

IIDA, I. Ergonomia, projeto e produção. São Paulo: Edgard Blucher, 2005.

SAAD, V.L. Análise Ergonômica do Trabalho do Pedreiro: o assentamento de tijolos. 2008. 124f. Dissertação (Mestrado em Engenharia de Produção) - Campus Ponta Grossa, Universidade Tecnológica Federal do Paraná, Ponta Grossa, 2008.

SHIDA, G.J.; BENTO, P.E.G. Método e Ferramentas Ergonômicas que Auxiliam na Análise de Situação de Trabalho. In: CONGRESSO NACIONAL DE EXCELÊNCIA EM GESTÃO, n. 8, 2012, Rio de Janeiro, Niterói. Anais eletrônicos... Disponível em: <http://www.excelenciaemgestao. org/Portals/2/documents/cneg8/anais/T12_0496_3097.pdf>. Acesso em: ago. 2014.

SMITH. L.K. Cinesiologia Clínica de Brunnstrom. Editora manole. Ed 5. São Paulo. 1997.

WISNER, A. A inteligência no trabalho: textos selecionados de ergonomia. Roberto Leal Ferreira (Trad.). São Paulo: FUNDACENTRO, 2003. 190p. 


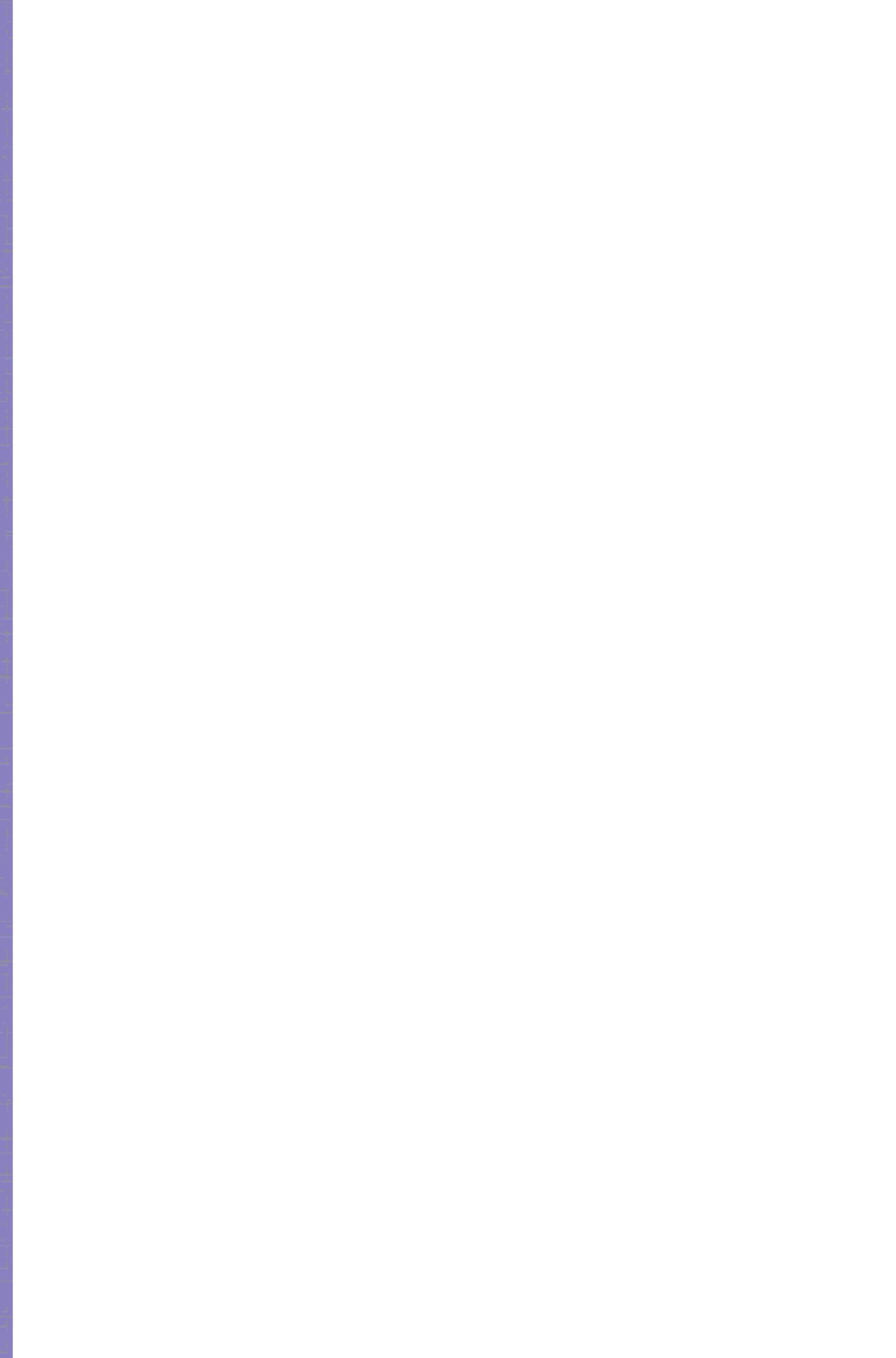




\title{
Embargos e Interdições em Canteiros de Obras: Uma Perspectiva Sistêmica'
}

\author{
Tarcisio Abreu Saurin
}

\section{Introdução}

As inspeções conduzidas por órgãos governamentais têm papel importante na garantia do atendimento à legislação de segurança e saúde no trabalho (SST) em canteiros de obras. De fato, pressões externas são normalmente necessárias quando se trata de requisitos não exigidos pelo usuário final, tais como aqueles ligados à SST.

Contudo, não há evidências conclusivas sobre os impactos das inspeções na redução dos índices de acidentes. Em parte, isso se deve a dificuldades metodológicas de isolar o efeito de inspeções. Um dos principais estudos quantitativos acerca do tema foi realizado por Levine et al. (2012) em uma grande amostra de empresas de vários setores nos EUA. As conclusões apontaram que as inspeções reduziram as taxas de acidentes, com nenhuma evidência de impactos negativos em termos de redução de empregos, vendas ou sobrevivência da empresa.

Embora estudos quantitativos possam fornecer generalizações estatísticas sobre a eficácia das inspeções, isso não significa que canteiros de obras individuais sejam imunes a uma mistura de impactos desejados e indesejados. Nesse sentido, o Pensamento Sistêmico (PS, systems thinking) permite uma análise mais abrangente

1 Este capítulo é uma versão condensada e adaptada de uma publicação em um periódico internacional: Saurin, T.A. 2016. Safety inspections in construction sites: a systems thinking perspective. Accident Analysis and Prevention, 93, 240-250. 
das inspeções de SST, ajudando a esclarecer os seus efeitos em contextos específicos. Neste capítulo, é discutido como o PS pode contribuir para uma melhor compreensão dos impactos das inspeções, bem como dos mecanismos que levam aos impactos.

A discussão é realizada com base em estudos de caso de canteiros de obras que foram interditados ou embargados por uma inspetoria governamental de SST. O autor esteve envolvido como observador participante nestes estudos de caso, que ocorreram ao longo de seis anos.

\section{Método de Pesquisa}

As inspeções foram analisadas segundo a perspectiva de quatro atributos do PS identificados por Wilson (2014). O primeiro atributo é a preocupação com o contexto, que implica em identificar fatores que influenciam o comportamento dos agentes, acarretando em dificuldades e oportunidades. A visão holística deve ser valorizada, buscando interações e mecanismos causais que estão distantes, no tempo e no espaço, das ações e decisões dos agentes (SKYTTNER, 2005). O segundo atributo é o reconhecimento das interações, o qual se contrapõe à ênfase do pensamento linear na compreensão apenas das partes. As interações possuem características peculiares em sistemas complexos, tais como a não proporcionalidade entre causas e efeitos, natureza dinâmica, feedback loops e incerteza (CILLIERS, 1998).

O reconhecimento de fenômenos emergentes é o terceiro atributo. Tais fenômenos são manifestações da variabilidade inesperada, surgindo das interações entre os agentes em vez de algum controle centralizado. Fenômenos emergentes têm propriedades novas, que não existem nos elementos individuais que interagem (CILLIERS, 1998). O quarto atributo diz respeito à consideração de diversas perspectivas. Os agentes de um sistema diferem entre si segundo diversas categorias, tais como níveis hierárquicos, divisão de tarefas, nível de especialização. Embora a diversidade crie dificuldades de coordenação, ela contribui para a tomada de melhores decisões (DEKKER, 2011).

Foram realizados 13 estudos de caso em canteiros de obras que estavam sob a jurisdição de uma inspetoria do trabalho com longa tradição de ser ativa, exigente e possuir inspetores (denominados auditores fiscais do trabalho) qualificados tecnicamente. Segundo dados coletados pela inspetoria de 2003 a 2009 (BRASIL, 2010), 46,9\% dos embargos e interdições ocorreram na construção civil, enquanto este setor foi responsável por $19 \%$ dos acidentes fatais no mesmo período.

As fontes de dados foram as mesmas em todos os casos, envolvendo: (i) observação participante; (ii) observação direta; (iii) análise de relatórios de interdição e embargo preparados pelos inspetores. Enquanto os dados provenientes dessas fontes 
foram reunidos ao longo dos seis anos. Em 2015, duas entrevistas semiestruturadas foram realizadas com dois inspetores. Os entrevistados foram escolhidos devido a sua experiência (> 20 anos no serviço de inspeção) e disponibilidade. Cada entrevista durou cerca de 1,5 hora, com foco na compreensão das atividades da inspetoria, bem como na visão dos inspetores acerca dos pontos fortes e fracos do processo de auditoria em si.

A observação participante foi a principal fonte de dados, uma vez que o pesquisador colaborou com as equipes de gerenciamento das obras na concepção e avaliação de medidas corretivas implantadas como resultado das inspeções. A oportunidade para a observação participante surgiu do fato de que, como resultado das inspeções, as construtoras têm recorrido a universidades em busca de assistência técnica. Assim, o pesquisador participou de diversas reuniões com as equipes gerenciais (cerca de 65 horas ou 5 horas por estudo de caso), além de uma reunião na sede da inspetoria (1 hora), em que os gerentes de um dos canteiros solicitaram esclarecimentos sobre as razões para a interdição e medidas de controle previstas.

As observações diretas permitiram verificar, nas próprias obras, as deficiências apontadas nos relatórios de interdição e embargo. Cerca de 80 horas de observações diretas foram realizadas (aproximadamente 6 horas por estudo de caso), variando de 2 a 10 horas por estudo.

Em relação à análise de documentos, os relatórios de interdição foram uma fonte de dados valiosa, visto que estes eram documentos detalhados, com a perspectiva dos inspetores sobre os perigos e como eles deveriam ser controlados.

\section{Resultados}

\subsection{Características das Interdições e Embargos Analisados}

A Tabela 1 apresenta as principais características dos estudos de caso em ordem cronológica, desde a paralisação mais recente até a mais antiga. As treze interdições e embargos investigados ocorreram ao longo de seis anos em doze diferentes canteiros. Apenas quatro inspetores diferentes estavam envolvidos nestes casos (20\% do total da inspetoria local) e a duração média das paralisações foi de 4,5 meses. Em sete casos $(53,8 \%)$, as construtoras recorreram ao sistema judiciário na tentativa de acabar com a interdição ou embargo. Os casos envolvendo litígios tiveram paralisações mais longas (5,7 meses) em comparação aos casos em que foram usados apenas os mecanismos administrativos regulares (3,2 meses). As construtoras comumente faziam duas rodadas de defesa administrativa antes de recorrer à opção judicial. 
Tabela 1 - Características das interdições e embargos analisados.

\begin{tabular}{|c|c|c|c|}
\hline $\begin{array}{l}\text { Propósito da } \\
\text { construção }\end{array}$ & Principais objetos de interdição e embargo & $\begin{array}{l}\text { Duração da } \\
\text { paralisação }\end{array}$ & $\begin{array}{l}\text { Disputa } \\
\text { legal? }\end{array}$ \\
\hline $\begin{array}{l}\text { (1) Habitação de } \\
\text { interesse social }\end{array}$ & $\begin{array}{l}\text { Proteções periféricas, falta de programa de } \\
\text { gerenciamento de estresse térmico, levantamento } \\
\text { manual de pesos, falta de proteção coletiva junto } \\
\text { ao parapeito de janelas }\end{array}$ & 3 meses & Não \\
\hline $\begin{array}{l}\text { (2) Ampliação } \\
\text { de um shopping } \\
\text { center }\end{array}$ & $\begin{array}{l}\text { Montagem de estruturas de concreto pré- } \\
\text { fabricado, montagem de estruturas metálicas }\end{array}$ & 6 meses & Sim \\
\hline $\begin{array}{l}\text { (3) Prédio } \\
\text { residencial }\end{array}$ & $\begin{array}{l}\text { Proteções periféricas, linhas de vida, plataformas } \\
\text { de proteção, transporte manual de cargas pesadas }\end{array}$ & 6 meses & Sim \\
\hline $\begin{array}{l}\text { (4) Ampliação } \\
\text { de um shopping } \\
\text { center }\end{array}$ & $\begin{array}{l}\text { Escavações, trincheiras, fundações, falta de } \\
\text { programa de gerenciamento de estresse térmico } \\
\text { *Mesmo canteiro de obras do item 2, que foi } \\
\text { interditado duas vezes pelo mesmo inspetor em } \\
\text { diferentes etapas da construção }\end{array}$ & 3 meses & Não \\
\hline $\begin{array}{l}\text { (5) Prédio } \\
\text { comercial }\end{array}$ & Linhas de vida, escavações, serra circular & 2 meses & Não \\
\hline $\begin{array}{l}\text { (6) Prédio } \\
\text { comercial }\end{array}$ & $\begin{array}{l}\text { Linhas de vida, proteções periféricas, falta de } \\
\text { programa de gerenciamento de estresse térmico }\end{array}$ & 5 meses & Sim \\
\hline $\begin{array}{l}\text { (7) Prédio } \\
\text { residencial }\end{array}$ & $\begin{array}{l}\text { Mesmos problemas que o canteiro } 2 \text {, além de } \\
\text { elevadores para o transporte de materiais, falta de } \\
\text { programa de gerenciamento de estresse térmico }\end{array}$ & 8 meses & Sim \\
\hline $\begin{array}{l}\text { (8) Prédio } \\
\text { comercial }\end{array}$ & $\begin{array}{l}\text { Proteções periféricas, elevadores para o transporte } \\
\text { de materiais }\end{array}$ & 5 meses & Sim \\
\hline $\begin{array}{l}\text { (9) Habitação de } \\
\text { interesse social }\end{array}$ & $\begin{array}{l}\text { Proteções periféricas, circulação de veículos } \\
\text { pesados dentro do canteiro de obras }\end{array}$ & 4 meses & Não \\
\hline $\begin{array}{l}\text { (10) Prédio } \\
\text { residencial }\end{array}$ & $\begin{array}{l}\text { Escavações, betoneiras, circulação de veículos } \\
\text { pesados dentro do canteiro, falta de programa de } \\
\text { gerenciamento de estresse térmico }\end{array}$ & 6 meses & Sim \\
\hline $\begin{array}{l}\text { (11) Prédio para } \\
\text { estacionamentos }\end{array}$ & $\begin{array}{l}\text { Proteções periféricas e linhas de vida *Mesma } \\
\text { empresa do canteiro 1, mas obra diferente }\end{array}$ & 4 meses & Não \\
\hline $\begin{array}{l}\text { (12) Prédio } \\
\text { residencial }\end{array}$ & $\begin{array}{l}\text { Andaimes suspensos, linhas de vida e proteções } \\
\text { periféricas }\end{array}$ & 3 meses & Não \\
\hline $\begin{array}{l}\text { (13) Prédio } \\
\text { residencial }\end{array}$ & $\begin{array}{l}\text { Andaimes suspensos * Mesma empresa do } \\
\text { canteiro } 10, \text { mas obra diferente }\end{array}$ & 4 meses & Sim \\
\hline
\end{tabular}

Com a exceção dos canteiros 1 e 8 (habitações de interesse social), os demais estavam localizados em áreas urbanas centrais. As obras eram relativamente grandes, 
tendo cerca de 100 trabalhadores no pico (obra 8) até 500 trabalhadores (obra 2). Não foram obtidos dados confiáveis para confirmar se a ênfase em grandes projetos era válida para todo o universo das inspeções. Caso fosse confirmada, tal ênfase estaria em contraste com estudos recentes na mesma região, os quais concluíram que obras menores tinham um nível muito mais baixo de conformidade com os regulamentos de SST (20\% contra 65\%) em comparação aos maiores (COSTELLA et al., 2014). Resultados similares têm sido obtidos em outros países (SINCLAIR; CUNNINGHAM, 2014).

A força de trabalho em todos os canteiros era em grande parte terceirizada (mais de $90 \%$ ) e as tecnologias eram típicas do setor de construção de edifícios residenciais e comerciais no Brasil: fôrmas de madeira montadas no local, estrutura de concreto armado e alvenaria com blocos cerâmicos ou de concreto. Tais tecnologias têm caráter artesanal e envolvem uso intensivo de mão de obra, sendo associadas a taxas de acidentes mais elevadas em comparação à construção industrializada (RUBIOROMERO et al., 2014).

\subsection{Análise dos Estudos de Caso sob o Ponto de Vista do Pensamento Sistêmico}

\subsubsection{Preocupação com o Contexto}

O conteúdo dos relatórios de inspeção indicou que os auditores tinham visão holística em termos de perigos antecipados pela legislação, uma vez que eles apontaram uma ampla gama de situações inseguras. No entanto, as práticas de gestão da segurança não costumavam ser objeto das inspeções, o que reflete a ênfase das normas brasileiras nas proteções físicas. Deste modo, as causas raízes dos riscos, que eram distantes no tempo e espaço em relação aos trabalhos na obra, não eram levadas em conta. Um dos inspetores entrevistados relatou frustração com o fato de que as mesmas empresas são notificadas várias vezes pelos mesmos problemas, em diferentes obras.

Um exemplo que ilustra problemas repetitivos refere-se às grandes diferenças entre como as proteções coletivas são imaginadas em projeto e como são implantadas na prática. A alta incidência dessas diferenças, em todos os estudos de caso, sugere que as causas raízes não estão ligadas a comportamentos individuais dos gestores e trabalhadores. Contudo, as inspeções limitavam-se a apontar as não conformidades, enquanto a gerência das obras costumava se restringir a correções de curto prazo, que muitas vezes implicavam em alterar o projeto para torná-lo aderente ao que estava em uso, em vez do contrário. Esse achado também sugere que, assim como ocorre em outras áreas do projeto das edificações, um "projeto como construído" das proteções coletivas pode ser pertinente. Com base nos dados coletados, as causas das diferenças entre projeto e prática podem ser: 
- O fato dos projetistas de proteções coletivas não serem contratados para fornecer assistência durante a fase de construção, o que aumenta a probabilidade de má interpretação do projeto;

- A falta de participação dos trabalhadores no projeto das proteções coletivas, o que é tanto um resultado do fator anterior como de práticas comuns no setor, que costuma valorizar pouco a participação dos trabalhadores;

- Uma cultura generalizada de "segurança baseada em papel", o que significa que a ênfase é colocada na necessidade de ter projetos e documentações apenas para fins legais. Assim como os anteriores, esse problema decorre de outros de natureza setorial, tal como o predomínio de contratos que enfatizam penalidades legais em detrimento do colaborativo entre as partes contratantes (SAKAL, 2005).

\subsubsection{Consideração de Diversas Perspectivas na Tomada de Decisões}

A necessidade de levar diversas perspectivas em conta ao avaliar riscos e propor medidas de controle parecia ser raramente utilizada pelos inspetores. As observações participantes e relatórios de inspeções indicaram que havia pouco espaço para "segundas histórias" e os inspetores usavam sua autoridade para decidir o que contava como risco iminente e grave. A diferença entre as perspectivas dos inspetores e gestores parecia ser ampla e difícil de ser conciliada. Em um estudo anterior na mesma região (ROCHA, 2011), os pontos de vista dos inspetores e os gerentes de obras foram substancialmente diferentes acerca das razões para as paralisações e as estratégias para reduzir a sua duração e frequência. Uma diferença semelhante nas percepções foi encontrada na África do Sul, onde, assim como no Brasil, cada uma das partes enfatizava as falhas da outra (GEMINIANI et al., 2013). Por exemplo, os construtores salientaram a falta de critérios harmonizados entre os inspetores, enquanto os responsáveis pela fiscalização enfatizavam que as empresas não tinham uma cultura de segurança.

Nos estudos de caso, a desconfiança mútua decorre de uma longa história de relações conflituosas, bem como de uma imagem negativa da indústria da construção como um todo - por exemplo, altas taxas de acidentes, más condições de trabalho e uma força de trabalho mal remunerada. Os sistemas complexos têm uma história pregressa que impacta a forma como os processos são gerenciados no presente (CILLIERS, 1998). O ambiente atual de processos judiciais pode ser interpretado como o pico de um passado de relações ruins, indicando um caminho evolutivo para sistemas similares.

Legislações altamente prescritivas também contribuem para as perspectivas conflitantes. Por exemplo, no estudo de caso 2, o inspetor exigiu que a montagem de treliças metálicas fosse feita a partir de um andaime, como prescrito pela NR-18 - 
Condições e meio ambiente do trabalho na indústria da construção. No entanto, o empreiteiro usava plataformas de transporte aéreo, o que permitia processos de trabalho mais flexíveis. Seguindo estritamente a norma, o inspetor focou em soluções no lugar de riscos a serem controlados.

Em geral, as observações participantes indicaram que, ao longo do tempo, a perspectiva dos inspetores foi adotada pelas construtoras, em termos da definição do que conta como risco inaceitável e medidas de controle adequadas. Isso está de acordo com a noção de que o nível de risco é tanto uma construção social como uma realidade objetiva (SLOVIC, 2001). Além disso, esse cenário estabeleceu padrões locais sobre o que é seguro ou não, embora o significado de "local" em tais casos possa ser restrito a uma obra ou empresa específica. Uma queixa frequente dos empreiteiros envolvidos nos estudos de caso era que eles tinham uma desvantagem competitiva em relação a outros empreendimentos que não foram submetidos a inspeções e que continuavam utilizando práticas de segurança menos exigentes.

A falta de consideração de diversas perspectivas também pode decorrer da "síndrome de prima donna". Prima donnas são profissionais reconhecidos pela sua competência técnica, assertividade e autoconfiança, embora possam ter insensibilidade para metas organizacionais maiores e dificuldades de trabalhar para alguém ou fazer parte de uma equipe (GIRARD, 2005). Dekker (2014) discute a psicologia de prima donnas, a qual ele associa com senso de direitos superiores e narcisismo. Embora essa pesquisa não tenha realizado uma avaliação desta "síndrome", que é promovida por um conjunto de fatores e não apenas por traços de personalidade (DEKKER, 2014), alguns elementos sugerem que pode ser útil investigar tal perfil em novos estudos. Por exemplo, os quatro inspetores envolvidos nos estudos de caso correspondem a apenas $20 \%$ de toda a equipe da inspetoria, e o mais exigente deles é amplamente considerado pelos empreiteiros como muito inteligente e ao mesmo tempo insensível a pontos de vista alternativos.

\subsubsection{Reconhecimento de Interações}

Em termos de reconhecimento de interações, as inspeções de segurança eram limitadas. O foco dos inspetores era encontrar "partes" danificadas, muitas vezes em um sentido literal. Assim, a preocupação com a qualidade de equipamentos, como correias, guindastes, guarda-corpos e elevadores era frequente. Testes laboratoriais eram muitas vezes solicitados como parte das inspeções. Contudo, a literatura de gestão da segurança tem indicado que partes confiáveis não implicam, necessariamente, em um sistema seguro e confiável (LEVENSON, 2011).

Conforme percepção de representantes das construtoras, o foco em partes físicas era devido a uma intenção tácita de desencorajar o uso de tecnologias que os inspetores consideravam inerentemente inseguras. Dois exemplos (Figura 1) estão relacionados ao uso de linhas de vida horizontais e plataformas de proteção. A intenção das inspeções 
era que tais tecnologias fossem substituídas por andaimes fachadeiros ou redes que, em princípio, reduziriam a necessidade de equipamentos de proteção individual.
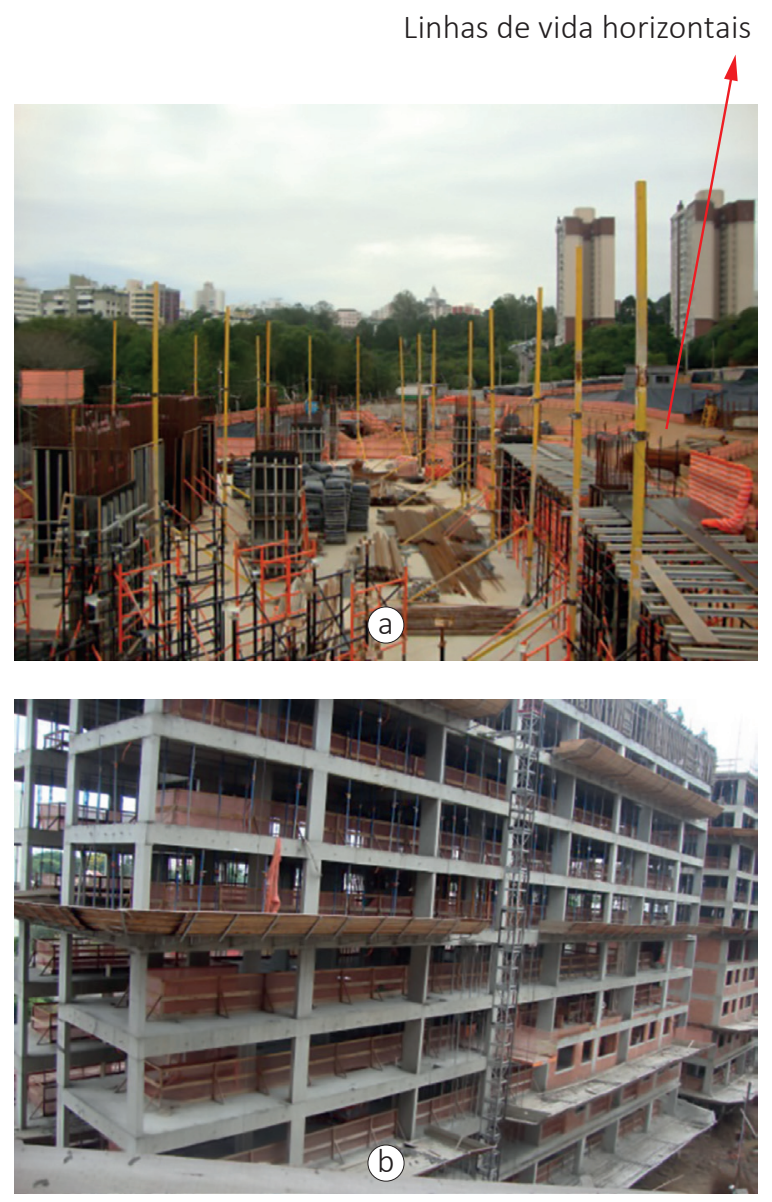

Figura 1 - a) linhas de vida horizontais entre os montantes verticais; b) plataformas para recolher restos de materiais.

De um lado, a busca por partes danificadas é necessária, visto que falhas em equipamentos críticos podem ter efeitos catastróficos e imediatos. Goh e Wang (2015) analisaram 11 projetos de linhas de vida horizontais em Singapura e concluíram que todos eles eram inadequados, proporcionando uma falsa sensação de segurança aos usuários. Em tais casos, a perspectiva sistêmica é menos relevante e uma sequência linear, com claras relações de causa e efeito, pode fornecer uma explicação satisfatória dos eventos que levam a um acidente (PERROW, 1984). 
De outro lado, a supervalorização da busca por partes danificadas tende a negligenciar outros tipos de acidentes que envolvem interações entre partes que isoladamente são confiáveis. Estes são descritos como acidentes sistêmicos por Perrow (1984). Em alguns dos estudos de caso, o pesquisador tomou conhecimento de acidentes que não tinham relação direta com as atividades interditadas ou que tiveram, como fatores contribuintes, mudanças na logística de operações da obra, as quais foram desencadeadas pelas próprias interdições.

\subsubsection{Identificação de Fenômenos Emergentes}

Os resultados apontaram que as próprias inspeções criavam as condições para fenômenos emergentes, caracterizados por consequências não antecipadas e não completamente passíveis de controle. De um lado, fenômenos emergentes desejáveis resultaram das inspeções, tais como inovações incrementais na gestão da segurança. Dois exemplos podem ser mencionados:

- Interdições frequentes devidas à falta de programas de gerenciamento de estresse térmico levaram as construtoras a realizar medições de temperaturas em vários canteiros de obras. Com base nos dados, regimes de trabalhodescanso foram implantados, a partir de certos níveis de temperatura. Essa prática é consistente com a recomendação para a concepção de práticas de gestão de estresse térmico que reflitam as condições climáticas locais (ROWLINSON et al., 2014).

- Devido à pressão dos inspetores, as plataformas ilustradas na Figura 1 têm sido gradualmente removidas dos canteiros de obras locais, sendo substituídas por andaimes fachadeiros ou redes. Como limitação, o pesquisador observou que as inovações mencionadas e outras similares são por vezes limitadas a um protótipo construído apenas para satisfazer os inspetores e acabar com a paralisação. Em tais casos, a gerência da obra, e possivelmente os inspetores, não acreditavam que a solução era de fato viável.

De outro lado, alguns fenômenos emergentes decorrentes das inspeções podem ser prejudiciais para a segurança. Os dois auditores entrevistados não puderam facilmente pensar em qualquer efeito desse tipo, o que é uma demonstração do valor do PS, uma vez que oferece uma nova perspectiva. Um dos efeitos negativos identificados refere-se aos impactos das interdições nos prazos e custos das obras. Tais impactos criam grandes pressões por eficiência quando os trabalhos são reiniciados, o que é prejudicial para a segurança (HAN et al., 2014). Por exemplo, no canteiro 7 (8 meses de interdição), vários clientes registraram ações judiciais contra a construtora, reivindicando compensações pelo atraso. Por sua vez, a construtora ingressou com uma ação judicial contra o governo federal, exigindo compensação financeira para as suas próprias perdas. 
Como outro impacto negativo, muitos trabalhadores buscam outros empregos informais durante as interdições. Tais empregos podem implicar trabalho em condições piores, indo contra o principal objetivo das paralisações. Em particular, a busca por empregos informais acontece quando o subcontratado não tem outra obra para transferir os trabalhadores, situação que é agravada quando o subcontratado não é pago pelo contratante principal, enquanto o canteiro de obras está embargado. Uma vez que subempreiteiros são muitas vezes pequenas empresas com recursos técnicos e financeiros limitados, paralisações longas ameaçam a sobrevivência da empresa.

Sendo ou não a paralisação longa, um fenômeno emergente observado em todos os estudos de caso foi o aparente aumento do nível de estresse entre os gestores. Relatos sugerindo tal aumento eram comuns (por exemplo, "devemos desistir de trabalhar na construção" - subempreiteiro envolvido no canteiro 1, "eu fiquei no escritório até de madrugada para organizar a papelada" - engenheiro de segurança do canteiro 2).

Em geral, os impactos negativos das inspeções podem ser interpretados como uma forma de perda institucional na indústria da construção, que em si é um fenômeno emergente. Esse tipo de perda refere-se a "sistemas institucionais, disposições estruturais e pressupostos cognitivos que apoiam e incentivam atividades desnecessárias na construção" (SARHAN et al., 2014). Os efeitos indesejados dos longos períodos de obras paralisadas podem até mesmo contribuir para a corrupção, que é uma reconhecida fonte de perdas na indústria da construção, em nível nacional e internacional.

\section{Conclusões}

O pensamento sistêmico revelou-se útil para a identificação de benefícios e oportunidades para a melhoria das inspeções. Inicialmente, cabe salientar o papel dos métodos de coleta de dados, que podem permitir análises similares em contextos de inspeções em outras regiões. A observação participante expôs o pesquisador ao complexo contexto real das inspeções. A diversidade de perspectivas foi levada em conta pelo uso de múltiplas fontes de dados, produzidos pelos inspetores (por exemplo, relatórios e entrevistas) e pela equipe gerencial das obras (por exemplo, reuniões para tomar decisões decorrentes dos embargos). O relativo grande número de estudos de caso (13) e o longo período de pesquisa (6 anos) facilitou a identificação de fenômenos emergentes, que se desenvolvem lentamente e muitas vezes ficam invisíveis para participantes internos ao sistema.

Além disso, os resultados indicaram que o pensamento sistêmico, quando aplicado às inspeções de segurança, pode ter foco nos seguintes objetivos (em itálico e negrito na Figura 2): (1) identificação dos agentes envolvidos no sistema associado às inspeções - um reprojeto deste sistema deve considerar explicitamente o papel de cada um destes agentes; (2) identificação de dificuldades e oportunidades 


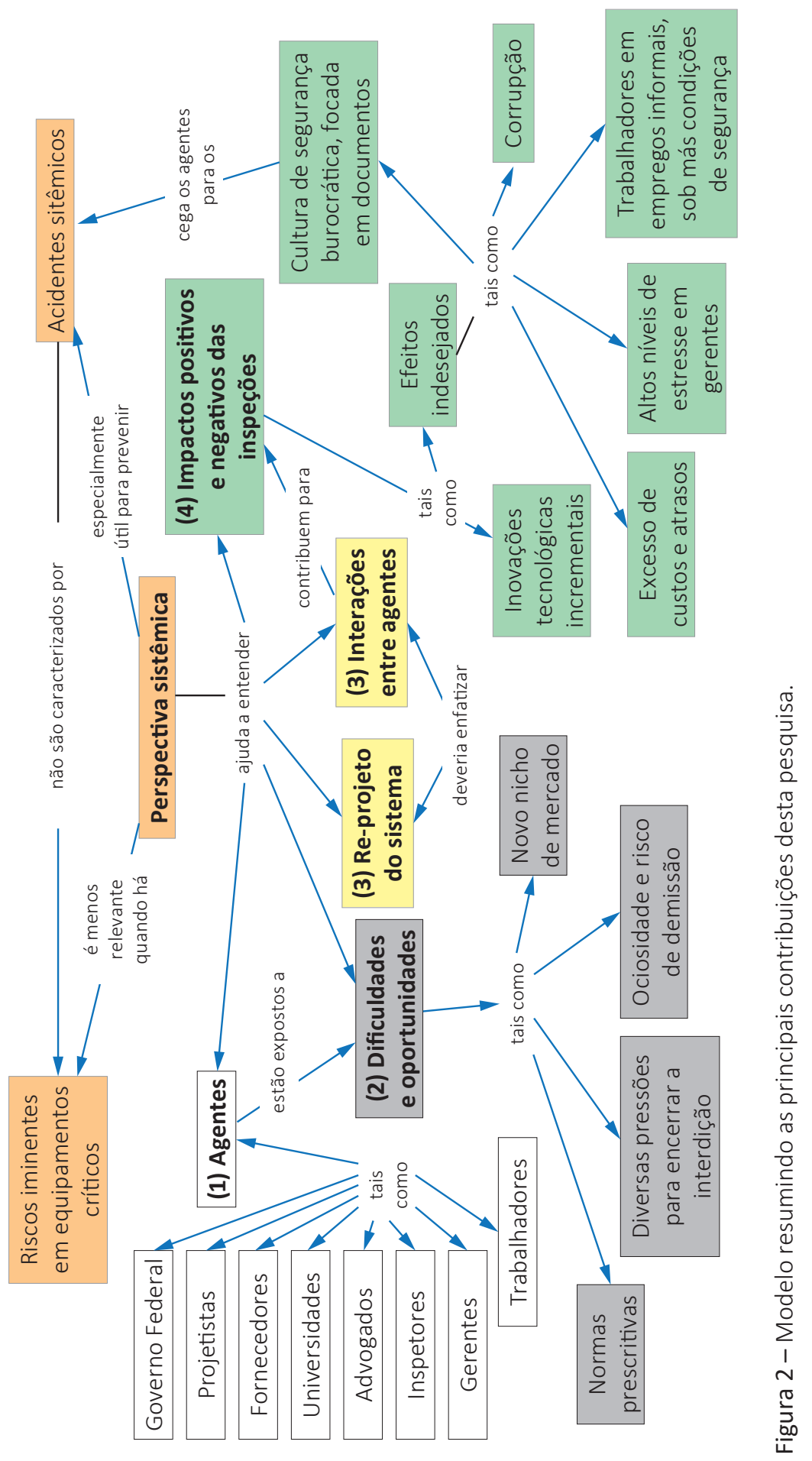


que orientam ações, decisões e interações entre os agentes; (3) identificação de interações entre os agentes, bem como recomendações para influenciar as interações, enfatizando o controle das causas raízes das deficiências detectadas pelos inspetores; (4) identificação dos impactos positivos e negativos das interações. Esses objetivos podem ser associados com os quatro atributos do pensamento sistêmico: (1) diversidade de perspectivas; (2) preocupação com o contexto; (3) interações; (4) fenômenos emergentes.

Embora este estudo tenha sido realizado apenas em uma região do Brasil, os resultados podem ser úteis para outras regiões e países com contextos similares, tais como: normas prescritivas de SST; uma história de relações conflitantes entre construtoras e órgãos de inspetoria; a falta de certificações de terceira parte para equipamentos de proteção coletiva; o baixo uso de tecnologias de construção industrializada, já que a pressão dos inspetores pode ser maior para a modernização. É provável que esse último fator seja mais presente nos países em desenvolvimento, nos quais tende a existir uma tensão entre a necessidade de tecnologias mais seguras e incentivos governamentais (por exemplo, impostos mais baixos) para o uso de métodos artesanais que empreguem mais trabalhadores.

\section{Referências}

BRASIL. Ministério do Trabalho e Emprego. Embargo e interdição: instrumentos de preservação da vida e saúde dos trabalhadores. A experiência da seção de segurança e saúde no trabalho - SEGUR-RS, Porto Alegre. 2010.

CILLIERS, P. Complexity and Postmodernism: Understanding Complex Systems. Routledge, London. 1998.

COSTELLA, M.F.; JUNGES, F.C.; PILZ, S.E. Avaliação do cumprimento da NR-18 em função do porte de obra residencial e proposta de lista de verificação da NR-18 - Ambiente Construído, v. 14, n. 3, p. 87-102. 2014.

DEKKER, S. Deferring to expertise versus the prima donna syndrome: a manager's dilemma. Cognition, Technology and Work, v. 16, p. 541-548. 2014.

DEKKER, S. Drift into failure: from hunting broken components to understanding complex systems. Ashgate, London. 2011.

GEMINIANI, F.; SMALLWOOD, J.; FEE, S. A comparative analysis between contractors' and inspectors' perceptions of the department of labour occupational health and safety inspectorate relative to South African construction. Safety Science, v. 53, p. 186-192. 2013.

GIRARD, N.J. Dealing with perioperative prima donnas in your OR. AORN J. v. 82, n. 2, p. 187-189. 2005. 
$\mathrm{GOH}, \mathrm{Y}$.; WANG, Q. Investigating the adequacy of horizontal lifeline system design through case studies from Singapore. Journal of Construction Engineering and Management, v. 141, n. 7. 2015. DOI: 10.1061/(ASCE)CO.1943-7862.0000989.

HAN, S.; LEEC, S.; MOHAMED, Y.; PENA-MORA, F. Toward an understanding of the impact of production pressure on safety performance in construction operations. Accident Analysis and Prevention, v. 68, p. 106-116. 2014.

LEVESON, N. Applying systems thinking to analyze and learn from events. Safety Science, v. 49, p. 55-64. 2011.

LEVINE, D.; TOFFEL, M.; JOHNSON, M. Randomized government safety inspections reduce worker injuries with no detectable job loss. Science, v. 336, p. 907-911. 2012.

PERROW, C. Normal Accidents: Living with High-Risk Technologies. Princeton University Press, Princeton. 1984.

ROCHA, E. Avaliação de embargos e interdições na construção civil: estudo de caso de uma construtora e incorporadora de Porto Alegre. Trabalho de Conclusão de Curso de Graduação em Engenharia Civil, UFRGS, Porto Alegre. 2011.

ROWLINSON, S.; YUNYANJIA, A.; LI, B.; CHUANJINGJU, C. Management of climatic heat stress risk in construction: A review of practices, methodologies, and future research. Accident Analysis and Prevention, v. 66, p. 187-198. 2014.

RUBIO-ROMERO, J.C.; SUÁREZ-CEBADOR, M.; ABAD, J. Modeling injury rates as a function of industrialized versus on-site construction techniques. Accident Analysis and Prevention, v. 66, p. 8-14. 2014.

SAKAL, M.W. Project alliancing: a relational contracting mechanism for dynamic projects. Lean Construction Journal, v. 2, n. 1, p. 67-79. 2005.

SARHAN, S.; PASQUIRE, C.; KING, A. Institutional waste within the construction industry: an outline. Proceedings of the 22. Annual Conference of the International Group for Lean Construction, p. 895-906. Oslo, Akademika Forlag. 2014.

SINCLAIR, R.; CUNNINGHAM, T. Safety activities in small businesses. Safety Science, v. 64, p. 32-38. 2014.

SKYTTNER, L. General Systems Theory Problems: perspective-practice. World Scientific Publishing Co., Singapore. 2005.

SLOVIC, P. The risk game. Journal of Hazardous Materials, v. 86, p. 17-24. 2001.

WILSON, J. Fundamentals of systems ergonomics/human factors. Applied Ergonomics, v. 45 , p. 5-13. 2014. 


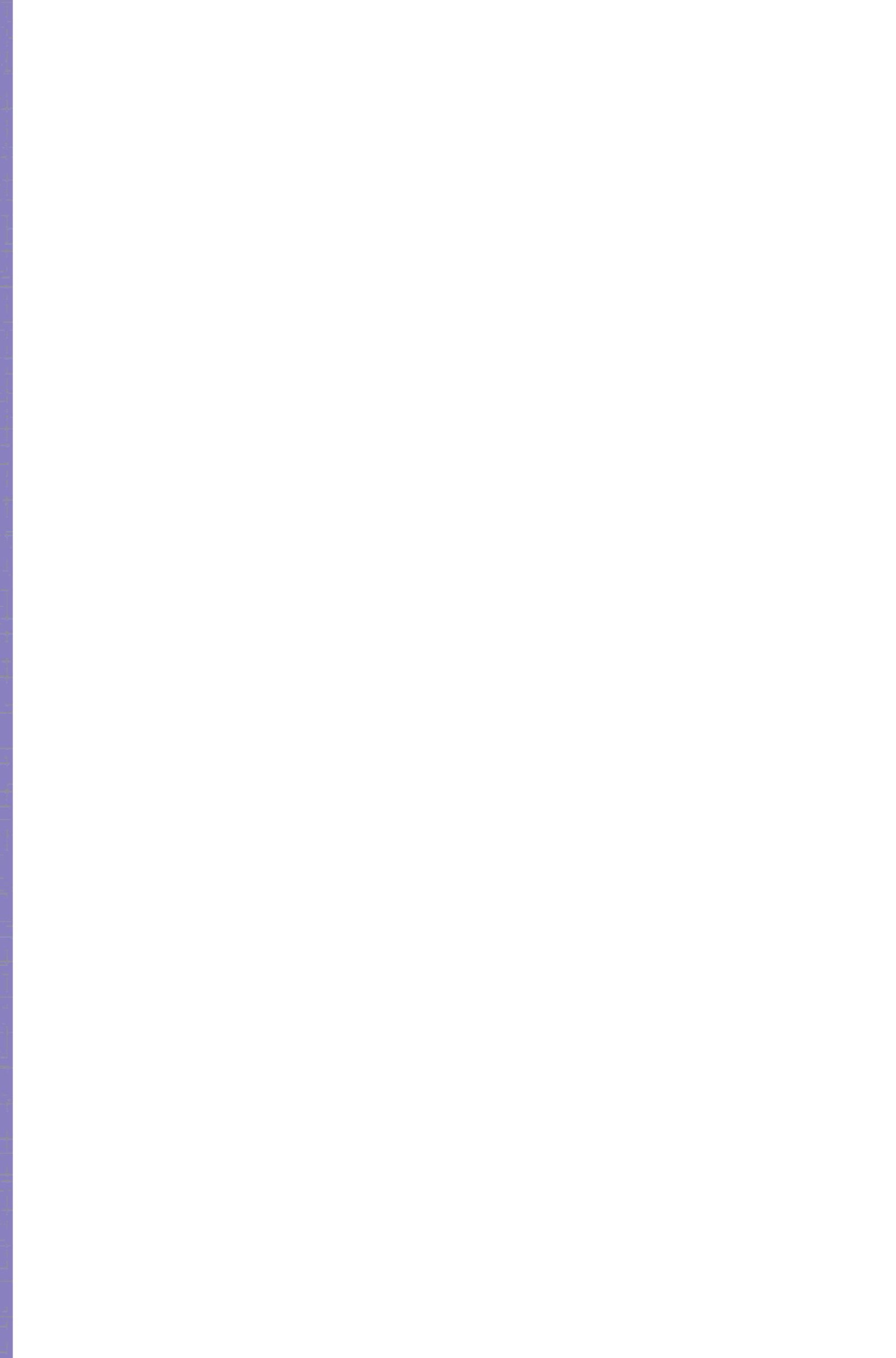




\section{Seção IV}

Subprojeto Soluções Tecnológicas

Sustentáveis para Instalações

Provisórias em Canteiros de

Obras (SPIPC)

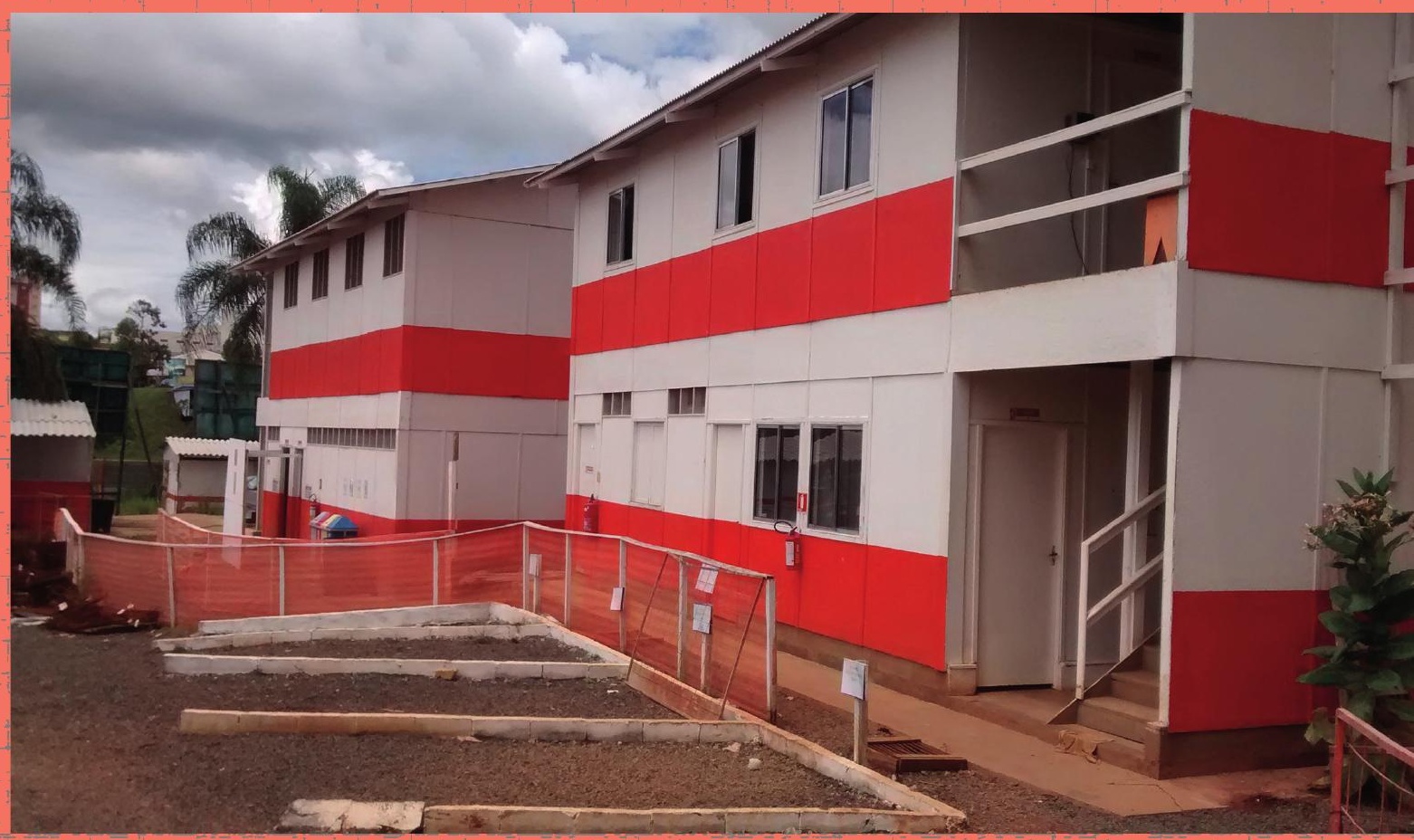




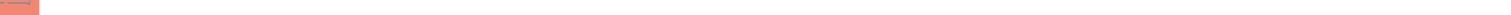




\title{
Instalações Provisórias Pré-fabricadas para Canteiros de Obras
}

\author{
Christine Miranda Dias \\ Sheyla Mara Baptista Serra
}

\section{Introdução'}

O canteiro de obras é a área de trabalho fixa e temporária, onde se desenvolvem operações de apoio e execução de uma edificação (BRASIL, 2015). As instalações provisórias ou construções temporárias podem ser entendidas como aquelas que servem de suporte para as atividades da obra e que são previstas para serem removidas ao fim da fase de execução.

A partir da obrigatoriedade de fiscalização das áreas de vivência regulamentada pela NR-18 - Condições e meio ambiente do trabalho na indústria da construção (BRASIL, 2015), as construções provisórias passaram a ser um dos itens mais observados pelo Ministério do Trabalho, por garantir condições mais dignas para o trabalhador (DIAS; SERRA, 2013). Dentre os ambientes descritos, encontram-se as instalações sanitárias, cozinhas, vestiários, refeitórios, ambulatórios, alojamentos, lavanderias e áreas de lazer. Apesar da existência da NBR 12284: Áreas de Vivência em Canteiros de Obras (ABNT, 1991), a NR-18 - Condições e meio ambiente do trabalho na indústria da construção se

1 O presente capítulo apresenta uma revisão e atualização do texto originalmente publicado como artigo de congresso (DIAS; SERRA, 2013). 
tornou mais aplicada, por solicitar que os ambientes apresentem condições de qualidade, segurança e bem-estar aos trabalhadores.

Mais recentemente, com a conscientização de que os canteiros necessitam ser projetados, passou-se a discutir também a incorporação de aspectos de sustentabilidade nas áreas de vivência no momento de sua concepção e produção, como a possibilidade de reuso das instalações após a desmobilização.

Durante a fase de projeto do canteiro de obras, o planejamento das condições de trabalho é tão importante quanto à disposição dos fluxos físicos de materiais necessários à execução dos serviços. Tendo em vista que os operários costumam permanecer, diariamente, cerca de nove horas no canteiro, entende-se a relevância de projetar ambientes adequados que proporcionem o mínimo conforto e satisfação. Além disso, segundo Cesar et al. (2011), adequadas áreas de trabalho promovem a elevação do moral do trabalhador, bem como a redução de riscos de acidentes.

Entende-se que o layout do canteiro não é um projeto único e fixo, pois enquanto a obra vai se desenvolvendo, ele assume diferentes configurações de acordo com a etapa em que se encontra. Assim, as áreas de vivência e administrativas também irão se modificar, fazendo parte de um ciclo de produção composto por construção, ampliação, demolição e reuso. Portanto, dependendo do sistema construtivo empregado nessas edificações, ocorre grande geração de entulho e desperdício de materiais que não serão reaproveitados em obras posteriores, gerando um novo custo de implantação.

Segundo Arslan (2007), as instalações temporárias podem ser construídas com materiais sustentáveis e componentes desmontáveis, recicláveis e, até mesmo, reutilizáveis, com baixo custo de produção.

Para atender a essas condições, existe atualmente um mercado de sistemas construtivos desenvolvidos especificamente para a utilização como ambientes provisórios, que podem ser armazenados e reutilizados inúmeras vezes, com boa qualidade de uso e operação, de acordo com as necessidades de cada obra (SANTO JR.; AZZOLINI, 2009).

As diferentes soluções tecnológicas para as instalações provisórias nos canteiros de obra apresentam-se como pré-fabricadas ou industrializadas, por serem produzidas em ambiente externo à obra, ou seja, em fábricas. Algumas soluções apresentam-se de forma padronizada para o mercado e, em outros casos, são elaborados projetos específicos para cada situação de canteiro, considerando aspectos básicos de modulação.

Assim, torna-se necessário conhecer melhor as características dos tipos de instalações existentes como forma de subsidiar o processo de decisão, considerando, entre outros aspectos, a sustentabilidade do produto e a determinação dos custos envolvidos. 
Desta forma, o objetivo deste capítulo é apresentar uma reflexão sucinta sobre as alternativas tecnológicas para as instalações provisórias identificadas no mercado brasileiro, bem como classificá-las segundo o material utilizado.

Este estudo utiliza-se do método de pesquisa de análise documental, por meio de revisões bibliográficas, pesquisas em sites comerciais e feiras de exposição voltadas às inovações na construção civil, a fim de identificar as atuais soluções tecnológicas desenvolvidas para instalações provisórias industrializadas.

\section{A Sustentabilidade das Construções Provisórias}

Reis et al. (2004) salientam que a expressão "provisória" ou "temporária" não deve ser confundida com um processo precário de concepção, principalmente por essas construções serem essenciais no início e durante as atividades de um canteiro de obras. No entanto, verifica-se que nem sempre as empresas de construção civil analisam aspectos de qualidade e manutenabilidade das instalações provisórias, sendo estas, em grande parte das obras, executadas de qualquer maneira, sem projetos executivos e por mão de obra não qualificada.

Um dos fatores do descaso refere-se ao curto período de uso das construções provisórias, uma vez que parte das áreas de vivência normalmente é transferida para os pavimentos com estrutura concluída, a fim de execução da periferia do empreendimento. Logo, essa característica transitória pode levar o empresário da construção a não querer investir uma quantia mais significativa nesses ambientes, os quais usualmente são feitos de improviso, com produtos de qualidade não adequada, que podem comprometer a integridade física da construção (OLIVEIRA; LEÃO, 1997).

Contudo, para Saurin e Formoso (2006), a atividade de planejamento e concretização do projeto do canteiro consome uma quantidade muito pequena de horas técnicas e de custos em relação à obra como um todo, não existindo justificativas para não ser realizado de maneira planejada. Para esses autores, os recursos despendidos são insignificantes se comparados aos seus benefícios.

Reis et al. (2004) recomendam que, antes de se adotar uma tecnologia sustentável para as construções provisórias, seja realizada uma análise criteriosa dos reais benefícios gerados pelos sistemas construtivos, conhecendo os impactos ambientais, econômicos e sociais do produto escolhido.

Como as instalações são similares às habitações e edifícios em geral, entende-se que elas necessitam atender a uma série de requisitos de desempenho, os quais devem ser identificados para a correta seleção e projeto desses locais. Rodrigo et al. (2012) 
apresentam os principais requisitos de desempenho que as instalações provisórias de canteiros de obras precisam atender, tomando-se como base metodológica a norma de desempenho brasileira e o referencial técnico do certificado ambiental AQUA habitacional (FCAV, 2010).

Mateus e Bragança (2004) sugerem a utilização de uma Metodologia de Avaliação Relativa da Sustentabilidade de Soluções Construtivas (MARS-SC), por meio da determinação de indicadores funcionais que auxiliam na determinação de uma nota de sustentabilidade para o produto. Segundo esses autores, o número de parâmetros avaliados é ajustado em função dos objetivos da avaliação, das características das soluções estudadas, das exigências funcionais a serem satisfeitas, das características do local e dos dados disponíveis. De modo geral, os indicadores e parâmetros de sustentabilidade propostos - ambiental, funcional (social) e econômico - estão apresentados no Quadro 1.

Quadro 1. Indicadores e parâmetros considerados na avaliação da sustentabilidade de construções provisórias.

\begin{tabular}{|c|c|c|c|}
\hline & \multicolumn{3}{|l|}{ Categorias de Indicadores } \\
\hline & Ambiental & Funcional (social) & Econômico \\
\hline \multirow{6}{*}{ 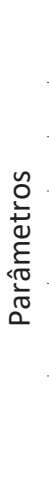 } & $\begin{array}{l}\text { Potencial de aquecimento } \\
\text { global }\end{array}$ & Isolamento sonoro & Custo de construção \\
\hline & Energia primária incorporada & Isolamento térmico & Custo de manutenção \\
\hline & Conteúdo reciclado & Durabilidade & Custo de reabilitação \\
\hline & Potencial de reciclagem & Comportamento ao fogo & $\begin{array}{l}\text { Custo de desmontagem/ } \\
\text { demolição }\end{array}$ \\
\hline & $\begin{array}{l}\text { Reservas remanescentes de } \\
\text { matéria-prima }\end{array}$ & Flexibilidade de utilização & Valor residual \\
\hline & $\begin{array}{l}\text { Quantidade de recursos } \\
\text { naturais utilizados }\end{array}$ & - & $\begin{array}{l}\text { Custo de tratamento para } \\
\text { devolução ao ambiente } \\
\text { natural }\end{array}$ \\
\hline
\end{tabular}

Fonte: Mateus; Bragança, 2004.

O modo como cada indicador influencia a sustentabilidade pode ser adequado ao contexto do empreendimento. A princípio, as três categorias de indicadores podem apresentar o mesmo peso na avaliação da sustentabilidade. Todavia, usualmente, as alternativas mais compatíveis com o ambiente são geralmente as mais caras. Assim, Mateus e Bragança (2004) sugerem que os pesos dos indicadores ambiental (40\%) e funcional (40\%) devem ser superiores ao do indicador econômico (20\%). 


\section{O Projeto das Instalações Provisórias}

Como toda edificação, torna-se necessária a realização de projetos que considerem as necessidades da obra, bem como as características dos sistemas construtivos pré-fabricados. Saurin e Formoso (2006) apontam a padronização do projeto das instalações provisórias como uma estratégia a ser utilizada por empresas que constroem obras com tipologias semelhantes. Para os referidos autores, essa padronização é ambientalmente justificada e recomendada devido à repetição do ciclo das instalações, independentemente da tecnologia empregada.

Para Degani (2012), o projeto das instalações provisórias deve considerar:

- Previsão de espaços para a gestão dos resíduos administrativos;

- Previsão de espaços para a gestão dos insumos da própria obra;

- Previsão de espaços ergonomicamente adequados para a acomodação das pessoas e seus fluxos nos locais de trabalho e de lazer;

- Previsão de espaços para o treinamento e comunicação com os trabalhadores;

- Proporcionar o bem-estar dos trabalhadores;

- Ter facilidade de limpeza;

- Atendimento às necessidades de conforto acústico e térmico, em conformidade com o clima e incidência de ventos no local do terreno;

- Desmontabilidade e reciclabilidade das instalações.

Os conceitos da industrialização de ciclo aberto ou de catálogo sugeridos por Bruna (1976) podem ser observados na maioria dos sistemas identificados. Isso significa que os fabricantes produzem estoque de seus componentes e criam um catálogo com as informações características de cada peça fabricada em sua empresa, indicando as qualidades físicas de resistência, isolação e peso. Além disso, os produtos são concebidos seguindo a coordenação modular e alguns dos princípios básicos de um sistema aberto, como: serem intercambiáveis (podem assumir diferentes posições, como forro ou painel); e serem combináveis (formando conjuntos maiores, com aditividade de peças). No caso das instalações provisórias pré-fabricadas em madeira, os componentes do projeto da construção temporária podem ser observados na Figura 1. 


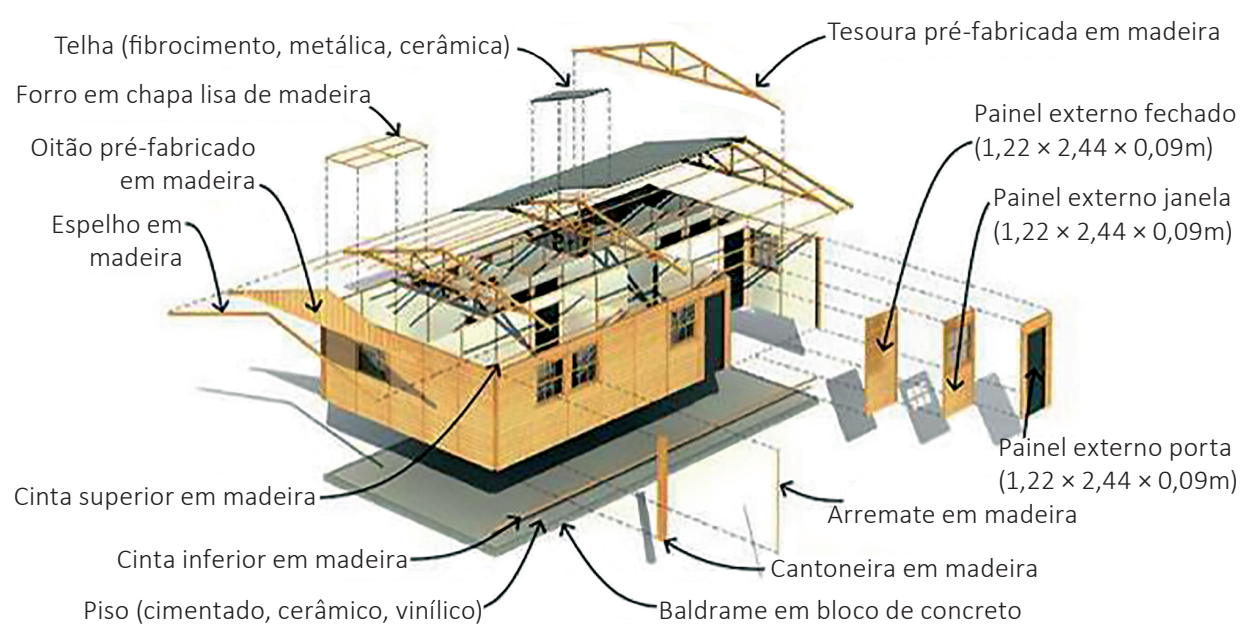

Figura 1 - Componentes de um sistema pré-fabricado em madeira para instalações provisórias em canteiro de obra. Fonte: Boff (2014).

Após a utilização, as instalações podem ser desmontadas e remontadas em outros canteiros de obra. Como forma de aumentar a vida útil do sistema, a desmontagem das instalações provisórias deve ser feita por operários especializados da própria empresa fornecedora de forma programada. Os componentes podem ser armazenados ou levados diretamente a outras obras, caso haja necessidade de uso imediato. O sistema pode apresentar vida útil de 20 anos, contanto que sejam tomados cuidados com a integridade do produto durante a montagem, desmontagem, armazenagem e transporte, segundo Boff (2004).

\section{Ciclo de Produção das Instalações Provisórias}

Segundo Dias (2013), o ciclo de vida das construções temporárias não é abordado de maneira detalhada pelos referenciais teóricos. Para a referida autora, existe certa semelhança com as construções convencionais, ou seja, em ambas são encontradas as etapas de planejamento, extração de materiais, execução ou montagem, uso, manutenção e desconstrução. Entretanto, é nesta última fase que se encontram as diferenças, pois, por ter um tempo de utilização reduzido, os aspectos referentes às necessidades e possibilidades de reuso e reciclagem aparecem de forma mais marcantes com a desmobilização das instalações provisórias no canteiro de obras.

Arslan e Cosgun (2008) defendem que as edificações temporárias podem ser desmontadas com uma perda mínima de energia e de material, tornando possível 
a reutilização e reciclagem de seus componentes, infraestrutura e superestrutura. A Figura 2 indica o ciclo de vida da reutilização e reciclagem de construções provisórias, realizado por Arslan (2007). Para o referido autor, o material gerado após desmontagem de um edifício pode ser categorizado em:

- material reciclado: material processado que depois de selecionado é processado em um novo material construtivo;

- material de reuso: material de construção que é novamente utilizado, sem alterar sua forma ou natureza;

- matéria-prima: material desmontado que é transformado em outra matériaprima para a engenharia.

Na Figura 2, são identificados os procedimentos possíveis e os fluxos dos componentes da construção após a desmontagem da instalação temporária:

- normalmente, os componentes principais (painéis e paredes) podem ser reutilizados, adaptados ou consertados para uso em um próximo edifício;

- os componentes secundários (vigas, pilares e estacas) podem ser processados da mesma forma que os principais ou se tornarem matéria-prima para novos componentes.

O mesmo autor demonstra graficamente que os componentes podem ser colocados à venda ou serem armazenados para uso futuro.

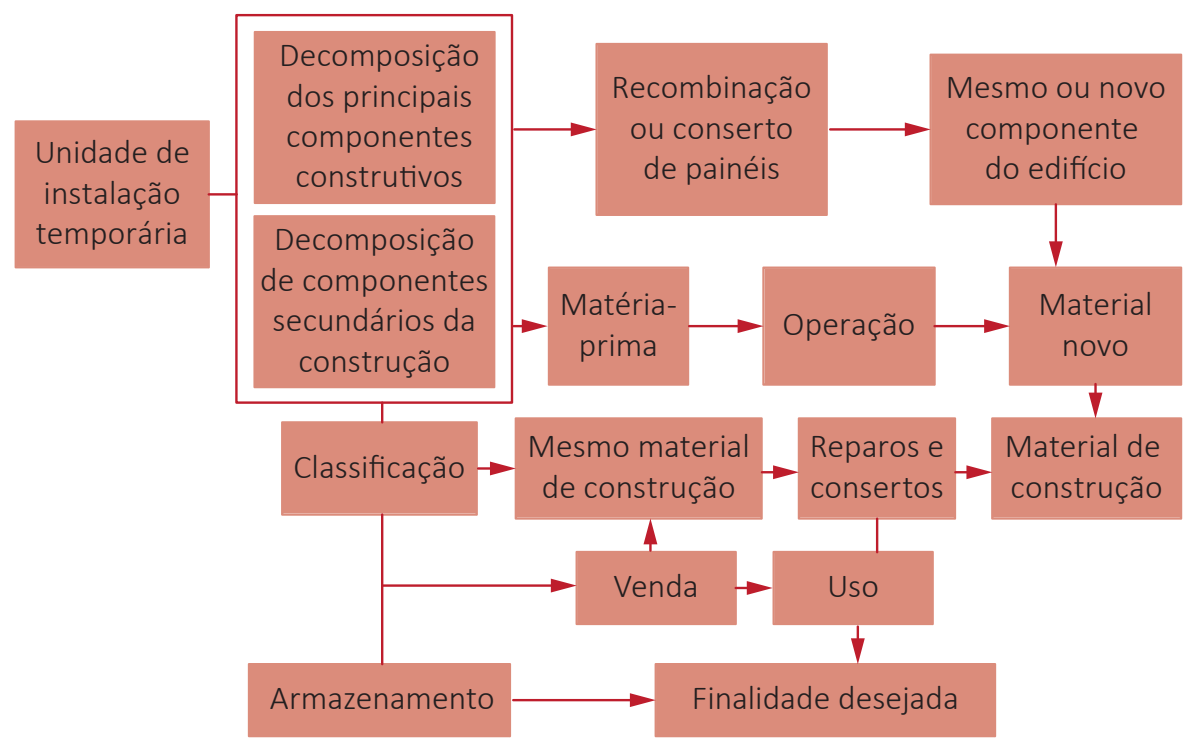

Figura 2 - Processos de reutilização e reciclagem das construções temporárias. Fonte: Traduzido de Arslan, 2007. 
Arslan (2007) complementa ainda que o ciclo de vida das instalações temporárias pode ser prolongado quanto maior for o investimento em métodos de reuso ou técnicas de reciclagem após a desmontagem. Em pesquisa posterior, Arslan e Cosgun (2008) verificaram que as construções provisórias que possuem longa duração apresentam-se como um ótimo investimento para as instituições que dispõem de recursos financeiros limitados, pois os custos despendidos com a aquisição dos sistemas podem ser diluídos ao longo do tempo.

\section{Tecnologias das Instalações Provisórias}

De acordo com Birbojm e Souza (2001), algumas construtoras costumavam fazer as escolhas das instalações provisórias sem conhecer as vantagens e desvantagens de cada alternativa, resultando em áreas de vivência mal projetadas, desconfortáveis e, muitas vezes, mais custosas.

Embora na maior parte dos canteiros predominem sistemas improvisados em chapas de madeira compensada, existem diversos critérios, como durabilidade e reaproveitamento, que podem auxiliar na escolha da tipologia das instalações provisórias (SAURIN; FORMOSO 2006).

A seguir, serão apresentadas as diferentes soluções tecnológicas identificadas por Dias e Serra (2013), no que se refere às construções temporárias pré-fabricadas comercializadas no mercado brasileiro. Será feita uma síntese sobre as principais características de cada alternativa, disponibilizadas pelas próprias empresas fabricantes ou por referências bibliográficas.

\subsection{Pré-Fabricados em Madeira}

O Sistema de pré-fabricados em madeira (Figuras 3 e 4) baseia-se na industrialização dos componentes formados por múltiplos painéis modulados, autoportantes, entregues prontos na obra. Os componentes são tratados contra ataques de micro-organismos, são montados de acordo com o projeto elaborado pelo fornecedor e possuem maior durabilidade do que o sistema tradicional em chapas compensadas, podendo ser reutilizados de cinco a sete vezes (BIRBOJM; SOUZA, 2001).

Podem ser utilizados diferentes tipos de madeira, inclusive o OSB (Oriented Strand Board) que são placas de madeira orientadas, coladas com resina fenólica de alta resistência a intempéries, que possuem resistência mecânica similar a do compensado. Sua alta resistência à delaminação e ao empenamento garante as condições higiênicas, durabilidade e aparência necessárias para a qualidade da edificação. As placas também são totalmente recicláveis, tornando o produto uma alternativa sustentável. 


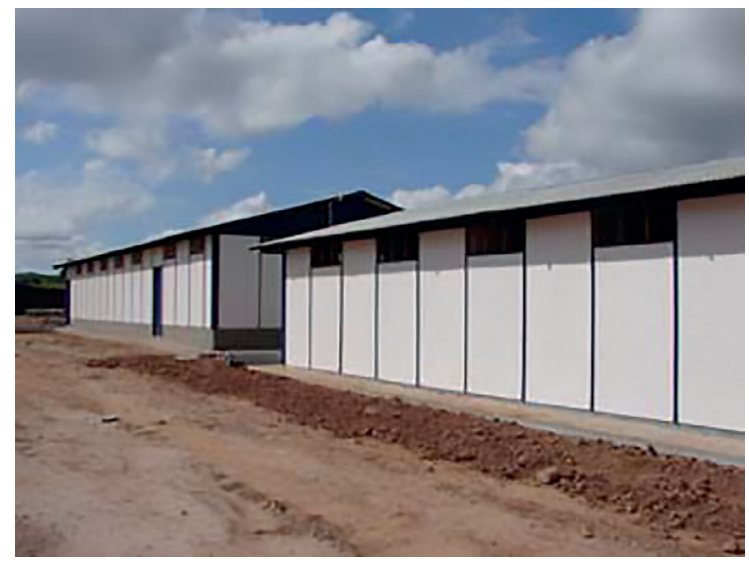

Figura 3 - Instalação provisória pré-fabricada em chapas OSB.

Fonte: http://www.Ipbrasil.com.br/aplicacoes/

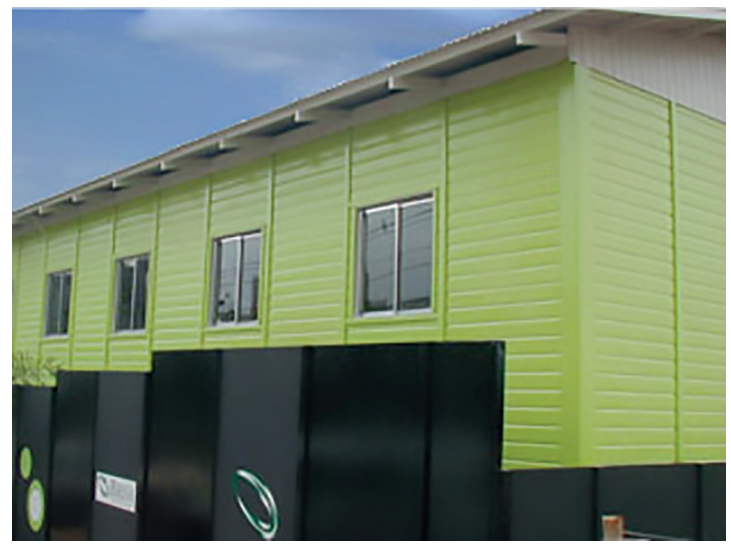

Figura 4 - Instalação provisória pré-fabricada em painéis estruturais em madeira tipo pinus. Fonte: http://canteiro.com.br/

Existem também soluções combinadas de "tecnologia Cement Wall", formada pela elevação de painéis estruturados com sarrafos em madeira de reflorestamento, revestidos interna e externamente com chapas de OSB e placas cimentícias, que aumentam a resistência à umidade, ao fogo, a danos de impacto, além de garantir conforto térmico e acústico (NOVO ESPAÇO, 2013).

Para a instalação das edificações em madeira, são necessárias fundações constituídas por baldrames, sapatas corridas ou radiers em concreto armado de acordo com as necessidades especificas de cada solo ou edificação. 


\subsection{Concreto Celular}

Trata-se de um sistema que utiliza tecnologia de módulos formados por placas de concreto celular e interligados por perfilados metálicos, conforme Figura 5. Como vantagens do sistema, estão o conforto térmico e acústico, a rapidez na execução e a compatibilidade com qualquer dimensão de projeto. Do mesmo modo, as placas de concreto celular são compostas com elementos inertes e inorgânicos que evitam agressões de pragas e fogo, proporcionam resistência às intempéries e possuem bom acabamento (Figura 6).

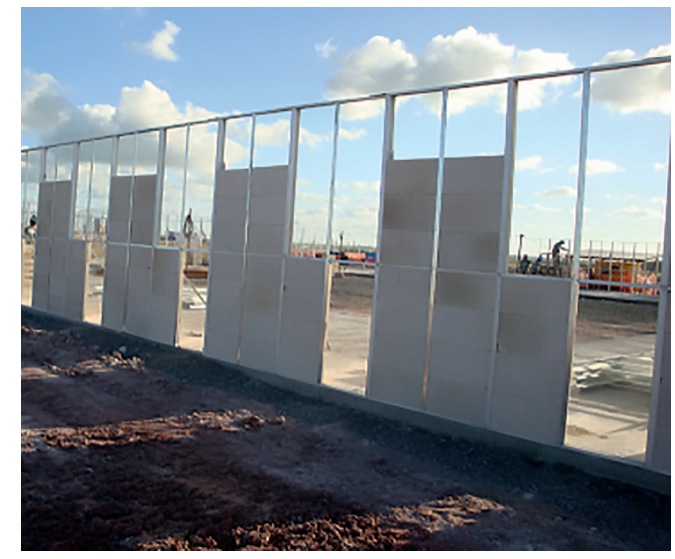

Figura 5 - Montagem da construção provisória em concreto celular. Fonte: http://www.novoespaco.com.br

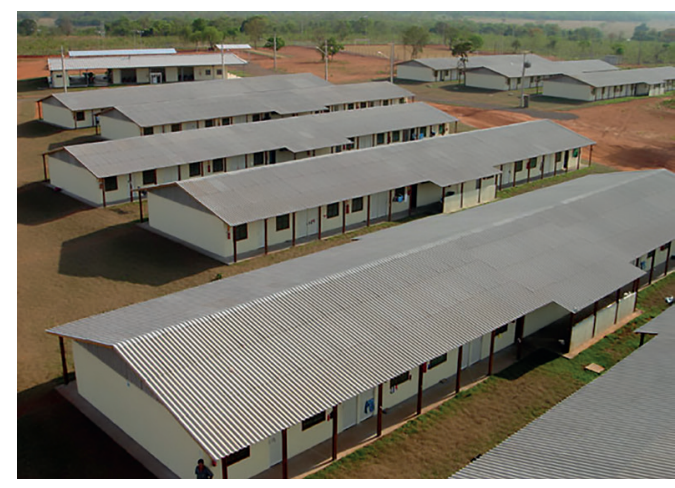

Figura 6 - Vista das construções provisórias em concreto celular. Fonte: http://www.prefacc.com.br/

Assim, como as construções pré-fabricadas em madeira, torna-se necessária a execução de fundações, tais como, baldrames, sapatas corridas ou radiers em concreto armado de acordo com as características do solo ou da instalação. 
A durabilidade desse tipo de sistema equivale à da construção convencional, podendo as edificações ser de caráter definitivo, caso necessário. A desmontagem pode ser executada com cuidados específicos, a fim de facilitar o reuso dos componentes.

\subsection{Contêiner Metálico}

Os contêineres metálicos são bastante utilizados devido à leveza, independência de fundações, facilidade de transporte, possibilidade de reaproveitamento, resistência contra intempéries, pequeno tempo de montagem e desmontagem e versatilidade com diferentes possibilidades de arranjos internos, sendo possível abrigar, inclusive, banheiros (Figura 7). Entretanto, Birbojm e Souza (2001) consideram o alto custo de locação e o considerável desconforto térmico e acústico, como as principais desvantagens de seu uso, sendo por isso necessário o uso de climatizadores ou ar condicionado (Figura 8).

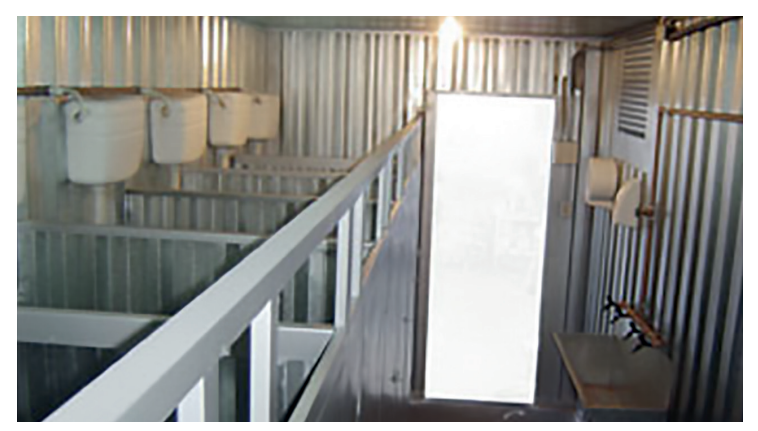

Figura 7 - Detalhe interno de um contêiner utilizado como banheiro. Fonte: http://www.gaccontainers.com.br/

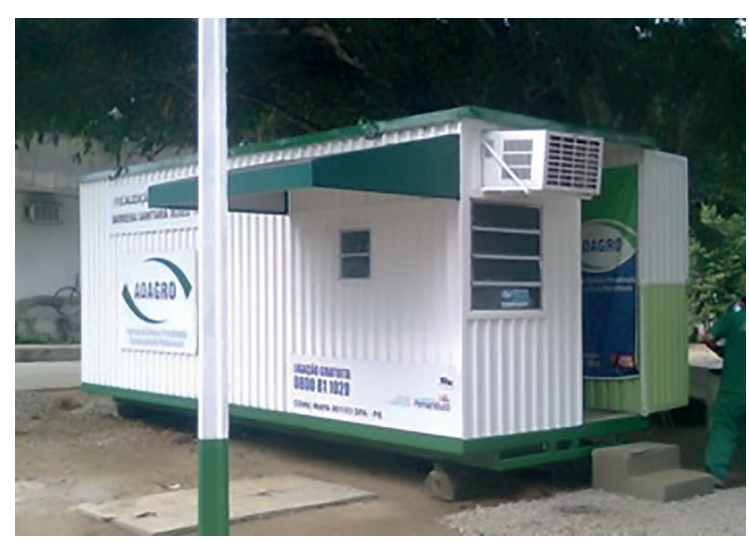

Figura 8 - Aparência externa do contêiner metálico com uso de ar condicionado. Fonte: http://www.megacontainers.com.br/ 
Existem atualmente no mercado também contêineres com solução termoacústica e uso de painéis que bloqueiam os ruídos, proporcionam maior conforto térmico e, com isso, melhoram a qualidade de vida do trabalhador (Figura 9). Esses painéis são formados por duas chapas de aço zincado, com espessura 1,90 mm cada, e chapa de EPS em seu interior (EUROBRAS, 2013).

Em contrapartida, Saurin e Formoso (2006) afirmam que apesar de existir a opção de compra de contêineres com isolamento térmico, o elevado custo dessa opção faz com que ela seja pouco utilizada. Assim, para minimizar esses impactos, os autores sugerem medidas simples a serem adotadas, como a pintura externa em cor branca, execução de telhado sobre o módulo e uma ventilação natural adequada composta por, no mínimo, duas aberturas.

Como mencionado, uma das vantagens desse sistema é o transporte dos elementos que podem ser feitos de forma conjunta (desmontados e empilhados) ou de forma montada (Figura 10). A compactação do volume de transporte reduz os custos operacionais, fazendo com que o contêiner incorpore alguns conceitos de sustentabilidade, com redução da emissão de gases tóxicos.

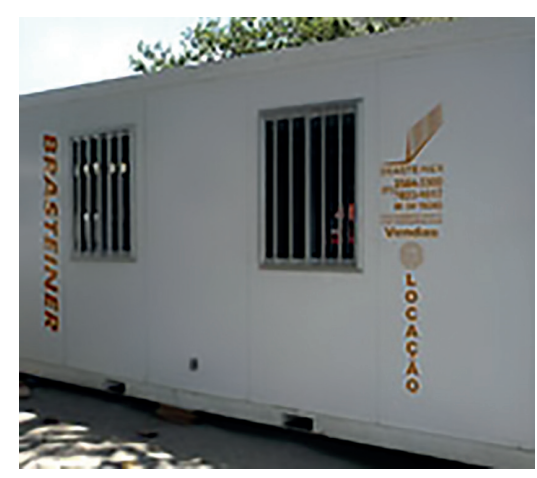

Figura 9 - Contêineres com solução termoacústica. Fonte: http://brasteiner.com.br/

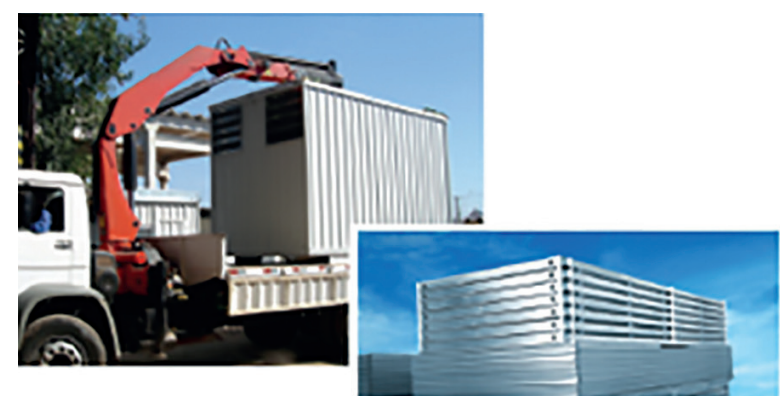

Figura 10 - Transporte dos contêineres montados ou desmontados. Fonte: http://www.eurobras.com.br/ 
A durabilidade dos contêineres é estimada pelos fabricantes em cerca de 20 anos, podendo ser reutilizado várias vezes. O menor peso do produto faz com que o contêiner não necessite de fundações, sendo necessário apenas um local nivelado e compactado.

\subsection{Módulos Metálicos Combináveis}

Os módulos metálicos combináveis derivados do tipo contêiner podem ser acoplados (Figura 11) e sobrepostos (Figura 12) para otimizar o uso do espaço físico no canteiro. Segundo os fabricantes, os módulos acomodam escritórios, sanitários, chuveiros, almoxarifados, dormitórios e outros ambientes.

Além da elevada resistência mecânica, as construções temporárias em aço galvanizado possuem vantagens relativas à montagem e desmontagem, não possuem necessidade de execução de fundações, bem como apresentam resistência às intempéries (BIRBOJM; SOUZA 2001). Porém, assim como o contêiner metálico, o inconveniente desse tipo de estrutura refere-se ao desconforto térmico, amenizados a partir da utilização de painéis isotérmicos tanto nas paredes quanto na cobertura ou o uso de ar condicionado.

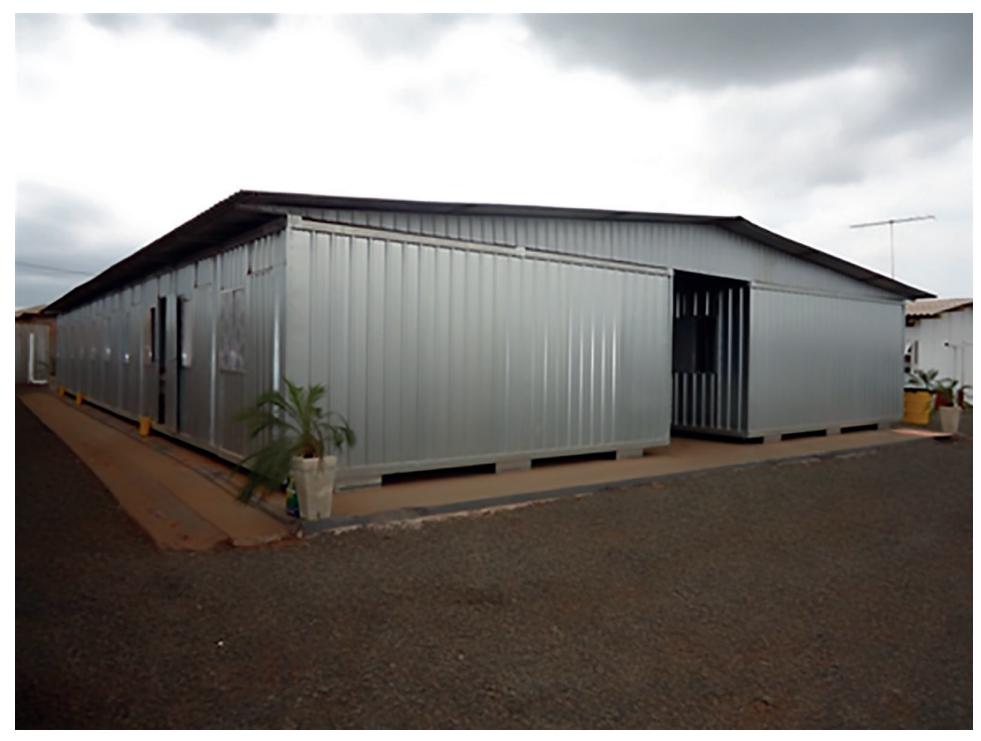

Figura 11 - Construção provisória em aço galvanizado. Fonte: http://cmcmodulos.com.br 


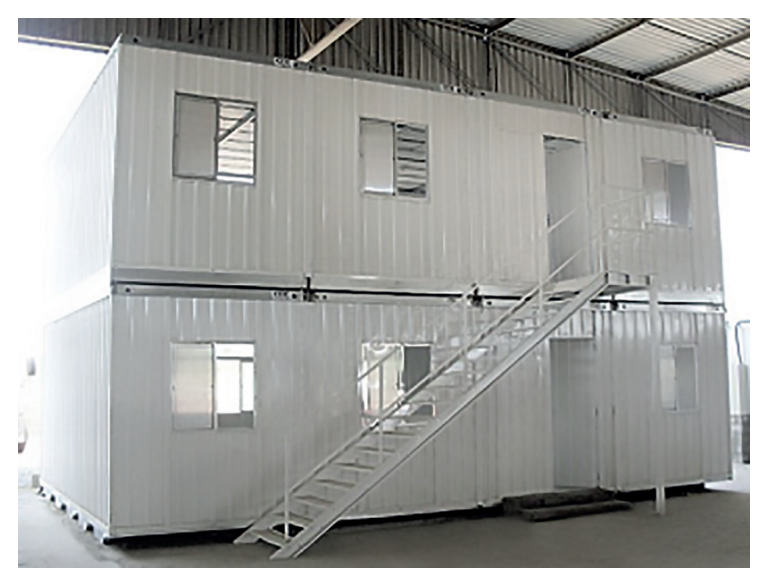

Figura 12 - Construção provisória com dois pavimentos em aço galvanizado. Fonte: http://cmcmodulos.com.br

A durabilidade das instalações é alta, sendo reutilizadas várias vezes, tal como o contêiner.

\subsection{Galpões Estruturados}

Outra solução é o galpão estruturado em lona de PVC (policloreto de vinila), observado na Figura 13, que são adequados tanto para o armazenamento de produtos quanto para o abrigo de pessoas em canteiros de obras. A estrutura de sustentação é composta por treliças em aço galvanizado que permitem um espaço interno totalmente aproveitável, sem colunas intermediárias (Figura 14). É necessária a execução de fundações diretas, fixando os perfis sobre uma base de concreto. O material de cobertura e revestimento apresenta alta resistência, durabilidade, impermeabilidade, é autoextinguível e possui tratamento antimofo (VINIGALPÃO, 2016).

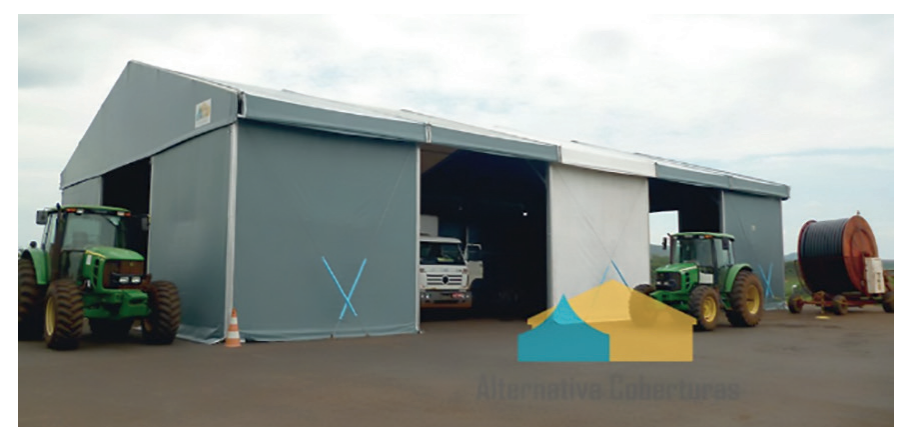

Figura 13- Vista externa de galpão estruturado. Fonte: http://alternativacoberturas.com.br/ 


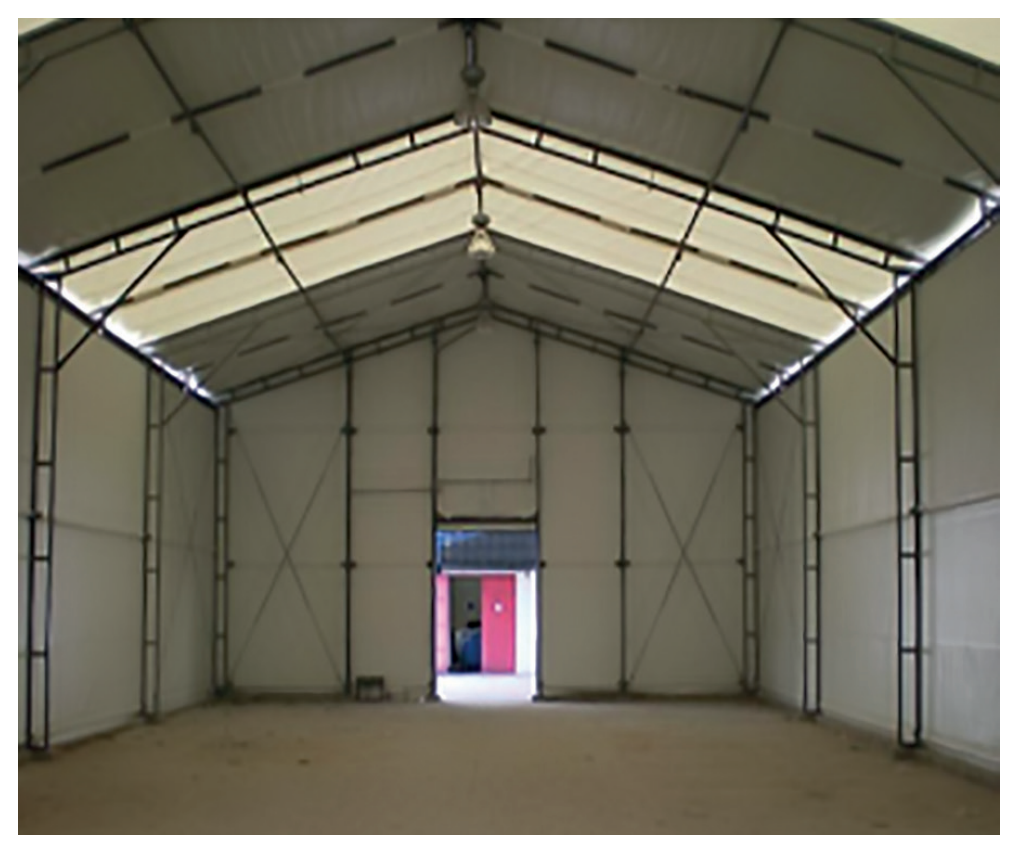

Figura 14- Vista interna de galpão estruturado sem colunas intermediárias.

Fonte: http://www.vinigalpao.com.br/

Apesar de sua montagem, transporte e desmontagem serem realizados com facilidade, sem geração de barulho e entulhos, os galpões costumam apresentar altura central e dimensões horizontais maiores com, no mínimo, quatro metros. Esse pode ser considerado um dos motivos de não serem amplamente utilizados, especialmente, quando os canteiros apresentam pouco espaço livre.

\subsection{Barracas e Tendas em Lona}

São sistemas modulares leves que oferecem abrigos resistentes, de rápida montagem, fácil transporte e que suportam grandes variações climáticas. As barracas e tendas em lona, exemplificadas na Figura 15, são instalações provisórias reaproveitáveis, que não geram resíduos (VRB, 2016). Uma estrutura em aço concede rigidez e formato às tipologias, as quais não necessitam de fundações específicas para serem utilizadas, ficando estável em qualquer tipo de solo, e, da mesma forma que os galpões estruturados, não apresentam obstáculos intermediários (Figura 16). 


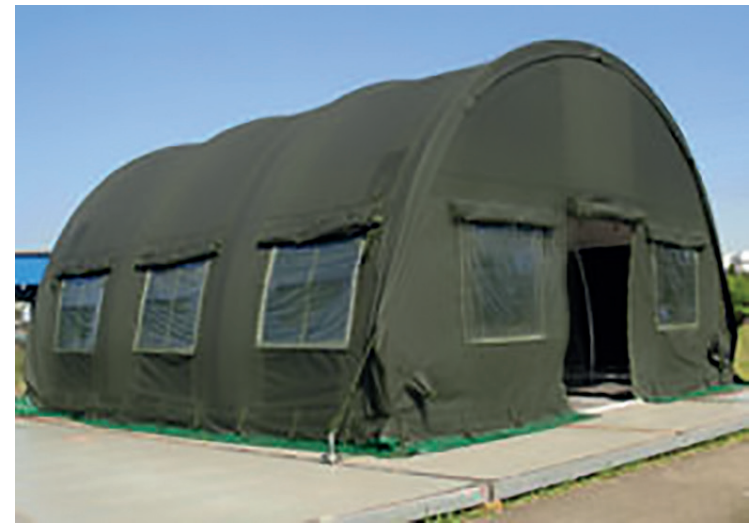

Figura 15 - Vista externa da barraca em lona. Fonte: http://vrb848.com.br

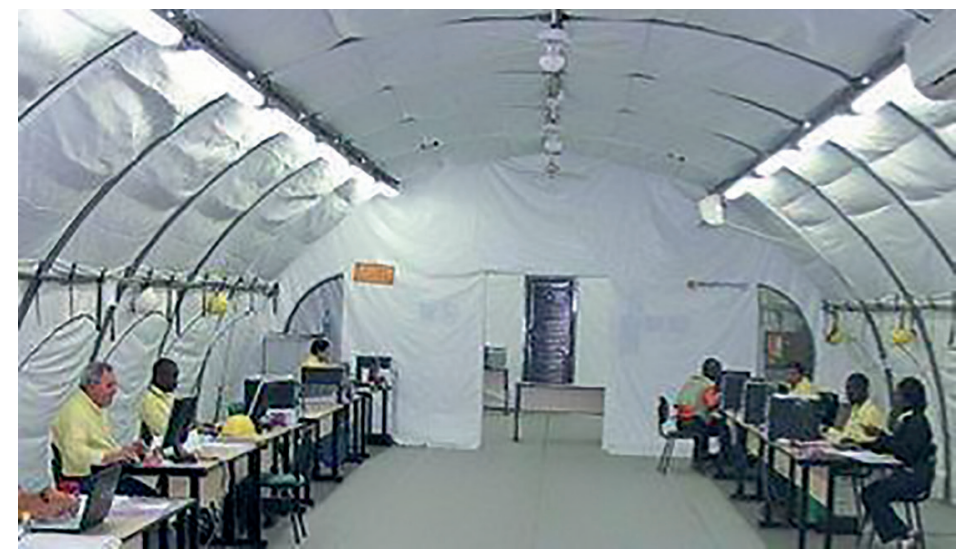

Figura 16 - Vista interna da barraca em lona. Fonte: Martins, 2013.

Segundo o fabricante, este produto é $100 \%$ reaproveitável, não gera resíduos que agridam ao meio ambiente, possui material que não propaga chamas e é concebido de acordo com as normas brasileiras, em especial a NR-18 - Condições e meio ambiente do trabalho na indústria da construção (VRB, 2016).

\subsection{Polietileno Reciclado (Plástico)}

Compõe-se de tecnologia de placas plásticas de polietileno reciclado (Figura 17), com estrutura de suporte de perfis " $\mathrm{H}$ " em policloreto de vinila (PVC) reforçados com aço em seu interior. As paredes de vedação são compostas por duas placas em polietileno de alta densidade reciclado, que possuem preenchimento em material isolante em poliestireno expandido, popularmente chamado de EPS (Figura 18) ou espuma de poliuretano, visando promover proteções acústica e térmica. 


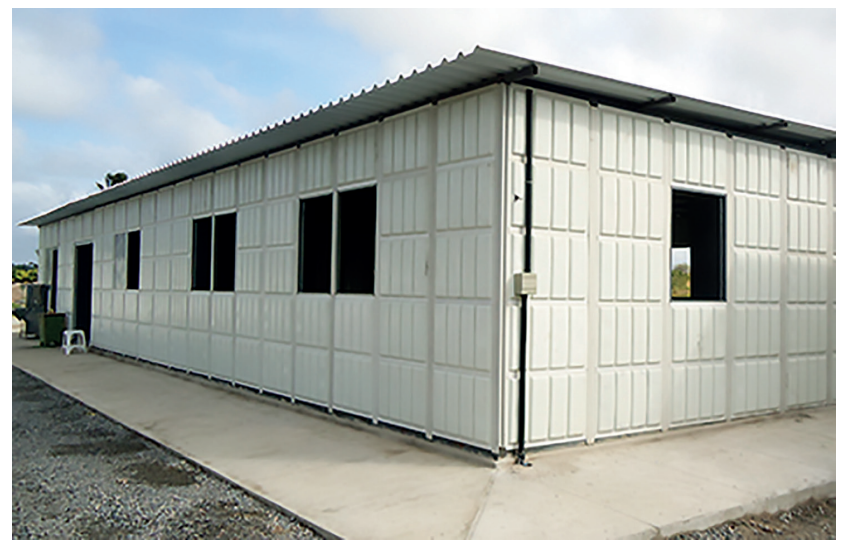

Figura 17- Instalação provisória em plástico. Fonte: http://www.impactoprotensao.com.br/

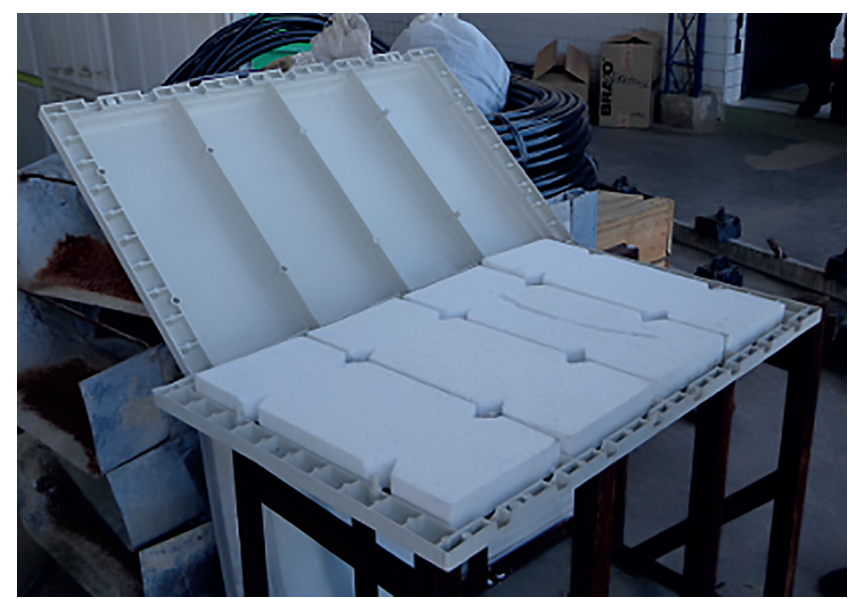

Figura 18- Preenchimento das placas com material termo acústico (EPS). Fonte: Dias, 2013.

A estrutura leve dispensa a execução de fundações, sendo necessária apenas a construção de uma base metálica com guias para suporte ao piso em terreno nivelado e compactado. O piso é formado por placas específicas para circulação. As telhas para cobertura são feitas a partir de telhas ecológicas ou convencionais existentes no mercado. A ventilação é garantida por meio de janelas de posicionamento flexível ou por meio da utilização de ar condicionado, tal como nos demais sistemas (IMPACTO PROTENSÃO, 2016).

A desmontagem, feita com cuidado, proporciona o reaproveitamento dos componentes em outros canteiros. 


\subsection{Painéis Estruturais de Chapas Especiais}

Outra solução diz respeito aos painéis PETI (Painéis Estruturais Termo Isolantes), que se constituem de duas camadas de chapas de aço zincado, preenchido ao meio com poliestireno expandido. Os mesmos podem ser autoportantes (Figura 19) ou de vedação (Figura 20).

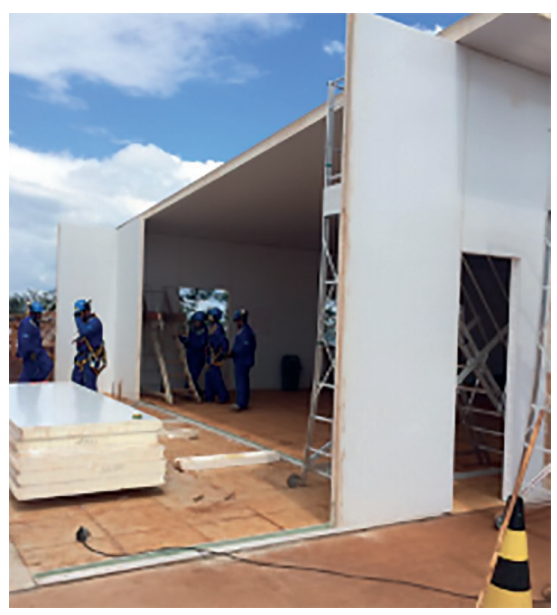

Figura 19 - Montagem de painéis PETI com perfis guia. Fonte: Almeida, 2015.

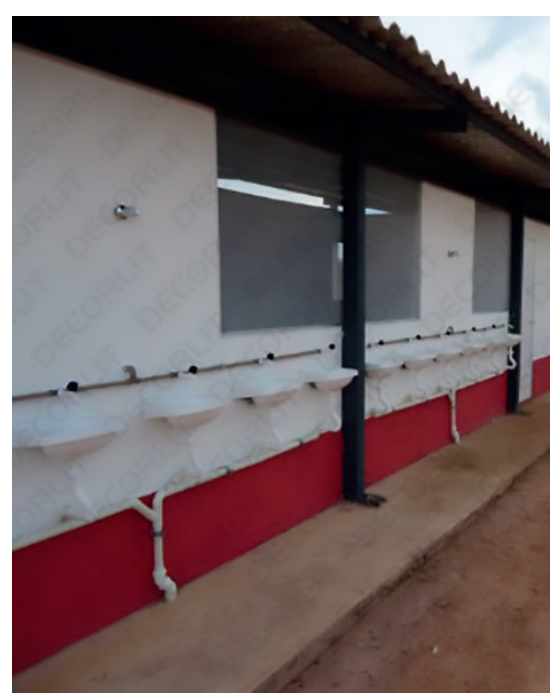

Figura 20 - Painéis PETI utilizados como vedação. Fonte: http://www.decorlit.com.br/ painel-eps-canteiro-obras.html 
Como fundação para os painéis autoportantes, pode-se utilizar a solução de radier ou sapatas niveladoras, nas quais são instaladas as guias metálicas (ALMEIDA, 2015).

Os fabricantes indicam a durabilidade de 10 anos, com garantia de assistência técnica e alta resistência aos agentes externos.

\section{Conclusões}

Todo canteiro de obra deve contar com áreas de apoio, representadas pelas instalações provisórias, durante a construção. Para que o canteiro de obras possa ser considerado sustentável, devem ser respeitados os aspectos ambiental, social e econômico na análise das soluções a serem adotadas. As empresas podem se conscientizar que o investimento em tecnologias traz benefícios, como melhor desempenho, mais qualidade no uso e possibilidade de várias reutilizações.

Dessa forma, as empresas construtoras devem analisar as opções disponíveis no mercado e compor os custos, considerando os processos de aquisição, implantação e manutenção, a durabilidade, o tempo de uso, a capacidade de reaproveitamento, a facilidade de montagem, transporte e desmontagem, o conforto termoacústico, entre outros.

Por meio deste trabalho, percebeu-se que o mercado fornecedor de construções temporárias encontra-se consciente da importância de apresentar diferentes produtos compatíveis com a sustentabilidade ambiental e com as necessidades das pessoas que trabalharão nas obras. É importante que as empresas fornecedoras passem a registrar o atendimento aos requisitos de pontuação do processo de certificação dos canteiros sustentáveis como estratégia de marketing.

Com este trabalho espera-se ter contribuído para apresentar as principais soluções das instalações provisórias disponíveis atualmente no mercado. Espera-se que as opções tenham como premissas principais a menor geração de resíduos no período de desconstrução, a diminuição dos gastos dos retrabalhos e busca da satisfação do trabalho. Alerta-se, contudo, que a análise econômica normalmente considera que as instalações provisórias pré-fabricadas têm um custo de aquisição mais elevado se comparadas aos sistemas tradicionais, mas possibilitam que o investimento seja distribuído ao longo do tempo de reuso.

\section{Referências}

ALMEIDA, L.R. Estudo de sistemas construtivos pré-fabricados modulares aplicados em canteiros de obras. 74f. 2015. Monografia de Curso de Especialização em Construção Civil da Universidade Federal de Minas Gerais (UFMG), Belo Horizonte, MG. 
ARSLAN, H. Re-design, re-use and recycle of temporary houses. Building and Environment, v. 42, n. 1, p. 400-406, jan. 2007.

ARSLAN, H.; COSGUN, N. Reuse and recycle potentials of the temporary houses after occupancy: Example of Duzce, Turkey. Building and Environment. v. 43, n. 5, p. 702-709, may 2008.

ASSOCIAÇÃO BRASILEIRA DE NORMAS TÉCNICAS. NBR 12284: Áreas de vivência em canteiros de obras - procedimentos. Rio de Janeiro, 1991.

BIRBOJM, A.; SOUZA, U.E.L. Construções temporárias para canteiro de obras. 2002. 23p. Boletim Técnico da Escola Politécnica da USP - Departamento de Engenharia de Construção Civil, Universidade de São Paulo, São Paulo.

BOFF, S. Veja os cuidados de instalação de alojamentos de madeira pré-fabricados para canteiros. Técnhe, ed. 206, maio 2014. Disponível em: http://techne.pini.com.br/ engenharia-civil/206/artigo311418-1.aspx. Acesso em: nov. 2016.

BRASIL. Ministério do Trabalho e Emprego. Norma Regulamentadora 18 (NR-18): Condições e meio ambiente de trabalho na indústria da construção. 2015. Brasília-DF. Disponível em: <http://trabalho.gov.br/seguranca-e-saude-no-trabalho/normatizacao/ normas-regulamentadoras/norma-regulamentadora-n-18-condicoes-e-meio-ambientede-trabalho-na-industria-da-construcao>. Acesso em: nov. 2016.

BRUNA, P. Arquitetura, industrialização e desenvolvimento. São Paulo: EDUSP/Perspectiva, 1976. Coleção Debates, n. 135.

CESAR, L.D.; ZANUTTO, T.D.; BISINOTTO, S.L.; SERRA, S.M.B.; SOUZA, L.C.L. Projeto do canteiro de obras: avaliação das instalações provisórias e dos fluxos físicos de materiais. In: Simpósio Brasileiro de Qualidade do Projeto no Ambiente Construído, 2., 2011, Rio de Janeiro. Anais... Associação Nacional de Tecnologia do Ambiente Construído, 2011, 13 p.

DEGANI, C.M. Canteiro de Obras de Baixo Impacto. 2012. Disponível em: http://www. feiraconstruir.com.br/bahia/pdfs/Palestra\%20Clarice\%20Menzes\%20Degani.pdf. Acesso em: jun. 2013.

DIAS, C.M. Etapas do Ciclo de Vida de Construções Provisórias para Canteiros de Obras. 119f. 2013. Trabalho de Conclusão de Curso apresentado ao Departamento de Engenharia Civil da Universidade Federal de São Carlos (UFSCar), São Carlos, SP.

DIAS, C.M.; SERRA, S.M.B. Overview of Industrialized Technological Solutions for Temporary Facilities in Construction Sites. 2013. In: Portugal Sustainable Buildings (SB13). Proceedings... Guimarães, Portugal, 2013.

FCAV (Fundação Carlos Alberto Vanzolini). Referencial técnico de certificação: edifícios do setorde serviços - processo AQUA. Coordenador: Francisco Ferreira Cardoso, São Paulo, 2010.

MARTINS, J. Espaços de vivência. Téchne, ed. 195, junho de 2013. Disponível em: http:// techne.pini.com.br/engenharia-civil/195/espacos-de-vivencia-planejamento-da-obra-edisponibilidade-de-294060-1.aspx . Acesso em: nov. 2016. 
MATEUS, R.; BRAGANÇA, L. Avaliação da sustentabilidade na construção: desenvolvimento de uma metodologia para a avaliação da sustentabilidade de soluções construtivas. 2004. In: Congresso sobre Construção Sustentável, 1, Portugal, 2004. Anais... Disponível em: http://repositorium.sdum.uminho.pt/handle/1822/7333. Acesso em: nov. 2016.

OLIVEIRA, M. E. R.; LEÃO, S. M. C. Planejamento das instalações de Canteiros de obras: aspectos que interferem na produtividade. In: Encontro Nacional de Engenharia De Produção, 17., 1997, Gramado. Anais... Associação Brasileira de Engenharia de Produção, 1997, 6 p.

REIS, R.P.A.; SOUZA, U.E.L.; OLIVEIRA, L.H. Alternativas e soluções de instalações hidráulicas provisórias em canteiros de obra. In: Encontro Nacional de Tecnologia do Ambiente Construído, 10., 2004, São Paulo. Anais... Associação Nacional de Tecnologia do Ambiente Construído, 2004, 13 p.

RODRIGO, A.G.; SOARES, P.V.P.T.; CARDOSO, F.F. Requisitos de desempenho para instalações provisórias em canteiros de obras. In: ENTAC 2012, XIV Encontro Nacional de Tecnologia do Ambiente Construído, 2012, Juiz de Fora- MG. Anais... v. 1. p. 1-7. 2012.

SANTO JR, A.P.E.; AZZIOLINI, R.L. Instalações elétricas provisórias em canteiros de obras: estudos de casos. 2009. 50 p. Trabalho de Conclusão de Curso de Engenharia Civil, Universidade da Amazônia, Belém, PA.

SAURIN, T.A.; FORMOSO, C.T. Planejamento de canteiros de obra e gestão de processos. Recomendações Técnicas Habitare. v. 3, 112 p., 2006.

\section{Sites Consultados}

EUROBRAS. Módulos Metálicos Habitacionais Termo acústicos. 2013. Disponível em: http://www.eurobras.com.br/produtos/modhabtermoacusticos/index.php. Acesso em: jun. 2013.

IMPACTO PROTENSÃO. Casa de Plástico: Canteiro Sustentável. 2016. Disponível em: http:// www.impactoprotensao.com.br/modulohabitacional/. Acesso em: nov. 2016.

NOVO ESPAÇO. Canteiros de Obra com Madeira e Placa Cimentícia. Disponível em: http:// www.novoespaco.com.br/placacimenticia.html. Acesso em: jun. 2013.

VINIGALPÃO. Características do Vinigalpão. 2016. Disponível em: http://www.vinigalpao. com.br. Acesso em: nov. 2016.

VRB. VRB 848 Sistemas Modulares. Disponível em: http://vrb848.com.br. Acesso em nov. 2016.

http://www.Ipbrasil.com.br/aplicacoes/

http://canteiro.com.br/

http://www.prefacc.com.br/ 
http://www.gaccontainers.com.br/

http://www.megacontainers.com.br/

http://brasteiner.com.br/

http://cmcmodulos.com.br

http://alternativacoberturas.com.br/

http://www.decorlit.com.br/painel-eps-canteiro-obras.html 


\title{
Projeto de Contêineres Metálicos para Instalações Provisórias em Canteiros de Obras
}

\author{
Adriana Gouveia Rodrigo \\ Danielle Gazarini \\ Francisco Ferreira Cardoso
}

\section{Introdução}

Um canteiro de obras é a área de trabalho fixa e temporária, onde se desenvolvem operações de apoio e de execução de uma obra, segundo a Norma Regulamentadora 18: Condições e Meio Ambiente de Trabalho na Indústria da Construção (BRASIL, 2015). Birbojm e Souza (2002) descrevem instalações provisórias como construções temporárias utilizadas para abrigar as operações de apoio e execução da obra, as quais serão removidas do local após a sua utilização, e que podem ser divididas entre internas e externas. As normas NR 18: Condições e meio ambiente de trabalho na indústria da construção (BRASIL, 2015) e NBR 12284: Áreas de vivência em canteiros de obras Procedimentos (ABNT, 1991) explicitam as áreas obrigatórias de apoio, que devem dispor, no mínimo, de: instalações sanitárias, vestiário, alojamento, local de refeições, cozinha (caso haja preparo de refeições), lavanderia, área de lazer e ambulatório (quando a frente de trabalho possuir mais de 50 trabalhadores); considera-se aqui como instalação provisória as áreas de escritórios.

O mercado oferece atualmente sistemas com maior ou menor grau de industrialização para a execução mais rápida de instalações provisórias, tais como sistema tradicional de chapa de madeira compensado, pré-moldado de madeira, 
contêineres metálicos, construções com estruturas metálicas desmontáveis, prémoldado de concreto e pré-moldado de fibra plástica.

Este capítulo volta-se aos contêineres metálicos para instalações provisórias em canteiros de obras. Tais estruturas são usualmente empregadas como um conjunto de módulos semelhantes, combinados horizontal e verticalmente, formando unidades contínuas, e complementados por estruturas próprias para a circulação de pessoas: escadas e passarelas. Possuem mecanismo de acoplamento e transporte, sendo vedados verticalmente por painéis que admitem diferentes soluções de produtos e preveem aberturas externas e internas, incorporando uma série de sistemas (água, esgoto, energia, iluminação, etc.).

Em geral, os contêineres metálicos possuem dimensões compatíveis com as de uma plataforma de caminhão de circulação em áreas urbanas - da ordem de 2,40 $\mathrm{m}$ de largura por 6,00 $\mathrm{m}$ de comprimento e 2,50 $\mathrm{m}$ de altura-e é usualmente transportado montado em sua configuração tridimensional. $\mathrm{O}$ transporte desmontado exige finalização da montagem nos canteiros de obras, mas reduz os custos do frete. $O$ caminhão usado para esse fim é normalmente equipado com guindaste hidráulico. $\mathrm{O}$ acoplamento dos contêineres na obra não exige pessoal especializado.

Em uma obra, à medida que os diferentes serviços são executados, as instalações do canteiro assumem características e configurações distintas, associadas às diversas fases da obra. Observa-se que, com as mudanças de fases, as instalações provisórias, muitas vezes, são construídas, ampliadas e, posteriormente, demolidas, gerando uma quantidade de entulho e desperdício de material e energia. A identificação dessas fases e das mudanças que ocorrem em cada uma delas, ajuda a compreender a evolução que se espera no desempenho almejado, ajuda também na elaboração de um projeto típico de instalação provisória e como ampliá-lo ou reduzi-lo para acomodar as necessidades de cada fase.

Embora a solução em contêiner metálico alinhe-se fortemente com o conceito de construção industrializada, a realidade mostra que seu uso se dá de forma desordenada, com projetos que seguem a prática usada no emprego de sistemas tradicionais de instalações provisórias.

O objetivo deste artigo é trazer elementos para a criação de um sistema modular em aço para instalações provisórias de obras, apresentando os principais condicionantes de projeto para essas instalações, com base em um programa de necessidades típico para essas estruturas, a fim de possibilitar que a sua configuração se transforme em função das diferentes fases das obras.

A pesquisa, apresentada em Rodrigo et al. (2015), baseou-se em entrevistas e visitas de campo guiadas por um roteiro, que investigou os seguintes itens: identificação da quantidade de trabalhadores por fase das instalações provisórias; caracterização por tipologia construtiva; razão das escolhas das tipologias; programa de necessidades; implantação das instalações provisórias no terreno; procedimento para projeto e responsável pelo projeto; e destinação das instalações provisórias ao final da obra. 
Foram selecionadas cinco grandes empresas construtoras da cidade de São Paulo. Cada uma delas indicou uma ou duas obras para a realização de visitas, totalizando oito obras na cidade de São Paulo, como mostra a Tabela 1. Foram entrevistados cinco responsáveis pelos canteiros de obras, um de cada empresa. Em duas das entrevistas estavam presentes também os representantes das empresas fornecedoras das instalações provisórias. A análise das visitas foi embasada no método de estudo de caso, conforme descrito em Yin (2005).

Tabela 1 - Empresas construtoras e obras correspondentes estudadas.

\begin{tabular}{llllll}
\hline Empresa & Obras & $\begin{array}{l}\text { Área do } \\
\text { Terreno }\left(\mathrm{m}^{2}\right)\end{array}$ & $\begin{array}{l}\text { Quantidade } \\
\text { de edifícios }\end{array}$ & $\begin{array}{l}\text { Número de } \\
\text { andares }\end{array}$ & $\begin{array}{l}\text { Número de } \\
\text { unidades }\end{array}$ \\
\hline A & A1 & 2.500 & 1 & 27 & 260 \\
\cline { 2 - 6 } & A2 & 2.029 & 1 & 27 & 185 \\
\hline B & B1 & 250.000 & 30 & 29 (média) & - \\
\hline D & C1 & 17.462 & 3 & 25 & 246 \\
\hline & D1 & 7.000 & 2 & 25 & 400 \\
\hline D2 & 2.500 & 1 & 16 & 44 \\
\hline
\end{tabular}

Fonte: Rodrigo et al., 2015.

Paralelamente às pesquisas de campo nas obras, foram realizadas quatro visitas de caráter exploratório aos fabricantes de instalações provisórias. O levantamento junto aos fabricantes permitiu que identificássemos os principais fornecedores de componentes e trouxe outras informações relevantes para o desenvolvimento do projeto do módulo metálico em aço.

\section{O Uso dos Contêineres Metálicos nas Diferentes Fases do Canteiro de Obras}

Souza (2000), pensando nas instalações do canteiro de obras, propõe as seguintes fases: 1) movimentação de terra, contenção da vizinhança e fundações; 2) estrutura do subsolo sob a torre e da periferia; 3) estrutura do restante da torre; 4) estrutura e alvenaria; 5) estrutura, alvenaria e revestimentos argamassados; 6) finalização da obra. Em relação à logística interna da obra, Nascimento (2014) propõe quatro fases para o canteiro: 1) mobilização até fundação; 2) fundação e estrutura; 3) início da alvenaria até a conclusão dos revestimentos; 4) acabamentos até entrega. 
Para Souza (2000), a primeira fase, ou seja, movimentação de terra, contenções e fundações, é normalmente marcada pela presença de subempreiteiros donos dos equipamentos, que não necessitam de alojamento, demando poucas construções provisórias no canteiro. Nas fases seguintes, as demandas por espaços de armazenagem e áreas de vivência aumentam, e deve-se pensar nos acessos para materiais, especialmente para realização da estrutura.

Em geral, as empresas visitadas utilizam, em um primeiro momento (fase 1), contêineres simples de aço com fechamentos verticais em chapa de aço galvanizada dobrada para servirem como instalações provisórias. Tal fase pode estender-se até o início da estrutura e, na maior parte dos casos, dura aproximadamente 3 meses.

Após as escavações e primeiras movimentações do solo, há preferência por instalações feitas em madeira (fase 2), que possuem maior flexibilidade em relação à movimentação do canteiro e têm um custo menor, segundo a percepção dos entrevistados. Pode-se dizer que essa fase acompanha o período de obra bruta e estende-se pelo maior tempo possível, em alguns casos até o final da obra.

Em um terceiro momento, já na fase final da obra, isto é, na etapa de acabamentos, é comum que parte das instalações provisórias migrem para dentro da área construída (fase 3- nem todas as obras visitadas consideram essa fase necessária).

Quanto à quantidade de trabalhadores, o total é variável conforme o tamanho da obra em questão. A Tabela 2 mostra a duração de cada fase e o número de funcionários, lembrando que, na tabela em questão, consideraram-se apenas os operários e não os funcionários administrativos.

Tabela 2 - Fases das obras: duração e número de funcionários.

Obras

Fases

\begin{tabular}{l}
\hline Duração (meses) \\
\hline$N^{\circ}$ de funcionários \\
\hline
\end{tabular}

\begin{tabular}{l}
\hline Obra \\
\hline Fases \\
\hline Duração (meses) \\
\hline$N^{\circ}$ de funcionários \\
\hline
\end{tabular}

\begin{tabular}{|c|c|c|}
\hline \multicolumn{3}{|c|}{$\mathrm{A} 1$ e $\mathrm{A} 2$} \\
\hline 1 & 2 & 3 \\
\hline 3 a 4 & $\mathrm{NI} *$ & $\mathrm{NI}$ \\
\hline 10 & 100 & 200 \\
\hline
\end{tabular}

\begin{tabular}{lll}
\hline B1 & & \\
\hline 1 & 2 & 3 \\
\hline 3 a 4 & 18 a 24 & 6 a 12 \\
\hline 35 & $400^{* *}$ & $400^{* *}$ \\
\hline
\end{tabular}

\begin{tabular}{|c|c|c|c|}
\hline \multicolumn{2}{|c|}{ D1 } & \multicolumn{2}{|l|}{ D2 } \\
\hline 1 & 2 & 1 & 2 \\
\hline 1 & 24 & 1 & 20 \\
\hline $\mathrm{NI}$ & 260 & $\mathrm{NI}$ & 175 \\
\hline
\end{tabular}

\begin{tabular}{ll}
\hline $\mathrm{D} 3$ & \\
\hline 1 & 2 \\
\hline 1 & 24 \\
\hline $\mathrm{NI}$ & 420 \\
\hline
\end{tabular}

*NI - Não Informado; **número de funcionários por cada subempreendimento (em 2015, espera-se 3.000 funcionários no total).

Fonte: Rodrigo et al., 2015. 
O faseamento da instalação provisória é necessário, pois as instalações em madeira levam de 1 a 2 meses para serem construídas. Assim, faz-se necessário que algo ainda mais provisório seja construído no decorrer desses meses, e normalmente opta-se por contêineres metálicos simples que ficam prontos para uso em poucos dias ou até mesmo horas.

O engenheiro das obras D1, D2 e D3 manifestou o desejo de que tal faseamento pudesse não ocorrer, já que a instalação provisória da fase 1 representa um trabalho a mais (desmobilizar a instalações da fase 1). Além disso, nos terrenos muito pequenos (comuns na cidade de São Paulo) é difícil de montar a nova estrutura com os contêineres da fase 1 ocupando um espaço considerável, além de representar um risco de segurança desnecessário. O mesmo engenheiro considera desnecessária a desmobilização antes do fim da obra, eliminando, portanto, a terceira fase para as instalações provisórias.

Corroborando com a ideia de permanência de um único sistema de instalação provisória e pensando na logística do canteiro de obras e na economia de recursos, o trabalho de Nascimento (2014) mostra que os contêineres devem permanecer até a fase 2, que compreende as atividades de fundação até as do início da execução dos serviços de alvenaria. Já estão presentes na obra a equipe de estrutura e muitas vezes também de periferia, e funcionários da execução das instalações elétricas e hidráulicas nas lajes. Para Nascimento (2014), o ideal é a permanência dos contêineres até que exista a possibilidade de mudança para o subsolo.

A fase 3 é vista como indispensável pelos engenheiros das obras A1, A2 e B1, por considerarem muito difícil terminar os trabalhos sem a desmobilização da instalação provisória (segundo eles, sempre há algum serviço a ser executado no local utilizado para a construção da instalação provisória, sendo o mais comum a instalação de brinquedos infantis ou áreas de lazer, churrasco, etc.). As obras C1 e E1 já fazem uso das áreas internas do edifício a partir da fase 2. Dessa forma, na obra E1, todas as instalações provisórias são internas e, na C1, apenas o refeitório é interno, durante as fases 2 e 3.

Nas entrevistas, destacou-se que normalmente o que condiciona a necessidade ou não da instalação da fase 3 é o que será construído sob a instalação provisória da fase 2. Assim, por exemplo, quando a instalação é construída sobre um futuro jardim, ela pode permanecer montada até o fim da obra, mas se sob ela houver programada a realização de alguma obra, mesmo que pequena, surge a necessidade de transferência das instalações provisórias para debaixo das lajes.

A possibilidade de existir uma única tipologia de instalação provisória, que permaneça até o fim da obra, é discutida em Said e El-Rayes (2013). Esses autores, porém, destacam que canteiros de obras congestionados, como os terrenos urbanos, frequentemente não têm espaço exterior suficiente para acomodar todas as instalações provisórias, sendo necessária a utilização do interior dos edifícios. 
A Tabela 3 mostra as principais tipologias construtivas de instalações provisórias encontradas. A instalação da fase 2 foi tratada como tipologia construtiva principal, visto ser a que permanece mais tempo na obra. O custo total pode ser dividido por algumas obras (quando a instalação é reutilizada, segundo relato dos entrevistados).

Tabela 3 - Tipologias construtivas das instalações provisórias.

\begin{tabular}{|c|c|c|c|c|c|}
\hline \multirow[t]{2}{*}{ Empresa } & \multirow[t]{2}{*}{ Fase 1} & \multirow[t]{2}{*}{ Fase 2} & \multicolumn{3}{|c|}{ Fase 2 (principal) } \\
\hline & & & Contratação & $\begin{array}{l}\text { Custo total } \\
\left(\mathrm{R} \$ / \mathrm{m}^{2}\right)\end{array}$ & $\begin{array}{l}\text { Custo por } \\
\text { obra }\left(R \$ / m^{2}\right)\end{array}$ \\
\hline A & $\begin{array}{l}\text { Contêiner chapa } \\
\text { dobrada }\end{array}$ & Madeira & Comprada & 325 & 175 \\
\hline B & $\begin{array}{l}\text { Contêiner chapa } \\
\text { dobrada } \\
\text { e madeira } \\
\text { provisório. }\end{array}$ & Madeira & $\begin{array}{l}\text { Fabricação } \\
\text { própria }\end{array}$ & 350 & 350 \\
\hline C & $\begin{array}{l}\text { Contêiner chapa } \\
\text { dobrada }\end{array}$ & Madeira & Comprada & 240 & 240 \\
\hline D & $\begin{array}{l}\text { Contêiner chapa } \\
\text { dobrada }\end{array}$ & $\begin{array}{l}\text { Madeira com } \\
\text { estrutura metálica }\end{array}$ & Comodato & - & 400 \\
\hline$E$ & $\begin{array}{l}\text { Contêiner chapa } \\
\text { dobrada }\end{array}$ & $\begin{array}{l}\text { Estrutura metálica } \\
\text { (sem teto) e PVC }\end{array}$ & Alugada & - & 210 \\
\hline
\end{tabular}

Fonte: Rodrigo et al., 2015.

A tipologia construtiva da fase 3 não consta na tabela, uma vez que envolve o uso temporário de áreas internas do edifício, normalmente se empregando partes das instalações da fase 2, como para compartimentalização de áreas, vasos sanitários, etc.

$\mathrm{O}$ uso dos contêineres foi observado apenas na fase $1 \mathrm{e}$ em todas as obras. $\mathrm{O}$ arranjo característico previu o uso de dois a três contêineres simples, normalmente montados deixando-se uma distância de 2 metros entre eles, sendo esse espaço coberto e utilizado como vestiário, local para pendurar toalhas ou refeitório. O cumprimento da NR 18 - Condições e meio ambiente do trabalho na indústria da construção (BRASIL, 2015), nessa fase, fica comprometido, tendo sido observado a falta de armários, refeitórios improvisados e revestimentos de vestiários inadequados. Outra constatação é o uso de construções sob a forma de aluguel, como no caso dos contêineres, ou sob a forma de comodatos.

O uso do contêiner simples de chapa dobrada, sem tratamento térmico e acústico, não é nem cogitado para a segunda fase (por nenhuma empresa), pois traria um grande incômodo aos trabalhadores. Nessa fase, a estrutura em madeira é considerada mais confortável, ainda que não seja completamente adequada. De 
maneira geral o contêiner simples de chapa dobrada é visto como provisório e, mesmo com o uso de ar-condicionado, não é confortável, segundo os entrevistados.

Contêineres de aço com desempenho superior (sobretudo devido aos vedos paredes e teto - com componentes que o isolam termicamente do ambiente exterior) foram considerados muito caros por todas as empresas entrevistadas. Além disso, as empresas alegam que, caso o contêiner fosse comprado, não haveria local para guardá-lo nos momentos em que ele não estivesse em uso e pagar aluguel para esse fim, durante toda a obra, poderia acarretar um gasto muito elevado.

Todas as empresas citaram o fato da instalação em madeira ter um custo menor que a instalação em aço (com desempenho equivalente). A adaptabilidade das instalações em madeira, embora citada como vantajosa pelos entrevistados, na prática mostrou-se difícil de ser feita.

Outros condicionantes na tomada de decisão para o sistema construtivo foram o serviço de montagem, desmobilização e, em alguns casos, até a transferência para outra obra, serviço que a empresa fornecedora da instalação em madeira oferece. O fornecedor parceiro da empresa " $D$ " disponibilizava inclusive um sistema de manutenção e limpeza diária.

Com relação à destinação das instalações provisórias ao final da obra, ficou clara a vantagem das instalações em aço. Por possuírem vida útil muito maior, podem ser reutilizadas inúmeras vezes apenas com manutenção. Segundo uma das empresas fabricantes de contêiner simples de chapa dobrada, um mesmo contêiner pode ser utilizado até 20 vezes, mediante manutenção. Além do mais, as instalações hidráulicas, tubulações e fiações, se corretamente integradas ao contêiner, podem ser reaproveitadas. Ao final da vida útil, quando a instalação chega a apresentar algum dano estrutural, o contêiner pode ser totalmente reciclado, pois o aço é reaproveitado sem qualquer perda de qualidade. No caso das estruturas e vedações de madeira, embora a reutilização seja possível, nota-se que somente a empresa " $\mathrm{A}$ " tenta viabilizá-la e, segundo a entrevista, nem sempre consegue. Quando consegue, reutiliza somente algumas partes. Nesse tipo de estrutura, ademais, as instalações hidráulicas, tubulações e fiações dificilmente são reaproveitadas.

\section{Condicionantes do Projeto de Contêineres Metálicos}

No levantamento realizado por Rodrigo et al. (2015), identificaram-se outras condicionantes de projeto para as instalações provisórias, típicas da cidade de São Paulo. Entende-se por condicionante de projeto as condições específicas encontradas nas obras visitadas com potencial para tornarem-se diretrizes de projeto: dimensões máximas, organização interna dos ambientes, identificação de necessidades de ampliação, dentre outras. 
Verificou-se que as empresas construtoras, na maioria dos casos, elaboram um projeto diferente para cada obra (com total liberdade de criação das instalações provisórias). Não se aproveita o mesmo projeto nem sequer em casos de terrenos com condições muito similares. Os fornecedores de instalações provisórias para canteiros de obras, igualmente, pouco trabalham com padronizações e inclusive a modulação é precária. Estas condições acarretam um considerável sobrecusto para as instalações provisórias, geração excessiva de resíduos e dificultam a gestão dos canteiros, dadas as inúmeras adaptações que ocorrem no decorrer do período das obras. É marcante a possibilidade de o projeto das instalações provisórias ser padronizado e modular, permitindo alguma customização, mas não a total liberdade, como é feito hoje. Quanto aos módulos de aço existentes, identificou-se que são genéricos e não projetados especificamente para o caso das instalações provisórias em canteiros de obras.

Para o projeto de um sistema modular em aço, antes de tudo, deve-se considerar o programa de necessidades. Observa-se que já existe um programa padrão, sobretudo para as áreas de vivência e higiene, que são obrigatórias pela Norma Regulamentadora 18: Condições e Meio Ambiente de Trabalho na Indústria da Construção (BRASIL, 2015), pela Norma Regulamentadora 24: Condições Sanitárias e de Conforto nos Locais de Trabalho, (BRASIL, 1993) e pela NBR 12284: Áreas de vivência em canteiros de obras - Procedimento (ABNT, 1991). As áreas de escritório não são normatizadas e existe uma variabilidade caso a caso, embora sempre estejam presentes pelo menos uma sala de reunião fechada, além de sala para o engenheiro, técnicos e estagiários e sala para o encarregado e almoxarifado.

Observa-se a necessidade de um espaço para treinamento e cursos para os operários, os quais podem ocorrer no refeitório, desde que projetados para atender às duas funções. Deve-se prever instalação de TV de plasma ou aparelho de projeção nesses locais. O projeto dos módulos metálicos deve prever instalação de equipamentos antirroubos e antivandalismo. Outra boa prática é o uso de pintura externa com possibilidade de marketing (ser adesivada, por exemplo).

Casos especiais, como a obra B1, em que existe inclusive a necessidade de sala blindada, auditório e uma cozinha industrial completa, não devem ser considerados na elaboração do projeto dos módulos para canteiros (devem ser sempre tratados como projetos especiais).

O projeto do sistema modular em aço para canteiros de obras deve prever ações voltadas à economia de energia e água, tais como: chuveiro com aquecimento solar; reuso de águas e uso de água da chuva; depósito de lâmpadas fluorescentes queimadas; cisternas para captação da água da chuva; aproveitamento da iluminação natural; e vedos que possibilitem a redução da carga térmica (o que não é viável utilizando-se apenas o aço nas vedações - deve-se prever vedações verticais e coberturas aptas a receber revestimentos internos ou externos). 
A funcionalidade dos espaços construídos, melhor aproveitamento dos espaços evitando a ociosidade, área de circulação reduzida e uso de divisórias internas somente quando necessárias são fatores que fazem parte das necessidades das empresas construtoras e devem ser considerados na elaboração dos projetos dos módulos.

Fatores externos como acessos limitados e terrenos pequenos também devem condicionar o projeto dos módulos, já que são circunstâncias comuns à maioria das metrópoles brasileiras. Como normalmente as instalações provisórias ficam confinadas nas áreas de recuo obrigatório, a dimensão desse espaço deve também condicionar a largura dos módulos, e não somente o tamanho do chassi do caminhão que irá transportá-lo, como no caso dos contêineres marítimos.

Para determinação da largura dos módulos, deve-se considerar ainda o tamanho das bobinas de chapas de aço dobradas existentes no mercado, além da modulação de outros componentes.

Outra condicionante é a prioridade que o estande de vendas costuma adquirir na locação do canteiro, restando às instalações provisórias a extensão que sobra do recuo, ou seja, deve-se prever o empilhamento dos módulos, a otimização do uso dos espaços, a redução de áreas de corredor e os espaços multiuso, sempre que possível. Locais destinados a armários devem estar sob ou sobre as mesas, reduzindo a área de piso da instalação dos escritórios.

As ligações com as redes de água e esgoto devem ser únicas, mas possíveis de serem adaptadas à condição e ao posicionamento de cada empreendimento. As entradas elétricas devem ser simples, preferencialmente sob a forma de uma tomada, por exemplo.

O projeto dos módulos para as áreas de vivência e higiene deve considerar, além das normas pertinentes, a estimativa do efetivo mínimo e máximo da obra, bem como as suas fases, para o planejamento das ampliações e adaptações. Por exemplo, módulos para banheiros e vestiários devem permitir ampliações e facilidade de interligação.

Tendo em vista as condicionantes identificadas nas visitas de campo e nas entrevistas, a Figura 1 apresenta um módulo base desenvolvido a partir do programa de necessidades para as áreas de vivência. As cinco configurações apresentadas atendem às exigências normativas, ou seja, tamanhos dos elementos e áreas de circulação. Tais configurações, quando combinadas lado a lado, permitem organizar as áreas de vivências para um número maior ou menor de funcionários. A Figura 2 apresenta três exemplos de combinações dos módulos, com variação no número de funcionários atendidos - 100, 180 e 260 funcionários -, a quantidade e disposição dos elementos também respeitam a normativa pertinente.

A proposta de instalação provisória modular apresentada nas Figuras 1 e 2 buscou reduzir as áreas de circulação e encontrar um tamanho ótimo de módulo base, que proporcione instalações com a menor área possível. 

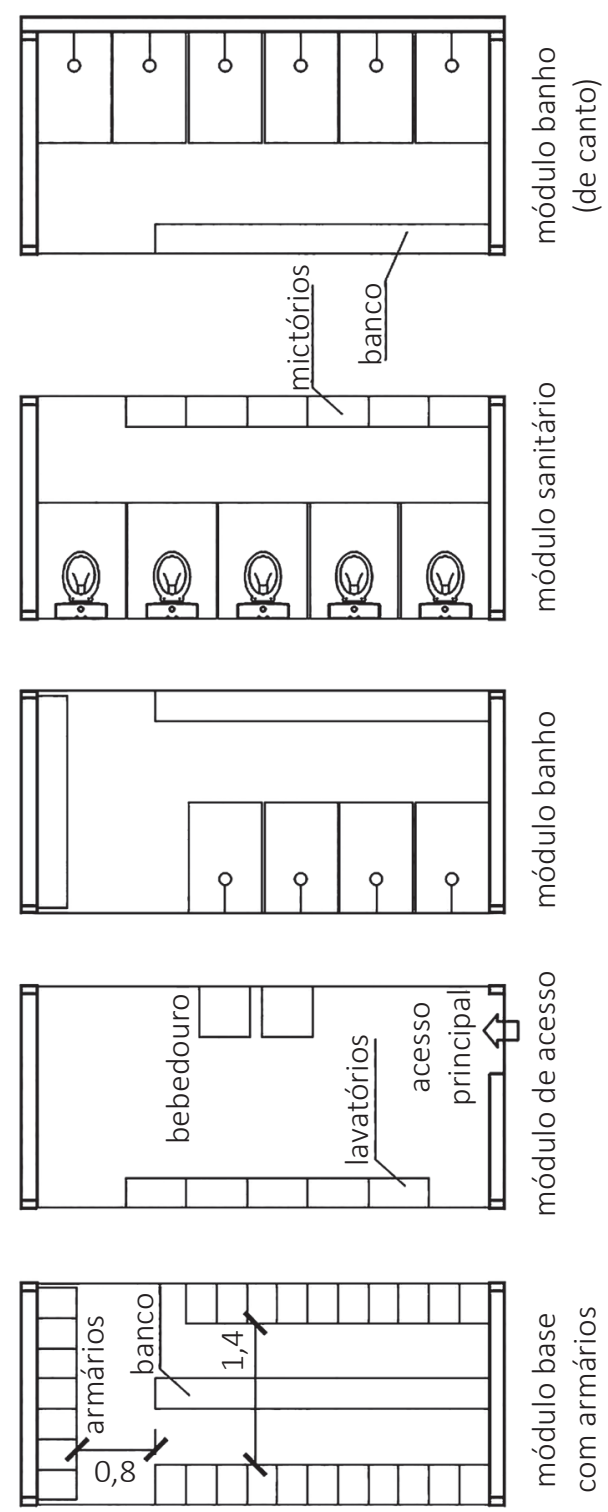

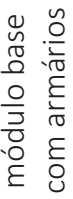

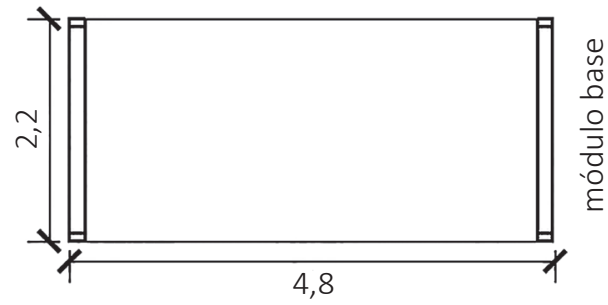

Figura 1 - Módulos para áreas de vivência. 


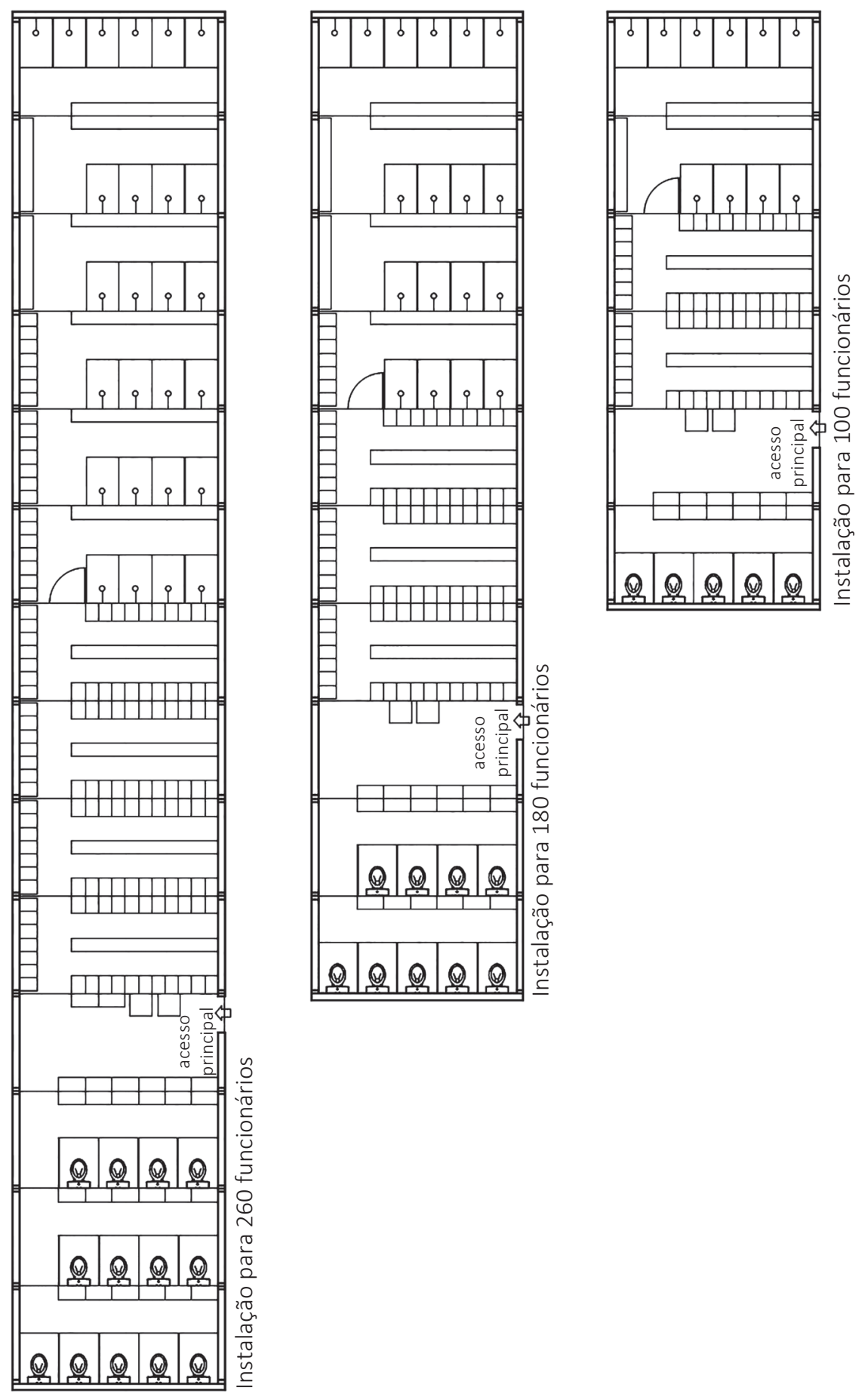

Figura 2 - Módulos combinados - áreas de vivência para 100, 180 e 260 funcionários. 
A Figura 3 apresenta, em caráter ilustrativo, uma proposta de projeto de instalação provisória completa - áreas de vivência e escritórios - feita a partir dos módulos base para um contingente de 100 funcionários. Nesta ilustração, considerouse que o período de almoço será dividido em dois turnos.

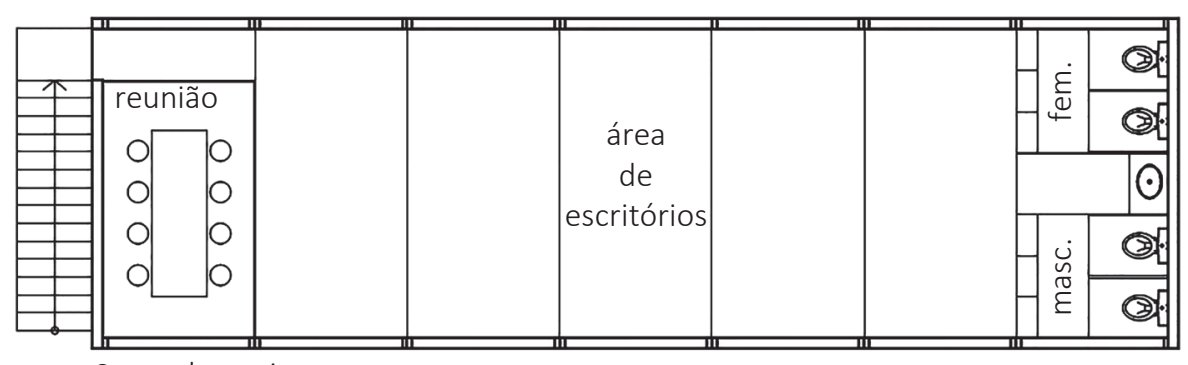

Segundo pavimento

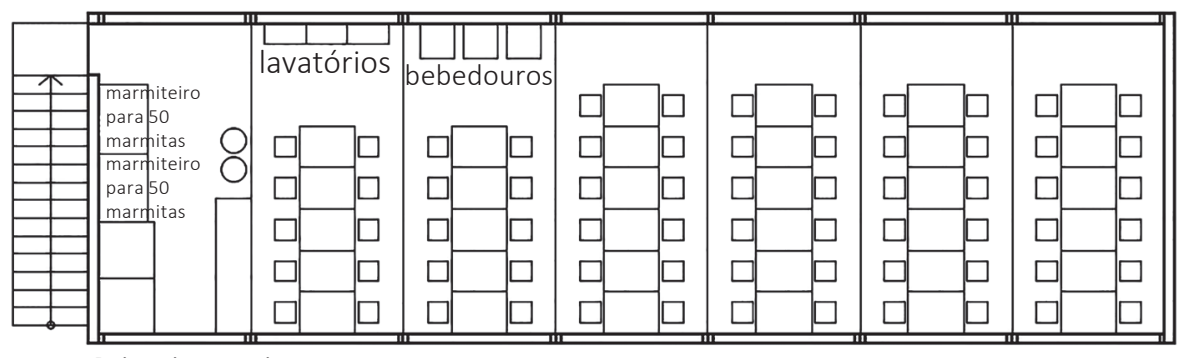

Primeiro pavimento

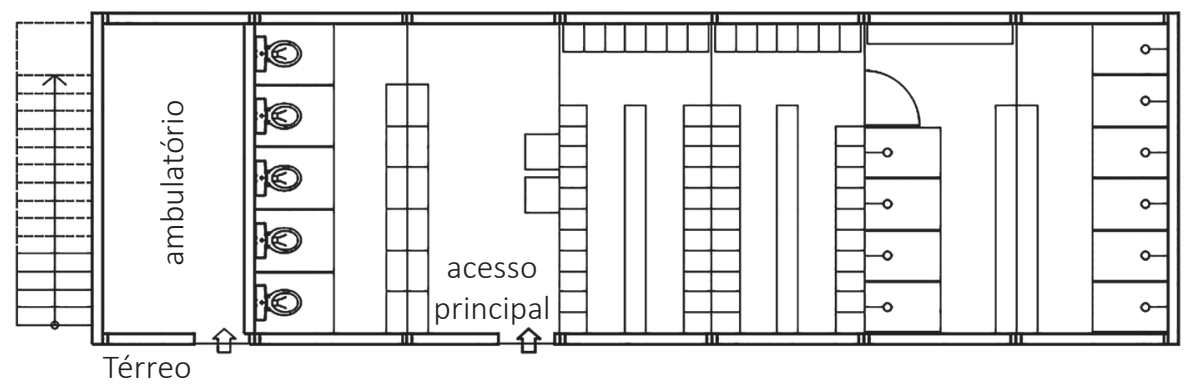

Figura 3 - Planta baixa de instalação provisória: áreas de vivência, refeitório e escritórios para obras com 100 funcionários.

\section{Conclusões}

O capítulo trouxe um estudo de campo que mostrou que as necessidades de instalações provisórias variam em função da fase da obra e, por conseguinte, das tipologias construtivas empregadas. Mostrou ainda que, embora os contêineres de aço sejam atualmente empregados, sobretudo, na fase inicial de uma edificação, quando a 
necessidade de áreas e as demandas para os espaços internos são bastante limitadas, a busca por soluções rápidas, sustentáveis e economicamente viáveis faz com que essas estruturas sejam uma solução capaz de permanecer em outras fases e oferecer um melhor desempenho.

A análise dos dados colhidos nas visitas às obras e aos fabricantes proporcionou a possibilidade de determinar uma instalação provisória típica dos canteiros, sob o ponto de vista da forma (normalmente restrita ao recuo obrigatório), da funcionalidade (ligação entre os ambientes, conforto ambiental) e das conexões com as redes de infraestrutura (água, esgoto, energia, etc.).

Diferentes autores discorrem sobre modelos computacionais e matemáticos criados para organização dos canteiros de obras, dentre eles pode-se citar Andayesh e Sadeghpour (2013) e Karan e Irizarry (2015). Ao analisar aos resultados desses trabalhos, percebe-se que tratam as instalações provisórias como se pudessem ter qualquer tamanho. Questões como modulação e padronização industrial dos sistemas construtivos dessas áreas pouco são levadas em conta. Existe uma oportunidade de desenvolvimento de trabalhos futuros que juntem as tecnologias computacionais a um modelo padronizado e customizável de instalação provisória.

A criação de um sistema único de instalação provisória em contêiner de aço, que possa ser aproveitado em todas as fases da obra, de montagem rápida e confortável e com a possibilidade de ser reutilizado em outras obras, representa uma necessidade iminente no setor da construção civil. Os módulos metálicos existentes são genéricos e não projetados especificamente para o caso das instalações provisórias em canteiros de obras. Nota-se, dessa forma, uma lacuna de mercado, já que um produto que atendesse às normas e fosse específico para o caso dos canteiros de obras geraria economia de custos, tempo e espaços internos.

\section{Referências}

ASSOCIAÇÃO BRASILEIRA DE NORMAS TÉCNICAS. NBR 12284: Áreas de vivência em canteiros de obras - Procedimento. Rio de Janeiro, 1991.

ANDAYESH, M.; SADEGHPOUR, F. Dynamic site layout planning through minimization of total potential energy. In: Automation in Construction, v. 31, 2013, p. 92-102.

BIRBOJM, A.; SOUZA, U.E.L. Construções temporárias para o canteiro de obras. Boletim Técnico 315. São Paulo: EPUSP - Departamento de Engenharia de Construção Civil, 42p. 2002.

BRASIL. Ministério do Trabalho e Emprego. Norma Regulamentadora 18 (NR-18): Condições e meio ambiente de trabalho na indústria da construção. 2015. Brasília-DF. Disponível em: <http://trabalho.gov.br/seguranca-e-saude-no-trabalho/normatizacao/ normas-regulamentadoras/norma-regulamentadora-n-18-condicoes-e-meio-ambientede-trabalho-na-industria-da-construcao>. Acesso em: jan. 2017. 
BRASIL. Ministério do Trabalho e Emprego. Norma Regulamentadora 24 (NR-24): Condições Sanitárias e de Conforto nos Locais de Trabalho, 1993. Disponível em: <http://trabalho.gov. br/images/Documentos/SST/NR/NR24.pdf>. Acesso em: jan. 2017.

KARAN, E.P.; IRIZARRY, J. Extending BIM interoperability to preconstruction operations using geospatial analyses and semantic web services. In: Automation in Construction, v. 53, 2015, p. 1-12.

NASCIMENTO, R.R. Logística na construção de edifícios. Estudo de caso em grande construtora. Monografia (especialização) - Tecnologia e Gestão na Produção de Edifícios. São Paulo, Universidade de São Paulo, Escola Politécnica, 2014.

RODRIGO, A.G.S.; GAZARINI, D.; CARDOSO, F.F. Condicionantes de projeto para as instalações provisórias em canteiros de obras na cidade de São Paulo. In: Proceedings of the Latin-American and European Conference on Sustainable Building and Communities: Connecting People and Ideas. July 21th - 24th, 2015, Guimarães, Portugal. Universidade do Minho and others. pp. 2495-2504.

SAID, H.; El-RAYES, K. 2013. Optimal utilization of interior building spaces for material procurement and storage in congested construction sites. In: Automation in Construction Journal, n. 31, 2013, p. 292-306.

SOUZA, U.E.L. Projeto e implantação do canteiro. São Paulo: O Nome da Rosa. 92p., 2000.

YIN, R.K. Estudo de caso: Planejamento e métodos. Tradutor Daniel Grassi. 3. ed. Porto Alegre: Bookman, 2005. 


\section{Fabricação, Montagem e Desmontagem de Instalações Provisórias para Canteiros de Obras}

Fernando Braga de Souza Sheyla Mara Baptista Serra

\section{Introdução}

Entre os vários ambientes previstos para o canteiro de obras estão as áreas de vivência (refeitórios, sanitários, vestiários, alojamentos, etc.) e as áreas administrativas (escritórios, salas de reunião, almoxarifados, etc.), que devem ser dimensionadas e projetadas para o uso correto. De acordo com Dias (2013), a distribuição das áreas de vivência e o posicionamento das instalações temporárias necessárias em uma obra são tradicionalmente feitos de maneira empírica, prevalecendo, muitas vezes, as experiências dos empreendimentos anteriores, sendo comumente executadas sem qualidade e por mão de obra não qualificada.

Em contrapartida, a Norma Regulamentadora NR-18: Condições e meio ambiente do trabalho na indústria da construção (BRASIL, 2015) solicita, desde sua reedição em 1995, que seja feita a elaboração do projeto do canteiro de obras e, mais recentemente, a "previsão de dimensionamento das áreas de vivência". Considerando a necessidade de incorporar benefícios sociais, econômicos e ambientais ao empreendimento durante a fase de execução, o planejamento do projeto ou layout do canteiro e a definição do sistema construtivo das instalações provisórias estão se tornando aspectos relevantes para melhorar a gestão das obras. 
Essas instalações são consideradas temporárias ou provisórias, ou seja, somente estarão presentes na obra durante a fase de execução e enquanto houver disponibilidade do local no canteiro. Depois são desconstruídas ou desmontadas e, eventualmente, remontadas. Neste caso, é interessante considerar que o processo de desmontagem tenha sido planejado e que a concepção do sistema construtivo preveja o reaproveitamento e remontagem (SOUZA, 2016). A pré-fabricação surge, então, como uma alternativa racionalizada e produtiva para uso em instalações provisórias (IP) do canteiro, facilitando as fases de montagem e de desmontagem, desde o processo de concepção do projeto.

Para Saurin e Formoso (2006), a combinação de espaço limitado com o amplo número de elementos que compõem um canteiro de obra torna a concepção do projeto do ambiente similar à montagem de um "quebra-cabeça", necessitando de criatividade por parte do projetista para encontrar soluções viáveis e adequadas à realidade do canteiro.

Neste sentido, a metodologia Building Information Modeling (BIM), que tem sido utilizada para a elaboração de projetos na construção civil (SACKS; PARTOUCHE, 2010), pode ser empregada para o desenvolvimento do projeto do canteiro de obras e de suas respectivas instalações provisórias.

Os aplicativos BIM possuem, em geral, bibliotecas com componentes típicos da indústria da arquitetura, engenharia e construção (AEC). Essas bibliotecas podem ser também acrescidas dos produtos e catálogos disponibilizados pelos fabricantes da construção provisória pré-fabricada. Deste modo, o projeto é feito por meio da composição de elementos de construção, o que o torna muito similar à lógica da construção pré-fabricada.

As oportunidades de uso dos modelos BIM no canteiro de obras para IP préfabricadas podem ser úteis para comparar o caso real ao modelo virtual 4D (que considera as três dimensões espaciais e o tempo), tanto no processo de montagem quanto no de desmontagem, visando otimizar esses processos.

A necessidade de projetos sustentáveis - adequados do ponto de vista econômico, social e ambiental - e a necessidade e possibilidade de reutilização das construções temporárias para uso em canteiro de obras justifica o uso de aplicativos para a concepção, projeto, montagem e desmontagem do processo de fabricação e execução das instalações provisórias em canteiro de obras. 


\section{Método de Pesquisa}

O trabalho desenvolveu-se tendo por base a pesquisa de Souza (2016). A investigação utilizou-se dos métodos de estudo de caso e de simulação, divididos em três etapas:

- Primeiramente, fez-se a revisão bibliográfica para estabelecer a base teórica necessária para o desenvolvimento da pesquisa.

- Em seguida, foram realizados os estudos de caso. Elaborou-se um roteiro para a coleta de dados acerca dos processos de projeto, fabricação, montagem, desmontagem e reutilização das IP pré-fabricadas. Foram desenvolvidos roteiros de investigação para os dois ambientes: a fábrica das IP e o canteiro de obras. A coleta de dados foi efetuada por meio de visitas e entrevistas.

- Por fim, foram propostas as simulações virtuais de fabricação, montagem e desmontagem das IP pré-fabricadas em madeira a partir dos levantamentos realizados, com o objetivo de definir antecipadamente o processo de produção, propondo melhorias e facilitando o treinamento dos operários envolvidos. Pretendeu-se também demonstrar a viabilidade de projetos voltados para os processos de montagem e desmontagem das IP.

Os programas utilizados foram:

- AutoCAD com recursos para projeto em CAD 2D, assim como recursos de CAD 3D integrados, permitindo modelagem 3D, desenho 3D e elaboração de maquete eletrônica.

- SketchUp é um software voltado para a modelagem e desenho 3D. O SketchUp Pro permite o uso de ferramentas de programação, diagramação, volumetria, desenvolvimento e detalhamento de desenhos, bem como gerar respostas a solicitações de informação.

- O MS Project é um programa gerenciador de projetos, que auxilia na construção do cronograma das atividades e que facilita a discussão entre os agentes da construção.

- O software Navisworks da Autodesk possibilita a revisão do projeto e simulação da construção, permitindo que se incorporem modelos 3D em uma disposição temporal.

A Figura 1 apresenta a sequência de etapas desenvolvidas durante a pesquisa. 


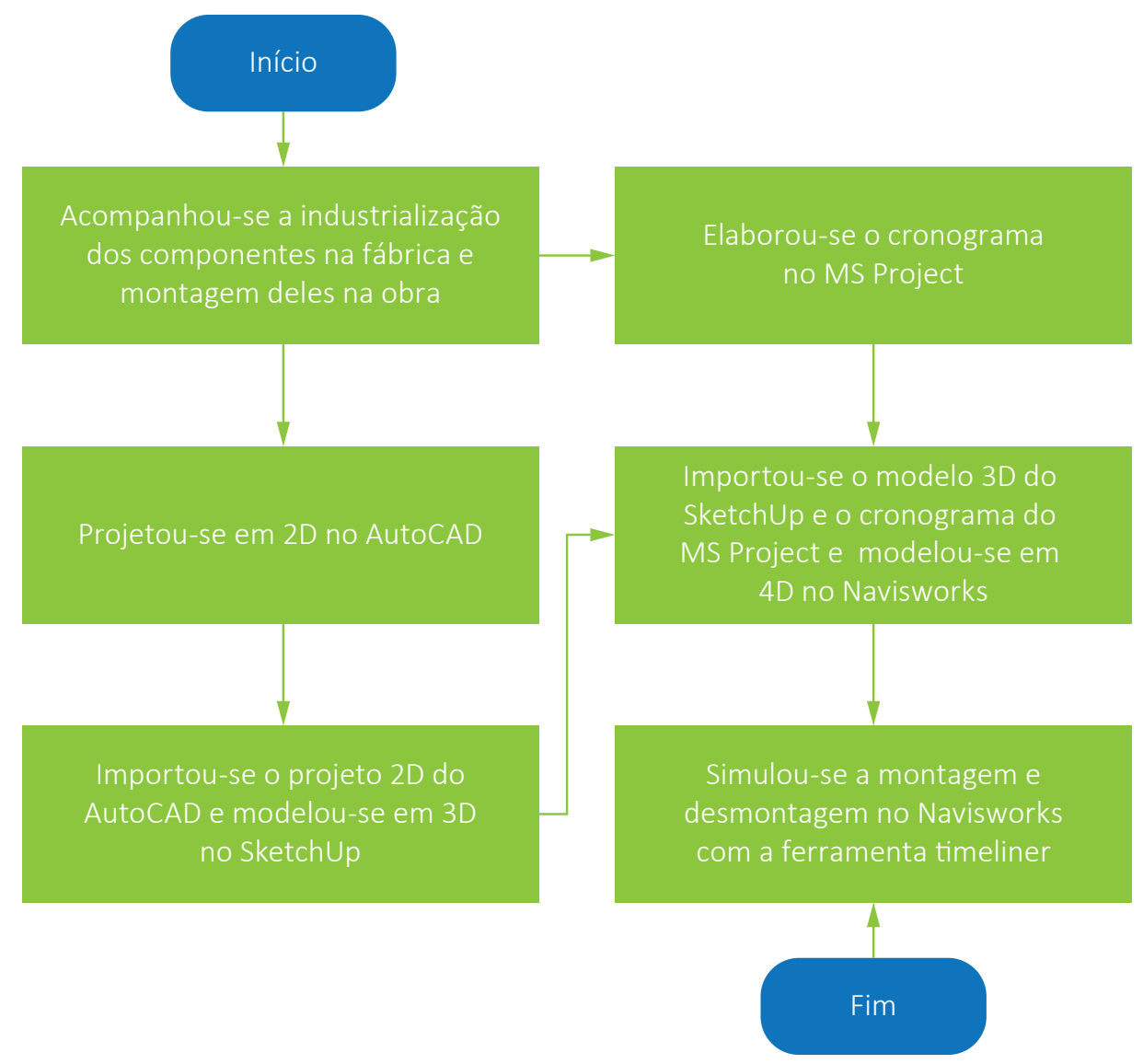

Figura 1 - Etapas para a simulação dos processos estudados. Fonte: Souza, 2016.

\section{Concepção de Sistemas Construtivos Pré-fabricados}

O termo pré-fabricação, no campo da construção civil, possui o seguinte significado: "fabricação de certo elemento antes do seu posicionamento final na obra", segundo Revel (1973). Para esse autor, a pré-fabricação em seu sentido mais geral pode ser aplicada à fabricação de componentes e sistemas construtivos, que são produzidos em indústrias e, posteriormente, transportados à obra para montagem da edificação.

A decomposição da unidade habitacional em partes ou elementos préfabricados faz com que a construção seja cada vez mais um processo de montagem do que de construção propriamente dito. A fabricação dos elementos é normalmente feita em indústrias cujo controle de qualidade da produção é maior e cuja exposição a 
intempéries é reduzida. Os elementos são normalmente padronizados e catalogados para o perfeito encaixe no sistema idealizado.

O projeto realizado com componentes pré-fabricados implica no conhecimento do projetista do processo de fabricação dos elementos, do transporte, da montagem e das ligações necessárias. Por esse motivo, é importante que todas essas etapas sejam determinadas logo na concepção do projeto. O projetista do sistema deve atuar como agente de integração entre as disciplinas, facilitando a padronização das soluções e compatibilidade entre os sistemas prediais adotados.

No caso dos projetos das IP pré-fabricadas, eles são concebidos, normalmente, pelo setor de projetos da empresa fabricante desse tipo de estrutura. Dias (2013) visitou três empresas fabricantes que, além de possuírem setor próprio de projetos, possuíam soluções padronizadas para as principais demandas do mercado, como almoxarifados, refeitórios, sanitários e vestiários. Várias empresas encontradas atualmente no mercado brasileiro, inclusive, disponibilizam as soluções padronizadas em seus sites comerciais.

A construção com componentes pré-fabricados, mesmo sendo provisória, pressupõe que o projetista e fabricante utilizem conceitos como construtibilidade, modularidade, desempenho e segurança. O diferencial desse tipo de construção é que o projeto deve comtemplar, necessariamente, o processo de desconstrução e remontagem.

Assim, de forma a desenvolver um conhecimento que contribua para o processo de desconstrução, Crowther (2002) propõe alguns princípios com foco na construtibilidade dos projetos com sistemas pré-fabricados, a saber:

- Redução do número de diferentes tipos de componentes: visa simplificar o processo de seleção no canteiro e aumentar o valor do componente;

- Uso de sistemas abertos em que as partes da construção são mais livremente intercambiáveis: permite alterações do layout por meio da relocação de componentes sem uma significativa modificação;

- Uso de modulação: componentes e elementos que são compatíveis com outros sistemas em termos dimensionais e funcionais;

- Uso de tecnologias montáveis compatíveis: não exige especialistas para a desmontagem;

- Uso de componentes com tamanho adequado aos meios de montagem: facilitar o manuseio em todas as fases (montagem, desmontagem, transporte, reprocessamento e remontagem);

- Provimento dos meios de manuseio dos componentes durante a montagem e desmontagem: prever pontos de conexão que podem ser necessários para içar ou suportar temporariamente os componentes; 
- Estudo de ligações e conexões para o reuso dos componentes: minimizar as quebras ou deformações dos componentes e materiais durante os processos de montagem, desmontagem e remontagem;

- Permissão da desmontagem paralela em vez da sequencial: um componente pode ser removido sem a quebra de outro componente; quando isso não for possível, o componente mais passível de reuso deve ter prioridade;

- Uso de sistemas pré-fabricados: reduzir o trabalho em canteiro e permitir um maior controle da qualidade e da conformidade dos componentes;

- Fornecimento de peças de reposição no canteiro: principalmente dos componentes quebrados ou danificados para não alterar o projeto da edificação;

- Manutenção das condições dos componentes: garantir a preservação dos componentes, como as dimensões do produto, tempo de vida útil e necessidades de manutenção.

Por meio das características citadas anteriormente, verifica-se o potencial de utilização do conceito de desconstrução visando às instalações provisórias em canteiro.

\section{Desconstrução}

Para Couto et al. (2006), a demolição seletiva ou desconstrução surgiu em virtude do rápido crescimento da demolição de edifícios e da evolução das preocupações ambientais da população. Segundo esses autores, a desconstrução de um edifício é um processo que se caracteriza pelo seu desmantelamento ou desmontagem cuidadosa, de modo a reduzir os resíduos e possibilitar a recuperação, reaproveitamento ou reuso dos materiais e componentes da construção.

Enquanto a demolição tradicional visa remover a edificação o mais rápido possível, a desconstrução ou demolição seletiva busca separar os materiais para o reuso e reciclagem (LIPSMEIER e GÜNTHER, 2002).

O procedimento de desconstrução deve ser planejado e documentado para que os envolvidos possam desenvolvê-lo de forma coordenada, eficiente, eficaz e segura (ITEC, 1995). A forma mais segura de realizar uma desconstrução é fazendo a desmontagem em sequência inversa ao processo de construção, retirando-se louças, cobertura, esquadrias etc., como pode ser visto no esquema da Figura 2. 

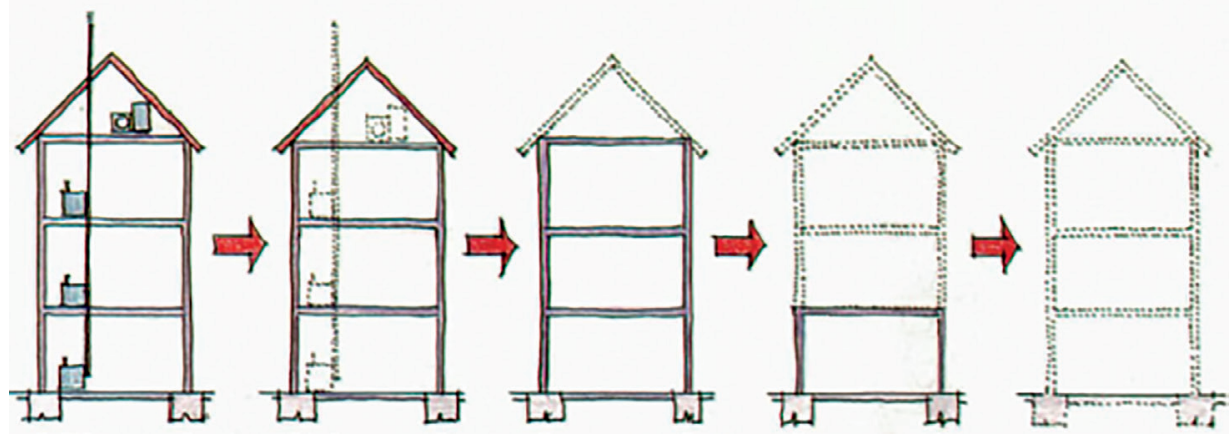

Figura 2 - Sequência de desconstrução de uma edificação. Fonte: ITEC, 1995.

O projeto para a desmontagem pode aumentar, inicialmente, o custo de produção. Contudo, a desconstrução em larga escala tem um grande potencial de trazer benefícios à sociedade (CROWTHER, 2002). Alguns dos benefícios da desconstrução em relação à demolição são segundo Kibert e Chini (2000):

- Diminuição do direcionamento de resíduo para aterros;

- Potencial reuso dos componentes construtivos;

- Maior facilidade de reciclagem dos materiais;

- Menor impacto ambiental.

De acordo com Kibert e Chini (2000), o processo de desconstrução preserva a energia incorporada investida na produção dos elementos, reduzindo o consumo de uma nova energia no processamento ou manufatura. A energia incorporada pode ser entendida como a energia requerida para produzir um produto, que inclui os processos de obtenção da matéria-prima, transporte, manufatura e de produção das máquinas e infraestrutura usada nessas atividades (MANFREDINI; SATTLER, 2005).

Segundo Lopes (2013), o projeto da desconstrução deve determinar a forma de reutilização, de transporte e de armazenamento dos materiais para reuso, e terminar o custo desse planejamento. Para essa autora, pode haver aumento dos custos e adição, em vez de redução, da energia incorporada ao projeto. Uma das recomendações é utilizar os materiais recuperados em locais próximos.

Para a desconstrução, são utilizados métodos não destrutivos. Os equipamentos recomendados para este processo são os que possibilitam a desmontagem dos componentes e o seu manuseio de forma segura e rápida, garantindo a integridade desses elementos.

Verifica-se potencial de aplicação da desconstrução para as instalações provisórias nos canteiros de obras. Como mencionado, o projeto deve prever esta situação, por isso, ele deve ser estudado com cuidado. A seguir serão citados métodos 
para o desenvolvimento do projeto de produtos que sistematizam o processo de montagem e desmontagem, podendo ser aplicado também na construção civil.

\subsection{Design For Assembly}

Design For Assembly (DFA), em português, Projeto para Montagem, é um método de análise que fornece uma estrutura de orientações para que o produto seja desenvolvido de forma a facilitar o processo de montagem, segundo Amaral (2007). Esse autor menciona que as bases do método são a redução das partes por meio da diminuição do número de peças por produto e da variedade de tipos de peças e mediante a utilização do conceito de coordenação modular. Com isso, busca-se a confecção de módulos, que podem ser montados, desmontados e trocados com mais facilidade.

De acordo com Kuo et al. (2001), a aplicação do DFA em projetos proporciona a simplificação de produtos, a redução do ciclo de produção, minimiza os custos de fabricação e montagem e possibilita que a fase de produção seja estudada de forma antecipada, evitando erros de projeto. Para vários autores, o objetivo principal do DFA é a redução do ciclo de produção e do custo envolvido. A concepção do processo de montagem, ainda, reflete um necessário planejamento no que diz respeito à conservação ambiental, uma vez que os projetos consideram a sustentabilidade dos produtos gerados.

Vivan e Paliari (2012) aplicaram o DFA a uma edificação em sistema construtivo pré-fabricado em Light Steel Frame e apresentaram várias diretrizes para o processo de projeto e sua consequente representação. Como recomendação, os autores mencionaram que a aplicação do DFA pode ser altamente facilitada pelo uso de tecnologia da informação a partir de softwares BIM.

No caso das IP, entende-se que o processo de produção dos componentes em fábrica pode se beneficiar também dos conceitos do DFA.

\subsection{Design For Disassembly}

O Design For Disassembly (DFD), em português, Projeto para Desmontagem, é o processo de concepção de produtos, de modo que eles possam ser rápida e facilmente desmontados no final de sua vida útil, de forma rentável, e que proporcione a reutilização e/ou reciclagem dos componentes (BOOTHROYD; ALTING, 1992).

A concepção do DFD, por sua vez, considera que todo o processo posterior de desmontagem é pensado durante o desenvolvimento do projeto inicial, o que acarreta grandes benefícios para o reaproveitamento dos materiais e, logo, em um maior cuidado com o impacto ambiental. O processo de reuso, reciclagem e potencial conserto dos materiais gerados têm sido designados por diferentes nomes. 
O DFD aplicado à construção de edifícios, segundo Guy (2003), precisa considerar a criação de um plano de desconstrução que considere a rotulagem dos materiais e dos componentes constitutivos, categorizando-os de forma antecipada. Durante o processo de desmantelamento, é importante priorizar a disposição dos materiais na ordem de reutilização, remanufatura, reciclagem ou eliminação. O plano de desconstrução também deve prever o planejamento da gestão, programação e requisitos de segurança do processo de desconstrução.

Neste sentido, Barkkume (2008) argumenta que a desconstrução de edifícios não ocorre da maneira simplificada, sendo uma atividade complexa, que requer grande contingente de pessoas para sua realização, com necessárias considerações de segurança e saúde. Por isso, deve ser antecipadamente preparada durante a fase de projeto do produto, considerando os princípios do DFD. Para o referido autor, a desconstrução é uma alternativa inteligente à demolição, com fins de salvar materiais, componentes e a energia incorporada total.

Segundo Guy (2003), a tendência em pré-comercializar materiais para reutilização e reciclagem fornece um incentivo econômico para a desconstrução. Assim, Guy e Ohlsen (2003) desenvolveram um software para facilitar a análise do "negócio" da desconstrução, permitindo que os empreiteiros estimem o custo e o potencial de receita. Usando o computador, a ferramenta apresenta dados sobre a viabilidade da desconstrução e identifica variáveis econômicas, como uso de mão de obra local e custos de materiais recicláveis. O programa foi inicialmente concebido para sistemas construtivos de madeira com um e dois andares.

O projeto das IP realizado com essa concepção de DFP deve compreender uma fase de estudo do processo de desmontagem, que oriente como os componentes das instalações provisórias podem ser desmontados de forma segura, adequada à preservação do meio ambiente e ajustada ao orçamento da obra.

\section{5. $\mathrm{O}$ uso do BIM}

O termo BIM ora é tratado como modelo (Building Information Model), ora como processo (Building Information Modeling). No Brasil, quando entendido como um modelo, o BIM é chamado de Modelo da Informação da Construção. Porém, quando pensado na forma de processo, é denominado de Modelagem da Informação da Construção (BIOTTO, 2012).

A modelagem de informações de construção, segundo Florio (2007), é o processo de geração e gerenciamento de informações da construção de um modo interoperável e reutilizável. Os sistemas BIM adotam modelos paramétricos dos elementos construtivos de uma edificação e permitem o desenvolvimento de alterações dinâmicas no modelo gráfico, que se refletem em todas as pranchas de 
desenho associadas, bem como nas tabelas de orçamento e especificações (COELHO; NOVAES, 2008).

No Brasil, as empresas enfrentam dificuldades inerentes à introdução de ferramentas BIM, devido à falta de profissionais capacitados e de disseminação do assunto. Scheer et al. (2011) mencionam que, para que os benefícios do BIM possam ser plenamente atingidos, existe a necessidade das etapas de desenvolvimento do projeto e do planejamento serem realizadas de forma integrada com os principais agentes envolvidos.

Segundo Dispenza (2010), o BIM pode seguir todas as etapas do processo produtivo do edifício: análise de viabilidade, projeto conceitual, detalhamento do projeto, análise e cálculo estrutural, documentação (projetos, cronogramas, orçamentos etc.), pré-fabricação, execução, apoio logístico, operação e manutenção, renovação e demolição. Assim, o BIM facilita e possibilita que as informações estejam disponíveis por todo o ciclo de vida de uso do edifício.

Além de a edificação permanente ser, naturalmente, o objeto de uso de BIM, as construções temporárias em canteiro de obra também podem contar com esse tipo de ferramenta em sua concepção. De modo geral, espera-se que as fases de montagem e de desmontagem no canteiro sejam mais bem implementadas a partir de um estudo específico com uso de programas BIM.

\section{Estudos de Caso e Simulações}

A seguir, serão apresentados os principais resultados do trabalho relacionados às etapas de fabricação, montagem e desmontagem das IP.

\subsection{Fabricação das Instalações Provisórias}

Foi visitada uma fábrica produtora de instalações provisórias para canteiro de obras, localizada na cidade de São Paulo, que se dispôs a colaborar com a pesquisa. A fábrica teve sua origem em 1988, com o intuito primeiro de comercializar madeira. Posteriormente, dedicou-se à venda de edificações pré-fabricadas em madeira, buscando soluções padronizadas, adaptáveis e viáveis financeiramente.

Durante a visita, foram feitos registros fotográficos, tal como os indicados nas Figuras 3 a 6, a seguir. Verificou-se que, como o processo de produção é padronizado, a montagem de cada componente é rápida, totalizando dois minutos para o corte da madeira, cinco minutos para a montagem da tesoura e quatro minutos para a montagem dos painéis. Após a montagem, os componentes são estocados e ficam disponíveis para expedição às obras. 


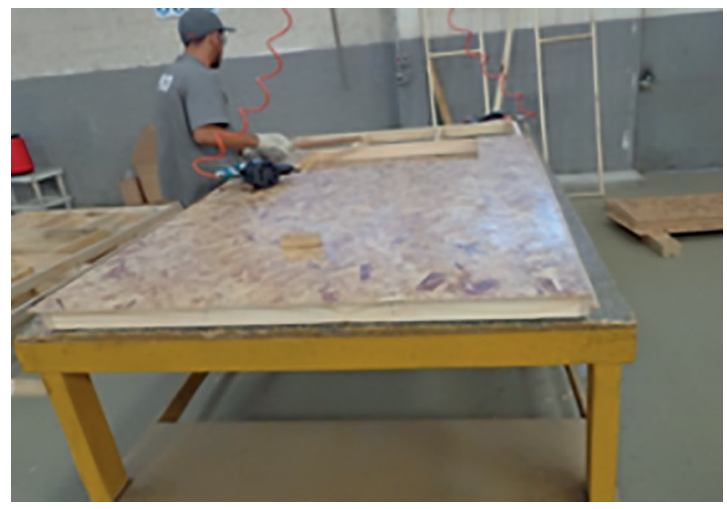

Figura 3 - Bancada para fabricação do painel. Fonte: Souza, 2016.

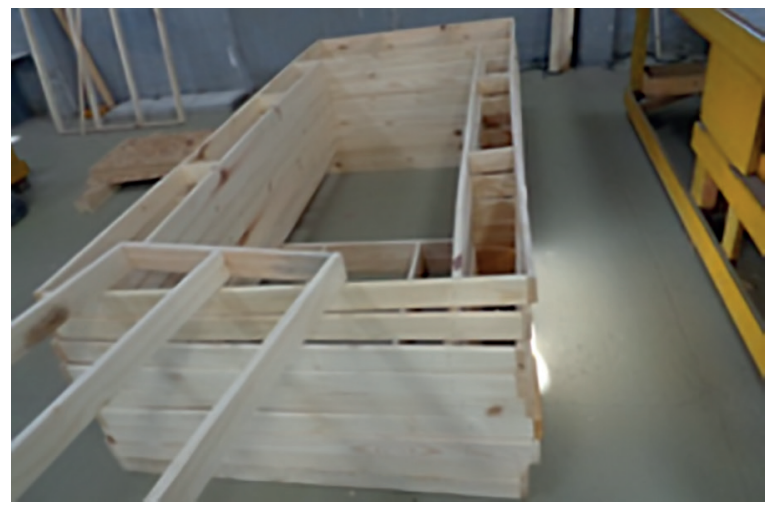

Figura 4 - Vista da estrutura dos painéis. Fonte: Souza, 2016.

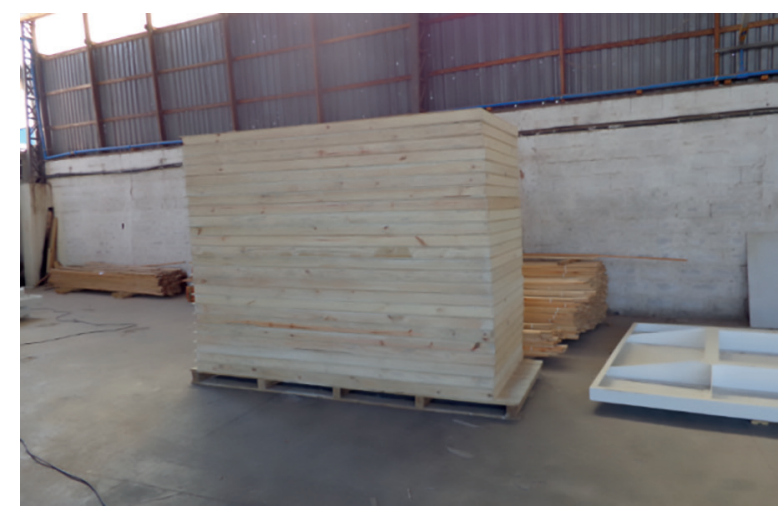

Figura 5 - Vista dos painéis estocados. Fonte: Souza, 2016. 


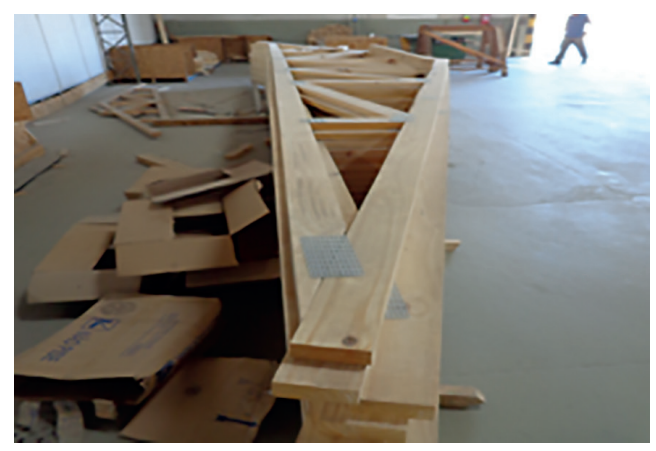

Figura 6 - Vista do estoque de tesouras da cobertura. Fonte: Souza, 2016.

A Figura 7 exemplifica o fluxograma do processo de fabricação dos componentes em madeira nessa fábrica, desde a extração da matéria prima em madeireira (compra de madeira certificada) até a estocagem e distribuição dos componentes.

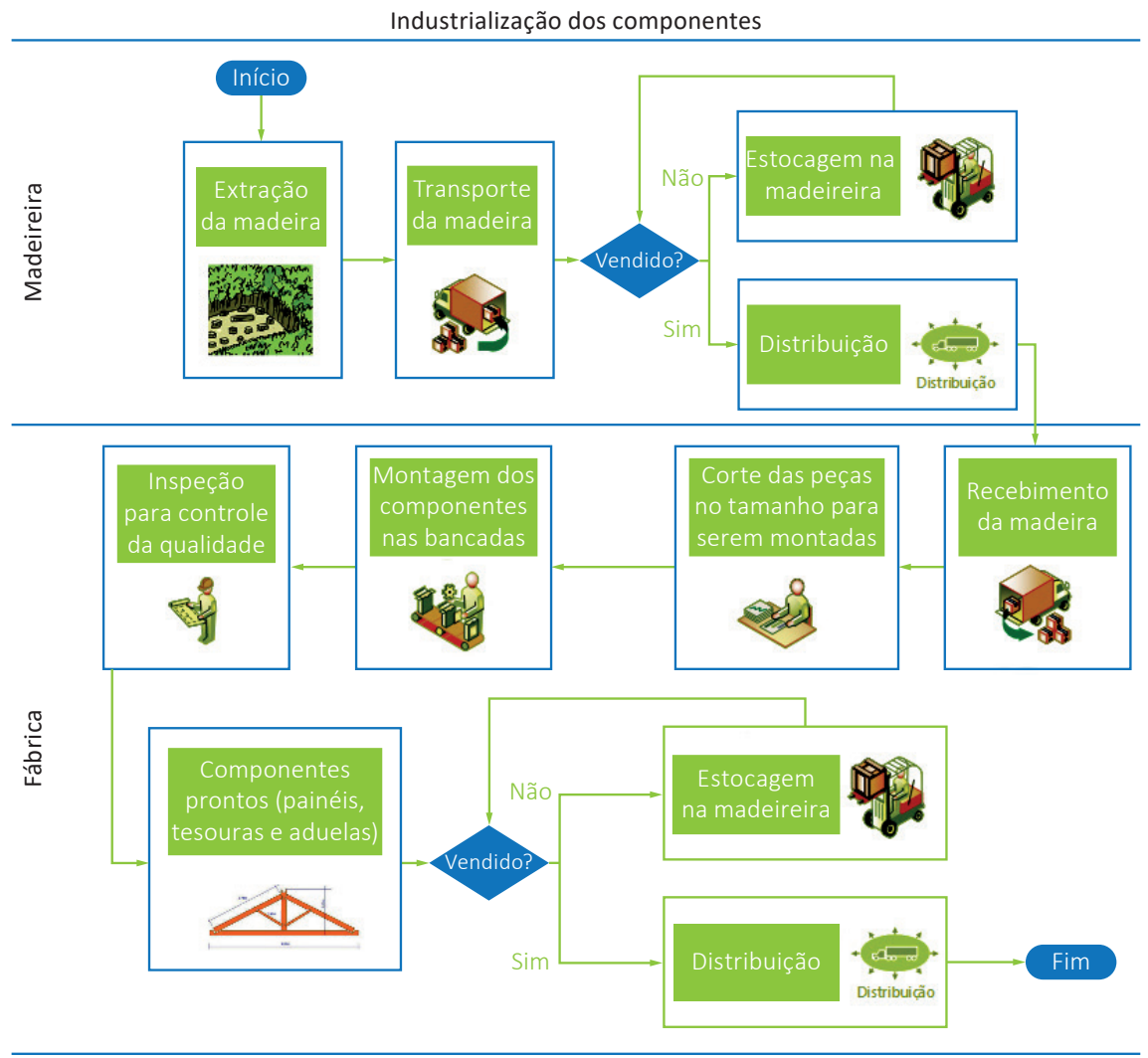

Figura 7 - Fluxograma do processo de fabricação dos componentes das instalações provisórias. Fonte: Souza, 2016. 
A partir do registro das etapas de produção, foi feita a simulação 4D da fabricação dos componentes, conforme Figura 8. Tal simulação foi obtida por meio da importação do modelo 3D e do planejamento da montagem no Navisworks. Primeiramente utilizou-se a ferramenta Autodesk Rendering para adicionar o tipo de material utilizado em cada elemento para que os componentes virtuais ficassem mais parecidos com o real. Foi necessário escolher a opção construction na ferramenta TimeLiner e associar cada componente do modelo 3D a uma atividade do planejamento, que podia ser visualizada e facilmente alterada no cronograma de Gantt. Depois, usou-se a opção simulate para exportar a animação em vídeo no formato "avi".

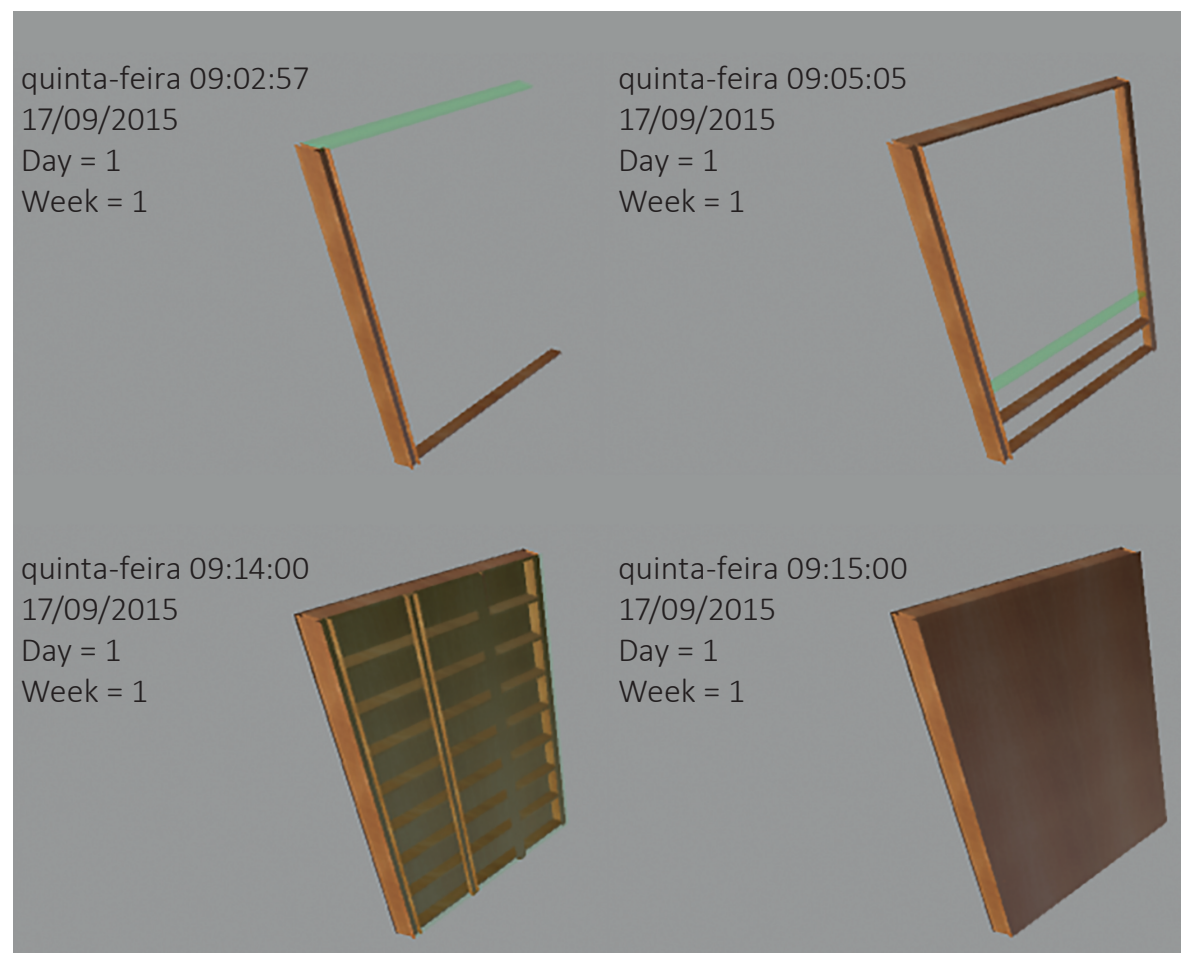

Figura 8 - Simulação 4D da fabricação do painel no Navisworks. Fonte: Souza, 2016.

O vídeo gerado pode servir para análise de melhorias e para o treinamento de operários, facilitando o processo de produção.

\subsection{Montagem das Instalações Provisórias no Canteiro de Obras}

Foi acompanhada a montagem das instalações provisórias pré-fabricadas de madeira, produzidas pela fábrica visitada. O canteiro de obras localizava-se numa área 
de cerca de $3.200 \mathrm{~m}^{2}$ na cidade de São Paulo e eram previstas quatro construções, de acordo com Figura 9. A tecnologia da edificação registrada com "perspectiva explodida" pode ser observada na Figura 10, na qual se veem os componentes padronizados previstos: painel, porta, esquadrias, tesoura do telhado, cobertura etc..

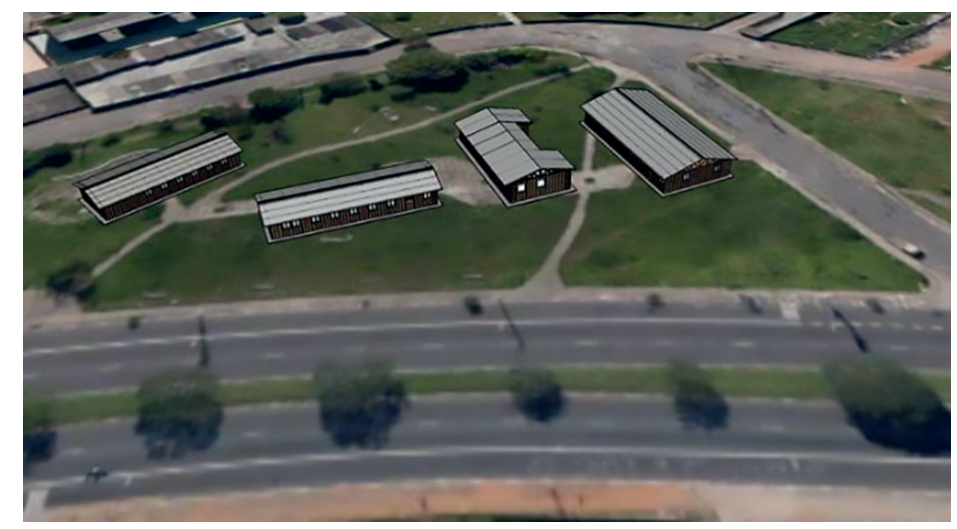

Figura 9 - Vista do canteiro de obras visitado - representação no SketchUp com mapa GoogleMaps. Fonte: Souza, 2016.

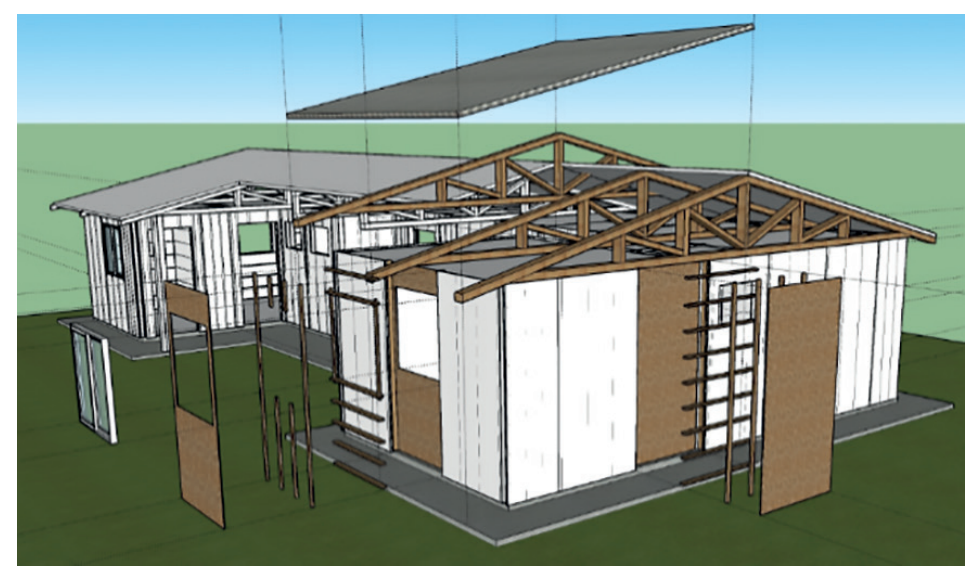

Figura 10 - Instalação provisória modelada e "explodida" no SketchUp. Fonte: Souza, 2016.

Foi escolhida uma das edificações previstas para ser modelada. Decidiu-se pelo detalhamento do projeto do escritório administrativo, conforme Figura 11, que possuía cerca de $200 \mathrm{~m}^{2}$. 


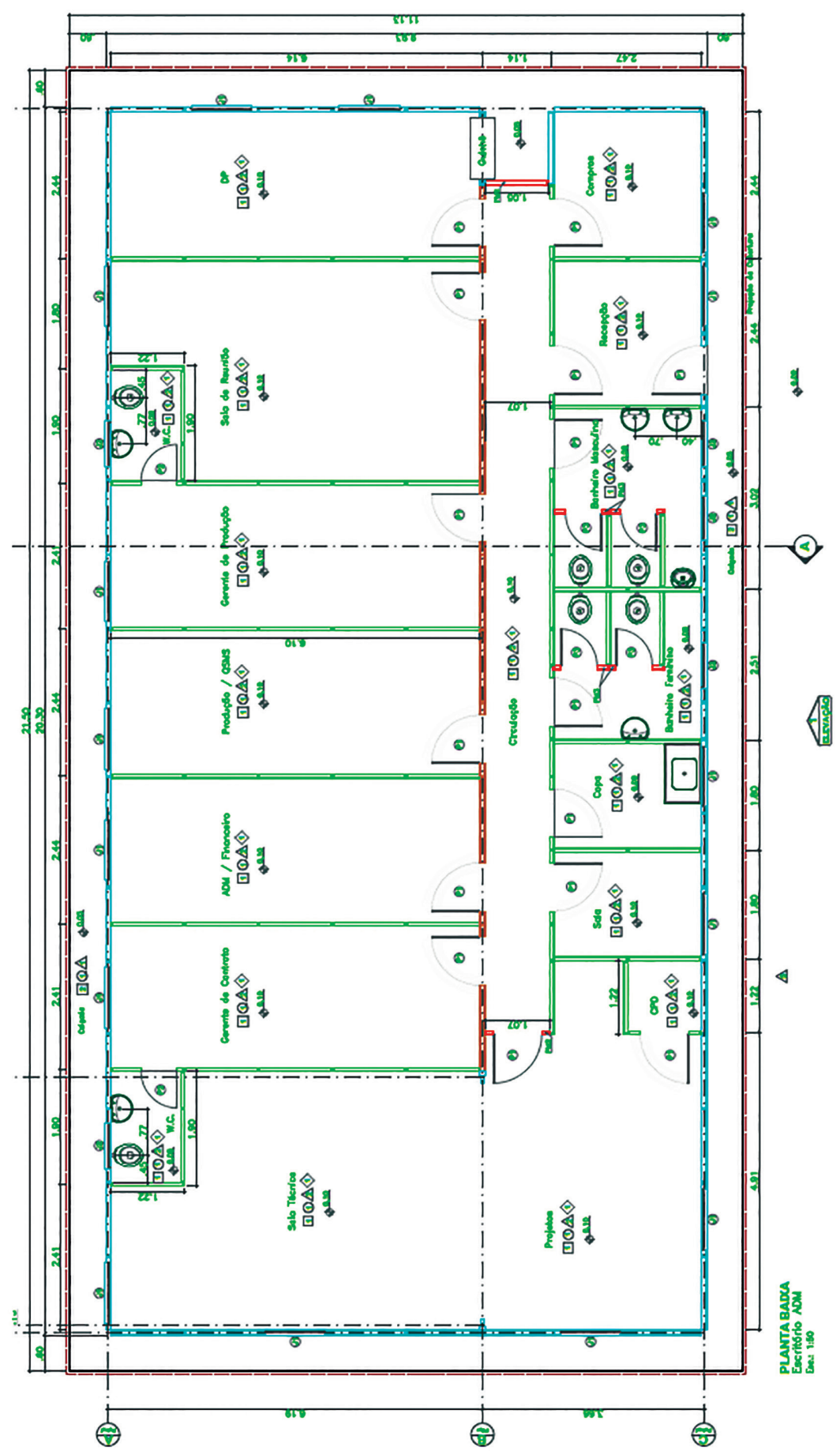

Figura 11 - Planta baixa da área administrativa. Fonte: Souza, 2016. 
As Figuras 12 a 15 mostram algumas fotos do acompanhamento da montagem das IP, sendo o primeiro passo a regularização do terreno, para que posteriormente se marcasse a fundação e se executasse o baldrame. Em seguida, inicia-se a montagem dos painéis (Figura 12). Posteriormente, instala-se uma cinta de amarração sobre os painéis e inicia-se a montagem do telhado (Figura 13). Os acabamentos finais são feitos em seguida, como a montagem de batentes para portas e janelas. Finalmente, coloca-se o forro (Figura 14) e instalam-se as peças sanitárias. A Figura 15 mostra a IP finalizada e pronta para o uso.

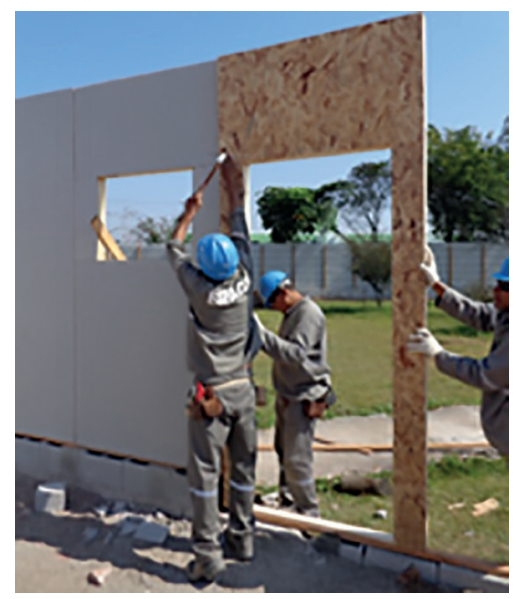

Figura 12 - Fixação dos painéis por meio de pregos com cabeça dupla. Fonte: Souza, 2016.

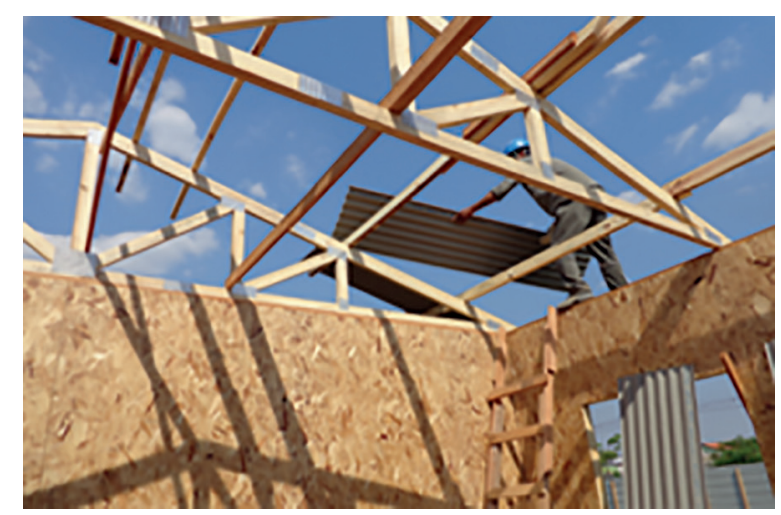

Figura 13 - Fixação das terças e telhas. Fonte: Souza, 2016. 


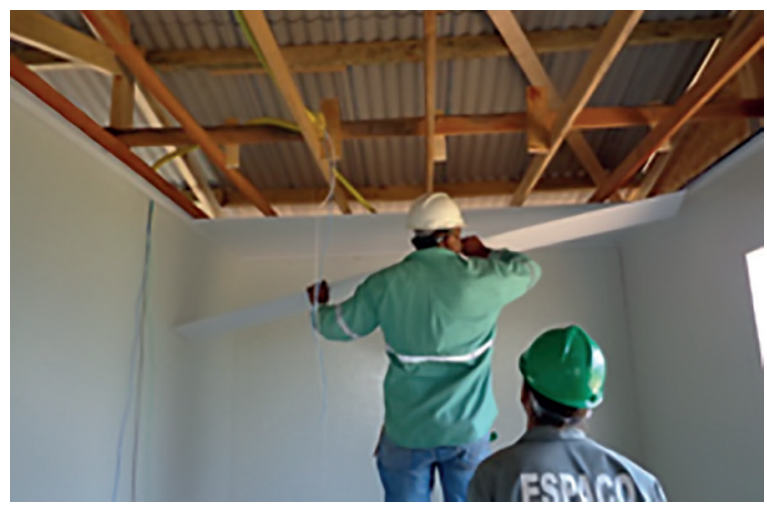

Figura 14 - Colocação do forro. Fonte: Souza, 2016.

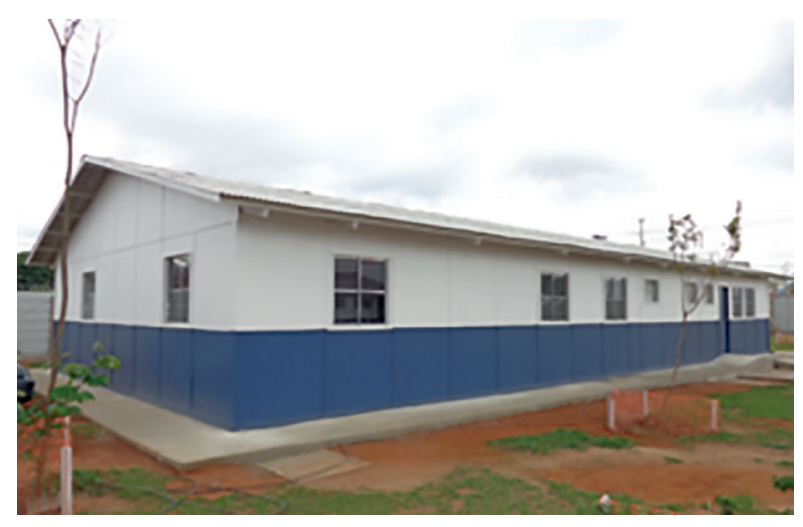

Figura 15 - Vista da obra finalizada. Fonte: Souza, 2016.

Durante o acompanhamento dos serviços, foi possível identificar alguns pontos de melhorias: (1) prover os módulos das aberturas (painéis) com as instalações prévias dos batentes - tal atividade poderia ter sido desenvolvida na fábrica em melhores condições operacionais; (2) alterar a sequência de atividades: antecipar a concretagem do contrapiso de forma a facilitar a execução dessa etapa e prover pavimentação para montagem da IP, melhorando a produtividade.

O processo de montagem dos componentes registrado durante a pesquisa está disposto na Figura 16, que sintetiza o processo realizado no canteiro até o acabamento final. 


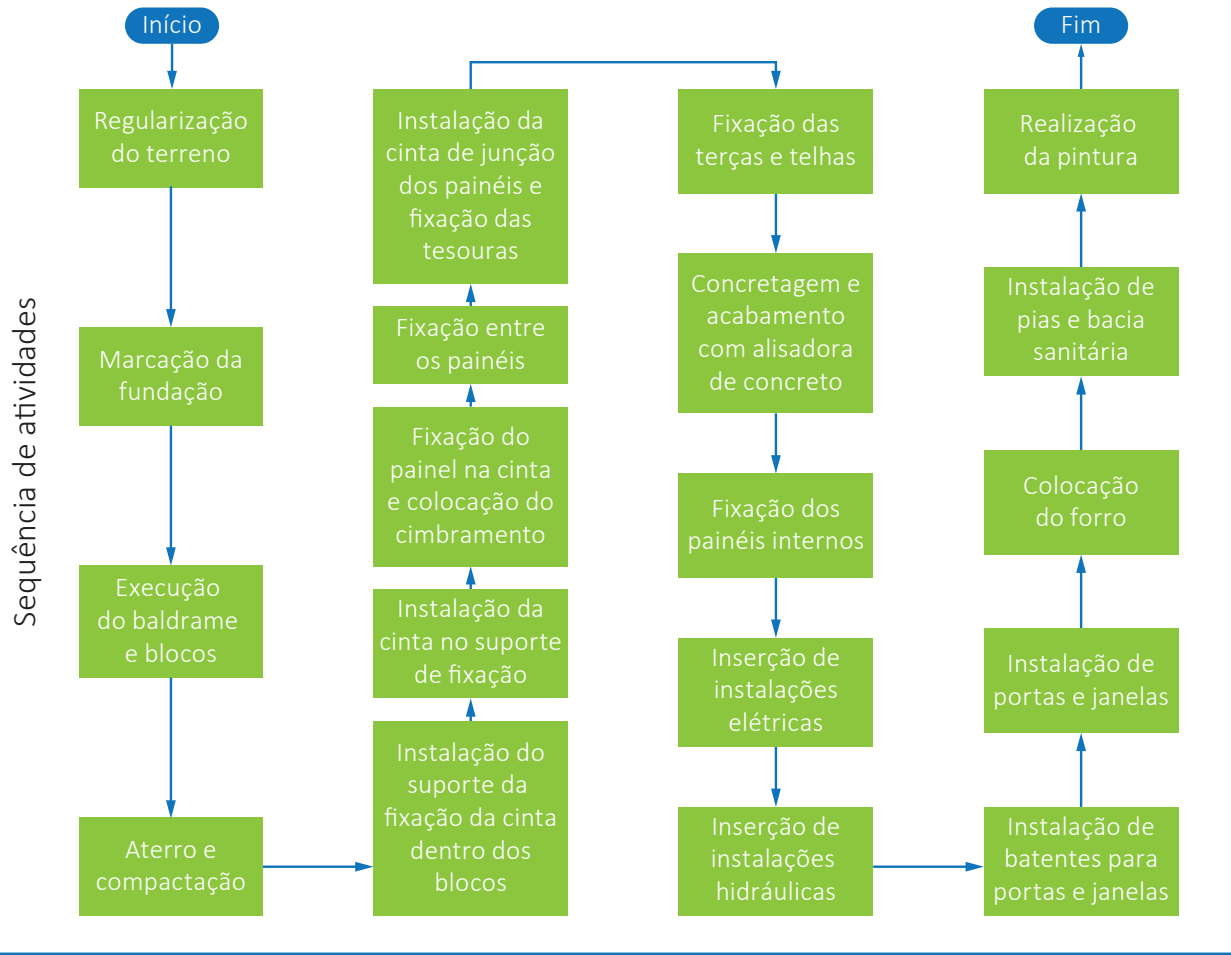

Figura 16 - Fluxograma de montagem dos componentes da IP na obra. Fonte: Souza, 2016.

Da mesma forma que o processo de fabricação, o processo de montagem das IP também foi simulado por meio da tecnologia BIM 4D, tal como na modelagem anterior. Usou-se também a ferramenta TimeLiner do Naviswork, conforme pode ser verificado na Figura 17.

A Figura 17 representa resumidamente algumas etapas do vídeo da simulação 4D no software Navisworks, na seguinte sequência: execução do baldrame, colocação de painéis, preparação para o telhado e obra concluída. 


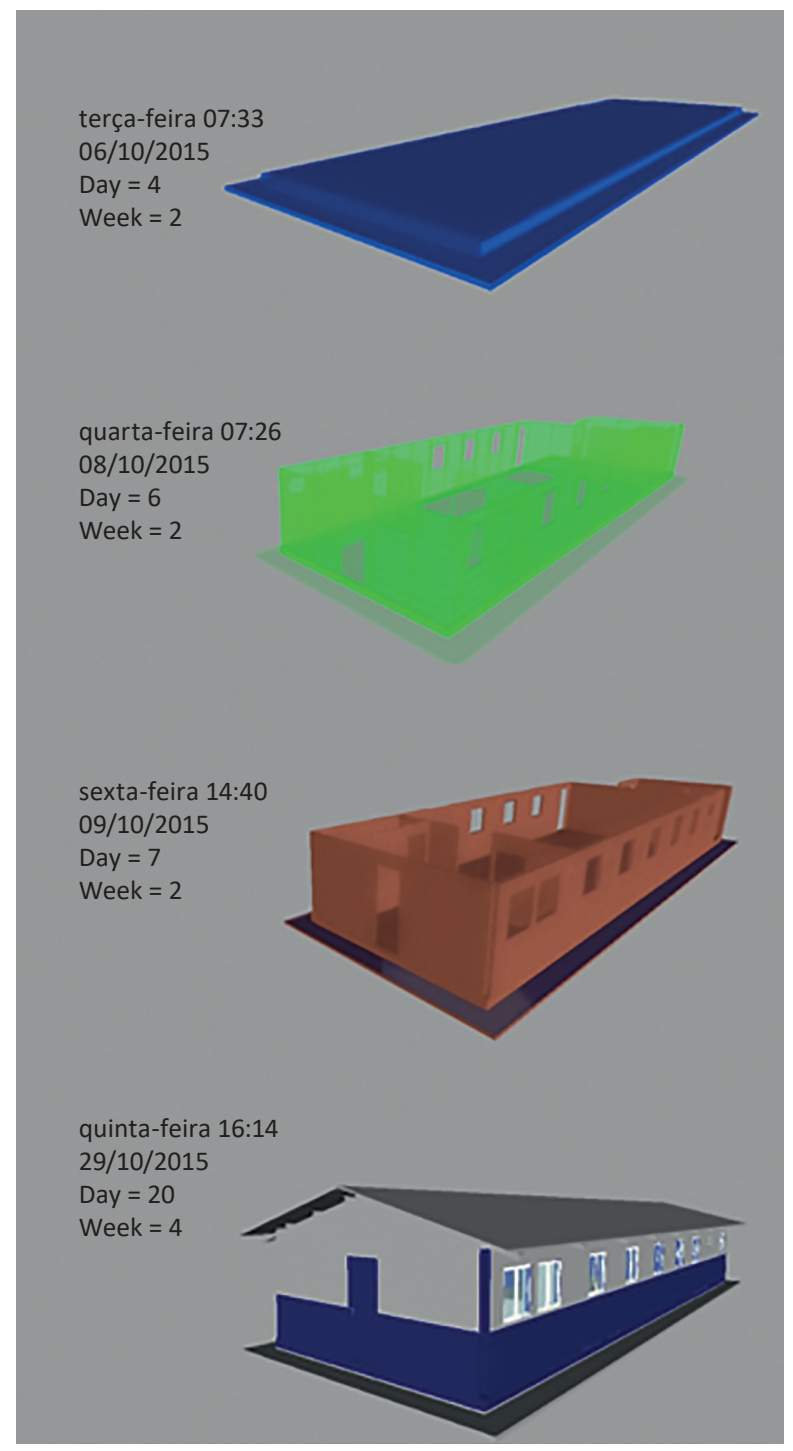

Figura 17 - Simulação 4D resumida da montagem da IP no Navisworks. Fonte: Souza, 2016.

\subsection{Desmontagem das Instalações Provisórias no Canteiro de Obras}

A simulação da desmontagem foi baseada em informações fornecidas pelo fabricante, pois não foi possível acompanhar tal etapa no canteiro de obras, durante o desenvolvimento do mestrado de Souza (2016). A desmontagem da construção foi considerada de maneira inversa à montagem observada no canteiro, tal como 
proposto por ITEC (1995). A Figura 18 ilustra o fluxograma das atividades previstas para a desmontagem, conforme relato do fabricante.

Desmontagem dos componentes na obra

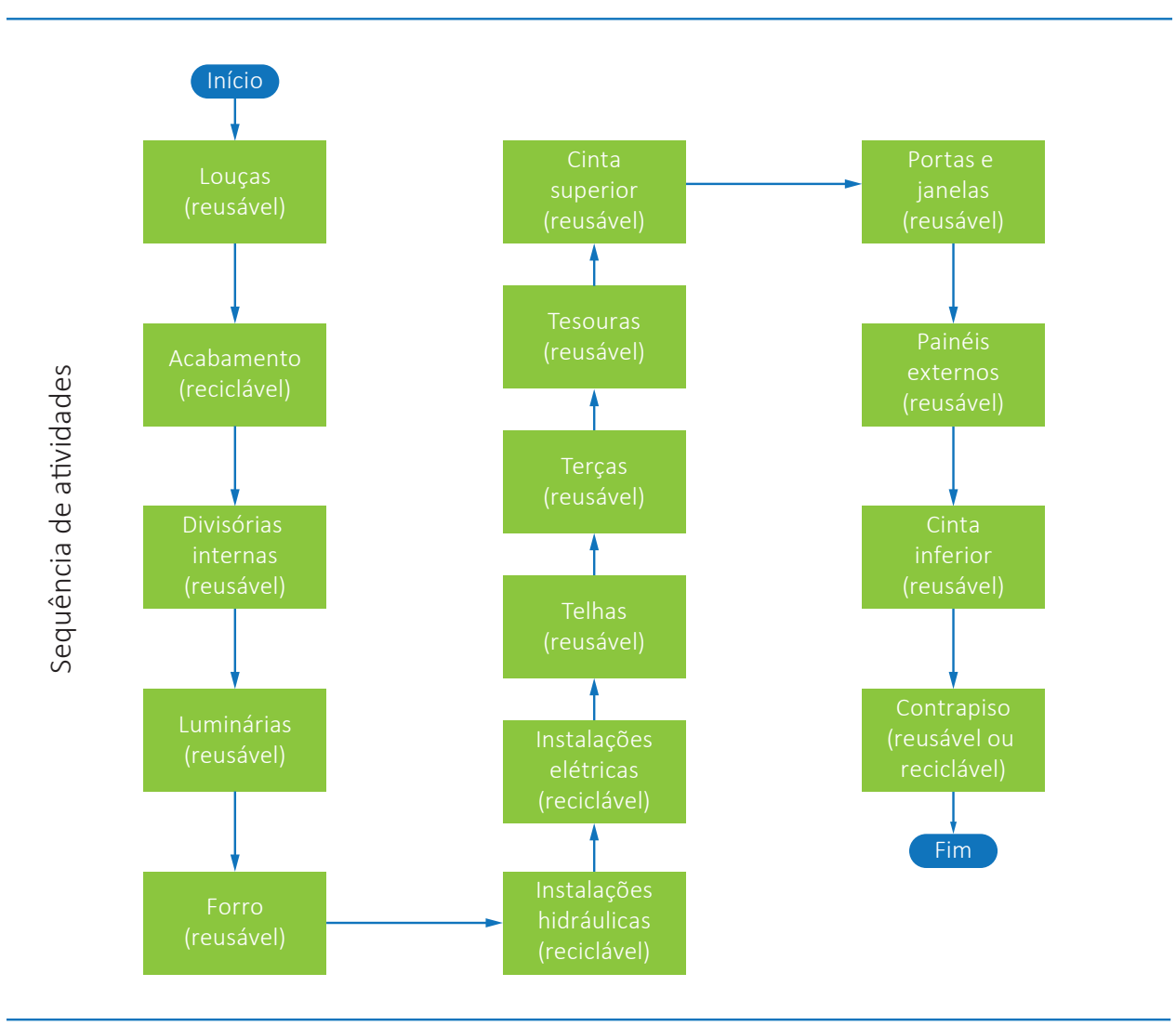

Figura 18 - Fluxograma de desmontagem dos componentes da IP na obra. Fonte: Souza, 2016.

A simulação 4D da desmontagem foi realizada com o mesmo modelo 3D da montagem, porém adaptou-se o planejamento no programa Navisworks de acordo com a sequência de desmontagem, conforme Figura 19. 


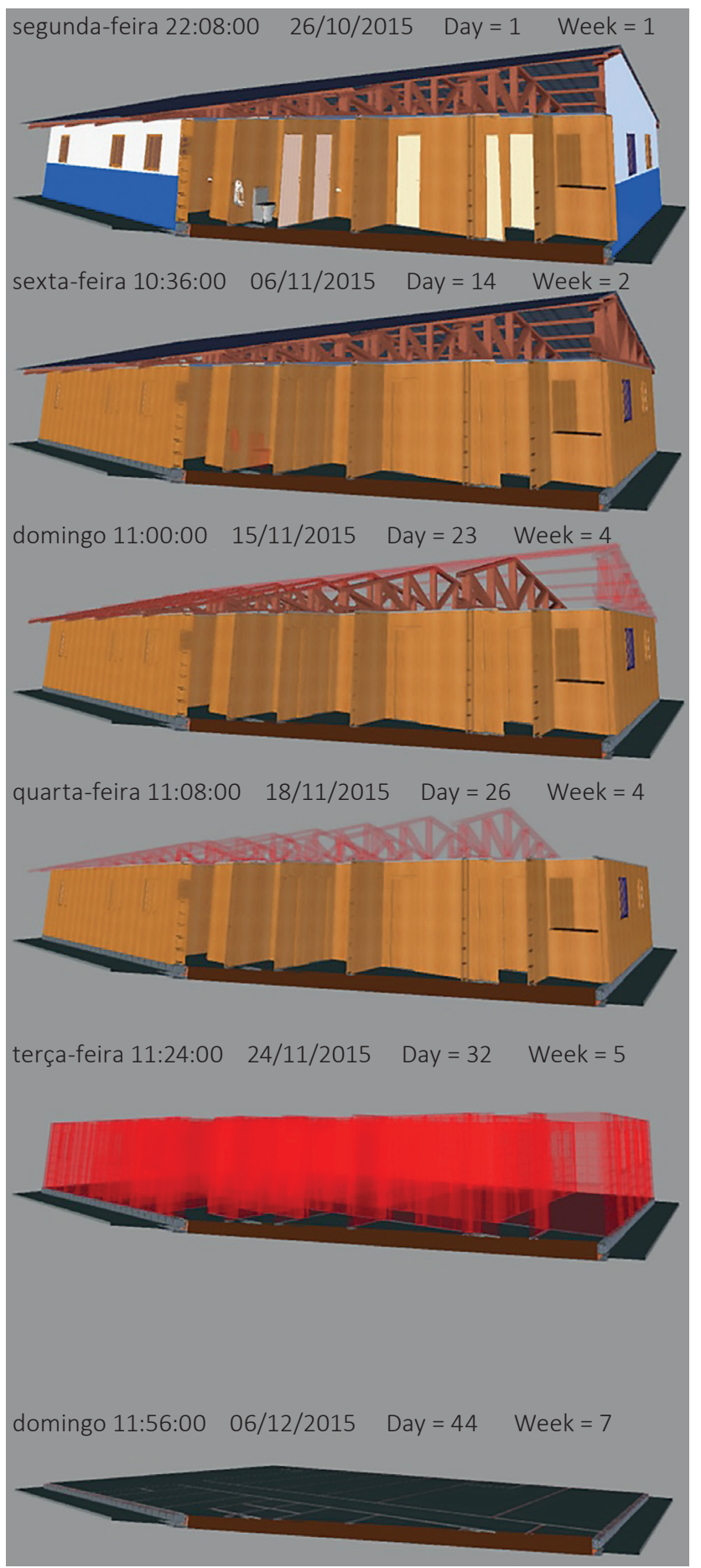

Figura 19 - Simulação 4D da desmontagem da IP no Navisworks. Fonte: Souza, 2016. 
A Figura 19 representa algumas etapas do vídeo da desmontagem dos componentes das instalações provisórias, na seguinte sequência: retirada das esquadrias e louças, retirada das telhas, das terças e das tesouras, retirada dos painéis e, por fim, é visualizado o contrapiso e a calçada, que permanecerão após a desmontagem, pois serão aproveitados para uma futura área pavimentada.

A simulação 4D da desmontagem foi modelada mais rapidamente devido à experiência anterior no Navisworks. Foi necessário alterar a opção construction para demolish na ferramenta TimeLiner. No cronograma, foi necessário alterar a duração prevista para a desmontagem. Depois, usou-se a opção simulate para exportar a animação em vídeo no formato "avi".

\section{Conclusões}

Este trabalho enfocou a importância do projeto para as IP considerando a possibilidade de desmontagem e remontagem e associando alguns benefícios ao se utilizar construções pré-fabricadas para canteiros de obras. A modelagem BIM 4D caracteriza-se como uma proposta inédita para a área de projetos, que facilita a visualização e simplificação das estruturas antes da montagem na obra.

Em relação ao acompanhamento durante a montagem, percebeu-se que as IP estudadas foram concebidas de modo a reduzir os resíduos gerados, pois foram poucos componentes cortados em obra. Destaca-se a necessidade de elaboração de um Projeto para Montagem e outro para a Desmontagem de forma compatibilizada, a fim de otimizar o uso da mão de obra, tempo e custo. No caso da desmontagem, devese prever a destinação dos materiais gerados a partir da desconstrução.

O potencial de uso do BIM para a fabricação dos componentes, do projeto do canteiro e de suas instalações pode ser percebido pelos agentes a partir desses exemplos. Além da visualização da concepção dos detalhes e do produto geral, é possível obter quantitativos de materiais e de serviços e, ainda, programar a montagem e a desmontagem. Na modelagem 4D, foi facilmente observado que alguns passos poderiam ser alterados como forma de melhorar a produtividade.

Os vídeos das simulações da construção foram gerados por meio da modelagem BIM 4D, sendo necessário contar com conhecimento dos processos de fabricação e de construção. Houve a necessidade de o pesquisador fazer várias simulações da modelagem virtual até chegar ao resultado que represente a realidade da melhor forma. Também foi necessário entender a integração entre os programas computacionais. Sabe-se que podem ser buscadas alternativas para combinação dos programas. 


\section{Referências}

AMARAL, A.T. O uso do método DFA (Design for Assembly) em projeto de produtos objetivando a melhoria ergonômica na montagem. 2007. 127f. Dissertação (Mestrado em Engenharia de Produção) - Universidade Federal de São Carlos, São Carlos.

BARKKUME, A. Deconstruction and Design for Disassembly. 2008. Disponível em <http:// www.academia.edu/178424/Deconstruction_and_Design_for_Disassembly>. Acesso em: dez. 2016.

BIOTTO, C.N. Método de gestão da produção na construção civil com uso da modelagem BIM 4D. 2012.182 f. Dissertação (Mestrado em Engenharia Civil) - Universidade Federal do Rio Grande do Sul, Porto Alegre.

BOOTHROYD, G.; ALTING, L. Design for Assembly and Disassembly. CIRP Annals Manufacturing Technology. v. 41, n. 2, 1992, pp. 625-636.

BRASIL. Ministério do Trabalho e Emprego. Norma Regulamentadora 18 (NR-18): Condições e meio ambiente de trabalho na indústria da construção. 2015. Disponível em: http://www. mte.gov.br/seguranca-e-saude-no-trabalho/normatizacao/normas-regulamentadoras/ norma-regulamentadora-n-18-condicoes-e-meio-ambiente-de-trabalho-na-industria-daconstrucao. Acesso em: dez. 2016.

COUTO, A.B.; COUTO, J.P.; TEIXEIRA, J.C. Desconstrução: uma ferramenta para a sustentabilidade da construção. In: Inovações Tecnológicas e Sustentabilidade, 2006, Anais... São Paulo. NUTAU 2006,

COELHO, S.B.; NOVAES, C.C. Modelagem de Informações para Construção (BIM) e Ambientes Colaborativos para Gestão de Projetos na Construção Civil. In: Workshop Brasileiro de Gestão do Processo de Projetos na Construção de Edifícios, 8., 2008. Anais... São Paulo, 2008.

CROWTHER, P. Design for Buildability and the Deconstruction Consequences. In: Design for Deconstruction and Material Reuse. CIB Publication, 272, 2002.

DIAS, C. M. Etapas do Ciclo de Vida de Construções Provisórias para Canteiros de Obras. 2013. 119f. Trabalho de Conclusão de Curso (Curso em Engenharia Civil) - Universidade Federal de São Carlos, São Carlos.

DISPENZA, K. The Daily Life of Building Information Modeling (BIM). 2010. Disponível em: http://buildipedia.com/aec-pros/design-news/the-daily-life-of-building-informationmodeling-bim. Acesso em: jan. 2016.

FLORIO, W. Contribuições do building information modeling no processo de projeto em arquitetura. In: Seminário TIC 2007 - Tecnologia da Informação e Comunicação na Construção Civil, 2007. Anais... Porto Alegre: TIC 2007.

GUY, B. Design for Deconstruction and Materials Reuse. 2003. Center for Construction and Environment, Gainesville, Florida; Scott Shell, Esherick, Homsey, Dodge \& Davis Architecture, San Francisco, CA. Disponível em: http://citeseerx.ist.psu.edu/viewdoc/ download?doi=10.1.1.624.9494\&rep=rep1\&type=pdf. Acesso em: dez. 2016. 
GUY, B.; OHLSEN, M. Creating business opportunities through the use of a deconstruction feasibility tool. Paper 3. 12p. 2003. In: CIB Publication 287. Proceedings of the 11th Rinker International Conference May 7-10, 2003 Gainesville, Florida, USA. Disponível em: http:// www.cce.ufl.edu/wp-content/uploads/2012/08/Deconstruction_and_Materials_Reuse. pdf. Acesso em: dez. 2016.

ITEC. Institut de la Tecnologia de la Construcción de Catalunya. Manual de Desconstrucción. 1995. Disponível em: <http://www20.gencat.cat/docs/arc/Home/LAgencia/Publicacions/ Residus\%20de\%20la\%20construccio/desconstr.pdf> Acesso em: dez. 2016.

KIBERT, C.J.; CHINI, A. R. Overview of Deconstruction in Selected Countries. CIB Publication 252, 2000.

KUO, T-C.; HUANG, S.H.; ZHANG, H-C. Design for manufacture and design for ' $X$ ': concepts, applications, and perspectives. Computers and Industrial Engineering. n. 41, 2001. p. 241260.

LIPSMEIER, K.; GÜNTHER, M. Manual Europeu de Resíduos da Construção de Edifícios. Minho: Institute for Waste Management and Contaminated Sites Treatment of Dresden University of Technology, v. 1, 2002.

LOPES, M. F. Implementação da desconstrução na indústria da construção nacional. $183 f$. 2013. Dissertação (Mestrado Integrado em Engenharia Civil) - Universidade do Minho, Portugal.

MANFREDINI, C; SATTLER, M.A. Estimativa da Energia Incorporada a Materiais de Cerâmica Vermelha no Rio Grande do Sul. Ambiente Construído, v. 5, n. 1, p.23-37, 2005.

REVEL, M. La prefabricacion em la construcion, 1.ed. 1973. Bilbao: Urmo. 457p.

SACKS, R.; PARTOUCHE, R. Empire State Building Project: Archetype of "Mass Construction". Journal of Construction Engineering and Management. v. 136, n. 6, p. 702-710, 2010.

SAURIN, T.A.; FORMOSO, C.T. Planejamento de canteiros de obra e gestão de processos. Recomendações Técnicas HABITARE. v. 3, 112p., 2006.

SCHEER, S.; CARVALHO, W.; SANTOS, A. Análise da situação atual e proposta para a produção e gestão de projetos civis em instituições públicas de ensino. In: Simpósio Brasileiro de Gestão e Economia da Construção (VII SIBRAGEC), 2011. Anais... Campinas, 2011.

SOUZA, F.B. Processo produtivo das instalações provisórias de madeira para canteiros de obras. 2016. 103f. Exemplar aprovado em qualificação de mestrado (Programa de Pósgraduação em Estruturas e Construção Civil) - Universidade Federal de São Carlos, São Carlos.

VIVAN, A.L.; PALIARI, J.C. Design for Assembly aplicado ao projeto de habitações em Light Steel Frame. Ambiente Construído, v. 12, n. 4, p. 101-115, 2012. 


\title{
Desempenho de Contêineres Metálicos para Instalações Provisórias em Canteiros de Obras
}

\author{
Francisco Ferreira Cardoso \\ Adriana Gouveia Rodrigo \\ Paula Venticinque Pompeu de Toledo Soares
}

\section{Introdução}

O uso de contêineres metálicos fabricados em aço para abrigo de atividades humanas ocorre no Brasil desde os anos 1980, inclusive em canteiros de obras. Nos anos recentes, coincidindo com o crescimento do setor da construção civil, houve uma mudança da qualidade dos produtos oferecidos no mercado. Paralelamente, se expandiu o reaproveitamento de contêineres marítimos não mais adequados ao transporte de cargas. Tal uso tem crescido motivado por fatores com impactos econômicos, como a rápida velocidade de montagem e a possibilidade de reuso, e também porque vão ao encontro dos objetivos de sustentabilidade perseguidos pelas empresas.

Para Birbojm (2001), as vantagens das instalações provisórias nos contêineres metálicos são flexibilidade, possibilidade de reuso, independência da fundação, facilidade de transporte, grande resistência a intempéries, curto tempo de montagem e desmontagem e grande número de arranjos internos, além da possibilidade de empilhamento, que reduz as necessidades de áreas no canteiro. A grande desvantagem, 
porém, é o pouco conforto, seguido dos custos iniciais mais elevados e limitações de marketing (as construções em madeira são mais facilmente adaptadas para visibilidade e divulgações, que são comuns, por exemplo, nos estandes de vendas).

Para os módulos sanitários, os contêineres mostram-se práticos, já que vêm completamente prontos, necessitando apenas de ligação com as redes. Por outro lado, a desvantagem é que, para contêineres que chegam montados na obra, deve-se prever o acesso de sua chegada e retirada, limitando as possibilidades de posicionamento. Outra limitação refere-se ao custo de locação, que pode inviabilizar o aluguel de contêineres para períodos muito longos. Já no caso da compra do contêiner, surge a necessidade da retirada dessa estrutura ao final da obra, podendo ser levada para outra edificação ou para um depósito.

Os contêineres marítimos trazem o risco de contaminação, conforme discutido em reportagem sobre o assunto (BARBOZA, 2015). Outro fator a ser considerado no reaproveitamento de contêineres marítimos é o peso elevado, maior que o dobro do peso de um contêiner construído para módulo habitável, fato que dificulta a logística de instalação, movimentação e desinstalação do canteiro de obras.

De todas as desvantagens de um contêiner, a mais marcante e que o estigmatiza é o desconforto, sobretudo térmico, mas também acústico, característica que associa o seu uso ao condicionamento artificial de ar e consequente gastos energéticos. Ideia que permanece mesmo se sabendo que o desempenho térmico pode ser melhorado pelo uso de revestimentos especiais das envoltórias, como mostra o trabalho de Costa (2015).

Como nas construções de caráter permanente, também nas provisórias a questão da sustentabilidade ambiental e social vem ganhando importância. Instalações com condições inadequadas de trabalho, normalmente, também estão associados a desperdícios de água e energia. Ainda sob o ponto de vista ambiental, é condenável o descarte e a não reutilização das instalações provisórias.

Além da questão do desempenho térmico e acústico, as instalações provisórias devem apresentar desempenho estrutural adequado, assim como oferecer estanqueidade à água. Na verdade, deve-se tratar o desempenho de tais instalações de forma sistêmica, semelhante à maneira como se tratam hoje as construções de caráter permanente, com a introdução da norma NBR 15575, conhecida como Norma de Desempenho.

Nesse contexto, o objetivo deste capítulo é discutir o desempenho de contêineres metálicos para instalações provisórias em canteiros de obras e apresentar a proposição de requisitos e critérios que contribuam para o seu correto projeto, fabricação, transporte e uso. O estudo aqui desenvolvido baseia-se no trabalho de Cardoso et al. (2013). 


\section{Tipologia dos Contêineres Metálicos}

Antes de se avançar no assunto, é preciso estabelecer uma tipologia de contêineres metálicos, no intuito de definir o tipo de contêiner que vai se abordado.

Os contêineres metálicos para instalações provisórias em canteiros de obras podem ser classificados:

- Quanto à origem: marítimos reaproveitados ou fabricados com finalidade específica;

- Quanto ao sistema estrutural: em estrutura reticulada, dotada de pilares, com fechamentos verticais sem função estrutural ou módulos cujos fechamentos verticais, em chapa de aço galvanizada dobrada formada a frio de seção trapezoidal, atuam também como estrutura. Ambos são dotados de plataforma formada por longarinas e transversinas que, no caso do segundo tipo, é responsável por, praticamente, toda a resistência do conjunto;

- Quanto ao uso e flexibilidade dos espaços internos: modelo vão livre, sem nenhuma divisória interna, utilizável, por exemplo, como escritório, depósito de materiais e vestiário ou modelo suíte, com banheiro e divisórias internas, podendo ser utilizado como escritório ou, ainda, modelo sanitário, com divisórias internas, bacias sanitárias, chuveiros, mictórios e pias; etc.;

- Quanto ao isolamento térmico oferecido: sem ou com isolamento, dotados de diferentes graus de desempenho.

O mercado oferece atualmente diferentes gamas de produtos, que se diferenciam tanto pelo sistema estrutural como pelo desempenho oferecido, com impactos significativos nos custos de locação e comercialização. Em termos de características dos produtos, além da questão estrutural e do uso dos espaços internos, é preciso considerar elementos como: os revestimentos nas paredes e isolamentos térmico e acústico, esquadrias de portas e janela, etc.

Outras variações podem ser observadas, como a forma de acesso ao produto comprados ou alugados ou obtidos sob a forma de comodatos. Finalmente, embora se fale em contêineres "metálicos", o metal utilizado é o aço.

Esse capítulo discute o desempenho de contêineres metálicos do tipo estrutura reticulada em aço, usados para instalações provisórias em canteiros de obras e fabricados com a finalidade específica de servirem a esse propósito. No que se refere ao uso e à flexibilidade dos espaços internos, as exigências de desempenho pouco variam. Quanto à presença do isolamento térmico, observa-se cada vez mais que as exigências de desempenho levam ao seu uso em um número crescente de produtos oferecidos ao mercado. 
O contêiner em estrutura reticulada apresenta a vantagem de poder se combinar tanto horizontalmente quanto verticalmente, podendo, ainda, ser empilhável de modo semelhante ao dos contêineres marítimos.

Em relação ao tempo de uso, tal tipo de instalação é considerado de uso prolongado, uma vez que é ocupado como espaço de trabalho durante o dia todo e por períodos que variam de dias a semanas, meses ou mesmo a poucos anos. Por outro lado, tem caráter transitório, visto ser utilizado e depois transferido para uso em outro local.

\section{Requisitos e Critérios de Desempenho para a Avaliação Técnica de Contêineres de Aço}

Discute-se a seguir diretrizes para a avaliação técnica de módulo tridimensional de aço do tipo contêiner empilhável usado em instalações provisórias para canteiros de obras, trazendo elementos que colaborem para o projeto de módulos capazes de atender às novas necessidades do mercado.

Tomou-se como base a norma NBR 15575: Edificações Habitacionais Desempenho (ABNT, 2013) e o documento europeu ETAG 023:2006 - Guideline for European Technical Approval of Prefabricated Building Units, semelhante a uma Diretriz para Avaliação Técnica de Produtos do Sistema Nacional de Avaliações Técnicas (SINAT) do Programa Brasileiro da Qualidade e Produtividade do Habitat (PBQP-H). Definiuse o tipo de módulo tridimensional estudado como o tradicionalmente utilizado em canteiros de obras nos países desenvolvidos e que, em visitas a obras e fabricantes brasileiros, mostrou-se um produto de oferta e uso crescentes no país (RODRIGO et al., 2015).

\subsection{Caracterização do Módulo Tridimensional}

O objeto a ser avaliado é o módulo tridimensional empilhável do tipo estrutura reticulada em aço, para uso em canteiros de obras, predominantemente em áreas administrativas e de vivência, do tipo contêiner de aço.

Do ponto de vista estrutural, são possíveis quatro tipos de módulo, que dão origem a diferentes combinações de montagem, conforme a Figura 1:

- Módulo tipo A - Unidade isolada, que funciona apoiada sobre o terreno e é capaz de se combinar com outros módulos apenas horizontalmente;

- Módulo tipo B - Unidade de baixo, que funciona apoiada sobre o terreno e é capaz de se combinar com outros módulos tanto horizontalmente quanto verticalmente para cima. A capacidade de suporte vertical Módulo tipo B deve ser declarada (no caso da Figura 1, até três módulos). 
- Módulo tipo C-Unidade intermediária, que funciona apoiada em um Módulo tipo B e é capaz de se combinar com outros módulos tanto horizontalmente quanto verticalmente para cima e para baixo. A capacidade de suporte vertical Módulo tipo $\mathrm{C}$ deve ser declarada (no caso da Figura 1, até dois módulos).

- Módulo tipo D - Unidade de cobertura, que funciona apoiada em um Módulo tipo B ou em um Módulo tipo C e é capaz de se combinar com outros módulos tanto horizontalmente quanto verticalmente para baixo.

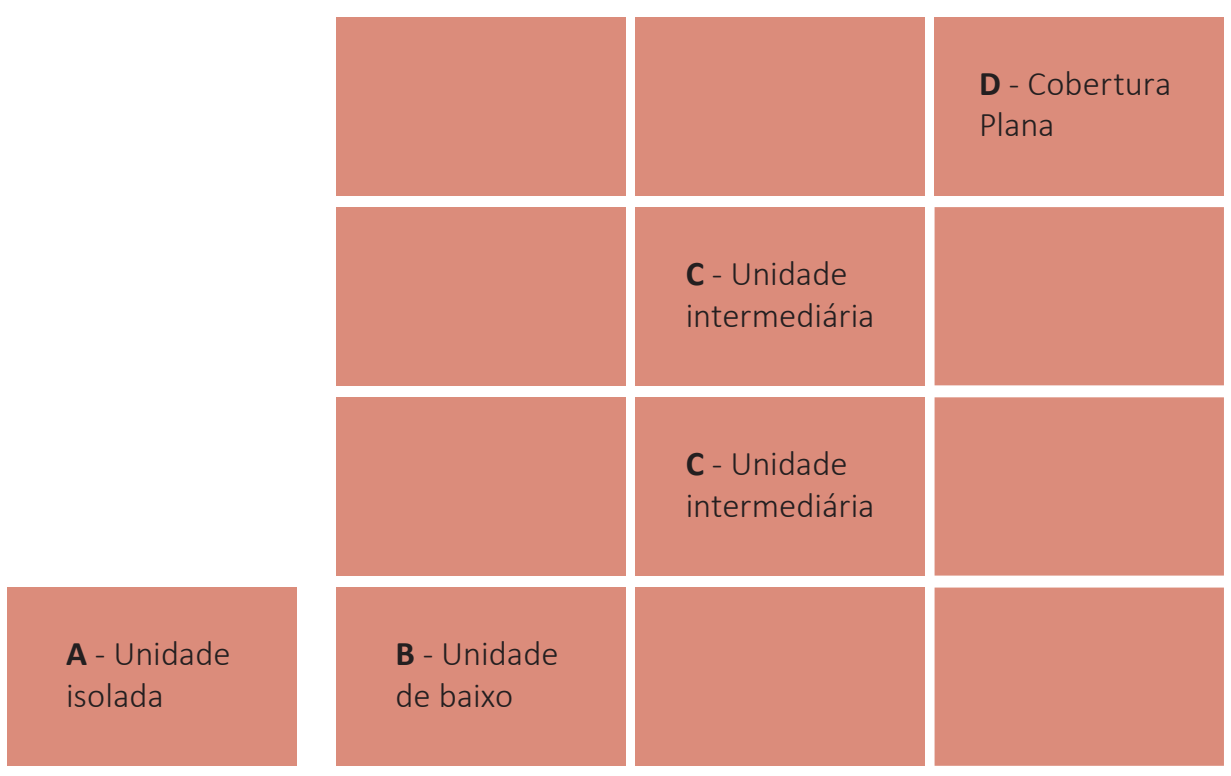

Figura 1 - Tipos de combinação vertical de módulos.

O empilhamento vertical e a conexão horizontal de módulos possibilitam a realização de diferentes arranjos espaciais, bem como a adaptabilidade do conjunto ao longo da duração da obra, por meio de ampliação, redução e rearranjo da combinação dos módulos.

O módulo é composto pelos seguintes materiais, componentes e elementos, nem todos necessariamente empregados:

- estrutura em aço com proteção anticorrosiva, é constituída por perfis dobrados formados a frio em diferentes configurações, com espessuras abaixo de $1 \mathrm{~mm}(0,47 \mathrm{~mm}, 0,65 \mathrm{~mm}$ e 0,80 mm) e aço com resistência mínima de escoamento de $230 \mathrm{MPa}$, constituída por estrutura vertical (Estrutura), chassi inferior (Piso), chassi superior (Cobertura). Em alguns casos, o conjunto inclui apoios, de altura variável, usualmente em aço, para elevar o módulo e para vencer desníveis do terreno; 
- sistemas de fixação constituídos de parafusos, rebites e chumbadores: fixação entre módulos, fixação do módulo ao apoio, fixação entre perfis de aço com parafusos ou rebites, fixação das chapas das vedações aos perfis de aço com parafusos ou rebites, fixação das telhas à estrutura da Cobertura, etc.;

- Vedações Verticais Externas e Internas (VVEI), sem função estrutural, usualmente feitas em chapa de aço dobrada formados a frio de seção trapezoidal, com espessuras abaixo de $1 \mathrm{~mm}(0,47 \mathrm{~mm}, 0,65 \mathrm{~mm}$ e $0,80 \mathrm{~mm}$ ) e com proteção anticorrosiva e eventual pintura, habitualmente complementadas com isolante térmico e absorvente acústico em suas faces internas. Outras soluções para as vedações verticais, com ou sem isolante térmico e absorvente acústico, podem ser consideradas, desde que atinjam os níveis mínimos de desempenho previstos, garantindo a habitabilidade do módulo;

- vedação horizontal superior montada no chassi superior (Cobertura), usualmente em chapa de aço dobrada formados a frio de seção trapezoidal (telha), com espessuras abaixo de $1 \mathrm{~mm}(0,47 \mathrm{~mm}, 0,65 \mathrm{~mm}$ e 0,80 mm), proteção anticorrosiva e eventual pintura, habitualmente complementadas com isolante térmico em sua face interna. Deve prever sistema para captação e escoamento de águas pluviais no caso dos Módulos dos tipos A e D;

- vedação horizontal inferior montada no chassi inferior (Piso), composta por revestimentos de piso em materiais diversos, como compensado naval ou outros derivados da madeira, revestimento de mantas vinílicas ou borracha. No caso de vedação horizontal inferior em contato com o solo, devem ser consideradas as ações externas específicas (Módulos dos tipos A e B), já no caso de pisos em áreas molhada, deve-se prever tratamento antifungos e impermeabilização (os revestimentos não fazem parte do objeto de avaliação da presente diretriz);

- isolantes térmicos, como poliuretano, poliestireno, placas de lã de rocha ou de lã de vidro, ou outros materiais. Tais componentes não fazem parte do objeto de avaliação da presente diretriz;

- materiais absorventes acústicos, como placas de lã de rocha ou lã de vidro e fibras cerâmicas. Esses elementos, no entanto, não fazem parte do objeto de avaliação da presente diretriz;

- componentes de acabamento interno de diferentes procedências, como placa cimentícia, régua de PVC (siding), chapa de OSB (Oriented Strand Board) e chapa de gesso acartonado (drywall). No caso de uso de placas de 
lã de rocha ou de lã de vidro, elas devem ser combinadas com material de acabamento interno adequado. Esses componentes, porém, não fazem parte do objeto de avaliação da presente diretriz;

- pinturas externas, compatíveis com os componentes estruturais e de vedação, que não serão objetos de avaliação da presente diretriz;

- pinturas e texturas internas, compatíveis com os componentes estruturais e de vedação, que não serão objetos de avaliação da presente diretriz;

- portas e janelas em aço, alumínio, PVC ou outro material, com ou sem vidros embutidos. Tais componentes não fazem parte do objeto de avaliação da presente diretriz;

- instalações elétricas, normalmente passadas pela estrutura e fixadas externamente nas vedações pelas suas faces internas, sendo adequadamente aterradas. Deve-se prever conexão externa para entrada da energia, quadro interno, disjuntores, uma ou duas tomadas internas, interruptores e luminárias; além da instalação de aparelho de ar condicionado, se for o caso. Tais instalações não fazem parte do objeto de avaliação da presente diretriz;

- instalações hidrossanitárias, no caso de módulo sanitário ou de apoio que exija a presença de água (copas e cozinhas), deve haver ponto de entrada de água e ponto de saída de esgoto, para conexões com redes. O módulo pode prever caixa inferior de dejetos, eventualmente com o uso de químicos; nesse caso, a conexão com o esgoto não é necessária. Essas instalações não fazem parte do objeto de avaliação da presente diretriz.

Os tipos de perfis de aço formados a frio que estruturam o módulo podem assumir diversas seções transversais, mas devem atender às dimensões mínimas e tolerâncias dimensionais estabelecidas na NBR 6355. A resistência de escoamento do aço deve estar de acordo com as exigências constantes na NBR 6673. No caso dos painéis de vedação, deve ainda observar a NBR 15253.

$\mathrm{O}$ aço utilizado nos perfis pode ter dois tipos de revestimento: zincado ou alumínio-zinco, ambos aplicados por processo continuo de imersão a quente. Como o revestimento garante o desempenho à corrosão, deve-se demonstrar que todos os elementos estruturais em aço possuem tal proteção.

Qualquer outro material ou componente pode ser empregado mediante identificação de suas características, segundo normas técnicas pertinentes ou critérios específicos, e mediante comprovação de adequação com o desempenho esperado do módulo. 


\subsection{Requisitos e Critérios de Desempenho}

Os requisitos de desempenho aqui definidos estão alinhados com os da NBR 15575, em suas diferentes partes, e estão organizados nos seguintes temas, que expressam as exigências dos usuários relativas à segurança, à habitabilidade e à sustentabilidade do módulo e das instalações dos canteiros de obras que o empregam:

1. Desempenho estrutural;

2. Segurança contra incêndio;

3. Segurança no uso e operação;

4. Funcionalidade e acessibilidade;

5. Conforto tátil e antropodinâmico;

6. Desempenho térmico;

7. Desempenho acústico;

8. Desempenho lumínico;

9. Estanqueidade à água;

10. Durabilidade e manutenibilidade;

11. Saúde, higiene e qualidade do ar;

12. Adequação ambiental: gestão de resíduos;

13. Adequação ambiental: gestão da energia;

14. Adequação ambiental: gestão da água;

15. Adequação ambiental: escolha de materiais.

Os requisitos e seus respectivos critérios de desempenho são apresentados nos itens 1 a 15, a seguir, preferencialmente sob a forma de quadros comentados. Cada requisito refere-se a um ou mais dos subsistemas do módulo.

\subsubsection{Desempenho Estrutural}

Os requisitos de desempenho estrutural visam assegurar o atendimento, durante a vida útil de projeto do módulo e sob as diversas condições de exposição (como ação do peso próprio; sobrecargas de utilização; atuações do vento; ações de transporte, montagem e desmontagem; e outros), às seguintes características do módulo:

- não ruir ou perder a estabilidade de nenhuma de suas partes;

- prover segurança aos usuários em situações como a ação de impactos, choques, vibrações e outras solicitações decorrentes da sua utilização normal;

- não provocar sensação de insegurança aos usuários devido a deformações de seus elementos;

- não prejudicar as manobras normais de partes móveis, tais como portas e janelas, nem prejudicar o funcionamento normal das instalações como consequência das deformações dos elementos estruturais. 
Em vista disso, o Quadro 1 traz o conjunto de exigências relacionadas ao desempenho estrutural.

Quadro 1 - Conjunto de exigências relacionadas ao desempenho estrutural.

\begin{tabular}{|c|c|c|c|c|c|}
\hline \multicolumn{2}{|c|}{ Requisito } & \multirow{2}{*}{$\begin{array}{l}\text { Critério } \\
\text { Estado limite } \\
\text { último }\end{array}$} & \multirow{2}{*}{$\begin{array}{l}\text { Aplicação } \\
\text { Estrutura } \\
\text { Piso } \\
\text { Cobertura } \\
\text { VVEI }\end{array}$} & \multirow{2}{*}{\begin{tabular}{|l} 
Indicador \\
Resistência e \\
estabilidade \\
estrutural
\end{tabular}} & \multirow{2}{*}{$\begin{array}{l}\text { Origem } \\
\text { NBR 15575-2 } \\
\text { ETAG } 023(4.1, \\
5.1 \text { e } 6.1)\end{array}$} \\
\hline 1.1 & $\begin{array}{l}\text { Resistência } \\
\text { estrutural e } \\
\text { estabilidade global }\end{array}$ & & & & \\
\hline 1.2 & Deformação & $\begin{array}{l}\text { Estado limite de } \\
\text { serviço }\end{array}$ & $\begin{array}{l}\text { Estrutura } \\
\text { Piso } \\
\text { Cobertura } \\
\text { VVEI }\end{array}$ & $\begin{array}{l}\text { Não deformar } \\
\text { excessivamente }\end{array}$ & $\begin{array}{l}\text { NBR 15575-2 } \\
\text { NBR 15575-4 } \\
\text { ETAG } 023(4.1, \\
5.1 \text { e } 6.1)\end{array}$ \\
\hline 1.3 & $\begin{array}{l}\text { Impactos de corpo } \\
\text { mole }\end{array}$ & $\begin{array}{l}\text { Energia de } \\
\text { impacto mínima } \\
\text { (J) }\end{array}$ & $\begin{array}{l}\text { Estrutura } \\
\text { Piso } \\
\text { Cobertura } \\
\text { VVEI }\end{array}$ & $\begin{array}{l}\text { Resistência e } \\
\text { deslocamentos } \\
\text { instantâneo e } \\
\text { residual }\end{array}$ & $\begin{array}{l}\text { NBR 15575-2 } \\
\text { NBR 15575-4 }\end{array}$ \\
\hline 1.4 & $\begin{array}{l}\text { Solicitação de } \\
\text { cargas verticais } \\
\text { concentradas }\end{array}$ & $\begin{array}{l}\text { Resistência a } \\
\text { cargas verticais } \\
\text { concentradas }\end{array}$ & $\begin{array}{l}\text { Piso } \\
\text { Cobertura }\end{array}$ & $\begin{array}{l}\text { Resistência e } \\
\text { deslocamento }\end{array}$ & NBR 15575-3 \\
\hline 1.5 & $\begin{array}{l}\text { Solicitação } \\
\text { de cargas } \\
\text { provenientes de } \\
\text { peças suspensas }\end{array}$ & $\begin{array}{l}\text { Capacidade } \\
\text { de suporte } \\
\text { para peças } \\
\text { suspensas }\end{array}$ & VVEI & $\begin{array}{l}\text { Inexistência de } \\
\text { danos quando } \\
\text { submetido à } \\
\text { carga de peça } \\
\text { suspensa }\end{array}$ & NBR 15575-4 \\
\hline 1.6 & $\begin{array}{l}\text { Solicitações } \\
\text { transmitidas por } \\
\text { portas para as } \\
\text { vedações verticais }\end{array}$ & $\begin{array}{l}\text { Ações } \\
\text { transmitidas por } \\
\text { fechamentos } \\
\text { bruscos de } \\
\text { portas }\end{array}$ & VVEI & $\begin{array}{l}\text { Resistência do } \\
\text { acoplamento } \\
\text { e da folha da } \\
\text { porta }\end{array}$ & NBR 15575-4 \\
\hline 1.7 & $\begin{array}{l}\text { Cargas de } \\
\text { ocupação em } \\
\text { guarda-corpos }\end{array}$ & $\begin{array}{l}\text { Resistência a } \\
\text { ações estáticas } \\
\text { horizontais, } \\
\text { verticais e de } \\
\text { impactos }\end{array}$ & $\begin{array}{l}\text { Guarda- } \\
\text { corpos }\end{array}$ & $\begin{array}{l}\text { Resistência do } \\
\text { guarda-corpo }\end{array}$ & NBR 15575-4 \\
\hline 1.8 & $\begin{array}{l}\text { Possibilidade de } \\
\text { caminhamento na } \\
\text { Cobertura }\end{array}$ & $\begin{array}{l}\text { Resistência } \\
\text { a cargas } \\
\text { concentradas }\end{array}$ & $\begin{array}{l}\text { Cobertura } \\
\text { acessível ao } \\
\text { usuário para } \\
\text { efeito de } \\
\text { montagem e } \\
\text { manutenção }\end{array}$ & $\begin{array}{l}\text { Carga vertical } \\
\text { concentrada } \\
\text { mínima e } \\
\text { forma de } \\
\text { deslocamento } \\
\text { das pessoas }\end{array}$ & NBR 15575-5 \\
\hline
\end{tabular}


Deve ser elaborado o cálculo estrutural específico para o módulo, por profissional habilitado, com a respectiva memória de cálculo. No caso de Vedações Verticais Internas e Externas (VVEI) estruturais, o espaçamento entre montantes, a quantidade de travessas, bloqueadores e de barras de contraventamento dependerão de cada projeto específico.

As VVEI, a vedação horizontal superior (Cobertura) e a vedação horizontal inferior (Piso) podem ser consideradas como componentes de contraventamento.

As cargas laterais (cargas de vento) devem ser consideradas conforme a NBR 6123, já o deslocamento horizontal no topo do módulo deve atender ao critério estabelecido na NBR 14762.

A memória de cálculo deve apresentar hipóteses de cálculo, cargas consideradas, verificação da estabilidade dos perfis, conforme a NBR 14762, dimensionamento de chumbadores de fixação do Piso ao apoio de fundação e dimensionamento das fixações entre módulos, no caso do empilhamento vertical.

Em relação à Cobertura, é preciso considerar o peso próprio dos materiais e cargas de vento característica da região mais crítica prevista para uso do módulo, atentando para a resistência das fixações entre perfis e para o espaçamento e espessura dos mesmos.

Na avaliação do requisito Deformação, sob a ação de cargas gravitacionais, de temperatura, de vento ou quaisquer outras solicitações passíveis de atuarem sobre o módulo, os componentes estruturais (perfis de aço) não devem apresentar deslocamentos maiores que os estabelecidos nas normas de projeto estrutural, estipuladas pela NBR 14762 e pela NBR 15575-2. Também não devem impedir o livre funcionamento de componentes como portas e janelas, nem prejudicar o funcionamento das instalações.

\subsubsection{Segurança Contra Incêndio}

Os requisitos de segurança contra incêndio são pautados em proteger a vida dos ocupantes, evitar a propagação de inflamação generalizada, proporcionar meios de controle e extinção do incêndio e dar condições de acesso ao corpo de bombeiros, incluindo a minimização de risco de colapso estrutural.

O Quadro 2 traz o conjunto de exigências relacionadas à segurança contra incêndio. 
Quadro 2 - Conjunto de exigências relacionadas à segurança contra incêndio.

\begin{tabular}{|l|l|l|l|l|l|}
\hline \multicolumn{2}{|l|}{ Requisito } & Critério & Aplicação & Indicador & Origem \\
\hline 2.1 & $\begin{array}{l}\text { Dificuldade } \\
\text { de inflamação } \\
\text { generalizada }\end{array}$ & $\begin{array}{l}\text { Propagação } \\
\text { superficial da } \\
\text { chama }\end{array}$ & $\begin{array}{l}\text { VVEI } \\
\text { Piso } \\
\text { Cobertura }\end{array}$ & $\begin{array}{l}\text { Índice máximo } \\
\text { de propagação } \\
\text { superficial (Ip) }\end{array}$ & NBR 15575-3 \\
NBR 15575-5 \\
\hline 2.2 & $\begin{array}{l}\text { Facilidade de } \\
\text { fuga }\end{array}$ & $\begin{array}{l}\text { Densidade } \\
\text { específica ótica } \\
\text { de fumaça }\end{array}$ & $\begin{array}{l}\text { VVEI } \\
\text { Piso } \\
\text { Cobertura }\end{array}$ & $\begin{array}{l}\text { Densidade máxima } \\
\text { específica ótica de } \\
\text { fumaça (Dm) }\end{array}$ & NBR 15575-3 \\
NBR 15575-5 \\
\hline $\begin{array}{l}\text { Minimização de } \\
\text { risco de colapso } \\
\text { estrutural }\end{array}$ & $\begin{array}{l}\text { Resistência ao } \\
\text { fogo }\end{array}$ & $\begin{array}{l}\text { Estrutura } \\
\text { Piso } \\
\text { Cobertura }\end{array}$ & Resistência ao fogo & NBR 15575-1 \\
\hline
\end{tabular}

\subsubsection{Segurança no Uso e Operação}

O módulo deve ser fabricado e as combinações de módulos devem ser projetadas de forma a prover segurança no uso e operação.

É necessário dar atenção especial às instalações elétricas, em conformidade com as normas pertinentes, no intuito de evitar choques e incêndios. O projeto deve impedir que o usuário se machuque, seja por esbarrar em quinas ou superfícies cortantes, seja por escorregar ou tropeçar (em frestas e desníveis).

O Quadro 3 traz o conjunto de exigências relacionadas à segurança no uso e operação.

Quadro 3 - Conjunto de exigências relacionadas à segurança no uso e operação.

\begin{tabular}{|l|l|l|l|l|l|}
\hline \multicolumn{2}{|l|}{ Requisito } & Critério & Aplicação & Indicador & Origem \\
\hline 3.1 & $\begin{array}{l}\text { Segurança na } \\
\text { utilização }\end{array}$ & $\begin{array}{l}\text { Partes expostas } \\
\text { cortantes ou } \\
\text { perfurantes }\end{array}$ & Módulo & $\begin{array}{l}\text { Inexistência de } \\
\text { partes expostas } \\
\text { cortantes ou } \\
\text { perfurantes }\end{array}$ & NBR 15575-1 \\
\hline 3.2 & $\begin{array}{l}\text { Resistência ao } \\
\text { escorregamento }\end{array}$ & $\begin{array}{l}\text { Coeficiente de } \\
\text { atrito dinâmico } \\
\text { de revestimentos } \\
\text { cerâmicos }\end{array}$ & Piso & $\begin{array}{l}\text { Coeficiente de atrito } \\
\text { dinâmico mínimo }\end{array}$ & NBR 15575-3 \\
\hline 3.3 & $\begin{array}{l}\text { Segurança na } \\
\text { circulação }\end{array}$ & $\begin{array}{l}\text { Inexistência de } \\
\text { desníveis e frestas } \\
\text { abruptos }\end{array}$ & Piso & $\begin{array}{l}\text { Medidas máximas de } \\
\text { desnível e de fresta }\end{array}$ & NBR 15575-3 \\
\hline 3.4 & $\begin{array}{l}\text { Segurança nas } \\
\text { instalações }\end{array}$ & $\begin{array}{l}\text { Prevenção de } \\
\text { choques elétricos } \\
\text { e de descargas } \\
\text { atmosféricas }\end{array}$ & Módulo & $\begin{array}{l}\text { Condições de } \\
\text { aterramento e } \\
\text { isolamento }\end{array}$ & NBR 15575-6 \\
\hline
\end{tabular}




\subsubsection{Funcionalidade e Acessibilidade}

O desempenho do módulo, no que se refere à funcionalidade e acessibilidade, depende do atendimento às exigências cabíveis da NR 18: Condições e meio ambiente do trabalho na indústria da construção e da NBR 12284: Área de vivência em canteiros de obra, relativas às condições e ao meio ambiente de trabalho.

Outros requisitos de caráter não obrigatório podem ser estabelecidos.

No que tange à funcionalidade, seu desempenho depende da flexibilidade que oferece para diferentes configurações de arranjo, capaz de acomodar os diversos ambientes de trabalho de uma instalação provisória de canteiro de obras: escritórios de dimensões variadas, sala de reuniões, copa, almoxarifados, vestiários, banheiros, etc. Além disso, deve ser capaz de se combinar com outros módulos horizontalmente e, em casos específicos, verticalmente (ver Figura 1 e diferentes tipos de módulos quanto à combinação do ponto de vista estrutural).

Conforme a destinação do módulo, ele deve ser capaz de atender a necessidades como a coleta e condução de água de chuva (Módulos tipo A e D da Figura 1), o abastecimento de água fria e quente e o esgotamento de água servida e esgoto. Além disso, deve prever sistemas de acoplamento adequado a redes de energia, água potável, drenagem e esgoto, conforme o caso.

Quanto ao mobiliário, deve-se dar preferência para porta de correr, no caso de armários acoplados ao módulo.

O projeto tem a necessidade de prever meios para manutenção segura da cobertura, quando se tratar de Unidade de cobertura (Módulo tipo D).

No que se refere à acessibilidade, o módulo deve possibilitar sua adaptação para portadores de deficiência física ou pessoas com mobilidade reduzida, incluindo a instalação provisória do canteiro de obras como um todo.

O Quadro 4 traz a exigência relacionada à funcionalidade e acessibilidade de caráter não obrigatório.

Quadro 4 - Exigência relacionada à funcionalidade e acessibilidade.

\begin{tabular}{|l|l|l|l|l|l|}
\hline \multicolumn{2}{|l|}{ Requisito } & Critério & Aplicação & Indicador & Origem \\
\hline 4 & $\begin{array}{l}\text { Condições e meio } \\
\text { ambiente de } \\
\text { trabalho }\end{array}$ & $\begin{array}{l}\text { Condições e meio } \\
\text { ambiente de } \\
\text { trabalho }\end{array}$ & Módulo & $\begin{array}{l}\text { Atendimento } \\
\text { à legislação }\end{array}$ & $\begin{array}{l}\text { NR 18 (seção 18.4) } \\
\text { NBR 15575-1 }\end{array}$ \\
\hline
\end{tabular}

\subsubsection{Conforto Tátil e Antropodinâmico}

O desempenho do módulo, no que se refere ao conforto tátil e antropodinâmico, depende da adequação ergonômica de dispositivos de manobra (trincos, puxadores, 
cremonas, guilhotinas, portas, janelas, torneiras, registros e descargas), bem como de medidas para evitar riscos de quedas.

O Quadro 5 traz o conjunto de exigências relacionadas ao conforto tátil e antropodinâmico.

Quadro 5 - Conjunto de exigências relacionadas ao conforto tátil e antropodinâmico.

\begin{tabular}{|l|l|l|l|l|l|}
\hline \multicolumn{2}{|l|}{ Requisito } & Critério & Aplicação & Indicador & Origem \\
\hline 5.1 & $\begin{array}{l}\text { Conforto tátil } \\
\text { e adaptação } \\
\text { ergonômica }\end{array}$ & $\begin{array}{l}\text { Adequação } \\
\text { ergonômica de } \\
\text { dispositivos de } \\
\text { manobra e força } \\
\text { para acionamento }\end{array}$ & Módulo & $\begin{array}{l}\text { Conforto tátil } \\
\text { e adaptação } \\
\text { ergonômica } \\
\text { Força e torque } \\
\text { máximos para } \\
\text { acionamento de } \\
\text { dispositivos de } \\
\text { manobra }\end{array}$ & NBR 15575-1 \\
\hline 5.2 & $\begin{array}{l}\text { Homogeneidade } \\
\text { e planicidade }\end{array}$ & $\begin{array}{l}\text { Regularidade } \\
\text { superficial }\end{array}$ & Piso & $\begin{array}{l}\text { Ausência de } \\
\text { irregularidades } \\
\text { na superfície }\end{array}$ & NBR 15575-3 \\
\hline
\end{tabular}

\subsubsection{Desempenho Térmico}

A NBR 15575 permite que o desempenho térmico do módulo seja avaliado de forma isolada ou segundo uma combinação dessas estruturas, a depender do canteiro de obras. As exigências aqui mencionadas referem-se ao módulo de forma isolada. É indispensável ressaltar, ademais, que as exigências de desempenho térmico estabelecidas na NBR 15575 reportam-se às características bioclimáticas das diferentes regiões brasileiras definidas na NBR 15220-3. Desse modo, os requisitos de desempenho às quais o módulo deve responder dependem da região ou das regiões onde é empregado.

As vedações externas (VVE e Cobertura) devem se adequar para propiciar bom desempenho térmico. Para tanto, é preciso considerar sua transmitância e capacidade térmica, de acordo com a NBR 15520-2.

Para atender aos requisitos 6.1 e 6.2 (Quadro 6), são aceitos cálculos simplificados (Procedimento Simplificado). Caso o módulo não atenda às exigências do Procedimento Simplificado, deve-se proceder à sua análise de acordo com simulação computacional, que comprove a melhoria das condições de temperatura de verão e inverno em seu interior (6.3) (Procedimento de Simulação), ou à realização de medições em protótipo, que comprovem o desempenho térmico do módulo (Procedimento de Medição).

Outro critério a ser avaliado refere-se às aberturas mínimas de ventilação a serem consideradas nas VVE (6.4). 
Quadro 6-Conjunto de exigências relacionadas ao desempenho térmico.

\begin{tabular}{|c|c|c|c|c|c|}
\hline \multicolumn{2}{|c|}{ Requisito } & \multirow{2}{*}{$\begin{array}{l}\text { Critério } \\
\text { Transmitância } \\
\text { térmica - U } \\
\left(\mathrm{W} / \mathrm{m}^{2} \mathrm{~K}\right)\end{array}$} & \multirow{2}{*}{$\begin{array}{l}\text { Aplicação } \\
\text { VVE } \\
\text { Cobertura }\end{array}$} & \multirow{2}{*}{$\begin{array}{l}\text { Indicador } \\
\text { Valor máximo } \\
\text { admissível de } \\
\text { transmitância } \\
\text { térmica U }\end{array}$} & \multirow{2}{*}{$\begin{array}{l}\text { Origem } \\
\text { NBR 15575-4 } \\
\text { NBR 15575-5 }\end{array}$} \\
\hline 6.1 & $\begin{array}{l}\text { Resistência } \\
\text { térmica }\end{array}$ & & & & \\
\hline 6.2 & Inércia Térmica & $\begin{array}{l}\text { Capacidade } \\
\text { Térmica - CT } \\
\left(\mathrm{kJ} / \mathrm{m}^{2} \mathrm{~K}\right)\end{array}$ & $\begin{array}{l}\text { VVE } \\
\text { Cobertura }\end{array}$ & $\begin{array}{l}\text { Valor mínimo } \\
\text { da capacidade } \\
\text { térmica CT }\end{array}$ & NBR 15575-4 \\
\hline 6.3 & $\begin{array}{l}\text { Desempenho no } \\
\text { verão e inverno } \\
\text { (Procedimento } \\
\text { de Simulação) }\end{array}$ & $\begin{array}{l}\text { Temperatura no } \\
\text { verão e no inverno }\end{array}$ & Módulo & $\begin{array}{l}\text { Temperatura } \\
\text { máxima de verão } \\
\text { e mínima de } \\
\text { inverno }\end{array}$ & NBR 15575-1 \\
\hline 6.4 & $\begin{array}{l}\text { Permeabilidade } \\
\text { do ar }\end{array}$ & $\begin{array}{l}\text { Área de abertura } \\
\text { para ventilação }\end{array}$ & VVE & $\begin{array}{l}\text { Área mínima de } \\
\text { abertura para } \\
\text { ventilação }\end{array}$ & $\begin{array}{l}\text { NBR 15575-4 } \\
\text { NR } 18 \\
(18.4 .1 .3)\end{array}$ \\
\hline
\end{tabular}

\subsubsection{Desempenho Acústico}

O projeto do módulo deve considerar, para o nível de ruído externo, um valor que seja compatível com o esperado para uma obra de grande porte. Em função desse nível, e de modo a alcançar o desempenho acústico exigido, o módulo deve oferecer um isolamento sonoro proporcionado por produtos dispostos em suas Vedações Verticais Externas (VVE) e Cobertura. Considerando os ruídos aéreos internos, da mesma forma, produtos são dispostos em suas Vedações Verticais Internas (VVI).

Para verificação do atendimento ao requisito de isolação sonora, pode-se optar por realizar medições do isolamento em campo ou em laboratório, cujos critérios de desempenho são diferentes.

Em ambientes onde a inteligibilidade da fala é necessária, ou onde estejam previstas atividades com grande fluxo de pessoas falando, como o caso dos refeitórios e salas de reunião, pode-se planejar um sistema de absorção acústica para melhoria da qualidade do som.

O Quadro 7 traz o conjunto de exigências relacionadas ao desempenho acústico. 
Quadro 7 - Conjunto de exigências relacionadas ao desempenho acústico.

\begin{tabular}{|c|c|c|c|c|c|}
\hline \multicolumn{2}{|c|}{ Requisito } & \multirow[b]{2}{*}{$\begin{array}{l}\text { Critério } \\
\text { Diferença } \\
\text { padronizada } \\
\text { de nível } \\
\text { ponderada a } \\
2 \text { m - D2m, } \\
\text { nT, W }\end{array}$} & \multirow{2}{*}{$\begin{array}{l}\text { Aplicação } \\
\text { VVE } \\
\text { Cobertura }\end{array}$} & \multirow[b]{2}{*}{$\begin{array}{l}\text { Indicador } \\
\text { Diferença } \\
\text { padronizada de } \\
\text { nível ponderada a } \\
2 \text { m da envoltória } \\
\text { mínima - D2m, } \\
\text { nT, W }\end{array}$} & \multirow{2}{*}{\begin{tabular}{|l|} 
Origem \\
NBR 15575-4 \\
NBR 15575-5
\end{tabular}} \\
\hline 7.1 & $\begin{array}{l}\text { Isolação ao som } \\
\text { aéreo da envoltória } \\
\text { (ensaio de campo) }\end{array}$ & & & & \\
\hline 7.2 & $\begin{array}{l}\text { Isolação ao } \\
\text { som aéreo da } \\
\text { envoltória (método } \\
\text { laboratorial) }\end{array}$ & $\begin{array}{l}\text { Redução } \\
\text { sonora } \\
\text { ponderada - } \\
\text { Rw }\end{array}$ & VVE & $\begin{array}{l}\text { Redução sonora } \\
\text { ponderada } \\
\text { da envoltória } \\
\text { mínima - Rw }\end{array}$ & NBR 15575-4 \\
\hline 7.3 & $\begin{array}{l}\text { Isolação ao som } \\
\text { aéreo da Vedação } \\
\text { Vertical Interna } \\
\text { (ensaio de campo) }\end{array}$ & $\begin{array}{l}\text { Diferença } \\
\text { padronizada } \\
\text { de nível } \\
\text { ponderada - } \\
\text { DnT, W }\end{array}$ & VVI & $\begin{array}{l}\text { Diferença } \\
\text { padronizada de } \\
\text { nível ponderada } \\
\text { da Vedação } \\
\text { Vertical Interna } \\
\text { mínima - DnT, W }\end{array}$ & NBR 15575-4 \\
\hline 7.4 & $\begin{array}{l}\text { Isolação ao } \\
\text { som aéreo da } \\
\text { Vedação Vertical } \\
\text { Interna (método } \\
\text { laboratorial) }\end{array}$ & $\begin{array}{l}\text { Redução } \\
\text { sonora } \\
\text { ponderada - } \\
\text { Rw }\end{array}$ & VVI & $\begin{array}{l}\text { Redução sonora } \\
\text { ponderada da } \\
\text { Vedação Vertical } \\
\text { Interna mínima - } \\
\text { Rw }\end{array}$ & NBR $15575-4$ \\
\hline
\end{tabular}

\subsubsection{Desempenho Lumínico}

O desempenho luminoso envolve iluminação natural e artificial, bem como o conforto visual. No entanto, a exigência que se trata aqui se relaciona apenas com a iluminação artificial, conforme a NBR 15575-1, expressa no Quadro 8.

Quadro 8 - Exigência relacionada ao conforto lumínico.

\begin{tabular}{|l|l|l|l|l|l|}
\hline \multicolumn{2}{|l|}{ Requisito } & Critério & Aplicação & Indicador & Origem \\
\hline 8 & $\begin{array}{l}\text { lluminação } \\
\text { artificial }\end{array}$ & $\begin{array}{l}\text { Nível de } \\
\text { iluminação } \\
\text { média artificial }\end{array}$ & $\begin{array}{l}\text { Ambientes } \\
\text { internos }\end{array}$ & $\begin{array}{l}\text { Níveis mínimos de } \\
\text { iluminação média } \\
\text { artificial }\end{array}$ & $\begin{array}{l}\text { NBR 15575-1 } \\
\text { NBR ISO/CIE 8995-1 }\end{array}$ \\
\hline
\end{tabular}

Não obstante, o projeto do módulo deve oferecer condições para que haja equilíbrio entre iluminação natural e artificial. Os ofuscamentos precisam ser evitados por meio de artifícios de transmissão indireta da luz, tais como bandejas de luz e aletas refletoras nas luminárias. 
O módulo necessita garantir ainda acesso à luz do dia. Na combinação de módulos da instalação provisória no canteiro de obras, o acesso à luz do dia deve ser garantido para cada um dos ambientes que a forma. Recomenda-se que haja uma janela (ou uma abertura com vidro, sem ventilação) no escritório de engenharia direcionada à obra.

Em locais de baixo fluxo de pessoas, deve haver circuitos elétricos de iluminação independentes; pode-se optar pelo uso de sensores de presença ou fotoelétrico (em escadas externas, por exemplo). Nas áreas de circulação externa, recomenda-se usar luminárias voltadas para o solo.

\subsubsection{Estanqueidade à Água}

A água é o principal agente de degradação de um amplo grupo de materiais e componentes de construção. Ela está presente no solo, na atmosfera, nos sistemas prediais e como decorrência de atividades de higiene e limpeza e de cocção. Por todos esses meios, ela pode atingir o módulo.

O módulo não deve permitir a entrada de água por meio da ascensão de umidade do solo pelos apoios (Pisos Módulos tipos A e B) e da infiltração de água de chuva pelas Vedações Verticais Externas (VVE) ou pela Cobertura. Adicionalmente, deve ser projetado para conviver sem o prejuízo demasiado causado pelas águas internas, por exemplo, decorrentes dos procedimentos de uso e limpeza dos ambientes, vapor de água gerado nas atividades normais de uso, condensação de vapor de água e eventuais vazamentos.

O Quadro 9 traz o conjunto de exigências relacionadas à estanqueidade à água.

Quadro 9 - Conjunto de exigências relacionadas à estanqueidade à água.

\begin{tabular}{|l|l|l|l|l|l|}
\hline \multicolumn{2}{|l|}{ Requisito } & Critério & Aplicação & Indicador & Origem \\
\hline 9.1 & $\begin{array}{l}\text { Estanqueidade à } \\
\text { água de chuva das } \\
\text { Vedações Verticais } \\
\text { Externas }\end{array}$ & $\begin{array}{l}\text { Estanqueidade, } \\
\text { considerando a } \\
\text { ação dos ventos }\end{array}$ & VVE & $\begin{array}{l}\text { Sinais de } \\
\text { infiltração } \\
\text { de água ou } \\
\text { umidade }\end{array}$ & NBR 15575-4 \\
\hline 9.2 & $\begin{array}{l}\text { Estanqueidade à } \\
\text { água de chuva da } \\
\text { Cobertura }\end{array}$ & $\begin{array}{l}\text { Estanqueidade, } \\
\text { considerando a } \\
\text { ação dos ventos }\end{array}$ & Cobertura & $\begin{array}{l}\text { Sinais de } \\
\text { infiltração } \\
\text { de água ou } \\
\text { umidade }\end{array}$ & NBR 15575-5 \\
\hline 9.3 & $\begin{array}{l}\text { Estanqueidade à } \\
\text { umidade ascendente } \\
\text { do Piso }\end{array}$ & $\begin{array}{l}\text { Estanqueidade } \\
\text { do Piso em } \\
\text { contato com o } \\
\text { solo }\end{array}$ & Piso & $\begin{array}{l}\text { Sinais de } \\
\text { infiltração } \\
\text { de água ou } \\
\text { umidade }\end{array}$ & NBR 15575-3 \\
\hline
\end{tabular}


Quadro 9-Continuação.

\begin{tabular}{|l|l|l|l|l|l|}
\hline \multicolumn{2}{|l|}{ Requisito } & Critério & Aplicação & Indicador & Origem \\
\hline 9.4 & $\begin{array}{l}\text { Estanqueidade } \\
\text { à água de uso } \\
\text { e lavagem dos } \\
\text { ambientes de } \\
\text { Vedações Verticais } \\
\text { e Piso }\end{array}$ & $\begin{array}{l}\text { Estanqueidade, } \\
\text { considerando } \\
\text { as ações } \\
\text { decorrentes dos } \\
\text { procedimentos } \\
\text { de uso e limpeza } \\
\text { dos ambientes }\end{array}$ & $\begin{array}{l}\text { VVEI } \\
\text { Piso }\end{array}$ & $\begin{array}{l}\text { Sinais de } \\
\text { infiltração } \\
\text { de água ou } \\
\text { umidade }\end{array}$ & NBR 15575-4 \\
\hline 9.5 & $\begin{array}{l}\text { Estanqueidade } \\
\text { das instalações } \\
\text { hidrossanitárias }\end{array}$ & $\begin{array}{l}\text { Estanqueidade } \\
\text { sob condições } \\
\text { normais de uso }\end{array}$ & $\begin{array}{l}\text { Instalações } \\
\text { hidrossanitárias }\end{array}$ & $\begin{array}{l}\text { Sinais de } \\
\text { vazamentos }\end{array}$ & - \\
\hline
\end{tabular}

\subsubsection{Durabilidade e Manutenibilidade}

O desempenho do módulo, no que se refere à durabilidade, volta-se para os componentes e elementos que merecem atenção especial quanto à resistência à corrosão, à umidade e ao ataque químico.

O mercado de contêineres de aço trabalha com duas alternativas para acesso ao produto: compra e locação. Embora em ambas haja interesse pelo estabelecimento de prazos de vida útil de projeto (VUP) - respectivamente, para as construtoras e para os locadores -, esta pesquisa optou pelo não estabelecimento de exigência compulsória em relação a esse tema. São apenas indicados prazos de vida útil de projeto dos elementos do módulo e sugeridas medidas preventivas a serem incorporadas ao projeto.

Não obstante, é importante assegurar a continuidade da capacidade funcional do módulo, a qual é potencializada pelo correto uso da instalação e pela realização de intervenções de manutenção pré-estabelecidas. Assim, um aspecto essencial para garantia de desempenho no que tange à durabilidade e manutenibilidade é a elaboração de um manual de uso, operação e manutenção. Dentre outros pontos, ele deve indicar a vida útil dos elementos e componentes do módulo, passar orientações sobre o uso e os períodos de manutenção e trocas desses constituintes da instalação, bem como trazer instruções para sua realização. Deve-se considerar, também, a facilidade ou meios de acesso para manutenção. Todos os componentes devem ser identificados segundo sua dimensão, geometria, propriedades significativas e tolerâncias. Deve-se ainda esclarecer os meios para a reutilização dos componentes descartados ao final de sua vida útil.

O Quadro 10 traz o conjunto de exigências relacionadas à durabilidade e manutenibilidade. 
Quadro 10 - Conjunto de exigências relacionadas à durabilidade e manutenibilidade.

\begin{tabular}{|c|c|c|c|c|c|}
\hline \multicolumn{2}{|c|}{ Requisito } & \multirow{2}{*}{\begin{tabular}{|l} 
Critério \\
Existência de \\
revestimento de \\
proteção (zincado \\
ou alumínio-zinco)
\end{tabular}} & \multirow{2}{*}{$\begin{array}{l}\text { Aplicação } \\
\text { Estrutura } \\
\text { Piso } \\
\text { Cobertura } \\
\text { VVEl }\end{array}$} & \multirow[b]{2}{*}{$\begin{array}{l}\text { Indicador } \\
\text { Massa do } \\
\text { revestimento por } \\
\text { unidade de área do } \\
\text { perfil }\left(\mathrm{g} / \mathrm{m}^{2}\right) \\
\text { Proteção à corrosão } \\
\text { de dispositivos de } \\
\text { fixação } \\
\text { Ausência de pontos } \\
\text { susceptíveis à } \\
\text { corrosão galvânica }\end{array}$} & \multirow{2}{*}{$\begin{array}{l}\text { Origem } \\
-\end{array}$} \\
\hline 10.1 & $\begin{array}{l}\text { Resistência à } \\
\text { corrosão de } \\
\text { perfis de aço } \\
\text { e dispositivos } \\
\text { de fixação }\end{array}$ & & & & \\
\hline 10.2 & $\begin{array}{l}\text { Resistência à } \\
\text { umidade }\end{array}$ & $\begin{array}{l}\text { Danos pela } \\
\text { presença de água }\end{array}$ & Piso & Ausência de danos & NBR 15575-3 \\
\hline 10.3 & $\begin{array}{l}\text { Resistência } \\
\text { ao ataque } \\
\text { químico }\end{array}$ & $\begin{array}{l}\text { Danos pela } \\
\text { presença de } \\
\text { agentes químicos }\end{array}$ & Piso & Ausência de danos & NBR 15575-3 \\
\hline 10.4 & $\begin{array}{l}\text { Permanência } \\
\text { do } \\
\text { desempenho } \\
\text { do módulo }\end{array}$ & $\begin{array}{l}\text { Manual de uso, } \\
\text { operação e } \\
\text { manutenção do } \\
\text { módulo }\end{array}$ & Módulo & $\begin{array}{l}\text { Existência de manual } \\
\text { de uso, operação e } \\
\text { manutenção }\end{array}$ & NBR 15575-1 \\
\hline 10.5 & $\begin{array}{l}\text { Vida útil de } \\
\text { projeto de } \\
\text { elementos do } \\
\text { módulo }\end{array}$ & $\begin{array}{l}\text { Incorporação } \\
\text { ao projeto } \\
\text { de medidas } \\
\text { preventivas }\end{array}$ & $\begin{array}{l}\text { Elementos } \\
\text { do módulo }\end{array}$ & $\begin{array}{l}\text { Medidas preventivas } \\
\text { incorporadas ao } \\
\text { projeto }\end{array}$ & NBR 15575-1 \\
\hline
\end{tabular}

\subsubsection{Saúde, Higiene e Qualidade do Ar}

O desempenho do módulo, no que se refere à saúde, higiene e qualidade do ar, volta-se, em primeiro lugar, aos cuidados para se evitar a contaminação da água a partir dos componentes das instalações, condição essencial à boa saúde dos ocupantes. Os componentes empregados devem garantir a salubridade e a qualidade da água, não transmitindo substâncias tóxicas nem a contaminando por meio de metais pesados.

Para evitar a contaminação biológica na instalação de água potável, todo componente da instalação deve evitar a impregnação de sujeira ou desenvolvimento de bactérias ou atividades biológicas. As instalações de esgoto não devem permitir o refluxo ou retrossifonagem, evitando a presença de odores.

Com relação à qualidade do ar interno, o sistema de ventilação deve prever boa distribuição do ar novo e a exaustão do ar viciado, ainda que por meio de ventilação natural. Por se tratar de um módulo para canteiro de obras, recomenda-se que as 
janelas e outras tomadas de ar externo prevejam sistema que impeça a entrada de material particulado do ar externo. Outra medida recomendável é procurar empregar tintas e adesivos à base de água, assim como de produtos com baixas emissões de Compostos Orgânicos Voláteis (COV), de formaldeídos e de elementos cancerígenos ou causadores de efeitos genéticos nocivos, principalmente no caso dos revestimentos de Vedações Verticais, Piso e Cobertura (forro) em contato com o ar interior.

O Quadro 11 traz a exigência relacionada à saúde, higiene e qualidade do ar.

Quadro 11 - Exigência relacionada à saúde, higiene e qualidade do ar.

\begin{tabular}{|c|c|c|c|c|c|}
\hline \multicolumn{2}{|c|}{ Requisito } & \multirow{2}{*}{$\begin{array}{l}\text { Critério } \\
\text { Independência } \\
\text { do sistema de } \\
\text { água }\end{array}$} & \multirow{2}{*}{$\begin{array}{l}\text { Aplicação } \\
\text { Instalação } \\
\text { de água } \\
\text { potável }\end{array}$} & \multirow[b]{2}{*}{$\begin{array}{l}\text { Indicador } \\
\text { Separação das } \\
\text { tubulações de água } \\
\text { potável e não potável ou } \\
\text { de fluido de qualidade } \\
\text { insatisfatória e uso de } \\
\text { componentes que não } \\
\text { transmitam à água } \\
\text { substâncias tóxicas ou } \\
\text { contaminantes }\end{array}$} & \multirow{2}{*}{$\begin{array}{l}\text { Origem } \\
\text { NBR 15575-6 }\end{array}$} \\
\hline 11.1 & $\begin{array}{l}\text { Contaminação } \\
\text { da água a } \\
\text { partir dos } \\
\text { componentes } \\
\text { das } \\
\text { instalações }\end{array}$ & & & & \\
\hline 11.2 & $\begin{array}{l}\text { Contaminação } \\
\text { biológica } \\
\text { da água na } \\
\text { instalação de } \\
\text { água potável }\end{array}$ & $\begin{array}{l}\text { Risco de } \\
\text { contaminação } \\
\text { biológica das } \\
\text { tubulações e } \\
\text { de estagnação } \\
\text { da água }\end{array}$ & $\begin{array}{l}\text { Instalação } \\
\text { de água } \\
\text { potável }\end{array}$ & $\begin{array}{l}\text { Material de fabricação } \\
\text { do componente da } \\
\text { instalação e não } \\
\text { empoçamento de água } \\
\text { (módulo testado) }\end{array}$ & NBR 15575-6 \\
\hline 11.3 & $\begin{array}{l}\text { Ausência } \\
\text { de odores } \\
\text { provenientes } \\
\text { da instalação } \\
\text { de esgoto }\end{array}$ & $\begin{array}{l}\text { Estanqueidade } \\
\text { aos gases }\end{array}$ & $\begin{array}{l}\text { Instalação } \\
\text { de esgoto }\end{array}$ & $\begin{array}{l}\text { Ausência de } \\
\text { retrossifonagem ou } \\
\text { quebra do selo hídrico }\end{array}$ & NBR 15575-6 \\
\hline 11.4 & $\begin{array}{l}\text { Qualidade do } \\
\text { ar interno }\end{array}$ & $\begin{array}{l}\text { Renovação } \\
\text { do ar e baixa } \\
\text { presença de } \\
\text { componentes } \\
\text { nocivos }\end{array}$ & Módulos & $\begin{array}{l}\text { Sistema de ventilação } \\
\text { adequado e uso de } \\
\text { materiais de baixa } \\
\text { emissividade }\end{array}$ & - \\
\hline
\end{tabular}

\subsubsection{Adequação Ambiental: Gestão de Resíduos}

Os requisitos de desempenho, no que se refere à adequação ambiental quanto à gestão de resíduos, dizem respeito às condições de armazenamento e triagem dos resíduos, considerando os fluxos de entrada e saída. 


\subsubsection{Adequação Ambiental: Gestão da Energia}

Os requisitos de desempenho, no que se refere à adequação ambiental quanto à gestão da energia, dizem respeito às medidas voltadas ao uso racional da energia, seja do módulo, seja da fábrica responsável pela sua produção.

\subsubsection{Adequação Ambiental: Gestão da Água}

Os requisitos de desempenho, no que se refere à adequação ambiental quanto à gestão da água, dizem respeito à presença de equipamentos economizadores nas instalações hidrossanitárias do módulo.

\subsubsection{Adequação Ambiental: Escolha de Materiais}

Os requisitos de desempenho, no que se refere à adequação ambiental quanto à escolha de materiais, dizem respeito à valorização de materiais que causem menor impacto ambiental, desde as fases de exploração dos recursos naturais até a sua utilização final.

\subsection{Qualidade na Fabricação, Montagem e Transporte do Módulo}

O fabricante do módulo deve implantar procedimentos para assegurar a qualidade da aquisição dos materiais e componentes do módulo e da sua fabricação, montagem, transporte e instalação no canteiro de obras.

\subsubsection{Qualidade dos Materiais e Componentes Empregados no Módulo}

O fabricante deve assegurar que a compra de materiais e componentes empregados na fabricação do módulo esteja em conformidade com os requisitos especificados de aquisição. Estes devem descrever claramente o que está sendo comprado, contendo especificações técnicas.

O fabricante deve realizar inspeção ou outras atividades necessárias para assegurar que o produto adquirido atenda aos requisitos de aquisição especificados.

\subsubsection{Qualidade da Fabricação do Módulo}

O fabricante deve assegurar que as diversas atividades envolvidas na fabricação do módulo estejam conformes com os requisitos especificados de produção, os quais devem descrever claramente como e com que recursos as atividades são executadas. 
O fabricante deve realizar inspeção ou outras atividades necessárias para garantir que as atividades realizadas atendam aos requisitos de produção especificados.

\subsubsection{Qualidade da Montagem do Módulo em Fábrica ou no Canteiro de Obras}

O fabricante deve assegurar que as diversas atividades envolvidas na montagem do módulo estejam conformes com os requisitos especificados. Estes devem descrever claramente como e com que recursos executam-se as atividades, no caso de serem efetuadas em fábrica ou no canteiro de obras.

O fabricante deve realizar inspeção ou outras atividades necessárias para assegurar que as atividades realizadas cumpram os requisitos de montagem especificados.

\subsubsection{Qualidade do Transporte e da Instalação do Módulo no Canteiro de Obras}

O fabricante deve assegurar que as diversas atividades envolvidas no transporte e na instalação do módulo no canteiro de obras estejam conformes com os requisitos especificados. Estes devem descrever claramente como e com que recursos executamse as atividades, no caso de serem realizadas pelo fabricante ou pela empresa construtora.

O fabricante deve realizar inspeção ou outras atividades necessárias para assegurar que as atividades realizadas atendam aos requisitos de transporte e instalação especificados.

\subsection{Documentos Técnicos Complementares}

A seguir listam-se as normas técnicas referenciadas:

- Associação Brasileira de Normas Técnicas (ABNT):

- NBR 6123:1998 - Forças devidas ao vento em edificações;

- NBR 6355:2012-Perfis estruturais de aço formados a frio - Padronização;

- NBR 6673:1981 - Produtos planos de aço - Determinação das propriedades mecânicas à tração;

- NBR ISO/CIE 8995-1:2013 - Iluminação de ambientes de trabalho. Parte 1: Interior;

- NBR 12284:1991 - Áreas de vivência em canteiros de obras Procedimento;

- NBR 14762:2001 - Dimensionamento de estruturas de aço constituídas por perfis formados a frio - Procedimento; 
- NBR 15220-2:2005 - Desempenho térmico de edificações - Parte 2: Métodos de cálculo da transmitância térmica, da capacidade térmica, do atraso térmico e do fator solar de elementos e componentes de edificações;

- NBR 15220-3:2005 - Desempenho térmico de edificações - Parte 3: Zoneamento bioclimático brasileiro e diretrizes construtivas para habitações unifamiliares de interesse social;

- NBR 15253:2005 - Perfis de aço formados a frio, com revestimento metálico, para painéis reticulados em edificações - Requisitos gerais;

- NBR 15575-1:2013 - Edifícios habitacionais de até cinco pavimentos: Desempenho - Parte 1: Requisitos gerais;

- NBR 15575-2:2013 - Edifícios habitacionais de até cinco pavimentos: Desempenho - Parte 2: Requisitos para os sistemas estruturais;

- NBR 15575-3:2013 - Edifícios habitacionais de até cinco pavimentos: Desempenho - Parte 3: Requisitos para os sistemas de pisos internos;

- NBR 15575-4:2013 - Edifícios habitacionais de até cinco pavimentos: Desempenho - Parte 4: Sistemas de vedações verticais externas e internas;

- NBR 15575-5:2013 - Edifícios habitacionais de até cinco pavimentos: Desempenho - Parte 5: Requisitos para sistemas de coberturas.

- Ministério do Trabalho e Emprego:

- NR 18 - Condições e Meio Ambiente de Trabalho na Indústria da Construção.

- Norma européia - EN:

- ETAG 023:2006 - Guideline for European Technical Approval of Prefabricated Building Units.

\section{Comentários Finais e Implicações para a Indústria da Construção Civil}

O capítulo mostrou que são diversos os contêineres usados em instalações provisórias de canteiros de obras oferecidos no mercado e propôs uma tipologia para essas estruturas. Com base nela, voltou-se ao módulo tridimensional empilhável do tipo estrutura reticulada em aço, usado predominantemente em áreas administrativas e de vivência.

Verificou-se que a busca por soluções de melhor desempenho técnico e econômico tem levado a um maior grau de exigência no que se refere a essas instalações, motivando os agentes do mercado a atender as aspirações em relação aos contêineres de aço. 
A fim de contribuir com essa evolução, discutiu-se o desempenho esperado para tais contêineres, propondo-se requisitos e critérios que contribuam para o seu correto projeto, fabricação, transporte e uso.

Para uma consideração mais aprofundada no assunto, incluindo os detalhamentos dos métodos de verificação e avaliação de cada requisito de desempenho e os ensaios e as inspeções in loco que devem ser realizados, os documentos que devem ser apresentados e os cálculos que devem ser realizados, em cada caso, deve-se consultar a diretriz completa proposta por Cardoso et al. (2013).

Complementarmente, poderá ser implementado um mecanismo de avaliação técnica, como se faz no Programa Brasileiro da Qualidade e Produtividade do Habitat (PBQP-H) - Sistema Nacional de Avaliações Técnicas (SINAT), no caso de produtos inovadores, por meio do estabelecimento de uma Diretriz para Avaliação Técnica de Produtos SINAT.

\section{Referências}

ASSOCIAÇÃO BRASILEIRA DE NORMAS TÉCNICAS. NBR 15575: Edificações Habitacionais Desempenho. 2013. Rio de Janeiro, Brasil.

BARBOZA, N. Contêineres. Construção Mercado, v. 169, ago. 2015, p. 80-81. Pini. São Paulo.

BIRBOJM, A. Subsídios para as tomadas de decisão relativas à escolha dos elementos do canteiro de obras. Dissertação (Mestrado) - São Paulo, Universidade de São Paulo, Escola Politécnica, 2001.

CARDOSO, F.F.; RODRIGO, A.G.; SOARES, P.V.P.T. Diretriz para avaliação técnica de desempenho de módulo tridimensional empilhável para instalação provisória em canteiro de obras: contêiner de aço. Relatório interno do Projeto CantecHIS - Tecnologias para Canteiro de Obras Sustentável. São Paulo: Finep, agosto de 2013.

COSTA, D.C.R.F. Contêineres metálicos para canteiros de obras: análise experimental de desempenho térmico e melhorias na transferência de calor pela envoltória. Dissertação (Mestrado) - São Paulo, Universidade de São Paulo, Escola Politécnica, 2015.

RODRIGO, A.G.S.; GAZARINI, D.; CARDOSO, F.F. Condicionantes de projeto para as instalações provisórias em canteiros de obras na cidade de São Paulo. In: Proceedings of the Latin-American and European Conference on Sustainable Building and Communities: Connecting People and Ideas. July 21th - 24th, 2015, Guimarães, Portugal. Universidade do Minho and others. pp. 2495-2504. 


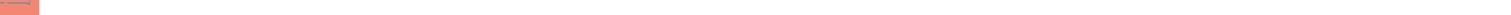




\title{
Contêineres Metálicos para Instalações Provisórias em Canteiros de Obras no Brasil
}

\author{
Débora Cristina Rosa Faria da Costa \\ Racine Tadeu Araújo Prado
}

\section{Introdução}

Os contêineres metálicos utilizados como instalações provisórias de canteiros de obra diferem dos contêineres marítimos quanto ao material de composição e à espessura das paredes. Enquanto os contêineres marítimos são confeccionados em aço corten, com espessura em torno de $1,3 \mathrm{~mm}$, os contêineres para canteiros de obras são compostos predominantemente de aço galvanizado, com espessura em torno de 0,65 mm, diferença de configuração que atribui aos contêineres marítimos peso duas vezes maior.

No setor da construção civil, existe um padrão construtivo para os contêineres, relacionado principalmente às dimensões adequadas para o transporte sobre caminhão, embora haja variações de composição de materiais e dimensões, dentro da gama de produtos disponíveis no mercado brasileiro. O padrão mais utilizado apresenta altura útil de 2,5 m, largura de 2,4 m e comprimento variável, frequentemente baseado na modulação de $3 \mathrm{~m}$, ou seja, há produtos com 3, 6 e $9 \mathrm{~m}$ de comprimento. São comercializados, em grande parte dos casos, sem qualquer tratamento térmico nas superfícies verticais. Muitos dos produtos disponíveis no mercado possuem um forro de $2 \mathrm{~cm}$ de poliestireno expandido (EPS) junto à superfície interna da cobertura, cuja função é o isolamento térmico, acrescido de uma chapa dura de material derivado de madeira, com espessura de $2,5 \mathrm{~mm}$, para melhoria da qualidade do acabamento. 
O setor da construção civil brasileiro adota diferentes tipologias de sistemas construtivos para as instalações provisórias de canteiros de obras, dentre as quais encontram-se os contêineres metálicos. A utilização de contêineres metálicos como instalações provisórias em canteiros de obras tem crescido, visto ser uma tipologia que apresenta vantagens sobre as demais, normalmente empregadas no mercado brasileiro. Características como rapidez e praticidade na montagem, facilidade de transporte e reutilização, assim como o baixíssimo potencial de geração de resíduos, são particularmente atraentes no momento da especificação das instalações para canteiros de obras. A Tabela 1 apresenta as principais características dos sistemas mais utilizados.

Tabela 1 - Comparação entre diferentes sistemas de instalações provisórias para canteiros de obras utilizados atualmente no Brasil.

\begin{tabular}{|c|c|c|c|c|c|}
\hline Item & $\begin{array}{l}\text { sistema } \\
\text { tradicional } \\
\text { de chapas } \\
\text { de madeira } \\
\text { compensada }\end{array}$ & $\begin{array}{l}\text { pré-moldado } \\
\text { de madeira }\end{array}$ & $\begin{array}{l}\text { contêineres } \\
\text { metálicos }\end{array}$ & $\begin{array}{l}\text { construções } \\
\text { metálicas } \\
\text { desmontáveis }\end{array}$ & $\begin{array}{l}\text { fibra } \\
\text { plástica }\end{array}$ \\
\hline $\begin{array}{l}\text { uso de mão de obra } \\
\text { para montagem }\end{array}$ & alta & média & baixa & média & baixa \\
\hline $\begin{array}{l}\text { tempo de montagem/ } \\
\text { desmontagem }\end{array}$ & alto & médio & baixo & baixo & baixo \\
\hline grau de industrialização & baixo & médio & alto & alto & alto \\
\hline $\begin{array}{l}\text { potencial de } \\
\text { reutilização }\end{array}$ & $\begin{array}{l}\text { baixo/ } \\
\text { nenhum }\end{array}$ & alto & alto & alto & alto \\
\hline versatilidade & alta & alta & alta & alta & baixa \\
\hline $\begin{array}{l}\text { grau de complexidade } \\
\text { da montagem }\end{array}$ & baixo & médio & baixo & baixo & baixa \\
\hline custo aluguel & baixo & - & alto & - & alto \\
\hline custo compra & baixo & baixo & alto & alto & alto \\
\hline $\begin{array}{l}\text { necessidade de } \\
\text { execução de fundação }\end{array}$ & alta & média & baixa & baixa & baixa \\
\hline $\begin{array}{l}\text { complexidade de } \\
\text { transporte }\end{array}$ & baixa & baixa & baixa & baixa & baixa \\
\hline $\begin{array}{l}\text { condição de conforto } \\
\text { térmico }\end{array}$ & média & média & baixa & baixa & - \\
\hline $\begin{array}{l}\text { potencial de geração de } \\
\text { resíduos }\end{array}$ & alto & alto & baixo & baixo & alta \\
\hline vida útil em anos & 3 & 3 & 12 a 18 & 12 a 18 & - \\
\hline
\end{tabular}

Fonte: Elaborada a partir de Saurin e Formoso, 2006 e Oliveira e Leão, 1997. 
A Tabela 1 organiza-se de modo a qualificar como positiva, mediana ou negativa cada uma das características apresentadas pelas principais tipologias utilizadas como instalações provisórias nos canteiros de obra. As células em vermelho apontam características negativas; as células amarelas, as características neutras; e as células verdes, as características positivas para cada quesito analisado.

Pode-se constatar, com base nas características avaliadas, que o sistema tradicional de chapas de madeira compensada é o que apresenta maior quantidade de pontos negativos, enquanto o sistema de contêineres metálicos apresenta a maior quantidade de itens positivos, evidenciando deficiências no que se refere aos custos iniciais de aquisição e aos níveis de conforto ambiental apresentados.

Saurin e Formoso (2006) realizaram estudo comparativo que permitiu a avaliação dos custos ao longo do tempo para três tipologias de instalações provisórias, conforme Figura 1: os contêineres metálicos, os compensados de madeira e um sistema mesclado entre contêineres utilizados no início e fim da obra, intercalados com o uso das instalações do próprio edifício em construção.

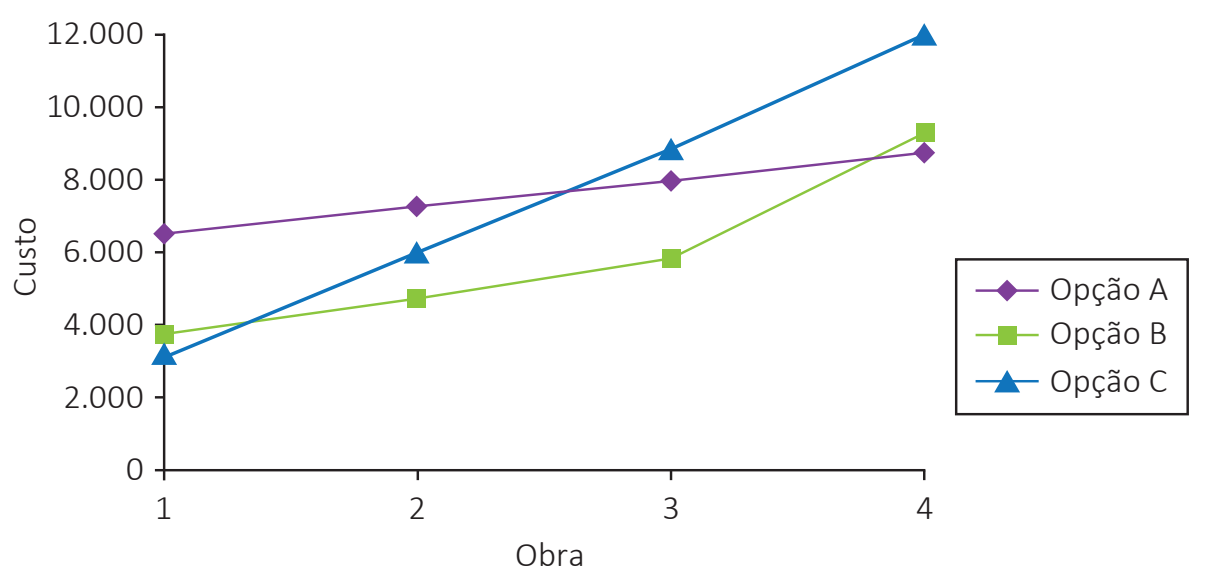

Figura 1-Comparação de custos entre as diferentes modalidades de instalações provisórias ao longo de sua utilização em sucessivas obras, segundo Saurin e Formoso, 2006.

Onde:

- Opção A: contêineres metálicos adquiridos definitivamente;

- Opção B: sistema racionalizado em chapas de compensado de madeira;

- Opção C: contêineres alugados durante três meses e utilização das instalações do edifício em construção nos demais períodos.

Como podem ser observados no gráfico da Figura 1, os custos iniciais são maiores para a utilização de contêineres metálicos, devido ao investimento feito para 
a aquisição, mas com o passar do tempo e a possibilidade de reutilização maior do que o sistema de compensados de madeira, os custos tendem a apresentar menor crescimento se comparados aos demais sistemas.

Segundo pesquisa de preços de contêineres realizada com fornecedores do mercado brasileiro no mês de junho de 2012, o valor da aquisição dos contêineres metálicos para instalação provisória em canteiros de obras equivaleria em média a 24 vezes seu custo mensal com aluguel. Os custos de manutenção, segundo um dos fabricantes consultados, aproximam-se 30\% do valor de aquisição, mas serão empregados somente após 10 anos de utilização do contêiner. Contudo, é possível amenizar os custos do investimento inicial de aquisição de contêineres optando pela locação dos sistemas modulares, modalidade disponível em muitas das empresas fornecedoras.

Como ressaltam Saurin e Formoso (2006):

Seja qual for o sistema utilizado, devem ser considerados os seguintes critérios: custos de aquisição, custos de implantação, custos de manutenção, reaproveitamento, durabilidade, facilidade de montagem e desmontagem, isolamento térmico e impacto visual. A importância de cada critério é variável conforme as necessidades da obra.

A durabilidade dos contêineres, segundo alguns fabricantes, é estimada em dez anos, sem significativa manutenção, sob as condições agressivas habitualmente existentes em canteiros de obras, sendo consideravelmente ampliada se reformados após esse período. Desse modo, das características negativas dos contêineres apresentadas na Tabela 1, as questões referentes aos custos de aquisição ou locação passam a ficar minimizadas quando se considera sua durabilidade e a possibilidade de reutilização.

O objetivo do presente trabalho é propor adequações às instalações provisórias em contêineres metálicos para canteiros de obras, a fim de que se possam atingir melhores condições de conforto térmico em sua utilização, bem como a redução da demanda energética quando do uso sob condicionamento artificial.

\section{Contêineres para Canteiros de Obras no Mercado Brasileiro}

O setor da construção civil adota um padrão construtivo para os contêineres metálicos, embora haja variações de composição de materiais e dimensões, dentro da gama de produtos disponíveis no mercado brasileiro. O padrão mais utilizado apresenta altura útil de 2,5 m, largura de 2,4 m e comprimento variável, frequentemente baseado na modulação de $3 \mathrm{~m}$. As paredes em aço possuem espessura frequentemente inferior a $1,0 \mathrm{~mm}$. 
Nos canteiros de obras, são majoritariamente utilizados nas funções de apoio administrativo das obras, como nos escritórios, refeitórios, sanitários e depósitos, ou então como alojamentos para os trabalhadores. Tais características de uso são determinantes para a compreensão de que - no caso dos contêineres - a abordagem quanto aos requisitos de conforto térmico e índices de temperatura adequados para o trabalho ou o descanso faz-se necessariamente diferente, conforme o uso a que se destinam, ainda que o projeto básico do contêiner seja o mesmo para os diferentes usos.

Embora os contêineres sejam ambientalmente adequados em muitos aspectos, suas características térmicas são extremamente insatisfatórias, o que acarreta a utilização praticamente constante de climatizadores de ar, a fim de viabilizar a ocupação humana. Esse fato contribui para o aumento do consumo de energia comparativamente a outros sistemas construtivos utilizados como instalações provisórias em canteiros de obras. Segundo Santamouris e Kolokotsa (2013), o volume de energia demandada pelo setor da construção civil varia conforme o país, permanecendo entre 35 a 40\% da demanda mundial por energia, se consideradas as etapas de construção e o pósocupação. Os mesmos autores ainda afirmam que a demanda por condicionamento de ar corresponde a 15\% do consumo mundial de energia.

Durante a realização da pesquisa experimental de mestrado que embasou este capítulo (COSTA, 2015), foram realizadas visitas a inúmeros canteiros de obras cujas instalações provisórias foram montadas em contêineres metálicos no município de São Paulo. A queixa mais frequente por parte dos trabalhadores foi quanto ao calor excessivo dentro das instalações, o que praticamente inviabilizaria a permanência humana sem condicionamento artificial. Contudo, durante uma das visitas ao canteiro, ocorrida em um dia extremamente frio de inverno, presenciou-se que, sob aquelas condições, o conforto térmico também estaria comprometido.

Dentre a imensa variedade de dimensões dos contêineres produzidos no mercado brasileiro destinados às instalações para canteiros de obras, há diferença entre os tipos de superfícies de acabamento e o tipo de tratamento térmico, de acordo com a finalidade a que se destinam. Para a presente pesquisa, interessam particularmente os contêineres destinados ao trabalho em escritório - haja vista que é o local onde ocorre maior tempo de permanência de trabalhadores - e os contêineres destinados aos alojamentos, nos quais os trabalhadores passam o tempo de repouso. As tipologias mais representativas da variedade de acabamentos e tratamentos térmicos serão apresentadas a seguir, tomando o módulo básico de 6,0 m de comprimento como referência, já que é um produto fornecido por grande parte das empresas do setor.

\subsection{Contêineres em Aço sem Tratamento Térmico}

Os contêineres em aço sem tratamento térmico têm sido utilizados nos canteiros de obras brasileiros tanto nos escritórios quanto nos alojamentos, como consta da 
Figura 2. A fim de contornar o desconforto térmico advindo do uso dessas instalações, adota-se a climatização artificial, que, consequentemente, incrementa os custos de obra, demandando grande quantidade de energia.
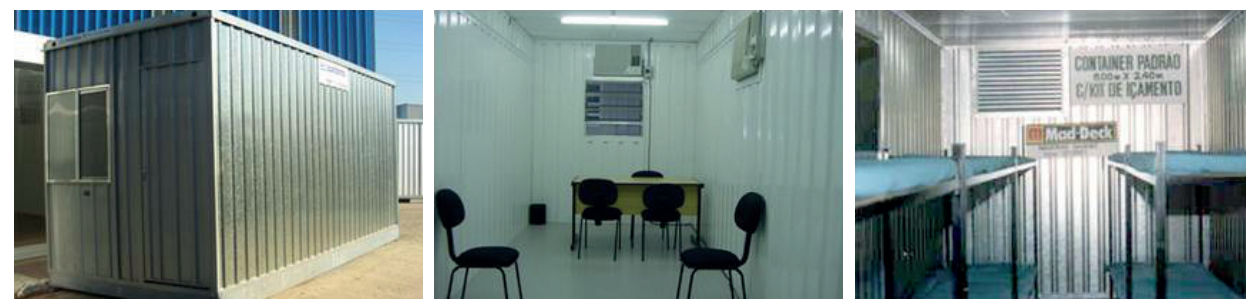

Figura 2 - Contêineres Metálicos sem tratamento térmico. Fonte: http://www.eurobras.com. $\mathrm{br} / \mathrm{view}$ ?id=eb13-0\&cat=tradicional e http://soldatopo.com. br/site/?produtos=belichesmetalicos-soldatopo.

\subsection{Contêineres Metálicos com Tratamento Térmico}

O mercado brasileiro oferece módulos tratados termicamente. Dentre as composições mais frequentemente desenvolvidas, é comum a utilização do isopor entre a chapa de aço externa e o forro interno, feito de material plástico ou de aglomerado de madeira. Tal tipologia de tratamento térmico aparece, em alguns casos, somente nas coberturas, ou ainda em coberturas e paredes. Adotam-se também, para cobertura e paredes, os painéis sanduíche, compostos por duas chapas de aço, normalmente pintadas de branco - dispostas como revestimento interno e externo - com a camada intermediária em poliuretano e espessura de $50 \mathrm{~mm}$, como apresentado na Figura 3.
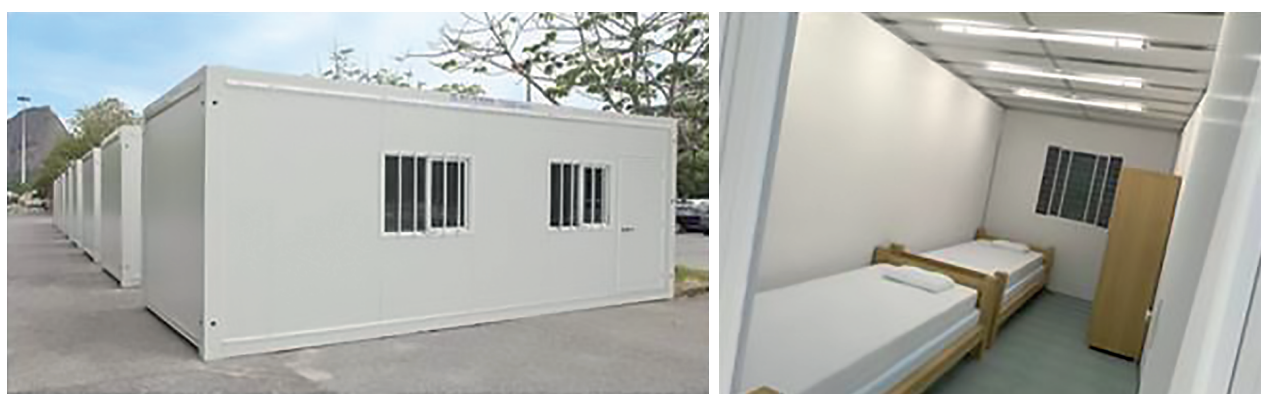

Figura 3 - Contêineres metálicos com tratamento térmico. Fonte: http://www.nhjdobrasil. com.br/pt-br/produtos/modulo-habitavel/ e http://www.eurobras.com.br/view?id=ebta10-0\&cat=origin 


\section{Método de Pesquisa}

A presente pesquisa foi executada por método experimental, com medições térmicas realizadas initerruptamente durante um ano. $O$ experimento localizou-se no município de Mairinque-SP, pertencente à Zona Bioclimática n 3 (ABNT, 2005). Foram utilizados três modelos experimentais em escala natural, conforme especificações a seguir:

Contêiner 1: em aço galvanizado, com 3 m de comprimento, 2,4 m de largura e 2,5 $\mathrm{m}$ de altura, piso em compensado de madeira de $2 \mathrm{~cm}$ de espessura, com revestimento plástico imitando madeira, disposto a $28 \mathrm{~cm}$ de altura do solo, contendo uma janela nas dimensões 0,99 $\mathrm{m} \times 0,92 \mathrm{~m}$ e porta de $0,77 \mathrm{~m} \times 2,11 \mathrm{~m}$, ambas do mesmo material da composição, mantidas fechadas durante o período de medições. Possui insterstícios que permitem a passagem do ar nas junções entre a cobertura e as paredes verticais.

Contêiner 2: composição idêntica à do Contêiner 1. A cobertura, no entanto, é acrescida de uma camada interna de poliestireno expandido (isopor) de $2 \mathrm{~cm}$ de espessura e de uma chapa dura de material derivado de madeira revestido internamente com fórmica bege fosca (Eucaplac). As junções do forro não permitem infiltração de ar como ocorre no Contêiner 1. As vedações verticais contém poliestireno de $2 \mathrm{~cm}$ de espessura nos interstícios existentes devido ao perfil do aço corrugado utilizado entre a chapa de aço e a chapa de madeira. O piso é confeccionado em compensado de madeira 2 $\mathrm{cm}$ de espessura, acrescido de revestimento plástico imitando madeira ${ }^{1}$.

Contêiner 3: composição idêntica à do Contêiner 1. Nesse Contêiner, no entanto, aplicou-se uma camada de $0,25 \mu \mathrm{m}$ de revestimento branco refletivo externamente, de forma homogênea, nas quatro superfícies verticais incluindo porta e janela - e na cobertura.

As medições foram executadas em todas as superfícies internas e externas da envoltória, com exceção da parte externa do piso, a partir da instalação de sensores térmicos, conectados a um datalogger.

1 A escolha de tipologia do Contêiner 2 deveu-se ao fato de este ser um dos produtos disponibilizados pelo fabricante ao mercado, na ocasião do experimento, conforme solicitado pelos pesquisadores. 


\section{Resultados}

\subsection{Avaliação do Comportamento Térmofísico de um Contêiner Metálico para Canteiro de Obras sem Tratamento Térmico na Envoltória}

Como apresentado na análise qualitativa das tipologias mais utilizadas como instalações para canteiros de obras brasileiros, observa-se que os contêineres metálicos possuem características que os tornam instalações ambientalmente amigáveis, considerando sua flexibilidade de usos, rapidez na montagem e desmontagem, grande possibilidade de reutilização, longa vida útil e baixa geração de resíduo. Seu aspecto térmico, no entanto, é insuficiente, o que frequentemente leva à necessidade de condicionamento artificial, acarretando alto consumo energético ou situações de desconforto quando empregado sob ventilação natural.

O aspecto térmico dos contêineres metálicos foi objeto de pesquisa experimental (COSTA, 2015), na qual foram realizadas medições em contêineres reais durante um ano, para que se pudesse caracterizar o comportamento termofísico dessa instalação, a fim de desenvolver estratégias de tratamentos térmicos da envoltória, no sentido de minimizar a necessidade de utilização de condicionamento artificial para a obtenção de níveis de conforto mais adequados em seu interior.

As análises experimentais foram realizadas no município de Mairinque - SP, situado na Zona Bioclimática Brasileira $n^{\circ} 3$ (ABNT, 2005), cujo clima pode ser descrito como tropical de altitude, com temperaturas amenas e predominância de chuvas no verão e noites frias no inverno. A caracterização termofísica dos contêineres foi realizada a partir de medições das condições climáticas do entorno, das temperaturas superficiais internas e externas da envoltória, bem como de variáveis que possibilitaram a análise de parâmetros de desempenho, conforto e estresse térmicos internos, como será apresentado a seguir.

Para a avaliação do Conforto Térmico foi utilizado o método do Conforto Adaptativo (ASHRAE, 2013), que possibilita a avaliação térmica de ambientes naturalmente ventilados. Tal método considera que há uma faixa relativamente ampla de satisfação térmica dos usuários que, podendo alterar variáveis relacionadas ao isolamento da roupa e aos controles de ganho de calor da edificação, como abertura e fechamento de portas e janelas, poderiam atingir índices satisfatórios de conforto sem que para tanto houvesse a necessidade de utilizar o condicionamento artificial. O método utiliza três categorias principais para a avaliação da satisfação térmica dos usuários: satisfação térmica de até $90 \%$ dos usuários, satisfação térmica de até $80 \%$ dos usuários (com tendência para o frio ou para o calor) e pontos localizados fora 
dos padrões de satisfação, situados em zonas cujos dados foram obtidos a partir de medições em situação de frio ou calor.

Os resultados obtidos a partir da medição realizada durante um ano no interior dos contêineres demonstraram que há insuficiência em relação ao comportamento termofísico da envoltória ao se avaliar o conforto térmico dos usuários tanto para situações de calor, quanto para situações de frio (Tabela 2).

Tabela 2 - Avaliação da satisfação térmica no interior do contêiner.

\begin{tabular}{|c|c|c|c|c|c|}
\hline Parâmetro & $\begin{array}{l}\text { Até } 90 \text { \% de } \\
\text { satisfação } \\
\text { térmica }\end{array}$ & $\begin{array}{l}\text { Até } 80 \% \text { de } \\
\text { satisfação } \\
\text { térmica } \\
\text { (tendência } \\
\text { ao calor) }\end{array}$ & $\begin{array}{l}\text { Até } 80 \% \text { de } \\
\text { satisfação } \\
\text { térmica } \\
\text { (tendência } \\
\text { ao frio) }\end{array}$ & $\begin{array}{l}\text { Fora dos } \\
\text { parâmetros } \\
\text { de satisfação } \\
\text { térmica } \\
\text { (calor) }\end{array}$ & $\begin{array}{l}\text { Fora dos } \\
\text { parâmetros } \\
\text { de satisfação } \\
\text { térmica (frio) }\end{array}$ \\
\hline Percentual (\%) & 13 & 2 & 5 & 31 & 49 \\
\hline
\end{tabular}

Os dados apresentados na Tabela 2 demonstram que a predominância de pontos situa-se fora dos limites de conforto considerados pelo método. O fato surpreendente, no entanto, é a constatação de que o maior percentual de pontos fora dos parâmetros de conforto refere-se a situações de frio para a Zona Bioclimática 3, e não de calor, conforme informações obtidas nos relatos colhidos em campo.

A insuficiência térmica da envoltória dos contêineres pode, porém, atingir níveis que levem a comprometer a condição de permanência do ser humano em seu interior em situações de calor, principalmente sob a incidência de radiação solar direta. Na pesquisa de mestrado citada previamente (COSTA, 2015), foram constatados momentos em que a temperatura do ar interno extrapolou o parâmetro do desconforto térmico, atingindo o que se denomina por estresse térmico. Sob situações de estresse térmico, o ser humano pode sofrer comprometimento de sua condição física, fato que respalda a NR-15 - Atividades e operações insalubres (BRASIL, 1978) estabelecer reduções da jornada de trabalho em tais situações.

Durante as medições, foram constatados episódios de estresse térmico no interior do contêiner sem tratamento térmico da envoltória, ocorridos principalmente nos horários mais quentes dos dias, em função da radiação solar direta a que essas instalações estavam submetidas. No mês de fevereiro - o mais quente do ano na região onde ocorreu o experimento - foram registradas até 4 horas por dia, em média, de condições de estresse térmico. Segundo a NR-15 - Atividades e operações insalubres, $82 \%$ do tempo sob estresse térmico registrado na pesquisa experimental, levaria a 
uma redução de jornada de 15 minutos a cada hora de trabalho, enquanto 18\% dos valores registrados levariam à redução de meia hora a cada hora trabalhada.

A envoltória apresenta insuficiência térmica também para situações de frio. No decorrer do ano experimental, foram registrados - durante as noites mais frias do ano e também durante o dia, no inverno, nos períodos sem radiação solar - momentos em que o frio ultrapassou a situação de desconforto, atingindo o que se pode considerar estresse térmico. Embora não tenham sido constatados momentos em que houvesse risco de congelamento ao corpo humano, durante o mês de agosto - mês mais frio no decorrer das medições - constatou-se até 15 horas diárias, em média, de temperaturas abaixo de $10^{\circ} \mathrm{C}$ no interior do contêiner.

Com relação ao desempenho térmico estabelecido pelos parâmetros da NBR 15575-1 (ABNT, 2013), a Norma de Desempenho, o contêiner sem tratamento térmico da envoltória também demonstrou insuficiência: no mês cujos resultados são de melhor desempenho térmico, somente durante treze horas por dia, em média, a temperatura interna permaneceu dentro dos parâmetros da norma, enquanto no pior mês registrado, a média foi de apenas quatro horas por dia dentro dos parâmetros de desempenho, que considera a diferença entre temperaturas do ar externas e internas.

A Figura 4 apresenta o registro de temperaturas no termômetro de globo localizado no interior do contêiner sem tratamento térmico. Os valores obtidos a partir das medições de temperatura com esse sensor aproximam-se significativamente dos valores da temperatura do ar interno, ou temperatura de bulbo seco, permenecendo a diferença entre as medições com os dois sensores situada na casa do décimo de grau.

(a)
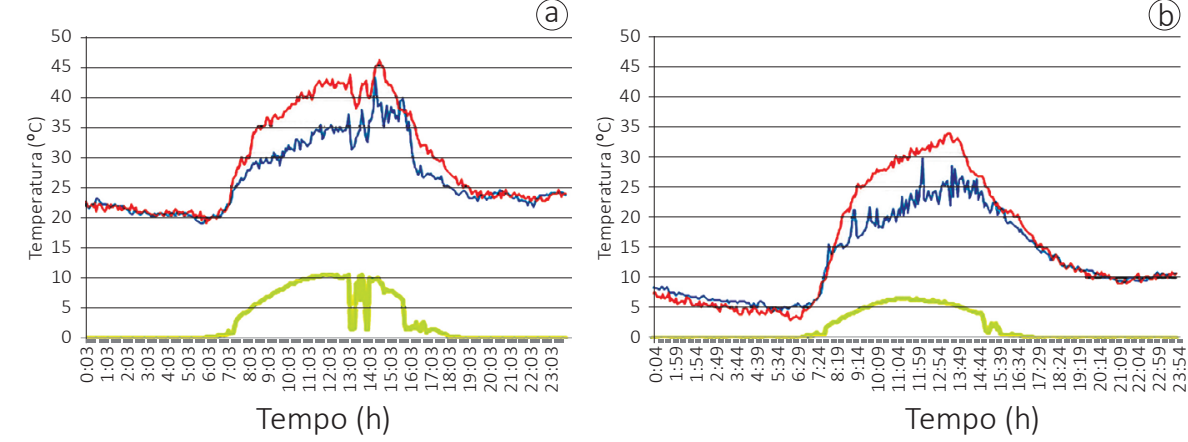

(b)

TBS Externa $\left({ }^{\circ} \mathrm{C}\right)$

Irradiação x 0,01 (W/m²)

Temperatura de Globo $\left({ }^{\circ} \mathrm{C}\right)$

Figura 4 - Comportamento do termômetro de globo no dia mais quente (a) e no dia mais frio (b) no interior do contêiner sem tratamento térmico. 
No verão, no horário mais quente, a temperatura de globo supera os $45^{\circ} \mathrm{C}$. No inverno, a temperatura no interior do contêiner atinge valor inferior a $4^{\circ} \mathrm{C}$ pouco antes do amanhecer.

\section{Estratégias de Tratamento Térmico para Contêineres em Canteiros de Obra}

Conforme apresentado nas análises do comportamento termofísico dos contêineres, o desempenho térmico da envoltória é insuficiente tanto para situações de frio quanto para situações de calor. As recomendações da NBR-15220-3 (ABNT, 2005) para o tratamento térmico da envoltória de edifícios convencionais situados na Zona Bioclimática Brasileira $n^{\circ} 3$ - local onde ocorreram as medições experimentais são a priorização da ventilação cruzada no verão e o aquecimento solar aliado à inércia térmica da envoltória no inverno. Os contêineres, no entanto, não se enquadram na categoria das edificações convencionais, dado que não têm inércia térmica significativa na envoltória e possuem limitações quanto à adição de massa térmica como estratégia de projeto, pois isso limitaria sua flexibilidade e mobilidade, parâmetros característicos desse tipo de instalação, sendo também algumas das características mais atraentes no momento de sua escolha como tipologia para canteiros de obras.

O experimento realizado na pesquisa de mestrado citada anteriormente (COSTA, 2015) contou com mais dois contêineres, além do contêiner sem tratamento térmico já descrito em análise do comportamento termofísico. O primeiro, dotado de tratamento da envoltória à condução, contava com uma camada de EPS de $2 \mathrm{~cm}$ sob a cobertura e no fechamento vertical, bem como com um forro de chapa dura de madeira de 0,25 mm para melhoria da qualidade de acabamento interno; o segundo, por sua vez, contava com tratamento da envoltória à radiação solar, tendo recebido aplicação de uma camada de 0,25 $\mu \mathrm{m}$ de revestimento refletivo branco em toda a envoltória, externamente.

\subsection{Diminuição do Ganho Térmico sob Radiação Solar - Uso Predominante em Programas de Ocupação Humana no Período Diurno ou em Ambientes Quentes}

A pesquisa experimental demonstrou que o contêiner com revestimento refletivo apresenta os melhores resultados quanto à diminuição do ganho de calor pela envoltória sob radiação solar direta ou em situações de calor, ainda que sem a presença de radiação solar. 
O revestimento utilizado no modelo experimental foi o produto Nanothermic 1, desenvolvido, fabricado e comercializado pela empresa Nanotech do Brasil. O revestimento é composto de partículas com elevados índices de refletância e emissividade, característica que confere ao produto a qualidade de atingir menores temperaturas superficiais, em comparação aos materiais convencionais. Sua aplicação é realizada de modo simples, com uma bomba de pressão e, se realizada sob temperaturas de amenas a quentes, possui excelente aderência às superfícies metálicas dos contêineres.

A Figura 5 apresenta o registro das temperaturas de globo registradas no interior do contêiner durante os dias mais quente e mais frio, respectivamente.

(a)
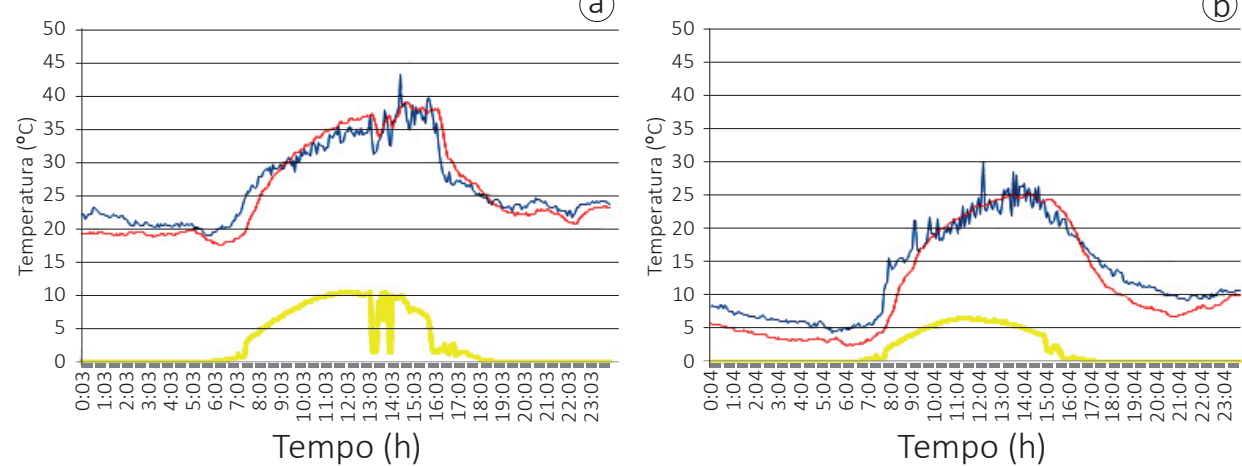

(b)

Tempo (h)

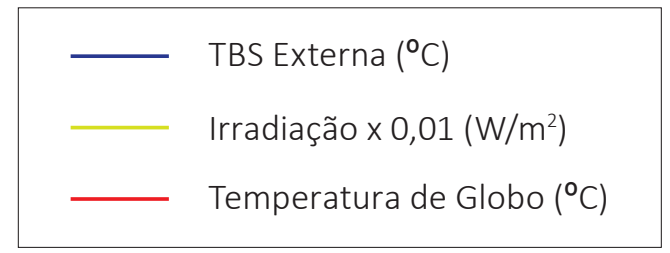

Figura 5 - Comportamento do termômetro de globo no dia mais quente (a) e no dia mais frio (b) no interior do contêiner com revestimento refletivo.

A temperatura de globo atinge os $38^{\circ} \mathrm{C}$ aproximadamente, na hora mais quente no dia de verão, enquanto no inverno, a menor temperatura registrada no interior do contêiner é inferior a $3^{\circ} \mathrm{C}$. O resultado de temperatura interna sob condição de calor no contêiner com revestimento refletivo foi o melhor valor obtido entre os três contêineres estudados. 


\subsection{Conservação do Calor no Interior do Contêiner: Uso Predominante em Programas de Ocupação Humana no Período Noturno}

Os resultados obtidos para o contêiner que recebeu tratamento térmico com o objetivo de aumentar a resistência à condução demonstram que o isolamento térmico executado com poliestireno expandido e chapa de madeira, como feito na cobertura, tem grande capacidade de redução do ganho de calor para o interior do contêiner, bem como na redução de perdas durante os períodos de resfriamento, como apresentado na Figura 6. Tal sistema de isolamento seria viável também para a utilização do contêiner com condicionadores de ar, diminuindo a demanda por energia elétrica para manter a temperatura dentro dos padrões de conforto, se comparado aos valores obtidos para o contêiner sem tratamento térmico.

(a)

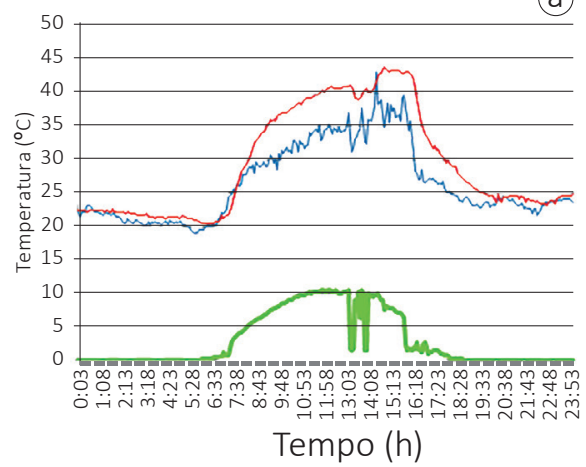

(b)

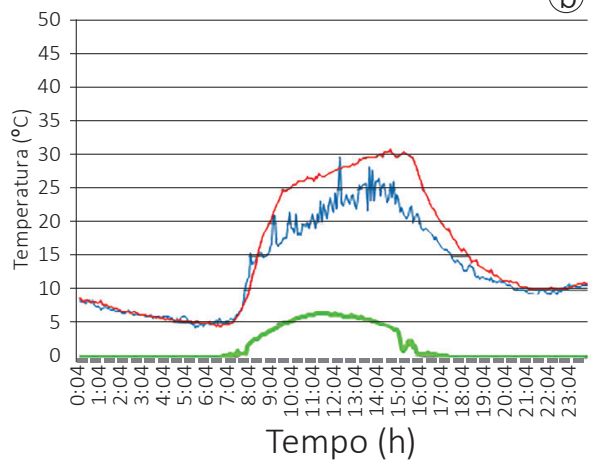

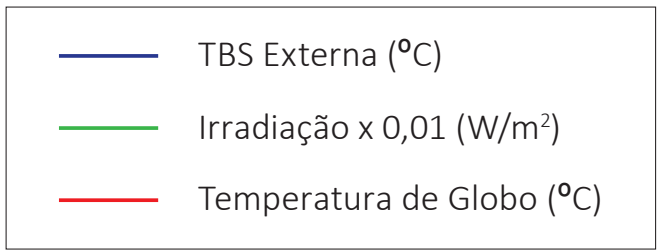

Figura 6 - Comportamento do termômetro de globo no dia mais quente (a) e no dia mais frio (b) no interior do contêiner com tratamento à condução.

No dia mais quente de verão, a temperatura interna atinge os $43^{\circ} \mathrm{C}$, aproximadamente, enquanto no dia mais frio de inverno, a temperatura de globo atinge os $5^{\circ} \mathrm{C}$, sendo esse o melhor resultado obtido para o frio entre os três contêineres estudados. 


\section{Comparação Anual entre os Três Contêineres - Soma dos Graus-hora}

O método dos graus-hora consiste na somatória das diferenças de temperatura entre a temperatura de referência ou temperatura de base - definida a partir de condicionantes locais - e as temperaturas medidas ou simuladas em determinado contexto.

As temperaturas de base são definidas em um intervalo no qual - para aquela determinada região climática - seja possível manter níveis de conforto sem que haja a necessidade da utilização de condicionadores artificiais (CIBSE, 2006). No presente estudo, foram consideradas como temperaturas de base os $20^{\circ} \mathrm{C}$ como temperatura mínima e $26^{\circ} \mathrm{C}$ como temperatura máxima. Tal definição implica no entendimento de que quando temperaturas abaixo de $20^{\circ} \mathrm{C}$ são registradas em medição, haveria a necessidade de aquecimento do ambiente, e quando temperaturas acima de $26^{\circ} \mathrm{C}$ são registradas, haveria a necessidade de resfriamento do ambiente.

O resultado final dos graus-hora é obtido pelo registro da diferença horária entre a temperatura de globo registrada e a temperatura de base. Se a temperatura de globo estiver acima dos $26^{\circ} \mathrm{C}$, a diferença é registrada como hora de resfriamento e, se estiver abaixo dos $20^{\circ} \mathrm{C}$, é registrada como hora de aquecimento. A somatória total das horas de aquecimento e resfriamento resulta no que se denomina graus-hora.

\subsection{Graus-hora de Aquecimento}

Conforme observado anteriormente, o registro das horas de aquecimento foi obtido nos momentos de ausência da radiação solar. No verão, tal fato ocorreu durante os períodos noturnos e, no inverno, a partir do momento em que a radiação solar direta desaparecia.

O resultado final apresentado na Figura 7 demonstra que os três contêineres alcançam valores altíssimos de horas de aquecimento, sendo o Contêiner à condução aquele que apresentou maior eficiência entre os três. Os resultados do Contêiner refletivo - cuja temperatura superficial externa é inferior à dos demais - foi extremamente negativo, demonstrando que em uma edificação cuja envoltória possui baixa resistência térmica, a temperatura superficial pode exercer influência sobre os níveis de conforto e o consumo energético. 


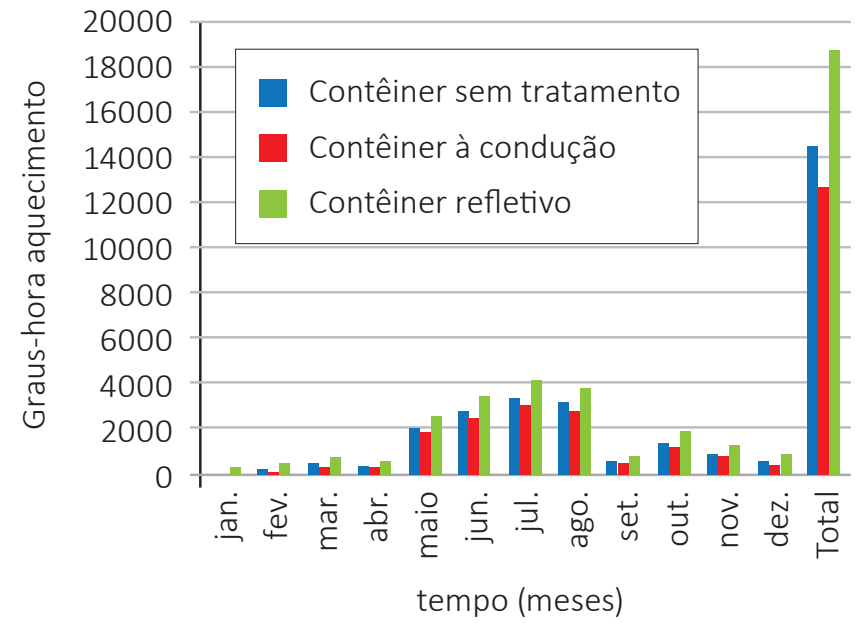

Figura 7 - Graus-hora: horas de aquecimento para os três contêineres.

\subsection{Graus-hora de Resfriamento}

As horas de resfriamento foram obtidas frequentemente sob a ação da radiação solar. Nota-se, como aparece na Figura 8, que os resultados finais são inferiores ao das horas de aquecimento, demonstrando que apesar de haver insatisfação por parte de usuários questionados em conversas informais quanto ao comportamento térmico dos contêineres no calor, seu desempenho térmico é ainda pior no frio.

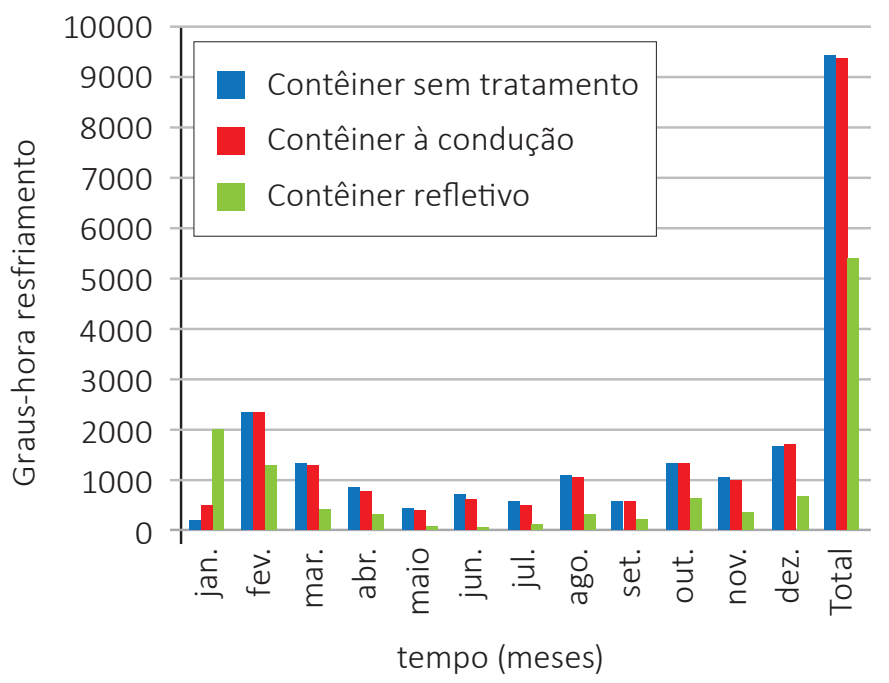

Figura 8 - Graus-hora: horas de resfriamento para os três contêineres. 
O Contêiner sem tratamento apresentou os piores resultados para as horas de resfriamento, totalizando 9423 horas. No Contêiner à condução, registrou-se $97 \%$ das horas de resfriamento obtidas no Contêiner sem tratamento, enquanto no Contêiner refletivo, obteve-se o surpreendente resultado de $38 \%$.

\section{Conclusões}

A envoltória dos contêineres metálicos possui características que a tornam insuficiente do ponto de vista do desempenho térmico. Sua baixa inércia térmica leva as superfícies a variações bruscas de temperatura, situação que consequentemente se registra também no interior dessas instalações. Dessa forma, quando se pretende a utilização sob condicionamento passivo, isto é, sem a utilização de condicionadores artificiais, é necessário que se determine previamente a localidade na qual o contêiner será utilizado, considerando principalmente suas condições climáticas, como também o tipo de uso predominante a que o contêiner será destinado: se diurno ou noturno. Seu desempenho térmico insuficiente prejudica a adoção de uma única solução de tratamento térmico da envoltória para toda e qualquer situação quando se objetiva o condicionamento passivo ou mesmo a redução do consumo energético para condicionamento artificial.

O Quadro 1 apresenta um resumo das diretrizes para uso mais adequado à obtenção de padrões aceitáveis de conforto térmico e eficiência energética nos climas brasileiros.

Quadro 1 - Tratamento térmico da envoltória para melhor desempenho térmico dos contêineres para canteiros de obras.

\begin{tabular}{|c|c|c|c|c|c|}
\hline & \multirow[b]{2}{*}{ Clima } & \multicolumn{2}{|c|}{ Com Condicionamento Artificial } & \multicolumn{2}{|c|}{ Sem Condicionamento Artificial } \\
\hline & & Quente & Frio & Quente & Frio \\
\hline \multirow{2}{*}{ 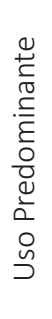 } & Diurno & $\begin{array}{l}\text { revestimento } \\
\text { refletivo + } \\
\text { isolamento à } \\
\text { condução }\end{array}$ & $\begin{array}{l}\text { isolamento à } \\
\text { condução }\end{array}$ & $\begin{array}{l}\text { revestimento refletivo } \\
\text { + isolamento à } \\
\text { condução sob a } \\
\text { cobertura }\end{array}$ & $\begin{array}{l}\text { isolamento à } \\
\text { condução }\end{array}$ \\
\hline & Noturno & $\begin{array}{l}\text { revestimento } \\
\text { refletivo + } \\
\text { isolamento à } \\
\text { condução }\end{array}$ & $\begin{array}{l}\text { isolamento à } \\
\text { condução }\end{array}$ & revestimento refletivo & $\begin{array}{l}\text { isolamento à } \\
\text { condução }\end{array}$ \\
\hline
\end{tabular}

A aplicação do revestimento refletivo apresenta-se como uma solução durável e de baixo custo para a utilização dos contêineres. Para que as propriedades do 
revestimento sejam amplamente aproveitadas na diminuição do ganho térmico, percebe-se que a utilização do revestimento resistente à radiação se faz adequada em contêineres que se destinem prioritariamente ao uso em atividades exercidas durante o dia nos canteiros de obras, como é o caso do trabalho nos escritórios, ou ainda em usos predominantemente noturnos em localidades de clima quente de dia e à noite. Ainda que haja necessidade da utilização de climatizadores artificiais no verão, a demanda por energia será minimizada.

$\mathrm{O}$ isolamento térmico da envoltória com os tradicionais materiais isolantes EPS, poliuretano e demais fibras - aplica-se aos casos nos quais se pretende conservar o calor internamente, como acontece nos contêineres destinados a dormitórios de trabalhadores em climas amenos ou frios. O isolante térmico também pode ser utilizado nos casos em que se pretende minimizar as trocas entre o ar externo e interno, como nas situações em que se opta por condicionamento artificial.

Para os climas quentes, a utilização de uma solução mista que empregue o revestimento refletivo externamente na envoltória somado ao tratamento da cobertura à condução teria grande potencial de diminuição de ganho térmico no interior dos contêineres.

No caso do uso em localidades quentes cuja necessidade de condicionamento artificial é premente, a demanda por energia seria minimizada com a utilização de ambos os tratamentos térmicos simultaneamente: a aplicação de revestimento refletivo e o isolamento térmico à condução na envoltória.

\section{Referências}

ASHRAE. American Society of Heating, Refrigerating and Air-Conditioning Engineers, INC. ASHRAE STANDART 55-2013. Thermal Environmental Conditions for Human Occupancy. 2013.

ASSOCIAÇÃO BRASILEIRA DE NORMAS TÉCNICAS. NBR 15220-3: Desempenho térmico de edificações - Parte 3: Zoneamento Bioclimático brasileiro e diretrizes construtivas para habitações unifamiliares de interesse social. 2005.

ASSOCIAÇÃO BRASILEIRA DE NORMAS TÉCNICAS. NBR 15575-1: Edificações Habitacionais - Desempenho Parte 1: Requisitos Gerais. 2013.

BRASIL. Ministério do Trabalho e Emprego. Norma Regulamentadora 15 (NR15) - Atividades e Operações Insalubres - Anexo III - Limites de Tolerância para Exposição ao Calor. 1978. Disponível em: <http://portal.mte.gov.br/data/ files/8A7C816A47594D040147D14EAE840951/NR-15\%20(atualizada\%202014). pdf>. Acesso em: nov. 2014.

CIBSE. The Chartered Institution of Building Services Engineers. Degree-days - theory and application - tm41 2006. [S.I.]: CIBSE, 2006. 
COSTA, D.C.R.F. Contêineres metálicos para canteiros de obras: análise experimental de desempenho térmico e melhorias na transferência de calor pela envoltória. Dissertação (Mestrado) - Escola Politécnica da Universidade de São Paulo. São Paulo, 2015.

OLIVEIRA, M.E.R.; LEÃO, S.M.C. Planejamento das Instalações de Canteiros de Obras: Aspectos que Interferem na Produtividade. ENEGEP 1997, 1997. Disponível em: <http:// www.abepro.org.br/biblioteca/ENEGEP1997_T3308.PDF>. Acesso em: jun. 2014.

SANTAMOURIS, M.; KOLOKOTSA, D. Passive cooling dissipation techniques for buildings and other structures: The state of the art. Energy and Buildings, v. 57, p. 74-94, fev. 2013.

SAURIN, T. A.; FORMOSO, C. T. Planejamento de canteiros de obra e gestão de processos. Porto Alegre: ANTAC, 2006. 


\title{
Sistema Pré-Fabricado em Pré-Moldado de Concreto para Instalações Provisórias de Canteiros de Obra
}

\author{
Nery Knöner \\ Fernando Menezes de Almeida Filho \\ Marcelo de Araújo Ferreira
}

\section{Introdução}

No Brasil, nas últimas décadas, houve um aumento significativo no uso de estruturas pré-fabricadas em concreto em virtude do desenvolvimento dos componentes e da facilidade de utilização desse sistema para obras comerciais, residenciais e esportivas, agregando vantagens, como rapidez e facilidade de execução, redução de desperdícios e segurança na montagem.

O sistema em pré-moldados de concreto proporciona uma construção limpa, racional e com menos desperdício de materiais, além de possibilitar maior conforto e bem-estar aos seus ocupantes. Como estratégia de concepção, procura utilizar componentes e processos padronizados, bem como aproveitar mais eficientemente os recursos disponíveis. Para Van Acker (2002), com os pré-moldados de concreto é possível atender os requisitos de industrialização, mesmo sem a produção em escala, obtendo um processo de produção eficiente, combinado com o trabalho especializado e a padronização de soluções construtivas. 
Segundo Serra et al. (2005), a industrialização da construção civil, por meio da utilização de peças de concreto pré-fabricados, promoveu, no Brasil e no mundo, um salto de segurança e organização nos canteiros de obras, devido ao uso de componentes industrializados com alto controle de produção, com materiais de qualidade, fornecedores selecionados e mão de obra qualificada.

A construção em elementos pré-fabricados em concreto não se limita apenas a fabricar peças fora do canteiro, mas engloba todo um sistema construtivo com características próprias, que devem ser preconizadas desde o início do projeto do empreendimento (FIB, 2012). Visto que o concreto possui boa inércia térmica e resistência ao fogo, os componentes gerados, como as paredes, podem ser projetados para atender determinadas especificidades, como reduzir os ruídos, devido à sua densidade.

Para Knöner (2014), o uso dos pré-moldados possui potencial de aplicação para instalações provisórias em canteiros de obra, considerando inclusive a necessidade da desmontagem e reutilização dos componentes em diferentes obras, além das outras vantagens levantadas. Para esse autor, a desmontagem com fins de remontagem é uma característica não comumente citada, mas deve ser considerada desde o início do processo de projeto.

Existem poucos fabricantes que fornecem opções de instalações provisórias em concreto pré-moldado no mercado brasileiro. Um deles é a empresa Prefacc (PREFACC, 1992) sediada em Uberlândia, Minas Gerais. Segundo o referido fabricante, trata-se de um sistema construtivo formado por placas de concreto celular autoclavado, com módulos de 0,60 m de largura, interligados por perfilados metálicos, que podem chegar até $3 \mathrm{~m}$ de altura. Entre os clientes da Prefacc, podem ser verificadas empresas de grande porte, consórcios e órgãos públicos.

Além deste tipo de instalações provisórias, são oferecidas pelo mercado diferentes soluções construtivas, como o uso de madeira ou de chapas metálicas (DIAS; SERRA, 2013), mas faltam dados para determinar o atendimento às condições de desempenho de cada solução.

Apesar da existência das soluções comerciais, no Brasil, a maioria das instalações provisórias dos canteiros de obras ainda é precária e não projetada com vistas ao seu melhor funcionamento. Considerada como uma instalação temporária, não se costuma seguir regras de projeto e de segurança, e somente em alguns casos, a NR18 - Condições e meio ambiente de trabalho na indústria da construção (BRASIL, 2015), que preconiza condições mínimas de uso e segurança, é atendida.

Também não são comumente considerados os requisitos de uso e operação desses tipos de instalações, como resistência estrutural, desempenho térmico, estanqueidade à agua, entre outros, os quais são prescritos pelas normas técnicas.

Dessa forma, este capítulo visa apresentar uma proposta de instalação provisória em pré-moldado de concreto para uso em canteiro de obra e, em seguida, 
analisar os principais requisitos técnicos identificados para a concepção de um sistema construtivo. A proposta surge também no contexto de encontrar um sistema eficiente, de construção rápida, econômico, com redução significativa na produção de resíduos e que proporcione qualidade do ambiente de trabalho.

O sistema construtivo desenvolvido possibilita atender a demanda de mercado para construção de canteiros de obra de acordo com os quesitos da NR-18 - Condições e meio ambiente de trabalho na indústria da construção (BRASIL, 2015) e NBR 12284 (ABNT, 1991). O sistema pré-fabricado atende aos requisitos de rapidez na montagem, eliminação de resíduo e baixo custo, além de utilizar um processo construtivo que pode ser reaproveitado várias vezes em outro canteiro.

\section{Método de Pesquisa}

O trabalho foi desenvolvido com base na pesquisa de mestrado de Knöner (2014). A pesquisa tratou de um estudo teórico e experimental, dividido em três etapas:

- A primeira etapa consistiu no estudo sobre a utilização de diferentes sistemas construtivos para aplicação em instalações provisórias, buscando identificar as principais características necessárias para essas estruturas;

- A segunda etapa consistiu no desenvolvimento de um projeto de instalações provisórias em pré-moldado de concreto de forma a agregar vantagens técnicas, econômicas, sociais e ambientais;

- A terceira etapa consistiu na realização de simulações teóricas por meio de ensaios de laboratório e da determinação dos parâmetros técnicos necessários para desenvolvimento do produto.

A fase de montagem e desmontagem do protótipo não foi desenvolvida por Knöner (2014) devido à duração do mestrado ser inferior ao tempo necessário para a elaboração do produto. Este trabalho foca na apresentação sucinta das etapas 2 e 3, que podem ser melhor verificadas no trabalho original.

O Anexo apresenta momentos da montagem do protótipo ocorrida em 2017.

\section{Sistema Proposto de Instalações Provisórias}

O sistema de pré-moldado de um pavimento foi criado inicialmente com propósito da habitação social, visando proporcionar moradias para a classe de baixa renda, com características de simplicidade, rapidez na montagem, viabilidade econômica e resistência. O sistema inicial foi adaptado para obra de instalação provisória atendendo às necessidades de montagem e desmontagem futura dos componentes pré-moldados. 
A Figura 1 mostra a planta da instalação provisória projetada para construção do protótipo, que se trata de um ambiente de escritório, formado por uma sala e um pequeno banheiro. A dimensão externa corresponde a $6 \mathrm{~m}$ de comprimento por $3,5 \mathrm{~m}$ de largura, com uma varanda de 1,5 m. O protótipo conta com as seguintes peças prémoldadas de concreto:

- Montantes ou Pilares: seção 10 x $10 \mathrm{~cm}$ e altura 3,20 m;

- Placas: dimensões $50 \times 100 \mathrm{~cm}$ e espessura $2,5 \mathrm{~cm}$;

- Elemento de fundação (apoio para pilar): dimensões $25 \times 25 \mathrm{~cm}$ e altura $12 \mathrm{~cm}$.

Na planta baixa (Figura 1), percebe-se que as paredes são formadas por placas, colocadas externa e internamente fixadas aos pilares, dotadas de um vão entre elas, que se configura como uma câmara de ar. Esta solução beneficia também a resistência térmica e conforto acústico do sistema construtivo.

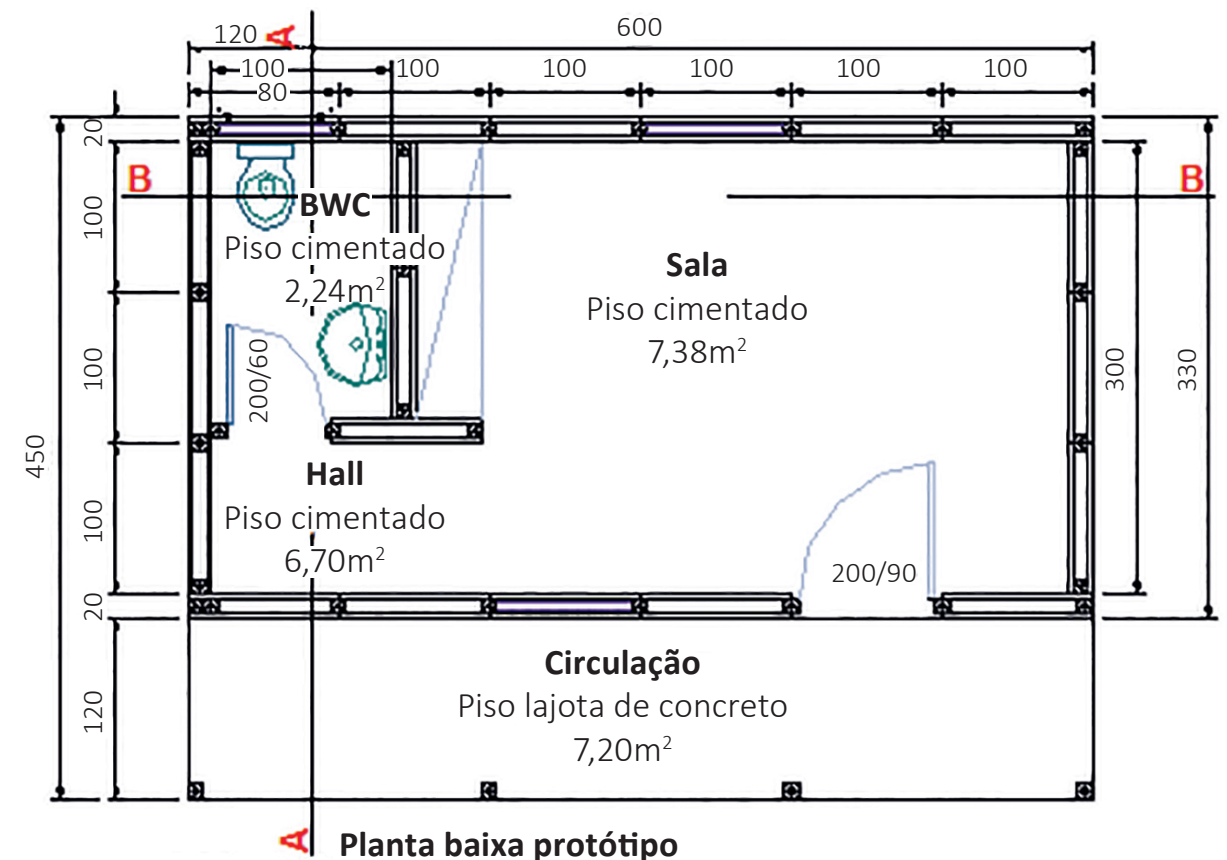

Piso lajota de concreto

$27,18 \mathrm{~m}^{2}$

Figura 1 - Planta baixa do protótipo para instalações provisórias. Fonte: Knöner, 2014.

Na Figura 2, é possível observar as dimensões e a forma de fixação do pilar ou montante sobre o elemento de fundação. O concreto para enchimento da fundação pode ser magro, uma vez que o pilar poderá ser retirado e reutilizado. 


\section{Montante}

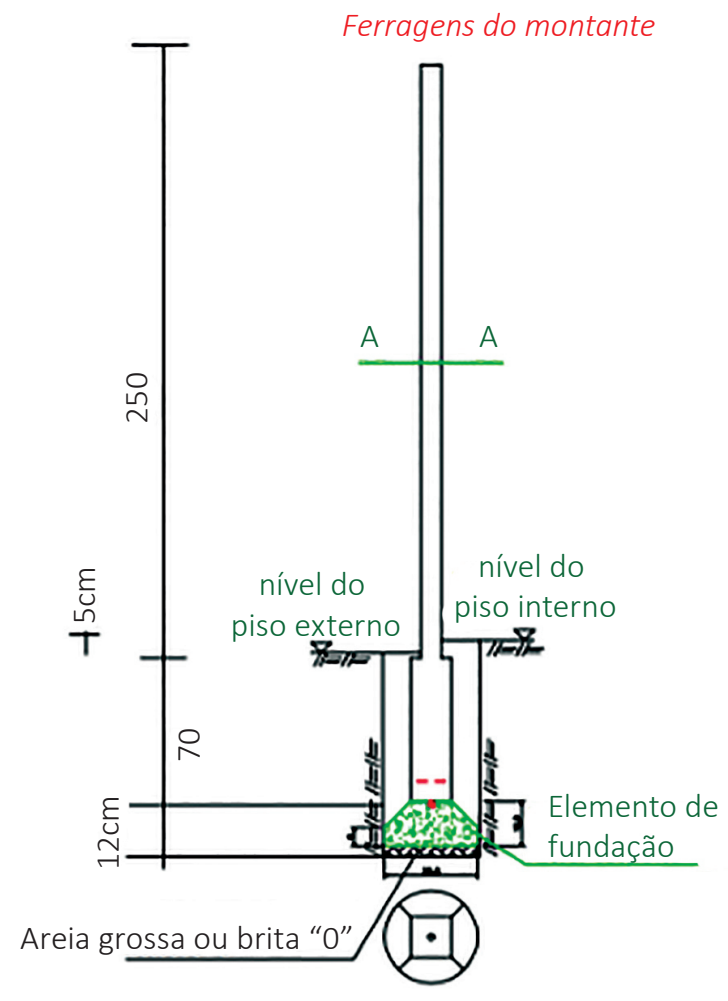

Figura 2 - Detalhe do montante e execução da fundação. Fonte: Knöner, 2014.

As principais características do sistema proposto são relacionadas a seguir:

- A instalação não necessita de fundação direta (blocos ou sapatas) nem possui vigas de baldrames, posto que foi desenvolvida uma peça especial para fixação do pilar na fundação;

- Os componentes dos montantes ou pilares foram feitos em concreto armado e possuem dimensão compatível atendendo o pé direito e a profundidade da fixação em solo;

- As paredes são formadas com duas placas de concreto fixadas externa e internamente nos pilares ou montantes com parafusos e buchas;

- Na parte superior da parede é fixado um perfil metálico tipo "U”, colaborando para a estabilidade das paredes e suporte para a estrutura metálica do telhado;

- Podem ser utilizados diferentes tipos de telhas, sendo a mais indicada a termoacústica; 
- As paredes não precisam ser rebocadas, apenas pintadas. Deve-se utilizar massa de vedação entre as placas que compõem as paredes externas;

- Todos os pontos elétricos - caixa de passagem, interruptores, tomadas são fixados no momento da concretagem das placas. Durante a montagem, as tubulações ficarão embutidas entre as placas. Outra solução possível é a concepção de instalações aparentes que poderão ser montadas após a finalização da estrutura do protótipo;

- Os pontos de água também foram concretados nas placas correspondentes. As tubulações hidráulicas de fornecimento de água potável também são fixadas durante a montagem e ficam entre as placas que compõem as paredes. Outra opção seria também o uso das instalações aparentes;

- Os batentes de porta e janelas encaixam-se entre os montantes e são de fácil colocação. Podem ser pré-moldados, metálicos ou de madeira. No caso estudado, optou-se por esquadrias metálicas para as janelas e madeira para as portas. As janelas devem ser encaixadas e simplesmente confinadas entre dois montantes, sendo necessária sua fixação durante a montagem do protótipo.

A Figura 3 mostra o Corte A-A da instalação provisória, podendo ser identificada a viga metálica de coroamento da estrutura de concreto pré-moldado e o uso previsto da telha termoacústica.

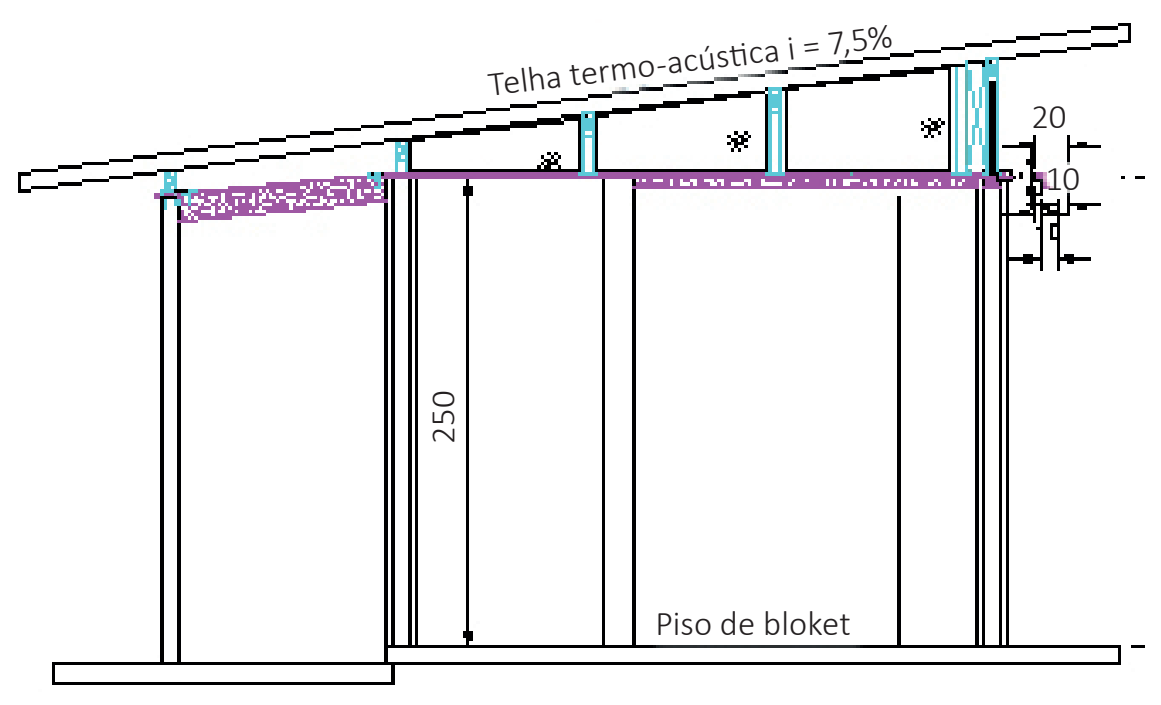

Vista lateral

Figura 3 - Corte A-A do protótipo para instalações provisórias. Fonte: Knöner, 2014. 
A Figura 4 mostra a perspectiva do protótipo de acordo com o projeto concebido.

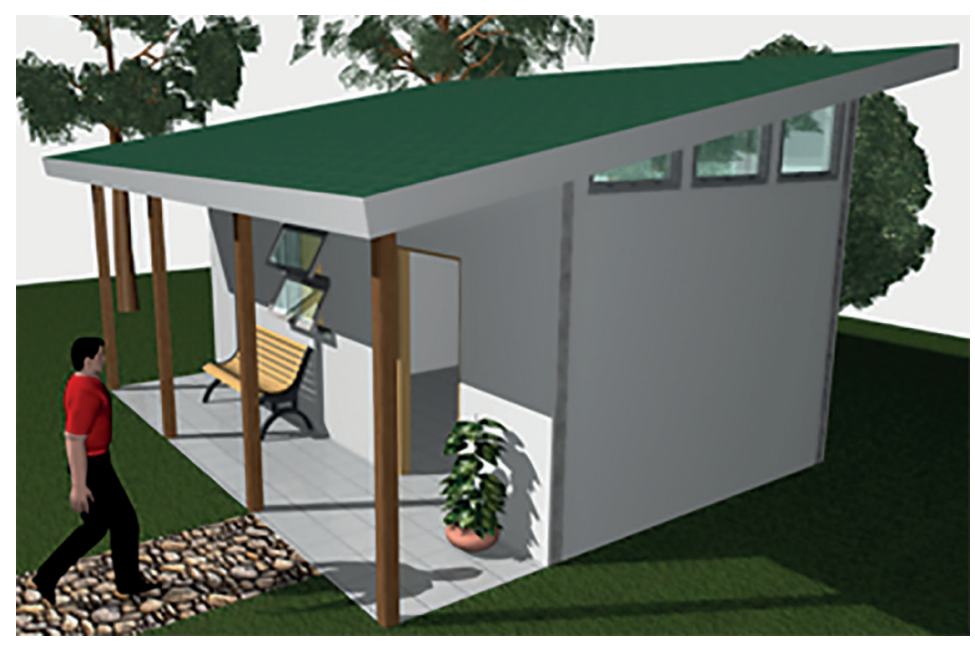

Figura 4 - Perspectiva do protótipo para instalações provisórias. Fonte: Knöner, 2014.

A partir da concepção do produto, procedeu-se ao cálculo e simulação matemática dos componentes do protótipo. Em seguida, foram realizados os testes experimentais nos componentes de concreto pré-moldado - pilares e placas - para posterior liberação da produção necessária para montagem do protótipo. Os demais elementos do sistema não foram ensaiados, pois o foco da pesquisa foi a análise do sistema construtivo denominado "parede".

\section{Confecção das Peças de Concreto do Sistema "Parede"}

As peças de concreto que compõem o fechamento das paredes da obra foram produzidas em concreto convencional, conforme descrito a seguir.

\subsection{Placas de Concreto}

Constituídas por concreto, cimento, areia, brita zero e tela com malha de 1-1/2", diâmetro médio $0,66 \mathrm{~mm}, \mathrm{f}_{\mathrm{yk}}=320 \mathrm{MPa}$, concreto de resistência característica $\mathrm{fck}=20 \mathrm{MPa}$, com as dimensões de $1,0 \mathrm{~m} \times 0,50 \mathrm{~m} \times 2,5 \mathrm{~cm}$ e peso médio de $30 \mathrm{~kg}$ por placa. Para confecção das placas, foi concebida a forma metálica mostrada na Figura 5. Deve ser passado um desmoldante que facilite a desforma da placa. A peça é concretada, vibrada e posta rigorosamente em nível, garantindo uma boa modelagem e cura. 


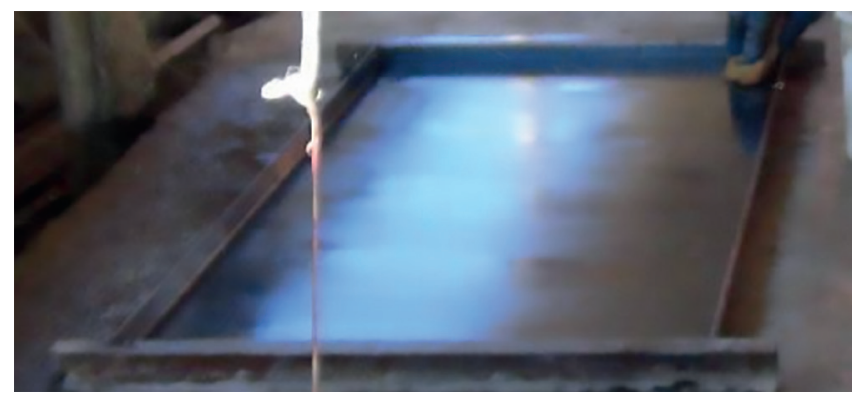

Figura 5 - Vista da forma metálica para confecção das placas de concreto pré-moldado. Fonte: Knöner, 2014.

Após 12 h da concretagem, a placa pode ser desmoldada e permanecer curando. As formas metálicas podem ser liberadas para concretagem da próxima placa.

\subsection{Montantes ou Pilares}

Para fabricação dos montantes, também se utilizou de uma forma metálica, de desmoldante e colocação de armaduras. A Figura 6 mostra a forma metálica do montante e a armadura do pilar posicionada ao lado. Foi dimensionado o uso de 4 ferros de diâmetro de 6,3 mm, CA 50, e estribos de diâmetro de 4,2 mm, CA 60, com espaçamento a cada $12 \mathrm{~cm}$. Utilizou-se o mesmo concreto das placas e o peso dos montantes ficou em torno de $75 \mathrm{Kg}$.

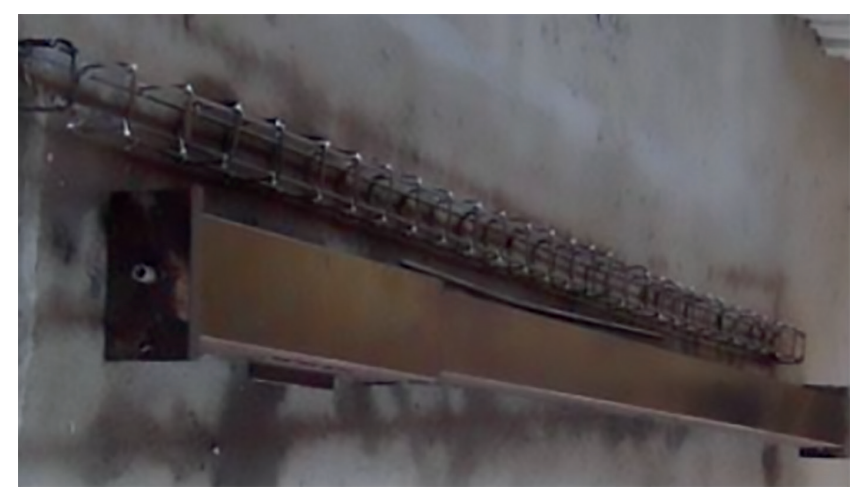

Figura 6 - Detalhe da forma e armadura dos montantes estruturais. Fonte: Knöner, 2014.

As formas foram preparadas, niveladas e limpas antes que fosse passado o desmoldante. As armaduras devem ser conferidas, garantindo-se um cobrimento mínimo das peças. Da mesma forma, a peça foi concretada, vibrada e posta rigorosamente em nível, garantindo uma boa modelagem e cura. 


\section{Análises Teóricas}

\subsection{Resistência ao Fogo}

De acordo com a NBR 5627 (ABNT, 1980), o critério básico de classificação das edificações em relação à resistência ao fogo é determinado em função do tempo de duração que um elemento estrutural deve resistir.

No caso dos painéis, a análise mais importante é a da transmissão de calor através da espessura do componente. Raramente o cobrimento das armaduras tem a função de absorver as tensões das etapas de desforma e transporte, sendo um fator predominante na determinação da resistência ao fogo dos painéis (Precast Concrete Institute (PCI), 1989).

Segundo NBR 14432 (ABNT, 2001), a determinação do TRRF (Tempo requerido de resistência ao fogo) é em função do tipo de ocupação da edificação e da sua altura. A mesma norma menciona que "estão isentas dos requisitos de resistência ao fogo estabelecidos nesta Norma as edificações cuja área total seja menor ou igual a 750 m²".

Entretanto, optou-se por analisar o parâmetro tendo por base a norma do $\mathrm{PCl}$ (1989) para painéis de concreto. Nesse caso, foi considerada a espessura da placa aproximadamente igual a $10 \mathrm{~cm}$ (2 polegadas), sem considerar a camada de ar entre as mesmas, e o tipo de concreto como leve (lightweight concrete). Com o ábaco disponível na publicação, obtém-se o resultado identificado na Figura 7. Ou seja, utilizando gráfico do PCl (1989) foi determinado o tempo de 50 minutos de resistência ao fogo.

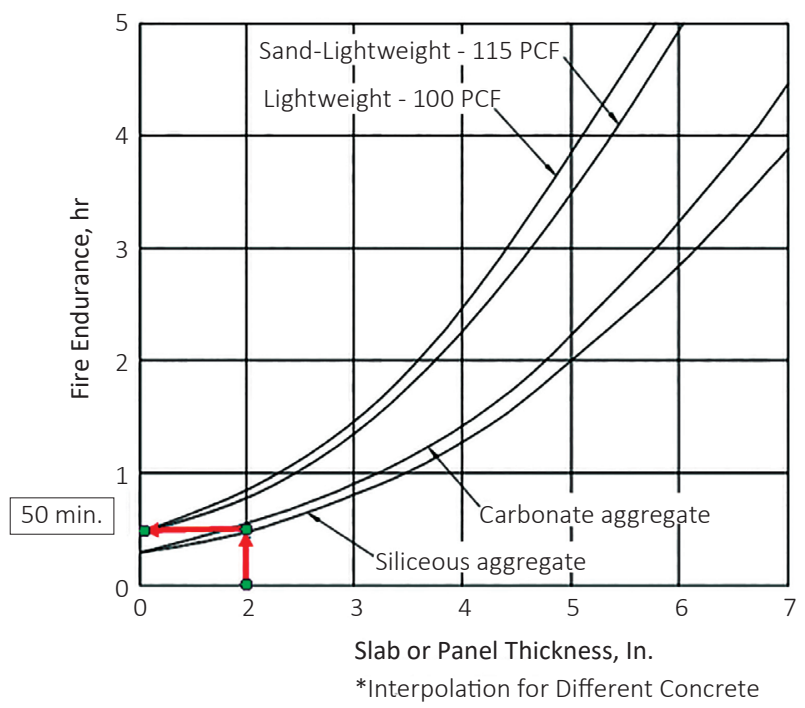

Figura 7 - Gráfico para determinação do tempo de transmissão de calor em concreto prémoldado considerando a espessura da placa. Fonte: PCl, 1989. 


\subsection{Desempenho Térmico}

Segundo NBR 15575 (ABNT, 2013), o objetivo é verificar se a transmitância térmica e capacidade térmica do sistema "parede" proporcionam desempenho térmico mínimo conforme estabelecido para cada zona bioclimática do Brasil, de acordo com NBR 15220 (ABNT, 2008).

Considerando a região de São Carlos, denominada região 4 devido a condição do clima da cidade, a NBR 15220 (ABNT, 2008) estabelece que as paredes devem ser pesadas e as coberturas devem ser leves. As paredes pesadas, conforme Tabela C.2 da referida norma, devem ter transmitância térmica $(U)$ menor ou igual a 2,2W/m2.k, atraso térmico $(\phi)$ maior ou igual a $6,5 \mathrm{~h}$ e fator solar (FSo) menor ou igual a 3,5 \%.

Como se sabe, a área total do protótipo é de $27 \mathrm{~m}^{2}$ e o pé direito médio é de $\mathrm{h}=2,80 \mathrm{~m}$, sabe-se também que as paredes possuem duas placas, com espessura de $2,5 \mathrm{~cm}$ cada. A câmara de ar de $10 \mathrm{~cm}$ entre as placas não é configurada como opção entre as tipologias de vedações. A Figura 8 mostra os parâmetros que são considerados na análise deste requisito.

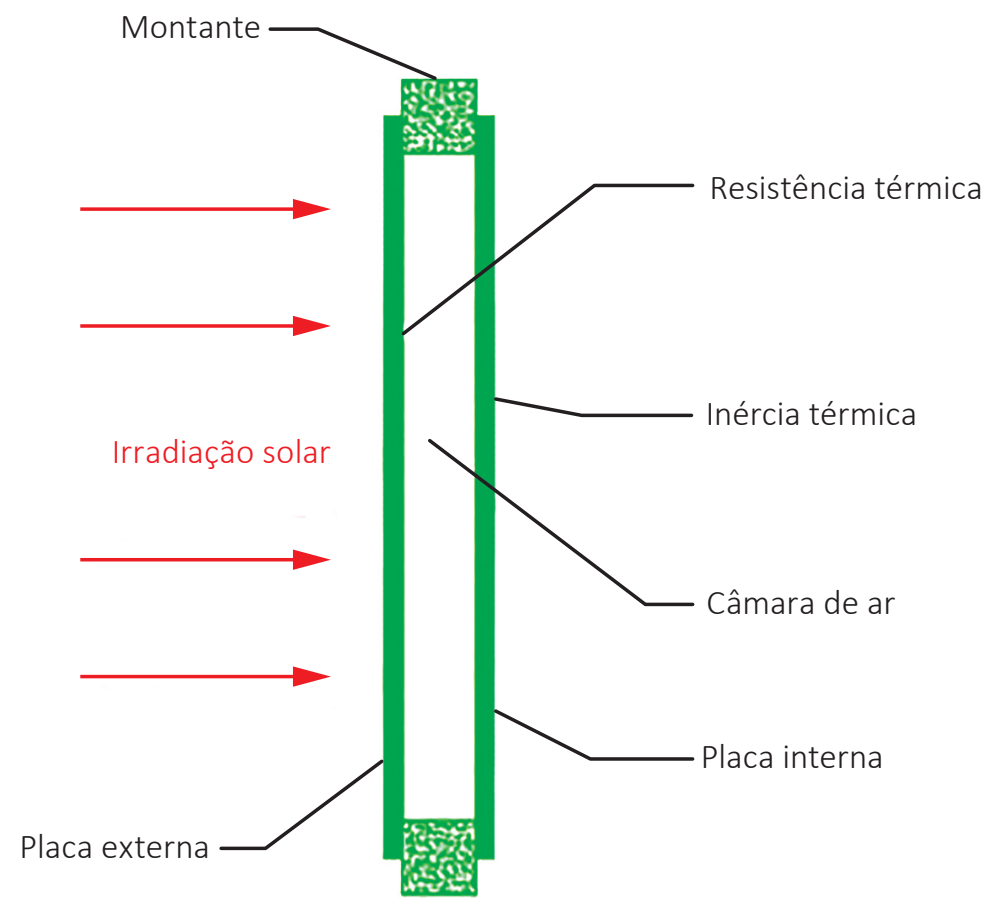

Figura 8 - Esquema do sistema "parede" em estudo quanto aos aspectos de desempenho térmico. Fonte: Knöner, 2014. 
Knöner (2014) verificou os cálculos de acordo com as normas, mas os valores encontrados para a cidade de São Carlos não as atenderam, pois o atraso térmico obtido numericamente foi de 2,2 h, quando deveria ser de 6,5 h.

Assim, entende-se que a análise foi prejudicada, já que não foi possível considerar a câmara de ar. Mas a espessura da placa pode ser ajustada em função da região bioclimática brasileira, aumentando ou diminuindo a inércia térmica.

Como exemplificação, a Figura 9 mostra que as propriedades de inércia térmica do componente podem ser variadas para atingir o nível de desempenho desejado, em qualquer parte ou região com diferentes climas (FIB, 2012).
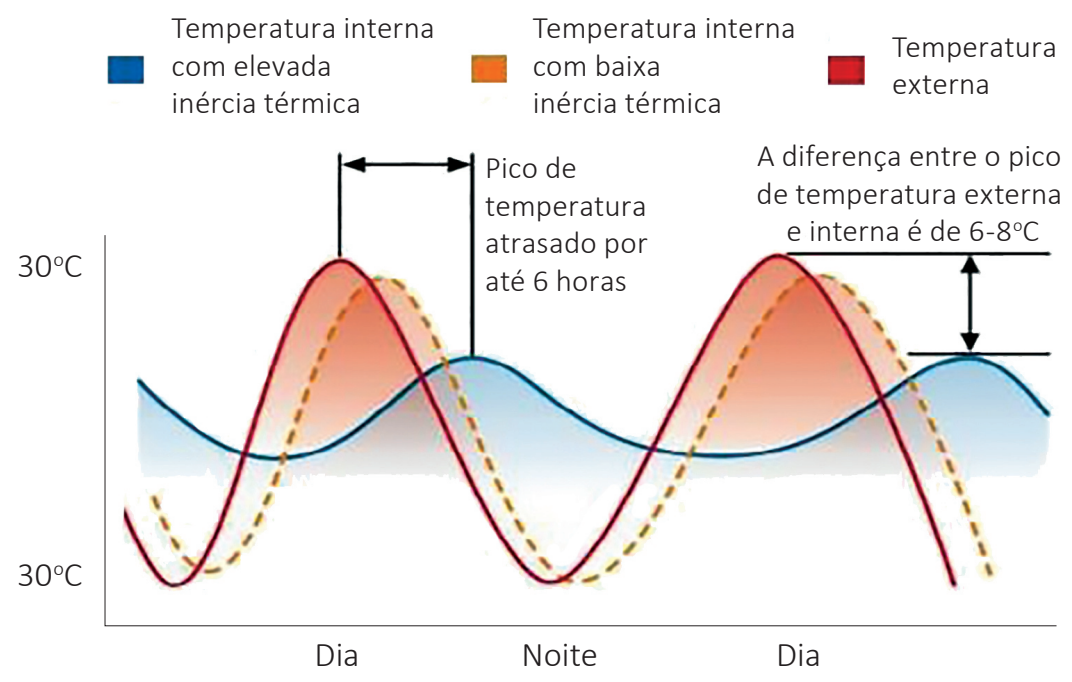

Figura 9 - Atraso da onda de calor devido à massa térmica do concreto. Fonte: FIB, 2012.

Assim, torna-se importante que essas variáveis sejam medidas em campo após a montagem do protótipo para comprovar as vantagens do sistema proposto. O resultado da elevada massa térmica tem influências na redução significativa do consumo de energia, sem necessidade de aquecimento ou resfriamento de forma artificial.

\section{Ensaios Experimentais em Laboratório}

\subsection{Ensaios de Compressão Centrada}

Foram realizados ensaios de compressão centrada nos montantes para aferir a capacidade resistente deles. A carga prevista no montante de concreto após levantamento das cargas existentes pode ser verificada na Tabela 1. 
Tabela 1 - Levantamento das cargas existentes no montante mais desfavorável.

\begin{tabular}{llll}
\hline Peça & Dimensão & Peso específico & Carga \\
\hline Peso próprio do pilar & $0,10 \times 0,10 \times 3,20$ & $2400 \mathrm{~kg} / \mathrm{m}^{3}$ & $0,80 \mathrm{KN}$ \\
\hline $\begin{array}{l}\text { Peso próprio das placas } \\
\text { (considerou-se a fixação de } 12 \text { placas } \\
\text { em cada pilar) }\end{array}$ & $0,025 \times 0,5 \times 1,0$ & $2400 \mathrm{~kg} / \mathrm{m}^{3}$ & $3,60 \mathrm{kN}$ \\
\hline $\begin{array}{l}\text { Cobertura metálica } \\
\text { (considerou-se a carga distribuída em }\end{array}$ & $27,18 \mathrm{~m}^{2}$ & & \\
32 pilares) & & $21,92 \mathrm{~kg} / \mathrm{m}^{2}$ & $0,19 \mathrm{kN}$ \\
\hline $\begin{array}{l}\text { Telha termoacústica: } \\
\text { (considerou-se a carga distribuída em }\end{array}$ & $28 \mathrm{~m}^{2}$ & & \\
32 pilares) & & $6,0 \mathrm{kgf} / \mathrm{m}^{2}$ & $0,06 \mathrm{kN}$ \\
\hline \begin{tabular}{l}
$\Sigma$ cargas verticais: $=$ \\
\hline
\end{tabular} & & & $4,65 \mathrm{kN}$ \\
\hline
\end{tabular}

Fonte: Knöner, 2014.

Considerando-se a carga máxima no montante majorada encontrou-se uma seção de armadura (As) igual a $0,15 \mathrm{~cm}^{2}$, sendo adotado $A s=1,27 \mathrm{~cm}^{2}$, que correspondeu a quatro ferros de diâmetro igual a 6,3 $\mathrm{mm}$. Considerou-se, no cálculo da armadura transversal, estribos de 4,2 mm com espaçamento de $12 \mathrm{~cm}$. Foi verificada e atendida a excentricidade máxima do montante para que resista uma compressão no concreto de 171 kN (valor da carga crítica de flambagem do montante). Foram ensaiados três montantes com a aplicação de força centrada até a sua ruptura, como pode ser observado na Figura 10.
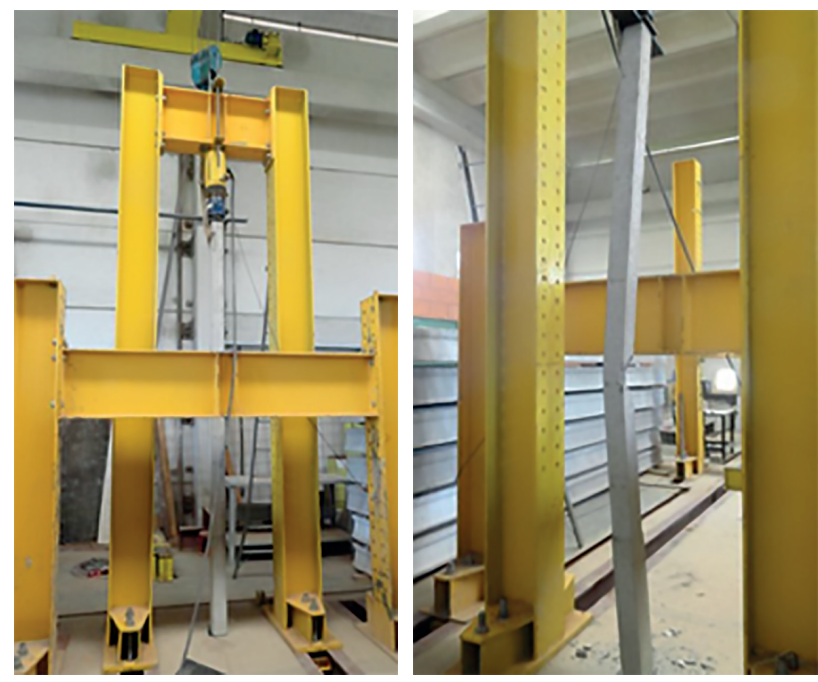

Figura 10 - Ensaio de compressão axial dos montantes. Fonte: Knöner (2014). 
Foram utilizados os equipamentos disponíveis no Laboratório de Pré-moldados (NETPRE) da UFSCar, principalmente a prensa hidráulica de 1000 kN. Os pilares se romperam devido à flambagem, resistindo à força axial esperada, conforme Tabela 2.

Tabela 2 - Resultados dos ensaios de compressão axial dos pilares.

\begin{tabular}{ll}
\hline Montante Ensaiado & Pu. exp. (kN) \\
\hline Montante 01 & 131,12 \\
\hline Montante 02 & 164,21 \\
\hline Montante 03 & 195,71 \\
\hline Média & 163,68 \\
\hline
\end{tabular}

Pu. exp.: Máxima capacidade obtida por meio de ensaio.

Fonte: Knöner, 2014.

Visto que a carga máxima verificada no montante que recebeu maior carga foi de $55 \mathrm{kN}$, com coeficiente de segurança mínimo verificado de $\gamma=2,38$, o pilar atendeu às necessidades de uso.

\subsection{Ensaio de Flexão da Placa de Concreto que Compõe a Parede}

Inicialmente foram avaliadas as placas pré-moldadas por meio de ensaios de flexão. A carga máxima prevista na placa foi de $1,20 \mathrm{kN}$, distribuída em dois pontos, com momento correspondente de $0,4 \mathrm{kN}$.m, conforme Figura 11. Foram considerados 31 diâmetros de armadura de tela, no sentido longitudinal da placa, cada diâmetro corresponde a $\mathrm{d}=0,50 \mathrm{~mm}$ e cada fio possui uma área de $\mathrm{A}=0,05 \mathrm{~cm}^{2}$. Somando a área total da seção da armadura encontra-se o valor de $A s=1,7 \mathrm{~cm}^{2}$, sendo a espessura da placa igual a 2,5 cm, largura de $50 \mathrm{~cm}$ e comprimento de $100 \mathrm{~cm}$, conforme já mencionado.

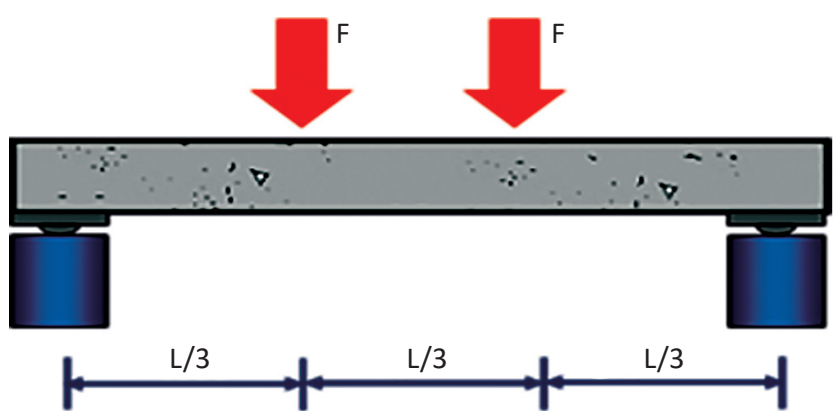

Figura 11 - Esquema de ensaio de flexão em placa pré-moldada. Fonte: Knöner, 2014. 
Com os ensaios, pode-se concluir que as placas pré-moldadas suportaram um momento máximo no meio do vão de $0,41 \mathrm{kN}$.m, referente à aplicação de uma força de 1,66 kN, dividida em dois pontos, conforme Figura 12. Tal resultado atende a NBR 15575: Edificações Habitacionais - Desempenho (ABNT, 2013).
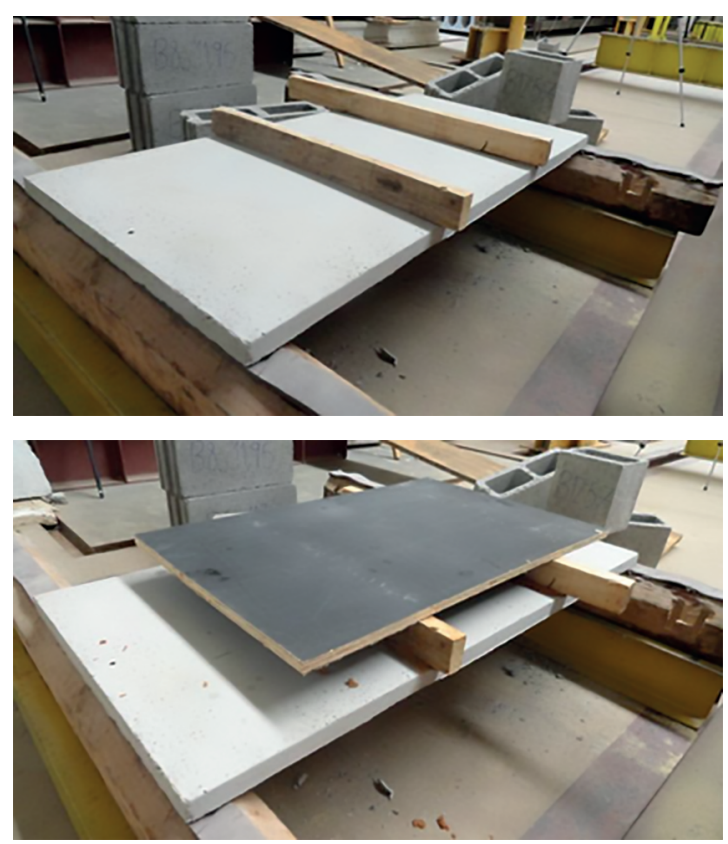

Figura 12 - Esquema de montagem das placas a serem ensaiadas. Fonte: Knöner, 2014.

Os resultados dos ensaios de flexão das placas pré-moldadas podem ser visualizados na Tabela 3.

Tabela 3 - Resultados dos ensaios de flexão nas placas pré-moldadas.

\begin{tabular}{lll}
\hline Peça Ensaiada & $P_{\text {u,exp }}$ & $M_{\text {vão }}$ \\
\cline { 2 - 3 } & $(\mathrm{kN})$ & $(\mathrm{kN} \cdot \mathrm{m})$ \\
\hline Placa 01 & 1,70 & 0,425 \\
\hline Placa 02 & 1,59 & 0,40 \\
\hline Placa 03 & 1,59 & 0,40 \\
\hline Placa 04 & 1,76 & 0,44 \\
\hline Média & 1,66 & 0,42 \\
\hline
\end{tabular}

$\mathrm{P}_{\text {u,exp }}$ : Máxima capacidade obtida por meio de ensaio; $\mathrm{M}_{\text {vão }}$ : momento no meio do vão.

Fonte: Knöner, 2014. 


\subsection{Ensaio de Carga Suspensa}

Inicialmente foi montado um sistema "parede" composto por dois montantes e seis placas aparafusadas de um lado apenas. A Figura 13 mostra que, no laboratório, os montantes foram dispostos no solo e as placas aparafusadas e fixadas com buchas de PVC na horizontal. Após a fixação de todas as placas em seus respectivos montantes, resultou um painel que foi erguido no local como painel tipo tilt-up.
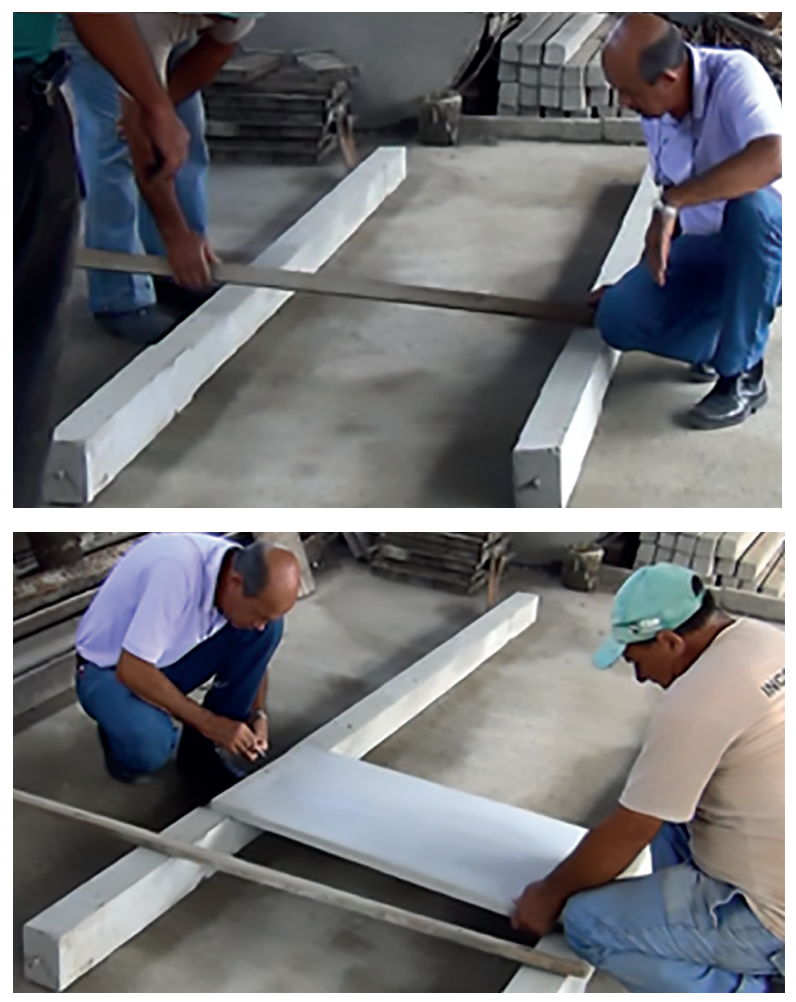

Figura 13 - Fixação das placas nos montante, montagem de um painel no solo. Fonte: Knöner, 2014.

Os ensaios a seguir consistem em submeter o sistema formado por montantes e placas aos esforços de momento fletor e de força cortante, por meio de aparelhagem ou dispositivos de carga compatível com a peça que se pretende ensaiar. Na análise da resistência ao ensaio de carga suspensa indicado pela NBR 15575: Edificações Habitacionais - Desempenho, parte 4 (ABNT, 2013), foi fixado um suporte em uma face da placa e parafusada com parafuso de $8 \mathrm{~mm}$ de diâmetro e $6 \mathrm{~cm}$ de comprimento, e bucha de PVC, tal como indicado na Figura 14. 


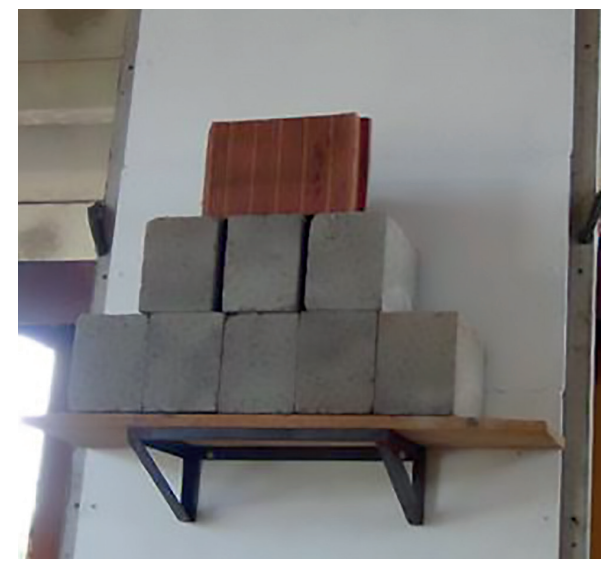

Figura 14 - Ensaio de carga suspensa na parede 1,20 kN período de 24 h. Fonte: Knöner, 2014.

O ensaio foi realizado com os dispositivos em laboratório, reproduzindo as situações previstas na NBR 15575: Edificações Habitacionais - Desempenho, sendo aplicada a carga em patamares de aproximadamente de $50 \mathrm{~N}$ e sem golpes, aguardando intervalo aproximado de 3 minutos entre os patamares de carregamento.

De início, o suporte foi carregado atingindo 1,0 kN e permaneceu com essa carga por $24 \mathrm{~h}$, sendo observado o deslocamento da placa em $\mathrm{dh}=1,0 \mathrm{~mm}$. O carregamento foi ampliado para 1,2 kN e, permanecendo por mais $24 \mathrm{~h}$, o deslocamento passou para $\mathrm{dh}=1,50 \mathrm{~mm}$. A carga ficou exposta por vários dias e não foram observadas alterações nos resultados.

Algumas observações:

- O deslocamento horizontal dh =1,5 mm foi observado na ligação do parafuso com a bucha de PVC;

- Não houve movimentação do sistema além do deslocamento verificado por relógio de deslocamento;

- Não houve fissuras nem movimentações;

- O sistema de fixação obedeceu rigorosamente a NBR 15575: Edificações Habitacionais - Desempenho, parte 4 (ABNT, 2013);

- Não houve restrições do fabricante do suporte para as cargas preparadas.

\subsection{Ensaio de Estanqueidade à Água}

A diretriz de ensaio consistiu em submeter, durante um tempo determinando, a face externa de um corpo de prova do sistema montado a uma vazão de água, criando uma película homogênea e contínua, com aplicação simultânea de uma pressão pneumática 
sobre essa face, seguindo as orientações da NBR 15575: Edificações Habitacionais Desempenho, parte 4 (ABNT, 2013). Com isso, espera-se que as águas das chuvas não venham a prejudicar o interior do ambiente de trabalho, com umidade ou infiltrações.

O corpo de prova foi constituído pelo sistema "parede", formada por placa externa de concreto com espessura de $2,50 \mathrm{~cm}$, concentrando a análise em duas placas, das quais uma pintada e a outra sem pintura, conforme Figura 15.

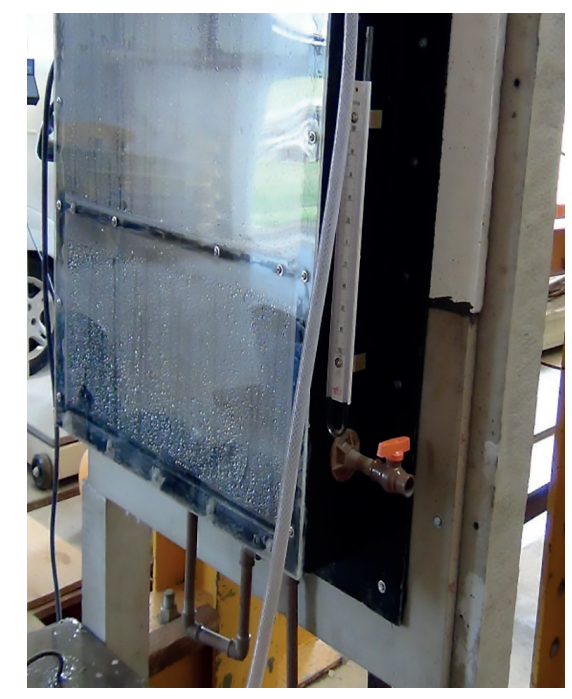

Figura 15 - Esquema de montagem do corpo de prova para ensaio. Fonte: Knöner, 2014.

Após $7 \mathrm{~h}$ de ensaio, apareceram pequenas manchas de água na face oposta da placa de $2,5 \mathrm{~cm}$ de espessura entre as placas.

\subsection{Ensaio de Corpo Duro}

A norma NBR 15575: Edificações Habitacionais - Desempenho, parte 4 (ABNT, 2013), estabelece um método para verificação da resistência do sistema de parede à deformação provocada pelo impacto de corpo duro. O ensaio consistiu na liberação pendural, em repouso, de massa conhecida a uma altura determinada. A aparelhagem consistiu em:

- Um corpo de impacto com forma (esfera) e massa (1 kg) conforme estabelecido na norma; NBR 15575: Edificações Habitacionais - Desempenho (ABNT, 2013);

- Dispositivo para medição dos deslocamentos com resolução de 0,1 mm.

O corpo de prova representou fielmente as condições do projeto, tipos de apoios e vinculações. O ensaio foi realizado no interior do NETPRE, utilizando um sistema "parede" em tamanho real. 
A execução do ensaio visou suspender por um cabo o impactador, liberando-o em movimento pendural, gerando a energia de impacto indicado na Tabela 4. Os impactos foram aplicados em pontos aleatórios e distintos, conforme Figura 16, com altura constante de $h=1,0 \mathrm{~m}$ para todos os lançamentos.

Tabela 4 - Representação e resultados dos impactos realizados sobre a placa.

\begin{tabular}{lllllllllll}
\hline Parâmetro por ponto $^{\circ}$ & 1 & 2 & 3 & 4 & 5 & 6 & 7 & 8 & 9 & 10 \\
\hline Dh $(\mathrm{mm})$ & 1,33 & 1,34 & 1,33 & 1,33 & 1,34 & 1,35 & 1,35 & 1,35 & 1,35 & 1,35 \\
\hline Ap $(\mathrm{mm})$ & 0,2 & 0,2 & 0,2 & 0,1 & 0,1 & 0,1 & 0,1 & 0,1 & 0,1 & 0,2 \\
\hline Daf $(\mathrm{mm})$ & 1,1 & 1,0 & 1,11 & 1,2 & 1,1 & 1,1 & 1,0 & 1,1 & 1,1 & 1,0 \\
\hline
\end{tabular}

Dh - Deslocamento horizontal medido no lado oposto da placa;

Ap - Afundamento na parede da placa de concreto;

Daf-Diâmetro do afundamento na placa.

Fonte: Knöner, 2014.

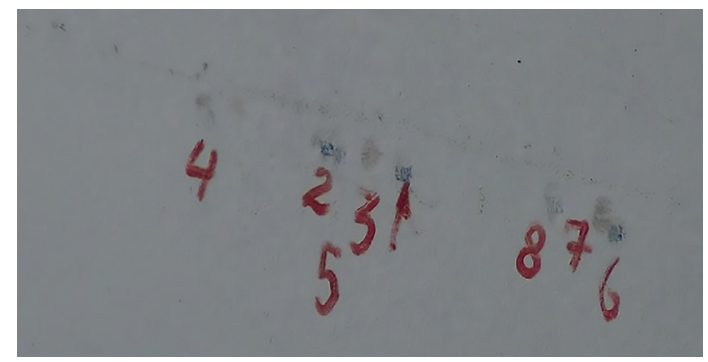

Figura 16 - Local nas placas dos impactos de corpo duro na altura de 1,0 m. Fonte: Knöner, 2014.

Verificou-se que os resultados atendem à NBR 15775 (ABNT, 2013) quanto ao desempenho recomendável do sistema em relação à resistência ao impacto de corpo duro nos níveis intermediário e superior, tanto para a vedação externa quanto interna. Com a energia de 10 Joules, não houve rupturas além das marcas. Tal resultado atende a NBR 15575: Edificações Habitacionais - Desempenho no nível M (mínimo de aceitação).

\subsection{Ensaio de Corpo Mole}

Este ensaio consistiu no lançamento de um saco de couro com altura de $90 \mathrm{~cm}$ e diâmetro de $35 \mathrm{~cm}$, contendo areia e serragem, que totalizava uma massa de $40 \mathrm{~kg}$, conforme os quesitos da NBR 15575: Edificações Habitacionais - Desempenho (ABNT, 2013) e NBR 11675 (ABNT, 2016). É permitida uma variação de $40 \mathrm{~cm}$ para cima ou para baixo no sistema de pêndulo, constituído de suporte (altura superior a da parede), 
fio de aço para sustentar o saco e sistema para medição dos resultados. Um registro do ensaio pode ser observado na Figura 17, na qual se verifica a placa rompida.

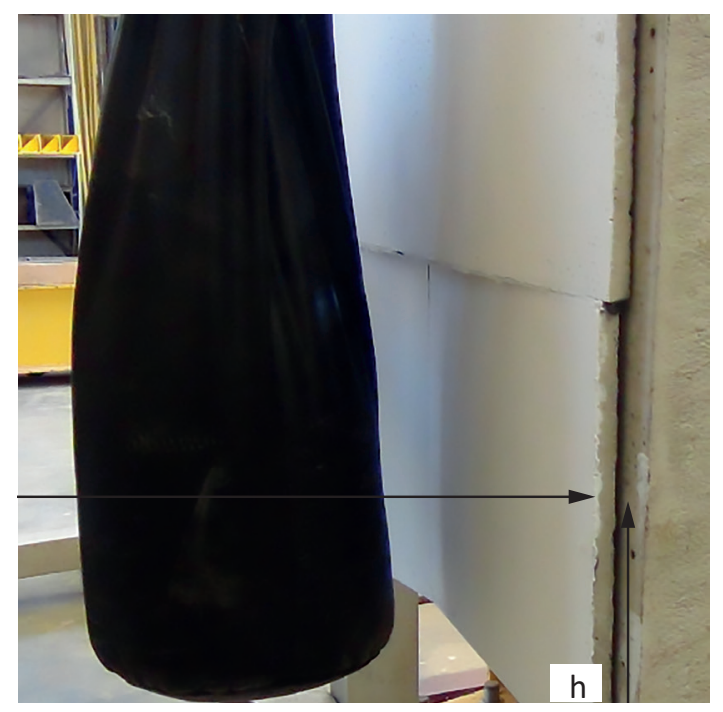

Figura 17 - Ensaio de corpo mole no sistema. Fonte: Knöner, 2014.

Esse ensaio teve como objetivo verificar a resistência do sistema à energia de impacto dos choques acidentais gerados durante a utilização da edificação ou choques provocados por tentativas de intrusões intencionais ou não.

Após o ensaio, verificou-se que a placa com altura mínima de $\mathrm{h}=30 \mathrm{~cm}$ não se rompeu. Com a altura intermediaria ( $h=0,90 \mathrm{~m}$ ), entretanto, a placa rompeu-se, como observado na Figura 17. De acordo com a NBR 15575: Edificações Habitacionais - Desempenho (ABNT, 2013), atendeu o limite inferior.

\section{Análise do Sistema Proposto}

Após a realização dos ensaios e simulação, bem como a consideração das características do sistema construtivo proposto, pode-se verificar as seguintes situações quanto aos parâmetros técnicos:

- Resistência ao fogo: Verificação teórica que o sistema suporta 50 minutos de incêndio, conforme PCI (1989);

- Desempenho Térmico: Possui um atraso térmico de 2,2 h. Não está de acordo com o mínimo desejado para a cidade de São Carlos, que é de 6,5 h; 
- Estrutura: atende as condições de serviço e estado limite último para as solicitações existentes nos componentes dos montantes (compressão) e das placas (flexão);

- Carga suspensa: Atendeu NBR 15575: Edificações Habitacionais - Desempenho (ABNT, 2013), nível superior "S";

- Estanqueidade: Atendeu NBR 15575: Edificações Habitacionais - Desempenho (ABNT, 2013), nível superior "S";

- Corpo duro: Atendeu NBR 15575: Edificações Habitacionais - Desempenho (ABNT, 2013), nível mínimo "M";

- Corpo mole: Atendeu NBR 15575: Edificações Habitacionais - Desempenho (ABNT, 2013), nível mínimo " $M$ ".

Em relação aos parâmetros de projeto, foram observadas as seguintes situações:

- Facilidade de Construção: a montagem das peças é possível com apenas dois trabalhadores, não sendo necessário o uso de equipamentos de grande porte. O uso de ferramentas elétricas, como parafusadeira, é recomendado;

- Reaproveitamento: existe a possibilidade de desmonte e transporte para outro lugar sem perdas de materiais e sem gerar resíduos significativos. Os componentes podem ser desmontados com cuidados, remontados e reaproveitados indefinidamente;

- Modulação: o projeto apresenta condições de modulação, facilitando a adaptação de acordo com as características do terreno, espaço disponível e necessidades de produção;

- Custos: o custo inicial maior é referente à fabricação das formas, que podem ser reaproveitadas; o custo de mão de obra é referente aos salários de um pedreiro e de um servente, que trabalharão inicialmente na fabricação e posteriormente na montagem;

- Durabilidade: considerou-se a mesma durabilidade das estruturas de concreto tradicional (mínimo de 50 anos);

- Resíduos: durante a produção dos componentes, pode ser considerado o reaproveitamento de resíduos da construção, mediante ensaios de qualidade dos agregados. Durante a montagem, pode haver perdas decorrentes de quebras e transporte inadequado; deve-se procurar treinar a mão de obra para obter menor desperdício. 


\section{Conclusões}

O sistema proposto mostrou ser simplificado do ponto de vista do projeto, sendo composto basicamente por montantes e placas separadas por uma camada de ar, isolando a camada interna da externa. A fixação das placas é simplificada, podendo ser facilmente desconectadas, em caso de manutenção ou remontagem.

As análises e ensaios realizados colaboraram para afirmar que o protótipo idealizado é viável e possui diversas vantagens em relação às soluções improvisadas comumente utilizadas em canteiros de obras. O uso de soluções pré-fabricadas aumenta a sustentabilidade, em termos ambientais, econômicos e sociais, além de melhorar as condições de trabalho.

Ressalta-se novamente que as normas consultadas não fazem referências às instalações provisórias. Entende-se que é necessário ir além do que exige a NR-18 Condições e meio ambiente de trabalho na indústria da construção (BRASIL, 2015) em relação às áreas de vivência, incorporando requisitos de desempenho do edifício. Considera-se importante que sejam propostos quesitos para as edificações provisórias, tal como relacionado pela NBR 15575: Edificações Habitacionais - Desempenho (ABNT, 2013), de forma que sejam garantidas as condições de sustentabilidade das instalações provisórias de canteiro de obra.

Foi possível concluir que o sistema construtivo proposto pode evoluir tecnologicamente e apresentar soluções diferenciadas conforme as necessidades dos empreendimentos e da cadeia produtiva na construção civil. Este trabalho procurou apresentar um resumo da viabilidade e necessidade de projetar as instalações das áreas de vivência em canteiro de obras, visando também ao conforto e à saúde do trabalhador.

\section{Referências}

ASSOCIAÇÃO BRASILEIRA DE NORMAS TÉCNICAS. NBR 11675: Divisórias leves internas moduladas - Verificação da resistência aos impactos. 2016. 7p. Rio de Janeiro, Brasil.

ASSOCIAÇÃO BRASILEIRA DE NORMAS TÉCNICAS. NBR 12284: Área de Vivência em Canteiros de Obra. Procedimento. 1991. 14p. Rio de Janeiro, Brasil.

ASSOCIAÇÃO BRASILEIRA DE NORMAS TÉCNICAS. NBR 14432: Exigências de resistência ao fogo de elementos construtivos de edificações - Procedimento. 2001. 15p. Rio de Janeiro, Brasil.

ASSOCIAÇÃO BRASILEIRA DE NORMAS TÉCNICAS. NBR 15220: Desempenho térmico de edificações. 2008. Rio de Janeiro, Brasil.

ASSOCIAÇÃO BRASILEIRA DE NORMAS TÉCNICAS. NBR 15575: Edificações HabitacionaisDesempenho. 2013. Rio de Janeiro, Brasil. 
ASSOCIAÇÃO BRASILEIRA DE NORMAS TÉCNICAS. NBR 5627: Exigências particulares das obras de concreto armado e protendido em relação à resistência ao fogo. 1980. Rio de Janeiro, Brasil. (cancelada)

BRASIL. Ministério do Trabalho e Emprego. Norma Regulamentadora 18 (NR-18): Condições e Meio Ambiente de Trabalho na Indústria da Construção. 2015. Disponível em: http://trabalho.gov.br/index.php/seguranca-e-saude-no-trabalho/normatizacao/normasregulamentadoras. Acesso em: nov. 2016.

DIAS, C.M.; SERRA, S.M.B. Overview of Industrialized Technological Solutions for Temporary Facilities in Construction Sites. 2013. In: Portugal Sustainable Buildings (SB13). Proceedings... Guimarães, Portugal, 2013.

FIB. Federation Internationale Du Beton. Guide to Good Practice: Precast Insulated Sandwich Panels. 2012. Commission 6 - Task Group T 6.11.

KNÖNER, N. Sistema pré-fabricado para aplicação em construções provisórias de canteiros de obra. 2014. 147f. Dissertação (Mestrado em Estruturas e Construção Civil) Universidade Federal de São Carlos, São Carlos, SP.

$\mathrm{PCl}$. Precast Concrete Institute. Design for Fire Resistance of Precast Prestressed Concrete. 1989. 2nd ed. 93p. Disponível em: http://kerkstra.com/uploads/resources/MNL-124-89_ Fire_Resistance.pdf. Acesso em: dez. 2016.

PREFACC. Edificações em Concreto Celular. 1992. Disponível em: http://www.prefacc.com. br/. Acesso em: dez. 2016.

SERRA, S.M.B.; FERREIRA, M.A.; PIGOZZO, B.N. Evolução dos pré-fabricados de concreto. In: 1. Encontro Nacional de Pesquisa-Projeto-Produção em Concreto Pré-moldado, Anais... 2005, USP, São Carlos - SP. v. 1. p. 1-10.

VAN ACHER, A. Manual de Sistemas Pré-fabricados de Concreto. 2002. Tradução: FERREIRA, M.A. 2003. 129f. Disponível em: <http://www.ft.unicamp.br/ cicolin/ST\%20725\%20A/mpf. pdf>. Acesso em: dez. 2016. 


\section{Anexo}

\section{Registro da montagem do protótipo para instalação provisória em pré-moldado de concreto para canteiros de obra}

Local: campus da UFSCar, São Carlos, SP

Período da montagem: fevereiro a maio de 2017

Empresa contratada: Fragalli Engenharia Ltda.

Convenente: Fundação de Apoio Institucional (FAI/UFSCar)

Projeto e responsável técnico: engenheiro civil Nery Knöner

Fotos e acompanhamento: profa. Sheyla Mara Baptista Serra e engenheiro civil José Luis Morelli

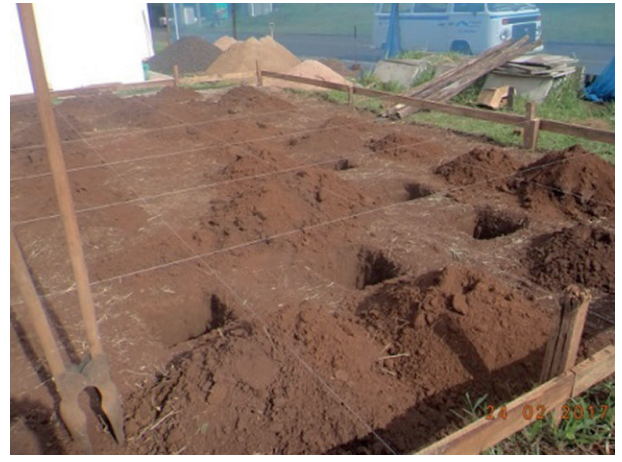

Figura 1 - Vista da locação dos furos referentes aos pilares da instalação provisória.

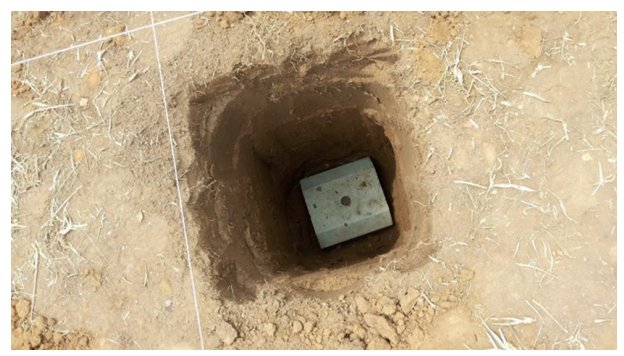

Figura 2 - Elemento de concreto para fixação do pilar.

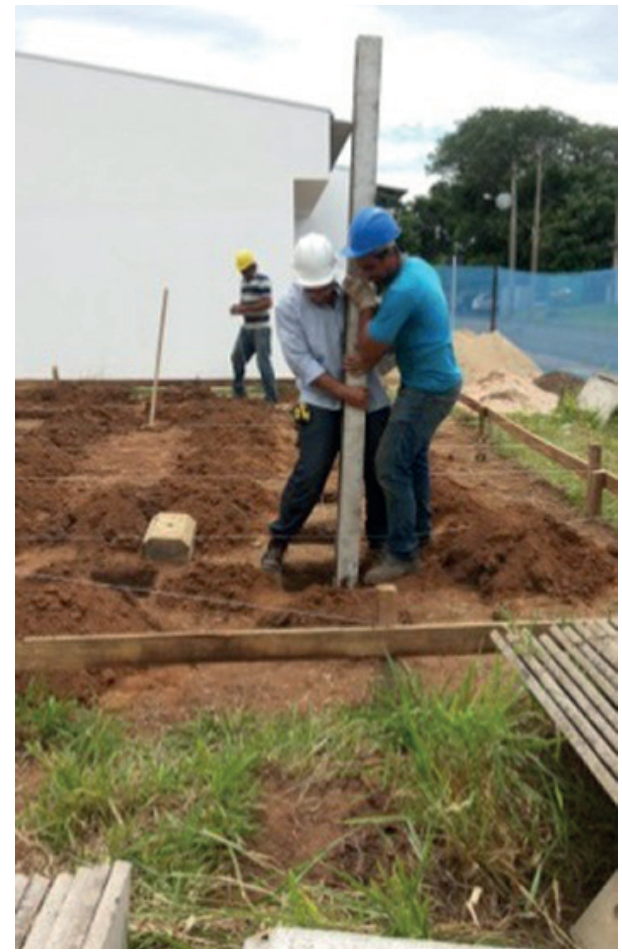

Figura 3 - Colocação do pilar de concreto pré-moldado. 


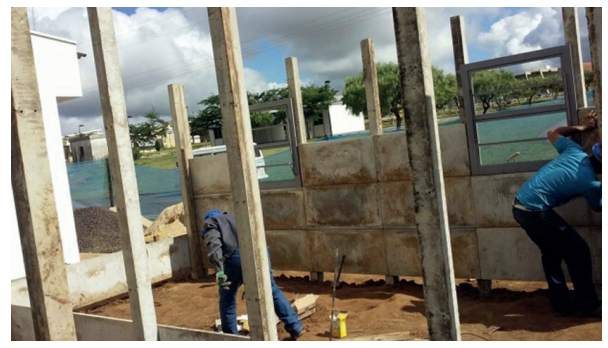

Figura 4 - Vista geral da montagem da IP.

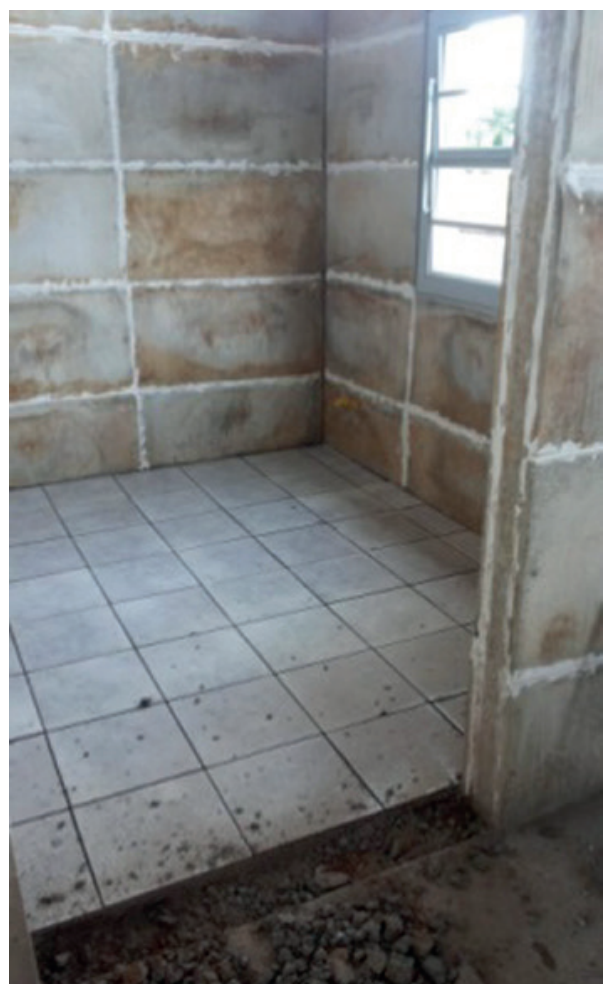

Figura 6 - Assentamento de piso cerâmico e calafetação das placas pré-moldadas de concreto.

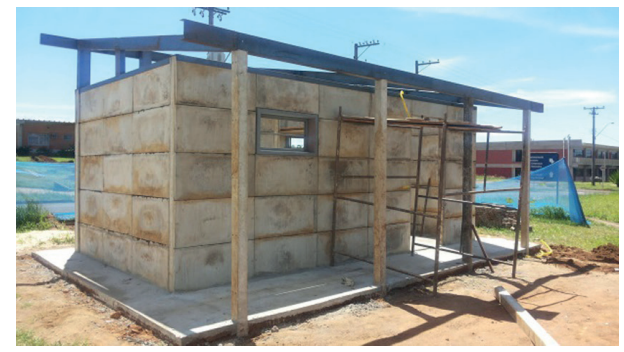

Figura 5 - Vista da montagem da estrutura metálica de coroamento e de fixação da cobertura.

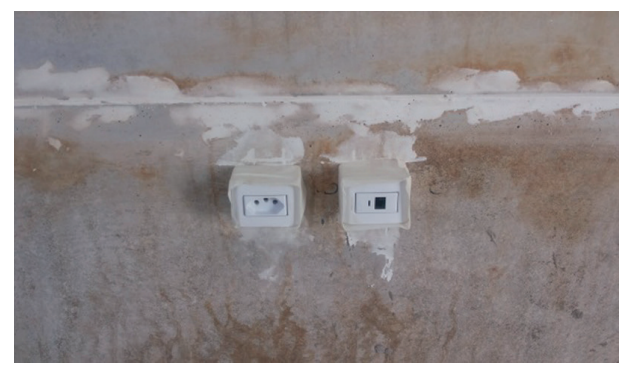

Figura 7 - Detalhe da fixação das instalações elétricas.

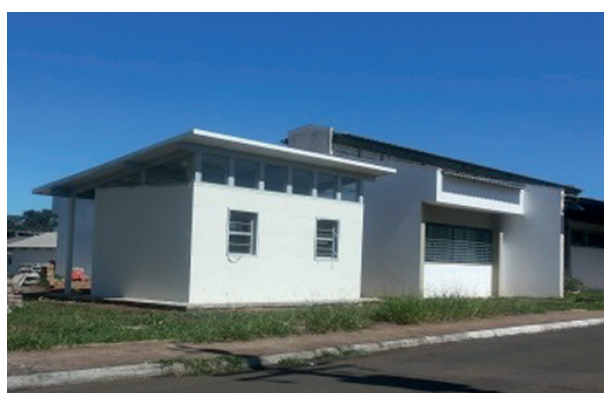

Figura 8 - Vista geral da IP após pintura e instalação dos vidros das esquadrias. 


\section{Seção V}

Subprojeto Desenvolvimento

de Tecnologias de Execução

Relacionadas a Métodos e

Sistemas Construtivos Inovadores

(SPTEC)

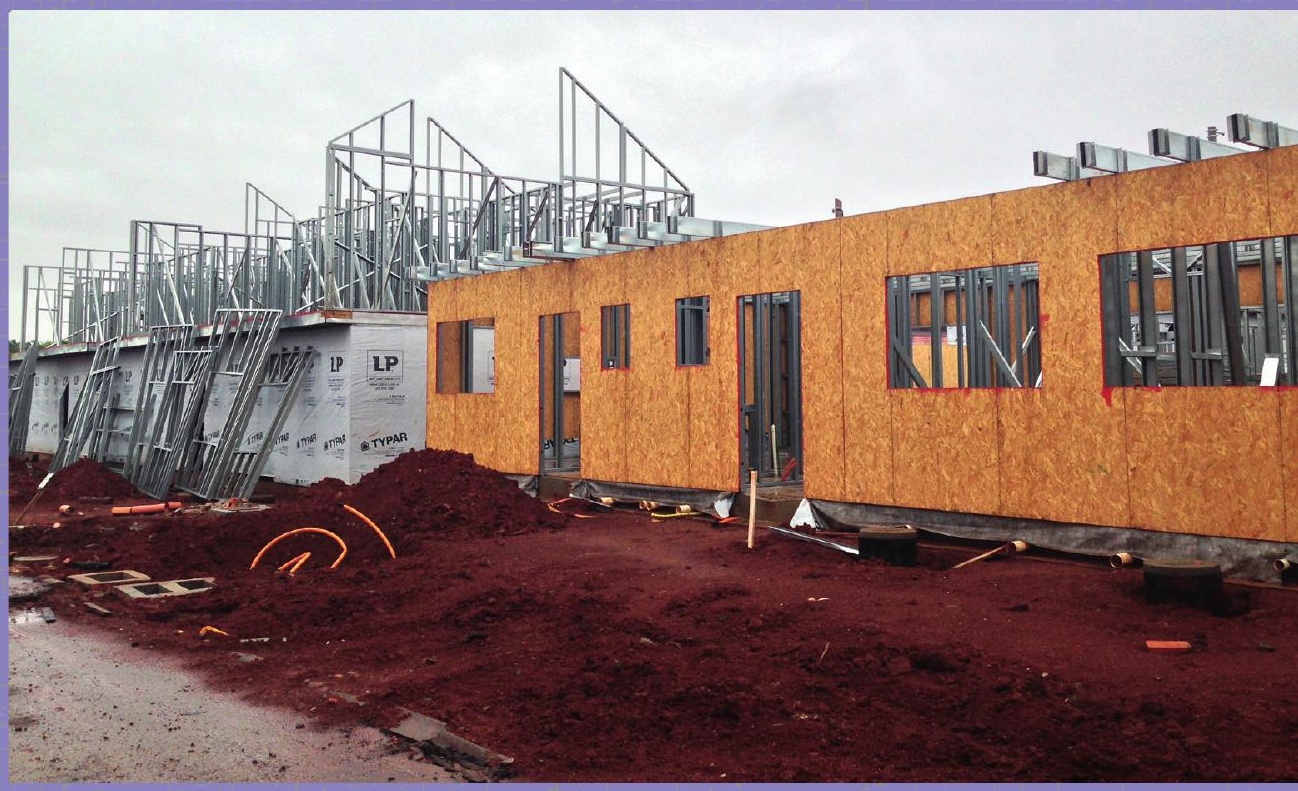




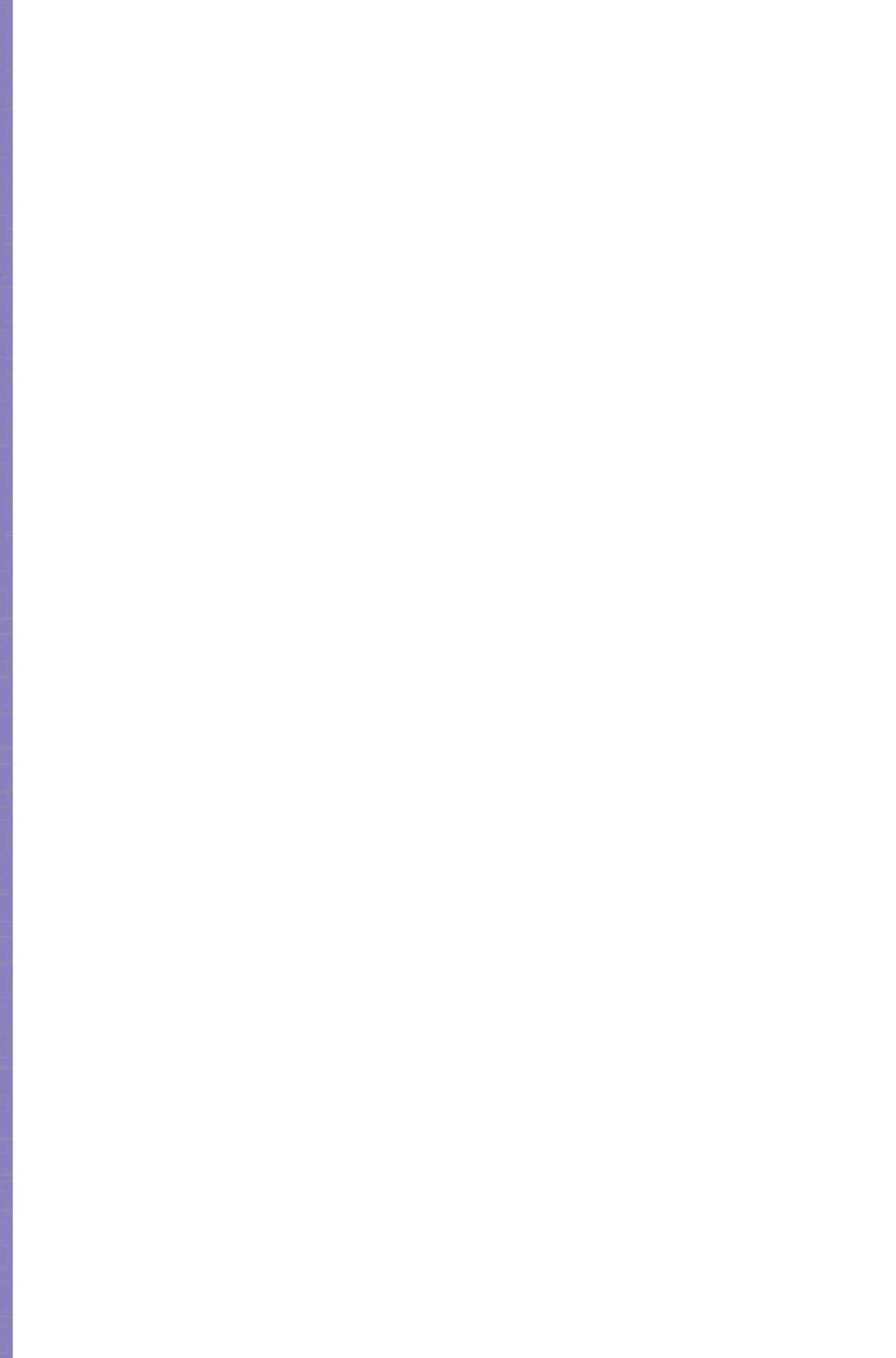




\title{
Novas Categorias de Perdas e sua Incidência em Sistemas Industrializados na Habitação
}

\author{
Lucila Sommer \\ Carlos Torres Formoso \\ Daniela Dietz Viana
}

\section{Introdução}

O uso crescente de sistemas industrializados em empreendimentos habitacionais constitui-se em uma das importantes estratégias adotadas pelo setor da construção civil para obter melhorias de eficiência e redução de prazos na entrega das obras. Entretanto, deve-se salientar que, para que isso aconteça, há a necessidade de mais esforços em planejamento, coordenação e controle dos sistemas de produção, a fim de que sejam obtidos os benefícios potenciais da industrialização.

Segundo Koskela e Vrijhoef (2000), a falta de sucesso na industrialização da construção deve-se principalmente à utilização de métodos de gestão baseados em conceitos de gestão da produção obsoletos, com foco apenas nas atividades de transformação. Em muitas situações, atenta-se apenas para a modernização e industrialização das atividades de transformação, sendo negligenciadas as atividades que não agregam valor, tais como transporte, estoques, esperas e inspeção (KOSKELA, 1992). Höök e Stehn (2008) sugerem que, embora os sistemas industrializados reduzam alguns tipos de complexidade e perdas existentes na construção, eles também introduzem outras fontes de dificuldade devido à necessidade de integrar diferentes unidades de produção (projeto, fábrica, logística e montagem) e ainda alteram os papéis de diferentes agentes da cadeia de suprimentos. 
A aplicação de conceitos e princípios da Filosofia da Produção Enxuta pode contribuir para a implementação de sistemas industrializados, visto que se busca um equilíbrio entre as melhorias nas atividades de transformação e a eliminação de atividades que não agregam valor. A Produção Enxuta é uma filosofia que emergiu na indústria automobilística do Japão e que mudou a forma de gestão dos sistemas de produção em diferentes setores ao longo das últimas décadas, sendo uma abordagem predominante em empresas de desempenho destacado em diferentes indústrias.

Este capítulo discute o conceito de perdas na construção, propondo uma forma de mapeamento dessas perdas, de forma a entender as relações de causa e efeito existentes. São destacadas três categorias de perdas, as quais normalmente não recebem a devida atenção no contexto da construção civil: trabalho em progresso, making-do e trabalho inacabado. Ao final, são discutidos brevemente os resultados de estudos sobre sistemas industrializados, que adotaram tais conceitos.

\section{O Papel das Perdas}

Na filosofia da produção enxuta, perdas são atividades desnecessárias que geram custos e não agregam valor ao produto final (SHINGO, 1996). Ohno (1997) propôs um conjunto de categorias de perdas existentes no Sistema Toyota de Produção com o objetivo de auxiliar na compreensão dos fundamentos da gestão da produção e orientar ações para a implementação de melhorias. São conhecidas como as Sete Perdas do STP: estoque, transporte, superprodução, defeito, espera, movimentação e processamento. A partir destas categorias originais, diversas propostas de novas categorias surgiram com a mesma finalidade, isto é, identificar oportunidades de melhoria nos sistemas produtivos, tais como acidentes, projeto de produtos que não atendem às necessidades dos clientes (WOMACK; JONES, 1996), investimentos de capital desnecessários (MONDEN, 1983), roubo e vandalismo (BOSSINK; BROUWERS, 1996). Segundo Shingo (1996), o papel principal das diferentes categorias de perdas é chamar a atenção para os problemas que existem em determinados contextos, mas que não são óbvios na perspectiva dos profissionais que atuam na prática.

A partir de uma revisão sistemática de literatura, Viana et al. (2012) fizeram uma análise crítica dos estudos sobre perdas na construção, chegando às seguintes conclusões:

- De forma geral, a revisão sistemática de literatura identificou que o número de artigos sobre perdas na construção é relativamente pequeno, considerando a relevância do tema; no setor da construção;

- Em muitos estudos, o conceito de perdas adotado não é apresentado de forma clara, mas somente discutido em um nível mais abstrato. Em geral, 
descreve-se apenas as medidas operacionais utilizadas para guiar a coleta de dados;

- Diferentes conceitos são adotados para descrever o mesmo tipo de perda, tornando difícil a realização de análises comparativas entre diferentes estudos. Por exemplo, diversos artigos discutem a incidência de retrabalhos em empreendimentos de construção (ASHFORD, 1992; LOVE et al., 2010), mas não discutem em profundidade o conceito de retrabalho. Alguns, ademais, não apresentam claramente a origem dos dados. Como consequência, as contribuições sobre como medir retrabalhos e suas causas fundamentais são muito limitadas;

- Diversos indicadores têm sido utilizados para medir perdas. Alguns são expressos em quantidades físicas, tais como o volume de entulho removido de canteiros de obras (POON et al., 2004), já outros são medidos em custos, tais como produtos defeituosos (BURATI; FARRINGTON; LEDBETTER, 1992) e retrabalho (HWANG et al., 2009). O tempo tem sido também utilizado como uma importante medida de perdas, principalmente com o objetivo de identificar a parcela de tempo que não agrega valor em um processo (YU et al., 2009).

Formoso et al. (2015) destacam a importância de se compreender a relação de causa e efeito que existem entre as diferentes categorias de perdas. Os referidos autores caracterizam essas relações como formas de propagação da variabilidade no processo de construção. A Figura 1 apresenta uma representação de tais relações de causa e efeito, levantadas a partir de diferentes estudos sobre perdas reportados na literatura. A figura está dividida em três zonas: (a) na parte superior, aparecem as categorias de perdas denominadas de terminais, ou seja, aquelas que são consequências de outras categorias de perdas; (b) na parte intermediária, são reunidas as categorias denominadas de perdas na produção, que se referem a fenômenos importantes na produção que devem ser controlados para evitar as perdas terminais; e (c) os processos predecessores da produção, que podem contribuir para a ocorrência de perdas. Tal mapeamento pode indicar as categorias de perdas que mais interagem com as demais, ou seja, aquelas que têm mais centralidade na rede de relação causa-efeito. Assim, o mapa sugere que o foco seja deslocado para as causas das perdas, em vez de tentar monitorar ou controlar as consequências das perdas na produção.

No presente trabalho, buscou-se investigar três categorias de perdas que tem um elevado impacto no desempenho da construção, particularmente quando se utiliza sistemas industrializados. São elas: making-do (KOSKELA, 2004; FORMOSO et al., 2011), falta de terminalidade (FIREMAN, 2012; ALVES, 2000) e trabalho em progresso (BASHFORD et al., 2003). Tais categorias de perdas estão fortemente relacionadas ao conceito de lote de produção, o qual se refere à realização dos processos em cada 
unidade de produção (ou controle), que pode ser um setor da obra, um pavimento, uma casa, ou um apartamento. A seguir, cada uma dessas categorias de perdas é discutida em mais profundidade.

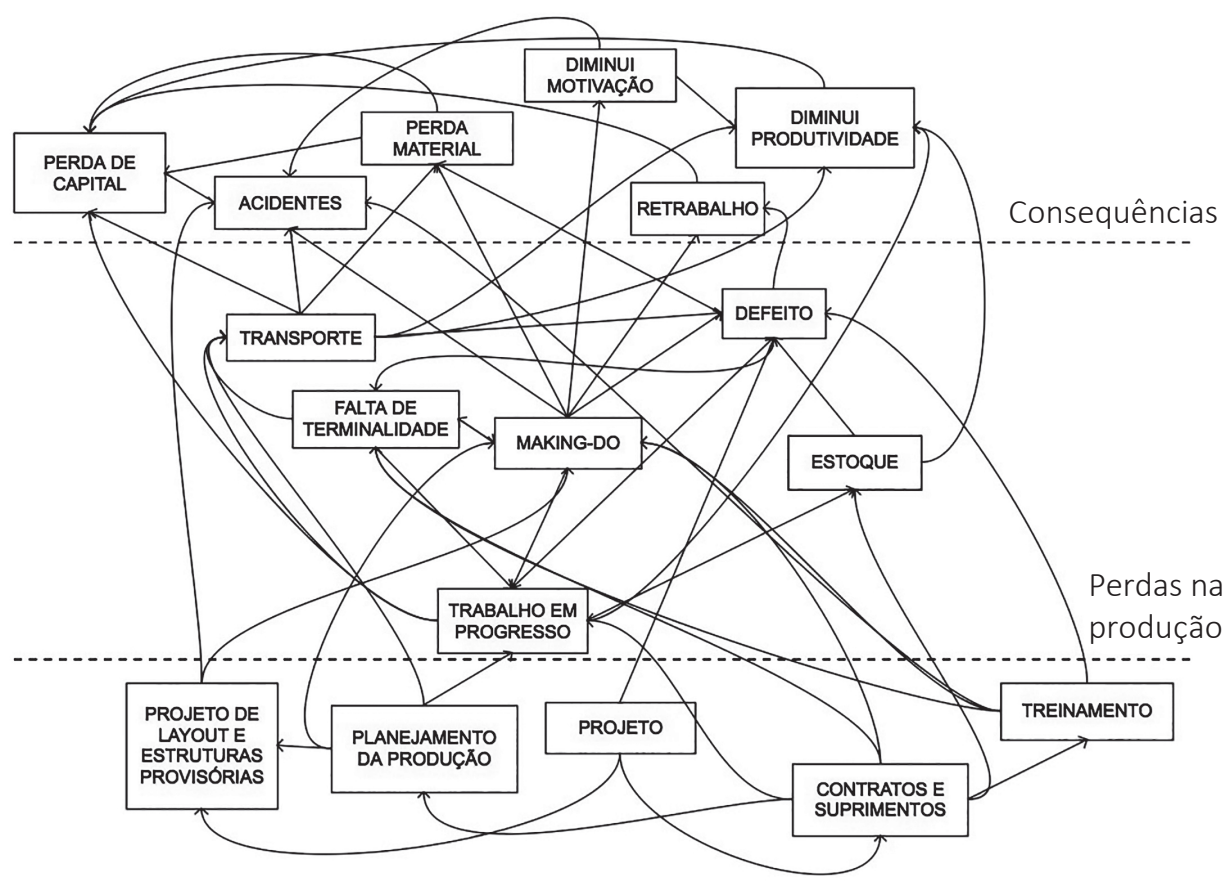

Etapas predecessoras à produção

Figura 1 - Rede Causal de Perdas na Construção. Fonte: Formoso et al., 2015.

\subsection{Trabalho em Progresso}

Trabalho em progresso pode ser associado às perdas por espera: ao se concluir uma determinada etapa, aguarda-se o momento de início da etapa seguinte. Para Shingo (1996), essa perda refere-se aos estoques de produto inacabado existentes entre as etapas de processamento, os quais podem estar associados a itens não concluídos que estão à espera do processamento. Tal estoque pode ser gerado em função de superprodução, ou seja, quando há excesso de estoques de produtos produzidos antecipadamente a espera de serem processados. No contexto da construção, esta perda normalmente é associada à espera entre processos (BULHÕES, 2009; SAFFARO, 2007) ou ao excesso de frentes de serviço abertas (BASHFORD et al., 2003).

As causas para o trabalho em progresso estão relacionadas a sistemas de produção que utilizam grandes lotes de produção, resultando no aumento do tempo 
de espera para um item ser processado. Outro fator que contribui para o surgimento dessa perda é a relação contratual tradicional da construção civil (SACKS et al., 2009). Tais contratos normalmente apresentam cláusulas de remuneração que estimulam a otimização local em detrimento da busca pelo melhor desempenho global do empreendimento. Esta situação faz com que as equipes subcontratadas busquem realizar trabalhos que resultem em uma maior produtividade, abrindo várias frentes de serviço, em vez de completar as atividades em lotes já iniciados.

\subsection{Falta de Terminalidade}

Segundo Alves (2000), a falta de terminalidade refere-se à não finalização das tarefas nos prazos estipulados e em conformidade com os critérios de qualidade préestabelecidos, requerendo o retorno posterior de alguma equipe para a realização de retrabalhos ou arremates. Assim, a falta de terminalidade contribui para o aumento de trabalho em progresso, pois o tempo para sua conclusão aumenta, assim como o tempo de liberação da unidade para atividades posteriores. Entre os fatores que influenciam a falta de terminalidade das tarefas, destaca-se o grau de definição dos pacotes de trabalho e o adequado sequenciamento dos processos. Além disso, muitas dessas atividades são realizadas informalmente, sujeitando-se às incertezas e aumentando a ocorrência de outros tipos de perdas na construção, devido à necessidade de refazer trabalhos já executados, aumentando a quantidade de retrabalho e de trabalho em progresso (FIREMAN, 2012).

Dificuldades na execução do controle da qualidade podem também ser uma possível causa do aumento do trabalho em progresso: se uma equipe não concluir adequadamente a sua tarefa, as falhas de qualidade são detectadas tardiamente, após o deslocamento da equipe para outra frente de trabalho, deixando o local em espera para ser corrigido.

\subsection{Making-do}

Segundo Koskela (2004), entende-se como making-do uma situação em que uma tarefa é iniciada sem que todos os recursos necessários estejam disponíveis para que o trabalho inicie ou continue adequadamente até o seu término. O termo "recursos" refere-se não somente a materiais, mas a todos os outros recursos, como máquinas, ferramentas, pessoal, espaço, condições externas, informações, entre outros. Sem as condições adequadas, podem ser realizadas improvisações para que seja dada continuidade ao trabalho das equipes, que realizam ações não especificadas a fim de que o serviço não seja interrompido. Diferentes formas de making-do podem ser identificadas em canteiros de obras (Quadro 1) e estão relacionadas aos recursos que não estão disponíveis no local e momento certos para o processamento (SOMMER, 2010). 
Quadro 1 - Categorias de Making-do Observadas em Canteiros de Obras.

\begin{tabular}{|l|l|}
\hline Categorias de Making-do & Definição \\
\hline Acesso/mobilidade & $\begin{array}{l}\text { Relativo ao espaço, meio ou forma de posicionamento } \\
\text { de quem executa as tarefas }\end{array}$ \\
\hline Ajuste de componentes & $\begin{array}{l}\text { Artifícios para uso de componentes não adequados à } \\
\text { realização das tarefas }\end{array}$ \\
\hline Área de trabalho & $\begin{array}{l}\text { Refere-se à bancada de trabalho ou área de apoio } \\
\text { durante as atividades realizadas }\end{array}$ \\
\hline Armazenamento & $\begin{array}{l}\text { Organização de materiais ou componentes em locais não } \\
\text { preparados para o seu recebimento }\end{array}$ \\
\hline Equipamentos/ferramentas & Criados ou adaptados para uso durante as atividades \\
\hline Infraestrutura para o trabalho & Criados ou adaptados para uso durante as atividades \\
\hline Proteção & Forma de uso dos sistemas de proteção \\
\hline Sequenciamento (FIREMAN, 2012) & Alteração na sequência de execução \\
\hline
\end{tabular}

Fonte: Sommer, 2010.

Para Fireman (2012), há uma forte relação entre perdas por making-do e a existência de pacotes informais, ou seja, pacotes de atividades que são executadas sem terem sido planejadas e cujos pré-requisitos nem sempre são verificados de forma sistemática. Consequentemente, falta de terminalidade das atividades, trabalho em progresso e aumento do lead time ${ }^{1}$ também podem ser observados devido aos pacotes de trabalho informais no canteiro de obras

O Making-do tem como causa principal as deficiências na realização do planejamento de médio prazo, em que as restrições não são devidamente removidas (FIREMAN, 2012; SOMMER, 2010). O início das tarefas sem que estejam disponíveis todos os recursos necessários e devido a reações das equipes para que o trabalho não seja interrompido podem ainda ter como consequência a diminuição da produtividade; desmotivação; perdas de materiais; retrabalho; redução da segurança; e redução da qualidade (FORMOSO et al., 2011).

Neste sentido, Formoso et al. (2011) destacam que, embora a elaboração e o cumprimento de procedimentos padronizados possam contribuir para a redução das perdas por making-do, tais medidas não são suficientes para a sua total eliminação. Os mesmos autores apontam também para a necessidade de se dedicar um esforço de projeto de processos e operações, por meio de, por exemplo, simulações 4D ou realização de protótipos físicos, e também a remoção sistemática de restrições em nível de médio prazo. Tais problemas são incidentes tanto em sistemas construtivos

1 Lead Time: Tempo de atravessamento contado do pedido até a entrega de um produto. 
tradicionais, como também em sistemas industrializados, embora nestes últimos existe um maior potencial para a sua redução, já que eles têm normalmente menores possibilidades de improvisação.

\section{Identificação e Mensuração das Perdas}

\subsection{Trabalho em Progresso}

O trabalho em progresso pode ser identificado pela quantidade de estoques intermediários de elementos já fabricados ou parcialmente montados ou pelas unidades produtivas finalizadas. Para sistemas que possuem etapas de pré-montagem, a quantidade de elementos pré-montados em relação ao que já foi montado indica a quantidade de trabalho em progresso relativamente ao total da obra. Em estruturas metálicas, geralmente esse indicador é medido em $\mathrm{kg}$ de aço, já em estruturas prémoldadas de concreto, em $\mathrm{m}^{3}$ de concreto. Pode-se também medir a aderência ao sequenciamento dos lotes, ao longo das diferentes etapas construtivas, e avaliar os ganhos de produtividade obtidos com os sistemas industrializados, no decorrer de toda obra.

O trabalho em progresso deve medir a quantidade de trabalho pronto a ser entregue na próxima etapa ou ao cliente final e aquela que está em espera, devendose adotar a mesma unidade de trabalho, capaz de atender diferentes serviços. Seguem os passos para quantificar o trabalho em progresso:

- Definir os lotes de controle (por exemplo, unidade, pavimento, casa, ou setor);

- Identificar todos os serviços que fazem parte do escopo da obra;

- Multiplicar o número de lotes pelo número de frentes de trabalho, a fim de se obter o número total de lotes de trabalho (LT);

- Definir um ponto de verificação dos serviços para o aceite do lote e a entrega do serviço seguinte;

- Contabilizar os lotes com tarefas já concluídas para cada serviço (LC);

- Contabilizar os lotes com tarefas em andamento para cada serviço (LA);

- Contabilizar o número de lotes em espera para iniciar um novo serviço (LE);

- Calcular o percentual de trabalho em progresso conforme a Equação 1:

$$
\text { Trabalho em Progresso }=\frac{L E}{L T} \times 100
$$

Semanalmente, ao verificar o andamento dos pacotes de serviço, o indicador pode ser atualizado. Da mesma forma, se for substituído na expressão acima LE por LC, tem-se como resultado o avanço físico da obra, Equação 2: 


$$
\text { Avanço Físico }=\frac{L C}{L T} \times 100
$$

\subsection{Falta de Terminalidade}

Da mesma forma que o trabalho em progresso, a falta de terminalidade pode ser medida por meio da identificação dos lotes que não estão prontos, impedindo o serviço subsequente de ser iniciado. Pode ser associado ao controle de qualidade e identificado mediante os serviços que apresentam não conformidades, ou apenas identificado por meio de lotes que foram iniciados, porém, estão sem equipe alguma realizando o trabalho. O número de frentes de trabalho existentes multiplicadas pelo número de lotes cujo trabalho foi iniciado e não finalizado ou aceito indica o volume de trabalho incompleto (LI), Equação 3.

$$
\text { Falta de Terminalidade }=\frac{L I}{L T} \times 100
$$

Outra abordagem para quantificar o trabalho em progresso é a realização de rotinas de controle da produção dos pacotes de trabalho que estão sendo executados. Ao identificar equipes trabalhando em pacotes que não foram planejados, denominados de pacotes de trabalho informais, deve-se verificar se o trabalho está associado a algum retrabalho, finalização do serviço não concluído na semana anterior e não planejado, arremates ou novas equipes iniciando serviços antes do previsto.

\subsection{Making-do}

A identificação e quantificação de making-do pode ser realizada pela observação direta das tarefas realizadas nos canteiros de obras e a sua comparação com padrões ou melhores práticas estabelecidas. Sommer (2010) propôs um protocolo para a mensuração desse tipo de perda, o qual foi complementado pelos estudos de Leão (2014) e Ibarra, Formoso e Lima (2016). As principais etapas deste protocolo estão apresentadas a seguir:

- Descrever a improvisação observada e fazer um registro fotográfico;

- Identificar os pré-requisitos que não estavam disponíveis;

- Analisar possíveis impactos devido à ação realizada;

- Categorizar os casos (conforme o Quadro 1) e identificar as suas possíveis causas; 
- Quantificar o percentual de cada categoria em relação ao total de eventos identificados. Pode-se também mensurar a incidência de making-do, de forma relativa, por meio da relação de pacotes de trabalho com improvisação e o número total de pacotes.

\section{Estudos de Caso}

\subsection{Obra com Estrutura Metálica}

A análise relativa ao trabalho em progresso foi a base para compreender o sistema de planejamento e controle da produção de uma empresa que projeta, fabrica e monta sistemas construtivos metálicos. Inicialmente, foi observado um alto índice de atraso na entrega das obras. A análise aprofundada das causas desse atraso apontou para problemas na estratégia de entrega de componentes por parte da fábrica. A partir de tal constatação, foi iniciado um estudo mais amplo, envolvendo os diferentes processos envolvidos na fabricação e entrega dos componentes para as obras.

Cada empreendimento era dividido em grandes etapas de produção que, por sua vez, eram divididas em subetapas, conforme o projeto executivo (estrutura primária, secundária, fechamento, telhas, etc.). Esta prática permite a redução do tamanho do lote de transferência entre cada uma das fases do processo, o que deveria reduzir o tempo de entrega. Entretanto, os incentivos dados aos departamentos relacionados ao processo de produção não estavam atrelados ao fechamento das subetapas, mas ao volume de produção.

Desta forma, cada departamento se beneficiava ao atingir uma determinada tonelagem de componentes produzidos. Esse incentivo fazia com que o departamento de projeto priorizasse os projetos mais fáceis e a fábrica produzisse os componentes mais pesados, criando um alto nível de estoque entre cada uma das fases e dificultando o envio dos componentes a obra. Para evitar o envio de peças que não pudessem ser montadas, as subetapas eram pensadas de forma a englobar todos os produtos necessários para a montagem dos componentes. A prática de priorizar produtos pesados fazia com que muitos componentes ficassem prontos muito antes dos demais produtos correspondentes ao seu lote.

A Figura 2 representa a quantidade de materiais armazenada no pátio de uma das fábricas, ressaltando o quanto desse total representava um lote completo para ser mandado para a obra. O departamento de logística, responsável pela entrega dos materiais à obra, tinha apenas uma parcela do estoque para ser efetivamente enviada à obra. 


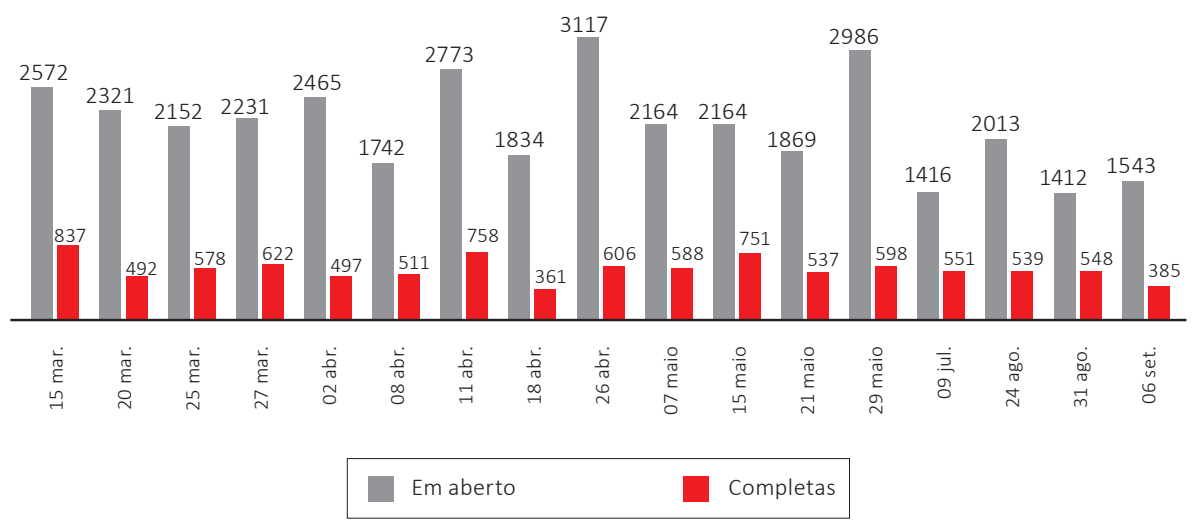

Figura 2 - Total de materiais estocados no pátio da fábrica (em toneladas).

Ao cruzar as informações sobre o tempo que os componentes aguardam no pátio da fábrica e quão antecipada foi a produção, observou-se um alto desalinhamento entre a fabricação e a real necessidade das peças. A Figura 3 apresenta esquematicamente essa comparação, em um dia de pátio. É possível observar que a maioria dos componentes armazenados foram produzidos antecipadamente, o que significa que não havia tempo disponível para alterações nos pedidos realizados pelos clientes. A empresa tinha uma abordagem centralizada de planejamento e controle da produção, e não costumava avaliar sistematicamente as reais demandas das obras. Cabe lembrar que em ambientes complexos, as demandas são emergentes e dinâmicas, sendo muito pouco aplicável um método de controle baseado na aderência a um plano definido apenas com base em estimativas de demanda de longo prazo.

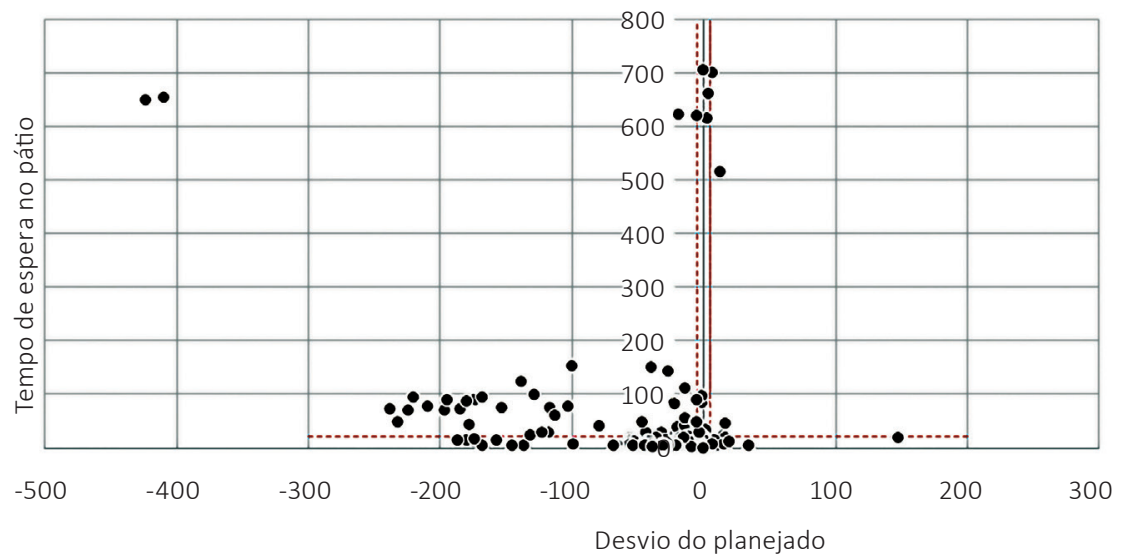

Figura 3 - Trabalho em progresso na fabricação dos componentes. 
A principal causa da espera dos componentes estocados no pátio era a falta de condições do canteiro para que se realizasse o descarregamento dos componentes, seja devido a restrições de espaço, seja devido à falta de equipes para produção.

O impacto dessa prática no canteiro de obras pode ser observado na Figura 4. A maioria (61\%) das subetapas esperam mais de 10 dias no canteiro antes de serem utilizadas na montagem, $25 \%$ foram entregues antecipadamente. A Figura 4 indica que receber os componentes de forma antecipada não reduzia o tempo de montagem, devido ao desalinhamento das entregas e fases da obra. Em outras palavras, os lotes entregues não eram os que a obra estava realmente necessitando.

Constatou-se também a ocorrência de tempos de espera negativos, ou seja, embora apenas parte dos componentes da subetapa estivesse disponível, o engenheiro da obra decidiu iniciar o processo de montagem de qualquer maneira, completando com componentes similares de outros lotes. Trata-se de um exemplo de making-do que ocorria nas obras.

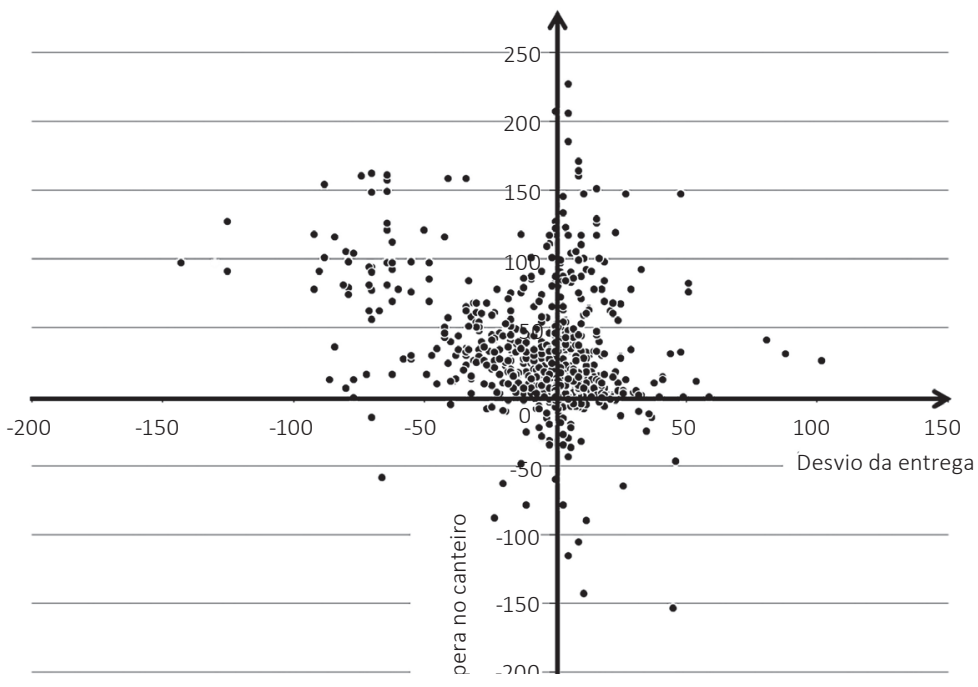

\begin{tabular}{lllll}
\hline & Entrega antecipada & No prazo & Em atraso & \\
\hline $\begin{array}{l}\text { Longo tempo no canteiro } \\
\text { (mais de 10 dias) }\end{array}$ & $21 \%$ & $30 \%$ & $10 \%$ & $61 \%$ \\
\hline $\begin{array}{l}\text { Pouca espera } \\
\text { (até 10 dias) }\end{array}$ & $3 \%$ & $24 \%$ & $7 \%$ & $34 \%$ \\
\hline $\begin{array}{l}\text { Uso antecipado } \\
\text { (antes de completar a entrega) }\end{array}$ & $1 \%$ & $3 \%$ & $1 \%$ & $5 \%$ \\
\hline & $25 \%$ & $57 \%$ & $18 \%$ & \\
& & & & \\
\end{tabular}

Figura 4 - Impacto das antecipações nos canteiros de obra. 
A análise do trabalho em progresso nessa empresa permitiu uma melhor compreensão das deficiências do sistema de planejamento e controle existente. Esse tipo de sistema é baseado em uma abordagem de planejamento centralizada, na qual os planos de longo prazo dificilmente são alterados. Isso dificulta que o sistema seja capaz de enfrentar o nível de incerteza inerente à natureza desse tipo de produção.

\subsection{Obra em light steel frame}

A identificação e monitoramento das perdas foi usada neste estudo para avaliar a implementação de um sistema construtivo por uma empresa construtora que tinha pouca experiência com esse tipo de sistema construtivo. A obra consistia na construção de sobrados, com estrutura em light steel frame. A partir da verificação do andamento da produção semanal, foram coletados dados que indicassem ações necessárias para se obter os resultados esperados a partir da escolha do sistema construtivo.

A base para a análise era o plano semanal, no qual eram descritas as tarefas planejadas, o lote e a equipe responsável pela tarefa. Nesse caso particular, o lote era representado por um conjunto de casas geminadas em fita. A partir dos dados de planejamento, o Quadro 2 foi usado como ferramenta de coleta de dados em campo. Todos os pacotes do plano eram transcritos para a ferramenta indicando o lote, a tarefa, a equipe e o tipo de pacote de trabalho, sendo todos eles formalmente planejados. A rotina de monitoramento consistia em verificar todo o trabalho que estava sendo realizado no canteiro. Caso o serviço não fizesse parte do plano, era indicado o local (lote), o que estava sendo realizado (descrição da tarefa), quem estava executando (equipe) e registrado como pacote informal, informando a causa: retrabalho, falta de terminalidade ou novos pacotes iniciados após elaboração dos planos. Se fosse identificado algum caso de making-do, eles eram também identificados quanto a sua categoria e causa. No final da semana, eram contabilizados os pacotes que tinham sido concluídos.

Quadro 2 - Ferramenta de Coleta de Dados.

\begin{tabular}{|c|c|c|c|c|c|c|c|}
\hline Lote & $\begin{array}{c}\text { Descrição da } \\
\text { Tarefa }\end{array}$ & Equipe & $\begin{array}{c}\text { Pacote de } \\
\text { Trabalho }\end{array}$ & Causa & $\begin{array}{c}\text { Conclusão } \\
\text { S/N }\end{array}$ & $\begin{array}{c}\text { Categoria } \\
\text { Making-do }\end{array}$ & Causa \\
\hline & & & & & & & \\
\hline & & & & & & & \\
\hline
\end{tabular}

A partir de cinco semanas de coleta, foi monitorado o número de pacotes de trabalho informais devido à falta de terminalidade: em média, 33\% dos pacotes observados eram informais, dos quais mais de $60 \%$ ocorriam em virtude da falta de terminalidade, gerando mais trabalho em progresso e tornando mais difícil o controle 
da produção. Inicialmente, a falta de cumprimento dos planos era atribuída às equipes de montagem devido apenas à baixa produtividade e ao pouco comprometimento com os planos. Entretanto, a partir da análise realizada, ficou evidente que as equipes não concluíam os pacotes planejados pela necessidade de realizar retrabalhos ou ajustes por conta de falhas de projeto, principalmente no que se referia à compatibilização entre a estrutura e o radier.

As atividades de logística foram analisadas separadamente, por evento identificado. Foram observadas perdas por transporte acima do esperado em decorrência de obstáculos nas rotas de acesso, limitações de altura ou dificuldade de acesso dos equipamentos utilizados para apoiar as atividades. Constatou-se ainda que $48 \%$ das perdas por transporte observadas ocorreram durante a execução de pacotes de trabalho formais, 39\% não estavam relacionadas a pacotes de trabalho e $13 \%$ ocorreram durante a execução de pacotes de trabalho informais. Em dois terços dos eventos de perdas por transporte, foi possível relacioná-las a outros tipos de perdas, tais como making-do, retrabalho, falta de terminalidade e trabalho em progresso.

Dentre os casos de making-do observados, 30\% foram identificados durante a montagem dos componentes do sistema light steel frame, enquanto $70 \%$ foram observados nas etapas de infraestrutura e instalações provisória da obra. Entre as principais causas desses tipos de perda, destacam-se algumas práticas tradicionais de projeto, tal como a falta de planejamento das estruturas de apoio, as quais eram frequentemente adaptadas pelas equipes, como nos exemplos da Figura 5. Adaptações foram observadas também durante as etapas de escoramento, devido à ausência de projeto ou componentes para a estabilização da estrutura durante o processo de montagem. Inicialmente, a equipe utilizou madeira, que logo foi substituída por componentes da própria estrutura, conforme ilustra a Figura 6.
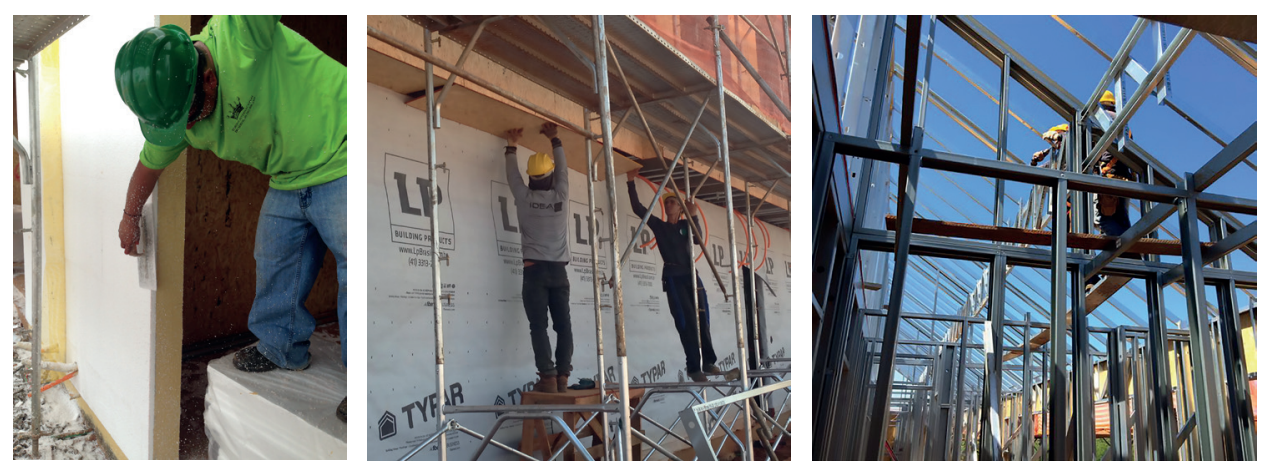

Figura 5 - Exemplos de Making-do devido à ausência de acesso adequado. 

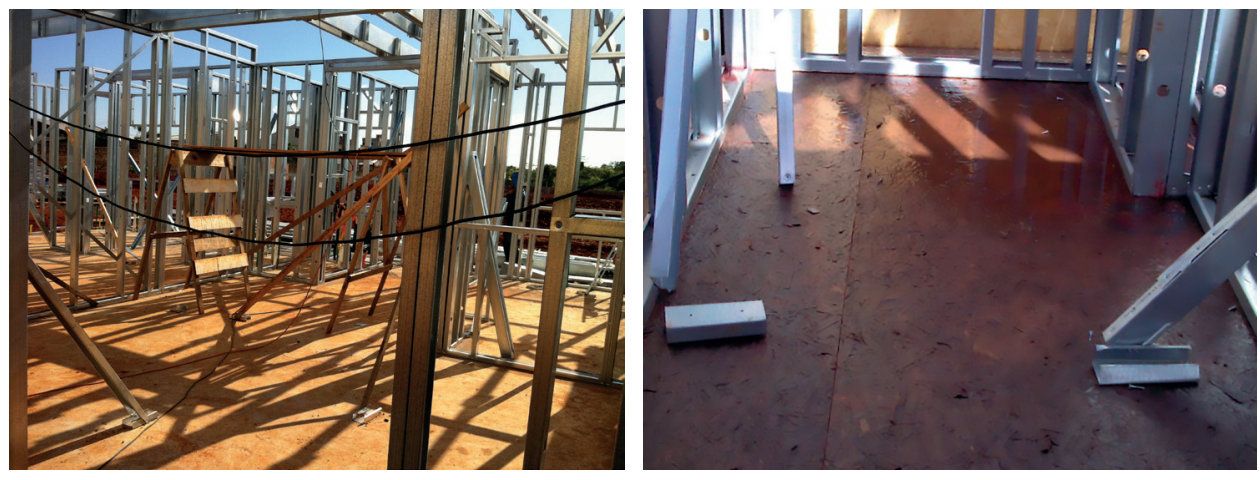

Figura 6 - Improvisações para componentes de escoramento.

No Quadro 3, estão sintetizadas as ações propostas para melhoria do desempenho da etapa de montagem das estruturas. Dentre as causas das perdas identificadas, destacam-se como necessárias as ações voltadas para as etapas de projeto do sistema de produção, planejamento da produção e de logística.

Quadro 3 - Ações identificadas a partir da análise das perdas.

\begin{tabular}{|l|l|l|}
\hline Perdas & Causas & Ações \\
\hline Falta de & Parâmetros de qualidade discutidos \\
Terminalidade & $\begin{array}{l}\text { pela equipe e seus fornecedores eram } \\
\text { pouco claros; } \\
\text { Encontro entre concreto e estrutura de } \\
\text { aço não detalhado; } \\
\text { Tolerância das fundações incompatível de } \\
\text { montagem capaz de ampliar a } \\
\text { comunicação, a transparência e } \\
\text { Lotes mutura grandes, até 8 casas com 2 } \\
\text { reduzir as perdas. } \\
\text { Reduzir tamanho do lote. }\end{array}$ & \\
\hline Transporte & $\begin{array}{l}\text { Acesso restrito ou obstruído; } \\
\text { Áreas de estoque não adequadas; } \\
\text { Empacotamento impróprio; } \\
\text { Equipamentos indisponíveis ou não } \\
\text { adequados. }\end{array}$ & $\begin{array}{l}\text { Planejamento da logística, } \\
\text { envolvendo a integração dos } \\
\text { planos de fabricação, logística e } \\
\text { montagem. }\end{array}$ \\
\hline Making-do & $\begin{array}{l}\text { Acesso inadequado ou falta de } \\
\text { mobilidade para execução das tarefas; } \\
\text { Áreas de estoque não adequadas; } \\
\text { Instalações provisórias inadequadas; } \\
\text { Equipamentos/Ferramentas não } \\
\text { disponíveis ou inadequadas. }\end{array}$ & $\begin{array}{l}\text { Rever meios de flexibilizar as } \\
\text { diferenças entre as tolerâncias dos } \\
\text { sistemas de fundações e de LSF. } \\
\text { Desenvolver PCP, principalmente } \\
\text { no que diz respeito ao processo de } \\
\text { identificar e remover restrições. }\end{array}$ \\
\hline
\end{tabular}




\subsection{Obra em Concreto Pré-Moldado}

Este estudo foi realizado em uma obra de construção de um edifício habitacional para baixa renda, com estrutura pré-fabricada de concreto, em Hong Kong. Nesse projeto havia um sistema para rastreamento eletrônico dos componentes de fachada pré-moldada, cujos dados foram utilizados para mensurar perdas entre os processos de fabricação, logística e montagem. Foram monitorados os tempos de espera para completar os lotes na fábrica, transporte e espera no canteiro. Já entre as etapas de estruturas e acabamentos, foi medido o trabalho em progresso e a falta de terminalidade. O lote de montagem da estrutura consistia na metade de um pavimento de $1.000 \mathrm{~m}^{2}$, composto por 23 painéis pré-moldados de concreto para fachada.

Os dados de rastreamento foram obtidos pela leitura de uma etiqueta inserida no painel com um código RFID², em 4 momentos: final da concretagem na fábrica, saída da fábrica, recebimento no canteiro e montagem. Os tempos foram quantificados conforme os lotes de produção, a partir das datas da primeira e última peça, para as seguintes variáveis:

- $\mathrm{TC}_{\mathrm{F}}$ - tempo de ciclo para fabricação do lote, medido pela leitura da data de concretagem do último painel do lote subtraindo-se a data de fabricação do primeiro e acrescentando-se o tempo de fabricação de um painel, descontados os dias não úteis;

- $\mathrm{TE}_{\mathrm{F}}$ - tempo do lote em espera para ser completado, medido pela diferença do tempo entre a fabricação do último componente e o primeiro, descontados os dias não úteis;

- TT - tempo de transporte do lote, medido pelo período entre a data de recebimento do lote menos a data de saída;

- $\mathrm{TE}_{\mathrm{C}}$ - tempo de espera do lote no canteiro, medido pelo período entre a data de montagem e a data de chegada no canteiro;

- $T L$ - tempo para logística, sendo $T L=T E_{F}+T T+T E_{C_{;}}$

- $\mathrm{TC}_{\mathrm{M}}$ - tempo de ciclo da montagem, medido pelo período entre as datas de concretagem das lajes de cada lote.

A partir do mapa do fluxo de valor, quantificou-se em 72 dias o tempo gasto desde o pedido até a conclusão do lote no canteiro (lead time). Destes, apenas 22 dias são necessários para o processamento. Com base em dados de 26 pavimentos, construídos por 52 lotes com 23 componentes, os resultados indicaram que, na

2 RFID- Identificação por radiofrequência ou RFID (do inglês "Radio-Frequency IDentification") é um método de identificação automática através de sinais de rádio, recuperando e armazenando dados remotamente através de dispositivos denominados etiquetas RFID. 
fabricação, ocorriam os maiores tempos de trabalho em progresso e variabilidade conforme observado nas Figura 7, 8 e 9.
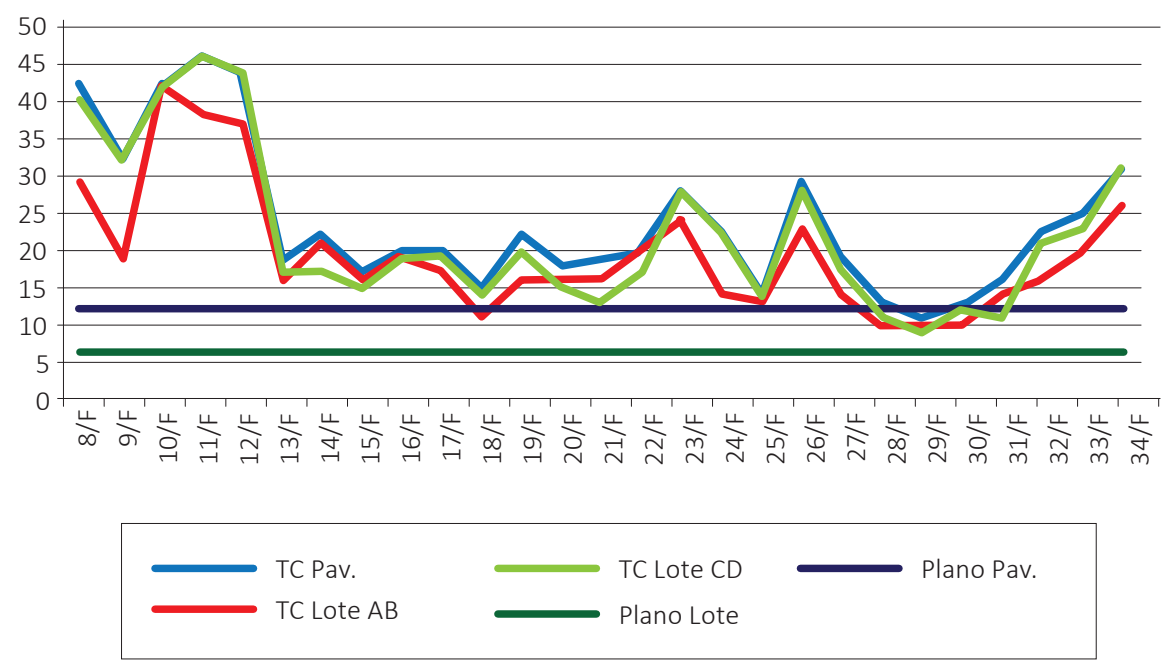

Figura 7 - Tempo de Ciclo de fabricação por lote e pavimento (dias).
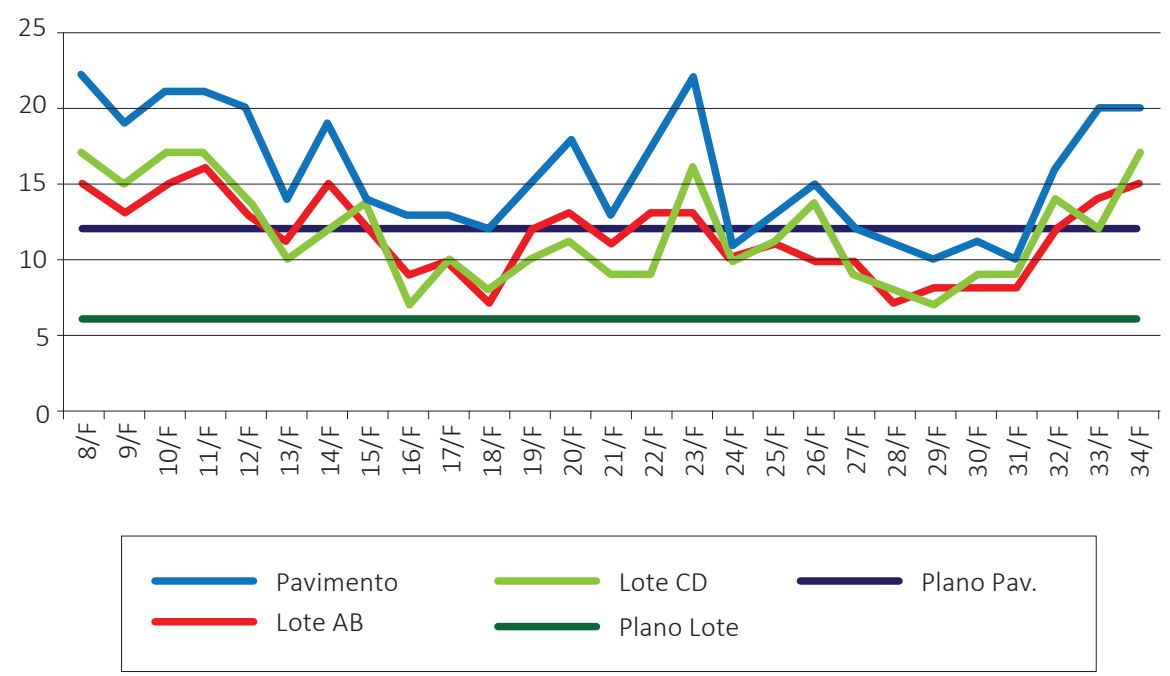

Figura 8 - Tempo de processamento na Fábrica (dias). 

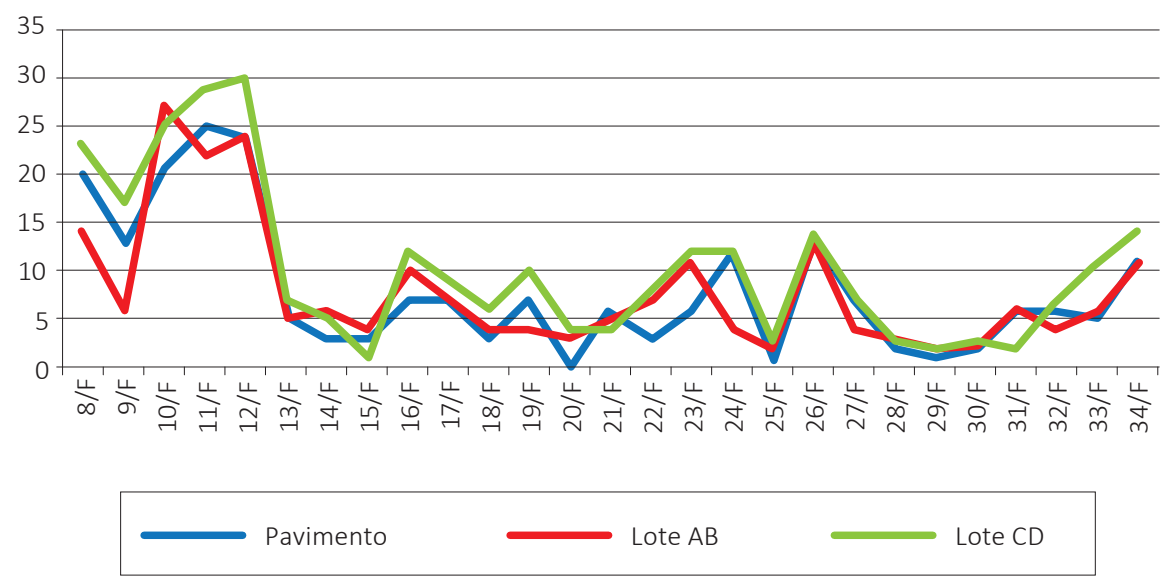

Figura 9 - Tempo de espera para completar o lote de entrega (dias).

Nas etapas de logística, representadas pelo tempo em estoque (Figura 10), em transporte (Figura 11) e pela espera no canteiro (Figura 12), foram calculadas as médias dos tempos dos componentes de cada lote. Inicialmente, a estratégia da fábrica foi iniciar a produção 3 meses antes do início da montagem para garantir o estoque mínimo de 4 lotes.

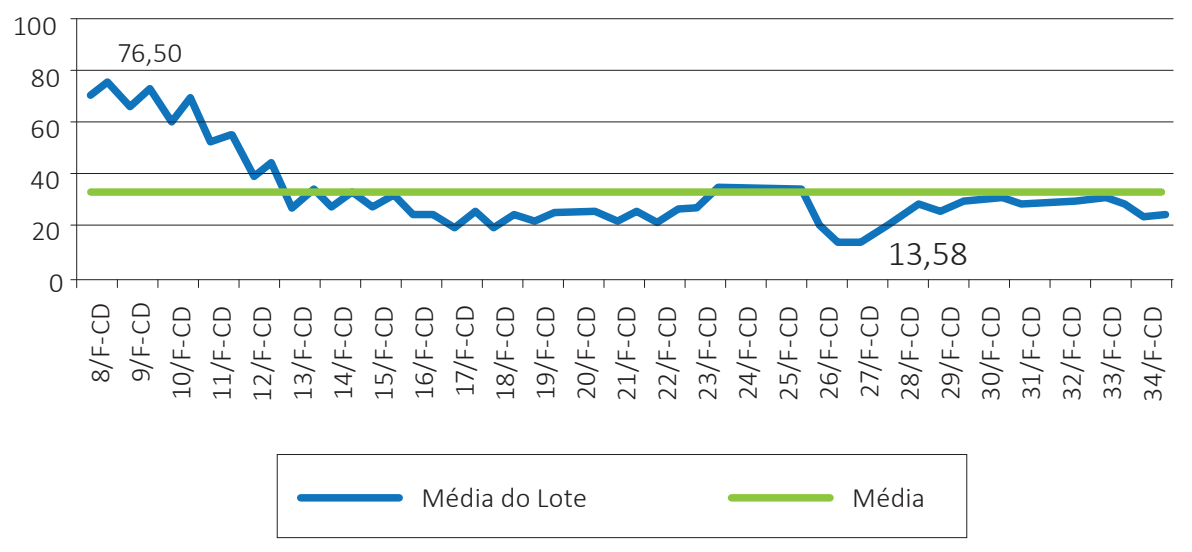

Figura 10 - Tempo médio do lote em estoque na fábrica em dias.

Uma das principais preocupações em relação à confiabilidade do processo de montagem era o tempo de transporte devido à fronteira existente entre a fábrica (na China) e o canteiro (em Hong Kong). Em função desse problema, foi definido um local 
próximo ao canteiro como área de estoque intermediário. Assim, atrasos na logística ou na montagem seriam absorvidos sem comprometer a confiabilidade de entrega.

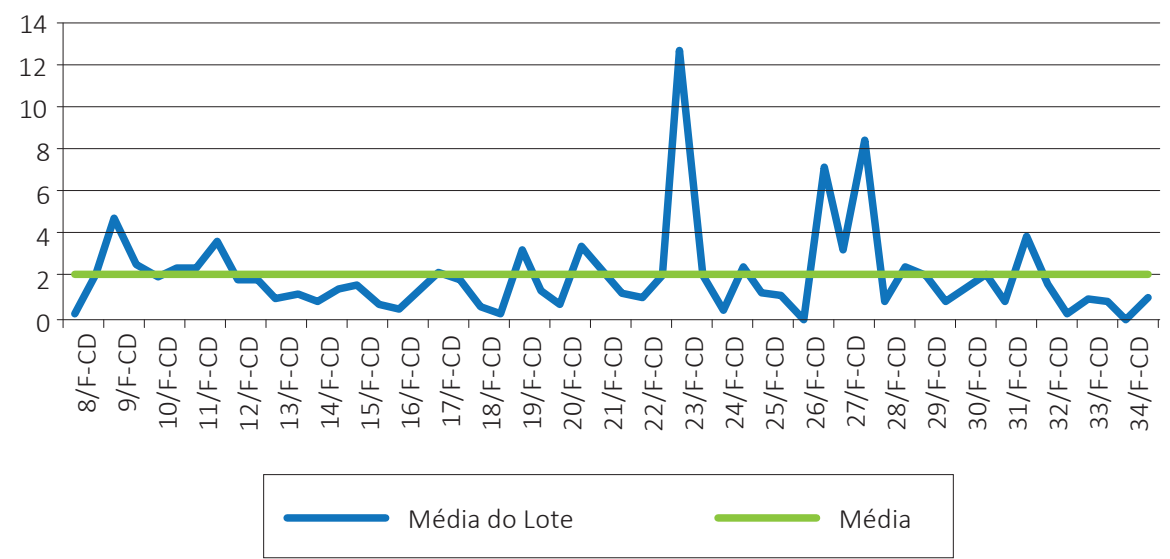

Figura 11 - Tempo médio do lote em transporte em dias.

Como o ciclo de execução do pavimento envolvia também a concretagem in loco de outros elementos estruturais, atrasos na montagem eram frequentes. A quantidade de componentes pré-moldados nessa obra era de apenas $30 \%$ do volume total de concreto.

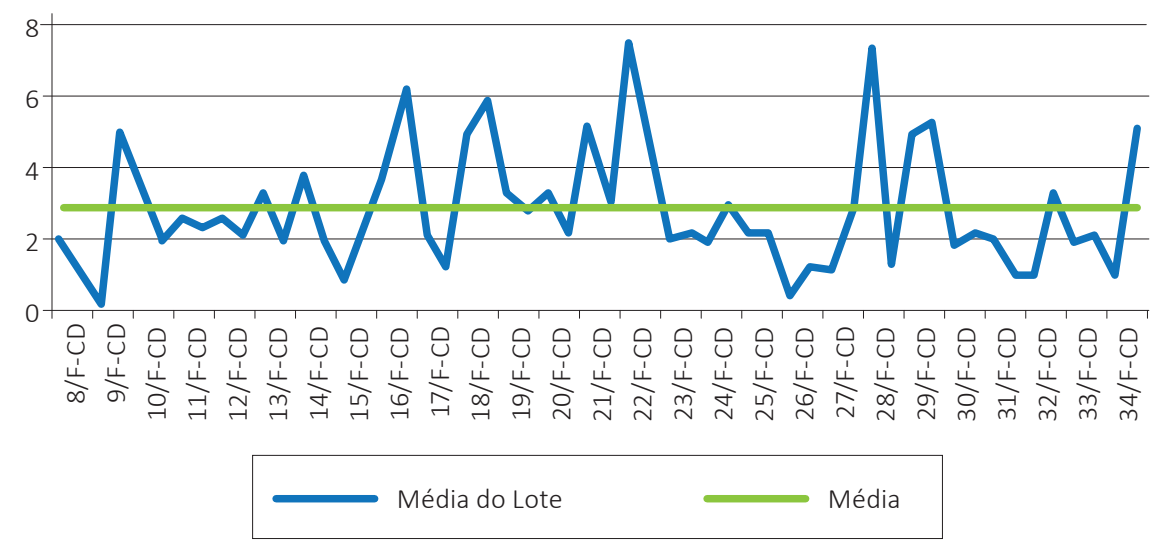

Figura 12 - Tempo médio de espera do lote no canteiro em dias.

A etapa de montagem, que envolvia a montagem dos componentes prémoldados e também de formas e estrutura de aço, havia sido planejada para entregar 
um pavimento a cada 6 dias, sendo o tempo de ciclo do pavimento previsto para 9 dias (Figura 13).

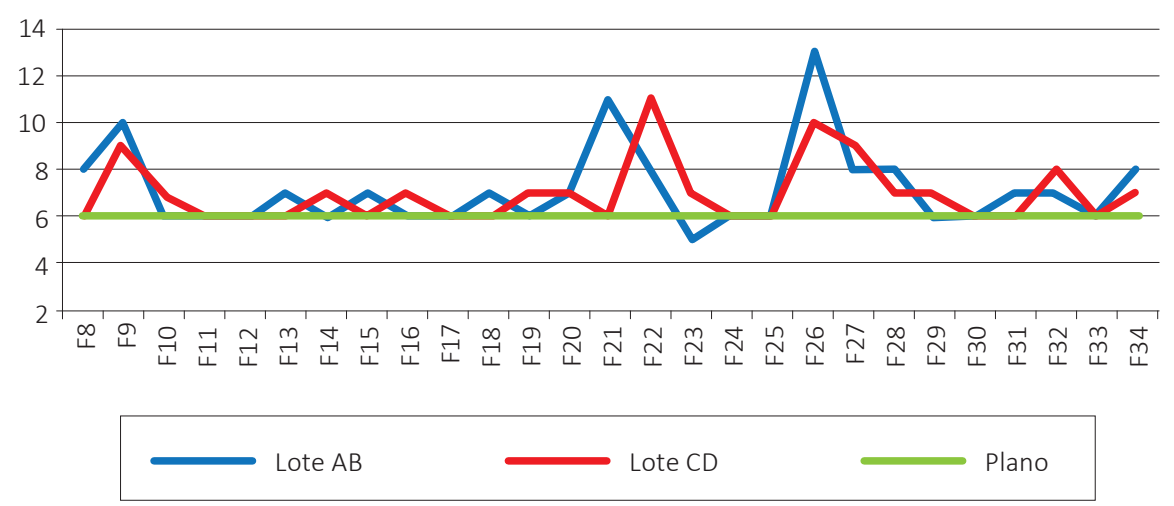

Figura 13 - Tempo de Ciclo Montagem do Lote (dias).

Com base na quantificação das perdas, feita a partir dos dados de rastreamento de componentes, foram identificadas oportunidades de melhorias no sistema de gestão da produção (Quadro 4), por meio do aumento da transparência entre diferentes áreas da empresa. Nesta análise, buscou-se questionar a visão tradicional de que se opera com recursos ilimitados à montante, o que resulta na não consideração das perdas nos processos de fabricação e logística.

Quadro 4-Síntese das Causas e Oportunidades observadas.

\begin{tabular}{|c|c|c|c|}
\hline & Fabricação & Logística & Montagem \\
\hline $\begin{array}{l}\text { Tempos } \\
\text { máx. e mín. }\end{array}$ & $20,17-76,50$ dias & $0,5-4,73$ dias & $0,5-7,54$ dias \\
\hline Causas & $\begin{array}{l}\text { Superprodução, } \\
\text { adaptação de formas, } \\
\text { lote planejado } \\
\text { diferente do entregue, } \\
\text { variabilidade na } \\
\text { montagem }\end{array}$ & $\begin{array}{l}\text { Trânsito, fronteira, } \\
\text { inspeções da qualidade, } \\
\text { estoque intermediário }\end{array}$ & $\begin{array}{l}\text { Atrasos do fornecedor } \\
\text { de concreto, } \\
\text { disponibilidade de mão } \\
\text { de obra, interrupções } \\
\text { de medidas de } \\
\text { segurança, processo de } \\
\text { aprendizagem }\end{array}$ \\
\hline Oportunidades & $\begin{array}{l}\text { Elaborar o projeto do } \\
\text { sistema de produção } \\
\text { conforme estratégia de } \\
\text { montagem a partir do } \\
\text { lote }\end{array}$ & $\begin{array}{l}\text { Aumentar transparência } \\
\text { entre fábrica e canteiro }\end{array}$ & $\begin{array}{l}\text { Padronização do } \\
\text { trabalho }\end{array}$ \\
\hline
\end{tabular}


$\mathrm{Na}$ interface com as outras frentes de trabalho, o trabalho em progresso foi medido em relação à etapa de acabamentos da edificação, conforme a Figura 14. Entretanto, foi constatado que parte dos ganhos obtidos com a rapidez na etapa de estruturas acabou sendo dissipado na etapa de acabamentos.
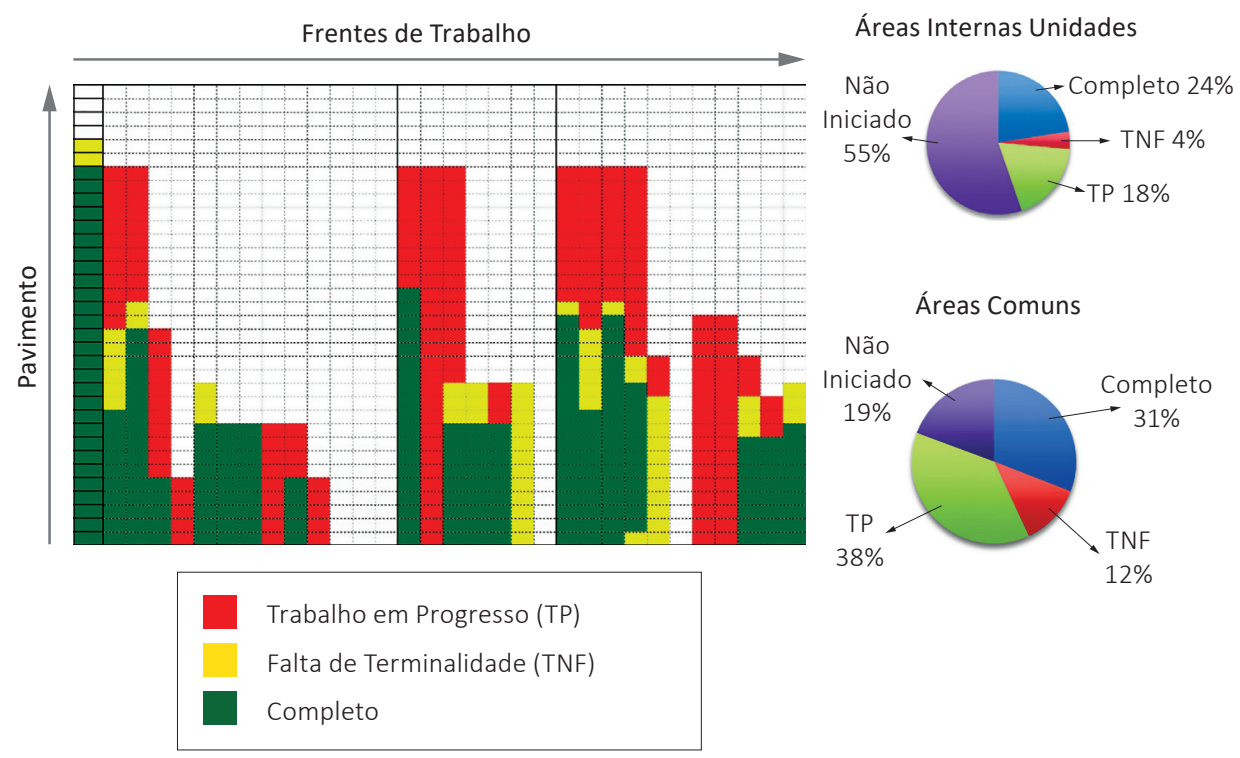

Figura 14 - Trabalho em progresso e falta de terminalidade na etapa de acabamentos.

\section{Conclusões}

Neste capítulo, procurou-se enfatizar que existe a necessidade de ampliar a abordagem de industrialização na construção em relação a alguns conceitos estabelecidos há mais de 50 anos, tais como produção em massa, robotização, racionalização, modulação e padronização. Avanços na gestão, sustentabilidade e tecnologia da informação devem ser incorporados na implementação de sistemas construtivos industrializados, a fim de se obter os benefícios esperados.

Diferentemente do que ocorre em outros setores industriais, os empreendimentos de construção são realizados por uma organização temporária, em torno de um produto único e envolve normalmente uma ampla cadeia de suprimentos, o que confere ao ambiente maior complexidade e incerteza quando comparado ao ambiente da manufatura. Nesse sentido, existe a necessidade de entender as principais categorias de perdas que ocorrem nesse ambiente específico e propor melhorias visando à sua eliminação. $O$ presente trabalho apresentou brevemente três estudos 
nos quais a análise das perdas por trabalho em progresso, falta de terminalidade e making-do trouxeram uma perspectiva diferente sobre os problemas existentes, que não eram percebidos facilmente pelos gestores envolvidos.

\section{Referências}

ALVES, T.C.L. Diretrizes para a gestão dos fluxos físicos em canteiros de obras proposta baseada em estudos de caso. Dissertação (Mestrado) - Universidade Federal do Rio Grande do Sul, Porto Alegre, 2000.

ASHFORD, J.L. The Management of Quality in Construction. London: E \& F Spon, 1992.

BASHFORD, H.H. et al. Implications of Even Flow Production Methodology for U.S. Housing Industry. Journal of Construction Engineering and Management, v. 129, n. June, p. 330337, 2003.

BOSSINK, B.A.G.; BROUWERS, H.J.H. Construction waste: Quantification and source evaluation. Journal of Construction Engineering and Management, v. 122, n. 1, p. 55-60, 1996.

BULHÕES, I.R. Diretrizes para implementação de fluxo contínuo na construção civil : uma abordagem baseada na Mentalidade Enxuta. Tese (Doutorado) - Universidade Estadual de Campinas, Campinas, 2009.

BURATI, J.L.J.; FARRINGTON, J.J.; LEDBETTER, W.B. Causes of Quality Deviations in Design and Construction. Journal of Construction Engineering and Management, v. 118, n. 1, p. 34-49, 1992.

FIREMAN, M.T. Proposta de método de controle integrado produção e qualidade, com ênfase na medição de perdas por making-do e retrabalho. Dissertação (Mestrado) Universidade Federal do Rio Grande do Sul, [s.I.], 2012.

FORMOSO, C.T. et al. An exploratory study on the measurement and analysis of making do in construction sites. $19^{\text {th }}$ Annual Conference of the International Group for Lean Construction. Anais... Lima: 2011

FORMOSO, C.T. et al. A conceptual framework for the prescriptive causal analysis of construction waste. $23^{\text {th }}$ Annual Conference of the International Group for Lean Construction. Anais... Perth: 2015

HÖÖK, M.; STEHN, L. Applicability of lean principles and practices in industrialized housing production. Construction Management and Economics, v. 26, n. 10, p. 1091-1100, 2008.

HWANG, B. et al. Measuring the Impact of Rework on Construction Cost Performance. Journal of Construction Engineering and Management, v. 135, n. 3, p. 187-198, 2009.

IBARRA, J.V.; FORMOSO, C.T.; LIMA, C. Model for integrated production and quality control : implementation and testing using. $24^{\text {th }}$ Annual Conference of the International Group for Lean Construction. Anais... Boston: 2016

KOSKELA, L. Application of the new philosophy to construction. Stanford, CIFE, Standord University, 1992. 
KOSKELA, L. Making-do - the eighth category of waste. $12^{\text {th }}$ Annual Conference of the International Group for Lean Construction. Anais... Helsing $\varnothing r$ : 2004

KOSKELA, L.; VRIJHOEF, R. The prevalent theory of construction is a hindrance for innovation. $8^{\text {th }}$ Annual Conference of the International Group for Lean Construction. Anais... Brighton: 2000

LEÃO, C.F. Proposta de Modelo para Controle Integrado da Produção e da Qualidade Utilizando Tecnologia de Informação. Dissertação (Mestrado) - Universidade Federal do Rio Grande do Sul, Porto Alegre, 2014.

LOVE, P.E.D. et al. Rework in Civil Infrastructure Projects: Determination of Cost Predictors. Journal of Construction Engineering and Management, v. 136, n. 3, p. 275-282, 2010.

MONDEN, Y. Toyota production system: Practical approach to pro - duction management, Industrial Engineering Management. Norcross, 1983.

OHNO, T. O Sistema Toyota de Produção: Além da produção em larga escala. Porto Alegre: Bookman, 1997.

POON, C.S. et al. Management of construction waste in public housing projects in Hong Kong. Construction Management and Economics, v. 22, n. 7, p. 675-689, 2004.

SACKS, R. et al. Visualization of Work Flow to Support Lean Construction. Journal of Construction Engineering and Management, ASCE, v. 135, n. 12, p. 1307-1315, 2009.

SAFFARO, F. A. Uso da prototipagem para gestão do processo de produção da construção civil. Tese (Doutorado) - Universidade Federal de Santa Catarina, Florianópolis, 2007.

SHINGO, S. Sistemas de Produção com Estoque Zero: o sistema Shingo para melhorias contínuas. Porto Alegre: Bookman, 1996.

SOMMER, L. Contribuições para um método de identificação de perdas por improvisação em canteiros de obras. Dissertação (Mestrado) - Universidade Federal do Rio Grande do Sul, Porto Alegre, 2010.

VIANA, D.D.; FORMOSO, C.T.; KALSAAS, B.T. Waste in construction: a systematic literature review on empirical studies. $20^{\text {th }}$ Annual Conference of the International Group for Lean Construction. Anais... 2012

WOMACK, J. P.; JONES, D. T. Lean thinking. New York: Simon and Schuster, 1996.

YU, H. et al. Development of Lean Model for House Construction Using. Journal of Construction Engineering and Management, v. 135, n. 8, p. 782-790, 2009. 


\title{
Linha de Montagem para a Produção de Habitações de Interesse Social Modular em Light Steel Frame
}

\author{
André Luiz Vivan \\ José Carlos Paliari
}

\section{Introdução}

Tradicionalmente, o processo de produção de edificações é caracterizado pela movimentação dos operários, máquinas (se necessário) e materiais em áreas que circundam o espaço ocupado pelo produto que está sendo construído, ou seja, o produto é fixo enquanto operários e máquinas movimentam-se em praticamente todo o recinto que forma o canteiro de obras. Além disso, grande parte das empresas construtoras procuram melhorias nas atividades de processamento, tornando-as mais eficientes em vez de torná-las mais eficazes (KOSKELA, 1992). Assim, entende-se que a mudança nas bases técnicas seja indispensável para a aplicação de inovações que rompam com o que tradicionalmente é praticado. Tal ação pode ser justificada pelo fato de que as práticas tradicionais na construção estão se tornando cada vez mais inadequadas, tendo em vista o crescimento contínuo da complexidade dos empreendimentos e da necessidade de rapidez de entrega dessas edificações (KOSKELA, 2000; KOSKELA; VRIJHOEF, 2001; KOSKELA, 2004; BERTELSEN et al.,2008).

Nesse sentido, mudanças nas bases técnicas de produção são uma das transformações mais fundamentais que podem ser introduzidas na indústria da construção. O uso de novos sistemas de produção, como os denominados flow shop, 
mostram-se adequados nesse contexto, em que as linhas de montagem são uma das técnicas que melhor definem tais métodos. De acordo com Gomes (2002), o termo flow shop representa os sistemas de produção projetados a fim de fazer com que os processos e os equipamentos necessários às tarefas estejam organizados conforme as etapas sequenciais de produção pelas quais o produto é fabricado. Bachega (2013) acrescenta ainda que os ambientes flow shop atuam, basicamente, em um fluxo de peças/materiais e os equipamentos são de uso dedicado e específico.

Tubino (1999) indica algumas vantagens do uso de ambientes flow shop, como o controle simplificado da produção, a facilidade em otimizar o sistema, a redução do lead time da produção, entre outras. Assim, considerando a produção de habitações em um ambiente flow shop, recorreu-se às linhas de montagem como método de produção. Na visão de Bautista e Pereira (2007), uma linha de montagem é formada por um determinado número de estações de trabalho, que são dispostas em série ou em paralelo, nas quais os serviços se desenvolvem por meio de um fluxo de produção. Os autores afirmam que tais estações são integradas por um sistema de transporte, cujo objetivo é suprir o elemento (ou produto a ser fabricado) de componentes e movimentar a produção de uma estação de trabalho a outra.

Tendo em vista o breve contexto apresentado, é necessário indicar a tecnologia mais adequada a uma perfeita combinação entre o produto e o sistema de produção. Dessa forma, foi selecionado o sistema construtivo Light Steel Frame (LSF), pois, simplificadamente, o LSF pode ser definido como um sistema formado por estrutura composta a partir da associação de elementos fabricados em perfis de aço conformados a frio, que constituem os elementos estruturais e associam-se a diversos outros sistemas, como o de vedação, o qual, geralmente, utiliza placas pré-fabricadas com capacidade de variar sua composição. Mas a principal vantagem do LSF pode ser identificada nos atributos dos seus elementos, que caracterizam a produção de edificações em LSF como essencialmente de montagem, fato que representa uma grande vantagem sobre sistemas construtivos baseados na alvenaria, por exemplo.

Dessa maneira, a justificativa do uso do LSF baseia-se em suas características de industrialização, inerentes aos seus processos e subprocessos, em relação às características de trabalho em uma linha de montagem que exige a pré-fabricação. Além disso, o LSF, como qualquer estrutura metálica, possui outro atributo representado pela precisão dimensional, de ordem de grandeza milimétrica de seus componentes, em função das características do aço e dos processos de fabricação dos componentes. Essa precisão pode ser mais difícil de ser obtida com outros materiais de uso comum na construção, como a madeira para o sistema Wood Frame.

Considerando a indústria da construção, o uso de um sistema produtivo definido por linha de montagem é algo pouco explorado, tanto no âmbito acadêmico quanto comercial. Assim, a adoção de linhas na indústria da construção implica que as casas, 
como produtos finais, sejam produzidas dentro de uma fábrica. Conforme afirmação de Lee e Englin (1989), casas manufaturadas são inteiramente produzidas em uma fábrica e, assim, oferecem uma grande vantagem econômica sobre casas construídas de maneira convencional. Em termos operacionais, o processo de produção de habitações industrializadas consiste em várias atividades realizadas em uma linha de montagem, que deverão ser muito bem planejadas para garantir uma construção contínua (sem imprevistos) (MEHROTRA; SYAL; HASTAK, 2003).

Assim, de acordo com o conteúdo exposto, foi proposto o desenvolvimento de um sistema de produção flow shop, utilizando linhas de montagem manuais como técnica de produção para unidades habitacionais modulares em LSF. O sistema desenvolvido foi modelado e simulado computacionalmente, no intuito de avaliar o seu comportamento, basicamente, em termos de rapidez de entrega das unidades habitacionais e redução de desperdícios.

\section{Metodologia}

O projeto de uma linha de montagem envolve a integração entre o projeto dos produtos, processos e o layout da fábrica, uma vez que os produtos devem ser desenvolvidos com base nas regras de projetos para produção e nas restrições produtivas entre tarefas (REKIEK; DELCHAMBRE, 2006). A fabricação de um item na linha de montagem é dividida em um conjunto de tarefas conhecidas, e, para cada estação de trabalho, é atribuído um subconjunto de tarefas denominadas "cargas de trabalho da estação", as quais são únicas e específicas para cada estação. Cada tarefa demanda um tempo de operação, que deve ser determinado em função das tecnologias de fabricação utilizadas e os recursos (máquinas, ferramentas, etc.) empregados (BAUTISTA; PEREIRA, 2007).

Assim, uma casa manufaturada é produzida em um ambiente controlado de uma fábrica e, uma vez concluída, é transportada para o destino final no qual será instalada e conectada com as demais instalações, como fundações e sistemas prediais (MEHROTRA; SYAL; HASTAK, 2005). Os autores mostram que, para a montagem da unidade habitacional, são necessárias várias estações de trabalho de diferentes tipos, as quais podem estar agrupadas em linhas principais, células de produção ou em linhas alimentadoras. Além disso, as estações de trabalho devem ser adequadas para comportar as ferramentas e máquinas necessárias para o desenvolvimento das atividades atribuídas. Após a realização de diversos estudos de caso em várias indústrias do ramo, Hammad (2002) e Mehrotra; Syal e Hastak (2005) sugerem uma divisão das tarefas de montagem de uma casa para uso em linhas de montagem, independente da tecnologia de construção, que serviu de base para o desenvolvimento do sistema proposto neste estudo. 
Com as devidas adaptações na proposta dos autores, portanto, foi desenvolvido o sistema de produção deste trabalho, bem como o seu respectivo modelo computacional, adequadamente validado para posterior simulação computacional. O modelo computacional foi elaborado no ambiente do software ProModel ${ }^{\circledR}$, desenvolvido pela ProModel Corporation $^{\circledR}$, obedecendo todas as premissas de programação do software para o correto funcionamento do modelo. No que tange à programação, destaca-se a lógica de cada estação de trabalho, que foi estruturada com a regra FIFO (First In First Out), como condição para recebimento e liberação dos elementos a serem processados ou já processados. Com relação aos recursos de transporte, estes foram definidos por plataformas de montagem. Tais recursos de transporte possuem atributos como velocidade, ponto de partida, aceleração, entre outros, que foram informados ao software e sofreram alterações ou não, dependendo das condições de simulação. Outros atributos como equipes e suas características e máquinas, como pontes rolante, também foram inseridos no modelo.

Por último, a construção do modelo também contempla as definições a respeito dos produtos. Além dos tempos de processamento que são característicos das tarefas de montagem, o software necessita que sejam informadas as quantidades de produção e as frequências de entrega de cada elemento. Assim, para o modelo, foram consideradas variações nos processos. Dessa forma, as porcentagens de variação foram obtidas considerando que, segundo Lane (2007), em sistemas de baixo volume de produção, é usual que os tempos variem em um intervalo máximo de menos 15\% e mais $15 \%$. O autor considera que essa variação é aceitável e, normalmente, o sistema a compensa naturalmente ao longo dos postos de trabalho.

Com essa variação, os tempos das estações de trabalho descritos nos resultados são entendidos como tempos padrão de processamento das atividades, possuindo limites inferior e superior definidos com base na variação descrita, de maneira que o lead time associado à tarefa de cada operário nos postos de trabalho variou dentro de tais limites. A variabilidade de processos atribuída ao modelo configura o caráter estocástico de suas simulações computacionais. Além disso, sendo um modelo estocástico, entende-se que o seu comportamento seja algo mais próximo do que seria observado em um sistema de produção real, dado que, por ser composto de linhas manuais, a variabilidade de processo é algo mais recorrente, mas com capacidade de ser melhor controlada por ser um ambiente de fábrica. A seguir, são apresentadas as informações relativas à lógica do modelo, principalmente com relação às variáveis incorporadas nele.

Além da programação básica que representa a sequência e o processamento das atividades de cada estação de trabalho, o modelo também foi alimentado com variáveis que foram utilizadas como parâmetros e medidas para comparação entre cenários. Como explicitado, todo o transporte dos módulos ao longo das linhas é feito 
pelas plataformas. Assim, houve a necessidade de não somente declarar e atribuir as plataformas como recursos de transporte, mas também determinar qual o melhor número desse recurso nas linhas e suas respectivas velocidades. Tais atributos das plataformas são classificados como variáveis independentes do modelo, no qual também se introduziu o WIP como variável independente. As variáveis dependentes no modelo são: Tempo de ciclo (C); Lead time; Tempos de espera e bloqueio; Eficiência do sistema (E).

Ainda dentro do contexto de lógica de funcionamento do modelo, destaca-se que ele foi programado a partir das premissas do Just-in-Time (JIT), com a associação do Kanban na programação das ordens de produção. Assim, algumas das variáveis anteriormente enumeradas também foram utilizadas para a programação do sistema JIT nos modelos. Junto a tais variáveis, também foram criados atributos, que são específicos da programação e assumem valores absolutos para cada cenário, necessários para o cálculo das variáveis dependentes. O cálculo dos tempos de ciclo, tempos de produção, WIP, etc. foi feito a partir da inserção dessas variáveis em determinadas linhas de comando do modelo, em associação com alguns comandos reservados ao ProModel $^{\circledR}$.

\section{Resultados}

\subsection{Unidade Habitacional em Light Steel Frame}

Foi projetada uma unidade habitacional composta pela união de quatro módulos de dimensões iguais, de acordo com as restrições técnicas e tecnológicas do sistema LSF. Com relação aos módulos, cada um possui dimensões que foram restringidas por dois fatores principais: transporte rodoviário e placas de vedação. Assim, para condições usuais de transporte rodoviário, uma das dimensões do módulo possui 2,60 m (largura) entre montantes externos, excluindo-se, portanto, as placas de vedações externas, acabamento e beiral. A segunda dimensão, embora mais livre, foi estabelecida em função da largura das placas de vedação (e suas juntas). Dessa forma, decidiu-se pelo uso de três placas e suas respectivas juntas, o que resultou em um comprimento de 3,59 m. Na Figura 1, pode ser analisada a planta da unidade habitacional.

Cada módulo possui uma estrutura independente, o que garante a sustentação de sua respectiva laje e cobertura sem a necessidade de estruturas especiais ou provisórias, de maneira que, uma vez concluídos, são apenas acoplados uns aos outros de acordo com o layout da arquitetura. A seguir, são apresentados alguns atributos mais específicos das unidades habitacionais e seus elementos.

A unidade projetada consiste em cinco cômodos divididos em quatro módulos de 9,42 m2 cada um, totalizando 37,66 $\mathrm{m}^{2}$ com o acabamento. O pé-direito de cada 
módulo alcança os 2,50 m, também considerando o acabamento no piso e laje. 0 beiral da casa possui 0,30 m e avança por todos os lados da edificação.

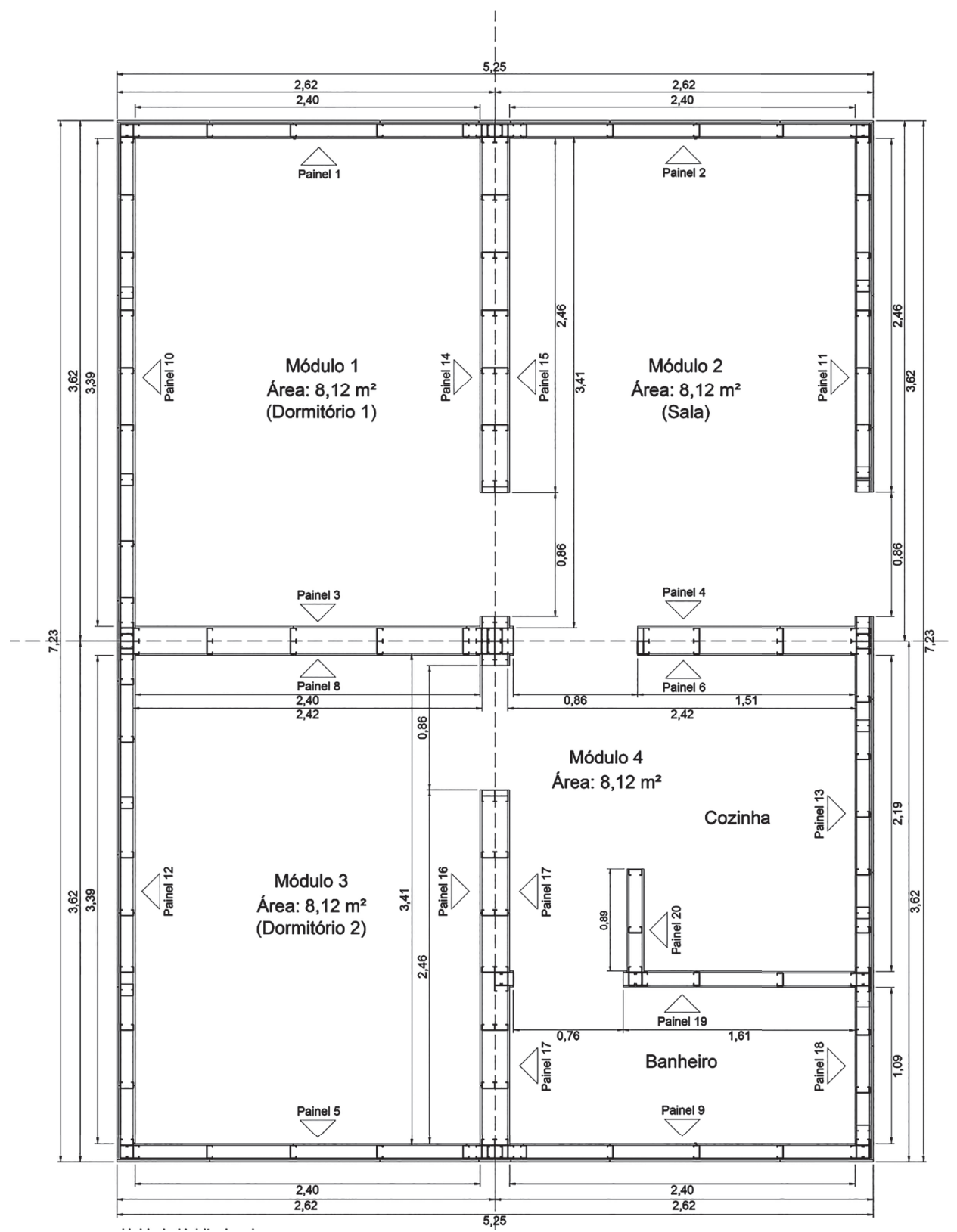

Figura 1 - Planta da unidade habitacional composta por quatro módulos. 
Com relação aos cômodos, os Módulos 1 e 3 representam os dois dormitórios da unidade. O Módulo 2 é destinado à sala de estar, comportando também a entrada da unidade. No Módulo 4, encontram-se um corredor de acesso, a cozinha e o banheiro, que contabilizam 1,93 $\mathrm{m}^{2}, 3,40 \mathrm{~m}^{2}$ e 2,52 $\mathrm{m}^{2}$ respectivamente. No que diz respeito à montagem final da unidade (acoplamento dos módulos), ela só é realizada quando os quatro módulos encontram-se em seu destino, que deve estar com as fundações concluídas.

A montagem de todos os elementos dos módulos obedece rigorosamente às características do LSF como sistema construtivo, tanto em termos de sequência de montagem quanto em termos de desempenho. Para melhor se adequar às características do sistema de produção, foi considerado o uso de kits (montados em células de produção) para instalações prediais, a exemplo do uso do PEX para instalações hidráulicas). Para os módulos 1, 2 e 3, o acabamento dos painéis é representado pelo uso de papel de parede previamente cortado, e o acabamento dos pisos é feito com laminado de madeira, cujas peças também são previamente cortadas. 0 módulo 4, por apresentar áreas molháveis, é revestido (nestas áreas) por vinil nas paredes e pisos. Externamente, todos os módulos são revestidos com siding vinílico fixado sobre a manta hidrofugante. As portas e janelas constituem kits e são fixadas com espuma de poliuretano nas aberturas correspondentes. Finalmente, a fixação de mata-juntas, rodapés e demais atividades de acabamento são executadas ainda com os módulos separados, restando as juntas externas e internas, oriundas do acoplamento entre os módulos, as quais são devidamente tratadas após a instalação final.

\subsection{O Sistema de Produção Proposto}

O sistema de produção é composto por uma linha de montagem principal em formato $U$, além de outras três linhas alimentadoras e células de produção. A linha principal, denominada Linha Alfa, foi concebida em formato $U$, com uma extensão linear de 385 m, composta por 15 estações de trabalho e 2 pontos de inspeção. Tal linha recebe elementos do LSF de 3 linhas alimentadoras: Linhas Beta e Gama, com 22 m, e linha Delta, com 62 m. As linhas alimentadoras são estruturadas por três estações de trabalho cada uma, com exceção da Linha Delta, que possui quatro estações. A estrutura destinada a receber as atividades de montagem é chamada de plataforma, a qual é transportada ao longo do tajeto por trilhos que seguem o curso das linhas. Por fim, há 10 células de produção que processam componentes para uso nas linhas alimentadoras e para uso na linha principal. O Quadro 1 mostra a atribuição de tarefas para a linha principal e as linhas alimentadoras, e o Quadro 2 indica as atividades atribuídas às células de produção.

Para a Linha Alfa, foi escolhido o formato $U$, pois, nesse arranjo, os operários podem ser colocados no centro do layout, possibilitando o monitoramento e auxílio 
mútuos sempre que necessário (REKIEK; DELCHAMBRE, 2006). Neste sentido, como afirma Miltenburg (2001a), o espaço central da linha torna-se uma área de troca de informações e aprendizado mútuo. Miltenburg (2001b) mostra que nesse formato, o fluxo de produção e a movimentação dos operadores podem ser atribuídos tanto no sentido horário quanto no anti-horário. Para essa configuração, o autor lembra o fato de haver um constante estoque de Work in Process (WIP) entre as estações de trabalho, o que também permite a visualização de desbalanceamentos.

Também foi considerado que todas as atividades das estações de trabalho devem ser desenvolvidas sobre plataformas de montagem com dimensões capazes de comportar a área ocupada por um módulo da unidade habitacional, alcançando uma altura que permita o trabalho dos operários. Para isso, configurou-se as plataformas com 4.40 metros de largura por 5.20 metros de comprimento. A distância adotada entre estações de trabalho, levando em conta as dimensões das plataformas, foi de 5.80 metros, sendo essa medida suficiente para abrigar 1 plataforma que fica em espera para entrar na estação seguinte.

Quadro 1 - Estações de trabalho e tarefas atribuídas.

\begin{tabular}{|l|l|}
\hline Estação & Descrição das Atividades \\
\hline I - Linha Principal Alfa \\
\hline Alfa 1 & $\begin{array}{l}\text { Alinhamento e preparo da plataforma; Montagem da estrutura do contrapiso e } \\
\text { vedaça inferior }\end{array}$ \\
\hline Alfa 2 & Instalação de kits hidráulicos \\
\hline Alfa 3 & Colocação de isolamento e de placas de substrato \\
\hline Alfa 4 & Fixação de painéis internos \\
\hline Alfa 5 & Fixação de painéis externos \\
\hline Alfa 6 & Fixação de laje e cobertura \\
\hline Alfa 7 & Verificação da estrutura do LSF \\
\hline Alfa 8 & Colocação de isolamento, fixação de OSB e membrana \\
\hline Alfa 9 & Fixar siding vinílico \\
\hline Alfa 10 & $\begin{array}{l}\text { Fixação de OSB e PVC nos beirais e fixação das telhas shingle; Fixação de portas e } \\
\text { janleas }\end{array}$ \\
\hline Alfa 11 & Revestimento na laje; Revestimento de paredes internas \\
\hline Alfa 12 & Revestimento na laje; Revestimento de paredes internas \\
\hline Alfa 13 & Revestimentos pisos \\
\hline Alfa 14 & Fixação de louças, metais e chuveiro \\
\hline Alfa 15 & Acabamentos interno e externo; Verificações finais de acabamento \\
\hline
\end{tabular}


Quadro 1 - Continuação.

\begin{tabular}{|l|l|}
\hline Estação & Descrição das Atividades \\
\hline II - Linhas Alimentadoras Beta, Gama e Delta \\
\hline Beta 1 & Posicionar guias e montantes; parafusar ambos os lados \\
\hline Beta 2 & Passar eletrodutos; colocação de isolamento; fixação do gesso acartonado \\
\hline Beta 3 & Tratamento de juntas entre placas \\
\hline Gama 1 & Posicionar guias e montantes; parafusar ambos os lados \\
\hline Gama 2 & Passar eletrodutos; colocação de isolamento; fixação do gesso acartonado \\
\hline Gama 3 & Tratamento de juntas entre placas \\
\hline Delta 1 & Posicionar vigas e sanefas; parafusar ambos os lados \\
\hline Delta 2 & Passar eletrodutos; colocação de isolamento; fixação do gesso acartonado \\
\hline Delta 3 & Tratamento de juntas entre placas \\
\hline Delta 4 & Fixação da cobertura \\
\hline
\end{tabular}

Quadro 2 - Células de produção.

\begin{tabular}{|l|l|}
\hline Célula & Atividade \\
\hline C-2 & $\begin{array}{l}\text { Processamento de tubos de conexões hidráulicas para esgotamento sanitário: } \\
\text { montagem dos kits; }\end{array}$ \\
\hline C-8 & $\begin{array}{l}\text { Processamento das mantas de isolamento, cortes nas placas OSB e cortes nas } \\
\text { membranas hidrofugantes; }\end{array}$ \\
\hline C-9 & Cortes e adequações nas placas de siding vinílico; \\
\hline C-10 & $\begin{array}{l}\text { Processamento do PVC para forro dos beirais e cortes para adequação das telhas } \\
\text { shingle; }\end{array}$ \\
\hline C11 & Cortes no revestimento para a laje; Cortes no papel de parede e vinil; \\
\hline C-13 & Cortes no piso laminado e no vinil; \\
\hline C-15 & Cortes e adequações em mata-juntas; \\
\hline C- $\beta 2$ & $\begin{array}{l}\text { Cortes e adequações nas chapas de gesso acartonado, eletrodutos, caixas de } \\
\text { passagem e kits hidráulicos; }\end{array}$ \\
\hline C- $\gamma 2$ & $\begin{array}{l}\text { Cortes e adequações nas chapas de gesso acartonado, eletrodutos, caixas de } \\
\text { passagem e kits hidráulicos; }\end{array}$ \\
\hline C- 84 & Montagem de tesouras, fixação de OSB nas tesouras. \\
\hline
\end{tabular}

Com relação ao fluxo das linhas, para fins de simulação, sugeriu-se a adoção do sistema chamado cart-on-track por não exigir altos níveis de automação e por permitir que o próprio operário controle a movimentação. Tompkins e White (1984) mostram que o mecanismo desse sistema baseia o percurso e a plataforma em um 
tubo rotativo. O funcionamento é relativamente simples e pode ser descrito da seguinte forma, conforme Aized (2010): a plataforma é engatada nos trilhos sendo movimentada pelo tubo rotativo, no qual está conectada uma roda de acionamento que pode ser rotacionada em ângulos que variam de 0 até 45o; assim, variando-se o ângulo, obtêm-se velocidades diferentes. A Figura 2 ilustra esse sistema. Dessa forma Tompkins e White (1984) mostram que as plataformas podem ser controladas de maneira independente, permitindo a alocação de várias plataformas no percurso. Isso é possível porque as plataformas podem ficar paradas quando a roda de acionamento estiver paralela ao tubo rotativo.

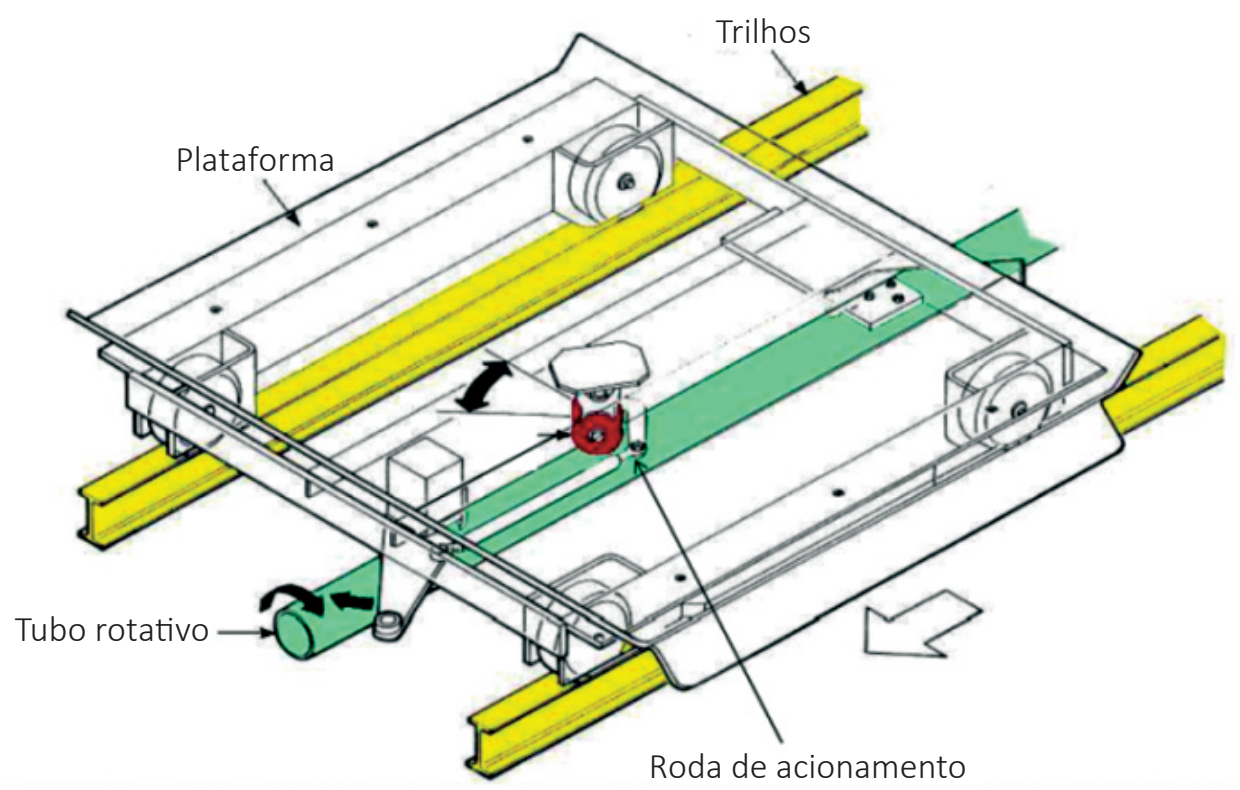

Figura 2 - Sistema cart-on-track. Fonte: Adaptado de Aized, 2010.

Ao longo das linhas, há alguns pontos em que existe a necessidade de mudança de direção das plataformas em função do layout do sistema e em função do retorno das plataformas. Nesse caso, foram considerados pontos de mudança aqueles em que os trilhos são rotacionados, a fim de que se alinhem em direção ao novo percurso. Esse mecanismo, conhecido como round track, é estruturado nos próprios trilhos das linhas de montagem e permitem as mudanças de direção necessárias quando não é possível ou viável o uso de esteiras. Assim, na Figura 3, é mostrado o layout do sistema proposto, com as orientações de fluxo e demais considerações necessárias para o funcionamento. 


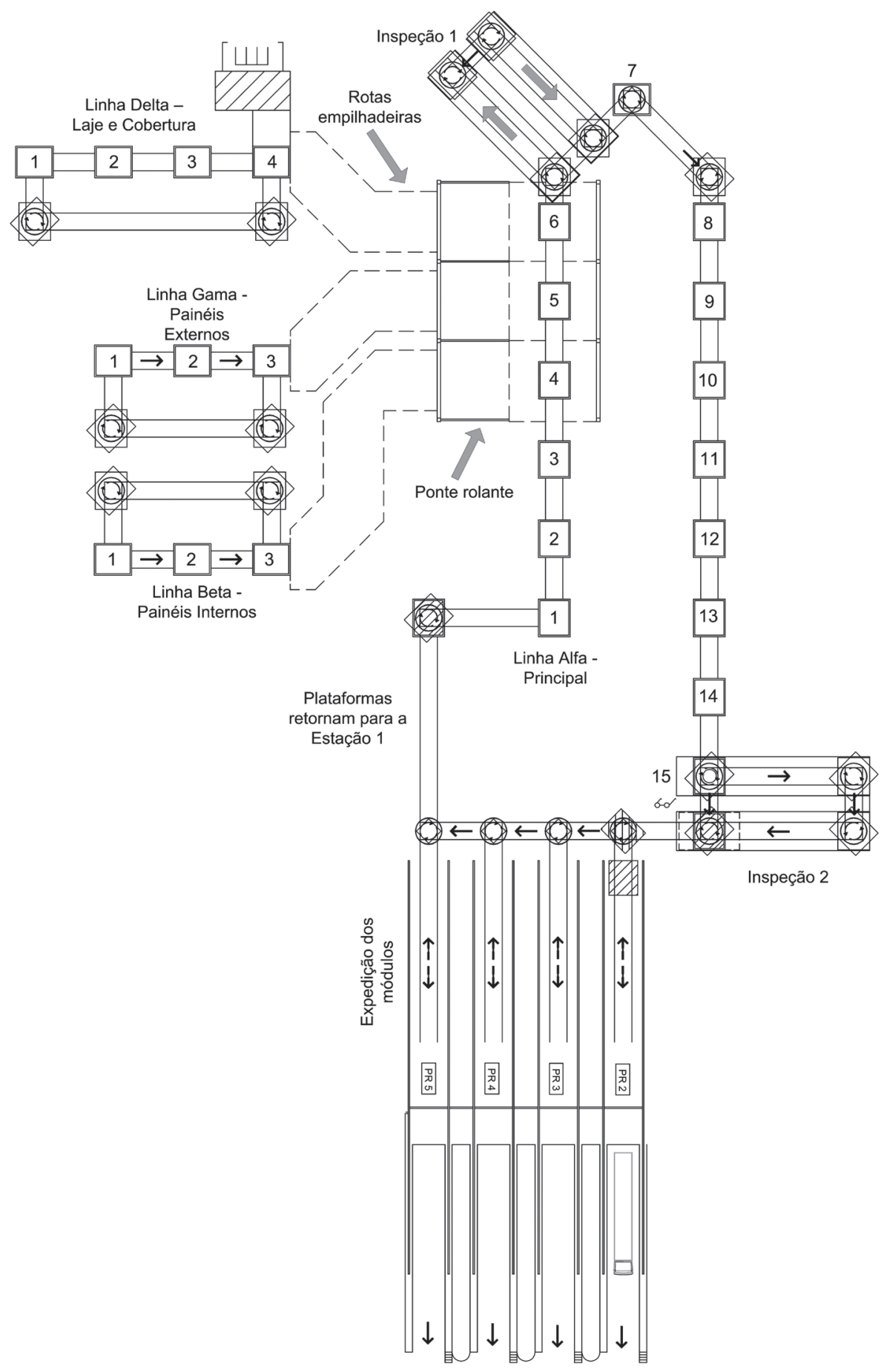

Figura 3 - Sistema de produção. 
Cada estação de trabalho desempenha atividades para o processamento de diferentes elementos e/ou componentes. Portanto, os tempos de processamento de cada estação variam de acordo com a sua finalidade, as ferramentas e/ou máquinas que estão sendo utilizadas e com a quantidade de operários que desempenham essas atividades. Os tempos de cada tarefa foram calculados com base em índices de produtividade da construção para o sistema LSF e na coleta de dados em obras residenciais que utilizaram tal sistema construtivo. Cabe destacar que algumas condições foram pré-estabelecidas para o cálculo dos tempos, sendo elas:

- Todas as atividades obedecem à sequência de montagem, determinada pelo projeto da montagem de cada elemento do módulo;

- Para cada estação, os movimentos são desempenhados por um montador e um ajudante;

- Nos locais onde há supermercados de componentes ou elementos grandes, montador e ajudante deslocam-se para carregar e transportar tais peças, impactando no valor final do tempo;

- Nos locais onde há supermercados de componentes pequenos, apenas o ajudante desloca-se para carregar e transportar, não impactando no valor final do tempo;

- Todas as peças e componentes nos supermercados estão dispostas no chão, exigindo que os operários se abaixem para carregar;

- As atividades de parafusamento são todas realizadas com parafusadeira elétrica ao alcance dos operários.

Assim, para a linha principal, os tempos de processamento dos módulos em cada estação de trabalho estão atribuídos na Tabela 1, bem como as equipes alocadas.

Tabela 1 - Tempos de processamento na linha principal e equipes alocadas.

\begin{tabular}{llllll}
\hline Estação & $\begin{array}{l}\text { Equipe } \\
\text { (operários) }\end{array}$ & $\begin{array}{l}\text { Módulo 1 } \\
(\mathrm{min})\end{array}$ & $\begin{array}{l}\text { Módulo 2 } \\
(\mathrm{min})\end{array}$ & $\begin{array}{l}\text { Módulo 3 } \\
(\mathrm{min})\end{array}$ & $\begin{array}{l}\text { Módulo 4 } \\
(\mathrm{min})\end{array}$ \\
\hline Alfa 1 & 2 & 33.0 & 33.0 & 33.0 & 33.0 \\
\hline Alfa 2 & 2 & 0 & 0 & 0 & 22.0 \\
\hline Alfa 3 & 2 & 26.0 & 26.0 & 26.0 & 26.0 \\
\hline Alfa 4 & 2 & 7.0 & 7.0 & 7.0 & 12.0 \\
\hline Alfa 5 & 2 & 7.0 & 7.0 & 7.0 & 7.5 \\
\hline Alfa 6 & 2 & 12.0 & 12.0 & 12.0 & 12.0 \\
\hline
\end{tabular}


Tabela 1 - Continuação.

\begin{tabular}{llllll}
\hline Estação & $\begin{array}{l}\text { Equipe } \\
\text { (operários) }\end{array}$ & $\begin{array}{l}\text { Módulo 1 } \\
(\mathrm{min})\end{array}$ & $\begin{array}{l}\text { Módulo 2 } \\
(\mathrm{min})\end{array}$ & $\begin{array}{l}\text { Módulo 3 } \\
(\mathrm{min})\end{array}$ & $\begin{array}{l}\text { Módulo 4 } \\
(\mathrm{min})\end{array}$ \\
\hline Inspeção & 1 & 5.0 & 5.0 & 5.0 & 5.0 \\
\hline Alfa 7 & 2 & 18.5 & 18.5 & 18.5 & 25.0 \\
\hline Alfa 8 & 4 & 21.5 & 21.5 & 21.5 & 21.5 \\
\hline Alfa 9 & 4 & 31.5 & 31.5 & 31.5 & 31.5 \\
\hline Alfa 10 & 4 & 30.4 & 30.4 & 30.4 & 30.4 \\
\hline Alfa 11 & 6 & 20.65 & 20.65 & 20.65 & 24.25 \\
\hline Alfa 12 & 6 & 20.65 & 20.65 & 20.65 & 24.25 \\
\hline Alfa 13 & 2 & 35.0 & 35.0 & 35.0 & 35.0 \\
\hline Alfa 14 & 2 & 0 & 0 & 0 & 30.0 \\
\hline Alfa 15 & 5 & 35.0 & 35.0 & 35.0 & 40.0 \\
Inspeção final & & & & & \\
\hline
\end{tabular}

Para as linhas alimentadoras, os tempos de processamento dos elementos podem ser visualizados na Tabela 2. Todas as estações das linhas alimentadoras possuem 2 operários alocados.

Tabela 2 - Tempos de processamento nas linhas alimentadoras.

\begin{tabular}{lllll}
\hline Elemento & \multicolumn{4}{l}{ Estações e tempos associados (minutos) } \\
\hline Painel interno 3 & $\beta 1(3.2)$ & $\beta 2(12.9)$ & $\beta 3(12.9)$ & - \\
\hline Painel interno 14 & $\beta 1(7.4)$ & $\beta 2(15.3)$ & $\beta 3(15.3)$ & - \\
\hline Painel externo 1 & $\gamma 1(4.6)$ & $\gamma 2(12.9)$ & $\gamma 3(12.9)$ & - \\
\hline Painel externo 10 & $\gamma 1(7.8)$ & $\gamma 2(15.3)$ & $\gamma 3(15.3)$ & - \\
\hline Laje e cobertura 1 & $\delta 1(12.4)$ & $\delta 2(17.0)$ & $\delta 3(17.0)$ & $\delta 4(24.8)$ \\
\hline Painel interno 4 & $\beta 1(5.7)$ & $\beta 2(12.9)$ & $\beta 3(12.9)$ & - \\
\hline Painel interno 15 & $\beta 1(8.2)$ & $\beta 2(15.3)$ & $\beta 3(15.3)$ & - \\
\hline Painel externo 2 & $\gamma 1(4.6)$ & $\gamma 2(12.9)$ & $\gamma 3(12.9)$ & - \\
\hline Painel externo 11 & $\gamma 1(9.0)$ & $\gamma 2(15.3)$ & $\gamma 3(15.3)$ & - \\
\hline Laje e cobertura 2 & $\delta 1(12.4)$ & $\delta 2(17.0)$ & $\delta 3(17.0)$ & $\delta 4(24.8)$ \\
\hline Painel interno 8 & $\beta 1(3.2)$ & $\beta 2(12.9)$ & $\beta 3(12.9)$ & - \\
\hline Painel interno 16 & $\beta 1(7.4)$ & $\beta 2(15.3)$ & $\beta 3(15.3)$ & - \\
\hline
\end{tabular}


Tabela 2 - Continuação.

\begin{tabular}{lllll}
\hline Elemento & \multicolumn{4}{l}{ Estações e tempos associados (minutos) } \\
\hline Painel externo 5 & $\gamma$ 1 (4.6) & $\gamma$ 2 (12.9) & $\gamma 3(12.9)$ & - \\
\hline Painel externo 12 & $\gamma 1(7.8)$ & $\gamma 2(15.3)$ & $\gamma 3(15.3)$ & - \\
\hline Laje e cobertura 3 & $\delta 1(12.4)$ & $\delta 2(17.0)$ & $\delta 3(17.0)$ & $\delta 4(24.8)$ \\
\hline Painel interno 6 & $\beta 1(5.7)$ & $\beta 2(12.9)$ & $\beta 3(12.9)$ & - \\
\hline Painel interno 17 & $\beta 1(7.4)$ & $\beta 2(15.3)$ & $\beta 3(15.3)$ & - \\
\hline Painel interno 19 & $\beta 1(5.7)$ & $\beta 2(12.9)$ & $\beta 3(12.9)$ & - \\
\hline Painel externo 9 & $\gamma 1(4.6)$ & $\gamma 2(12.9)$ & $\gamma 3(12.9)$ & - \\
\hline Painel externo 13 & $\gamma 1(6.1)$ & $\gamma 2(10.4)$ & $\gamma 3(10.4)$ & - \\
\hline Painel externo 18 & $\gamma$ 1 (2.7) & $\gamma 2(4.55)$ & $\gamma 3(4.55)$ & - \\
\hline Painel externo 20 & $\gamma$ 1 (1.5) & $\gamma 2(4.15)$ & $\gamma 3(4.15)$ & - \\
\hline Laje e cobertura 4 & $\delta 1(12.4)$ & $\delta 2(17.0)$ & $\delta 3(17.0)$ & $\delta 4(24.8)$ \\
\hline
\end{tabular}

\subsection{Simulação Computacional}

Assim, com as variáveis do modelo devidamente configuradas, foi iniciada a simulação computacional. A seguir, são apresentados os resultados dessa simulação com os resultados dos tempos de ciclo médios, lead time médio e níveis máximos de trabalho em progresso, organizados na Tabela 3.

Tabela 3 - Tempos de ciclo dos módulos e da unidade habitacional.

\begin{tabular}{llll}
\hline Produto & Tempo de ciclo médio & Lead time médio & WIP máximo \\
\hline Módulo 1 & $242.27 \mathrm{~min}$ & $121.59 \mathrm{~min}$ & 7 \\
\hline Módulo 2 & $242.36 \mathrm{~min}$ & $121.68 \mathrm{~min}$ & 7 \\
\hline Módulo 3 & $242.46 \mathrm{~min}$ & $121.79 \mathrm{~min}$ & 7 \\
\hline Módulo 4 & $242.65 \mathrm{~min}$ & $122.00 \mathrm{~min}$ & 7 \\
\hline Unidade habitacional & $242.65 \mathrm{~min}$ & $487.06 \mathrm{~min}$ & - \\
\hline
\end{tabular}

Analisando os resultados da Tabela 3 nota-se que o tempo de ciclo da unidade habitacional é de $242.65 \mathrm{~min}$. e o lead time médio é de $487.06 \mathrm{~min}$., que em horas representa, respectivamente, 4.04 horas e 8.12 horas, ou seja, uma unidade habitacional completa leva pouco mais de 8 horas para ficar pronta, sendo o sistema capaz de entregar uma unidade a cada 4 horas. Já o WIP teve um valor registrado de 7 unidades para cada módulo, o qual é controlado pelo sistema Just-in-Time programado 
no modelo simulado. No que diz respeito ao desempenho das estações de trabalho, na Tabela 4 estão as porcentagens relativas ao comportamento das estações da linha principal e das linhas alimentadoras.

Tabela 4 - Estado das estações de trabalho.

\begin{tabular}{lllll}
\hline Estações & \% Operação & \% Ociosa & \% Espera & \% Bloqueada \\
\hline Alfa 1 & 56,57 & 2,07 & & 41,36 \\
\hline Alfa 2 & 8,49 & 2,05 & & 89,46 \\
\hline Alfa 3 & 45,02 & 1,28 & & 53,69 \\
\hline Alfa 4 & 14,18 & 1,17 & 31,05 & 53,6 \\
\hline Alfa 5 & 12,15 & 1,18 & 28,08 & 58,6 \\
\hline Alfa 6 & 20,46 & 1,12 & 12,41 & 66,01 \\
\hline Alfa 7 & 35,09 & 0,92 & & 64 \\
\hline Alfa 8 & 36,96 & 0,69 & & 62,35 \\
\hline Alfa 9 & 52,71 & 0,54 & & 46,74 \\
\hline Alfa 10 & 99,59 & 0,41 & & \\
\hline Alfa 11 & 68,53 & 31,47 & & \\
\hline Alfa 12 & 68,6 & 31,4 & & \\
\hline Alfa 13 & 56,87 & 43,13 & & 0,15 \\
\hline Alfa 14 & 13,03 & 86,82 & & 56,35 \\
\hline Alfa 15 & 61,74 & 38,19 & 0,07 & 59,19 \\
\hline MÉDIA & 43,33 & 16,16 & 7,96 & 59,08 \\
\hline Beta 1 & 23,56 & 8,19 & & 38,24 \\
\hline Beta 2 & 55,6 & 5,63 & & 38,77 \\
\hline Beta 3 & 55,34 & 6,66 & & 38,71 \\
\hline MÉDIA & 44,83 & 6,83 & 0,00 & \\
\hline Gama 1 & 22,19 & 6,51 & & 48,34 \\
\hline Gama 2 & 48,02 & 5,82 & & \\
\hline Gama 3 & 48,19 & 6,12 & & \\
\hline MÉDIA & 39,47 & 6,15 & & \\
\hline Delta 1 & 21,25 & 12,4 & & \\
\hline Delta 2 & 28,93 & 11,88 & \\
\hline Delta 3 & 29,11 & 11,81 & & \\
\hline Delta 4 & 42,07 & 11,71 & & \\
\hline Média & 30,34 & 11,95 & & \\
\hline & & & & \\
\hline
\end{tabular}


Pela Tabela 4, nota-se que as estações de trabalho passam grande parte do tempo ocupadas, desempenhando as tarefas necessárias para a conclusão dos produtos. Com os resultados apresentados, pode-se calcular a eficiência do sistema de produção. O cálculo da eficiência da linha pode ser feito pelo uso da Equação 1:

$$
E=\frac{W C}{M \times C}
$$

O uso dessa equação depende, portanto, do conteúdo de trabalho (WC), número de estações de trabalho (M) e tempo de ciclo (C). De acordo com a soma dos valores dos tempos de processamento médios para os quatro módulos, o WC é identificado pelo valor de 1.550,40 min. Já o valor de M é de 15 estações de trabalho (tendo em vista que as alimentadoras não participam diretamente do processamento dos módulos, atuando apenas como fornecedoras de componentes), e o tempo de ciclo (C) é de 242.65 min. Assim, a eficiência do sistema é de (Equação 2):

$$
E=\frac{1550.40}{15 \times 242.65}=0.4259=42.59 \%
$$

Os resultados dessa simulação mostram que é possível entregar habitações de qualidade em poucas horas, sendo necessário, para isso, a promoção da inovação tecnológica como atributo essencial. O sistema proposto foi capaz de entregar uma casa a cada 4 horas, quantidade que, em termos de índices correntes na construção civil, representa algo muito difícil de ser obtido, tendo em vista as atuais condições de produção.

Além disso, os desperdícios, quando comparados ao de sistemas tradicionais de construção, são drasticamente reduzidos. Por ser um sistema fabril, o desperdício de materiais é menor e possui um nível de controle mais favorável do que num canteiro de obras, por exemplo. Destaca-se que, em termos de desperdício, o sistema proposto apresenta uma de suas maiores vantagens em face dos métodos tradicionais, tendo em vista que as denominadas atividades de fluxo são reduzidas e controladas de acordo com a demanda do sistema.

\section{Conclusões}

A contribuição dos resultados deste estudo, tanto no âmbito acadêmico quanto prático, pode ser identificada em dois pontos principais. O primeiro deles é a definição de um layout de produção específico para unidades habitacionais em LSF, fato pouco explorado na literatura e com resultados inexpressivos sob o ponto de vista do conceito de linhas de montagem. O segundo refere-se ao resultado da simulação computacional, que permitiu o estudo do comportamento do sistema de produção e, 
consequentemente, a compreensão da relação de causa e efeito entre as variáveis dos modelos, garantindo a sintonia entre os elementos do sistema.

Considera-se que os resultados apresentados são de importância para o avanço da construção civil. O desenvolvimento do layout e os resultados apresentados pelas simulações mostram que é perfeitamente possível implementar meios de produção mais eficazes e que não fazem parte da rotina da construção na maioria dos países. Associado a isso, o sistema construtivo LSF corrobora para o aumento da qualidade das edificações, tendo em vista as características de industrialização de seus componentes. Além disso, os ciclos de produção obtidos (pouco mais de 4 horas) representam um prazo de entrega incomum nas atuais condições da construção civil brasileira. A rapidez de entrega e montagem das casas mostram que é possível entregar habitações com qualidade em pouco tempo e com baixa utilização de recursos, em termos comparativos com os tradicionais canteiros de obras.

Nesse sentido, é necessário destacar a contribuição deste estudo para a redução do déficit habitacional no país. A rapidez de entrega das casas, associado à qualidade que o sistema LSF pode garantir, além do baixo uso de recursos, mostram que as políticas adotadas pelo poder público são, geralmente, ineficazes, pois não contemplam a inovação tecnológica na construção. Pelo contrário, incentivam o uso das velhas técnicas de construção. Como demonstrado, seria possível reduzir o déficit habitacional apenas com algumas mudanças que garantem tanto melhores condições de trabalho para os operários quanto melhores níveis de qualidade para as casas que são entregues.

Outro ponto de relevância a ser destacado diz respeito à flexibilidade do sistema de produção proposto. Apesar das simulações terem sido executadas para a montagem de módulos que formam uma unidade habitacional, o sistema de produção também poderia ser utilizado apenas para a montagem de painéis, por exemplo, o que resultaria em tempos de ciclo mais baixos ainda. Outra opção seria a mudança do sistema construtivo. Tendo em vista que o sistema de produção é essencialmente manual, o LSF pode ser substituído pelo Wood Frame, sem grandes adaptações, uma vez que os dois sistemas são semelhantes.

Ainda com relação à flexibilidade do sistema, outro ponto a ser destacado diz respeito aos modelos que podem ser montados. A princípio, qualquer modelo pode ser entregue pelo sistema de produção, desde que as questões relativas à modulação e requisitos do sistema construtivo sejam obedecidas. Nesse sentido, é possível entregar uma grande variedade de modelos que podem abranger diferentes tipos de mercado, levando-se em conta que cada modelo implica em tempos de ciclo e lead time diferentes.

Finalmente, o desempenho do modelo pode ser encarado como realístico, tendo em vista que os tempos de processamento foram obtidos a partir de medições 
em obras e da análise da literatura, associado ao fato de terem sido atribuídas variações a tais tempos. Além disso, os tempos atribuídos nas estações de trabalho podem ser efetivamente reduzidos, dado que o fator de aprendizagem e a experiência das equipes influenciam diretamente no comportamento das estações. Assim, a variação dos tempos programada nos modelos pode ser significativamente reduzida, e os tempos padrão de processamento podem, também, ser reduzidos, mesmo não havendo automação das atividades.

\section{Referências}

AIZED, T. In: Future Manufacturing Systems. Tauseef Aized (Ed.). p. 121-137. Intech. 2010. BACHEGA, S.J. Simulação de sistemas de coordenação de ordens em ambiente de produção flow shop. Tese. Programa de Pós-Graduação em Engenharia de Produção. UFSCar. São Carlos. 2013.

BAUTISTA, J.; PEREIRA, J. Ant algorithms for a time and space constrained assembly line balancing problem. European Journal of Operational Research. 177. p. 2016-2032. 2007.

BERTELSEN, S.; HENRICH, G.; KOSKELA, L.; ROOKE, J. Construction physics. Proceedings of the 15th Annual Conference of the International Group for Lean Construction. 2008.

GOMES, M.L.B. Um modelo de nivelamento da produção à demanda para a indústria de confecções do vestuário segundo os novos paradigmas da melhoria de fluxos de processos. Tese (Doutorado em Engenharia de Produção) - Programa de Pós-Graduação em Engenharia de Produção - Universidade Federal de Santa Catarina. Florianópolis - SC, 2002.

HAMMAD, A.A. Simulation modeling for manufactured housing processes. Master's Thesis, University of Cincinnati, Cincinnati, OH. 2002.

KOSKELA, L. An exploration towards a production theory and its application to construction. VTT Technical Research Centre of Finland. 2000.

KOSKELA, L. Application of the new production philosophy to construction.Stanford, EUA, CIFE, Technical Report, n. 72. 1992.

KOSKELA, L. Lean construction as a movement towards theory-based construction management. Salford Centre for Research and Innovation (SCRI). International Symposium, Salford, UK. 2004.

KOSKELA, L.; VRIJHOEF, R. Is the current theory of construction a hindrance to innovation? Building Research and Information, v. 29. 2001.

LANE, G. Made-to-order Lean: Excelling in a High-mix, Low-volume Environment. Productivity Press, 2007.

LEE, A.; ENGLIN, J. Using a model and empirical data to analyze manufactured home conservation retrofits. Energy and Buildings, v. 13, n. 1, p. 73-83, 1989. 
MEHROTRA, N.; SYAL, M.; HASTAK, M. Manufactured housing production process and layout design. Bridges, v. 10, n. 40671, p. 43, 2003.

MEHROTRA, M.; SYAL, M.; HASTAK, M. Manufactured housing production layout design. Journal of Architectural Engineering, v. 11, n.1, p.25-34. 2005.

MILTENBURG, J. One-piece flow manufacturing on U-shaped production lines: a tutorial. IIE Transactions, v. 33, n. 4, pp. 303-321. 2001b.

MILTENBURG, J. U-shaped production lines: a review of theory and practice. International Journal of Production Economics, v. 70, n. 3, p. 201-214. 2001 a.

REKIEK, B.; DELCHAMBRE, A. Assembly line design: the balancing of mixed-model hybrid assembly lines with genetic algorithms. Springer Series in Advanced Manufacturing. UK. 2006.

TOMPKINS, J.A.; WHITE, J.A. Facilities planning. New York: John Wiley, 1984.

TUBINO, D.F. Sistemas de produção no chão de fábrica. Porto Alegre: Bookman, 1999. 


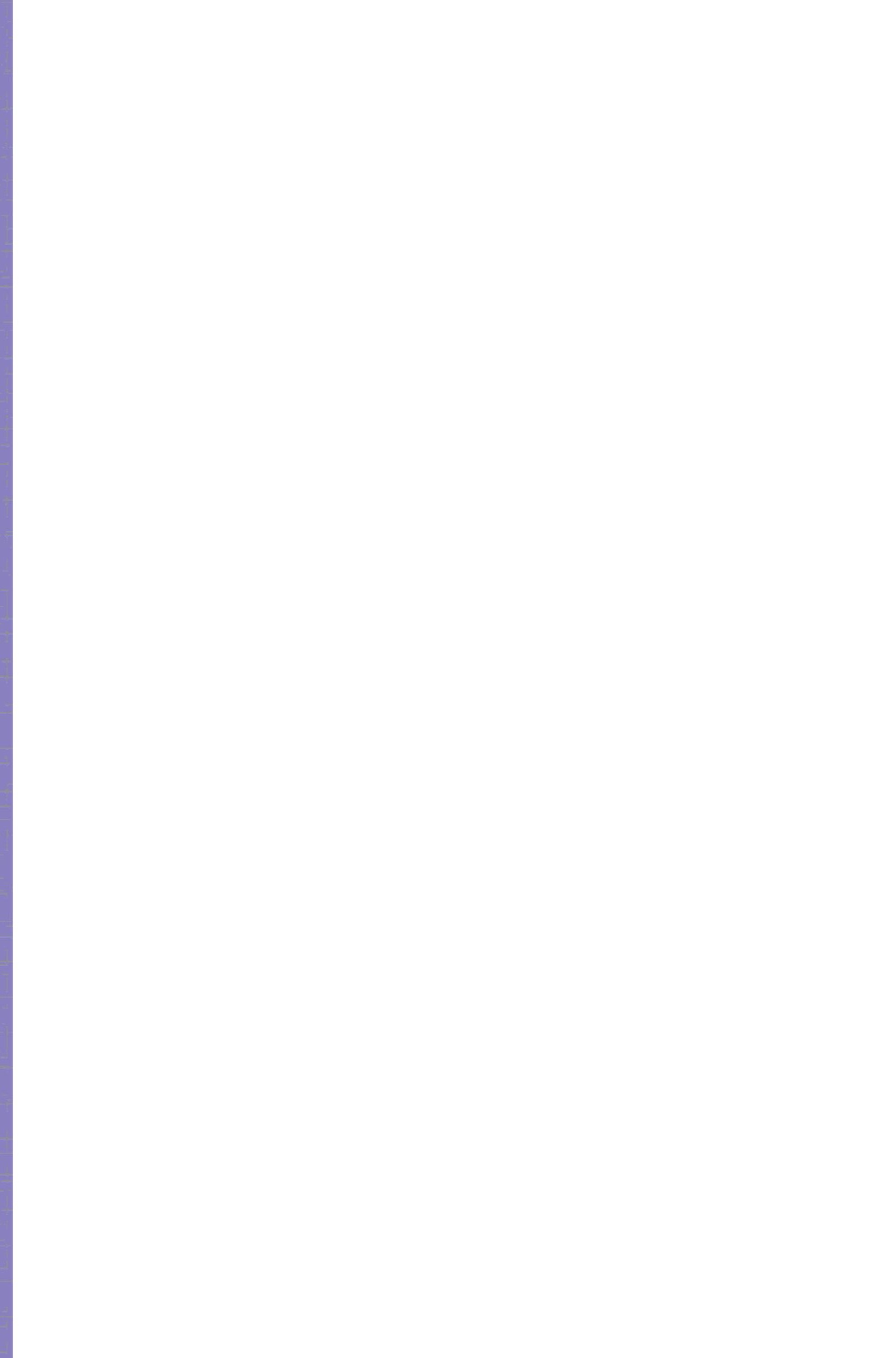




\title{
Avaliação do Processo de Revestimento com Argamassa Projetada: Aspectos Econômicos e Ambientais
}

\author{
Cristina Toca Pérez \\ Dayana Bastos Costa \\ Jardel Pereira Gonçalves
}

\section{Introdução}

Entre os sistemas de revestimento disponíveis no mercado brasileiro, o sistema com uso de argamassa é o mais utilizado (PARAVISI, 2008). Esse tipo de revestimento pode ser constituído de mais de uma camada, sendo denominadas de emboço e reboco, ou pode possuir apenas uma camada, chamada de massa única (PARAVISI, 2008).

No intuito de melhorar o desempenho dos processos, o mercado da indústria da construção civil vem implantado inovações tecnológicas, como o sistema de revestimento por meio de argamassas projetadas (CRESCENCIO et al., 2000). No entanto, poucos são os estudos que têm avaliado os impactos dos sistemas de execução de revestimentos com argamassa projetada, principalmente do ponto de vista econômico e ambiental.

O objetivo principal do presente capítulo é apresentar os resultados de uma pesquisa que visa avaliar o processo de revestimento com argamassa projetada do ponto de vista de seus aspectos econômicos e ambientais, a partir de quatro estudos 
de caso realizados na região metropolitana de Salvador. Para tanto, foi definido um conjunto de indicadores que orientaram tal avaliação de desempenho e, finalmente é feita uma comparação entre os estudos.

\section{Sistema de Revestimento com Argamassa por Projeção}

O sistema de projeção mecânica trata-se da aplicação de argamassa por meio de equipamentos de projeção em uma superfície a ser protegida ou recuperada, com espessura média variável de 3 a $5 \mathrm{~cm}$. Duas classificações podem ser utilizadas para categorizar o sistema de revestimento com argamassa por projeção, quais sejam: (a) segundo a forma de projeção; e (b) segundo a mobilidade da argamassa no canteiro (PARAVISI, 2008).

O sistema de revestimento classificado segundo a forma de projeção pode ser divido em contínuo ou descontínuo. O processo contínuo é realizado por meio de bombas que aplicam a argamassa no substrato sem interrupções no processo, desde que haja uma alimentação constante. As bombas de projeção convencionais são exemplos de processo contínuo. O processo descontínuo é realizado por projetores a ar comprimido, nos quais a argamassa é colocada diretamente em um recipiente, havendo uma quebra do processo de aplicação (CRESCENCIO et al., 2000; PARAVISI, 2008). O projetor por spray a ar comprimido (canequinha) é um exemplo de processo descontínuo.

Quanto à classificação segundo a mobilidade da argamassa, tem-se a subdivisão em sistemas estacionários e móveis. No primeiro, há a utilização de silos que distribuem a argamassa por via seca ou por via úmida até o local de aplicação. No transporte por via seca, o silo é pressurizado e, acoplado a ele, existe um compressor responsável por bombear a mistura seca até o local de aplicação, onde será adicionada água. No transporte por via úmida, a mistura de água ocorre no misturador abaixo do silo, produzindo a argamassa. O sistema móvel utiliza argamassa ensacada e, junto com o equipamento de mistura (misturador e bomba), são transportados entre os pavimentos nos quais será realizada a projeção (CRESCENCIO et al., 2000; PARAVISI, 2008).

\section{Indicadores para Avaliação do Sistema de Revestimento com Argamassa por Projeção}

A presente seção apresenta um conjunto de indicadores econômicos e ambientais que podem ser usados para avaliar o processo de execução de revestimentos com argamassa ou outros processos construtivos. 


\subsection{Avaliação Econômica}

A seguir, serão discutidos os indicadores para avaliação econômica.

\subsection{1 Índices de Produtividade}

Para mensuração da produtividade, dois índices podem ser utilizados, quais sejam: Razão Unitária de Produção (RUP) e Porcentagem de Tempo Produtivo (PTP).

A RUP é representada pela razão entre entradas (homens-hora demandados) e saídas (quantidade de serviço executado), conforme proposto por Souza e Mekbekian (2006). Um dos indicadores possíveis de serem levantados é a RUP cumulativa, que, segundo Souza e Mekbekian (2006), deve ser calculada por meio da razão entre os somatórios dos homens-hora demandados e das quantidades de serviço produzidas diariamente, durante todo o período de estudo (Equação 1).

$$
\mathrm{RUP}_{\mathrm{c}}=\frac{\sum \mathrm{Hh}}{\sum \mathrm{QS}}
$$

Onde:

RUPC = Razão Unitária de Produção cumulativa $\left(\mathrm{Hh} / \mathrm{m}^{2}\right)$;

$\Sigma \mathrm{Hh}=$ Somatório dos homens-hora demandados ao final do período de estudo (Hh);

$\Sigma Q S=$ Somatório da quantidade de serviço realizada ao final do estudo $\left(\mathrm{m}^{2}\right)$.

O PTP representa a porcentagem de tempo total do processo destinado a atividades que agregam valor ao produto (SANTOS; FORMOSO; HINKS, 1996). No processo de revestimento de argamassa por projeção, tais atividades são realizadas pela equipe direta, ou seja, trabalhadores envolvidos diretamente com o processo. Esse indicador pode ser calculado por meio da técnica de Amostragem do Trabalho (OLIVEIRA et al., 1995), que será discutida no item 4. Esse indicador é calculado a partir da Equação 2, conforme a seguir.

$$
\mathrm{PTP}=\frac{\mathrm{OP} \times 100}{\mathrm{OT}}
$$

Onde:

PTP =Porcentagem de Tempos Produtivos em atividades que agregam valor (\%);

$\mathrm{OP}=$ Número de observações identificadas na realização de atividades produtivas pela equipe direta;

OT = Número total de observações realizadas durante as atividades da equipe direta. 


\subsection{2 Índice de Perdas por Variação de Espessura}

A variação percentual de espessura média em relação à especificada em projeto tem o objetivo de medir as perdas de argamassa devido à espessura do revestimento, as quais são causadas pela falta de esquadro e de prumo das estruturas e alvenarias (PALLIARI et al., 2001). Para o cálculo desse indicador são realizadas medições em 30\% das taliscas de todas as superfícies a serem revestidas e utiliza-se a Equação 3.

$$
\operatorname{Var}_{\text {espessura }}(\%)=\left[\left(\mathrm{e}_{\text {média }}-\mathrm{e}_{\text {projeto }}\right)-1\right] \times 100
$$

Onde:

Var. $_{\text {espessura }}^{=}$Variação da espessura média em relação à especificada em projeto (\%);

$\mathrm{e}_{\text {média }}=$ espessura média $(\mathrm{cm})$;

$\mathrm{e}_{\text {projeto }}=$ espessura de projeto $(\mathrm{cm})$.

O cálculo do Indicador de Perdas por Variação de Espessura (Pvar. esp. ) é realizado a partir da fórmula expressada na Equação 4, que, por sua vez, é uma adaptação da fórmula proposta por Costa (2005).

$$
\text { Pvar. }_{\text {esp. }}=\frac{\mathrm{CR}-\mathrm{CP}}{\mathrm{CP}}
$$

Onde:

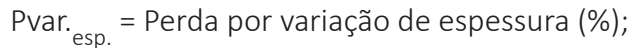

$C R=$ Consumo real necessário $\left(e_{\text {média }} \times\right.$ área produzida $)\left(\mathrm{m}^{3}\right)$;

$C P=$ Consumo previsto segundo a espessura de projeto $\left(e_{\text {projeto }} \times\right.$ área produzida $)\left(\mathrm{m}^{3}\right)$.

\subsubsection{Indicador de Perdas por Transporte}

As perdas por transporte podem ser definidas como todas as atividades de movimentação de materiais que geram custo e que não adicionam valor (PÉREZ; COSTA, GONÇALVES, 2016). Para o cálculo das perdas por transporte, foi adotado o indicador Percentual do Tempo Total destinado em Atividades de Transporte (PTAT), proposto por Pérez et al. (2016).

O PTAT objetiva identificar o tempo total destinado a atividades de transporte (necessárias, evitáveis e desnecessárias) em relação ao tempo total gasto pela equipe direta, a partir da Equação 5.

$$
\text { PTAT }=\frac{\text { OTAT }}{\text { OT }}
$$


Onde:

PTAT = Percentual do Tempo total destinado em Atividades de Transporte (\%);

OTAT = Número total de observações realizadas sobre a equipe direta executando Atividades de Transporte;

OT = Número total de observações realizadas durante as atividades da equipe direta.

\subsection{Avaliação Ambiental}

A seguir, serão discutidos os indicadores para avaliação ambiental.

\subsubsection{Nível de Pressão Sonora}

Para lida (2005), fisicamente, o ruído é uma mistura de vibrações, medidas em uma escala logarítmica, em uma unidade chamada decibel (dB). Acima do limiar da percepção dolorosa, pode produzir danos ao aparelho auditivo. O indicador Nível de Pressão Sonora (NPS) determina a intensidade do sonido que gera uma pressão sonora instantânea. Para a coleta deste indicador, duas medidas são realizadas. A primeira delas é feita junto aos equipamentos de mistura em funcionamento, e a outra, no local de projeção. A NR-15 - Atividades e operações insalubres (BRASIL, 2014) determina os seguintes valores para um determinado período de tempo:

- $\mathrm{L}_{\text {máximo }}=$ Valor máximo de NPS alcançado durante o estudo (dBA);

- $\mathrm{L}_{\text {mínimo }}=$ Valor mínimo $(\mathrm{dBA})$.

A classificação dos riscos de ruído estabelecidos pela NR-15 - Atividades e operações insalubres (BRASIL, 2014) é apresentada a seguir:

- Risco grave e iminente - NPS acima de $115 \mathrm{~dB}(\mathrm{~A})$;

- Risco grave - NPS acima de $100 \mathrm{~dB}(\mathrm{~A})$ e abaixo de $115 \mathrm{~dB}(\mathrm{~A})$;

- Risco médio - NPS entre 85 dB(A) e $100 \mathrm{~dB}(\mathrm{~A})$;

- Risco leve - NPS acima de $80 \mathrm{~dB}(\mathrm{~A})$ e abaixo de $85 \mathrm{~dB}(\mathrm{~A})$.

\subsubsection{Consumo de Água na Projeção}

Para estudar o consumo de água na produção de argamassas, fez-se necessário analisar o consumo de água por metro cúbico de argamassa produzido em central (SILVA; VIOLIN, 2013). Neste sentido, para o cálculo do consumo de água total no processo de revestimento com argamassa projetada é levado em conta o consumo de água para a elaboração do traço da mistura e o consumo de água para a limpeza dos equipamentos, conforme a Equação 6. 


$$
A=\frac{A_{\text {traço }}+A_{\text {equipamento }}}{V_{\text {real }}}
$$

Onde:

A = Água total consumida na projeção $\left(\mathrm{m}^{3} / \mathrm{m}^{3}\right)$;

$A_{\text {traço }}=$ Água consumida no traço $\left(\mathrm{m}^{3}\right)$;

$\mathrm{A}_{\text {equipamento }}=$ Água consumida na lavagem dos equipamentos $\left(\mathrm{m}^{3}\right)$;

$V_{\text {real }}=$ Volume de argamassa produzida $\left(\mathrm{m}^{3}\right)$.

É importante ressaltar que o valor de água gasto no traço da argamassa é variável com o fator A/Arg (água versus argamassa), podendo ser considerada a quantidade de água recomendada pelo fabricante da argamassa industrializada para a elaboração da mistura. Assim, o consumo de água no traço é o produto entre a constante dada pelo fabricante e a quantidade de argamassa utilizada, conforme Equação 7.

$$
A_{\text {traço }}=C_{\text {traço }} \times Q_{\text {argamassa }}
$$

(Equação 7)

Onde:

$\mathrm{A}_{\text {traço }}=$ Água consumida no traço $\left(\mathrm{m}^{3}\right)$;

$C_{\text {traço }}=8,5$ litros de água para cada $50 \mathrm{Kg}$ de argamassa $=\left(0,00017 \mathrm{~m}^{3} / \mathrm{kg}\right)$;

$\mathrm{Q}_{\text {argamassa }}=$ Quantidade de argamassa utilizada $(\mathrm{kg})$.

Para o cálculo da água consumida na lavagem dos equipamentos, pode-se levar em consideração as leituras dos hidrômetros antes e depois da projeção, descontado o consumo de água no traço, conforme a Equação 8.

$$
A_{\text {equipamento }}=\left[\left(L_{f}-L_{i}\right)\right]-A_{\text {traço }}
$$

Onde:

$\mathrm{A}_{\text {equipamento }}=$ Água consumida na lavagem dos equipamentos $\left(\mathrm{m}^{3}\right)$.

$\mathrm{L}_{\mathrm{f}}=$ Leitura final do hidrómetro $\left(\mathrm{m}^{3}\right)$;

$\mathrm{L}_{\mathrm{i}}=$ Leitura inicial $\left(\mathrm{m}^{3}\right)$;

$\mathrm{A}_{\text {traço }}=$ Água consumida no traço $\left(\mathrm{m}^{3}\right)$.

\subsubsection{Consumo de Energia Elétrica do Sistema de Projeção (E)}

O consumo de energia elétrica leva em consideração a potência dos equipamentos envolvidos no processo (argamassadeira e bomba de ar comprimido), bem como o tempo de funcionamento deles, conforme a Equação 9.

$$
E=\frac{P \times d}{V_{\text {real }}}
$$


Onde:

$E=$ Energia consumida pelos equipamentos $\left(\mathrm{Kwh} / \mathrm{m}^{3}\right)$.

$\mathrm{P}=$ Potência do equipamento $(\mathrm{W})$;

$d$ = Duração do equipamento em funcionamento (h);

$\mathrm{V}_{\text {real }}=$ Volume de argamassa produzida $\left(\mathrm{m}^{3}\right)$.

\section{Método de Pesquisa}

Este trabalho foi desenvolvido por meio de quatro estudos de caso na Região Metropolitana de Salvador, na Bahia, no período de setembro de 2012 até setembro de 2014. Cada estudo de caso foi desenvolvido em quatro etapas, conforme apresentado no Quadro 1.

Quadro 1 - Períodos e Etapas dos Estudos de Caso.

\begin{tabular}{|l|l|l|l|l|}
\hline Etapas da pesquisa & Estudo A & Estudo B & Estudo C & Estudo D \\
\hline $\begin{array}{l}\text { Seminário de } \\
\text { apresentação }\end{array}$ & $15 / 09 / 2012$ & $11 / 03 / 2013$ & $04 / 06 / 2013$ & $30 / 04 / 2014$ \\
\hline $\begin{array}{l}\text { Identificação dos } \\
\text { fluxos físicos }\end{array}$ & $16 / 09 / 2012$ & $12 / 03 / 2013$ & $\begin{array}{l}06 / 05 a \\
12 / 05 / 2013\end{array}$ & $\begin{array}{l}06 / 05 a \\
12 / 05 / 2014\end{array}$ \\
\hline $\begin{array}{l}\text { Coleta dos } \\
\text { indicadores }\end{array}$ & $\begin{array}{l}17 / 09 \text { a } \\
06 / 12 / 2012\end{array}$ & $\begin{array}{l}13 / 05 a \\
12 / 04 / 2013\end{array}$ & $\begin{array}{l}13 / 05 a \\
17 / 07 / 2013\end{array}$ & $\begin{array}{l}13 / 05 \\
17 / 07 / 2014\end{array}$ \\
\hline Avaliação do estudo & $\begin{array}{l}07 / 12 / 12 \text { a } \\
01 / 02 / 2013\end{array}$ & $\begin{array}{l}13 / 04 a \\
01 / 05 / 2013\end{array}$ & $\begin{array}{l}18 / 07 \text { a } \\
30 / 07 / 2013\end{array}$ & $\begin{array}{l}18 / 09 \text { a } \\
05 / 09 / 2014\end{array}$ \\
\hline
\end{tabular}

A primeira etapa consistiu na realização de um seminário no canteiro de obra de cada estudo, visando explicar aos engenheiros e estagiários quais seriam as atividades realizadas durante as visitas a campo, assim como a designação das atribuições tanto da equipe de pesquisa como da equipe de obra. A segunda etapa correspondeu à identificação dos fluxos físicos a partir do mapeamento de todas as atividades de fluxo de materiais e mão de obra. A terceira etapa consistiu na coleta de indicadores, conforme Quadro 2. É importante mencionar que a coleta de indicadores em cada obra foi diferenciada, devido aos objetivos estabelecidos para cada estudo. Os estudos A, B e C tiveram como foco uma análise mais geral sobre o processo de revestimento de argamassa por projeção, abordando aspectos econômicos e ambientais. O estudo D focou na avaliação desse sistema construtivo, do ponto de vista das perdas por transporte, como parte da dissertação de mestrado de Pérez (2015). A última etapa envolveu a avaliação final do estudo e a comparação entre os casos quando possível. 
Quadro 2 - Indicadores coletados em cada estudo.

\begin{tabular}{|l|l|l|l|l|l|l|l|l|}
\hline & \multicolumn{3}{|l|}{ Aspectos Econômicos } & \multicolumn{3}{l|}{ Aspectos Ambientais } \\
\cline { 2 - 9 } & $\begin{array}{l}\text { Índices de } \\
\text { Produtividade }\end{array}$ & $\begin{array}{l}\text { Índice de Perdas } \\
\text { por Variação } \\
\text { Espessura }\end{array}$ & $\begin{array}{l}\text { Índices de } \\
\text { Perdas por } \\
\text { transporte }\end{array}$ & $\begin{array}{l}\text { Nível de } \\
\text { Pressão } \\
\text { Sonora }\end{array}$ & $\begin{array}{l}\text { Consumo } \\
\text { de água }\end{array}$ & $\begin{array}{l}\text { Consumo } \\
\text { de energia }\end{array}$ \\
\cline { 2 - 9 } & RUP & PTP & Pvar. ${ }_{\text {esp. }}$ & PTAT & NPS & A & E \\
\hline Estudo A & $X$ & - & $X$ & - & $X$ & $X$ & $X$ \\
\hline Estudo B & $X$ & - & $X$ & - & $X$ & - & - \\
\hline Estudo C & $X$ & - & - & - & $X$ & - & - \\
\hline Estudo D & - & $X$ & - & $X$ & - & - & - \\
\hline
\end{tabular}

O Quadro 3 resume as principais características dos casos e da coleta geral de dados, destacando-se os períodos de coleta, a descrição dos empreendimentos e a descrição dos processos de revestimento com argamassa estudados. Neste trabalho, foi considerado revestimento à base de argamassa, tanto o sistema emboço/reboco como o de massa única.

Quadro 3 - Características dos Estudos de Caso.

\begin{tabular}{|l|l|l|l|}
\hline & $\begin{array}{l}\text { Caraterização da } \\
\text { coleta }\end{array}$ & $\begin{array}{l}\text { Descrição do } \\
\text { Empreendimento }\end{array}$ & $\begin{array}{l}\text { Descrição do Processo de } \\
\text { revestimento com argamassa }\end{array}$ \\
\hline Estudo A & $\begin{array}{l}10 \text { semanas } \\
32 \text { visitas de 2-3h }\end{array}$ & $\begin{array}{l}\text { Residencial alto padrão } \\
1 \text { torre de } 20 \text { andares }\end{array}$ & $\begin{array}{l}\text { Revestimento Interno } \\
\text { Projeção estacionária por via } \\
\text { úmida }\end{array}$ \\
\hline Estudo B & $\begin{array}{l}5 \text { semanas } \\
17 \text { visitas de 3-4h }\end{array}$ & $\begin{array}{l}\text { Empresarial } \\
\text { 2 torres de 23 e 15 andares }\end{array}$ & $\begin{array}{l}\text { Revestimento Externo sem } \\
\text { vãos } \\
\text { Projeção estacionária por via } \\
\text { úmida }\end{array}$ \\
\hline Estudo C & $\begin{array}{l}6 \text { semanas } \\
25 \text { visitas de 3-4h }\end{array}$ & $\begin{array}{l}\text { Residencial alto padrão } \\
\text { torres de 28 andares }\end{array}$ & $\begin{array}{l}\text { Revestimento Externo com } \\
\text { vãos } \\
\text { Projeção móvel }\end{array}$ \\
\hline Estudo D & $\begin{array}{l}13 \text { semanas } \\
32 \text { visitas de 4-6h }\end{array}$ & $\begin{array}{l}\text { Residencial alto padrão } \\
8 \text { torres de 16 andares }\end{array}$ & $\begin{array}{l}\text { Revestimento Interno } \\
\text { Projeção móvel }\end{array}$ \\
\hline
\end{tabular}

\subsection{Coleta de Dados}

Para a coleta e o registro das informações, foram utilizadas ferramentas e técnicas, envolvendo tanto a obtenção de dados qualitativos como quantitativos. Além 
disso, foram utilizados como fontes de evidências a análise de documentos, observação direta, anotações de campo, entrevistas e percepções das pessoas envolvidas e documentação fotográfica.

A seguir, são apresentadas as principais ferramentas, técnicas e instrumento utilizados para a coleta dos indicadores.

\subsubsection{Planilha de Controle da Produtividade}

Essa ferramenta foi utilizada para monitorar a produtividade dos operários, por meio de medições de quantidades produzidas e homem-horas gastas em ciclos de produção bem definidos. Os dados dessa ferramenta permitiram calcular a Razão Unitária de Produção (RUPc).

\subsubsection{Amostragem do Trabalho}

Essa técnica permite determinar como o operário utiliza seu tempo, o qual é dividido em tempos produtivos, auxiliares (transporte necessários, transportes auxiliares e outras atividades auxiliares) e improdutivos (transporte desnecessários e outras atividades improdutivas) (PÉREZ et al. 2016). A partir do uso dessa técnica, foi possível o cálculo dos indicadores Porcentagem de Tempo Produtivo (PTP) e Percentual do Tempo total destinado em Atividades de Transporte (PTAT).

\subsubsection{Planilha para o Controle de Argamassa}

Foi utilizado o método proposto por Costa (2005) para o controle da argamassa produzida. Tal método permitiu o controle diário das quantidades de argamassa que eram utilizadas no revestimento. Essas medidas eram obtidas com o apoio dos trabalhadores da central de argamassa. A partir do uso dessa ferramenta, foi possível o cálculo da Quantidade de argamassa utilizada (Qargamassa).

\subsubsection{Planilha para o Controle de Água}

Foi desenvolvida uma planilha para controlar a água incorporada na mistura e na limpeza dos equipamentos. Nessa planilha, eram anotadas as leituras dos hidrômetros antes e depois da projeção. A partir do uso dessa ferramenta junto com a Quantidade de argamassa utilizada ( $\mathrm{kg}$ ), foi possível calcular o Indicador Consumo de água na projeção (A). 


\subsubsection{Planilha para o Controle de Energia}

Foi criada uma fol ha de cálculo para controlar a energia gasta pelos equipamentos. Nessa planilha, era anotado o tempo total que os equipamentos permaneciam em funcionamento. A partir do uso dessa ferramenta junto com a Qargamassa, foi possível calcular o Indicador Consumo de Energia (E).

\subsubsection{Decibelímetro}

O Medidor de Nível de Pressão Sonora (MNPS), também chamado de decibelímetro, é um instrumento utilizado para realizar a medição dos NPS, e, consequentemente, intensidade de sons, já que o NPS é uma grandeza que representa razoavelmente bem a sensação auditiva de volume sonoro, quando ponderada. Esse equipamento é normalmente calibrado para ler o nível de som em decibéis (uma unidade logarítmica) (RODRIGUES et al., 2009). Dessa forma, tal equipamento permitiu, nesta pesquisa, coletar o Indicador Nível de Pressão Sonora (NPS).

O Quadro 4 apresenta um resumo dos instrumentos, técnicas e ferramentas utilizadas para a coleta dos indicadores utilizados no presente trabalho.

Quadro 4 - Instrumentos, Técnicas e Ferramentas utilizadas para a coleta dos indicadores.

\begin{tabular}{|l|l|}
\hline Indicador & Instrumentos, técnicas e ferramentas utilizadas \\
\hline Índices de produtividade & $\begin{array}{l}\text { Planilha para o controle da produtividade } \\
\text { Amostragem do trabalho }\end{array}$ \\
\hline Índice de perdas por variação de espessura & Planilha para o controle das espessuras \\
\hline Índice de perdas por transporte & Amostragem do trabalho \\
\hline Nível de pressão sonora & Decibelímetro \\
\hline Consumo de água & $\begin{array}{l}\text { Planilha para o controle de água } \\
\text { Planilha para o controle de argamassa }\end{array}$ \\
\hline Consumo de energia & $\begin{array}{l}\text { Planilha para o controle de energia } \\
\text { Planilha para o controle de argamassa }\end{array}$ \\
\hline
\end{tabular}

\section{Avaliação do Processo de Revestimento de Argamassa}

A seguir, são apresentados os resultados da análise econômica e ambiental do processo de revestimento com argamassa projetada para os estudos realizados nesta pesquisa. 


\subsection{Avaliação Econômica}

\subsubsection{Indicadores de Produtividade (RUPc e PTP)}

Os resultados do indicador de produtividade Razão Unitária de Produção Cumulativa (RUPc) nos Estudos A, B e C devem considerar as variáveis existentes em cada processo, as quais levaram aos resultados registrados, tais como configuração da equipe, tipo de sistema utilizado, tipo de transporte utilizado para a movimentação dos funcionários, dificuldades construtivas, entre outros, conforme apresentado no Quadro 5. Denominou-se, neste trabalho, equipe de produção de argamassa os funcionários encarregados das funções de dosagem e projeção da argamassa. Foram considerados pedreiros aqueles que realizavam apenas as funções de acabamento, como sarrafamento e desempeno.

Quadro 5 - Informações para o cálculo do Indicador RUPc nos Estudos A, B e C.

\begin{tabular}{|l|l|l|l|}
\hline & Estudo A & Estudo B & Estudo C \\
\hline Tipo de revestimento & Interno & $\begin{array}{l}\text { Externo sem } \\
\text { vãos }\end{array}$ & $\begin{array}{l}\text { Externo com } \\
\text { vãos }\end{array}$ \\
\hline Tipo de projeção & $\begin{array}{l}\text { Projeção } \\
\text { estacionária por } \\
\text { via úmida }\end{array}$ & $\begin{array}{l}\text { Projeção } \\
\text { estacionária por } \\
\text { via úmida }\end{array}$ & Projeção móvel \\
\hline $\begin{array}{l}\text { Equipamento de transporte para a } \\
\text { movimentação dos funcionarios }\end{array}$ & - & $\begin{array}{l}\text { Plataformas } \\
\text { aéreas }\end{array}$ & $\begin{array}{l}\text { Balancim } \\
\text { suspenso } \\
\text { mecanizado }\end{array}$ \\
\hline $\begin{array}{l}\text { Relação pedreiros: serventes: equipe } \\
\text { de produção de argamassa }\end{array}$ & $12: 3: 3$ & $8: 3: 3$ & $4: 2: 3$ \\
\hline RUPc pedreiro $\left(H \mathrm{~h} / \mathrm{m}^{2}\right)$ & 0,45 & 1,26 & 0,76 \\
\hline RUPc servente $\left(\mathrm{Hh}^{2} \mathrm{~m}^{2}\right)$ & 0,11 & 0,50 & 0,43 \\
\hline $\begin{array}{l}\text { RUPc equipe de produção de } \\
\left.\text { argamassa (Hh/m }{ }^{2}\right)\end{array}$ & 0,67 & 0,33 & 0,46 \\
\hline
\end{tabular}

Como pode ser observado no Quadro 5, os valores encontrados apresentaram uma variação entre 0,11 e 1,26 Hh/m². Comparando-se as RUPc, observa-se que o Estudo B apresentou o menor RUPc para a equipe de produção de argamassa $\left(0,33 \mathrm{Hh} / \mathrm{m}^{2}\right)$ entre os três estudos realizados. Porém, esse mesmo estudo apresentou o maior RUPc dos pedreiros $\left(1,26 \mathrm{Hh} / \mathrm{m}^{2}\right)$. Essa defasagem entre as equipes de produção e pedreiros pode ser explicada devido à reduzida frente de trabalho encontrada no canteiro, fato que propiciava à equipe de produção projetar uma grande área em apenas 2 horas de trabalho, ficando ociosa o restante do tempo (Figura 1). 
Entre os fatores que contribuíram para a maior produtividade dos pedreiros no Estudo $\mathrm{A}\left(0,45 \mathrm{Hh} / \mathrm{m}^{2}\right)$, dentre os três estudos, destaca-se a facilidade de movimentação dos trabalhadores, por se tratar do revestimento interno, assim como o tamanho da equipe, formada por 12 pedreiros (Figura 2), que conseguiu acompanhar a grande capacidade do equipamento de projeção.

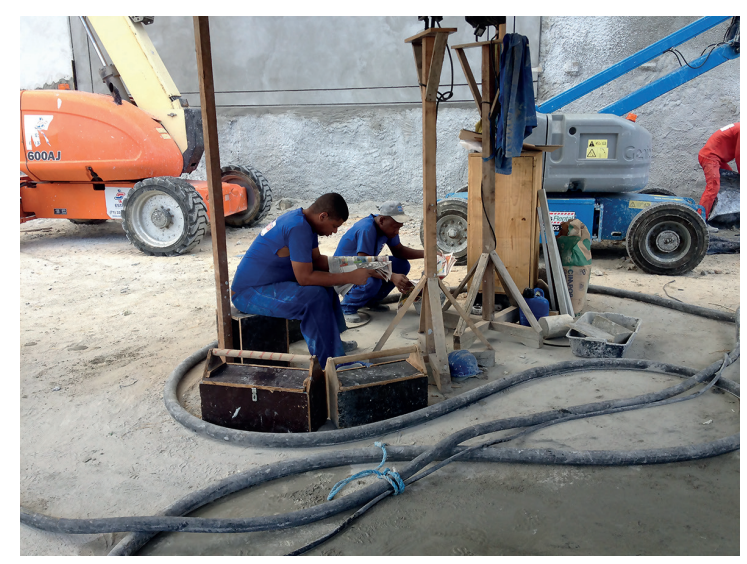

Figura 1 - Equipe de produção de argamassa do Estudo B ociosa. Fonte: Autores.

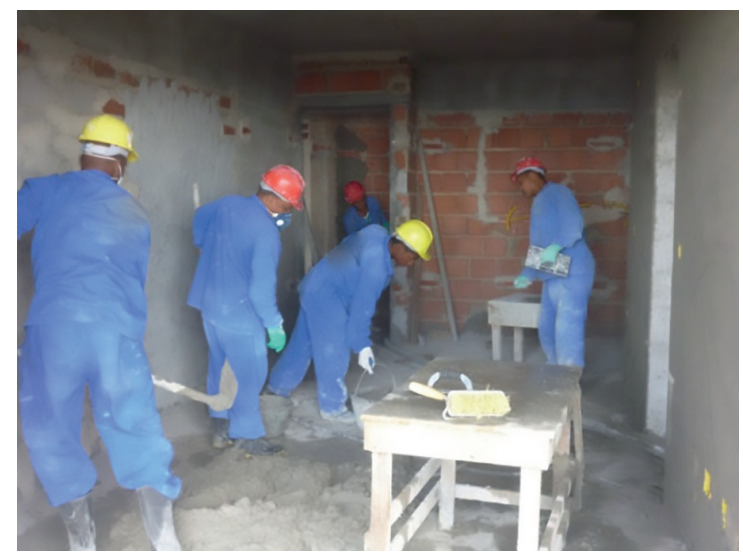

Figura 2 - Cinco funcionários trabalhando num único ambiente no Estudo A. Fonte: Autores.

Os dados da amostragem de trabalho para o cálculo do indicador PTP coletado no Estudo D foram comparados aos dados do estudo de Paravisi (2008), por ter sido o único estudo a calcular este indicador (Figura 3). 


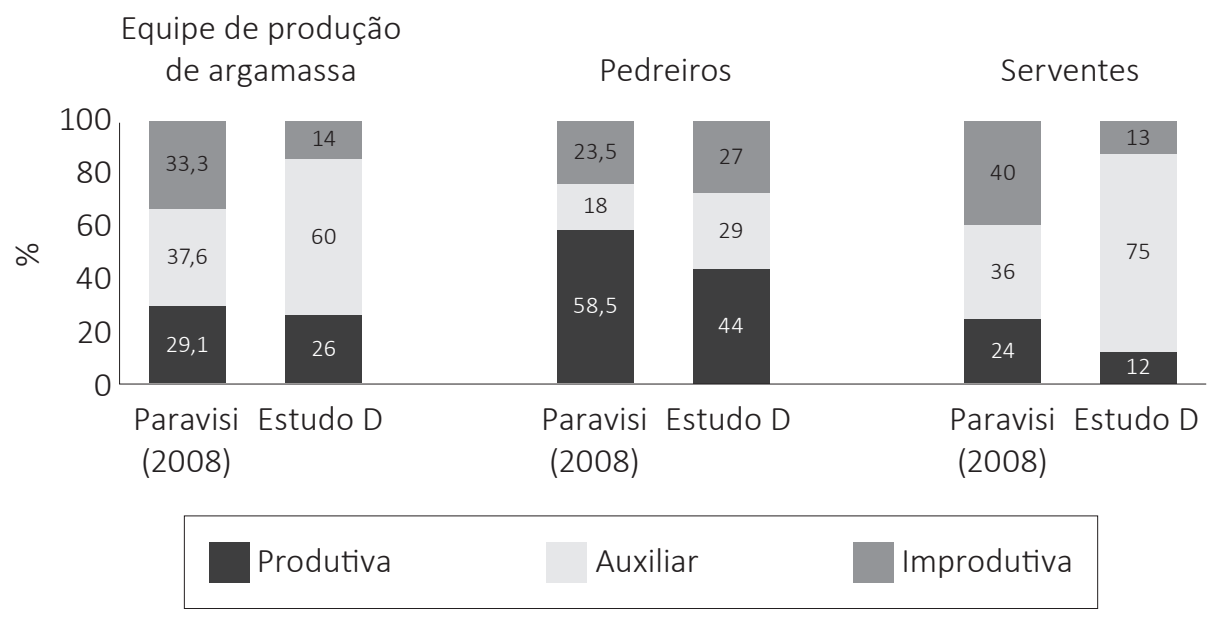

Figura 3 - Comparativo amostragem do trabalho no Estudo D com Paravisi (2008).

Observa-se, pela amostragem do trabalho, que a Porcentagem de Tempo Produtivo (PTP) da equipe de produção de argamassa foi de $26 \%$. Ao se separar os indicadores por função, no entanto, constata-se, no estudo $D$, que a produtividade da equipe de pedreiros foi de $44 \%$ e da equipe de serventes $12 \%$. Percebeu-se, no Estudo $D$, que as atividades de sarrafamento realizadas pelos pedreiros não acompanhavam o ritmo da projeção, embora os pedreiros dessa atividade apresentassem grandes tempos produtivos.

\subsubsection{Perdas por Variação de Espessura}

Nos Estudos A e B, foi calculado o Índice de Perdas por Variação de Espessura (Pvar. esp.), conforme apresentado no Quadro 6.

Quadro 6 - Indicadores utilizados para o cálculo da Pvar. esp.

\begin{tabular}{|l|l|l|l|l|l|l|}
\hline & $\begin{array}{l}\mathrm{e}_{\text {projeto }} \\
(\mathrm{cm})\end{array}$ & $\begin{array}{l}\mathrm{e}_{\text {média }} \\
(\mathrm{cm})\end{array}$ & $\begin{array}{l}\text { No de } \\
\text { amostras }\end{array}$ & $\begin{array}{l}\text { Área produzida } \\
\left(\mathrm{m}^{2}\right)\end{array}$ & $\begin{array}{l}\mathrm{CP} \\
\left(\mathrm{m}^{3}\right)\end{array}$ & $\mathrm{CR}\left(\mathrm{m}^{3}\right)$ \\
\hline Estudo A & 2,5 & 2,7 & 2131 & $16.653,16$ & 416,33 & 449,64 \\
\hline Estudo B & 2,0 & 3,0 & 50 & 1099,90 & 32,99 & 49,49 \\
\hline
\end{tabular}

A partir do Quadro 6, pode-se observar que em ambos estudos a espessura média executada ultrapassou o valor do projeto, de modo que a Variação da espessura (Var. espessura) foi de $8 \%$ para o Estudo A e de 50\% para o Estudo B. Em consequência, o Pvar. esp. foi de $8 \%$ para o Estudo A e de 50\% para o Estudo B. O alto valor encontrado de 
Pvar. esp. no Estudo B pode ser devido, entre outros fatores, à menor representatividade das amostras coletadas, em virtude da dificuldade de coletar tais amostras por se tratar de revestimento de fachada. Outro fator influenciador pode ter sido a falta de esquadro e de prumo das estruturas e alvenarias, propiciando a necessidade de incorporação de mais argamassa, conforme pode ser observado na Figura 4. No Estudo $B$, foi inclusive necessária a instalação de tela de PVC para garantir a aderência entre camadas, conforme indicado pela NBR 13749 (ABNT, 1996), nas áreas com espessuras maiores a 4,0 cm (Figura 5).

Comparando os resultados encontrados com trabalhos prévios, destaca-se que Paliari et al. (1999) encontrou perda por sobre-espessura dos revestimentos com argamassa de $82 \%$ e Costa (2005), de $21 \%$.

Analisando a distribuição das espessuras (Figura 6) dentro dos intervalos de valores mínimos e máximos nos Estudos $A$ e B, observa-se que $61,0 \%$ das espessuras do Estudo A e $30 \%$ das espessuras do Estudo B estão no intervalo de 2,0 a 3,0 cm, medidas recomendadas pela norma NBR 13749 (ABNT, 1996). No entanto, há espessuras com valores muito acima de 4,00 cm, observadas em $9 \%$ dos valores para o Estudo A e 22,5\% para o Estudo B. Estas espessuras requerem especial atenção por contribuir com as perdas e por deixar o revestimento vulnerável a falhas futuras, principalmente com um maior risco de descolamento, situação que foi identificada em várias ocasiões no Estudo B (Figura 7).

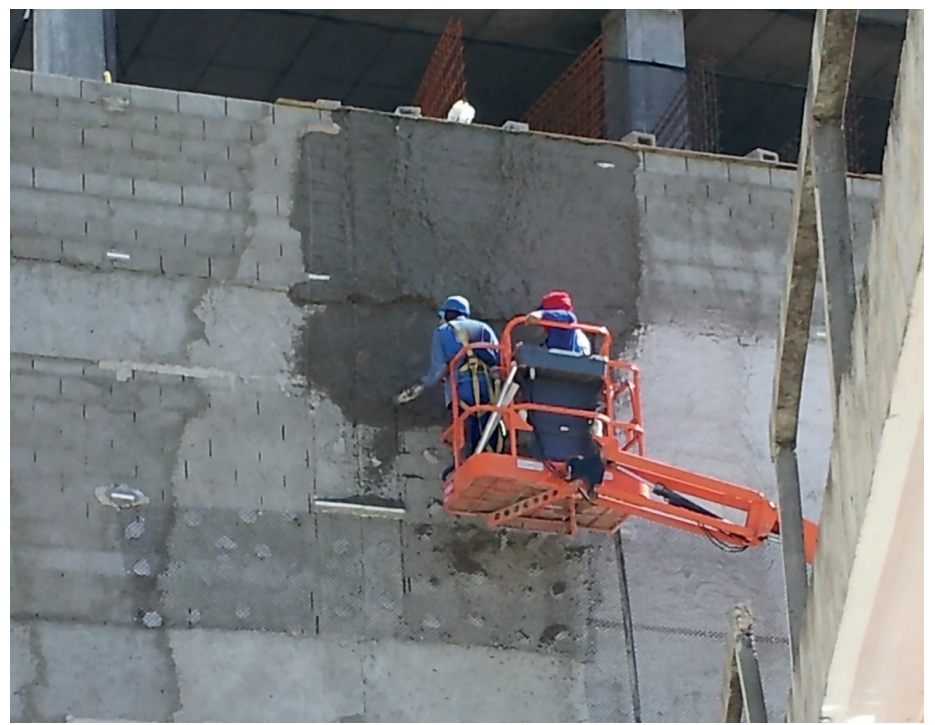

Figura 4 - Falta de esquadro entre a alvenaria e a estrutura. Fonte: Autores. 


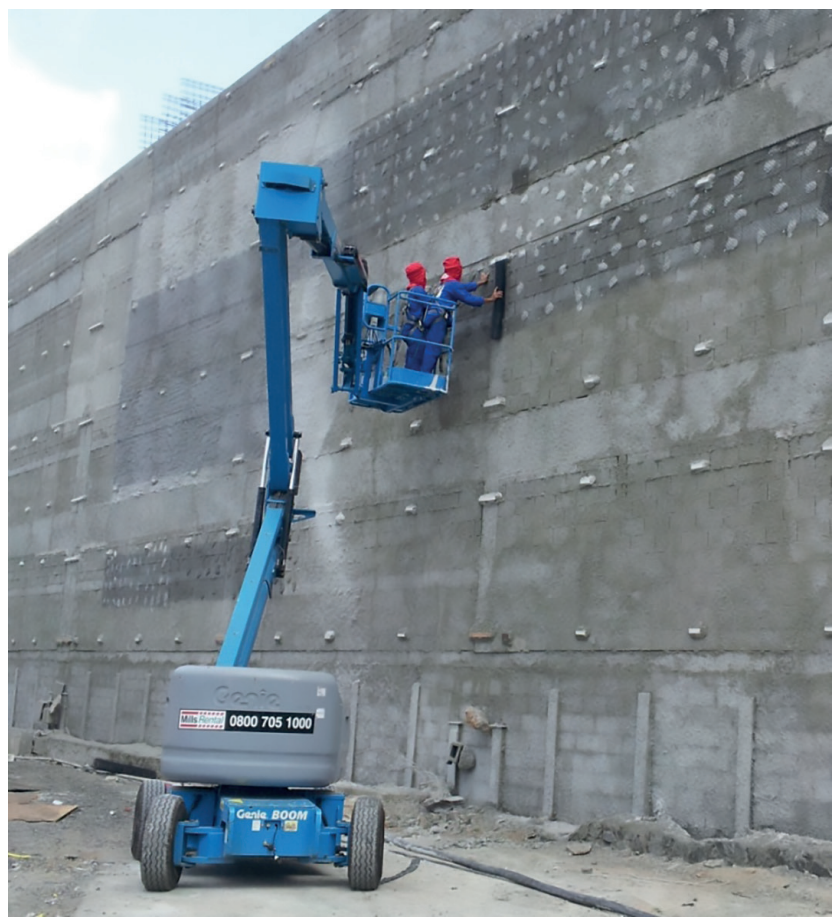

Figura 5 - Aplicação de tela de PVC. Fonte: Autores.

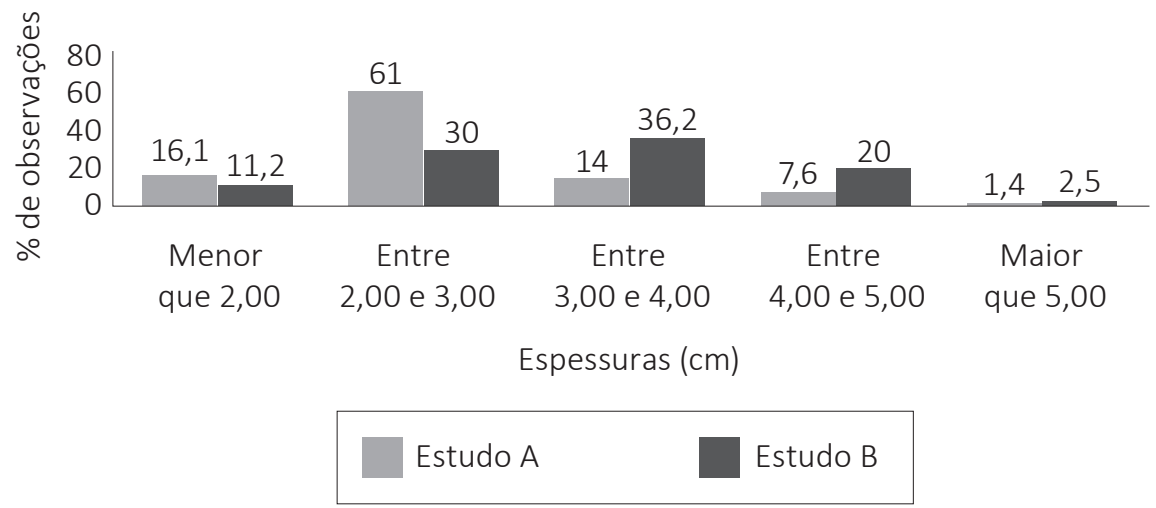

Figura 6 - Distribuição das espessuras do revestimento nos Estudos A e B. 


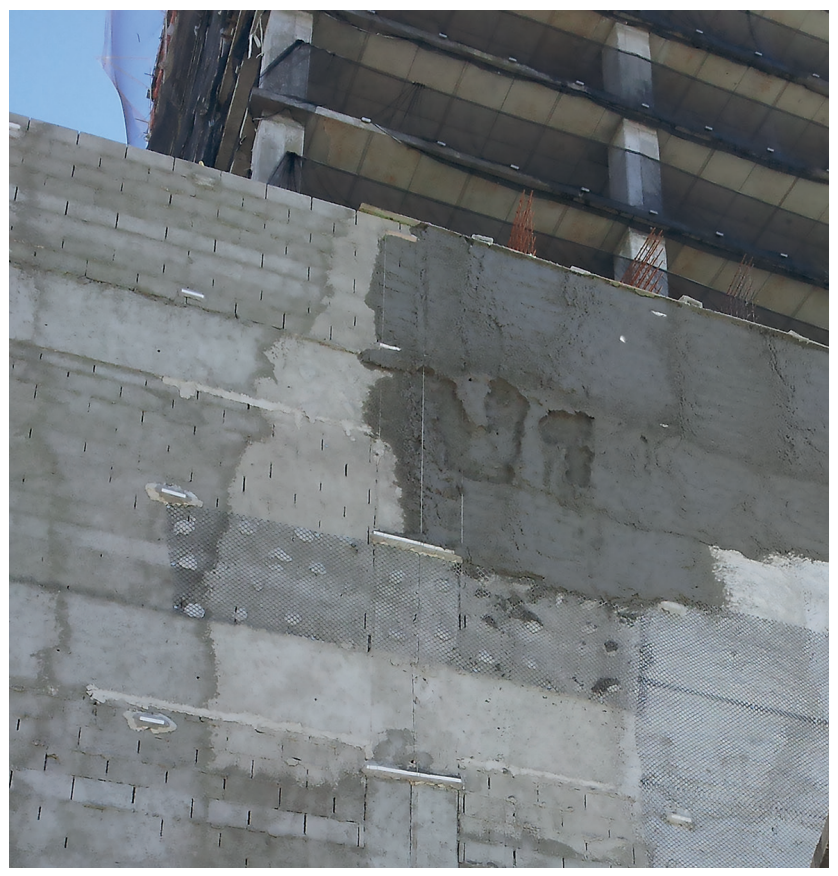

Figura 7 - Descolamento. Fonte: Autores.

Apenas no Estudo D foi identificada o Percentual do Tempo total destinado em Atividades de Transporte (PTAP). As informações obtidas a partir das observações aleatórias indicaram que $34 \%$ do tempo total do processo de revestimento com argamassa ensacada e projeção móvel é destinado a atividades de transporte. Tais Tempos destinados a Atividades de transporte são divididos em: transportes necessários (16\%), como a movimentação dos sacos no elevador cremalheira; transportes evitáveis (15\%), como a movimentação dos sacos entre um estoque secundário e um estoque terciário no andar; e transportes desnecessários (3\%), como a movimentação de um pallet com sacos até um local não preparado para o estoque final da argamassa, conforme apresentado na Figura 8. Neste estudo, ainda foram identificadas algumas das principais causas das perdas por transporte (PÉREZ; COSTA, GONÇALVES, 2016) no processo estudado (Figura 9). 


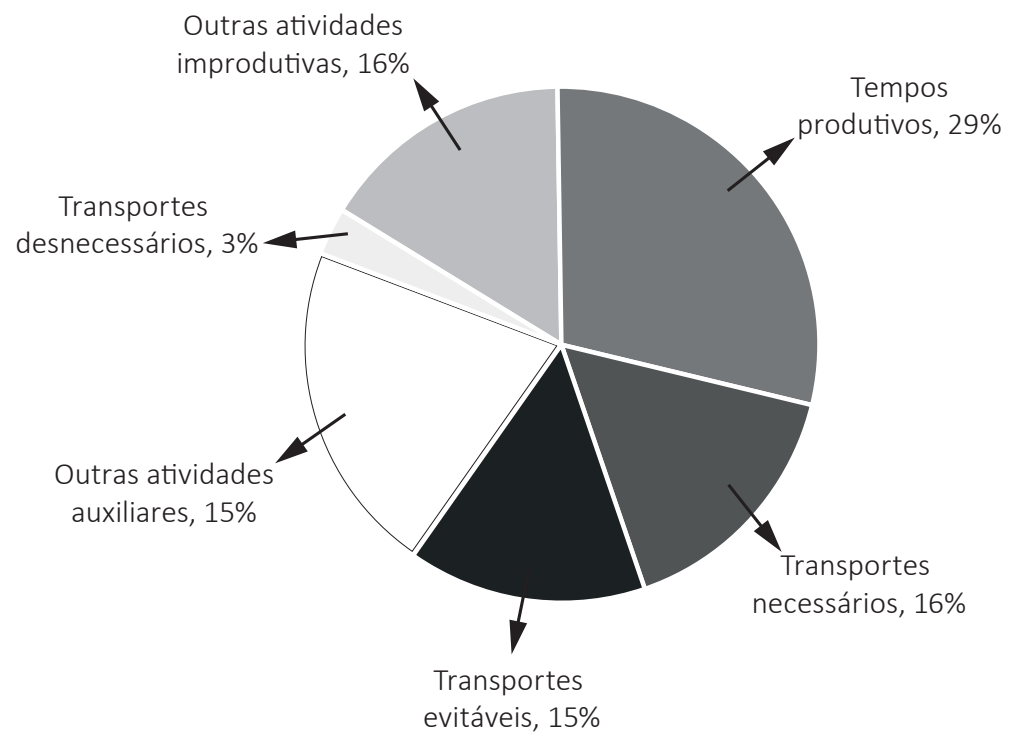

Figura 8 - Resultados da Amostragem de Trabalho no Estudo D. Fonte: Pérez, Costa e Gonçalves, 2015.

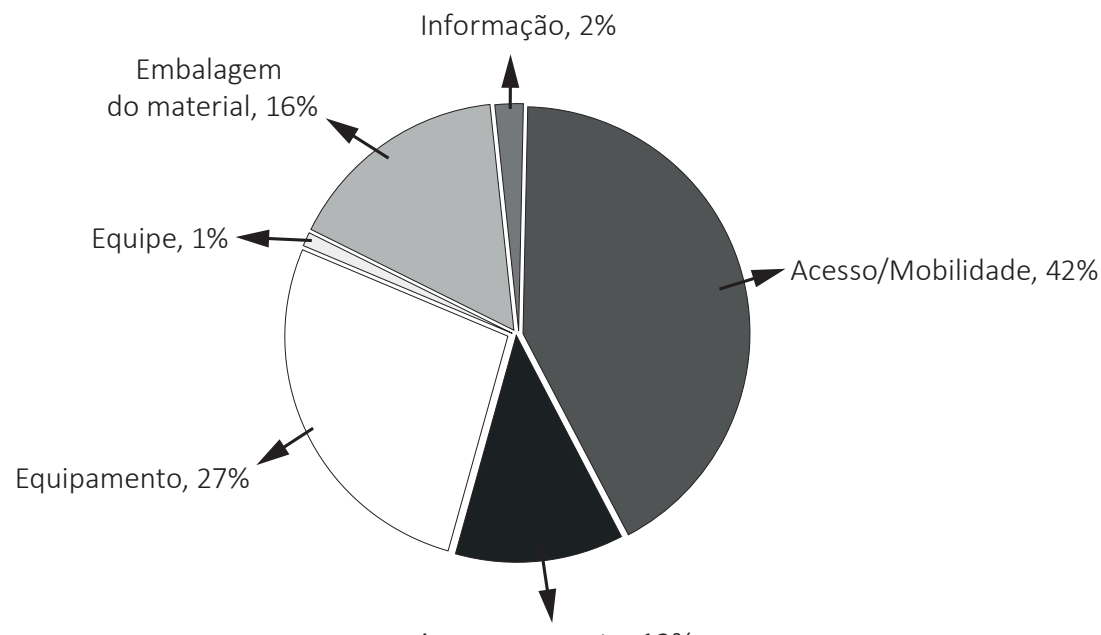

Armanezamento, 12\%

Figura 9 - Causa das perdas nas atividades de transporte. Fonte: Pérez, Costa e Gonçalves, 2015.

A seguir, são apresentados, nas Figura 10, Figura 11 eFigura 12, alguns exemplos das principais causas das perdas por transporte no Estudo D. 


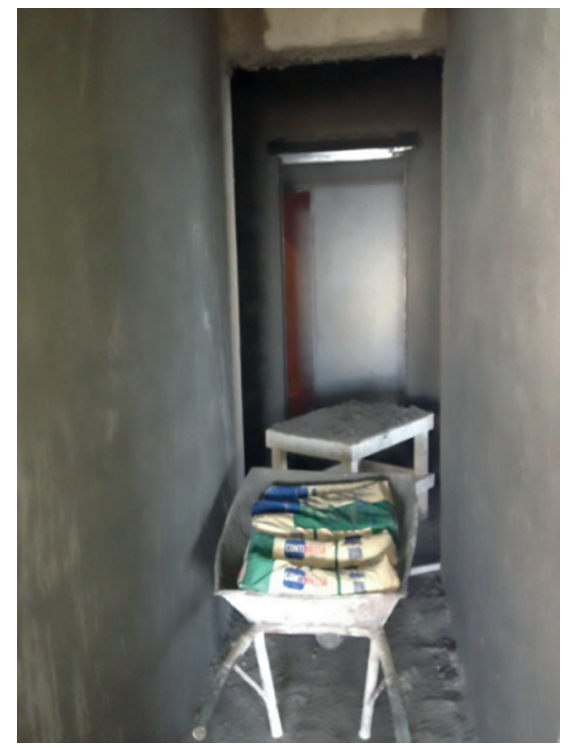

Figura 10 - Perda por acesso (um banco situado na via de acesso dificulta o transporte da argamassa com o carrinho de mão). Fonte: Autores.

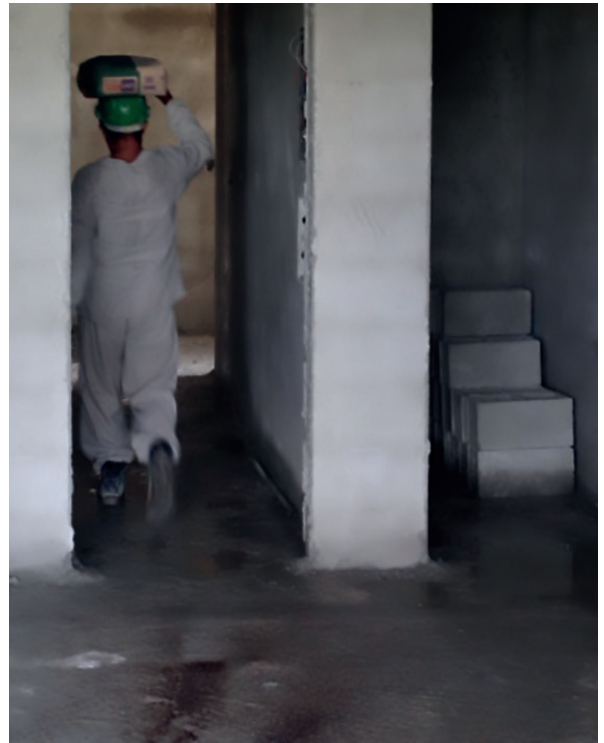

Figura 11 - Perda por equipamento (funcionário transportando sacos manualmente devido à falta de carrinho de mão). Fonte: Autores.

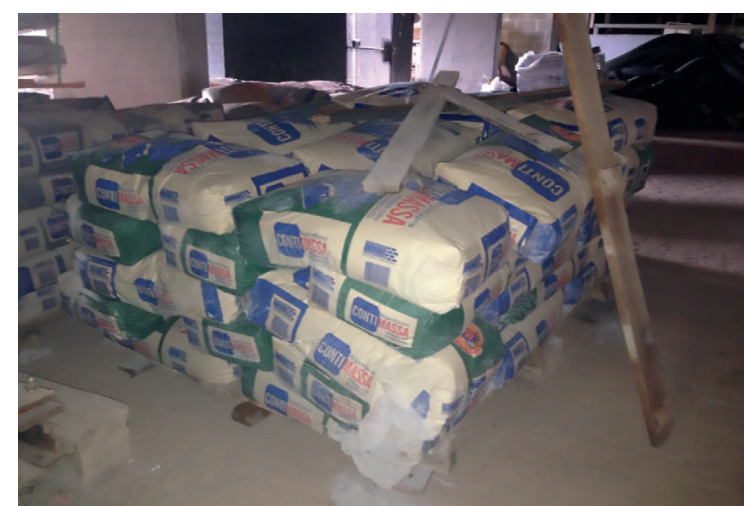

Figura 12 - Perda por embalagem do material (sacos rasgados). Fonte: Autores.

O cálculo dos indicadores econômicos nos estudos indicou que as produtividades do sistema estacionário por via úmida e do sistema de projeção móvel são muito semelhantes, sendo de extrema importância, em ambos os sistemas, um adequado dimensionamento da equipe. No entanto, o sistema de projeção móvel, por ser menos industrializado, destina mais tempo que o sistema de projeção móvel em atividades auxiliares, principalmente em atividades de transporte. 


\subsection{Avaliação Ambiental}

\subsubsection{Nível de Pressão Sonora (NPS)}

O Quadro 7 apresenta os Níveis de Pressão Sonora (NPS) nos locais da realização das medidas, quais sejam: junto aos misturadores e no local da projeção, nos canteiros dos Estudos A, B e C.

Quadro 7 - Nível de Pressão Sonora nos Estudo A, B e C.

\begin{tabular}{|l|l|l|l|}
\hline & Estudo A & Estudo B & Estudo C \\
\hline Tipo de sistema & $\begin{array}{l}\text { Projeção estacionária } \\
\text { por via úmida }\end{array}$ & $\begin{array}{l}\text { Projeção estacionária } \\
\text { por via úmida }\end{array}$ & Projeção móvel \\
\hline $\mathrm{L}_{\text {máximo }}(\mathrm{dBA})$ & 95,0 & 90,3 & 72,5 \\
\hline $\mathrm{L}_{\text {mínimo }}$ (dBA) & 61,3 & 76,9 & 60,0 \\
\hline $\begin{array}{l}\text { Identificação dos } \\
\mathrm{L}_{\text {máx }} \text { e } \mathrm{L}_{\text {mín no }} \text { empreendimento }\end{array}$ & & & \\
\hline
\end{tabular}

Conforme se observa no Quadro 7, os NPS obtidos nos estudos A (95dBA) e B $(90,3 \mathrm{dbA})$ ultrapassam o limite de tolerância de 85 dBA, para a exposição máxima de 8 horas, durante jornada de trabalho, conforme os limites da NR-15 - Atividades e operações insalubres (BRASIL, 2014). Esses valores permitem afirmar que o nível de ruído gerado pelos equipamentos do sistema de projeção estacionaria por via úmida são superiores aos níveis de ruído do sistema de projeção móvel, possivelmente devido à menor potência necessária do misturador móvel para a projeção em decorrência da energia disponível.

\subsubsection{Consumo de água}

No Estudo $A$, foi calculado o consumo de água $(A)$ necessário para a realização do revestimento de dez andares (Figura 13), tendo uma representatividade de 50\%, na medida em que o empreendimento estudado tinha 20 andares. Os valores encontrados mostram que o consumo total de água para a realização de $209,62 \mathrm{~m}^{3}$ de argamassa 
foi de $104,5 \mathrm{~m}^{3}$, obtendo-se, portanto, um valor de $0,5 \mathrm{~m}^{3} / \mathrm{m}^{3}$ para o indicador de Água total consumida na projeção. Cabe ressaltar que menos da metade da Água consumida é gasta no Traço Atraço $\left(54,53 \mathrm{~m}^{3}\right)$.

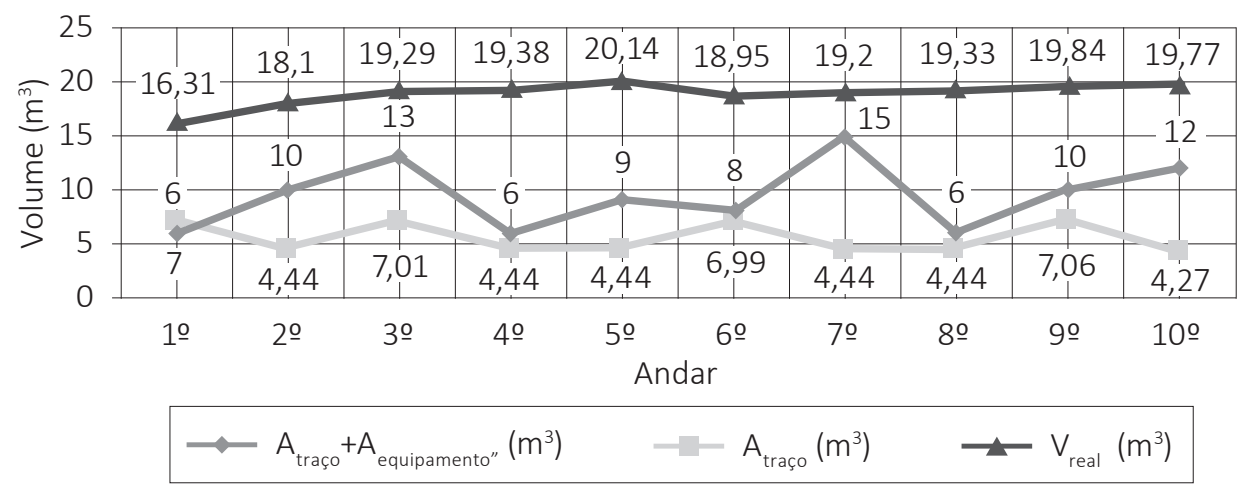

Figura 13 - Consumo de Água total, consumo de Água no Traço e Volume Total de argamassa produzida.

Na Figura 13, observa-se a grande diferença entre o consumo de água total e o consumo de água incorporado na mistura (Atraço), obtida por meio das leituras dos hidrômetro acoplado à boca do reservatório de água (Figura 14). Tal discrepância é decorrente de um consumo excessivo de água na limpeza dos equipamentos (Figura 15).

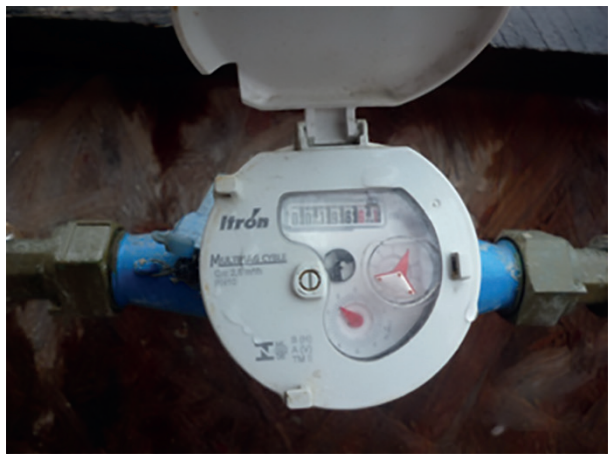

Figura 14 - Hidrômetro acoplado à boca do reservatório de água para a mistura. Fonte: Autores.

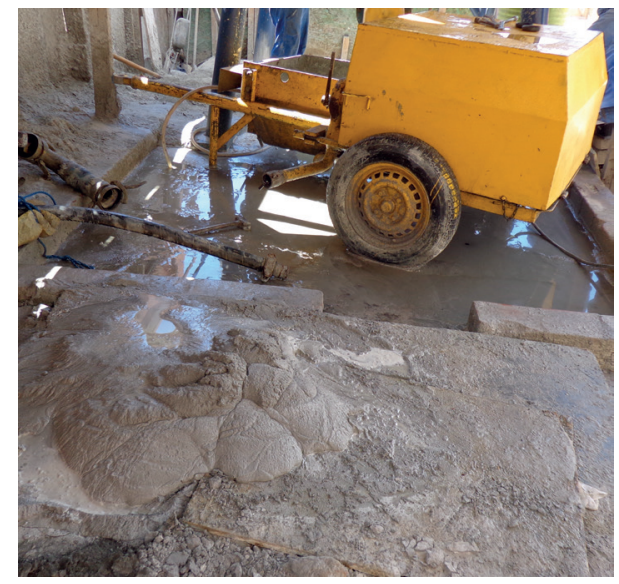

Figura 15 - Limpeza dos equipamentos de mistura. Fonte: Autores. 


\subsubsection{Consumo de energia}

No Estudo A, foi calculado o Consumo de energia elétrica do sistema de projeção (E) durante os meses de estudo, conforme apresentado no Quadro 8. Observa-se que a energia consumida para a projeção de um metro cúbico de argamassa foi em média $1,99 \mathrm{Kwh} / \mathrm{m}^{3}$. O gasto total de energia para a projeção representa $9 \%$ da energia total consumida no mês.

Quadro 8-Energia consumida no Estudo A.

\begin{tabular}{|l|l|l|l|l|l|l|}
\hline & $\begin{array}{l}\text { Energia } \\
\text { consumida no } \\
\text { mês (Kwh) }\end{array}$ & $\begin{array}{l}\text { Dias de } \\
\text { projeção }\end{array}$ & $\begin{array}{l}\text { Energia } \\
\text { consumida } \\
\text { na projeção } \\
\text { (Kwh) }\end{array}$ & $\begin{array}{l}\text { Volume de } \\
\text { argamassa } \\
\text { produzida } \\
\text { (Vreal) }\left(\mathrm{m}^{3}\right)\end{array}$ & $\begin{array}{l}\text { Energia } \\
\left(\text { Kwh/m }{ }^{3}\right)\end{array}$ & $\begin{array}{l}\text { \% de } \\
\text { energia } \\
\text { gasta na } \\
\text { projeção }\end{array}$ \\
\hline Setembro & 2496,78 & 19 & 223,44 & 105 & 2,13 & 9 \\
\hline Outubro & 3231,78 & 22 & 258,72 & 145 & 1,78 & 8 \\
\hline Novembro & 2622,78 & 22 & 258,72 & 140 & 1,85 & 10 \\
\hline Dezembro & 746,45 & 5 & 58,80 & 26 & 2,26 & 8 \\
\hline
\end{tabular}

Por fim, o levantamento dos indicadores ambientais nos estudos indicou que o sistema estacionário por via úmida apresenta maiores impactos que o sistema de projeção móvel, do ponto de vista do NPS, consumo de água e energia.

Dessa maneira, a opção de utilizar projetores de ar para a realização do revestimento, além de contribuir com a qualidade dessa atividade (PARAVISI, 2008), pode ser uma forma de aumentar a produtividade, diminuir as perdas por espessura e aumentar o tempo destinado a atividades produtivas, entre outras. Porém, esse sistema apresenta maiores impactos ambientais diretos, tendo em vista o NPS, o consumo de água gasto para a limpeza dos equipamentos e a energia utilizada pelos equipamentos de projeção (Figura 16). No entanto, a partir de uma ponderação mais ampla, considerando os impactos indiretos, a redução do prazo das atividades reduzirá também atividades inerentes ao funcionamento da obra como um todo. Deste modo, uma análise mais aprofundada e individualizada é de grande importância, já que tal ganho de produtividade pode acarretar na compensação dos impactos ambientais diretos. 


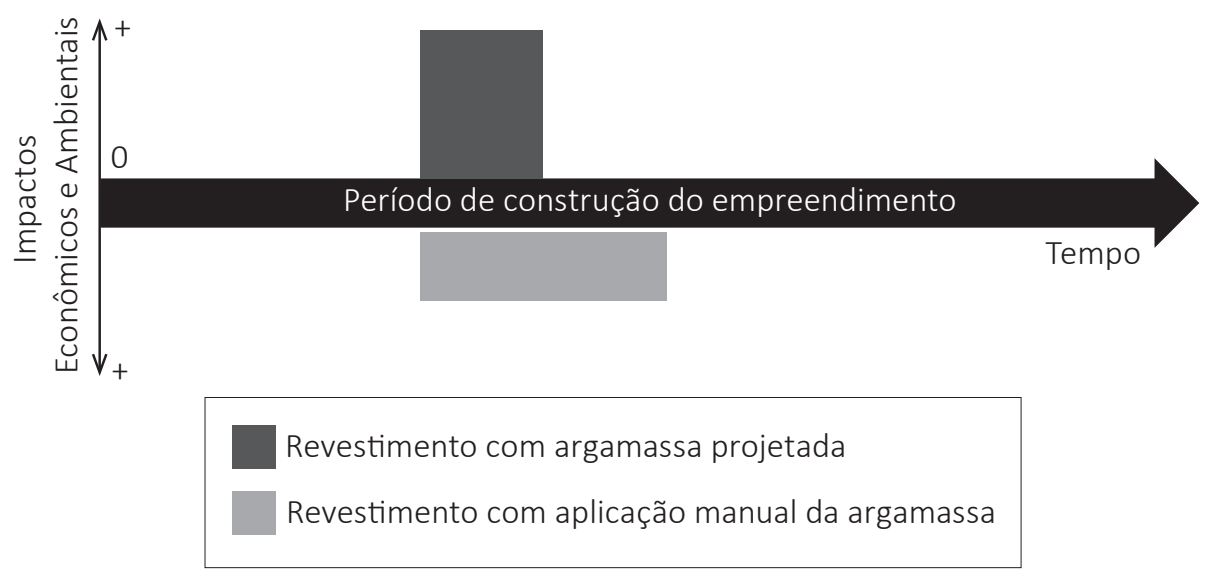

Figura 16 - Comparação dos impactos econômicos e ambientais ao longo do período de construção de um empreendimento.

\section{Conclusões}

O presente capítulo apresentou uma análise econômica e ambiental do processo de revestimento com argamassa projetada a partir dos indicadores coletados em quatro estudos de caso realizados na região metropolitana de Salvador.

Entre os indicadores econômicos utilizados o PTP e o PTAT foram aqueles que exigiram um maior esforço na sua coleta, devido à necessidade do uso da técnica da amostragem de trabalho, consumindo bastante tempo de pesquisa. Por outro lado, esses indicadores permitiram realizar uma quantificação dos tempos destinados em atividades produtivas e de transporte no processo estudado. Já o indicador RUPc mostrou-se como um indicador de coleta bastante simples, feita a partir da planilha de controle da produção. Os resultados obtidos a partir da coleta da RUPc foram importantes para a quantificação da produtividade dos sistemas de projeção. Por último, embora o indicador Pvar. ${ }_{\text {esp. }}$ demande uma coleta de amostras das espessuras das superfícies a revestir, nem sempre de fácil acesso, sua análise é importante porque a variação de espessura é apontada como uma das principais fontes de perdas de argamassa no processo de revestimento com argamassa.

Já entre os indicadores utilizados para a avaliação ambiental, o indicador NPS é de simples coleta, demandando apenas o uso de um decibelímetro. Para o cálculo do Consumo de água na projeção (A), observa-se a necessidade da existência de um hidrômetro no reservatório para a realização efetiva do controle de água utilizado. Tal equipamento apresenta um custo baixo em relação ao benefício econômico que o 
referido controle pode trazer. Por fim, a coleta do Indicador Consumo de Energia (E) mostrou-se simples, tendo sido realizada a partir das informações dos equipamentos oferecidos pelo fabricante e de outras informações obtidas com as planilhas de controle de argamassa, também de fácil aplicação.

Do ponto de vista da avaliação dos sistemas de argamassa projetada estudados nesta pesquisa, a coleta de indicadores de produtividade indicou que os sistemas de projeção estacionários por via úmida apresentam ganhos de produtividade em relação ao sistema de projeção móvel. De acordo com resultados obtidos, o sistema de projeção estacionário por via úmida utilizado nas obras A e B apresenta o NPS mais elevado (95 dBA) que o sistema de projeção móvel ( $72,5 \mathrm{dBA})$. Conclui-se que os operadores das argamassadeiras analisadas estão submetidos a níveis de ruídos aceitáveis. Ainda assim, ações de mitigação dos ruídos são recomendadas. Os resultados obtidos na coleta do Indicador Energia consumida para a projeção (E) indicaram que são gastos em media 1,99Kwh para a projeção de um metro cúbico de argamassa. O gasto total de energia para a projeção representa $9 \%$ da energia total consumida no mês no canteiro da Obra A.

\section{Referências}

ASSOCIAÇÃO BRASILEIRA DE NORMAS TÉCNICAS. NBR 13749: Revestimento de paredes e tetos de argamassas inorgânicas - Especificação. Rio de Janeiro, 1996.

BRASIL. Ministério do Trabalho e Emprego. Norma Regulamentadora 15 (NR-15): Atividades e Operações Insalubres. 2014. Disponível em: <http://portal.mte.gov.br/data/ files/8A7C816A47594D040147D14EAE840951/NR-15\%20(atualizada\%202014).pdf>. Acesso em: nov. 2014.

COSTA, F.N. Processo de produção de revestimento de fachada de argamassa: problemas e oportunidades de melhoria. 2005. Dissertação (Mestrado em Engenharia Civil) - Programa de Pós-graduação em Engenharia Civil, UFRGS, Porto Alegre.

CRESCENCIO, R.M.; PARSEKIAN, G.A.; BARROS, M.M.S.B.; SABBATINI,F.H. Execução de revestimento com argamassa projetada. São Paulo, 2000. EPUSP.

IIDA, I. Ergonomia: projeto e produção. 2. ed. rev. e ampl. São Paulo: Edgard Blücher, 2005. OLIVEIRA, M.; LANTELME, E.; FORMOSO, C. T. Sistemas de indicadores de qualidade e produtividade para a construção civil: manual de utilização. 2. ed. rev. Porto Alegre: Serviço e Apoio às Micro e Pequenas Empresas do Rio Grande do Sul - SEBRAE/RS, 1995.

PALIARI, J.C.; SOUZA, U.E.L.; ANDRADE, A.C. Levantamento de perdas/consumo de argamassas de revestimento em obras de construção de edifícios brasileiras. In: III Simpósio Brasileiro de Tecnologia de Argamassas, Vitória, 1999. Anais... Vitória, 1999, p. 175-724.

PALIARI, J.C.; SOUZA, U.E.L.; ANDRADE, A.C. Estudo sobre consumo de argamassa de revestimentos interno e externo nos canteiros de obras. In: Simpósio Brasileiro de Gestão da Qualidade e Organização do Trabalho no ambiente Construído, 2o, Fortaleza, CE, 2001. 
PARAVISI, S. Avaliação de sistemas de produção de revestimentos de fachada com aplicação mecânica e manual de argamassa. Dissertação (Mestrado em Engenharia Civil) Núcleo Orientado Para Inovação da Edificação, Programa de Pós-Graduação em Engenharia Civil, Universidade Federal do Rio Grande do Sul, Porto Alegre, 2008.

PARAVISI, S.; MASUERO, A.B.; BONIN, L.C.; ISATTO, E.L. Produção de argamassa com bomba de projeção. Revista Téchne. PINI. Edição 145. Abril, 2008.

PÉREZ, C.T.; COSTA, D.B.; GONÇALVES, J.P. Identificação, mensuração e caracterização das perdas por transporte em processos construtivos. Ambiente Construído, Porto Alegre, v. 16, n. 1, p. 243-263, jan./mar. 2016. ISSN 1678-8621, Associação Nacional de Tecnologia do Ambiente Construído. http://dx.doi.org/10.1590/s1678-86212016000100072

RODRIGUES, P.P.; CATAI, R.E.; AGNOLETTO, R.A.; FERREIRA, M.R.C.; GUDEIKI, I.J.B.; MATOSKI, $A$. Análise dos níveis de ruído em equipamentos da construção civil na cidade de Curitiba. 2009. Revista Produção. ISSN 1676 - 1901 / v. IX, n. III, 2009.

SANTOS, A.; FORMOSO, C.T.; HINKS, J. Method of Intervention on the Flow of Materials in Buildings Processes. In: ANNUAL CONFEENCE OF THE INTERNATIONAL GROUP FOR LEAN CONSTRUCTION, 4., Birmingham, 1996. Proceedings... Birmingham, 1996.

SILVA R.R.; VIOLIN, R.Y.T. Gestão da água em canteiros de obras de construção civil. VIII EPCC Encontro Nacional de Produção cinetífica, 2013. Anais... 2013

SOUZA, R.; MEKBEKIAN, G. Qualidade na aquisição de materiais e execução de obras. CTE. São Paulo, PINI, 1996. 


\section{Conclusões: Avanços e Perspectivas Futuras}

O presente livro representa uma importante contribuição aos agentes da indústria da construção civil e aos pesquisadores, compilando recomendações práticas e reflexões teóricas úteis para a melhoria da sustentabilidade e das condições de trabalho nos canteiros de obras. Vale ressaltar que todos os trabalhos relatados neste livro decorrem, em maior ou menor grau, das colaborações entre pesquisadores e representantes da indústria. Embora a importância dessa colaboração não seja novidade, é preciso reiterar seu caráter imprescindível para garantir a relevância e disseminação dos conhecimentos produzidos. Nesse sentido, ao longo do projeto que permitiu a elaboração deste livro, nas cidades das universidades que fazem parte da Rede de Pesquisa CANTECHIS, foram realizados diversos workshops visando à discussão e disseminação dos resultados.

De modo geral, os resultados apresentados neste livro apontam que as tecnologias para canteiros de obras sustentáveis e com condições de trabalho mais adequadas vêm sendo objeto de melhorias incrementais, muitas vezes por parte de iniciativas isoladas de empresas e profissionais.

Na seção do subprojeto de Diagnóstico das necessidades de inovações tecnológicas para canteiros de baixo impacto ambiental (SPDIG), a partir dos três trabalhos apresentados nos Capítulos 1, 2 e 3, identificou-se como desafio a exigência inicial de um compromisso dos diversos intervenientes capazes de possibilitar o desenvolvimento de canteiros de obras com baixo impacto ambiental, com destaque para as construtoras, fornecedores da indústria da construção, órgãos regulamentadores e instituições financiadoras. Com a contribuição de tais agentes, é possível a aplicação efetiva das práticas e estratégias, além da utilização de produtos de construção com menor impacto ambiental, social e econômico. Muitas das práticas identificadas ao longo destes trabalhos têm valores significativamente baixos para implantação, porém os retornos do investimento podem ser intangíveis, como o aumento da competitividade e a melhoria da imagem da empresa perante os clientes e a sociedade em geral.

Por outro lado, observou-se a importância dos órgãos regulamentadores e das instituições financiadoras para o estabelecimento de políticas que demandem e 
encorajem ações mais sustentáveis. Espera-se que os órgãos e instituições possam estabelecer incentivos próprios para o desenvolvimento de materiais e tecnologias para construção capazes de proporcionar o uso racional dos recursos, seja energia, água ou materiais, bem como menores emissões e resíduos, de modo a tornar mais rápida e efetiva a implantação dessas práticas com menor impacto ambiental, social e econômico. Este subprojeto mostrou ainda o potencial de investigação concernente ao estabelecimento de indicadores para o monitoramento dessas práticas e classificação do nível de sustentabilidade adotado, sendo importante definir metas progressivas e meios para acompanhar e divulgar os avanços do setor.

Um dos subprojetos mais desafiadores diz respeito à emissão de materiais particulados por requerer estudos experimentais de campo e envolver variáveis diversas, como questões meteorológicas (direção e velocidade do vento, pluviometria, umidade e temperatura), diferentes atividades construtivas no canteiro e fatores externos, como o arranjo físico do canteiro, a distância entre os pontos de coleta e a construção, a proximidade dos pontos de coleta e atividades, a distância entre pontos de coleta, a altura das construções e as contribuições externas.

O capítulo 4 trouxe uma parte dos resultados do referido subprojeto ao discutir medidas para o controle da poeira, que podem mitigar alguns efeitos causados pela poluição do ar, trazendo inúmeros benefícios para os diferentes intervenientes da construção. Assim, em relação aos construtores, pode-se falar em uma provável melhora na reputação empresarial, além de evoluções nas relações com trabalhadores, vizinhança e clientes. Para a vizinhança, por sua vez, pode-se falar em melhoria na saúde. O monitoramento e os estudos relativos à qualidade do ar no entorno das construções, todavia, devem ser contínuos, dado os impactos e transtornos que as atividades de construção causam à vizinhança da obra.

Na seção do subprojeto sistemas de proteções coletivas (SPSPC), os seis capítulos apresentados ofereceram critérios de escolha entre as tecnologias disponíveis, indicando-as como exemplos de melhorias incrementais. Ademais, descreveram boas práticas que ainda não são de amplo conhecimento dos profissionais. De outro lado, como exemplo de tecnologia recente, cujos benefícios e dificuldades de uso ainda são pouco conhecidos, o emprego de Veículos Aéreos Não Tripulados (VANTs) foi discutido no nono capítulo.

Neste subprojeto, diversas oportunidades de novas investigações foram levantadas, como a avaliação e o aperfeiçoamento de tecnologias que, embora sejam antigas, recentemente se consolidaram e estão em expansão, tais como: andaimes fachadeiros, redes de segurança e novos tipos de linhas de vida. Além disto, foi 
mostrado que se faz importante avaliar e aperfeiçoar tecnologias de informação emergentes, como uso dos VANTs, sistemas eletrônicos de alerta sobre riscos e controle por meio de radio frequência (RFID) e uso de dispositivos computadorizados móveis. Por fim, concluiu-se que é essencial desenvolver tecnologias inovadoras para o treinamento de profissionais de todos os níveis, como novos trabalhadores (mais suscetíveis a acidentes) e terceirizados que ficam pouco tempo na obra, além de se estimular tanto a implantação de simuladores, em escala real ou realidade virtual no computador, como a integração do uso das tecnologias a novas abordagens de gestão da segurança (por exemplo, engenharia de resiliência).

A questão da segurança do trabalho é fator essencial para que a sustentabilidade seja efetivamente alcançada no canteiro de obra em todos os seus níveis, principalmente no aspecto social de resgatar a dignidade e saúde do trabalhador.

Os seis capítulos do subprojeto instalações provisórias em canteiros de obras (SPIPC) discutiram duas facetas dos desafios atualmente colocados para adoção de tais facilidades: pelo lado da demanda, destaca-se o crescente nível de exigência por parte dos órgãos normativos e reguladores, das construtoras e dos trabalhadores por construções de melhor desempenho, mais econômicas e saudáveis; pelo lado da oferta, observa-se uma mudança na diversidade e qualidade dos produtos disponíveis, para melhor responder a tais exigências. Verificou-se a existência de vários produtos disponíveis no mercado brasileiro para as instalações provisórias, com valor agregado, e a possibilidade de continuar evoluindo no desempenho, seja por meio de pequenas melhorias ou desenvolvimento de novos produtos.

Nesse contexto, os capítulos apresentam duas propostas de melhoria baseadas nos experimentos realizados pela Rede CANTECHIS, que resultaram em soluções de maior nível de sustentabilidade. A primeira se caracterizou por ser uma melhoria incremental para aumentar o desempenho térmico e a economia de energia dos módulos tridimensionais em aço - os contêineres. A segunda proposta é referente ao desenvolvimento de um sistema construtivo de pré-moldados de concreto, visando ao atendimento das normas técnicas de desempenho e à reutilização dos componentes.

Tais iniciativas mostraram a necessidade de continuar pesquisando e o desafio da proposição de novas soluções que considerem a verificação do nível de desempenho das edificações. As instalações provisórias são, muitas vezes, utilizadas como escritórios dos canteiros de obra e deveriam ter as condições de conforto e segurança necessárias para que os trabalhadores possam desempenhar suas funções com produtividade e saúde. 
Os resultados do subprojeto voltado às tecnologias construtivas (SPTEC) indicaram a interdependência entre as tecnologias de processo e produto. Concluiu-se pela necessidade do uso de princípios e práticas gerenciais, como aqueles associados à sustentabilidade e construção enxuta, que criem condições organizacionais favoráveis ao uso das tecnologias de produto e garantam a sua melhoria contínua.

Destaca-se a proposição de novas categorias de perdas inseridas no contexto da filosofia da produção enxuta, com aplicação em sistemas construtivos industrializados, trazendo uma perspectiva diferente sobre a ocorrência de perdas nos canteiros de obras e relação de causalidade, muitas vezes não percebidas pelos gestores de obras. Como complemento, insere-se também a proposição de indicadores econômicos e ambientais para avaliação do desempenho de processos construtivos, com ênfase no processo de revestimento com argamassa projetada.

Além do foco no desempenho das atividades de construção realizadas nos canteiros de obras, sob o ponto de vista gerencial, econômico e ambiental, com a proposição de métodos e indicadores de avaliação, um dos resultados do SPTEC transcende os canteiros de obras, com o desenvolvimento de um sistema de produção flow shop, utilizando linhas de montagem manuais como técnica de produção para unidades habitacionais modulares em LSF. O sistema modelado e simulado computacionalmente se mostrou factível, contribuindo para a discussão e avanço da industrialização da construção civil no país.

Uma vez que os resultados apresentados neste livro refletem tecnologias existentes no período em que a pesquisa foi realizada, iniciado de fato em 2011 e finalizado em 2017, eles estão, portanto, sujeitos à melhoria contínua. Para maior aprofundamento sobre as questões levantadas, devem ser procurados os trabalhos acadêmicos que resultaram do subprojeto, não incluídos no livro.

Percebeu-se que algumas situações contextuais observadas podem influenciar a natureza dos canteiros sustentáveis e oferecer melhores condições de trabalho em um futuro próximo, tais como: a gradativa industrialização dos processos construtivos, o crescente uso das tecnologias da informação, a constatação do envelhecimento da força de trabalho, as mudanças na legislação trabalhista, as mudanças climáticas, as normas técnicas focadas em desempenho, a crescente complexidade e interdependência entre os agentes da cadeia produtiva. Em função disso, uma dimensão da sustentabilidade dos canteiros de obras, que possivelmente crescerá em importância, diz respeito à sua resiliência ou capacidade adaptativa frente a um futuro contexto mais incerto e dinâmico. 
Ao longo do projeto, várias situações positivas foram encontradas e outras foram implantadas. A elaboração deste livro apoia-se na divulgação dessas ações e na conscientização de mais profissionais atuantes no setor. Com o projeto CANTECHIS, foi possível capacitar uma nova geração de pesquisadores, que estão conscientes e dominam ferramentas gerenciais e conceitos que podem trazer melhorias efetivas para a indústria da construção civil brasileira.

A equipe de pesquisadores envolvida no CANTECHIS tem a expectativa e entende como necessária a continuidade do apoio das agências de fomento para promover discussões e ações que possam levar adiante a efetiva melhoria da sustentabilidade ambiental e das condições de trabalho na construção civil.

\author{
Tarcísio Abreu Saurin \\ Dayana Bastos Costa \\ Francisco Ferreira Cardoso \\ Sheyla Mara Baptista Serra
}

(Organizadores) 

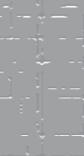

O projeto de pesquisa CANTECHIS - Tecnologias para Canteiro de Obras Sustentável de Habitações de Interesse Social (HIS) - também denominado Rede CANTECHIS, se caracteriza como uma resposta à Chamada Pública MCT/FINEP/Ação Transversal Saneamento Ambiental e Habitação 06/2010.

Quatro universidades formaram a rede de pesquisa colaborativa: Universidade Federal da Bahia (UFBA), Universidade Federal do Rio Grande do Sul (UFRGS), Universidade Federal de São Carlos (UFSCar) e Universidade de São Paulo (USP).

A Rede CANTECHIS se iniciou em 2011 e teve duração até março de 2017 e tratou do tema: "desenvolvimento de soluções tecnológicas aplicadas a canteiros de obras de empreendimentos habitacionais, especialmente de interesse social, visando à sustentabilidade ambiental e melhoria das condições de trabalho".

A ênfase do projeto decorreu da expansão das habitações de interesse social (HIS) por meio de programas governamentais, como o Programa Minha Casa Minha Vida (PMCMV), das crescentes preocupações com sustentabilidade ambiental, segurança do trabalho e necessidade de reduzir as perdas no setor da construção civil.

O projeto CANTECHIS, integralmente apoiado pela FINEP, foi estruturado em cinco subprojetos que tratam de temáticas relacionadas entre si, a saber:

- SPDIG - Diagnóstico das principais necessidades de soluções tecnológicas em canteiro de obras de empreendimentos de habitação de interesse social;

- SPSPC - Aperfeiçoamento de sistemas de proteção coletiva em canteiros de obras de empreendimentos do PMCMV;

- SPEMP - Desenvolvimento de soluções para redução da emissão de materiais particulados em canteiros de obras de HIS;

- SPIPC - Soluções tecnológicas sustentáveis para instalações provisórias de canteiros de obras de HIS;

- SPTEC - Desenvolvimento de tecnologias de execução relacionadas a métodos e sistemas construtivos inovadores para empreendimentos do PMCMV, com foco em sistema construtivo industrializado.

Durante os seis anos de desenvolvimento da rede colaborativa foram realizados vários trabalhos e atividades, que podem ser consultados na página do projeto http://www.cantechis.ufscar.br/.

Este livro apresenta contribuições dos cinco subprojetos, oferecendo exemplos práticos e reflexões teóricas relevantes para pesquisadores e outros agentes da construção civil que desejam conhecer melhor as tecnologias que colaboram para tomar o canteiro de obras mais sustentável e seguro.

Financiadora:

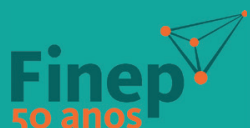

Executoras:

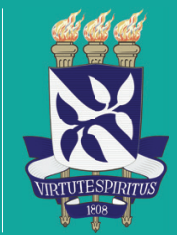

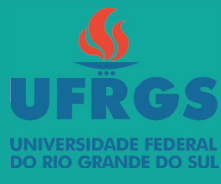

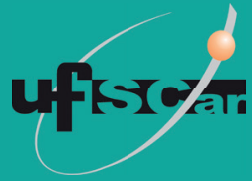

Convenente: 